\title{
ACCIDENTAL
}

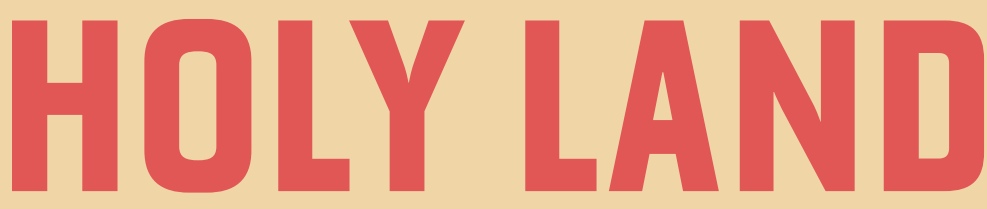

\section{The Communist Revolution in Northwest China}

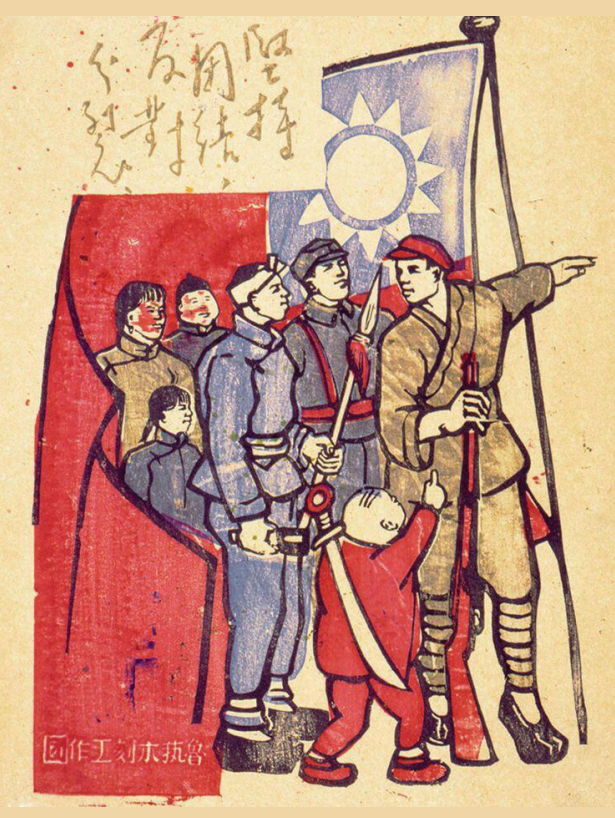

JOSEPH W.ESHERICK 
Luminos is the Open Access monograph publishing program from UC Press. Luminos provides a framework for preserving and reinvigorating monograph publishing for the future and increases the reach and visibility of important scholarly work. Titles published in the UC Press Luminos model are published with the same high standards for selection, peer review, production, and marketing as those in our traditional program. www.luminosoa.org 

Accidental Holy Land 
The publisher and the University of California Press Foundation gratefully acknowledge the generous support of the Sue Tsao Endowment Fund in Chinese Studies. 


\section{Accidental Holy Land}

The Communist Revolution in Northwest China

Joseph W. Esherick

甲ㅜ

UNIVERSITY OF CALIFORNIA PRESS 
University of California Press

Oakland, California

(C) 2022 by Joseph W. Esherick

This work is licensed under a Creative Commons CC BY-NC-ND license. To view a copy of the license, visit http://creativecommons.org/licenses.

Suggested citation: Esherick, J. W. Accidental Holy Land: The Communist Revolution in Northwest China. Oakland: University of California Press, 2022. DOI: https://doi.org/10.1525/luminos.117

Names: Esherick, Joseph W., author.

Title: Accidental holy land : the Communist revolution in northwest China / Joseph W. Esherick.

Description: Oakland, California : University of California Press, [2022] | Includes bibliographical references and index.

Identifiers: LCCN 2021029482 | ISBN 9780520385320 (paperback) |

ISBN 9780520385337 (ebook)

Subjects: LCSH: Communism-China-Shan Gan Ning Bian Qu. |

Communism-China, Northwest-History-2oth century. |

Revolutions-China-History-2oth century. |

Shan Gan Ning Bian Qu (China)-History.

Classification: LCC HX420.S48 E74 2022 | DDC 335.43/45-dc23

LC record available at https://lccn.loc.gov/2021029482

Manufactured in the United States of America

$\begin{array}{llllllllll}31 & 30 & 29 & 28 & 27 & 26 & 25 & 24 & 23 & 22\end{array}$

$\begin{array}{llllllllll}10 & 9 & 8 & 7 & 6 & 5 & 4 & 3 & 2 & 1\end{array}$ 
For Mom and $\mathrm{Ye} W a$

Two extraordinary women 



\section{CONTENTS}

List of Illustrations ix

Preface $x i$

Acknowledgments $x x v$

1. Frontier Foundations for Revolution 1

2. Shaanxi's Early Communist Movement 31

3. Bandits and Bolsheviks $\quad 58$

4. The Rocky Road to Revolution 87

5. Accidental Holy Land 123

6. Dawn of the Yan'an Era 161

$\begin{array}{ll}\text { Conclusion } & 196\end{array}$

Appendix: Informants 211

Glossary $\quad 213$

Abbreviations Used in Notes 221

Notes 223

Bibliography $\quad 289$

$\begin{array}{ll}\text { Index } & 307\end{array}$ 



\section{L L U S T RATIONS}

\section{MAPS}

1. Shaanxi Province 2

2. Mid-Qing gentry distribution 15

3. Shaanxi population change 25

4. Late Qing gentry distribution 26

5. Northern Shaanxi 95

6. Long March 124

7. Shaanbei Communist base: 1935127

8. Shaanbei Communist base: 1936139

9. Shaan-Gan-Ning: 1938167

10. Anding County: $1937-40177$

11. Shan-Gan-Ning: 1940183

FIGURES

1. Yongningshan 20

2. Cliff caves 21

3. Wei-Hua Uprising, 192852

4. Liu Zhidan 59

5. Xie Zichang 67

6. Xuejiazhai 83

\section{TABLES}

1. Distribution of Communist Party workers, September 192755

2. Tax burden of new regime 189 

Yan'an is China's "revolutionary holy land." Every year thousands of tourists visit the city as part of the Chinese Communist Party's program of Red tourism to "consolidate their faith in pursuing the road of socialism with Chinese characteristics and realizing the great rejuvenation of the nation under the leadership of the [Communist Party]." In Yan'an, they visit the caves occupied by Mao Zedong, Zhou Enlai, and other party leaders during the eight-year War of Resistance again Japan and absorb the official history of this Communist base in the massive Memorial Hall of the Revolution. Yanan was the capital of the Communists' ShaanGan-Ning Border Region, which spanned northern Shaanxi (Shaanbei 陕北), several counties in eastern Gansu, and one in Ningxia. Mao and the party Center arrived in Shaanbei in 1935 and did not leave until 1948. They made Yan'an "the cradle" of the Chinese Revolution. Here Mao gave his famous Talks on Literature and Art, developed the concepts of mass line, self-reliance, and New Democracy, and labeled the United States a "paper tiger." Yan'an was the crucible that made the Chinese Communist Party what it is today.

When Mao and the party Center arrived, they did not envision this glorious future for Shaanbei. Indeed, they sought mightily to escape this arid, povertystricken backwater to richer lands in southern Shaanxi, or the North China plain, or even safe refuge along the Soviet border. Yan'an and the eventual ShaanGan-Ning Border Region became a revolutionary holy land by accident. The history of the Communist revolution in Shaanbei is not a simple story. Our account starts centuries earlier, as rebellions devastated vast areas of Shaanbei and as drought, famine, and migration shaped and reshaped the local environment. When idealistic young intellectuals found hope in vaguely understood MarxistLeninist ideas, they embarked on a revolutionary course that was marked by 
dismal failures, missed opportunities, and costly victories. There were Communist bandits fighting in the hills of Shaanbei long before Mao and the party Center arrived in 1935. This is a history of their revolution, a revolution with many conflicting actors, in constantly changing circumstances, involving a series of contingent events. What happened was not inevitable, but it is explicable.

While a small but persistent revolutionary movement was growing in Shaanbei, roughly fifteen hundred kilometers to the south Mao and his comrades left the Jiangxi soviet and embarked on the harrowing retreat later celebrated as the Long March. On the march, 90 percent of Mao's army was lost, and when he arrived to combine with the Shaanbei guerrillas, the entire force had only thirteen thousand ill-armed soldiers. By the end of the War of Resistance, there were a million men fighting under the Communist banner, and little more than a year after Mao left Shaanbei, his People's Liberation Army emerged victorious in the civil war against Chiang Kai-shek’s (Jiang Jieshi 蒋介石) Nationalist Party and proclaimed the founding of the People's Republic of China.

During the war against Japan, Yan'an became a Mecca for progressive youth, eager to escape what they saw as a conservative, corrupt, and effete Nationalist regime, contribute to the war against Japan, and build a new China that would represent the interests of workers, peasants, and middle-class patriots. They welcomed the frugal collective life in the caves of Yan'an and trained at Resistance University (Kangda 抗大) to be cadres in the guerrilla areas behind Japanese lines. At Kangda they heard lectures by Mao and the other Communist leaders and, in general, emerged with a new faith that in Yan'an they were seeing the seeds of China's future. They were not wrong.

In the final years of the Jiangxi soviet, Mao Zedong was very much in eclipse. His star rose during the Long March, and when the American journalist Edgar Snow interviewed him in Shaanbei in 1936, he was already acknowledged as the party's leader. The essays that would become the Thought of Mao Zedong were mostly written during the Yan'an era: "On Practice" (1937), "On Contradiction" (1937), “Talks at the Yan'an Forum on Literature and Art” (1942), and the three brief pieces that Chinese students memorized during the Cultural Revolution: "Serve the People" (1944), "In Memory of Norman Bethune" (1939), and "The Foolish Old Man Who Removed the Mountains" (1945). ${ }^{2}$ By the end of the war, at the Seventh Party Congress, the Thought of Mao Zedong was officially enshrined in the party constitution. Yan'an marked the true beginning of the Mao era in Chinese history.

A wealth of excellent scholarship has analyzed the Yan'an era. The earliest works concentrated on the seminal texts of Mao Zedong. In a lifetime of meticulous research, Stuart Schram excavated the original texts of Mao's works and explored the "Sinification of Marxism" in his writings. ${ }^{3}$ We learned how Mao buttressed his theoretical credentials to counter the influence of Wang Ming, the bookish young rival who returned from Moscow in 1937. Subsequent research has deepened our understanding of the tutors and ghostwriters who contributed to Mao's 
corpus, often borrowing freely from Stalinist tracts. ${ }^{4}$ Gradually we have recognized that for all of his innate nationalism, Mao still regarded the Chinese Communist Party (CCP) as a branch of the Communist International (Comintern). The long and complex history of cooperation and conflict between the Chinese and Russian parties has been the subject of much fine research, especially by the careful and well-informed Chinese historian Yang Kuisong. ${ }^{5}$

No analysis of the Shaan-Gan-Ning Border Region can escape the shadow of Mark Selden's pathbreaking study, The Yenan Way in Revolutionary China. Selden's sympathetic portrait of "popular participation and egalitarian values" in a border region dedicated to a "vision of liberation and human possibility" has been the object of much criticism, but his book remains the seminal study of ShaanGan-Ning. Selden provides the best narrative of the rise of the Shaanbei revolutionary movement out of the local "bandit subculture," describes the land revolution that created the preconditions for a new order and the spartan living and revolutionary commitment of local cadres, and analyzes the new regime that implemented major social and political changes through elections, mass mobilization for land reclamation, and thought reform. Selden later admitted that some of his conclusions, especially on the Rectification Campaign, were too sanguine, but he continues to defend the basic thrust of his analysis. ${ }^{6}$ His generally positive assessment of the local regime received support from Peter Schran's careful study of economic development in the region, which Schran judged "quite effective in meeting the basic needs not only of the Communist movement but also of the base-area population."7 Pauline Keating has added a detailed study of the land reclamation and cooperative movement, calling attention to regional variations in the social ecology of Shaan-Gan-Ning, differences that will shape the narrative of this book in important ways. ${ }^{8}$ In Chinese, Zhu Hongzhao has written a vivid account of daily life in Yan'an - of time and money, of dancing, love, and lice, bold young women and coerced political marriages, and the ever-encroaching domain of politics. ${ }^{9}$

One specific criticism of Selden's study, which also affects Schran's positive analysis of Shaan-Gan-Ning economic policy, came from the US-trained Taiwan scholar Chen Yung-fa, one of the world's leading authorities on CCP history. Chen explored opium cultivation in the border region and argued that "without the opium trade, the economic improvements Mark Selden found in ShaanGan-Ning would have been simply impossible." ${ }^{10}$ Chen's documents refer only to a "special product" (techan 特产), but his conclusion that this product was in fact opium, exported to gain cash to buy medicine and other critical imports, is widely accepted. During my own archival and field work in Shaanbei in 1989, opium was one topic I was explicitly forbidden to investigate. Nonetheless, the cultivation of poppy, usually by the army, and the export of opium were an open secret in Shaanxi, and some older peasants-often ignoring frantic signals from government minders - had no hesitation in admitting this fact. 
The major challenge to Selden's analysis of the Yan'an era has come from a series of studies focusing on the Rectification Campaign of 1942-43. There is no doubt that the campaign played a major role in unifying the party behind Mao and in disciplining those who held divergent views. Selden stressed the need for the campaign when the exigencies of guerrilla warfare behind Japanese lines required a combination of party discipline and local initiative that was difficult to achieve through normal bureaucratic routines. He also recognized that Mao's reliance on political campaigns to affect social and political change reflected a distinctive style of Maoist politics that lasted until the Cultural Revolution. ${ }^{11}$ After the Cultural Revolution, the negative side of such campaigns became clear, and a different analysis of rectification emerged.

In an important early article, Peter Seybolt described the deliberate use of terror to generate conformity among intellectuals and lower-level party cadres. ${ }^{12}$ Chen Yung-fa's Yan'an's Shadow is a direct challenge to Selden's rosy vision of the Yan'an Way. Chen particularly noted the extraordinary excesses of the campaign as loyal cadres were targeted when the Rectification Campaign moved from political study to cadre investigation and finally a frenzied attempt to uncover imagined traitors. ${ }^{13}$ From the Mainland, Gao Hua painted a similar picture, stressing Mao's particular responsibility for the campaign as he struggled against rivals in the party, and linking rectification to a consistent history of bloody purges from the Jiangxi soviet era to the Cultural Revolution. ${ }^{14}$ An important study by Frederick Teiwes examined the Yan'an origins of the CCP's rectification politics and the gradual perversion of procedural norms after $1949 \cdot{ }^{15}$ All of these studies uncovered significant new evidence to illustrate the complex political dynamics and deep psychological impact of the campaign, with important implications for our understanding of Yan'an's role in the evolving political culture of Mao's China.

For methodological advances and conceptual sophistication, the most consequential contribution to our understanding of the Rectification Campaign is David Apter and Tony Saich's Revolutionary Discourse in Mao's Republic. Apter and Saich had unprecedented access to major actors and victims of the Rectification Campaign and combined evidence from these oral histories with Saich's unparalleled knowledge of CCP history and Apter's important conceptual insights. Though occasionally marred by factual errors, exaggerated language, and theoretical excesses, the book paints a powerful picture of the "discourse community" created by the Rectification Campaign and a Mao-centered "master narrative of revolution." Above all, they describe the near-religious experience of "exegetical bonding," in which party members endured an extended process of criticism and self-criticism to eradicate their past "selfish" history before they were reintegrated into the party as new people. In this process, the authors note the critical impact of Stalinist methods and the "Short Course" on the history of the Communist Party of the Soviet Union, an important adjustment of the earlier "Sinification of Marxism" model. ${ }^{16}$ 
All of this scholarship demonstrates the seminal importance of Yan'an as a "revolutionary holy land" that was the source of ideas, practices, and models that shaped the entire Mao era and continue to influence party politics to this day. Of course, as many scholars have noted, Yan'an and the Shaan-Gan-Ning Border Region were a very special case. As an isolated base in Northwest China, far from Japanese lines and accepted however reluctantly by Chiang Kai-shek and the Nationalist Party, Shaan-Gan-Ning enjoyed a level of security and untrammeled party power that did not prevail in the other Communist bases. Furthermore, it was precisely in those other bases behind Japanese lines that the greatest wartime expansion of Communist power occurred. As a result, it has been persuasively argued that the real determinants of Communist success must be sought in the other bases. ${ }^{17}$

This argument is certainly justified. The Shaan-Gan-Ning experience was not comparable to the process unfolding behind Japanese lines. Even more importantly for this study, events in Yan'an were not representative of what was happening in the rest of Shaan-Gan-Ning. Yan'an was largely occupied by outsiders, either Red Army veterans who had arrived with the Long March or young urban students and intellectuals who came to join the patriotic struggle against Japan. But the revolution made in Yan'an would not have been possible without the secure base that surrounded it. Yan'an's "revolutionary holy land"-or Mao's "revolutionary simulacrum," to use Apter and Saich's term-was possible only because Yan'an was also the center and capital of the Shaan-Gan-Ning Border Region. This book is about the long and complex process that created that border region.

My own research interests have long focused on social movements of rebellion and revolution. From books on the 1911 Revolution and the Boxer Uprising to articles on the mass protests of 1989, I have sought to understand the socioeconomic conditions that caused normally peaceful people to rise in protest, and the political and military configurations that allowed such protests to gain momentum and even succeed. ${ }^{18}$ Most people most of the time busy themselves making a living, raising a family, caring for elders. Petty disputes with neighbors, social elites, or even agents of the state are common, but they rarely rise to the level of mass protest. On occasion, protests do occur, and even more rarely these protests expand to overthrow the state. Rarest of all, and consequently the focus of intense scholarly interest, are those occasions when protests become revolutions, producing fundamental change in the social and political system. Having come of age academically during the 1960s, I experienced the antiwar protests of the United States and was inspired by such comparative tours de force as Barrington Moore's Social Origins of Dictatorship and Democracy. ${ }^{19}$ Like many China scholars of my generation, I was fascinated by the momentous changes that we know as the Chinese Revolution.

In the midst of the Vietnam War, we seemed to live in an age when peasants were remaking the world. From China to Vietnam to Cuba and Nicaragua, peasants 
played a leading role in the resistance to imperialism and class oppression. Peasant society, long dismissed as hopelessly backward and conservative, now reappeared as a seedbed of revolution. Marx's dismissal of the peasants as like "potatoes in a sack," resistant to collective action and often used by the conservative opponents of proletariat revolution, was turned on its head..$^{20}$ There was an academic fascination with peasant revolution, and China was the classic example. Teaching courses on this topic, I was both inspired and frustrated by the comparative and theoretical literature on the topic. In Peasant Wars of the Twentieth Century, Eric Wolf proposed the critical role of a "tactically mobile peasantry," while Jeffery Paige's Agrarian Revolution found a "general association between sharecropping and Communist revolution."21 James Scott's Moral Economy of the Peasant was enormously influential, but his thesis that colonialism and capitalism broke down the moral economy of peasant villages seemed a poor fit for the Communist revolution in the hinterland. ${ }^{22}$ Samuel Popkin's challenge to Scott in The Rational Peasant introduced the useful category of "political entrepreneur," but few Asian scholars were persuaded that Popkin's rational choice model applied to their peasants. ${ }^{23}$

While these comparative analyses consumed the attention of American and European scholars, the Chinese were generating a rich literature on "peasant wars" (nongmin zhanzheng 农民战争), a term that derived from Engels' work on the peasant wars in Germany. They saw in China's long history of peasant rebellions the deep roots and precedent for their own "proletarian"-led revolution. ${ }^{24}$ In general, the findings of China scholars in the US and Europe fit poorly with either the Chinese scholarship or the theoretical literature. In her study, Rebels and Revolutionaries in North China, Elizabeth Perry found not continuity but a clear disjuncture between the Nian rebels and the Communist revolutionaries in northern Anhui. ${ }^{25}$ In a lifetime studying Chinese peasant protests, Lucien Bianco concluded that few were motivated by landlord oppression of tenants, but more by opposition to state exactions ${ }^{26}$ Studies of the Communist movement found a variety of relevant local social conditions and political dynamics, few of which conformed neatly to the theoretical and comparative literature. ${ }^{27}$

In addition to this interest in peasant society and collective action, a second orientation has shaped the intellectual agenda of this book. Since editing a volume titled Local Elites and Patterns of Dominance, I have been impressed by the variety of local social formations that underlay China's unified political system. To understand the multiple ways in which political unity and social diversity interacted, I was led first to local history and then to a research trajectory in which the locale constantly shifted. From a study of Hunan and Hubei for the 1911 Revolution, I moved to the North China plain for the Boxer book, and now to the loess plateau of the Northwest for the Communist revolution. While some scholars stick to one familiar locale and produce ever more sophisticated studies, I feared repetition and a law of diminishing returns and moved on to fresh terrain. 
Over the course of a long career, I have also felt the need for an ever-narrower focus to produce the sort of granular social history that I most admired and aspired to emulate. Reform and Revolution in China compared the military-led revolution in Hubei to the gentry-led movement in Hunan. In The Origins of the Boxer Uprising, I shifted from a provincial focus to the county, where the data revealed a sharp distinction between southwest Shandong, which produced the Big Sword Society, and northwest Shandong, where the Boxers rose. The Boxer book was also researched after the resumption of diplomatic and cultural relations between the United States and China, so I was able to survey the countryside from which the Boxers emerged. Brief though that fieldwork was, it left an indelible impression of the diversity of Chinese villages. Consequently, when I embarked on research in Shaanbei, the focus was on the village level. My fieldwork was in villages that the Communists had studied in the 1940s, and my archival work collected documents from the counties where those villages were located.

In the articles that resulted from that research, I sought to understand the social transformation of rural society in the course of the Communist revolution. One obvious conclusion was the critical role of the Communist Party, but I became deeply skeptical of any reified notion of the party. Though composed largely of peasants, it was not a peasant party; nor was it an alien military-political structure working its will to transform rural society. There were clear identifiable differences between the village party, the district ( $q u$ 区) party, the county party, and the central party authorities. The concerns, interests, and revolutionary ambitions differed at each level. Yet the party needed a programmatic language that could, in a sense, rhyme at each level. It made no sense to complain about Marxist dogmatism to village cadres, but one could urge them to be flexible as they carried out the orders of higher authorities. Through this research and in these articles, I advocated the development of an "anthropology of the party" to understand how these various levels learned to work together. ${ }^{28}$

This left me with a dilemma that in the end proved unsolvable. The rural surveys articulated the shortcomings that higher party authorities found among rural cadres, and to some extent I could discern the implementation of policies to address these problems - improved study of party history and policies, criticism of cadres who cared too much about family affairs, purging of those whose membership in the Society of Brothers (Gelaohui 哥老会) left them with divided loyalties. But I could not see the debates at the party Center that produced the new policies, nor the orders to midlevel party authorities on how to carry them out, much less the county-level discussions on how to implement these orders. The inner workings of the party were invisible to me, and I had no way to become an anthropological participant observer. Here a key barrier was the fact that the documents I was able to read in 1989 in the Shaanxi Provincial Archives belonged to the ShaanGan-Ning government, not to the Communist Party. All of the party archives were 
in the Central Archives in Beijing, and all but the most trusted Chinese official historians were denied access to those records. For many years, Chinese colleagues told me, "Just wait until the old men die" and access would improve. But after waiting into the twenty-first century, long after Deng Xiaoping and other leaders of that era had left this world, I realized that archival access, far from improving, was worsening. By 2011, when I returned to the Shaanxi archives, even the materials I had read twenty years earlier had been closed. Finally, around the time I retired from the University of California, San Diego, Shen Zhihua (沈志华), the senior Chinese historian of the Cold War, told me: "Old Joe, those archives will never open in our lifetime. Just write!”

This book is the product of that sound advice. The injunction to get on with it and write with the material at hand suggested a solution to several historiographic problems. Throughout the long years of research on Shaan-Gan-Ning, I had determinedly avoided Yan'an. The local revolutionary movement was never active in Yan'an, and the Communists entered the town only after the Xi'an Incident of December 1936. During the war, Yan'an was dominated by outsiders: the party Center, Long March veterans from the south, and patriotic students and intellectuals from the coastal cities. Yan'an was a world apart, but by focusing on the founding of the Shaan-Gan-Ning Border Region I could avoid undue attention to the anomalous case of wartime Yan'an. Second, the founding of Shaan-Gan-Ning was itself a complex story worth telling, full of dramatic episodes of giddy enthusiasm, bitter conflicts, and pyrrhic victories. Most of the time, the guerrillas were fighting in the hills and communicating via simple oral commands, so the scant documentation is less the product of political censorship by modern party bureaucrats than the result of the exigencies of the revolutionary moment. In addition, since most of the action occurred before Mao and the party Center arrived, the documents that survive do not appear to have been subject to such intense political scrutiny, and I am reasonably confident that they reflect an accurate record of the communications of the time. Finally, as we shall see below, before Mao discovered from a newspaper the existence of the Shaanbei soviet, his intent was to lead the Red Army to the safety of the Soviet border to rest, recuperate, and receive military assistance from the CCP's Soviet comrades. Had this course been followed, the Chinese Revolution would certainly have taken a very different course. For this reason, the founding and survival of a relatively secure soviet base in Shaanbei was of critical importance to the final course of the Chinese Revolution.

The founding of the Shaan-Gan-Ning Border Region is itself a tale worth telling. ${ }^{29}$ Far from the coastal regions of foreign influence, and an area where most peasants tilled their own fields, the region suggests that the party's conventional narrative of revolution against imperialist penetration and feudal landlords makes more sense as agitprop than as a theoretical framework for historical analysis. Poor transport hindered commercial development, so it is difficult to see market penetration threatening the moral economy of the peasant. As one of the poorest 
regions of China, Shaanbei certainly had no "revolution of rising expectations," and given its exceptionally sparse population in the wake of natural disasters and the Muslim Rebellion of the late nineteenth century, demographic models of revolution are not relevant. ${ }^{30}$ The one social science model that seems to apply to the Shaanbei case is a relatively obvious but nonetheless important one: a weak state provided opportunities for bandit activities that could develop into systemic challenges to state authority. ${ }^{31}$ This was clearly a consideration for all of the Communist bases, which were located in the hills along provincial borders. In general, however, it is not the general models of social science that help us understand the Shaanbei revolution, but the shifting complex of social, economic, political and military forces that are best explored through historical methods.

As a graduate student at Berkeley, I was once assigned Marc Bloch's French Rural History in a graduate seminar, and, to my mentor's dismay, I questioned the relevance, for China scholars banned from the country, of a text that advocated walking the hedgerows to understand medieval cropping patterns. That professor, of course, was Frederic Wakeman, who was instrumental in the initiative to open China to American researchers. It was with the support of the Committee on Scholarly Communication with China that I first had the opportunity to conduct research in China, and that project on the Boxer Uprising provided my first taste of rural fieldwork. I can say without embarrassment that no aspect of historical research gives me more pleasure than hiking through Chinese villages and interviewing old peasants. Since 1989, I have visited Shaanbei more than a dozen times, in research excursions ranging from a few well-packed days to over a month. When I first visited in 1989, participants in the revolution were still alive, and I sat with them in dim smoke-filled earthen caves, some in mountain villages that could be reached only on foot. With local assistants who helped penetrate the local dialect, I found these peasant informants refreshingly matter-of-fact. Though their memories were shaped by decades of "recalling bitterness," they were old enough to ignore cadres who offered politically correct versions of events. While old soldiers were often eager to stress the dramatic tales of battles they had fought, I remain convinced that properly collected oral histories that invite peasants to tell their own stories and stick to the facts can be immensely valuable. ${ }^{32}$

This study has unquestionably been informed by these oral histories, and by decades of familiarity with the geography of northern Shaanxi. The heart of the narrative, however, is based on the contemporary documentary record. The reports, directives, decisions, and communications of the party have been collected and published in a number of compilations by party historians over the years. Most of these collections were published in the 1980 s and '9os for internal use (neibu 内部), but over the years they have become publicly available to greater or lesser degrees. There are party history offices at every level of the state apparatus, and their duty is to provide the documentation to support the various decisions the party has made on its history. Most important for our purposes is 
the 1945 "Resolution of Some Historical Questions," which affirmed the correctness of Mao's line over the years, opposing the "right opportunism" of the 1920 s and the "left opportunism" of Wang Ming and the Russian-trained Internationalist faction in the 1930s. ${ }^{33}$ Despite the clear political purpose of these collections, there is general agreement that the documents themselves are authentic, and they have been widely used by professional historians. In addition, different compilations have been made by party offices in both Shaanxi and Gansu, and by provincial and local offices; these have included different documents, sometimes suggesting slightly different interpretations. As in so many other respects, the party has not been monolithic in its presentation of history.

The party Center also made regular reports to the Communist International, which were preserved in Moscow. Many documents from the Russian archives have been published and translated. They are often a good deal more detailed and precise, suggesting that one did not dissemble to one's Comintern superiors. For a time in 1989, I was able to read documents from the Shaan-Gan-Ning Border Region archives in Xian, and these were extremely valuable for their unvarnished discussion of the problems confronted in the early years of the border region. During fieldwork, I read and copied documents from county archives. The Academia Historica (Guoshiguan 国史館) and Bureau of Investigation (Diaochaju 調查局) archives in Taiwan also provided important materials from the national government's perspective. Finally, libraries in China and the US contain a number of newspapers and journals published in the Guomindang areas, many from Xian, that provided useful information on social, economic, and political developments in Shaanxi.

It goes without saying that none of these documents can be read as an unvarnished version of the truth. Any historical document is written from a particular perspective at a particular moment in time with a particular purpose. Communist Party documents can be especially opaque as local committees aver their fealty to the prevailing party line, confess minor shortcomings, and present a variety of excuses for the sorry state of the revolution in their area. One must plow through thousands of pages of party cant on the rising tide of revolution inspired by the success of the latest Soviet Five Year Plan before discovering that the Xian party in the early 1930 s had only a dozen members. In the end, however, these documents provide the best sources on the size, composition, and distribution of the party. They are essential in developing a contemporary chronology of shifting party policy and major revolutionary actions, and they reveal the specific challenges that the local party faced as it sought to mobilize different classes and groups in ways that were consistent with central party mandates.

In some areas, however, official party documents must be supplemented with the memoirs of participants. Published party documents tend to gloss over disputes within the party and for security reasons usually avoid naming individuals, unless the person has already defected to the enemy, lest a courier be intercepted 
and arrested by the state. Since much of our story revolves around major differences within the party, memoir accounts are essential to discern the nature of and participants in a dispute. Naturally, any memoir includes a good deal of special pleading, so it must be read with an acutely skeptical eye, but modern Chinese memoirs present special problems. For one, memoirs of party leaders are reviewed by official censors before publication, allegedly to protect state secrets, but in fact to ensure conformity to official decisions on party history. This means, for example, that the usual test of multiple sources to confirm a fact may not apply: it may simply reflect the requirement that all follow the party line. In addition, the incentives to conform to the official narrative are considerable: they not only involve one's own reputation in history but also affect the status and privileges-from housing to health care to employment opportunities-of one's descendants. ${ }^{34}$

Despite all this, there are many cases where the contemporary documentary record is insufficient and must be supplemented by memoir accounts. In general, it is my conviction that the earliest memoirs are the most reliable: the passage of time dulls the memory and overlays it with official versions of what the history should be. This general rule brings us immediately to a special set of participant recollections: the accounts given at the High Cadre Conference of 1942 and the Symposium on Northwest Revolutionary History in 1945. The accounts of the 1940 s are the earliest versions we have, but they were presented in the extraordinary context of the Rectification Campaign, at a meeting presided over by Gao Gang with the specific purpose of attacking those who had purged him in 1935. As we shall see, the Shaanbei party was bitterly divided into two factions who debated sharply in 1942, and again at the time of the Seventh Congress in 1945. These speeches include a wealth of self-justification and score-settling, but all sides of the intraparty dispute were allowed to speak, the debate was lively, and the record I have used includes even interjections from the floor. Finally, the 1945 Symposium served as something of a counterweight to the High Cadre Conference, for it immediately followed the Seventh Congress, and there was substantial criticism of Gao Gang for including only factional allies in his seven nominees to the Central Committee. ${ }^{35}$ It is likely that Shaanbei dissatisfaction with Gao Gang's hard-fisted rule was a factor in his transfer to the Northeast and his replacement in the Northwest Bureau by the mild-mannered Xi Zhongxun. For these reasons, despite the uniformity of view that the Rectification Campaign produced in most areas of party life, I am confident that used with care, the combination of the 1942 and 1945 accounts of the Shaanbei revolution add significantly to our understanding of the revolutionary process.

The account presented here is basically a chronological narrative of the founding of the Shaan-Gan-Ning Border Region. Chapter 1 provides the setting: the geography of arid, poor, and isolated Shaanbei, the history of repeated devastation in the rebellions of the late Ming and the Sino-Muslim Hui of the mid-nineteenth century. The result was a twentieth-century backwater of sparse population, small 
villages, and weak lineages in Yan'an Prefecture in the west, but the gradual development of a new political, economic, and cultural center along the Wuding River in the northeast. Chapter 2 charts the early history of the CCP, rising in the schools of the northeast and gathering strength when the united front with the Nationalist Party earned the support of the left-leaning warlord Feng Yuxiang. Feng had just returned from the Soviet Union with Soviet arms and advisers, and Communists joined his armies while students organized peasant associations in the villages around their schools. All of this came to an end in 1927 when Chiang Kaishek turned against the Communists and Feng soon followed suit; but Feng never carried out a bloody purge like Chiang's in Shanghai, and the memory of the early united front survived in the military of Northwest China.

The early 1930s produced the two faces of the Communist movement in Shaanxi: guerrillas organizing bandits and militia in the north, Bolsheviks trying to build an urban base in the richer Guanzhong region of the Wei River valley. In chapter 3 we meet two key guerrilla leaders, Liu Zhidan in the west along the Shaanxi-Gansu border and Xie Zichang from Anding County in the east. The two both competed and cooperated until the Bolshevik leaders of the Shaanxi party urged Liu to move his guerrillas south, leading to a disastrous defeat, followed by the arrest and defections of the provincial leadership and a new low for the revolutionary movement in Shaanxi. The collapse of the provincial committee liberated the guerrillas from dogmatic party leadership, and in chapter 4 we see the dramatic growth of the Shaanbei soviet. Left on his own, Liu Zhidan found new allies to rebuild his guerrilla band, while Xie Zichang returned to build on the school-based party in the east. When Xie died from a wound in early 1935, Liu combined his military strength with Xie's party organization to capture six county seats in an unprecedented series of military victories. These victories, however, were quickly followed by the arrest and purge of Liu and his key lieutenants as his critics in the party gained new strength from the arrival of Xu Haidong's army from the Hubei-Henan-Anhui (Eyuwan) Soviet in Hubei. Liu was rescued only by the arrival of Mao Zedong and the party Center from Jiangxi.

As Mao's column of the Long March headed toward a planned refuge along the Soviet border, he learned of Liu Zhidan's base in Shaanbei and headed there. In chapter 5 we see Mao's desperate attempts to escape the poverty of Shaanbei, along with his efforts, consistent with the Comintern's new united front policy, to find new allies to confront the growing menace of Japanese invasion. An attempt to fight through Shanxi failed but resulted in the death of Liu Zhidan and several of his key officers, depriving Shaanbei of its most effective revolutionary leader. A second attempt to reach the Soviet border through Ningxia and across the Gobi Desert had to be abandoned. By December 1936, the party's Shaanbei base had been reduced to a few poor counties along the Shaanxi-Gansu border. Soon, however, the party's multiple efforts to court allies bore fruit when Zhang Xueliang's Northeast Army and Yang Hucheng's Northwest Army kidnapped 
Chiang Kai-shek in the Xian Incident and forced a united front against Japan. Chapter 6 describes the process whereby the party's small base was expanded into the Shaan-Gan-Ning Border Region. With the Xian Incident, the party Center moved into Yan'an, and Chiang Kai-shek provided a modest subsidy for the Red Army. Hard negotiations over the terms of the united front continued until after full-scale war with Japan broke out in July 1937. The border region assumed its final shape only after growing political and military friction between the Nationalist and Communist parties and armies resulted in Chiang Kai-shek's forces seizing a large territory in Gansu, in response to which the Communists recalled an army from Shanxi to seize control of the wealthier area around Suide in the east. Only at this point did the Shaan-Gan-Ning Border Region become a truly secure base, but in this exchange the Communists gained control of an area with considerable landlord gentry power, and the experience of developing policies of revolutionary base building there would serve them well as they expanded into other parts of China.

Revolutionary history has a special place in China. The legitimacy of the People's Republic of China relies in part on its revolutionary origins. Mao Zedong's portrait still hangs over Tiananmen Square, and the nearby National Museum celebrates the revolution in a massive exhibit on the "Road to Rejuvenation." In recent years, the regime's identification with the revolution has been enhanced under Xi Jinping, the first true "princeling" to rule China and the son of a Shaanxi man who rose to power in Shaan-Gan-Ning. China's appeal to its revolutionary past is hardly unique. The memory of the French Revolution still looms large in that country, and the ideals of liberté, égalité, fraternité remain central to French political culture. Americans still celebrate the Fourth of July and the Declaration of Independence; the founding fathers still shape our public discourse; and the constitution they drafted centuries ago retains a legitimacy across the political spectrum despite a surfeit of anachronistic provisions. Of the great revolutions of history, only the Russian Revolution has lost its hallowed status, though Lenin remains entombed in Red Square.

China's attachment to revolution is unique only in the long history of commitment to the revolutionary process. China's first revolution, in 1911, ended two millennia of imperial rule and ushered in the Republic of China. When the chaos and confusion of warlordism prompted calls for a new beginning, Sun Yat-sen's Nationalist Party reorganized with Russian help and launched the National Revolution of the 1920s. When Chiang Kai-shek assumed Sun's mantel as leader of the Nationalist Party, he broke with Sun's Communist and Russian allies but not with Sun's commitment to revolution: the Communists were condemned as "counterrevolutionaries." Even apolitical intellectuals called for a revolution in language, culture, education, family values, and gender relations. The Chinese commitment to revolution remained a central feature of its political culture at least through the Great Proletarian Cultural Revolution of the 1960s. ${ }^{36}$ 
To understand this process, it is instructive to return to Max Weber's classic essays "Politics as a Vocation" and "Science as a Vocation." Though uncomfortable with the notion of history as a science, I fully endorse Weber's injunction that the scholar must separate issues of "fact" from questions of "value" and that even "inconvenient facts" must be acknowledged. ${ }^{37}$ The historian's task is to discover what happened and why. While I am prepared to acknowledge that the Communist Party and its People's Liberation Army defeated a foe with superior arms and a stronger economic base, this fact alone does not demonstrate broad popular support for revolution or some metaphysical logic of liberation. In his learned book Historians' Fallacies, David Hackett Fischer condemns the "fallacy of identity," which argues that great events must have great causes. ${ }^{38} \mathrm{~A}$ central argument of this book is that even an event as momentous as the Chinese Revolution must be understood as the result of a long process of multiple contingent events. Local, national, and international environments provided a critical context; local and regional social formations shaped and constrained behavior; and yet the agency and political choices of individual and group actors were critical in determining the particular events whose cumulative effect was the revolutionary process. In the end, the old maxim holds true: God is in the details. 
In a project that has taken more than thirty years to complete, one accumulates more debts than this brief note can possibly summarize. I began this research knowing little about the history of the Communist Revolution, Northwest China, or the geography and social formations of northern Shaanxi. A regrettably incomplete journal of my travels, conversations, and impressions over the years has left many details of the encounters that inspired the ideas in this study lost in the mist of time and the failing memory of an aging China scholar. What I write here is inevitably a grossly incomplete acknowledgment of the many people who assisted me in this prolonged effort to probe the origins of the Communist movement in Northwest China.

Acknowledgments such as this conventionally conclude with heartfelt but desultory thanks to one's spouse and family. In this case the first credit must be given to my wife. Ye Wa knew Shaanbei from her rural life during the Cultural Revolution, earned her degree at Northwest University, and worked at the Shaanxi Institute of Archaeology. Without her background, local knowledge, and many connections, this research would have been impossible. She has had to live with this project through most of our married life. Her patient endurance, grace, and support during all these years are beyond what any words of gratitude can convey. Our daughter Lisl and my son Chris also joined us in Xian and endured that memorable time and too many subsequent years when their father was preoccupied with teaching and writing this book.

The Committee on Scholarly Communication with the People's Republic of China funded the initial research for this project, and I am particularly grateful to Robert Geyer and Perry Link for their assistance and support, especially for allowing me to retreat to Shaanbei following the State Department's order to 
leave China after June 4, 1989. My official host in Xian was the Shaanxi Academy of Social Sciences, but the Shaanxi Institute of Archaeology, then a branch of the Academy, stepped in to provide critical logistical and other support when the former proved more impediment than ally. Later financial and research support was received from the University of California, San Diego's Hsiu Endowment for Chinese Studies. Subsequent research trips to Shaanbei were facilitated by Renmin University, Peking University, and Yan'an University. Dozens of Chinese provided oral histories that were invaluable in reconstructing Shaanbei life in the revolutionary period. Their backgrounds are listed at the end of this volume.

The archival research for this volume was facilitated by a number of institutions over the years: the Bureau of Investigations archives and Academia Historica (Guoshiguan) in Taiwan; the Shaanxi Provincial Archives, Mizhi County Archives, Shenmu County Archives, Yanchang County Archives, Yulin Prefectural Archives, and Zhidan County Archives in the PRC; and the Hoover Institution Archives in the US. I am much indebted to the professional staff of these organizations for their assistance. The Shaanxi Provincial Library, Peking University Library, University of California, San Diego Library, and University of California, Berkeley Library have provided invaluable sources, and I am particularly indebted to James Cheng at UC San Diego and He Jianye in Berkeley for their assistance in locating rare materials. Jin Zhixia and Ashely Chiu assembled the population, examination, and education data used in the first chapter.

Over the years, portions of this research were presented in lectures and seminars at Yale, Princeton, Chicago, Cambridge, École des Hautes Études, Stanford, UC San Diego, Colorado, and Harvard; in China at Peking University, Renmin University, Northwest University, Shaanxi Normal University, Yan'an University, East China Normal University, and Central China Normal University; and by Zoom organized by the Chinese University of Hong Kong Press, publisher of the Chinese version of this study. Discussants, critics, and commentators in those sessions provided invaluable inspiration for years of thought and suggestions for further research. In addition, my graduate students over twenty years at UC San Diego inspired me through their unfailing quest to understand China in all its complexity, causing me to rethink many old shibboleths with their persistent questions. While my feeble attempts to keep up with their diverse projects may have delayed the completion of this study, the questions they raised surely made it richer.

A full list of all of the colleagues who have provided advice and criticism of this research would fill many pages of text and probably implicate scholars who would prefer to avoid any association with the project. I would, however, be remiss without mentioning many who have been particularly helpful in memorable ways. I trust that these friends and colleagues will understand my decision to list people in alphabetical order, avoiding any implication of responsibility that other choices might entail. I would thus like to thank the late Stephen C. Averill, Lucien Bianco, 
Thomas A. Brady, Jeremy Brown, David Chang, Timothy Cheek, Chen Yung-fa, Feng Chongyi, Joseph Fewsmith, Gao Zaibin, David S. G. Goodman, Linda Grove, Brent Haas, Han Gang, He Jianye, Huang Daoxuan, Ishikawa Yoshihiro, Esther Jacobson, Jiao Nanfeng, David Johnson, Miles Kahler, Hasan Kayali, John Kennedy, Li Ling, Li Rui, Lin Hsiao-ting, Liu Dong, Luo Zhitian, Ma Min, Roderick MacFarquhar, Stephen MacKinnon, Meng Fanzhi, Barry Naughton, Niu Dayong, Michael Nylan, Elizabeth J. Perry, Paul Pickowicz, Kenneth Pomeranz, Qi Pengfei, Qiu Ronghua, Sidney Rittenberg, William Rowe, Orville Schell, Mark Selden, John S. Service, James Sheehan, Shen Zhihua, Shi Xingbang, Shi Yan, Shi Yaojiang, Matthew Sommer, Michael Szonyi, Tang Xiaofeng, Hans van de Ven, Eric Van Young, Lothar von Falkenhausen, Wang Qisheng, Yang Kuisong, Yang Liwen, Wen-hsin Yeh, Ernest P. Young, Zhang Houde, Zhang Jishun, Zhang Zailin, Zheng Hong, Zheng Xiaowei, and Zhou Yuefeng. It goes without saying that none of these people is in any way responsible for the errors that remain in this study, and many would disagree with a number of its conclusions.

Finally I would like to thank the cartographers $\mathrm{Hu}$ Tao at Harvard, Jia Xiaoxin in Beijing, and Liao Hsuanming in Taiwan, who prepared the maps for this volume from the incomplete and often shifting instructions that I supplied. My gratitude also to Mike Hurley, who prepared a splendid index. Needless to say, any errors that remain in the maps and index are entirely the fault of the author. 



\section{Frontier Foundations for Revolution}

Shaanxi has been both central and peripheral to the course of Chinese history. In ancient times it was the core of Chinese civilization. The alleged tomb of the legendary Yellow Emperor lies 150 kilometers north of the provincial capital. The first emperor established his capital near Xi'an, and from the third century BCE to the tenth century $\mathrm{CE}$ the great ancient dynasties were centered here. In modern times, as we shall see, Generalissimo Chiang Kai-shek was kidnapped by his own generals in Xian, held hostage until he agreed to join the Communists in a united front against Japanese aggression. And yet, despite this ancient eminence and recent notoriety, Shaanxi in modern times has been a backwater, far from the economic and political centers in Shanghai and Beijing, relegated to a position in what was called the Northwest, a "backward" region in need of opening and development (kaifa xibei 开发西北). In the words of an early twentieth-century American visitor, "It is old and isolated ... so isolated that the Pekinese speak of it as though it were a foreign country."

The ancient capitals were established in Guanzhong, the area "between the passes" in the fertile valley of the Wei River. The Wei River valley extends three hundred kilometers from west to east, with low hills separating it from Gansu to the west, and the formidable Tongguan (潼關) Pass, which Westerners called "the Gibraltar on the Yellow River," protecting Guanzhong from enemies on the North China plain to the east. ${ }^{2}$ Guanzhong is bordered on the south by the Qinling (秦岭) range, which separates the rich rice-growing regions of South China from the arid wheat and millet fields of the north. The moisture-bearing monsoon rains of summer originate in the southern oceans, and their progress north is blocked by each successive mountain range. The Wei River valley is well watered in the rain shadow of the Qinling, and the plain north of the Wei is broad and well served by irrigation canals that date from ancient times (see map 1). ${ }^{3}$ 


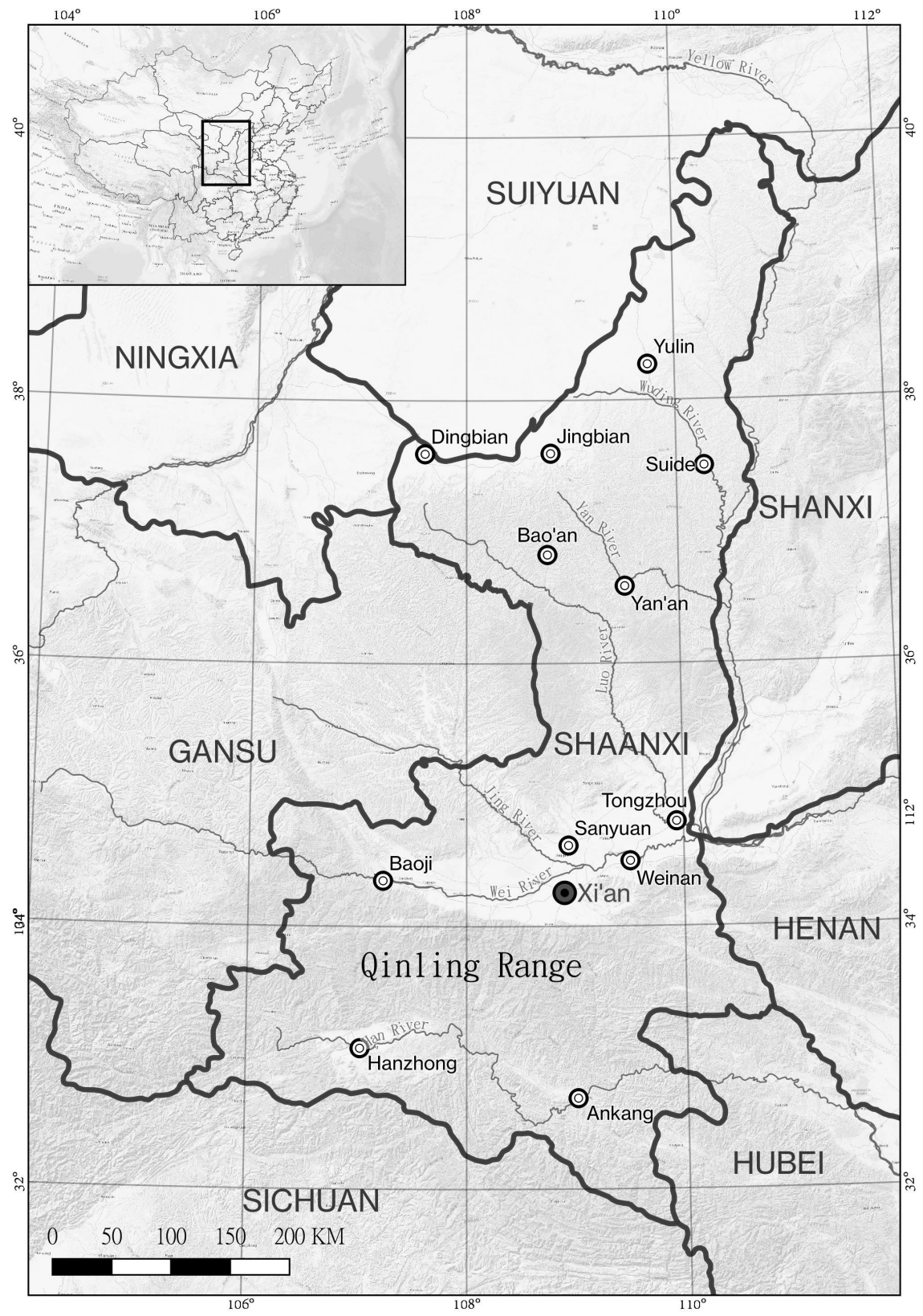

MAP 1. Shaanxi geography. 
South of the Qinling range lies southern Shaanxi (Shaannan 陕南) on the upper reaches of the Han River, which flows into the Yangzi at Wuhan. Before the nineteenth century, this was still a frontier region, far from the centers of political power, that attracted unruly migrants. In the late eighteenth century, it was wracked by a persistent White Lotus Rebellion that took years for the Qing authorities to suppress. ${ }^{4}$ In the modern era, the regular rains south of the Qinling and the gradual expansion of trade up the Han River gave a decent level of prosperity to the region. ${ }^{5}$ In 1936-37, after the Long March brought the Red Army to northern Shaanxi, Mao Zedong wished to transfer his forces to this richer Shaannan region, but Chiang Kai-shek preferred to keep the Communists bottled up in the poorer hills of the north.

Northern Shaanxi, with Yan'an at its center, is our main concern. This is where the local Communists established their base in the 1930s, where the Long March ended in 1935, and where the Communist Party established its headquarters during the long War of Resistance against Japan (1937-45). The north is unquestionably the poorest part of Shaanxi Province, indeed one of the poorest regions of the empire. Annual rainfall in Shaanxi decreases as one moves north, with the Qinling mountains blocking the southern storms, and the Lüliang mountains (吕梁山) in Shanxi to the east checking humid air from the Pacific. Republican era (1912-49) figures put annual rainfall at one-third the Xi'an average, while presumably more systematic contemporary statistics suggest that around Yan'an it was one half that of Shaannan, and perhaps two-thirds of the Guanzhong heartland. Within Shaanbei, rainfall decreases as one moves north toward the Great Wall and the Gobi Desert beyond. Throughout the region, rainfall is less reliable than in Guanzhong, more concentrated in a few summer months, and often coming in torrential downpours that erode the hillsides. The northern latitude leaves the frost-free agricultural growing seasons significantly shorter, and yields lower, than on the southern plains. ${ }^{6}$

Chinese accounts, ancient and modern, invariably describe Shaanbei as a land where “the soil is barren and the people are poor" (diji minpin 地㾉民贫). ${ }^{7}$ In fact, except in the far north, where spring winds from the Gobi Desert bring sandstorms that add grit to the soil, most of Shaanbei is covered by a thick layer of the same loess soil that covers most of the Northwest. ${ }^{8}$ The whole area, including much of eastern Gansu, forms China's loess plateau, the thick loess layer a product of millennia of blown dust deposits that combined with decomposed grasses adding rich organic material to the soil. Loess soil readily absorbs and retains rainwater, which is then drawn to the surface to nourish crops. ${ }^{9}$ Shaanbei's soil is not barren, but Shaanbei differs from other regions of the province in that rainfall is too scarce and unreliable to add moisture to the soil. In addition, the rivers cut deep gorges, leaving little level valley land for irrigated cultivation. Most Shaanbei fields are on high plateaus or rounded treeless hillsides and depend entirely on adequate rainfall at appropriate points of the growing season. To make matters worse, 
the Luo River (洛河), which cuts through Shaanbei from northwest to southeast, originates in the acrid lands of northeastern Gansu and carries flood waters heavy in salt that are unsuitable for irrigation and damage the limited fields on the valley floor. ${ }^{10}$

Sparse rainfall kept population density low, and the barren hills provided little organic material to nourish the soil. This led to a form of extensive agriculture that frustrated Communist cadres eager for increased production. Especially after the nineteenth-century rebellions drastically reduced the population along the Gansu border, there was plentiful land available, and peasants developed the habit of moving to new fields as the soil was depleted, rather than applying fertilizer to enhance productivity on the land under cultivation. As one report put it: "The local peasants use little fertilizer, often applying none at all to hill land and little on the valley floor." ${ }^{\prime 1}$ The harsh environment and the peasants' response to it left the area desperately poor. When a consular officer visited Yan'an in the early Republic, he called it "the centre of the most desolate area, by far the poorest region I have traversed in China outside the actual deserts." ${ }^{12}$ Edgar Snow concurred, calling it "one of the poorest parts of China I had seen."13 Snow's wife, visiting a year after his historic 1936 trip to the Communist base, agreed that she had "never seen such poverty as among the peasants in Shensi, where famine is perennial." ${ }^{14}$

\section{ANCIENT FRONTIER}

Modern Shaanbei may have been unbearably poor, but it had a proud if troubled ancient history. Most local accounts begin with the battles of the thirdcentury BCE Qin general Meng Tian against the nomadic Xiongnu invaders to the north, and his supposed grave near the town of Suide is still the object of veneration..$^{15}$ With the ancient capital in Xi'an, northern Shaanxi was a strategic corridor for incursions from the Central Asian steppe, a contested zone on the frontier between sedentary agriculturalists and horseback nomads. Modern histories are often constructed around a narrative of ancient glory in defense of the empire and a lamented era of modern decline. ${ }^{16}$ In the Song dynasty (960-1279), northern Shaanxi was divided and contested with the Tangut Western Xia kingdom, with the noted Chinese scholar Fan Zhongyan directing the defense from Yanan, leaving writings, poems, and steles for later ages to revere. A border garrison was located at the town of Jintang, the twentieth-century home of Liu Zhidan, hero of the Shaanbei revolution. ${ }^{17}$

The Ming dynasty (1368-1644) followed almost a century of Mongol rule. In its early years, the Ming pursued an aggressive policy to subdue its Mongol foes, but after this strategy led to disastrous defeats including the capture of one Ming emperor, the court shifted to a more defensive posture. The new policy generated China's great age of wall building, with Shaanbei a critical and costly line of defense. Over the fifteenth and sixteenth centuries a stamped earth wall with intermittent signal towers manned by small garrisons was built across the northernmost 
counties of Shaanbei. The wall was just south of the Ordos Desert, which separated Shaanbei from the great northern bend of the Yellow River. ${ }^{18}$ The headquarters for this section of the wall was the town of Yulin (榆林), on the edge of the desert in northeastern Shaanxi. The commander there oversaw a section of the wall that stretched from Shanxi across all of Shaanbei and into what are now Gansu and Ningxia to the west. The Ming statutes called for 55,379 soldiers with 33,105 horses, camels, and mules. ${ }^{19}$ This large military establishment was supposed to be selfsupporting, growing its own provisions in military colonies (tuntian 屯田) that occupied most of the land along the northern border. But the land here was poor to begin with and the colonies enhanced deforestation, which further degraded the local ecology. The soldiers, most of whom were recruited elsewhere, were not efficient farmers in the far north. As a result, most of the fields were rented to local peasants. The soldiers were regarded as “guests” (kebing 客兵) whose expenses were more than Shaanbei could provide, requiring substantial infusions from the imperial treasury. ${ }^{20}$

This whole system came crashing down in the seventeenth century, with disastrous consequences for both Shaanbei and the Ming dynasty. Having ruled China for over two centuries, the Ming was showing predictable signs of corruption, discord, and decay. In the 1590s, a protracted war in Korea, sparked by the invasion of Japan's new strongman Hideyoshi, had seriously strained the dynasty's finances. Then came the rising challenge of the Manchus in the Northeast, who would soon conquer the Ming and establish their own dynasty, the Qing, in 1644. Making matters worse, the entire globe was enduring falling temperatures and failing harvests in the Maunder Minimum, sometimes referred to as the Little Ice Age. ${ }^{21}$ Colder weather, a reduced growing season, and then a period of prolonged drought brought the Shaanbei agricultural economy to the point of collapse. It was precisely in Shaanbei that the rebellions began that toppled the Ming.

Drought and famine began in 1628 with the usual consequences: people fed on bark and leaves, wives were sold, children were abandoned, and there were frequent reports of cannibalism. With imperial finances strapped, soldiers went unpaid and official posthouses were closed, throwing their employees out of work. With refugees foraging for food, ex-soldiers and petty functionaries formed the leadership of bandit gangs that turned to looting and violence to survive. Large bands in fancy clothes stolen from the rich could number in the thousands, though they were armed mostly with spears, swords, and farm tools. The two most famous rebel chieftains came from Shaanbei. Zhang Xianzhong had been a soldier near Yan'an, rebelled in 1630, and ended his career as a psychopathic killer who decimated the western province of Sichuan. His more moderate and successful rival was Li Zicheng from Mizhi, a groom from a post station that was closed in the Ming budget cuts. It was Li Zicheng who ultimately captured Beijing to topple the Ming dynasty in 1644, before the Manchus entered the struggle and drove him back to Shaanbei and his demise. ${ }^{22}$ 
Li Zicheng and Zhang Xianzhong were certainly the most famous peasant rebels to emerge from Shaanbei, and Li did harbor a certain affection for his homeland, returning to rename his native county "Protected by Heaven” (Tianbao 天保), building a palace and restoring his family's ancestral tombs that the local elite had dug up and destroyed. ${ }^{23}$ To this day there is a large and gaudy temple in his honor in Mizhi. However, both $\mathrm{Li}$ and Zhang soon abandoned Shaanbei to campaign and forage in richer areas of southern Shaanxi, the North China plain, and, in Zhang Xianzhong's case, the Yangzi valley. ${ }^{24}$ Shaanbei, however, did not return to peace. Instead, the ground was occupied by lesser rebels who went by such colorful names as “Never Muddy” (Buzhanni 不沾泥), “Monk Wang” (王和尚), and “Top God” (Shenyikui神一鬼). ${ }^{25}$ Poorly armed and lacking many firearms, the rebels were rarely able to take walled towns or cities but instead ravaged the countryside for years on end. ${ }^{26}$ On the government side, military weakness led to counterproductive tactical decisions. On the one hand, the cost of confining and feeding prisoners produced a preference for summary executions. When commanders were offered bonuses for head counts, the result was the needless slaughter of innocents. When this engendered the predictable resistance, the policy shifted to encouraging rebels to surrender with offers of clemency and positions in the depleted armed forces. But that only resulted in repeated rebel surrenders (including key leaders like Li Zicheng) when they found themselves trapped, only to have them rise again after a period of rest and recuperation. The whole bloody process finally ended when the Manchus entered China, proclaimed the new Qing dynasty in Beijing, and sent a large force of Manchu and Mongol cavalry to cross the Yellow River into Shaanbei and suppress the remaining rebel bands. ${ }^{27}$

QING RULE: PEACE, RECOVERY,

AND ONGOING POVERTY

The Manchus were frontier conquerors from the Northeast allied with Mongol cavalrymen from the northern steppe. Tracing their legitimacy to the great steppe empires of Genghis Khan, the Manchus held a conception of empire that extended well beyond the ethnically Han empires of the past. During the course of the long Qing dynasty (1644-1911), Manchu banners, as their military units were called, campaigned in the north and west to incorporate all of Mongolia, Tibet, and the Turkic regions now known as Xinjiang. ${ }^{28}$ With this expanded conception of empire, the Northwest assumed new strategic significance during the Qing. Xian housed the first and largest Manchu garrison outside of Beijing, and there were other large military bases along the Yellow River in Ningxia to the northwest and guarding the entrance to Shaanxi at Tongguan in the east. Together, these garrisons would consume up to a quarter of the provincial budget. ${ }^{29}$ Throughout the Qing, Shaanxi would be logistically critical in support of military campaigns both on Sichuan's Tibetan borderlands and in Xinjiang. This was the case both for the eighteenth-century conquest of the west and for its reconquest after the rebellions 
of the nineteenth century. ${ }^{30}$ Given this critical strategic position, it is not surprising that through most of the Qing only Manchus served as governor or governorgeneral in Shaanxi. ${ }^{31}$

While this new strategic role placed increased burdens on the province, there was one important respect in which Qing rule reduced the demands on Shaanbei. The Ming had invested heavily in constructing the Great Wall across northern Shaanxi, and the expense of construction and the large garrisons necessary for defense imposed significant burdens on the local peasants. We have seen in the rebellions of the late Ming the depth of the discontent that this caused, especially when sparked by natural disasters for which the government was unable to provide relief. Now under the Qing, the Mongols were included within the empire, their princes incorporated into the ruling coalition. The border between agrarian and nomadic cultures had disappeared and with it the need to defend the Great Wall. The military headquarters in Yulin remained-and its prosperous walled city would continue as the Shaanbei center of military power through the republican erabut seven of the ten Ming offices were closed, and the official quota for soldiers on the frontier was reduced from fifty-five thousand to nine thousand. ${ }^{32}$

With peace restored to the frontier, markets opened for trade with the Mongols. The most prominent items of trade were wool, fur, and hides, all coming from the sheep, goats, and other herds in the region. Mongols were eager participants in this trade, exchanging the products of their herds for tea, cloth, liquor, tobacco, and other goods from the Chinese heartland. Firearms were strictly banned from this trade, there being limits to official trust of mobile Mongol bands on the vast northern grasslands. ${ }^{33}$ A significant trade route opened on the flatlands north of the old wall, with Ningtiaoliang (寧條梁) in Jingbian County emerging as an important commercial center. In a telling sign of the new reign of peace, the town lacked a wall, though it was larger than any of the nearby political centers. As the MongolChinese border dissolved, growing numbers of Chinese migrants rented Mongol lands to bring the steppe under cultivation. While conflicts did not stop altogether, a generally peaceful coexistence prevailed on the northern frontier. ${ }^{34}$

Despite the return of peace and limited trade along the border, Shaanbei had suffered greatly from the famine and rebellions of the late Ming. With the population scattered or killed by natural and human disasters, most of the arable land had not been returned to production. For county after county, the provincial gazetteer reported taxable lands that were five to ten times the amount of land actually under cultivation. ${ }^{35}$ One early Qing official described the problem: "In the entire realm, Yan'an has the most wasteland, with hundreds of miles of bare mountains on all sides." To adjust for low yields in Shaanbei, the Ming system had counted between five and nine $m u$ (畧 = one-sixth of an acre) as one; but with inflexible tax quotas to fulfill from the reduced land under cultivation, Qing officials now demanded that one $m u$ of land pay taxes for six. This was rarely possible, and some counties were sixteen years behind on their tax payments. With good official connections, certain magistrates were able to gain reductions, but none were as low as 
the Ming rates. ${ }^{36}$ To attract new migrants to return arable land to cultivation, tax exemptions were offered for the first three years; but once that time elapsed, taxes were assessed at the full amount. That was nine times the Ming rate, and peasants simply packed up and moved on. ${ }^{37}$

One further fiscal problem had long plagued the province. Shaanxi was a critical point in the official post road system that linked the empire, and with more traffic going to the far west, the Qing expansion only made the problem worse. The roads, bridges, fords, post houses, and inns for official travelers had long been maintained by the general population through a system of corvée labor. The Qing had simplified and commercialized this system by collecting the corvée (ding 丁) tax as part of the land tax. In most of the empire, this amounted to a 20 percent increase in the land tax. ${ }^{38}$ In Shaanxi, the corvée tax was much higher, in some Shaanbei counties adding 80 percent to the land tax. ${ }^{39}$ One magistrate gained such popularity by closing post houses and eliminating tax-collecting fords that a shrine (shengci 生祠) was erected in his honor while he was still alive. ${ }^{40}$ Still, post houses and inns were essential to carry official messages and personnel in this vast, strategic, and sparsely populated borderland, so the taxes to support them remained high. ${ }^{41}$

Despite the heavy taxes, the early Qing was a fairly peaceful time in Shaanbei. One of the few exceptions was a 1667 uprising that seems more comical than threatening to the social order. The uprising, in the department of Suide, was led by a military officer from nearby Dingbian with the auspicious name Zhu Long (朱龍), or imperial dragon of the Ming ruling house. In Suide, a poor fellow called Fourth Son Zhou (周四儿) was injured in a mining accident, leaving a snakeshaped scar on his back that he called his "dragon in the flesh." Through some coincidence Zhou came to know Dragon Zhu, and one night a thief entered Zhu's room while he was asleep. Zhu woke and the clever thief knelt in a plea for mercy, saying he had been overcome by the red glow of the officer's body and a red dragon emanating from his nose. Dragon Zhu told this story to his new friend Zhou, who may well have arranged the whole incident. The red dragon was interpreted as a portent of imperial destiny, and Zhou suggested a rebellion. Dragon Zhu replied that his four or five hundred men were insufficient for the task, and Zhou promised that his impoverished home west of Suide could provide tens of thousands of followers with just 3,00o taels of silver. Zhu gave him the money, which Zhou used to buy a vast quantity of walnuts that were loaded on a dozen donkeys to return to his home.

Back in Suide, Zhou made a great show trading walnuts at a loss, buying dear and selling cheap. The starving villagers asked the source of his sudden wealth. He replied that his new friend, Dragon Zhu, had given him 10,00o taels to go into business, and he would loan it to them in small sums if they promised to repay the interest each month. Many were desperate for cash, and he carefully wrote down their names and ages and told them to return on the next market day. Zhou then rushed back to Dingbian, showed his ledger with the names of people he had 
allegedly enlisted in his army, adding that a show of force would stiffen their resolve. On the appointed day, Dragon Zhu and his troops hid nearby as Zhou went to the market. When the peasants came to pay their interest, Zhou revealed his plan to rebel. They protested that they had only come to pay their interest, but Zhou fired a signal shot and Zhu's force surrounded the market, executing several who refused to go along with the plan. That was enough for the rest, whom Zhou led to loot a nearby village. The booty from that raid attracted thousands more, who soon took the town of Suide when the magistrate fled and the local commander surrendered. The magistrate hurried to Xi'an with the seal of office, and a large Manchu force was dispatched to quell the uprising. While the incident showed that in the early Qing there were many famished peasants ready to follow a Ming pretender in rebellion, the quick suppression suggested that the new Manchu order was not under serious threat. ${ }^{42}$

\section{A CULTURE OF POVERTY}

Shaanbei was renowned for its poverty. With scant and unreliable rainfall and little irrigation, it was the classic region where the farmers "relied on Heaven to eat" (kao Tian chifan 靠天吃饭). Other than millet, beans, and sorghum planted on the bare plateaus and hillsides, there were few crops. Soybeans were rare, and doufu was not part of the diet. Tobacco was grown around Lanzhou in Gansu, but rarely on the Shaanbei plateau. There was too little water for cotton, and Shaanbei was too far north for mulberry and silkworms. This prevented the growth of the handicraft textiles common elsewhere in China. Cloth was imported, and Shaanbei men were renowned for wearing unlined sheepskin jackets year round. ${ }^{43}$ The only supplementary income came from flocks of sheep and goats tended by small boys, especially in the west along the Gansu border. ${ }^{44}$ Sometimes poor families rented sheep from the wealthy, which their sons herded for a portion of the wool. ${ }^{45}$ These herds provided the only local products of significant commercial value: the wool, hides, lambskin, and a few felt rugs that were traded for such necessary imports as cloth. ${ }^{46}$ Even pigs were scarce, and pork was rarely eaten. While the rest of China experienced significant commercial expansion, with teeming local markets, increased handicraft production adding women and children to the labor force, and local and regional divisions of labor raising productivity and improving living conditions, Shaanbei was left behind.

In addition to environmental limits on a diverse agricultural economy, the lack of convenient transport was a major barrier to the development of commerce. There were no navigable rivers anywhere in Shaanbei. All transport moved overland. Even in 1936, the one motor road reached only to Yan'an. ${ }^{47}$ In earlier times, traffic moved on narrow dirt trails that followed the twisting river valleys or wound up and down the hills. Dusty in winter and impassably muddy in the summer rains, one frustrated traveler found them "execrable."48 Lacking cheap water transport or even wheeled carts over the narrow trails, commercial traffic moved on 
mules, donkeys, or camels, making it exceptionally expensive. With little profit to be made, locals were not drawn to commerce, and the few merchants and artisans serving the local economy were largely outsiders, usually from Shanxi. ${ }^{49}$ Expensive and perilous transport made it extremely difficult to import grain in times of famine. ${ }^{50}$

With little commerce and a sparse population, Shaanbei had few towns of any size. Yulin, the military center of the region with a significant garrison and a strong wall, was probably the largest town, with a population of around ten thousand. Even Yan'an and Suide, the two political and cultural centers where the triennial official examinations were held, had less than that number. Most county seats in the region had one to two thousand residents, and a few like Ansai and Wupu had fewer than fifty families. ${ }^{51}$ In towns, as in the countryside, living conditions were exceptionally simple. As most visitors noted, the people lived in caves, though one should not imagine these dwellings as anything like the natural caverns of prehistoric peoples. The thick loess soil easily held a vertical slope, so it was possible to carve from the hillside a cave home with an arched ceiling and to cut an opening above for the stove's chimney, which also wound under and warmed the earthen bed or kang (炕). Once the walls had dried and been whitewashed, these caves were quite comfortable, cool in summer and easily warmed in winter. Prosperous families faced the front in stone, sometimes quite elaborately designed. ${ }^{52}$ Though cave dwellings were economical and comfortable, they were also the product of a significant shortage of wood. North of a band of forest that separated Shaanbei from the Wei River valley, the northern hills were basically barren. Not only did this deprive the local population of building materials, but fuel for cooking and heating posed a significant challenge. Stalks of corn and sorghum and such sticks as could be gathered from bushes provided the only fuel. ${ }^{53}$

The impoverished and "backward" local economy took its toll on the local population. The lives of the peasants and herders who made up the vast majority of Shaanbei denizens were bitter, to the extent that the local term for peasants was simply "hardship person" (shoukuren 受苦人)..$^{54}$ In gazetteer descriptions of local customs, no term is more common than "simple" (chun). Sometimes it was given a positive spin, establishing a link to the virtue of being simple and honest (chunhou 淳厚), and the official handbook giving capsule descriptions of each county praised the local population for showing no signs of extravagance. ${ }^{55}$ Given the poverty of the region, there was indeed little extravagance; but the real meaning of the term was certainly that the people were unsophisticated (chunpu 淳朴). Education was an expensive luxury for most families. In the words of the provincial gazetteer, "The land is barren and the people are poor; few attend school or are literate. As to the reason, most complain they are poor and have no resources for schooling, so that many clever youngsters end up spending their whole lives tilling the fields or tending flocks." ${ }^{56}$ One mid-Qing official found that in the first eighty years of the dynasty, eight counties along the northern border had not produced a single successful candidate in the provincial examinations. He asked the emperor 
for a special provision that one of the roughly fifty slots in the triennial examinations be reserved for these counties, a minimal act of affirmative action that was approved. ${ }^{57}$ With little contact with the wider world, Shaanxi was, in the words of an early twentieth-century Western visitor, "conservative and tradition-clinging even for China." ${ }^{58}$ Conservatism certainly did not bother the compilers of local gazetteers, but even Qing observers were troubled by prevalent popular beliefs that they regarded as superstitious. Much like the Communists in the twentieth century, they decried the widespread belief in ghosts and spirits and the reliance on shamans and spirit possession rather than medical professionals to cure illness. ${ }^{59}$

Twentieth-century visitors, both Chinese and Westerners, often complained that Shaanbei people were dirty. A typical visitor reported that Shaanbei people "are very dirty. They never bathe. They never used to even wash their faces. They bathe three times in a lifetime: at birth, marriage and death." ${ }^{60}$ There is little doubt that these accounts are accurate, but they reflect not inattention to hygiene but a lack of water. Especially for those who lived in hillside villages, a trip to the nearest stream might take half an hour, and not every household had ready access to a well. Complaints about the customs of Shaanbei people were not new. Qing dynasty writers were also troubled by what they saw. One Qing gazetteer noted five virtues: wealth was not a key consideration in marriage; righteousness was honored in friendship; the people were respectful of the dead and generous in their charity; and women were not seen in the markets. But it also noted one key failing. Shaanbei people were lazy: farmers did not irrigate their fields, grow vegetables, or plant trees; women did not spin or weave; and men did not engage in commerce. ${ }^{61}$ Modern visitors detected a certain stubbornness in these habits, finding the locals both lazy and proud. ${ }^{62}$

The classic expression of outsider views was a widely known poem by a Qing scholar cautioning his son against coming to Yan'an. He listed seven reasons, which read, in part

Pitiful scholars earn a licentiate's robes and then quit, their talent just enough to enter school when they stop writing, hanging a plaque above their gate and thinking it sufficient honor. They eat their simple steamed buns and never go on to Xian. As for examination success, forget it!

Pathetic women with messy hair full of cinders, rough blackened hands and a foul and putrid mouth. Her pants show her legs and her feet [which should be bound and small] are as wide as a donkey's hoofs. Where are the rolling waves of the bedchamber? As for beautiful painted ladies, forget it!

[Men in] unlined sheepskin jackets, worn all through the year without ever taking them off; tall, pointed winter caps; thick and wide padded pants, silk lining unthinkable in favor of what is rough and durable. At night, they cover themselves with a felt rug, never using a quilt. As for clothes of gauze and silk, forget it!

Guests are eagerly welcomed, children offering a rough pot of tea. You are feasted with panbread and scallions, peppers and vinegar, then thick flatbread with pickled vegetables. Ox and lamb hoofs, still covered with hair, are gobbled up in a rush. If you're thinking of fine seafood and delicacies, forget it! 
As for shelter, the low damp caves are made of earth; sunlight never enters in summer, and they leak in the rain. In the alcoves and on the sides, the walls are covered with soot from oil lamps. With horseshit and ox piss on the floors, the filth and stench are everywhere. If you are thinking of carved beams and painted pillars, forget it! $!^{63}$

Such descriptions betray both the arrogant disdain of officials from the wealthier parts of China and the vast cultural gap between them and the native population. On the other hand, the accuracy of such accounts should not be dismissed entirely. As we shall see below, when the Communists arrived in Shaanbei they too despaired that the "human material" was inadequate to make a modern revolution. ${ }^{64}$

It is important to remember that Shaanbei was a frontier zone, with the culture and habits of a land where pastoral and agricultural populations met. For much of China's early history the area was not inhabited by Han Chinese, and much of the modern population bears the marks of this diverse racial mix, with tall noses, strong jawbones, and even blue eyes. ${ }^{65}$ It is not surprising, therefore, that the population had many of the rough habits of the frontier. While the people were praised for being "simple," they were also described as "tough and fearless" (qianghan 强悍). ${ }^{66}$ Some gazetteers noted that, while these martial habits made the people loyal, they also made them willful, even arrogant. ${ }^{67}$ In Shaanbei, the success rate in the military exams was far greater than in the civil exams. ${ }^{68}$ The weak educational system made it difficult if not impossible to compete with the scholars of Guanzhong, and there were neither teachers nor local models of refined Confucian norms. Living in the outdoors and clambering over the hills as youths, young men learned to ride and shoot rather than to sit in a classroom and memorize the classics.

Shaanbei was not just a frontier but also a land of persistent natural and human disasters. We have seen the drought and rebellions of the late Ming, and both would return with a vengeance in the late nineteenth century. Such disasters inevitably turned much of the population into refugees. When the troubles subsided, the barren land was gradually repopulated by migrants from elsewhere. This was not a land of long-settled villages and ancient lineages with graveyards reminding the residents of multiple generations of ancestors. Lineage halls and genealogies were virtually non-existent. If a couple lacked an heir, it was common elsewhere in China to adopt from a brother or a cousin or at least within the patriline. In Shaanbei, however, such close relatives might not exist, so adoption outside the lineage was common. ${ }^{69}$ Weak lineages were the product of a mobile population of recent migrants, but given the importance of kinship elsewhere in China, their absence had a significant impact on local customs and culture.

When a migrant moved into a village, he might offer his young daughter to a local family in exchange for land rights. ${ }^{70}$ There was nothing unusual about giving away a daughter, but this arrangement gave an outsider access to village land and also made him the father-in-law of the young heir of a family with enough means to give away land. The practice was unusual enough for official comment, but it 
was not condemned. By contrast, the custom of women taking a second husband to care for her children, or even to support a disabled or unsatisfying first husband (zhaofu yangfu 招夫养夫), was definitely frowned upon. Matthew Sommer has examined instances of this practice in legal cases, and it was often a hired laborer who gained sexual access to a wife in exchange for his farm work. That appears to have been the case in Shaanbei, and it would be another example of the way in which mobile young men gained unusual status in village life. ${ }^{71}$ The most remarkable evidence of weak lineage structures was an inheritance practice reported in Dingbian, in the far northwest. While the usual practice gave equal inheritance rights to all male heirs, in Dingbian first priority went to a daughter's sons, then to the sons of the wife's sisters; only if none of these were available did the land go to sons in the patriline. An early twentieth-century survey said that this practice led to only 10 percent of the land staying within the patriline. ${ }^{72}$

In the 1930s, there were numerous reports that Shaanbei was rife with venereal disease. One sympathetic visitor to the Communist base wrote that "among Shaanbei people, 80-90 percent have VD."73 One consequence of poor hygiene, unsterile birthing practices, and widespread VD was an unusually high rate of infant mortality. ${ }^{74}$ Hostile witnesses blamed the VD on loose sexual norms brought by the Communists and the large number of single youths who flocked to the area after $1936 .^{75}$ It is likely, however, that years of warfare and revolution brought young soldiers into the region with sexual demands that were not conducive to genital hygiene. There were also Qing dynasty complaints of shared wives and casual sex. ${ }^{76}$ Though conventional sources are notoriously reticent about sexual practices, it is likely that high mortality rates leaving a substantial number of unattached widows, together with frequent mobility by young men in search of work and the comforts of home, produced conditions conducive to sexual mores that were looser than the Confucian norm.

In a land prone to natural and human disasters, the population was regularly replenished by migrants from other, more densely settled regions. As the son of one local official noted, young men who left their homes to seek their fortune preferred rich lands to poor, and nearby lands to far. Shaanbei was the last choice of migrants. In addition, new migrants had to borrow money for seed and tools to get started on new land. Wealthy households were few, and interest rates high. If they could not make enough to repay the loans, they just left and moved on. The net result was that those who came and stayed were unscrupulous rascals who cheated the local population and just made trouble. ${ }^{77}$ Another gazetteer offered an account of one form that this trouble might take: beggar bands as large as a hundred that called themselves "holy ants" (mama shen 螞螞神). With whole families of men, women, and children, on horses and donkeys but carrying no food, they begged in isolated villages, often stealing from untended households, or luring the women out and distracting them as one member of the gang went in to look for valuables. One nimble specialist carried a collection of keys to open the family lockbox and steal jewelry or valuables. While claiming to be famine refugees, they were really 
"lazy vagrants who do not work." ${ }^{8}$ Such combinations of refugees and unscrupulous rascals were the product of a harsh environment that offered little reward for long hours of harsh toil in the fields.

With an impoverished, mobile, and frequently unruly population, Shaanbei was an unattractive posting for a late Qing official. The provincial gazetteer reported that in the mid-Qing, there were few openings because honest officials lacking ambition often served for long terms. Then came the rebellions of the nineteenth century, to which we will turn presently. "For thousands of $l i$ [ 1 li equaling about one-half kilometer] there was no sign of life. . . Y Yan'an Prefecture was worst. A great prefecture was like a desert outpost. Whenever a vacancy occurred, most thought only of a few fine days in the capital; why would they think of devoting themselves to slow recovery?" The author, however, regarded this as more than a recent phenomenon: "Although this was in part the product of the times, we cannot exclude the fact that in [Qing] times they could not appoint talented men to secure order, but only those who treated office as a pasture or a place to redeem past failings." ${ }^{\prime 9}$ Shaanbei, it seems, attracted officials who had failed elsewhere, or those who sought to graze the local landscape for personal profit and then move on. The Bao'an gazetteer was equally downbeat: there was no joy in the posting, capable officials were rare, only timeservers coming. It had been this way since Ming times, when, according to an official of the time, local magistrates were either elderly lower-degree holders or petty education officials who had been promoted. When a man was selected for a Shaanbei posting he would appeal to friends and fellow officials to intercede on his behalf: his parents were old and he could not take a distant appointment; or his health was poor and he could not endure the cold. After several months of this he might get a better appointment. "The court selects officials to suit a locality; why should it select a posting for an official?"80

The number of local officials with regular examination degrees was fewer than half and declined over the course of the dynasty. The statistics in the provincial gazetteer confirm the impression of a Ming official: irregular appointments were frequent, and they increased over time. In addition, terms were short and getting shorter. In roughly a third of the cases, appointments were less than one year. Given the time it took to travel from Beijing, the appointment was probably never taken up. ${ }^{81}$ There are numerous examples of acting officials, often petty education officials who would not normally qualify for a magistrate posting. The undeniable conclusion is that the Qing state apparatus in Shaanbei was very weak.

The weak state structure was particularly important given Shaanbei's sparse gentry presence. In his classic work on the Chinese gentry, Chung-li Chang (Zhang Zhongli) wrote that "the gentry acted as intermediaries between the government officials and the local people." ${ }^{22}$ Local officials were, by law, prohibited from holding office in their native province. They were, inevitably, outsiders, and dependent on local elites to carry out their vast fiscal, judicial, educational, and security duties. As degree-holding members of local society, gentry possessed social status equivalent to local officials and unique access to them. Gentry cooperation was 
Mid-Qing Juren Distribution per 100,000 Pop. Over 10 Years

$\square<0.75$

$\square 0.75-1.5$

$\square 1.5-3$

$\square>3$

- County Boundary

River
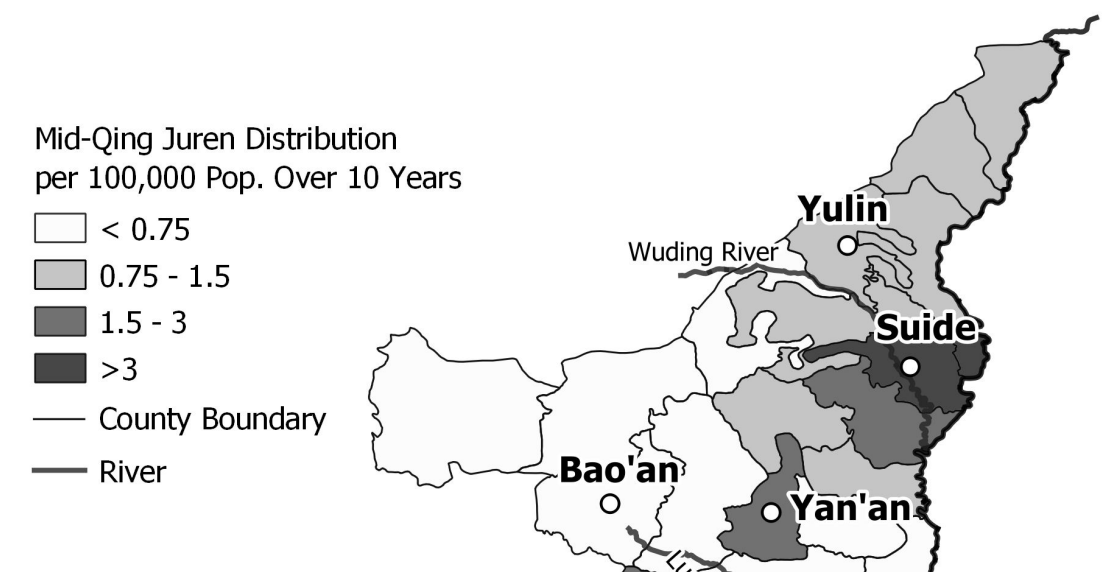

А
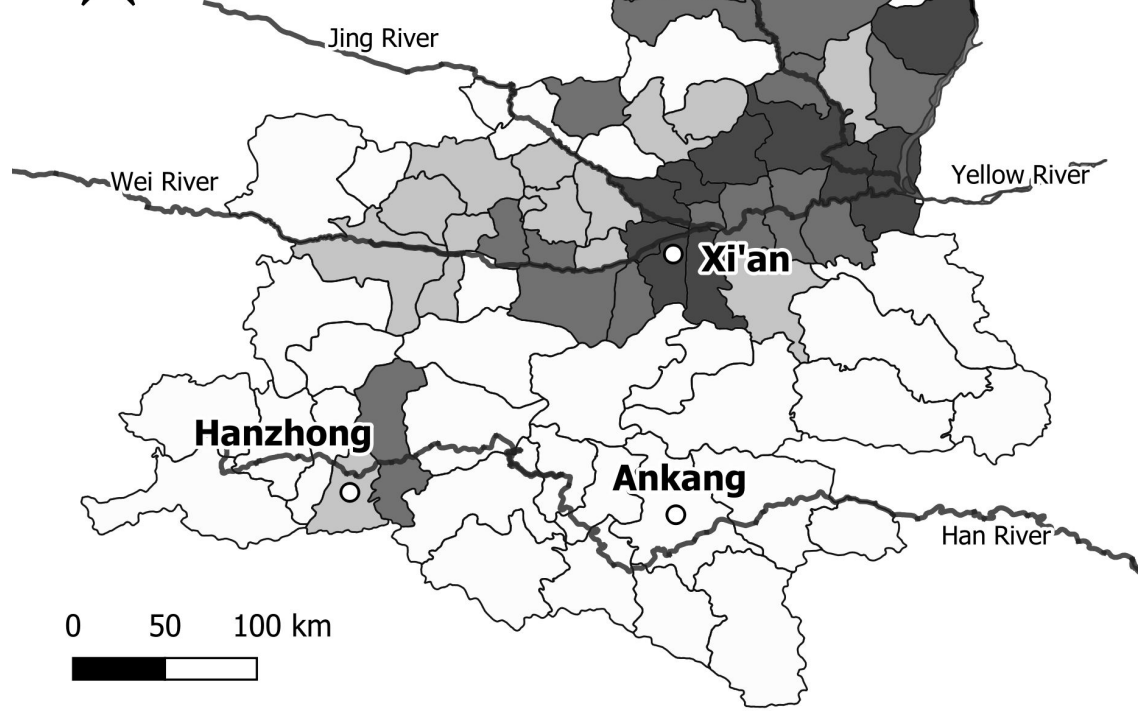

MAP 2. Mid-Qing (Qianlong-Jiaqing reigns) juren distribution by county: average number of provincial degrees awarded every ten years per 100,000 population. SOURCE: Juren figures from Shaanxi tongzhi xutongzhi 7:3505-3692; population from Shaanxi shengzhi: renkou zhi, $332 \mathrm{ff}$.

indispensable to the smooth operation of the polity. The problem, in Shaanbei, was that there were very few degree-holding gentry members to buttress the local regime. Formal gentry status required passing the provincial juren examination, but the weak educational system in Shaanbei meant that few local scholars could compete with the elites of Guanzhong. As map 2 shows, most of the Guanzhong heartland produced more than three juren per one hundred thousand population over ten years, while most of Shaanbei had fewer than half that number and a vast stretch along the Luo River had fewer than one-fourth. 
This meant that in most of Shaanbei, those with gentry status held the lower licentiate degree, a shengyuan, or what was colloquially called a xiucai. There was a local quota for licentiates, and while the quota was lower in the poor counties of Shaanbei, every county got some licentiates, even with minimal educational qualifications. As a result, in Shaanbei, gentry (shen) became the term used for local functionaries. In Jingbian, for example, the county was divided into five sections, each centered on a fortified stockade (bao or pu 堡) that was headed by a gentry chief (zongshen); then in the countryside, each section had four or five "dispersed gentry" (sanshen), each responsible for about twenty small villages. ${ }^{83}$ There was no suggestion that these gentry had any formal literary qualifications; they were simply rural functionaries called gentry to maintain social order in the countryside. This practice was so well established that in the republican era such rural functionaries as baojia officials of the Guomindang regime were routinely called gentry. ${ }^{84}$

\section{REBELLION}

As with much of China, the crisis came in the middle of the nineteenth century. As was often the case, Shaanbei was the passive victim of events that had their origin elsewhere. In most general histories, the crisis of the late Qing is associated with the impact of Western imperialism and the opening of China to trade, diplomatic missions, missionaries, and opium. In the Opium War of 1839-42 and the series of conflicts that followed through the nineteenth century, the proud Qing Empire was repeatedly defeated by the superior military forces of Britain, France, and finally Japan. These humiliating defeats spurred a process of reform and modernization that, while slow and halting, would eventually transform the Chinese nation. For most Chinese of the time, however, and certainly for residents of inland provinces like Shaanxi, it was not foreign invasion that affected them but domestic rebellions. Foremost among these was the Taiping Rebellion, which rose in the hills of southwestern China in 1850, established its capital in Nanjing in 1853, and occupied much of the Yangzi valley for over a decade. Inspired by a charismatic leader with an ersatz version of Christianity, vague notions of land reform and communal living, and a virulent hatred of the Manchus, the rebellion posed a direct threat to Qing rule and resulted in millions of deaths before Nanjing was retaken in 1864 and the last rebels were eliminated soon thereafter. ${ }^{85}$ Less organized and generally nonideological was the Nian Rebellion, a powerful force of rural rebels whose cavalry raided much of the North China plain from 1851 to $1868 .{ }^{86}$ Finally, in the southwestern province of Yunnan, a multiethnic rebellion with Muslim leadership established an independent sultanate that lasted from 1856 to $1873 .{ }^{87}$ These rebellions, plus the Muslim Rebellion that would rise in the Northwest, shook the very foundations of the Qing state and posed an existential threat to the established order.

As rebellion wracked much of the empire through the 1850s, Shaanxi remained peaceful. The relatively prosperous Wei River valley was able to provide soldiers, grain, and tax revenues to support the Qing defense against rebellion. Though 
the redeployment of resources produced cuts in some Shaanbei military rations and desertions by soldiers, the province seemed a bastion of peace and order in a time of turmoil. ${ }^{88}$ Still, Shaanxi remained sensitive to the threat of religiously inspired rebellion. The White Lotus Rebellion at the turn of the nineteenth century had disturbed southern Shaanxi for years, and the official account of the Muslim Rebellion was in an extended gazetteer section on "suppressing religious rebels" (pingding jiaofei 平定教匪) that began with the rise and fall of the White Lotus. ${ }^{89}$ Nineteenth-century Shaanxi officials were especially fearful of the powerful combination of religious commitment and political dissent.

In August 1861, the Xianfeng emperor died in his summer palace north of Beijing, having abandoned the capital to French and British occupation after his disastrous policies scuttled a peaceful resolution of the Second Opium War. The five-year-old Tongzhi emperor was installed on the throne, but foreign occupation and disarray in the court inspired the Taiping to launch another assault on Beijing. The campaign failed, but one Taiping column entered Shaanxi from the southeast and drove north toward the Wei River. ${ }^{90}$ With many Shaanxi soldiers fighting the rebels elsewhere, the authorities adopted the popular expedient of raising local militia to confront the Taiping incursion. Though local militia were effective in combatting rebels throughout the country, the Shaanxi justification included some unusual tactical details. Along with the conventional stress on gentry leadership and official support, the Shaanxi proposal noted the willingness of peasants to defend their homes and families but not to fight distant battles. It was essential to arm the peasants with firearms, but only a few days of training were necessary. Militia were most useful to deter rebels, their mere presence sufficient to alert rebel spies. If the rebels in fact attacked, the peasants, concerned mostly to protect their families, could not be expected to fight to the death; but they could fire their guns from a safe distance in an effort to scare off the enemy, then flee if the attempt failed. Finally, the particular advantage of local militia in mountain villages was noted. Knowing the mountain trails and local terrain, they could harass the enemy and pick off laggards in a long column. In addition, "Mountain people are simple, sturdy, brave and long-suffering. They are used to danger far more than the weak and fickle people of the plains." ${ }^{1}$

As Shaanxi began to organize and arm militia, local officials confronted a particular problem. The Wei River valley was home to a large number of Sino-Muslims called Hui or Huihui (回回). They had come to the area centuries earlier as traders but now spoke the local Chinese dialect and lived in separate communities organized around a local mosque and imam called an ahong (阿言). There were one to one and a half million Hui in Shaanxi, representing about one-tenth of the population, but almost half were concentrated in Tongzhou Prefecture, near the Shanxi border in the broad plain where the Wei, Luo and Yellow rivers came together. ${ }^{92}$ In the seventeenth century, Sino-Muslims further west had been influenced by Sufi sects originating in the Middle East, but the Shaanxi Hui adhered to a more conservative Gedimu tradition that sought common ground with Confucian 
ethics. Nonetheless, the different religious traditions, avoidance of pork and alcohol, separate communities, and rejection of intermarriage made ethnic tensions inevitable, so that racist stereotypes of Hui as haughty, violent, and foul-smelling were common. In his classic study of the Hui, Jonathan Lipman aptly described them as "normal but different, Sinophone but incomprehensible, local but outsiders." ${ }^{\text {"93 }}$ As a result of this ethnic divide, the predictable effect of militia organizing in Shaanxi was the creation of separate and competing Muslim and Han Chinese militia.

Community conflict was a constant feature of Chinese society. Lineages along China's southern coast engaged in bloody feuds that could last for generations, and conflict with one's neighbors could be an integral part of communal solidarity. ${ }^{94}$ Communal conflict between Han and Hui villages was a long-standing fact of life in Shaanxi, with Han complaining that Hui herds trampled their crops, and Hui objecting to discrimination in the local markets. As disputes persisted in the eighteenth century, the Manchu rulers abandoned their commitment to equal treatment of all ethnicities and endorsed harsher penalties toward Hui, whom they regarded as the aggressors. In 1862, a petty conflict over bamboo prices sparked the larger conflict. That the controversy began in a market was predictable, for this was the place where the two communities came together. Each side appealed to its agents among the yamen runners (tax and police agents in the local administration), but when the provincial militia commander, an intemperate member of the Han gentry, arrived to settle the dispute, he was killed, and rumors immediately spread that the Han intended to massacre the Hui in revenge. With Han and Hui both organized in militia, communal violence quickly escalated into outright rebellion until the entire Wei River valley was filled with bands of marauding Hui. Occasional incursions by Taiping and Nian rebels from the south added to the general chaos. The Qing state allied with Han militia in defense, and by the middle of the decade, with the exception of a small peaceful community in Xian, the Hui were driven from the province. ${ }^{95}$

The retreating Hui took refuge in Gansu, which already had a substantial Muslim population. Most assembled in Dongzhiyuan, a relatively prosperous valley in the poor east Gansu prefecture of Qingyang. From there, they made numerous attempts to return to their richer homeland in the eastern Wei valley. Traveling under the leadership of their imams in vast armed migrations including whole families of women and children, they were repeatedly blocked by Qing forces at the Shaanxi border. ${ }^{96}$ Despite appeals from their Gansu colleagues, the Shaanxi officials and gentry were adamant that the Hui should not return. In the words of the Shaanxi governor:

In my humble opinion, the Gansu Hui can be conciliated, but the time has not come where that is possible in Shaanxi. The Gansu Hui have always been simple and timid [yunuo愚懦]; they were coerced into joining the Shaanxi rebels. There is no deep enmity between them and the Han. The Shaanxi Hui, however, are both cunning and brazen [jiaohan 狡悍]; often pacified, they repeatedly rebel. Since the rebellion began, they have massacred hundreds of thousands of Han. If we were to err on the 
side of lenience, the people of Shaanxi, recalling the pain of their fathers and seeking the revenge due to sons, would certainly not live with them in peace. In addition, the property of the rebels has already been given to new migrants, who have sincerely followed our instructions. We certainly cannot take fields already tilled by others and turn them over [to former rebels]. If it is proposed that separate areas be laid out so that Han deal with Han and Hui deal with Hui, how could you expect the surviving Han to relinquish their lands to the surrendered Hui? The wrongs of the past are so deep that suspicions are sure to arise in the future. ${ }^{97}$

Simply put, the Guanzhong-based Han gentry and officials would not allow the Hui to return. Unfortunately, Shaanbei paid the price. The north was sacrificed for peace in the heartland. ${ }^{98}$

Hundreds of thousands of Shaanxi Hui had fled to Dongzhiyuan. In search of food, they began raiding the surrounding countryside, where in 1867 the harvest was already suffering from drought. ${ }^{99}$ Soon east Gansu villagers organized to protect their grain supply. Some were recognized as local militia, but when these defensive forces turned to extracting resources elsewhere, they became "militia bandits" (tuanfei). ${ }^{100}$ The result was precisely the mix of protective and predatory strategies that Elizabeth Perry has described among the Nian of the North China plain. ${ }^{101}$ Seeking first to defend their own communities, they were soon forced to prey on others. As stored grain was exhausted, unemployed farmers began raiding for food. As officials hoarded grain to feed the army, more peasants were forced into banditry. ${ }^{102}$ Soon they were leading bandit armies numbering in the thousands and adopting pithy noms de guerre: Smithy Gao the Second (高二鐵匠) or Fifth Master Zhang (張五大人). ${ }^{103}$ The most famous of these was Dong Fuxiang, a northern Gansu native who joined the militia to fight the Hui, then led an enormous army of his own until induced to surrender. He went on to play a major role in the suppression of the Hui Rebellion in Gansu and the far west, ending his career as a xenophobic general in the Qing army who led the siege of the foreign diplomatic quarter during the Boxer Uprising in 1900. ${ }^{104}$

As eastern Gansu was stripped clean, both Hui and bandits turned to Shaanbei. The worst years were 1866-67. Both groups moved down the Luo River, through Bao'an, and on to the counties beyond. Sometimes the Hui gathered bandits and ex-soldiers to add military strength to their bands; sometimes the Hui found the bandits unruly and sought to discipline them. Always, the sources stress, the purpose was foraging for grain. ${ }^{105}$ Some Hui clearly hoped to follow the Luo all the way to their homeland, where it flowed into the Wei River. As before, these were whole communities of women, children, and old people. At one point in 1867, the Hui sought an alliance with Nian rebels fighting in the area, in a vain attempt to acquire sufficient military strength to fight their way home. ${ }^{106}$

In the end, it was the peasants of Shaanbei who suffered. Shaanbei was weakly defended against this rebel onslaught, much of the military having been withdrawn to protect the provincial center or sent to fight the rebels in Gansu. ${ }^{107}$ Left to their own devices, the peasants fled to the walled towns, mountain-top 


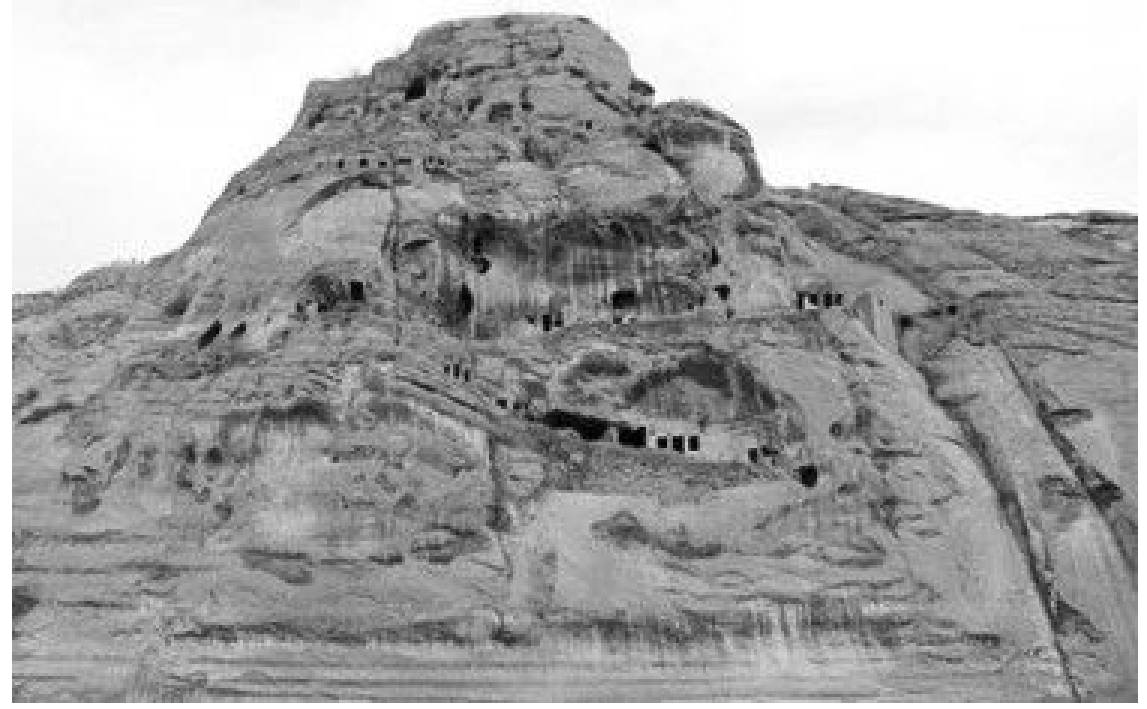

FIGURE 1. Yongningshan. This limestone fortress withstood the Muslim Rebellion and later served as a temporary refuge for the Bao'an County government.

stockades, or cliffside caves. The rebels and bandits were poorly armed: accounts have them fighting with swords or even rocks. Rarely did they have firearms. ${ }^{108}$ Sometimes, through sheer numbers, the Hui or local bandits breached the low and crumbling walls of a county seat, where they looted for food and treasure and killed or scattered the population. ${ }^{109}$ Mostly they raided isolated and undefended rural communities. ${ }^{110}$ The few and poorly paid government soldiers also looted the local population, so the peasants were made victims by both sides of the conflict. ${ }^{111}$

Bao'an, a poor county in the far northwest of the province and home of the Shaanbei Communist leader Liu Zhidan, provides a good example of the suffering brought by the rebellion. The Luo River ran through the county and provided an invasion route for both Hui and militia-bandits from Gansu. The small county seat was weakly defended with a crumbling wall. It quickly fell to the rebels, who looted everything valuable, destroyed the public buildings, and scattered the population. The magistrate fled, and no replacement came for three years. The county administration under a deputy magistrate relocated to the only secure location, the limestone mountain fortress of Yongningshan. With several levels of caves carved into the red limestone, access trails that were easily blocked, and a well that provided drinking water for a thousand, Yongningshan was the most secure of many such forts in Bao'an, and the refuge of the county government in republican times as well (see figure 1). Yongningshan was the one refuge that survived the rebellion. The other mountain forts all fell when the rebels besieged them and cut off their water. 


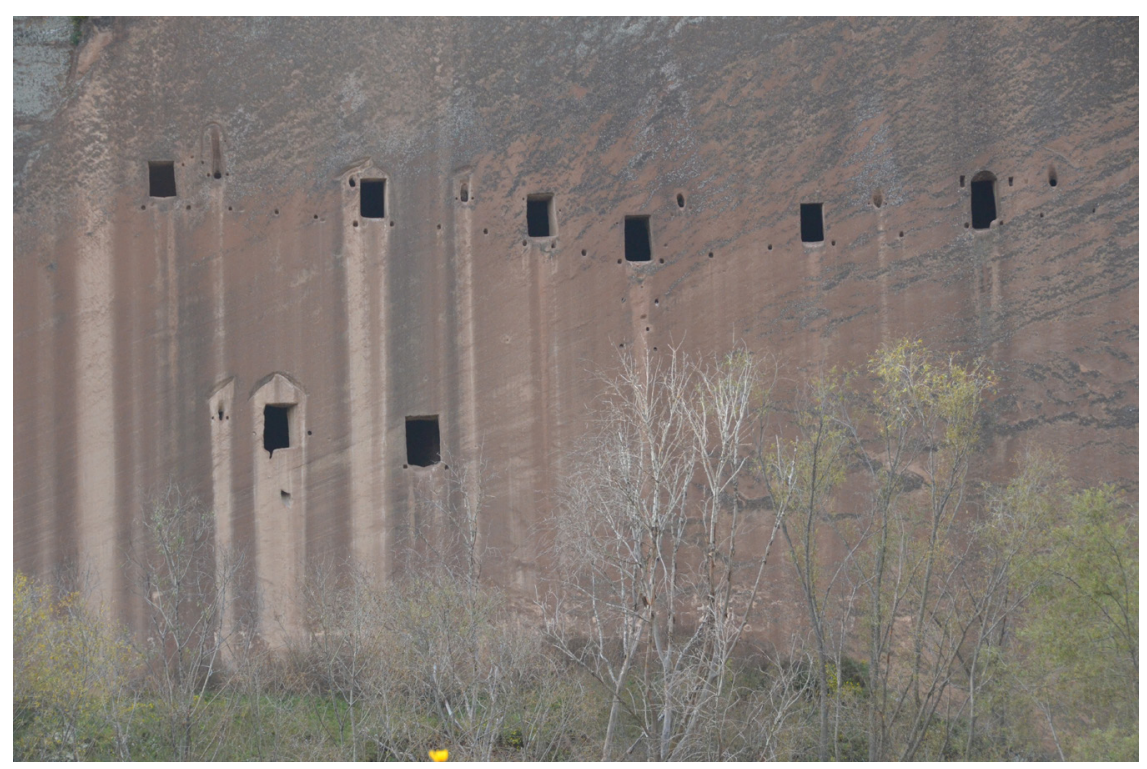

FIGURE 2. Cliff caves in Shaanbei. These caves served as a refuge from bandits or rebels. (Photo by author.)

In isolated villages, the usual defense against rebels or bandits was to retreat to a small cave cut in a steep rock hillside. The cave was accessed by a rope ladder that could be pulled up when the enemy approached, and food and water were moved inside for the emergency. Even now, one can see these cliffside refuges scattered throughout Shaanbei (see figure 2). These cliffside caves, however, were not always secure against hungry rebel hordes. Desperate for food, they would build a fire at the base of the cliff to asphyxiate the inhabitants, forcing some to leap to their death. Then, once the inhabitants had died or surrendered, a simple ladder was constructed to access the cave. In the end, most of the population fled or perished. Those who survived rallied to the support of local bandits for protection against the Hui, the devil whom you knew being preferable to the alien Other. When the rebellion was finally over, the government called for those who had cooperated with the bandits to turn themselves in. In a county whose pre-rebellion population was 51,500 , only 170 families responded to the call. ${ }^{112}$

\section{SUPPRESSION OF THE REBELLION}

Northwest China was governed by a single governor-general located in Lanzhou, the capital of Gansu. Through most of the Qing, this strategic position was held by a Manchu official. Gansu, however, was a poor province with over half the population Muslim. ${ }^{113}$ Many Hui joined the rebellion, and most were sympathetic. 
Understandably, Gansu officials favored more lenient pacification policies, but Shaanxi officials insisted on military suppression. In 1866, as rebellion raged across Gansu, a mutiny in Lanzhou forced the court to take decisive action. The Hunanese general Zuo Zongtang was appointed governor-general with a clear mandate to suppress the rebellion. By this time, however, the far west had fallen under an Islamic regime headed by Yáqub Beg from neighboring Khoqand. Zuo had been a crucial leader in the suppression of the Taiping Rebellion, and now his services were available for the last remaining threat to the dynasty. He was delayed for a year as he finished off the Nian rebels, but soon he began a systematic effort to return the vast Northwest to Chinese control. ${ }^{114}$

From the beginning, Zuo Zongtang's priority was the recapture of the far west. Xinjiang's Muslim-majority region had been added to the empire only during the Qing, and officials there had been Manchus and their Mongol allies. Zuo Zongtang's reconquest would bring it under Han Chinese rule, and he prepared carefully for the assault. Zuo was convinced that the Shaanxi-Gansu military was weak and unable to fight, and he was determined to bring his own army from central China. ${ }^{115}$ For this, he used his substantial connections in Shanghai to raise the funds for the men, arms, ammunition, and wagon trains to move his forces west. ${ }^{116}$ A zealous student of geography, Zuo was meticulous about logistics and planned for a protracted campaign. As his army paused for a time in Guanzhong, he busied his men repairing the roads and planting trees that shaded the route for a century. ${ }^{117}$ Methodical, resolute, and focused on the long term, Zuo carefully built his supply lines in a strategy that involved first pacifying Shaanxi, then defeating the Hui in Gansu, and finally reconquering Xinjiang. ${ }^{118}$ Unfortunately, Shaanbei, once again, would suffer in the process.

The problems resulted largely from Zuo Zongtang's supply lines. In addition to the main supply line through Guanzhong to Lanzhou and on to Xinjiang, there was a second supply line across Shaanbei to support the assault on the main Hui base in Jinjibao, on the east bank of the Yellow River as it flowed north into present-day Ningxia. Grain moved on pack animals along narrow trails from Shanxi, across the Yellow River, through a military garrison in Suide and then across the border counties of the north. Hui rarely ventured into this area-perhaps because their wish was to return to their homeland to the south. But the supply route became a prime target for bandit gangs and former soldiers, especially those under Dong Fuxiang, whose band numbered forty to fifty thousand at its peak. ${ }^{119}$

As Dong Fuxiang and others raided in the area, they picked up more local adherents as "the defeated bandits everywhere rallied to them." ${ }^{20}$ According to some accounts, Dong and these local bandits were better than the Hui and begged rather than raiding for food. ${ }^{121}$ Elsewhere, however, these "militia-bandits" were responsible for destroying the key border town of Ningtiaoliang, as well as the county seat of Jingbian. ${ }^{122}$ Eventually, in early 1869 , an arrangement was made. Dong Fuxiang's father approached Zuo Zongtang's key general with an offer 
to surrender. After some negotiations, an agreement was reached in which Dong's forces were enrolled as porters for Zuo's supply train. Dong soon proved himself as a fighter in the long battle against the Hui stronghold and began his rise in the Qing army. Shaanbei, at last, gained a measure of relief from rebel and bandit depredations. ${ }^{123}$

Two years earlier, however, another disturbance was a harbinger of trouble to come. In 1867, Zuo Zongtang's troops in Suide mutinied under the leadership of a Society of Brothers (Gelaohui) group from Hubei. The Society of Brothers, sometimes known as the Brothers and Elders, was a sworn brotherhood often called a "secret society," though later in Shaanbei its membership was hardly secret. It originated among soldiers and other unattached males in the Yangzi valley. With secret rituals for initiation and mutual recognition, it mostly served as a support network for young men, increasingly for those engaged in such semi-criminal activity as opium smuggling or protection rackets. It was prominent in the midYangzi military forces, and especially those of Zuo Zongtang, where it provided a degree of solidarity for men away from home in a dangerous occupation. As the incident in Suide and a similar mutiny further south demonstrated, the Society of Brothers could also provide leadership for acts of resistance. In Suide, the motives were purely economic. The soldiers were behind on their rations, and with their officers occupied elsewhere, the grain depot provided a ready target. They seized the granary, raided some local offices, and headed off in mutinous flight but were soon interrupted, apprehended, and roundly punished. The incident showed that along with a temporary peace, Zuo Zongtang's army had brought a disruptive new organization to the area. The Society of Brothers would play a leading role in the 1911 Revolution that ended Qing rule in Shaanxi, and it maintained substantial local power well into the era of Communist rule. ${ }^{124}$

\section{EFFECTS OF THE REBELLION}

The most obvious and measurable impact of the rebellion was a devastating reduction in the Shaanbei population. Gazetteers and official visitors routinely spoke of cities in ruin, traveling for great distances through the countryside without seeing a single family, and wolves roving through the mountains. ${ }^{125}$ Neighboring Gansu was the same, with Zuo Zongtang reporting that "all around the towns and forts have suffered massacre and plunder; there are hardly any people left. In [eastern Gansu], for a thousand $l i$ the fields are barren; one sees only white bones and yellow weeds. There are no signs of life, the horror of this disaster is unprecedented." ${ }^{126}$ Even fifty years later, a Western traveler noted "the daily sight of deserted and ruined villages" in Shaanxi and Gansu, which "have never recovered from the desolation of the Mohammedan Rebellion."127

Population figures from the late Qing are spotty and unreliable, so a precise accounting of the extent of devastation is impossible. In addition, the rebellion was 
followed by a ruinous drought in 1877-78, and the effects of the two disasters cannot be separated. The area along the Shaanxi-Gansu border was the worst affected. In Bao'an, an 1896 census counted only 8 percent of the pre-rebellion population, while early twentieth-century surveys in neighboring Ansai and Yan'an reveal 27 and 30 percent respectively. ${ }^{128}$ More immediate post-rebellion reports suggest that in Yan'an Prefecture only 20 percent of the population survived. ${ }^{129}$ In eastern Gansu, the situation was similar, with one plausible estimate of 70 percent population loss. ${ }^{130}$

The effects of the rebellion were long-lasting. I have calculated the population change between the relatively reliable census data of the 1820 s and the 1930s. The results are shown in map 3. The light band that runs from the northwest and generally follows the route of Hui and bandit raiders down the Luo River to the Wei represents the area of greatest destruction. As we shall see below, this was also the region in which the Communist guerrilla movement under Liu Zhidan would grow. Also important for the later history of Shaanxi is the significant population growth along the upper reaches of the Han River in southern Shaanxi. For our purposes, however, the most important trend is the rearrangement of the population centers in northern Shaanxi.

As the map shows, in contrast to the significant population drop in the west, the numbers in the northeast actually grew. Yulin, always the military center of Shaanbei, and neighboring Mizhi, whose magistrate had repaired the walls as the rebellion spread in the west and south, held off the rebels; and these counties saw their populations increase significantly after the rebellion. In Mizhi, the poor western region suffered from the rebellion, but wealthier villages east of the Wuding River had sturdy stockades where peasants could seek refuge during the relatively brief rebel incursions, and the local economy quickly recovered. ${ }^{131}$ Neighboring Suide, which hosted a substantial garrison along Zuo Zongtang's supply route, also grew, its 1902 population exceeding the pre-rebellion total. ${ }^{132}$ This growth was in part spurred by an increase in economic activity related to the distant treaty ports and global economy that were transforming coastal China. In the late nineteenth century, the popularity of fur coats and felt hats brought a growing demand for the traditional fur and hide exports of the Northwest. Representatives of foreign trading firms in Tianjin came to the Northwest to buy up the products of the local herds, and it was Shaanbei's more accessible northeastern counties that became the key entrepots. ${ }^{133}$ In Suide, some conservatives grumbled over the decline of traditional virtues as the new logic of the marketplace spread. ${ }^{134}$

As the economy of the northeast recovered, the local elite prospered as well. Map 4 gives a picture of late Qing gentry members (juren) as a percentage of population. As in the mid-Qing map 2, Shaanbei lagged far behind the prosperous counties of the Wei River valley, with their well-developed education systems and 


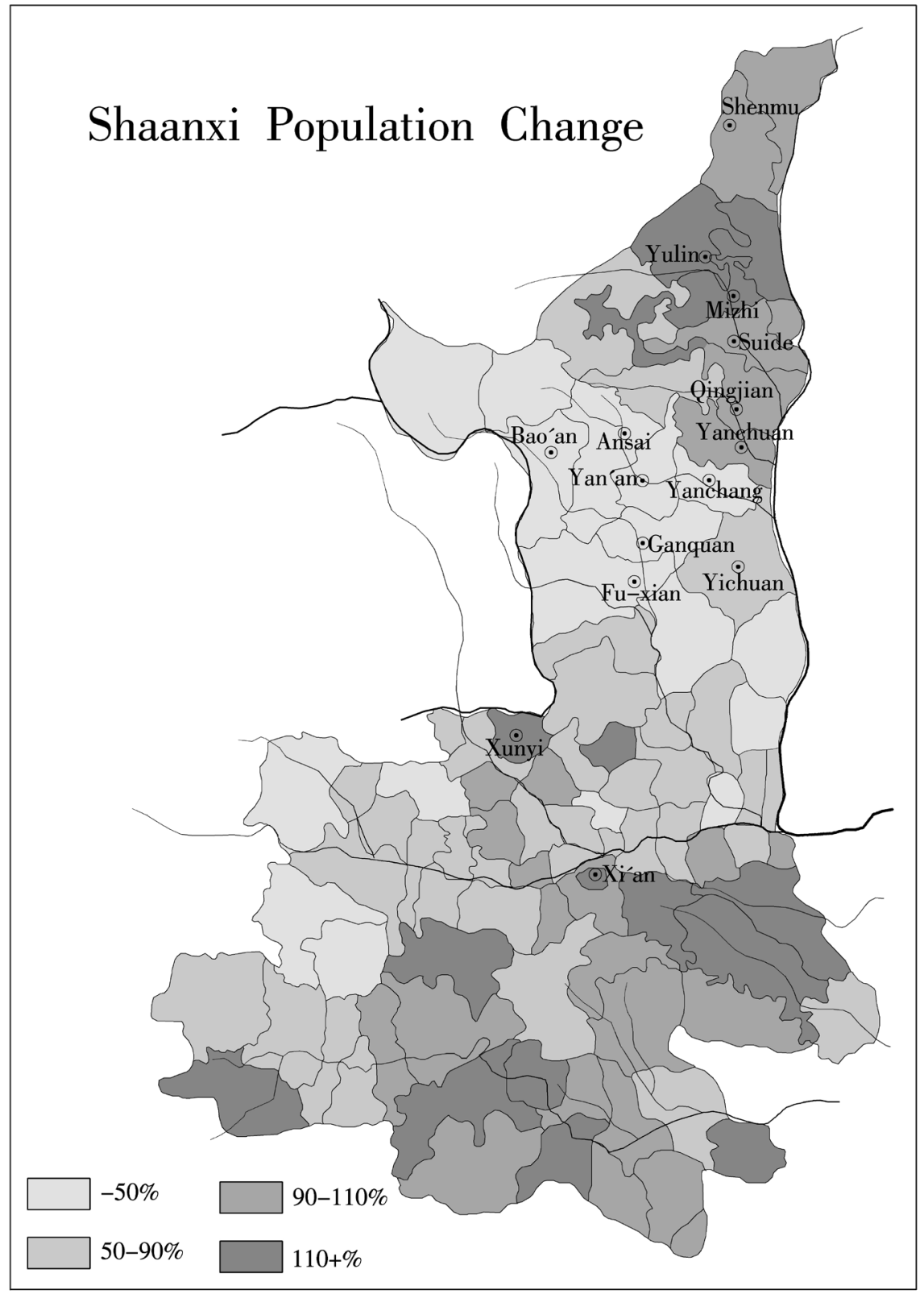

MAP 3. Shaanxi population in 1930 s as a percentage of 1820 s, showing demographic effect of Muslim Rebellion. There was a marked population decline west and south of Yan'an, while population increased in the northeast and in southern Shaanxi. SOURCE: Population for $1820 \mathrm{~s}$ same as Map 2. Population for 1930 is author's estimate based on July 1937 "Shaanxi gexian baojia hukou tongjibiao," Tongji cailiao yuekan 2, no. 5 (1937), and "Minguo 24 nian Shaanxi fenxian renkou shu," Tongji zailiao (1939). 


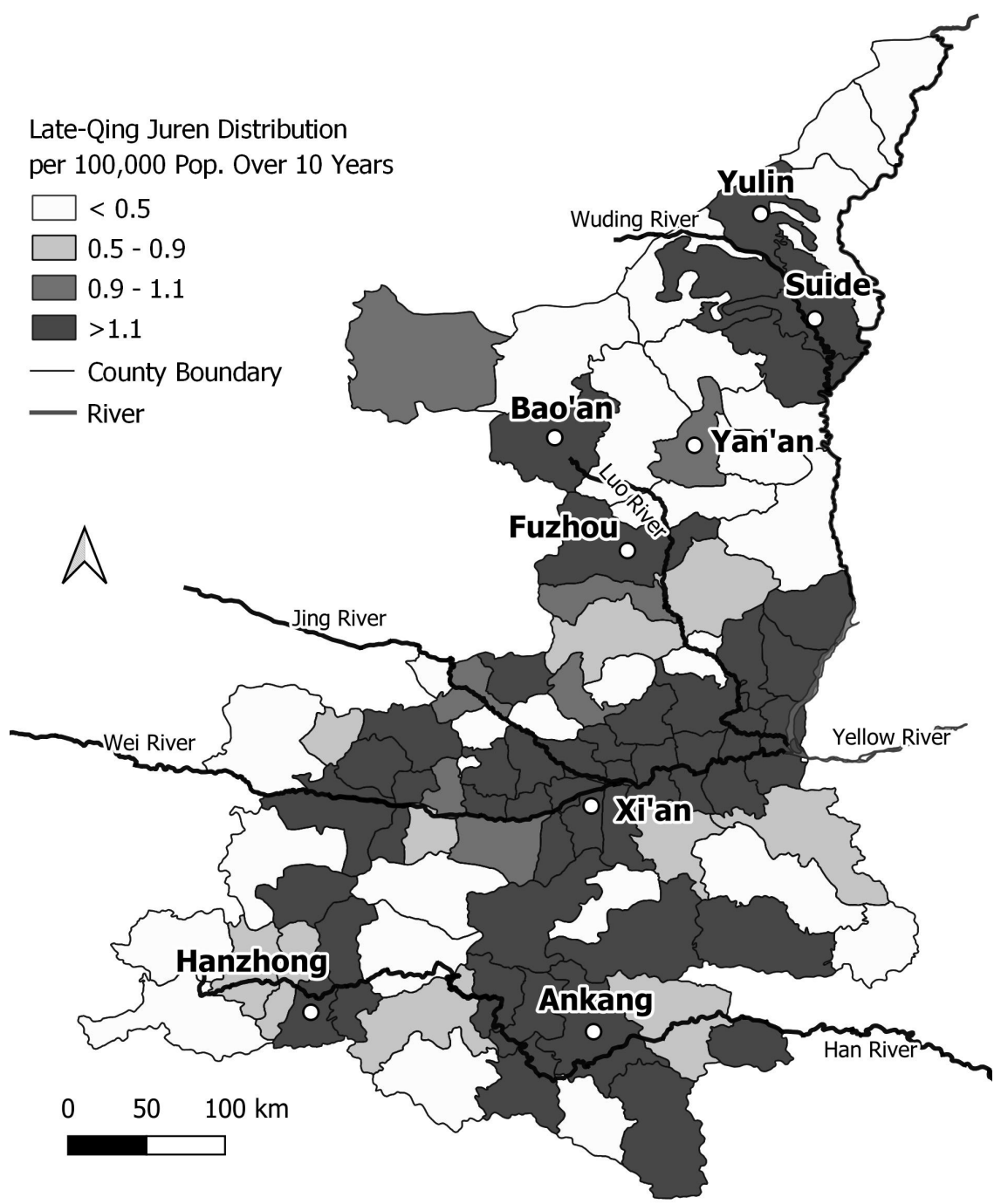

MAP 4. Late Qing (Tongzhi-Guangxu reigns) juren distribution by county: average number of provincial degrees awarded every ten years per 100,000 population. SOURCE: Juren figures same as Map 2; Population from 1930 same as Map 3.

established gentry networks. In addition, a comparison with map 2 reveals that southern Shaanxi was now competing successfully in the exams, while Shaanbei continued to trail behind. Within Shaanbei, the emergence of a dominant northeastern core that is shown by the population statistics is even more pronounced in gentry figures. Yulin and Mizhi were significant centers of gentry power with over three juren per hundred thousand population over forty years, comparable to most Guanzhong counties, though many in the Wei River valley (including 
counties where the population had been reduced by the elimination of the Hui) had twice this number. Suide, where the prefectural examinations were held, had a significant number, as did Fuzhou, which as an independent department was higher in the administrative hierarchy than an ordinary county. Yan'an, by contrast, went into sharp decline. As a prefectural capital, it produced a respectable nine juren in the mid-Qing reigns of Qianlong and Jiaqing (1735-1820). Then in the final years of the dynasty, it produced only two, compared to the eighteen from Mizhi and twenty-three from Yulin. The one apparent exception in the lagging northwest was Baoan. Its 1.8 juren per 100,000 population looks quite respectable until one realizes that this represents a single higher-degree holder (the only one in the entire Qing reign), an impressive achievement only because the county's post-rebellion population was so small. More importantly, further scrutiny reveals that the successful candidate was not from Bao'an at all but a native of Hubei, no doubt the son of an officer who had come with Zuo Zongtang's army. ${ }^{135}$

There were many ways in which a strong gentry influenced local governance. As we have seen above, degree-holding gentry were the social equals of county magistrates and served as effective representatives of the local community. One important function was leading appeals for tax remissions in times of poor harvests. As major landowners, the gentry were key beneficiaries of such relief, but the general population profited as well. Though Shaanxi suffered from major droughts in 1877-78 and again in 1900, most of the successful appeals for tax relief came from the Wei River valley, and in Shaanbei, from Yulin. ${ }^{136}$ In the late Qing, Mizhi and Suide became the cultural centers of Shanbei, with the best schools and the strongest landlord gentry elites. ${ }^{137}$ Mizhi lay between the political and military centers of Yulin and Suide and came to be recognized as a major cultural center, with a Confucian academy and a strong system of primary schools. ${ }^{138}$ These schools formed the foundation for the educational system of the republican era, with the northeastern counties along the Wuding River attracting students and future Communists from the entire region. As centers of education and orthodox gentry authority, this area stood in striking contrast to the counties of the northwest, where, as we have seen above, exam-qualified gentry were absent and the term gentry was applied to ordinary rural functionaries without academic qualifications.

\section{THE END OF EMPIRE}

At the dawn of the twentieth century, Shaanxi sank deeper into its modern status as a "backward" corner of the empire. The final decline of the Qing began in 1895, when its military was defeated by the forces of its rapidly modernizing neighbor, Japan. Ambitious reformers convinced the young Guangxu emperor to launch an impressive program of reform, but the Empress Dowager Cixi intervened to quash 
the effort and soon allied with xenophobic princes to support the antiforeign Boxer Uprising. This in turn sparked intervention by an international expedition, which occupied the capital and drove the court to refuge in Xian. There it rested in deep seclusion while foreign diplomats and Qing officials ultimately decided not to hold the empress dowager responsible for the Boxer catastrophe but to allow her to preside over the final years of the dying dynasty. ${ }^{139}$

Though later histories would focus on its impending demise, the last years of the Qing were in fact characterized by a vigorous program of economic, social, and political reform. The Confucian examinations were replaced by a modern school system whose curriculum included science and foreign languages. Students traveled abroad to absorb the new knowledge necessary for a modern state. A New Army was mandated with Western weapons and training. Industry was promoted, railways were built, and chambers of commerce were founded in cities across the country. In coastal cities, streets were paved, widened, lighted, and patrolled by police, while municipal reforms brought parks, museums, libraries, streetcars, and department stores. The imperial government replaced the old Six Boards with modern ministries of finance, communications, and foreign affairs and initiated constitutional reform with gentry-elected provincial and national assemblies. ${ }^{140}$

These dramatic changes had little impact in Shaanxi and none at all in Shaanbei. Shaanxi's New Army existed in name only, ${ }^{141}$ and provincial interests blocked efforts to build a railway to Xian with foreign loans. Mechanized industry was unknown; and education reform was slow and essentially confined to the Wei River valley. ${ }^{142}$ Elsewhere in China, great hope was placed in the constitutional reforms, designed to unify the country with a new sense of national purpose. Prominent gentry were elected to leading positions in the provincial assemblies, in preparation for constitutional government with a cabinet responsible to an elected legislature. ${ }^{143}$ Shaanxi, however, was a marginal participant in this movement, with Shaanbei particularly excluded. The provincial assembly franchise was essentially limited to gentry members, and the Shaanbei gentry was exceptionally weak. Only three of the sixty-six provincial assembly members came from Shaanbei, while twenty-two represented the provincial capital. ${ }^{144}$

On October 10, 1911, a mutiny among soldiers in Wuchang, the capital of Hubei Province, set off a revolution that soon spread through most of southern China and by February 1912 had toppled the Qing dynasty and ended two millennia of imperial rule. The 1911 Revolution launched China on nearly a century of revolution that would last until the Cultural Revolution finally convinced Chinese leaders that revolution was not always the best solution to the nation's problems. ${ }^{145}$ Shaanxi, on October 23, was one of the first provinces to join the revolutionary movement. The uprising in Shaanxi, however, differed markedly from that in the south, where progressive members of the provincial assemblies joined New Army officers to establish the new regime. In Shaanxi, by contrast, a small group of revolutionaries relied on the substantial influence of the Society of Brothers to carry out their insurrection. 
Anti-Manchu sentiment drove the revolutionary movement in Shaanxi. Students read old texts describing the Manchus' atrocities when they conquered China centuries earlier, and some Shaanxi scholars promoted arcane versions of Ming loyalism. In the quest for new learning, some students went to study in Japan, where they came in contact with Sun Yat-sen and other revolutionaries who in 1905 founded the Revolutionary Alliance (Tongmenghui 同盟會). Backward and isolated as Shaanxi was, Northwest students in Japan were few, and most came from a couple of schools in Xi'an and Sanyuan. About thirty joined the Revolutionary Alliance. ${ }^{146}$ On their return to China, many became teachers and quietly spread radical ideas in the new schools, but a few joined the army, where their anti-Manchu message was embraced by common soldiers in the Society of Brothers. As we have seen, the Society of Brothers came to Shaanxi with Zuo Zongtang's army from the Yangzi valley. For young men away from the comfort and companionship of home and family, the brotherhood offered a familiar and supportive community. Each lodge (tang 堂 or shantang 山堂) of the Brothers had its own leader, often a charismatic figure who might compete or cooperate with other leaders of the society. The rituals of sworn brotherhood, which included drinking the blood of a freshly killed chicken mixed with wine, created bonds of loyalty that are most comparable to those of the Mafia. ${ }^{147}$ The strength of the society, both in the army and later in bandit gangs in the north, made it virtually inevitable that revolutionaries - from the Revolutionary Alliance of the late Qing to the Communists of the 1930s-would join the Society of Brothers in search of young men willing to fight for their cause. ${ }^{148}$

In the summer of 1910, a number of young revolutionaries and Society of Brothers members gathered at Xi'an's famous Great Goose Pagoda (Dayanta 大雁塔) for a solemn blood oath of alliance against the Qing. ${ }^{149}$ Above all, the two groups were united in their opposition to the Manchus, whose large, idle, and ineffective garrison was a visible target of displeasure. When the Manchu governor cut salaries in the army, restlessness among the ordinary soldiers of the brotherhood increased. ${ }^{150}$

When the Wuchang Uprising broke out in the south, revolutionaries and Brothers in the Shaanxi army quickly met to respond. On October 22, they broke into the poorly guarded armory, distributed a mismatched batch of weapons and ammunition, and quickly took command of the city. The next day they launched an all-out assault on the Manchu quarter, breached the walls with their cannons, killed well over a thousand Manchus, and scattered the survivors to fend for themselves. With Society of Brothers soldiers in the lead, Xi'an witnessed the greatest massacre of Manchus in the country, but the city was now firmly in revolutionary hands. ${ }^{151}$

The revolutionaries now controlled Xian, but in North China, Shaanxi alone had joined the insurrection. The Manchu governor escaped to Gansu to organize an offensive from the west, and the court dispatched an army to take the fortress at Tongguan in the east. The new military government in Xian expanded the army from one brigade to eight regiments, which at full strength represented a fourfold 
increase. ${ }^{152}$ The key commanders proved effective in fighting off the Manchu loyalists, but the individual Society of Brothers lodge leaders each required a post for himself, resulting in four competing power centers. All of the focus was of course on the Guanzhong region. ${ }^{153}$ The north was left to fend for itself.

The schools that had nourished the Revolutionary Alliance scarcely existed in Shaanbei, so the 1911 Revolution there was entirely the work of the Society of Brothers. In Yulin, Brothers in the army led the uprising, targeting a corrupt prefect but also gaining a degree of cooperation from the local daotai until he was summoned to Xian and killed on the way. Most of the surrounding counties followed Yulin's lead to support the revolution, ${ }^{154}$ but in Suide, with its powerful militia and gentry leadership, the Society of Brothers "robbers" were executed or driven off. In Yan'an, the Society was reported to be "more numerous in proportion to the population ... than anywhere else in Shensi." The local military commander asked more funds to defend the city, but when the gentry refused, he fled. The local head of the Society of Brothers was an illiterate flour shop owner, and he was put in charge to maintain order. ${ }^{155} \mathrm{~A}$ similar process seems to have taken place throughout Shaanbei. Society of Brothers leaders in the army made deals with local elites and officials to assume or share power, and a new "revolutionary" regime was established. ${ }^{156}$

The new Republic of China soon proved a great disappointment. The Revolutionary Alliance represented a general discontent with Manchu rule, but real power lay with the powerful New Army in the north and its creator, Yuan Shikai. Yuan was a military man who had risen to a commanding position in the Qing bureaucracy before he was dismissed in 1909 by the regent for the young last emperor. In the end, the court was forced to recall Yuan as prime minister, from which position he negotiated the abdication of the emperor and his own elevation to president of the Republic. Yuan's generals soon became the warlords who dominated most of China. In Shaanxi, however, it was not Yuan's troops that held power but the commanders who rose with the Society of Brothers-led revolution. They and opportunist followers became the base of the new regime. Lacking funds, the Shaanxi warlords soon turned to promoting and taxing opium production to support their expanded armies. When soldiers went unpaid, they turned to banditry. Isolated from any prospect of economic development, the province lagged farther and farther behind the coastal regions. Shaanxi was certainly ready for another revolution. But it would be a long time coming. 


\section{Shaanxi's Early Communist Movement}

In many respects, the Communist movement in Shaanxi resembled that in other Chinese provinces: young men in elite schools, inspired by new ideas and motivated by a passionate patriotism, gathered with friends to share concerns and publish journals advancing an increasingly radical vision of social transformation and national regeneration. But Shaanxi was not like other provinces, and inevitably the concerns of these young men reflected the conditions of their physically isolated and culturally conservative home. To understand the long and tortuous journey traversed by the revolutionary movement in Shaanxi, we must grasp both its general and its particular characteristics. The former allowed it to join the larger revolutionary movement in China; the latter let it sink roots in the fertile soil of Shaanxi. The two tendencies persisted throughout the history of the revolution, periodically manifest in sharp conflicts between local and national leaders. Although northern Shaanxi became the center of the Communist movement from 1935 to 1948, the tension between the local party and the Center endured. To understand this dynamic, we must start with the Shaanxi party's early history.

\section{MAY FOURTH AND THE NEW CULTURE MOVEMENT}

In the early Republic, Beijing was both the political and the cultural capital of China. The presidency of Yuan Shikai ended with his death in 1916, following Yuan's abortive attempt to restore monarchial rule. Yuan was succeeded by a series of brief and ineffective warlord governments, whose conservatism and incompetence frustrated the high hopes of the 1911 Revolution. Sun Yat-sen was driven into exile, and his Revolutionary Alliance was reorganized as the Nationalist Party (Guomindang, or Kuomintang in an earlier spelling), which struggled through its own internal divisions to maintain a fragile base in Sun's home province of Guangdong, far to the south. 
Through these troubled years, China's intellectuals engaged in wide-ranging debates over the source of China's problems and the way forward. Many were in Beijing, and ambitious and talented students from across the country were attracted to the distinguished faculty and intellectual dynamism of Peking University or to the new pedagogy of the less expensive Beijing Higher Normal School. As college students at elite schools, they were a privileged and talented group. Though many came from rural families of moderate means, they had teachers and associates who inspired and supported them to seek the new learning promoted in China's coastal cities. Shaanxi students were a distinct minority in the national capital, and they tended to stick together-one group forming an eating club to enjoy their local cuisine. Beijing food was not to their taste, and a substantial meal of Shaanxi dishes brought them together on Sundays and holidays. ${ }^{1}$ They lived in an area popular among young students; Mao Zedong had lived in a neighboring compound during his Beijing sojourn in 1918. ${ }^{2}$ Their greatest concern was the dismal condition of their native province, and they formed a Shaanxi student association to appeal for an end to chronic internecine warfare, publishing a small handbill entitled “Anguished Words on the Shaanxi Disaster" (Qinjie tonghua 秦劫痛话) to expose the "dark and backward" side of their home. ${ }^{3}$

Among these students were Wei Yechou, from a rural family in Xingping near Xian, and Li Zizhou, son of a silversmith in Suide, northern Shaanxi. The two had studied together in Xian under a progressive teacher inspired by Sun Yat-sen's program for China's revival, and they arrived in Beijing in time to participate in the May Fourth Movement of 1919, the patriotic student movement protesting the Versailles Peace Treaty's granting of the German concessions in Shandong to Japan rather than returning them to China. The intellectual dynamism spawned by the May Fourth Movement produced a flood of spirited student publications, and in January 1920 the Shaanxi activists joined this tide with a magazine called the Shaanxi Clarion (Qinzhong 秦钟).

In the May Fourth era, progressive intellectual life in Beijing was infused with enthusiasm for the New Culture ideals of science and democracy, and the Shaanxi Clarion fully reflected that spirit. ${ }^{4}$ Its founding principles were freedom, justice, and human rights - the ideals of the Republican Revolution that had been frustrated by imperialism and warlordism. Evoking the common image of China as a sleeping giant, it sought to awaken (juewu) the youth of Shaanxi to realize that "the old [Confucian] virtues are not appropriate for life in the present age." Wei Yechou introduced his Shaanxi readers to "The New Thinking beyond Tongguan," the pass that had long sheltered the province from invasion but that now blocked the introduction of new ideas from the coast. The heart of this new thinking was "1. a scientific attitude, 2. a democratic spirit, and 3. a progressive view of life." Above all Wei urged a critical spirit toward the ancient shibboleths of Chinese culture, urging young people to always ask "Why?"6 When May Fourth youths advocated for science, they meant precisely this critical spirit-not some later notion 
of progress through technological advance. Future issues promoted democracy, using the May Fourth rendering as “de-mo-ke-la-xi” (德莫克拉西) rather than the later minzhu (民主)—a usage that underlined its Western implications of liberal democracy. ${ }^{7}$

The Shaanxi Clarion quickly aroused the opposition of conservative civil and military officials in Shaanxi for everything from its use of the vernacular baihua to its criticism of Confucianism and promotion of radical ideas of gender equality. ${ }^{8}$ This opposition plus internal divisions led to the collapse of the journal in the summer of 1920, replaced in the following year by Common Progress (Gongjin 共进), house organ of a student association of the same name. Four years later, Wei Yechou reflected on the origins of the Society for Common Progress: "Our association was born in response to the confused and immature cultural movement that came with the May Fourth Movement. Its pure-minded search for improvement and innovation was romantic, its ideas unfocused, and all sorts of problems were discussed. .. Because we began as a group of friends, we stressed friendship and common feelings, and thought that good friends were the same as comrades [tongzhi]." The lack of unifying principles and the different conditions under which members lived gave rise to a variety of different opinions, and soon a split deprived the society of almost half its members. ${ }^{9}$ By the time of this speech, Wei was already a member of the Chinese Communist Party (CCP) and was urging a more disciplined approach to political struggle, but that would take time to evolve. The founding charter of the Society for Common Progress had indeed referred to its members as "comrades," but in 1922 that term reflected a shared "interest in self-cultivation" and the society required of its members certain minimum standards of "taste and character." ${ }^{10}$ At its start, this was a gathering of progressive intellectuals committed to leading their province forward as much by the example of their personal virtue as by the content of their political program.

Like its predecessor, Common Progress ran articles on a variety of classic themes of the New Culture movement: use of the vernacular language, reform of education, opposition to the worship of Confucius, criticism of patriarchy as the social foundation of despotism, the elimination of arranged marriage, the evils of opium, the peril posed by the threat of imperialism and warlordism, and hopes for a future guided by the awakened youth of China. ${ }^{11}$ Over time, leftist political themes colored this agenda of social and cultural change, but this was hardly a steady process toward Marxist orthodoxy. The progressive youth of Shaanxi were struggling, each in his own way (for they were still all male), toward a more viable political strategy in a national and local context that was constantly in flux. The evolution of these young intellectuals' radicalism is reflected in their journal's discussions of Bolshevism and the Russian Revolution.

When Russia’s October Revolution brought the Bolsheviks to power in 1917, the news reached China through foreign media, which were either hostile or noncommittal. A dramatic turning point came in July 1918 when Li Dazhao, the energetic 
and influential librarian at Peking University, published a series of articles in praise of the revolution. Li Dazhao, a popular figure among Beijing's young radicals, a "fatherly patron" in the apt words of Hans van de Ven, is generally recognized as one of the founders of the Chinese Communist Party, ${ }^{12}$ though he was not present in 1921 when a small group of intellectuals gathered in Shanghai for the first party congress. Li's initial writings on the Russian Revolution reflected populist views and a chiliastic enthusiasm more than any rigorous Marxism. ${ }^{13}$ Both Li Zizhou, himself a Peking University student, and Wei Yechou were among his acolytes, and he later allegedly introduced both into the CCP. ${ }^{14}$ It is not surprising, then, that the Shaanxi radicals' journals presented a view of Bolshevism quite distinct from any orthodox Marxism-Leninism.

The first discussion of Bolshevism came in the penultimate issue of the Shaanxi Clarion. It began by criticizing the contemporary term for Bolshevism, Guojidang (过激党, literally “radical party"), as an incorrect translation introduced by the "little Japanese imperialists." Dismissing Marxist economic theories of production and distribution as beyond the author's concern, the article identified three fundamental principles of Bolshevism: overturning militarism, overthrowing the privileged class (teshu jieji 特殊阶级), and ending private property. Its aim was "equality, happiness, justice and humanity." Despite this rather naive understanding of Bolshevism, the article concluded on a surprising note: the way to avoid Bolshevism was to build a secure, free, egalitarian, and democratic China. At this stage, in the summer of 1920 , the Shaanxi Clarion was still introducing Bolshevism as a radical path to be avoided through the introduction of democratic reforms. ${ }^{15}$

By the summer of 1922, Common Progress was acting more like a front for the CCP. In July, it reprinted the June 15, 1922, declaration of the party. This declaration, coming after the party had joined Sun Yat-sen's Nationalist Party in a united front, identified the Communist Party as the "vanguard of the proletariat" but stressed the need to work with democratic forces since the proletariat was not yet mature enough to take power. The concrete measures that the journal proposed were very much in line with progressive intellectual opinion and Nationalist Party orthodoxy: tariff reform and the abolition of extraterritoriality, elimination of the warlords, universal suffrage, freedom of speech and assembly, progressive taxation, and equal rights for women. ${ }^{16}$ Even while celebrating the sixth anniversary of the Russian Revolution, Common Progress declared, "Of course China's problems are not the same as Russia's problems; and we absolutely cannot say that what they did is what we should do." ${ }^{17}$ At this point, the Russian Revolution was an inspiration, not a model.

If there was one point that divided Communists and Nationalists, it was the issue of class struggle. Common Progress was filled with discussions of class, but they bore little resemblance to Marxist classes defined by the relations of production. Li Zizhou published a poem in 1923 in honor of the railway workers killed when the northern warlords suppressed their strike in the infamous "February 7 
Incident." It opened with the line "The class war has begun," but the class he referred to was not the proletariat but "the class of common people" (pingmin jieji 平民阶级). ${ }^{18}$ A 1924 article titled “Class Struggle and Class Consciousness" referred to popular discussions of the "armed class" and the "unarmed class." On the one hand, this reflected a common preoccupation with the fight against militarism; on the other hand, the reference to an "unarmed class" (wuqiang jieji 无枪阶级) was a pun that put intellectuals in the place of the "proletariat" (wuchan jieji 无产阶级). ${ }^{19}$ This commitment to intellectual primacy was most explicit in a notable article by Liu Tianzhang, a founder of the Society for Common Progress, one of the most prolific contributors to its journal, a later Communist, and soon a martyr of the revolution. Imagining Shaanxi after the expulsion of a hated warlord, he proposed a “regency of the intellectual class" (zhishi jieji shezheng 知识阶级摄政) and later described the emerging world as "the age of intellectual dictatorship" (zhishi jieji zhuanzheng shidai 知识阶级专政时代). ${ }^{20}$

Over time, these young radicals recognized that students and intellectuals alone could not transform China. But their vision was still far from a rigorous Marxism. In 1925, the Second Congress of the Society for Common Progress identified China's "two big classes": "One is the imperialists and their warlord tools, the running dogs of the warlords, the politicians and officials, evil gentry and corrupt functionaries, and all evil powers combined to form the ruling class. The other [class] is the mass majority oppressed by this ruling class: the peasants, workers and small merchants, the ruled class." ${ }^{21}$ This was a very broad conception of "class," essentially dividing the world between the imperialists and their warlord allies on the one hand, and the broad mass of the Chinese people on the other. It reminds us of Mao Zedong's early article "The Great Union of the Popular Masses."22 More importantly, it coincided with the Nationalist Party's commitment to a broad popular movement against the twin ills of warlordism and imperialism.

\section{REFORMING A BACKWARD PROVINCE}

In the respects just enumerated, the young radicals who would soon lead the Communist Party in Shaanxi were much like early Communists elsewhere: young male patriots, exposed in the coastal cities to May Fourth ideals of science and democracy, opponents of autocracy, militarism, and imperialism, inspired by the Russian Revolution but not entirely clear about what Marxism-Leninism meant, and enthusiastic supporters of a revolutionary movement led by Sun Yat-sen and backed by the Communist Party. In other respects, their concerns and convictions were very much shaped by the specific conditions of their province.

No stereotype was more pervasive than the isolation and backwardness of Shaanxi, and indeed of China's entire Northwest. The Shaanxi Clarion compared progress in the rest of China to Shaanxi, "far in the west, with transport inconvenient and news sparse. The place is so dreary, the people so antiquated and 
stubborn, there is no one to promote the new culture or new ideas." ${ }^{23}$ An article on "the shame of Shaanxi" attributed the province's conservative culture to "inconvenient communication and the lack of external stimulation." ${ }^{24}$ To overcome this isolation, a railway linking Xian to the coast had been planned since the late Qing, but it would not be completed until December 1934. Foreigners also referred to the "old and isolated province of Shensi" and observed that from Beijing it took longer to reach Xian than London. ${ }^{25}$ Isolated in the interior, Shaanxi was left behind while others forged ahead, and the sense of despair among its youth was palpable: "Our Shaanxi is in a remote area, far from those [new] tides [of learning], and life still follows the old ways. If things go on like this, not only will we be unable to compete with the West, we won't even be able to catch up with other provinces."26

The cause that aroused the most passion among these young intellectuals was opposition to the warlords who ruled their province. Anti-warlord sentiment was certainly not unique to Shaanxi: it was a pervasive theme of May Fourth writings. Warlords represented a new military class that offended Chinese traditions of civilian rule, frustrated the new intellectuals' ambitions for political leadership, and contravened global opposition to militarism in the wake of World War I. ${ }^{27}$ In Shaanxi, the first object of their criticism was Chen Shufan, the military officer and Society of Brothers member who had joined the 1911 uprising at the last moment, then risen to power by ingratiating himself with Yuan Shikai and his warlord successors. Though Chen was a Shaanxi native, his harsh rule was widely resented by progressive intellectuals. ${ }^{28}$ The early 1920 s brought a prolonged and bitter campaign against Liu Zhenhua, the Henan warlord who dominated Shaanxi from the fall of 1921. This movement combined righteous intellectual opposition to the "armed class" with a parochial commitment to provincial rule by Shaanxi men. ${ }^{29}$ There was broad support for self-government, and while the activists wanted to import new ideas to lead their "backward" province forward, they did not want political leadership to come from outsiders. Routinely condemned as a "Henan bandit warlord," Liu was blamed for the incessant conflict among the province's petty local warlords, the promotion of opium cultivation for tax revenue, the corruption of officialdom, and the decline in social order. He came to represent everything that was wrong with Shaanxi under warlord rule. ${ }^{30}$

In China's coastal provinces, change was in the air: the spread of new ideas from the May Fourth movement, educational reform, improvements in communication, new municipal governance, and even a burst of industrial activity while Europe was still recovering from World War I. Meanwhile, in Shaanxi, things seemed to be moving in the opposite direction. Commentators noted three things that left their province worse than under the empire: warlords, opium, and bandits. The 1911 Revolution brought a massive increase in the size of the military, as Shaanxi revolutionaries fought Qing loyalists from Henan to the east and Gansu to the west. When bands from the Society of Brothers seized power in the counties, Shaanxi was consumed by competing military satraps, each seeking to secure and 
expand its base. Needing funds, these local militarists increased taxes. The opium tax was the most profitable, as the late Qing efforts at opium prohibition were reversed and warlords mandated opium production for its tax revenue, resulting in widespread cultivation in the best-irrigated fields. ${ }^{31}$

The spread of banditry was another corrosive consequence of warlord rule. The process began with the fall of the Qing in 1911, but the size of bandit gangs and the severity of their attacks increased in the 1920s. In the constant battles between competing warlords, defeated soldiers either joined a bandit gang or abandoned their weapons and fled, a choice that made guns available to outlaw gangs. Bandits preyed on commerce, thus retarding economic development, and made it difficult for students to travel to Beijing, enhancing the province's isolation from modern influences. ${ }^{32} \mathrm{~A}$ long and persuasive article in Common Progress on "the bandits of Shaanxi" argued that bandits had been rare under the Qing. Largely concentrated in the Huanglong mountains north of the Wei River valley, they had rarely attacked innocent villagers. ${ }^{33}$ Foreigners traveling through Shaanxi before the 1911 Revolution agreed. In 1908-9, an American surveying party passing through northern Shaanxi reported that in the hills south of Yanan, where occasional robberies had once occurred, an improved road and a nearby garrison had eliminated the problem. ${ }^{34}$ The Common Progress article attributed the republican era banditry to the "uneducated revolutionaries" and Society of Brothers thugs (liumang) who had led the 1911 Revolution. To an earlier generation of revolutionaries, the Society of Brothers was a popular force to overthrow Manchu rule. Now the Society represented poorly educated, culturally conservative, and unruly elements who welcomed their bandit Brothers into the army. The result, however, was that "the more you pacify, the more bandits there are." Unpaid soldiers would mutiny, occupy a town, then await pacification and a path to official recognition, increased funding, and promotion in the regular army. Others would observe this practice and "see becoming a bandit as a road to wealth and position." Sometimes decent law-abiding peasants joined a bandit gang to gain advantage in a local feud; and unemployed former students might "see bandit gangs as a disbursement office." In the end, officials were responsible for Shaanxi's banditry: "If bandits were not protected and nourished by officials and armed by officials, the bandit scourge would not spread without end." ${ }^{35} \mathrm{~A}$ foreign traveler had a similar analysis: bandits in Shaanxi were "mostly ex-soldiers and Ko Lao Hui men [Society of Brothers], and are composed of the same material as the provincial troops, with whom they exchange roles from time to time."36

As we shall see, a later generation of Communists would again view bandits as a revolutionary force to be harnessed; but the Common Progress radicals saw them as a plague on the people. Their solution was not so different from that of the late Qing: to "arouse upright gentry to organize militia and seek a path to local selfgovernment." ${ }^{37}$ Unfortunately, to raise a militia, the best option was often to recruit the bandit gang that had occupied a town to await "pacification." Brigands had so 
entered the fabric of Shaanxi politics and society that tufei was a term routinely applied to one's opponents, and "bandit" can be a misleading translation. By and large, these were not Robin Hood bands hiding in the woods. They occupied villages and towns in bands that might number in the hundreds. Often better-armed and more determined fighters than local militia, they could be a formidable military force. When they supported themselves by collecting protection money from the local population, they were not so different from a tax-collecting local warlord. In any event, they were most surely a part of the "armed class" and a force that the radical intellectuals opposed.

In this grim context of warlords, opium, and bandits, the new schools springing up in Shaanxi became the primary force for change and flash points of conflict with the authorities. Once they finished their studies in Beijing and other coastal cities, progressive students were reluctant to take jobs in a provincial administration they so bitterly opposed. ${ }^{38}$ The new schools provided a refuge, often under the protection of sympathetic local elites. Students and progressive teachers were constantly at odds with conservatives in the education establishment, and student strikes abounded. Naturally, most new schools were in the Wei River valley, especially in Xi'an and Sanyuan, the commercial and cultural center north of the river. But Shaanbei had modern schools in the richer and better educated northeast of the province.

In 1916, Jing Yuexiu was appointed commander of the garrison in Yulin, a post that he held until he died in 1936, shot when his pistol dropped and discharged while he was relaxing with his opium pipe. Jing was a military school graduate from a prosperous merchant family in Pucheng in Guanzhong, a member of the late Qing provincial assembly who qualified not from any academic degree but from his family's wealth. His younger brother had studied in Japan and returned to found the Shaanxi branch of the Revolutionary Alliance. Well connected to both revolutionaries and Society of Brothers leaders of the 1911 Revolution, Jing Yuexiu distinguished himself in defense of the new regime and in 1916 was appointed to command in Yulin. For twenty years, he served as the "local emperor" (tuhuangdi) of Shaanbei, settling disputes with the Mongols, hunting bandits, and taxing opium fields to support his army. He promoted local education, industry, and military modernization. Although Jing would later become a fierce anti-Communist, in the early 1920 s his support of the Nationalist Party and promotion of local education, industry, and military modernization made him an ally of the early progressives. ${ }^{39}$

Yulin Middle School, established by Jing Yuexiu to serve all twenty-three counties of Shaanbei, was an early center of radical activism. Du Bincheng, from a prominent gentry family in neighboring Mizhi, returned from Beijing Higher Normal School to reform education in Yulin, first as education director and after 1918 as principal of Yulin Middle School. In the early 1920s, he would hire both Wei Yechou and Li Zizhou as teachers. Among their students would be two men who later led the guerrilla movement in Shaanbei: Liu Zhidan and Xie Zichang. 
When Gao Gang, the most prominent Shaanbei leader of the wartime period and a national leader until purged in 1953, was kicked out of his local school for leading a protest against "slavish education," Du Bincheng took him in at Yulin Middle School. ${ }^{40}$ Wei Yechou's teaching position in Yulin would soon be ended by conservative opposition; but in 1924 the provincial Fourth Normal School was established in Suide, the second relatively prosperous political center in northeast Shaanxi, and Li Zizhou (himself a Suide native) was named principal. Protected by a sympathetic magistrate, Li promoted the Society for Common Progress and the Nationalist Party among his students and used them to recruit a smaller elite group into the Communist Party. ${ }^{41}$

In the 1920s, under Li Zizhou's influence, Suide became the center of progressive activism in northern Shaanxi. In general, party organizers from outside the region found it hopelessly backward, "two to three centuries behind the southeast provinces." ${ }^{2}$ It did not seem a promising base for revolution. Repeating the old shibboleths, they wrote that "in Shaanbei, the land is barren and the people few; most peasants' enthusiasm for revolution is behind Hanzhong [southern Shaanxi] or Guanzhong." ${ }^{43}$ But Suide was a cultural center in the region, with a local elite of liberal leanings, prohibiting opium and gambling and allowing young women to cut their hair, wear skirts, and walk the streets to school. The local party looked to Li Dazhao in Beijing for leadership, and in addition to Li Zizhou, the Peking University librarian sent several students to teach and organize there. At Suide Normal, Li Zizhou openly taught Marxist texts and strongly supported Sun Yat-sen's program of alliance with Russia. The local military was small but supportive, and Communist officers soon commanded most of the units. Communist control of the educational establishment was critical, and the party was able to appoint its members to teaching positions in local primary and middle schools. ${ }^{44}$ Through the schools they promoted cultural issues popular with the young: opposing foot-binding and arranged marriages, supporting young women who chose to bob their hair. Conservative teachers who continued to insist on traditional virtues of obedience and reverence to ancient wisdom were a favorite target of student protests. These same issues, however, reflected a certain isolation from the great mass of peasants, and when students attacked "superstition" in local temples, many villagers organized “spirit soldiers" (shenbing 神兵) to resist. ${ }^{45}$

By late 1926, both Wei Yechou and Li Zizhou had left northern Shaanxi. Though radical activity and peasant organizing continued in the counties around Suide, the center of cultural conflict shifted to the more developed educational system in the Wei River valley. In the area around Xian, students engaged in repeated protests and strikes against conservative administrators, Confucian education, prohibitions on young women's new haircuts, and warlord attacks on students; over such national issues as the Washington Conference and Japanese aggression in Manchuria; for the National Congress promoted by Sun Yat-sen in 1925; and in mourning of Sun's death in the spring of that year. ${ }^{46}$ 
Although party history accounts describe massive protests led by Communist activists in the student movement, contemporary records paint a different picture. The first central party agents arrived in 1922 from Wuhan, representing the Socialist Youth Corps (Zhongguo shehui zhuyi qingniantuan 中国社会主义青年团). They reported in 1924 that they were unable to operate openly in "bleak and sunless Shaanxi." ${ }^{\prime 7}$ Dependent on the Center for financial support, they repeatedly appealed for funds. ${ }^{48}$ All of their activities were based in the schools, and progress required the leadership of the few Communist teachers. ${ }^{49}$ Even in the schools, Communist numbers were miniscule, and the party was more successful in dominating student organizations than in reaching the mass of students. ${ }^{50}$ They faced competition from anarchists on the left and Nationalist Party conservatives on the right. ${ }^{51}$ Even those sympathetic to communism felt the country was not ready for it, and they fully supported only the Guomindang's program of national revolution. ${ }^{52}$ In early 1925, Xi'an had two competing Socialist Youth cells of only a dozen members each. They distrusted each other deeply, especially the non-student members whose loose morals led to suspicions of "hooliganism" (mangqi 讯气). The straitlaced Socialist Youth leaders were offended when members of the rival clique watched operas, visited prostitutes, or smoked opium. ${ }^{53}$ Obviously, the early progressives' commitment to personal virtue continued in the formative period of the Shaanxi party. In northern Shaanxi, without the leadership of committed teachers, even when students "awakened" to the new culture, this only meant that they were "drunk with maudlin poetry and thoughts of love." 54

To the extent that leftist students and intellectuals gained influence in Shaanxi, it was through their ties to the Nationalist Party and connections to local elites with power and influence. The journal Shaanxi Clarion listed Du Bincheng in Yulin and the Nationalist Party veteran Yu Youren in Sanyuan as distributors, providing excellent cover for its radical ideas. ${ }^{55} \mathrm{Du}$ Bincheng would soon leave Yulin and enter the entourage of Shaanxi warlord Yang Hucheng, where he would maintain contacts with and offer assistance to beleaguered party members. Yang himself had clear leftist sympathies. After his father was executed by a Qing magistrate, he had joined the 1911 Revolution and then a bandit army claiming to "rob the rich and aid the poor." He was protected by Jing Yuexiu and befriended by Wei Yechou when recovering in Yulin from defeat in Guanzhong, and he became one of the militarists most sympathetic to the party's leftist agenda, providing funds for Wei Yechou's radical journal in Xi'an. ${ }^{56}$ Yu Youren was another critical patron. A Sanyuan native from a merchant family of some means, he had passed the provincial juren examination in the late Qing before running afoul of the authorities for anti-Manchu sentiments, then went to Shanghai, where he edited several influential newspapers for Sun Yat-sen's Revolutionary Alliance in 1910-12. In the early years of the Republic, Sun sent him back to Shaanxi to establish a northern base for his revolutionary movement, and in $1918 \mathrm{Yu}$ commanded the National Pacification Army (Jingguojun 靖国军) together with Hu Jingyi, a veteran of 
the 1911 Revolution. The National Pacification Army would control fourteen counties in the Wei River valley, concentrated on the northern side of the river and centered in Yu's home county, Sanyuan. ${ }^{57}$

Sanyuan lay on the fertile Guanzhong plain, its fields watered by a series of canals built as early as the Warring States period (475-221 BCE).$^{58}$ Lying on the road to Gansu, it was, in the words of one Western visitor, "a city of great commercial importance." ${ }^{59}$ More importantly, it had more and better schools than any place in the province-indeed, under the Qing, the provincial education commissioner was based there, not in the provincial capital. ${ }^{60}$ In the 1920 , when most counties had at best a single middle school, Sanyuan had a teachers' college, two middle schools, a vocational school, and a girls' school. With active student unions, student publications, lots of extracurricular activities, and a sympathetic local government, it attracted the best and most politically active students from all the surrounding counties. ${ }^{61}$ In 1925, when Xian students got into a fight with the local warlord, went on strike, and then had their student union suppressed, Wei Yechou led the activists to Sanyuan, where they continued their protest until the unpopular warlord was driven from the province. ${ }^{62}$ With a history of connections to Sun Yat-sen's revolution and the protection of the National Pacification Army, Sanyuan provided a particularly fertile ground for revolutionary organizing. In Sanyuan, one report boasted, half of the students supported Sun Yat-sen's Three People's Principles and admired the Communist Youth members' promotion of Sun's program. Another quarter were troublemakers who opposed everything; and the final group was apolitical bookworms. ${ }^{63}$

Communists played a vital role in the Shaanxi revolution of the 1920s, but the revolution they were organizing was a national revolution, and they operated in the context of a united front with the Nationalist Party. This united front, furthermore, had a peculiar nature in which members of the CCP joined the Nationalist Party and acted in its name. As one contemporary document put it, "In all our work, in the military or among peasants, we operate in the name of the K.M.T. [sic]." ${ }^{64}$ In fact, the Nationalist Party apparatus in Shaanxi was largely built by Communists, acting on a Center directive that "wherever there is no Guomindang organization, the Communist Party should assist in establishing it." ${ }^{65}$ At the provincial level, a Communist edited the Guomindang party paper; Li Zizhou headed its organization department; and Wei Yechou was responsible for propaganda and a delegate to the Second Nationalist Party Congress. Indeed, though Wei is always claimed as a leader and soon a martyr of the Communist movement, he was a determined practitioner of what would later be condemned as an "opportunist" line of working through the Nationalists. It is often difficult to determine from his actions where his primary loyalties lay. ${ }^{66}$

An internal party document reported the consensus of early CCP members in 1925:

We can see that [activist youth] are very much in favor of communism, but they fear it is difficult to put it into practice. We must realize that our organization can 
only spread its message secretly and cannot reveal its operations. We should maintain covert relations with similar organizations domestically and internationally and work together for future realization [of our ideals]. Our present actions must be none other than working and propagandizing for the national revolution, carrying out our program though other organizations. Indeed, the recent sudden revival of the Nationalist Party and the propaganda on its behalf are entirely due to our party's activists' joining it. ${ }^{67}$

The result, however, was that whatever Communist activists may have contributed to this early stage of the revolution, and however much they pledged allegiance to and sought financial support from the CCP Center domestically and the Comintern internationally, the public face of the revolution in the 1920 s was a national revolution under the flag of the Guomindang.

The aroused youth in the new schools would provide much of the leadership and energy for this revolution. By the mid-1920s, however, it was clear that intellectuals alone could not transform China. The revolution would require military force. For this, the Nationalists had established the Whampoa Military Academy in Guangzhou, with financial support, armaments, and instructors provided by the Soviet Union. Balancing this Communist influence was the academy's commandant, Chiang Kai-shek. In the name of the Nationalist Party, such Shaanxi Communists as Liu Zhidan were sent there for training, and in all eighty students were sent from Sanyuan. ${ }^{68}$ The revolution would also require a popular base. For this, in Guangzhou, the Nationalists founded the Peasant Movement Training Institute (Nongmin yundong jiangxisuo 农民运动讲习所), briefly headed by Mao Zedong and designed to train young cadres to enter the countryside to organize peasants. In a predominantly rural province like Shaanxi, all acknowledged that the driving force of revolution would come from the peasantry. Sanyuan sent a number of young men to train for this task in Guangzhou. ${ }^{69}$

All this activity was further energized by the wave of anti-imperialist sentiment that swept the country following the May 3oth (1925) Incident, in which British-led police shot unarmed student protesters in Shanghai. The revolutionary movement in Shaanxi was certainly gaining strength when in 1926 Chiang Kai-shek launched the Northern Expedition to unify the country under the Nationalist Party banner. In the wake of that military expedition, the peasant movement spread rapidly in the Yangzi valley, especially in Hunan, where Mao Zedong was a key leader. ${ }^{70}$ The process in Shaanxi was similar. There the arrival of Feng Yuxiang and his Guominjun carried the revolutionary movement to a new stage.

\section{FENG YUXIANG AND THE NATIONAL REVOLUTION}

\section{IN SHAANXI}

Feng Yuxiang — famed as the "Christian warlord" who allegedly baptized his troops with a fire hose-was a relatively progressive militarist, who sought to train and 
discipline his troops, imparting a commitment to ethical behavior and a concern for popular welfare. He gained celebrity in 1924 when he turned on his commanders, captured the national capital, drove the retired Qing emperor from his palace in Beijing, and renamed his army the Guominjun (National People's Army). His growing power and relatively progressive policies attracted the attention of the Soviet Union, which was searching for a North China ally to balance and coordinate with the Nationalist Party in the south, and Feng began receiving arms from the Soviets. Soon, however, his army suffered setbacks and was reduced to a base in Chahar and Suiyuan, present-day Inner Mongolia. Seeking to revive his fortunes, Feng traveled to the Soviet Union in the spring of 1926 and at the same time dispatched emissaries to Guangzhou to discuss an alliance with the Nationalist Party. On the way to Moscow he was joined by Yu Youren, who promoted the alliance with the Nationalists and, presumably, Shaanxi as a suitable base for Feng's troops. When Feng returned in August, he was accompanied by Soviet military advisers and Chinese Communists who had been studying in Moscow, including Deng Xiaoping. A tortuous supply line was established to bring military equipment through Mongolia. Meanwhile, Feng was added to the National Party's Central Executive Committee, and in September a grand ceremony was staged at Wuyuan on the Inner Mongolian steppe, in which Feng swore his troops to the ideals of Sun Yat-sen's revolution and friendship with such countries as supported it-namely the Soviet Union. ${ }^{71}$

In the fall of 1926, Feng led his army on a rapid march through Gansu to Shaanxi, relieving an extended siege of Xian by the warlord Liu Zhenhua, who had returned to the province in the spring, and driving Liu's army back to his native Henan. By early 1927, the entire Wei River valley was under the command of an army allied with the Nationalist Party and the Soviet Union. After years of struggling in the darkness of a "backward" region, suddenly there was hope for a "revolutionary Northwest" far from the reach of the imperialist powers. ${ }^{72}$ With a direct overland link to the Soviet Union, Shaanxi emerged as the northern front of the National Revolution, balancing the power of Guangzhou, where, in the wake of Sun Yat-sen's death, right- and left-wing forces were engaged in an increasingly bitter struggle for control of the Nationalist Party.

In Shaanxi, leftists played a prominent role in the new regime. After his trip to Moscow, Yu Youren was regarded as a sincere leftist, and he assumed the post of Shaanxi governor. Yu quoted Lenin in his writings, circulated Leninist pamphlets, and supported workers' rights and world revolution. One pamphlet, "Communism and the Communist Party," was openly sold in party and army bookstores. ${ }^{73}$ A Sun Yat-sen Academy was established on the grounds of Northwest University to train cadres for the new regime. It was headed by several Communists, including Li Zizhou. ${ }^{74}$ A parallel Sun Yat-sen Military Academy was set up for the army, and here Communist influence was even more pronounced. It was headed by Shi Kexuan, a Moscow-returned Communist, its political department was led 
by another Communist, and Deng Xiaoping, Li Zizhou, Liu Zhidan, and several Soviet officers joined the instructional staff. ${ }^{75}$ The academy's cadets, including the later Shaanbei leader Gao Gang, would provide an important leftist military force, but the Communists also inserted themselves into Feng's National People's Army, where 80-90 percent of the political officers were said to be Communist Party members. ${ }^{76}$ Two commanders who would later have repeated interactions with the Communists, Yang Hucheng and Deng Baoshan, were regarded as particularly progressive and open to the party's message. ${ }^{77}$ Propaganda work was stressed, and Communists played leading roles in editing the Nationalist newspapers and journals in Shaanxi. ${ }^{78}$ The party's success in penetrating the new government was so pronounced that it was later criticized as overreach: "The party led comrades to occupy government offices as though they could carry out C.P. [sic] dictatorship." 79 Careerism was a threat to the party's revolutionary mission: "Comrades all race to work in the government, are divorced from the masses, and see the party as a rice bowl, a road to official position." ${ }^{0}$

As they sought to direct the revolution in Shaanxi, the Communists' most urgent task was party-building: increasing party membership and improving discipline. In February 1927, there were only 338 members in the Shaanxi CCP. ${ }^{81}$ In March came a call to increase this number to 1,200 within three months, of whom two-thirds were to be peasants. ${ }^{82}$ Soon the target was increased to 3,00o4,000 members. ${ }^{83}$ In fact, membership increased to 2,170 by May (plus roughly 200 in the army), of whom 52 percent were intellectuals, 30 percent peasants, 4 percent workers, 5 percent police or soldiers, and 8.5 percent others. There were only 58 women in the party, all "intellectuals" (probably students). ${ }^{84}$ The Communist Youth League saw a similar increase, from 525 to 2,400 members. ${ }^{85}$ But the party wanted more than just numbers, it wanted disciplined revolutionaries. Firm discipline and secret work should replace the "romantic" behavior of the past. ${ }^{86}$ The Suide branch was criticized for lax organization that allowed a spy to enter, and for being "ideologically rather simple-minded." ${ }^{77}$ The criticism was no doubt warranted, for the Suide members had mobilized around such cultural issues as opposition to foot-binding and arranged marriage, and to the "superstitious" practices of peasant society. In later memoirs, Communists recruited at this time recall being invited to join the Communist Party and having to ask what it was. One recruit from this era was introduced to the term soviet (suweiai 苏维埃) and was unsure if it was a person or a place. These youths were plainly joining the party with little knowledge of its basic doctrines. What inspired them was the reputation of the local party leader: personal connections and character were more important than ideology. ${ }^{88}$ The provincial authorities were not pleased. The Weinan committee was accused of clique struggles and localism that represented a "counterrevolutionary attack on party discipline." ${ }^{99}$ It was not easy to turn the loose group of friends who had gathered in the Society for Common Progress into a disciplined revolutionary organization. ${ }^{90}$ 
The party made the efforts required of a proletarian vanguard to organize workers in Xian, ${ }^{91}$ but the real focus of activism was the peasantry. The notion that it was only Mao Zedong and his 1927 "Report on the Peasant Movement in Hunan" that turned the party's attention to the peasantry is a myth. The Shaanxi provincial committee recognized that "the Chinese Revolution is now in the peasant revolution stage." ${ }^{92}$ By 1927, the activists sent to the Peasant Movement Training Institute in Guangzhou had returned, and local institutes of the same name were established in Sanyuan and in Shaanbei's Anding County. Students were trained to go into the surrounding countryside to organize peasant associations. The spread of these associations reflected proximity to the schools where the party was most active: Sanyuan and surrounding counties, Weinan in the eastern Guanzhong region, and Suide and surrounding counties in Shaanbei. In all, it was claimed, 370,000 peasants were enrolled (over 200,000 in another document), though the extent of these peasants' revolutionary commitment is debatable. ${ }^{93}$ As elsewhere in China, it was young students, many from rural families, who led the effort. Party operatives found that rural teachers were among the most successful peasant organizers, and in counties like Anding every rural branch was headed by a teacher. ${ }^{94}$ Keeping in mind that it required some family resources to afford a middle school education, most of these men came from families of at least moderate means. The movement that they promoted was appropriately limited. In the villages, activists were encouraged to join with rich peasants and "enlightened gentry" to oppose local bullies or bandit gangs. "In the current peasant movement, we cannot raise overly radical slogans, such as opposing miscellaneous taxes or participation in government." Organizers were specifically reminded to support Feng Yuxiang and Yu Youren..$^{95}$

The injunction to support Feng and Yu was particularly important, for it reflected the fact that the peasant movement in Shaanxi was an integral part of the National Revolution. Just as histories of the Chinese Revolution link the Hunan peasant movement to Mao Zedong and his later rise in the Communist Party, so do histories of Shaanxi focus on the leading role of the Communist Party in the peasant movement there. That leading role is undeniable, but it is equally true that the peasant movement was an integral part of the united front policies and was carried out in the name of the Nationalist Party. When a peasant congress was held in a Shaanbei county's Confucian temple, the portraits on the wall were of Sun Yat-sen and Lenin. ${ }^{96}$ The peasant associations everywhere relied on the active support of local governments and the military. The head of the provincial education bureau was a Communist, and he was able to appoint leftists as county education officials, who in turn appointed Communists and other progressives to the schools that became the local centers for peasant organizing. ${ }^{97}$ The support of Feng Yuxiang's army was also important. Feng specifically ordered his troops to assist in the establishment of peasant associations in their areas of operation. ${ }^{98}$ The CCP would later complain that their own efforts paled 
in comparison to Feng's: "Old Feng used the [1927] May Day celebrations to swear to support the interest of workers and peasants and to advance the world revolution. He went all out to steal the limelight as a Red. In contrast, our propaganda seemed very ordinary. When we put out our own leaflets, there was little response. Obviously, the minds of the masses have been numbed by Old Feng's Red rhetoric." 99 The peasant movement spread as rapidly as it did precisely because it was protected and supported by the authorities-and especially by those who controlled the guns.

As elsewhere in China, the peasants, once aroused, were not easily restrained. Both Communist and Nationalist propaganda attacked "local strongmen and evil gentry" (tuhao lieshen). ${ }^{100}$ In Shaanxi, bandit gangs, which were often disbanded or unpaid soldiers who preyed on the rural population, were another target of the peasant movement. To confront these local opponents, the peasant movement organized self-defense forces (ziweidui), though it was rare for these organizations to have more than a few firearms, usually supplied by sympathetic soldiers in Feng's army. ${ }^{101}$ The whole purpose of the movement was to empower peasants to assert their rights against those who oppressed them. Above all, they confronted those who extracted money: tax collectors. Surcharges on the land tax and expansion of various new taxes-on salt, meat, flour, tobacco, tea, lumber, and especially on opium - were some of the most hated aspects of warlord rule. ${ }^{102}$ Accordingly, at the height of the peasant movement, tax offices were targeted and records burned, and tax collectors were beaten and sometimes killed. The "evil gentry" who were targeted were often those responsible for tax collection. ${ }^{103}$ In general, the Shaanxi peasant movement of the 1920 s conforms to the pattern identified by Lucien Bianco: it was not a class struggle of peasants against landlords but a struggle of peasants against an extractive state. ${ }^{104}$

The party's injunction against attacking "miscellaneous taxes" was in vain. It was precisely these taxes that the peasants hated. But in opposing them, they threatened the revenues of Feng Yuxiang's regime. He was willing to tolerate this for a time. Even after Chiang Kai-shek turned on the CCP with the Shanghai massacre of April 1927, Feng Yuxiang wavered and seemed to lean toward the left Guomindang regime in Wuhan. But in June he met with Chiang in Xuzhou and correctly read the political winds. He threw in his lot with the Generalissimo, banned the peasant movement, and closed the Communist-edited publications. ${ }^{105}$ The radical stage of the National Revolution in Shaanxi came to an abrupt end. Feng sent the Soviet advisers in his army back to Russia and expelled the leading Communists from Shaanxi, some of whom he also sent to Russia. His was not a bloody purge on the Shanghai model-in an oft-cited phrase, the Communists were "politely escorted from the province" (lisong chujing 礼送出境)—but it drove the party underground and left its remaining operatives vulnerable to elimination. The revolution in Shaanxi had entered a new stage. ${ }^{106}$ 


\section{THE PARTY ON ITS OWN}

The early growth of the revolutionary movement in Shaanxi was fundamentally linked to the united front between the Nationalist and Communist parties. That unity did not end overnight—not with Chiang Kai-shek's April coup in Shanghai, not with Feng Yuxiang's change of heart in June. Many Communists still hoped to work with the left wing of the Guomindang in Wuhan. An emergency meeting of the party Center met in that city on August 7, 1927, with the new Comintern representative, Besso Lominadze, firmly in charge. The absent party leader, Chen Duxiu, was accused of right opportunism and blamed for the party's defeat at the hands of the Chiang Kai-shek. Nonetheless, the party still hoped to work with the left wing of the Guomindang, organizing uprisings in its name. The old leadership was also accused of unduly restraining the peasant movement, and the party now called for "systematic, planned peasant insurrections, organized on as wide a scale as possible." It recognized, however, that insurrections would require party-controlled military forces, and in this context Mao Zedong issued his famous dictum that "political power grows out of the barrel of a gun." The party now called for active propaganda on behalf of rural revolution, with soviets added to the agenda of the Communist Party in November $1927 .{ }^{107}$

Li Zizhou had been sent from Xian to attend the emergency meeting, but he arrived in Wuhan after it had adjourned. ${ }^{108}$ His oral report to the Center was remarkably frank and obviously prepared without prior knowledge of the Center's new line. According to Li, the Shaanxi party was 80 percent intellectuals. Having previously dealt largely with local magistrates, members had difficulty adjusting to mass work. Furthermore, the opportunities for peasant mobilization were limited. In the Wei River heartland, 8 o percent of the peasants owned their own land. Their main complaint was excessive taxes and the usurious loans needed to pay them. In Shaanbei, there was plenty of open land, and taxes were again the main complaint-especially the opium tax. Even in the peasant associations, most members were owner-cultivators and unmoved by overly radical slogans. With regard to Feng Yuxiang, Li cautioned against opposing him right away, urging work within the Guomindang and the Shaanxi government. ${ }^{109}$

The Center would have none of this, and Li was roundly criticized. Working with Feng Yuxiang and his army was wrong, just a "game of warlords and politicians." Dismissing Li's local knowledge of land distribution in Shaanxi, it insisted on land confiscation and a "land to the tiller" slogan. While Li claimed that Shaanxi bandits lacked any sense of justice (yiqi 义气) and that "in Shaanxi, you could say that there is no difference between soldiers and bandits," the Center insisted that "most bandits are poor suffering peasants" and claimed the Hunan experience had demonstrated that "rascals and thugs [dipi liumang 地㾂流讯] are brave peasants." ${ }^{\prime 10}$ The defense of the radical actions of rascals and thugs had been one of the controversial portions of Mao Zedong's report on the peasant 
movement in Hunan, and Mao had been a key participant in the August 7 emergency meeting. ${ }^{111}$ Now his view prevailed in the Center's response to Li Zizhou and the Shaanxi party.

Soon after Li's return, the newly formed Shaanxi-Gansu Provincial Party Committee held its first enlarged meeting on September 26. The local party was in turmoil, and defeatism was widespread. Between five and six hundred members left the party when Feng Yuxiang withdrew his support of the revolution, and in September the membership was down to $1,681 .^{112}$ In the summer months, peasants were busy in the fields and students had left school for vacation, bringing rural organizing to a halt. ${ }^{113}$ In northern Shaanxi, the warlord Jing Yuexiu had turned against the revolution in July, suppressed party work, temporarily closed the radical schools in Suide and Yulin, and brought enough pressure on the radical students and teachers to halt most party activity. Once one of the strongest party branches, the Suide party was now accused of careerism, and a split broke out between student and teacher factions. Other than small-scale underground work, much of the party's revolutionary movement in Shaanbei collapsed. ${ }^{114}$

The September 1927 meeting of the Shaanxi-Gansu provincial committee initiated a new stage for the party organization in the Northwest. Prior to this, there had been no provincial committee, and local branches had been loosely coordinated. The committee was based in Xi'an, and the inclusion of Gansu in its name was more aspirational than real: Gansu had few party members, most were scattered in the army, and the committee's reports dealt almost exclusively with Shaanxi. ${ }^{115}$ When Li Zizhou returned with the decision of the August 7 emergency meeting, the new provincial committee accepted it as a "directive of the Comintern" and promised to "absolutely follow the directives of the Center." Dissenters were invited to leave the party. ${ }^{116}$ The Shaanxi party was moving toward a new era of disciplined operation. Still, it was not entirely clear how best to follow the new line, especially the injunction to continue working with the left Guomindang.

The provincial leaders were acutely conscious of Feng Yuxiang's history of close cooperation with the Soviet Union and were reluctant to oppose him openly. ${ }^{117}$ When the Center criticized the Shaanxi party for its vacillation on Feng, the local leadership placed its hopes on Yu Youren, still regarded as a reliable leftist. As $\mathrm{Yu}$ Youren was the Guomindang's political leader in Shaanxi, and Feng Yuxiang had already left for Henan, this seemed a plausible strategy; but in August, Yu left for Wuhan, and the Shaanxi party lost its last major left Guomindang ally. ${ }^{118}$ The provincial party leadership was painfully aware of the school-based party's weakness and isolation, describing many members as "hack teachers, small gentry, and petty politicians" with "zero influence among the masses."119 Members were afflicted with a "bookish [shusheng 书生] attitude” regarding peasants as backward and ignorant. The Center was particularly critical of the Shaanxi party on this point, and the provincial leadership readily adhered to the new line, endorsing land distribution and a reliance on such previously scorned elements as "Red 
Spears, bandits, and thugs." ${ }^{120}$ In a popular slogan of the day, the party would now "oppose the ways of bookworms and little ladies, promote the spirit of thugs and viragos." ${ }^{21}$ Still, little came of these efforts and the real focus of the party's revolutionary ambitions was units of the Shaanxi military.

Two officers whom the party regarded as particularly sympathetic were Yang Hucheng and Deng Baoshan. Party members shared similar backgrounds with junior officers in these armies and were able to infiltrate the military through school or other social connections. ${ }^{122}$ Yang Hucheng would play an important role in the later history of Communist-Nationalist relations, releasing Communists from prison when he rose to dominate the province in 1931, and allying with the Northeast warlord Zhang Xueliang to kidnap Chiang Kai-shek in the Xian Incident of 1936. In 1927, Yang followed Feng Yuxiang to Henan, and the Shaanxi Communist leader Wei Yechou went with him as political commissar. That collaboration would not last. Wei soon began organizing peasants in neighboring Anhui, then joined an uprising in April 1928 in which he was arrested and executedone of the early martyrs of the Shaanxi revolution. ${ }^{123}$ Deng Baoshan, who had been chief of staff to Yu Youren, remained in Shaanxi and welcomed endangered Communists and other leftists into his army. ${ }^{124}$ These sympathetic military officers managed to protect known Communists whom they regarded as progressive patriotic comrades. The party Center, however, wanted uprisings. They got them, but they would be few, short-lived, and insignificant threats to the new regime.

The military risings of 1927-28 were all based in areas where the Communists had had some success organizing during the united front period. The first began in Qingjian, a Shaanbei county separated from Shanxi by the Yellow River, famous for its sweet dates and smooth millstones. Its towns featured opium dens and crafty gamblers, and the population was tough and quick to fight. Qingjian lay just south of Suide, site of the normal school where Li Zizhou, as principal, had built the strongest party branch in Shaanbei. Anding, just west of these two counties, was also a party stronghold. Though based in and growing from the local schools, the party had been quite successful in infiltrating the junior officer corps of the local army. ${ }^{125}$ That is where it placed its hopes. The most promising unit was a brigade, garrisoned in five counties around Qingjian, commanded by Shi Qian, who was a popular type of Shaanxi martial artist; they were swordsmen (daoke 刀客) known for their sense of social justice, many of whom had joined the Society of Brothers in the 1911 Revolution. ${ }^{126}$ Shi had enrolled in the army in 1911 and risen through the ranks despite being crippled in an early battle. ${ }^{127} \mathrm{He}$ was both a powerful opium dealer and, like other veterans of the 1911 Revolution, a friend of Shaanbei progressives. In the 1920s, he sent one of his officers, Li Xiangjiu, to Beijing, where he lived with Li Zizhou, joining the Society for Common Progress and later the Communist Party. Shi's son and godson also joined the party. During the radical period in early 1927, Shi welcomed radical student activism and sent his own soldiers to help organize peasant associations. In neighboring Anding, the local garrison was 
headed by Xie Zichang, a later leader of the Shaanbei revolution, and he too mobilized students and sent soldiers to organize peasants. ${ }^{128}$

After its September meeting, the provincial committee sent Tang Shu, a Whampoa graduate and Hebei native, to lead an uprising in Qingjian. Jing Yuexiu, the Yulin warlord, suspicious of long-gowned students agitating among his soldiers, invited Shi Jian to his fiftieth birthday party in Yulin and had him assassinated. Li Xiangjiu, by then a battalion commander in Shi's army, hailed from Shi's home county and, to avenge his patron's death, assumed command and led a mutiny on October 12. Xie Zichang's unit from neighboring Anding joined the uprising. A well-armed rebel force of perhaps six to seven hundred men confiscated money and opium from local merchants, then moved south through Yanchang and Yanchuan counties and occupied Yichuan, disarming some troops, executing hostile officers, and confiscating more money and opium, which Tang Shu took to Xian to support the provincial committee. The Xian-based committee doubted the revolutionary potential of Shaanbei, especially when the Center was urging greater attention to the working class. In the eyes of the provincial committee, "Shaanxi is the most backward province in China; and Shaanbei is the most backward part of the province. It is completely a small peasant economy. The large-scale production of modern industry is something that Shaanbei people have yet to even dream about." ${ }^{129}$ The committee doubted the political maturity of the Shaanbei Communists and wanted the mutinous soldiers to continue south to link up with more politicized troops in the Wei River valley. On Tang's return, his efforts to enforce political orthodoxy quickly sparked conflict with Li Xiangjiu, who preferred to make a deal with other Shaanbei militarists. Soon there was wavering, then opposition and defections among the troops, who had joined the mutiny to avenge their local commander and certainly preferred to remain with their families in Shaanbei rather than follow a stranger to an uncertain fate in Guanzhong. Tang Shu, an outsider and a Whampoa military man, paid little heed to these concerns, or to the local party's desire to mobilize peasant support. His exclusive focus on military tactics proved ill advised. The Yan'an garrison was sent to suppress the revolt, and by January most of the rebels had surrendered. Tang Shu fled south to fight again, Li Xiangjiu abandoned the party's revolutionary movement, and Xie Zichang led a small band to continue guerrilla operations in Shaanbei. ${ }^{130}$

A much larger uprising broke out in early 1928 in the eastern Guanzhong counties of Weinan and Hua-xian. The Wei-Hua Uprising involved both local students and peasants and an army unit under effective Communist control. During the united front period, Communists dominated the Sun Yat-sen Military Academy, with Soviet advisers and Communist instructors. Its cadets, augmented by new recruits, formed a brigade under the academy's commandant, Shi Kexuan. Shi led his troops out of Xian with the intent to link up with the Communist-led units in Shaanbei. But Shi was assassinated in July $1927,{ }^{131}$ and soon afterward the effort to lead the Qingjian rebels south to join his army failed as well. Another Communist, 
Xu Quanzhong, assumed command. At this time, the Shaanxi party was still trying to put together a coalition of local warlords to oppose Feng Yuxiang. ${ }^{132}$ With this in mind, Xu led his brigade to join the army of a warlord from his native county in southeastern Shaanxi. In the spring of 1928, that force was sent to Shaanxi's eastern border to block the return of Feng's allies. By this time, Xu's army had been joined by Tang Shu, Liu Zhidan, and Xie Zichang, fresh from the failed Qingjian Uprising. They came as representatives of the provincial committee and shared the party's growing skepticism toward Xu's willingness to work with local warlords. ${ }^{133}$

By early 1928, the party was moving in an increasingly leftist direction. In January, the Center admonished the provincial party that the peasant movement must "change from a peaceful petition movement relying on political influence to fierce direct action against landlords and warlords." ${ }^{\prime 34}$ The students in the WeinanHua-xian party had been organizing peasants since 1925; there were over five hundred Communists in the region in the fall of 1927; and the party claimed over one thousand in March 1928, of whom 75-80 percent were peasants- "the largest number and the best composition of all branches in the province."135 The party was based in the schools, and in a pattern reminiscent of conflicts elsewhere, the education system was marked by competition between conservative and progressive factions. ${ }^{136}$ When the school year opened after the Chinese New Year holiday, a violent dispute broke out in a village outside of Weinan. There, in a converted temple that had been shared by schools of the two factions, the conservativesemboldened by the collapse of the united front-closed the Communist-run school, fired the teachers, and forced the students to join their school or go home. Fortuitously, the provincial party leaders were just then passing through the county on the way to Shanghai for instructions. On their advice, the local party mobilized older students and teachers from the local middle school to escalate the conflict. A major theme of the National Revolution of the 1920 s had been opposition to local strongmen and evil gentry (tuhao lieshen); now the Wei-Hua activists proclaimed that "all landowners are strongmen and all gentry are evil." 137 They attacked the conservative educators, killing two and badly injuring others, one of whom was thrown into a well. ${ }^{138}$ By their own account, the local activists' purpose was to

1. Eliminate the pernicious vestiges of opportunism through extraordinary actions,

2. Cause all comrades to leave party offices and enter the villages,

3. Learn violent action through practice,

4. Through limited action promote a general uprising in all of Weinan. ${ }^{139}$

A sharp government response closed most of the Communist-run schools, but Communist organizing, tax resistance, and a large May Day demonstration kept the movement alive. Despite the local party's determined efforts to mobilize peasants, the origins of the movement and the identity of the key organizers show that 


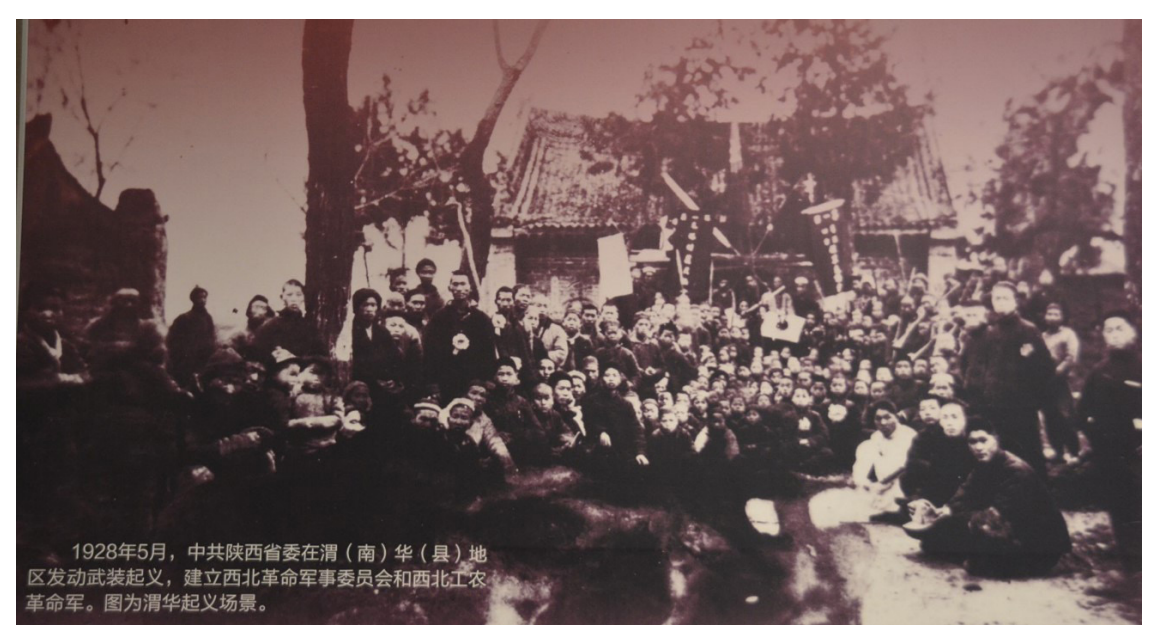

FIGURE 3. Wei-Hua Uprising of May 1928. The center of the photo is filled with childrenstudents at the local school. Their teachers are on the right, in long gowns. (Photo by author from Nanliang Revolutionary Memorial Hall.)

the local party was still a school-based operation. A photo from the time shows mostly students and teachers in long gowns (see figure 3 ).

With a popular uprising brewing in Wei-Hua, Tang Shu, Liu Zhidan, and Xie Zichang led a force of seven to eight hundred soldiers away from Xu Quanzhong's brigade, which had just suffered a serious defeat from Feng Yuxiang's army advancing from Henan. They proclaimed their band to be the Northwest Worker-Peasant Revolutionary Army (西北工农革命军) and marched to join the Wei-Hua party in a military uprising. Together with the local party, they attacked local elites, killing as many as sixty, and announced their intention to establish a soviet. But night attacks on local elites were not popular; the uprising's timing in the midst of the wheat harvest was ill chosen; and Wei-Hua, at the eastern end of the Guanzhong plain, was on a motor road and close to the regime's center of political and military power. After a month, both the uprising and the local party were crushed with the help of local militia and Red Spears, who, contrary to the Center's expectations, proved to be enemies, not allies, of the revolution. Tang Shu was killed; Liu Zhidan and Xie Zichang fled to Xi'an and then Shaanbei to fight another day. ${ }^{140}$

The Qingjian and Wei-Hua Uprisings have been given inflated prominence in official histories of the Shaanxi revolution, in part because of the participation of Xie Zichang and Liu Zhidan, the two heroes and martyrs of that revolution. ${ }^{141}$ Both of these uprisings were hastily and poorly organized efforts, responses to unrealistic calls from the party Center for armed uprisings and the formation of rural soviets. The Communist leaders quarreled over strategy and tactics, and their troops had no particular commitment to a soviet revolution. The local 
Communists had established their reputations as progressives on cultural issues and as able defenders of Sun Yat-sen's nationalist revolution, men who had worked together with local military officers and progressive members of the local elite. ${ }^{142}$ Transforming their movement into a disciplined Communist Party would still take some doing.

\section{TOWARD A LENINIST PARTY}

The Shaanxi-Gansu Provincial Party Committee was only formed in July 1927. It was led by intellectuals from the Society for Common Progress, and its secretary was the Peking University graduate Geng Bingguang. Geng shared the same skepticism toward radical peasant revolution for which Li Zizhou had been criticized in Wuhan, insisting that "Shaanbei peasants truly are backward." He had not been supportive of the radical uprisings and was soon attacked by the aggressive head of the youth league, a future alleged "Trotskyite" whom Geng found "truly obnoxious." 143 The youth league radicals were more in tune with the party Center, and by early 1928, Geng was replaced as party secretary and expelled from the party. ${ }^{144}$ The new leftist leadership vigorously rejected the notion of a "backward Northwest" and endorsed a program of "Red Terror" to combat the Guomindang's White Terror. Under the new policy, the party vowed to "oppose all large and small warlords, arouse war between the masses and the warlords, kill all local strongmen, landlords, and official functionaries, carry out a thorough land revolution, and establish a congress of workers and peasants." ${ }^{145}$

This was the line that supported the radical actions of Wei-Hua, and the result was disastrous. In February 1928, the Shaanxi party claimed 2,900 members, twothirds in the Wei-Hua and Sanyuan areas, where student-organized peasant associations had been most successful. ${ }^{146}$ By the spring of 1929, membership had fallen to 1,300 , most now in Shaanbei. The Guanzhong party had been decimated, only a dozen or so remaining in Xi'an, a similar number in Hua-xian, and Weinan the strongest branch with 120 members. ${ }^{147}$ Defectors informed on their former comrades or enticed them to join the left Guomindang or such now-forgotten progressive groups as the New Party (Xindang 新党) or the Evolution Society (Jinhuashe 进化社). The provincial leadership was forced to hide in gentry-style mansions, divorcing itself from the masses. ${ }^{148}$ In late 1928 and again in early 1929 , the leadership organs were exposed by defectors, leading to widespread arrests, the second of which captured Li Zizhou, who died in prison in June 1929. ${ }^{149}$ Following Wei Yechou's death in 1928 and Geng Bingguang's expulsion from the party, Li Zizhou's demise brought to a close the era of Beijing-trained Society for Common Progress progressives in the Shaanxi party organization. Their policies of cooperation with local elites and leftist members of the Guomindang were no longer welcome, and a new generation of leaders emerged to carry out the line of the party Center and the Communist International. 
The old policy of working within the Nationalist Party was condemned as a “parasite policy" (jisheng zhengce 寄生政策). ${ }^{150}$ "In the past, the Shaanxi party lived completely within the Guomindang. Because everything they did was for the Guomindang, they lacked any independent proletarian political standpoint or mass base. Even now, some party members are nostalgic for their time within the Guomindang and do not want to leave." 151 The new leadership would permit no such collaboration. They even banned membership in the Society for Common Progress, thus losing their front organization and abandoning the progressive public sphere to the opposition. ${ }^{152}$ The party would be exclusive, cohesive, and above all disciplined. The new provincial committee complained that before its founding, "We paid too little attention to discipline. There was only individual action, not party action." Now, with a renewed emphasis on discipline, members regarded as unreliable were expelled. ${ }^{153}$ Some were assassinated, leading to lasting grudges against the perpetrators. ${ }^{154}$ Unfortunately, the expulsion or defection of wavering members made the rest of the party vulnerable to arrest following identification by former comrades, and then the choice of death or an extended jail sentence-or they could themselves defect, and many did. As the White Terror threatened party operatives, security and secrecy became a paramount concern. During the united front period, the party could communicate by registered mail. ${ }^{155}$ Now they wrote on the back or between the lines of innocuous-looking letters, using a secret disappearing ink provided by the Center in Shanghai. ${ }^{156}$ Couriers carried reports and were enjoined to remember addresses and avoid writing them down. ${ }^{157}$

The party was being transformed into a close-knit band of professional revolutionaries. This was, after all, a Leninist party, a branch of the Communist International. But the local operatives had been drawn to the party by webs of personal connections and the influence and prestige of progressive teachers. Now those personal webs were being sundered, replaced by organizational imperatives of a different sort. "Party organs are an organization of professional revolutionaries, an organization of proletarian science." ${ }^{158}$ In the fall of 1927, it was reported that 646 individuals - 29 percent of Shaanxi's total party membership-were party workers. The distribution, while surely reflecting the final stages of the united front period, is significant. Forty percent were directly involved in the party's own operations. The peasant movement (19 percent), the youth movement (12 percent), and workers in the Guomindang (10 percent) got the next priority, with smaller numbers working in the army, government, and on workers' and women's issues. By the end of 1927 , there should have been no more cadres working in the government or the Guomindang, and presumably most of the others suffered greatly from the purge, concentrating the remainder in communications, propaganda, and organizational work of the party itself (see table 1).

How were these party workers supported? Data on party finances represents one of the blank spots in the voluminous publications on party history. Presumably 
TABLE 1 Distribution of Shaanxi Communist Party workers, September 1927

\begin{tabular}{lcc}
\hline Type of work & Number & Percentage \\
\hline Party work & 254 & 40 \\
Peasant movement & 124 & 19 \\
Workers' movement & 28 & 4 \\
Work in Guomindang & 66 & 10 \\
Youth work & 77 & 12 \\
Women's work & 20 & 3 \\
Political work in army & 33 & 5 \\
Work in government & 10 & 2 \\
Communist Youth League work & 30 & 5 \\
TOTAL & 642 & 100 \\
\hline
\end{tabular}

SOURCE: Report on party work to first enlarged meeting of provincial committee, September 26, 1927, in SXGMWJ, 2:114-17.

much of the data was lost or destroyed during government raids on party offices; but given the number of reports that survive, it is clear that archival custodians have chosen to keep most financial material confidential. This may have been to disguise revenue from illicit or politically suspect sources, but most probably it was to conceal local party organizations' heavy dependence on Central and ultimately Comintern financing. In the early years of party organizing in Shaanxi, we see repeated appeals to the Center for support but few references to specific amounts. ${ }^{159}$ Under the united front, many party operatives had jobs in education, journalism, government, the army, or the Nationalist Party. They were presumably supported in this way, and any assistance from the party Center was probably funneled through the Guomindang or Feng Yuxiang's army with its substantial array of Soviet advisers. ${ }^{160}$ Shaanbei's strongest branch, in Suide, had enough well-paid teachers that it was able to support its own operations and still send $\$ 100$ per month to the provincial party. ${ }^{161}$ The end of the united front brought this stage to a close, and once again party workers had to appeal to the Center for support. We have one detailed budget for August-October 1927 that is quite revealing. During this time, monthly support from the Center increased from $\$ 123.00$, to $\$ 500.00$, to $\$ 877.30$. The Center realized that the amount it was giving for living expenses was clearly inadequate, as the monthly stipend increased from four to seven to nine dollars per person. There were also rising expenses for local branches, subsidies for clothing and bedding, assistance to the Communist Youth League, printing and courier expenses, and expenses to establish and rent space for party offices, for room and board of visiting cadres, and for travel. ${ }^{162}$

These figures are generally consistent with other scattered reports on financial matters. In his report to the Center in August 1927, Li Zizhou cited monthly expenses of over $\$ 1,000$ per month and requested a subsidy of $\$ 900 .{ }^{163}$ A 1929 
report mentions a monthly subsidy of $\$ 600 .{ }^{164}$ These funds were never enough. Party cadres in local branches received only three to four dollars per month for living expenses, barely enough for food, much less clothes and housing. ${ }^{165}$ Even at the provincial level, cadres were surviving on two bowls of sweet potatoes per day. Women were not getting enough to eat after childbirth, seriously endangering their health. ${ }^{166}$ The Shaanxi party's financial crisis was made worse by the repeated raids on party offices. In January 1929, the party had just received $\$ 1,000$ from the Center when its offices were raided and the entire sum was lost. ${ }^{167}$ One senses, in these reports, considerable frustration with the paltry support that basic-level cadres received from the Center. This was not without cause. The bulk of the funding from the Communist International supported the Center and its Shanghai operations; only 23 percent went to the provinces. Furthermore, district-level cadres in Shanghai received a monthly stipend of $\$ 19$ (the equivalent of an industrial worker's wage), while provincial cadres in Shaanxi received less than half that amount. ${ }^{168}$ Party workers in the provinces often felt that they were doing the basic-level dirty work on starvation wages while cadres at the Center were living in luxury. Understandably, such complaints are not explicit in the party's internal communications, but they are prominent in the public declarations of defectors: "[Central Committee members] live in foreign-style homes, eat well, ride in automobiles, and even go to dance halls and movies. They have more ways of wasting money than the big capitalists. Meanwhile, the lower-level party workers live in conditions that are difficult to endure; working on an empty stomach is normal for them. If they make a little mistake, they are demoted, given a warning or even dismissed from the party." 169

Such criticism might well be voiced by defectors. Among those who remained in the party, the more common response was subservience to the Center and to the Communist International that funded its operations. In clear contrast to communications from the united front period, provincial reports from late 1927 tend to begin with declarations of servile obedience to the Center and the International. It is striking to compare Li Zizhou's frank report on confusing conditions in Shaanxi, dated the day before the August 7 emergency meeting, and the provincial committee's fawning declaration a month later that "the directive of the International is exceptionally correct!" 170 There is no denying that in a formal sense, the Chinese Communist Party was a branch of the Communist International. The Comintern had played a critical role in the party's founding and a decisive role in determining which of several rival Marxist groups would become the official Communist Party. ${ }^{171}$ But early party leaders like Chen Duxiu and Li Dazhao were nationally prominent intellectuals with outstanding reputations in their own right and some ability to shape the decisions of the party. A similar state of affairs prevailed in the provinces. Such party leaders as Wei Yechou and Li Zizhou carried the prestige of higher education in Beijing and personal relations with party elders like Li Dazhao. With the party Center preoccupied managing complex relations with the 
Guomindang leadership and Chiang Kai-shek's armies, the early Shaanxi party had some ability to chart its own course.

All that changed in 1927. The founders of the Shaanxi party would soon be dead. The new generation of leaders was younger, less educated, and less well known. Their local base was small and fast disappearing. Most importantly, they were entirely dependent on the party Center for their finances and indeed for their survival. It is hardly surprising that this new leadership would prove compliant to the Center's line, even as that line shifted from month to month. In the years ahead, a new direction would come not from the provincial leadership in Xian but from the unruly bands of guerrillas operating in the hills of northern Shaanxi. 


\section{Bandits and Bolsheviks}

Rebuilding the revolutionary movement was a slow and painful process. The Shaanxi provincial leadership was a small group of committed Bolsheviks who struggled in vain to mobilize a proletarian revolution in a region without an industrial base. The real work of making revolution fell to guerrilla bands operating along the Shaanxi-Gansu border, organizing bandits, soldiers, and some poor peasants in the sparsely populated hills of the north. The provincial party was wary of the scruffy composition of these guerrilla gangs. It sought to transform them into a more disciplined Red Army by linking them to the party's early rural strongholds in Sanyuan and the Wei River valley. When this effort failed, the new Twenty-Sixth Red Army was ordered south of the Wei to the site of early activism in the Weinan-Hua-xian area. The result was a disastrous military defeat, and in 1933 the Shaanxi revolutionary movement again faced extinction. The only ground for hope came when arrests and defections eliminated most of the provincial leadership, liberating the guerrillas to develop their own strategy. ${ }^{1}$

\section{LIU ZHIDAN AND THE SHAAN-GAN BORDER REGION}

The leader of the guerrilla movement and hero of the Shaanbei revolution was Liu Zhidan, from the poor, isolated, and sparsely populated county of Bao'an in the northwest. A student of party elder Wei Yechou at Yulin Middle School and graduate of the Whampoa Military Academy, Liu was killed in battle in 1936, shortly after the arrival of Mao Zedong and the main forces of the Red Army. In 1937, Bao'an was renamed after this martyr of the Shaanbei revolution, and party history accounts of Liu's exploits became so hagiographic that it is difficult to locate the real person. Photos and early descriptions show a slight, sinewy man with thick eyebrows and a prominent nose, features of many older Shaanbei families who intermarried with the Turkic people who roamed this region long ago (figure 4). Bao'an informants who knew him say he was a little cockeyed and did not look you 


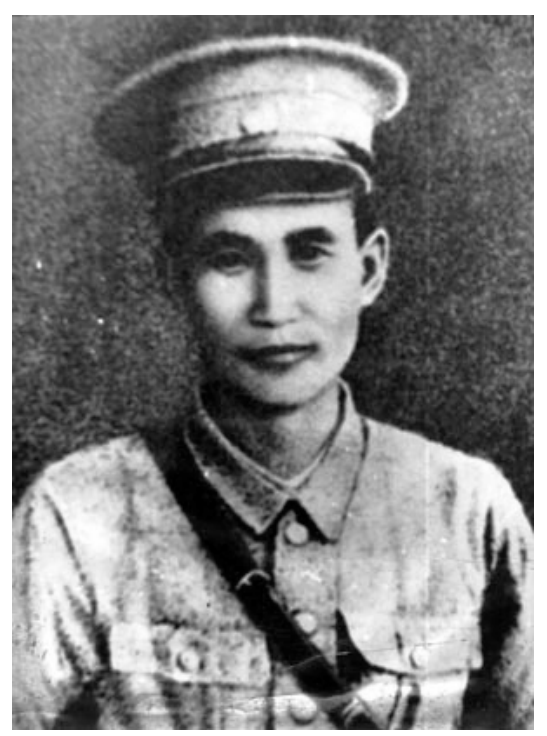

FIGURE 4. Liu Zhidan in Whampoa uniform. (Source: Wikimedia.)

in the face-though this description is absent from published accounts. ${ }^{2}$ When Edgar Snow visited Bao'an in 1936, he described the recently killed Liu as a "chaotic warrior" and a "modern Robin Hood, with the mountaineer's hatred of rich men."3 That seems close to the mark.

Liu came from a prominent local family in Bao'an, making him a "small local strongman" (xiao tuhao 小土豪), in the words of one press account. ${ }^{4}$ His ancestors had acquired substantial landholdings when they returned to Bao'an following the devastation of the Muslim Uprising in the late Qing. ${ }^{5}$ Liu's official biography and other sources state that his grandfather held a gongsheng degree and his father was a xiucai. ${ }^{6}$ These claims of academic credentials and examination success are problematic. In republican era Shaanbei, teachers with some classical learning were often called xiucai. The grandfather's gongsheng degree is even more problematic. One of Liu's half brothers says that his grandfather never attended school, only listened at the window of a local school. This is unlikely to have been enough to pass the rigorous exams. The answer is almost certainly that there were county quotas for such lower examination degrees and that the Lius' modest learning was enough so it could be at least locally acknowledged as befitting such honors in this poor frontier district. ${ }^{7}$ Liu's grandfather had a local reputation as a fair and just man, and his father was a teacher, a paperer for windows, and a clerk in the local militia. The hamlet in which Liu was born had only four households, but it lay on a main road to the west and Liu's father ran a small inn, so by Bao'an standards it counted as a town. ${ }^{8}$ Despite these humble circumstances, this was a family with some local standing, and Liu's father was respected for launching a lawsuit against excessive taxation by a corrupt magistrate. ${ }^{9}$ 
Born in 1903, Liu benefited from his family's prominence. He studied a classical curriculum with his father and grandfather, then at age fifteen transferred to the county primary school in Yongningshan-the mountain stronghold to which the county government had retreated to escape bandits. Two years later Liu married a local girl. He was ready to continue his studies, and this was the time when families found their sons a supportive spouse. ${ }^{10}$ Liu planned to continue his studies in Xian, but bandits made the trip too perilous, and in 1922 he went to middle school in Yulin. Already nineteen years old and married, he was much more mature than middle school students today, but not unusual for Shaanbei at this time. He took remedial courses to overcome deficiencies in English and mathematics, but his skill in Chinese allowed him to make extra money ghostwriting essays and entrance papers for his classmates. In Yulin, he was active in the student association and was introduced to Marxism by Wei Yechou. He joined the Common Progress Society and then the Communist Party, and in 1925 was selected to attend the Whampoa Military Academy in Guangdong. During the National Revolution of the 1920s, he was back in Shaanxi, holding political positions in Feng Yuxiang's army, then participated in the Wei-Hua Uprising of $1928 .{ }^{11}$

Returning to Bao'an following the setbacks of the Great Revolution, Liu was appointed as education inspector by a progressive local magistrate who had studied with him in Yulin. He used the post to travel about in a student uniform, organizing young people in peaceful struggles to combat the famine then ravaging the population: forcing grain sales at low prices and compelling the well-off to distribute food to the poor. ${ }^{12} \mathrm{He}$ was no doubt aided in these efforts by his softspoken, approachable, and socially adept manner. Liu was not given to large public meetings: we have few accounts of any memorable speeches. His strength was person-to-person human relations, and he was able to get along with anyone, poor peasants or military officers, bandits or members of the local elite. ${ }^{13}$ Himself a man of the periphery, he readily embraced the local customs and values. Sensitive to conservative views on gender relations, he cautioned members of his guerrilla bands against mixing with women. ${ }^{14}$ In a region where sharing an opium pipe was an important part of male bonding, Liu himself smoked until party superiors forced him to quit in $1933 .{ }^{15}$ To recruit members of the powerful Society of Brothers, he became a sworn brother and assumed a position of some status in the society. As he later wrote, “There are many Brothers [Gelaohui] in the Soviet area. They are righteous folks who have helped us a lot and with whom we have had a long relationship." ${ }^{16}$

Despite his early membership in the Communist Party, there is no evidence that Liu was a systematic political thinker. His view of the party and its purposes was simple. The party "represents the interests of the broad masses, opposes imperialism, feudalism, compradors, corruption, and oppressive taxes." ${ }^{17}$ He showed little interest in the party as an elite revolutionary vanguard: "Whoever wants to join the revolution can join the party." 18 The aim of the revolution was "to establish 
a democratic regime, let the tiller have his own land without oppressive taxation. Let the peasants pass their days in peace. ${ }^{19}$ Even when the party promoted a strict proletarian line against landlords and rich peasants, Liu focused his attacks on "gentry strongmen [haoshen] and landlords." ${ }^{20}$ He favored the broadest possible revolutionary alliance: "uniting not only all peasants, craftsmen, merchants, and scholars but also gentry, militia heads, and Society of Brothers members who have a good conscience and do not oppress the peasants."21 To the revolution in Shaanbei he brought a commitment to equality and popular rule (however vaguely conceived) and an unshakable optimism..$^{22}$ A critical element of Liu's appeal was his personal commitment to these egalitarian ideals. He maintained much of the May 4 notion that one's personal conduct was an important component of political commitment. Sewing to patch his own clothes, cooking for his men, giving up his horse for a wounded soldier, sleeping outside when others occupied all available beds: these stories abound in recollections of Liu Zhidan, and while they smack of typical party hagiography, they have a ring of truth. ${ }^{23}$ The one luxury he allowed himself was chain-smoking expensive Hataman cigarettes. ${ }^{24}$

Liu was primarily a military man, a man of violence. In 1925 , on his way to the Whampoa Academy, he traveled via Sanyuan to attend a convention of the Common Progress Society. There he left a passionate message: "Comrades! Lead the oppressed people to attack imperialism. Spare no sacrifice! Fight through the bloody road. The future will be bright and happy!"25 His personal asceticism, his readiness to sacrifice and “endure bitterness" (chiku 吃苦), was an integral part of the military lifestyle that he embraced. ${ }^{26} \mathrm{His}$ simple living, sharing the tough life of a guerrilla, earned him the loyalty of his men. But he could also be ruthless. Once he shared an opium pipe with a militia commander whose weapons he coveted and then, once his prey was appropriately relaxed, disarmed and killed him. ${ }^{27} \mathrm{On}$ another occasion he slit the throat of a turncoat responsible for the death of a comrade and let him bleed to death overnight. ${ }^{28}$

One key to Liu Zhidan's success as a guerrilla fighter was his intimate knowledge of Shaanbei geography. Those who fought with him called him a "living map." ${ }^{29}$ He seemed to know where each stream led, the easiest path over a hill, the safest approach to a town. The deep gullies, patches of woodland, and high loess plateau of the area were undoubtedly suitable to guerrilla warfare, but familiarity with the physical and human geography was required. In this early stage of armed struggle, the area along the Shaanxi-Gansu border was most important. Both sides of the border were sparsely populated after the devastation of the Muslim Rebellion of the 1860s. Famine in the 1870s and again in 1928-29 had slowed recovery. A sparse population meant that land was relatively plentiful, and in some areas whole hills could be claimed by new migrants. In this respect it was quite different from the more densely populated areas of Mizhi and Suide, along the Wuding River in the northeast of the province, where land was more concentrated in the lands of the gentry elite. ${ }^{30}$ 
In this poor, isolated, and thinly populated region, the republican state was particularly weak. The Shaanxi-Gansu border region lay between three competing warlords: Yang Hucheng in Xian, Ma Hongkui in Ningxia, and Jing Yuexiu in Yulin. Technically, Jing Yuexiu was responsible for Bao'an and the surrounding Shaanxi counties, but these counties were far from Jing's base in the northeast and too poor to offer any incentive to invest his limited political capital or military resources. ${ }^{31}$ Though often called the "local emperor" of Shaanbei, Jing himself and most of his army were from Pucheng, in the Wei River valley. An outsider in the north, he was reluctant to strengthen the local militia. ${ }^{32}$ The Gansu side of the border was even more unsettled. Separated from the provincial capital by the Liupanshan mountain range, eastern Gansu (Longdong 陇东) was the home of competing petty warlords who preyed on the sparse and impoverished population. ${ }^{33}$ The civil administration was ineffective and usually corrupt, with magistrates changing as each new militarist came to power. ${ }^{34}$

A weak and divided state and a geography of deep gullies, wooded hills, and sparse population created a ready environment for guerrilla warfare; but before there were Communist guerrillas there were bandits. As noted above, banditry was such a persistent problem in this area that the county government of Baoan had withdrawn to the natural defenses of Yongningshan (figure 1). The fact that Bao'an was on the Gansu border made it particularly vulnerable: bandits could easily flee to the next province, where the authorities were reluctant to pursue them. The chaotic politics of republican China and lack of a trusted judiciary made the problem worse. Analyzing the social origins of banditry is challenging, though Phil Billingsley's study of neighboring Henan suggests patterns common in Shaanxi. ${ }^{35}$ Several of the known bandit leaders were small merchants or shop workers who turned to criminal activity because of some dispute in which they felt wronged and without legal recourse. Others were former soldiers, opium smugglers, or martial artists, men living on the commercial fringes of agrarian life, or village bullies with a taste for power. Soldiers from the small warlord armies who left the army when rations were cut were particularly important. ${ }^{36}$ These men had the military skills to become leaders of bandit gangs, but it is likely that many of the nameless men around them were poor peasants escaping the poverty and dull routines of agrarian toil. Invariably they were young men, in their teens or twenties, usually still unmarried and inclined to a risky life. The power of the Society of Brothers, which played such an influential role in the 1911 Revolution, and such "superstitious organizations" as the Red Spears (Hongqianghui 红枪会) also testifies to the extent of criminal activity in the area, for they both participated in petty crime-gambling, opium smuggling, and prostitution-and protected their members from prosecution. ${ }^{37}$ The invulnerability rituals of the Red Spears were shared by the Hard Bellies (Yingdu 硬肚), who led an anti-tax protest in Bao'an in the 1920s. ${ }^{38}$

With banditry rife on the Shaanxi-Gansu border, the well-to-do naturally sought to defend themselves with local militia. Power and influence in this region 
depended on control of the gun. The vast majority of local elite families lived within well-armed fortified stockades. ${ }^{39}$ But we should resist assuming a simple conflict between aggrieved and impoverished bandits and self-protecting local elites. Bandits and militia coexisted in a distinctly symbiotic relationship. In this depopulated border region, many villages and towns had been abandoned. ${ }^{40}$ Bandit gangs would occupy these places, often large bands with hundreds of fighters. Such bands could be well armed; the bandits were tough fighters who knew how to use their weapons and were familiar with the local terrain. ${ }^{41}$ An attack on these bands by militia or even local warlords would entail significant casualties. Accordingly, it was not uncommon for warlords to give bandit gangs unit designations and assign them militia duties in the area. For the bandits, this assured some immunity from attack and provided salaries, provisions, weapons, and a measure of legitimacy. This dynamic produced an area dominated by "bandit warlords" (tufei junfa 土罒军阀). ${ }^{42}$ If these bandit-militia were not paid on time, as was often the case in times of fiscal stringency, they would mutiny and return to their bandit ways. ${ }^{43}$

Some militia were genuine self-defense organizations of local villagers, but often they were protecting peasants from the exactions of tax collectors and warlords as well as those of bandits. Especially after the famine of 1928-29, impoverished peasants, even if poorly armed, organized to defend against the unbearable taxes of the local state. ${ }^{44}$ If the state's exactions violated local norms, the response could be violent. One attempt to collect taxes during a wedding ceremony resulted in the assassination of the local strongman guilty of the offense. ${ }^{45}$ In general, no simple model associating militia or bandits with specific class interests can accurately capture the complex dynamics of this troubled border region. What is clear is that the area underwent significant militarization, and violence was becoming routine. Power mattered, and especially the power of the gun.

When Liu Zhidan returned to Bao'an in 1928, his initial organizing followed the approach of the 1920s-working through the education system with the support of a sympathetic magistrate. The county education commissioner and principal of the higher primary school at Yongningshan were both Communists, and they were able to appoint comrades and sympathizers to influence students in local schools. ${ }^{46}$ The students naturally came from families of some means, and one informant reported that these early Communists all came from wealthy families. ${ }^{47}$ Soon, however, Liu shifted his attention from organizing students (who were scarce in Bao'an) to approaches more suited to his own military training. He gained an appointment in the local militia with which his father had served, under a local commander with whom the Liu family was related by marriage. The commander regarded Liu as a rival, but also a powerless young intellectual, and boasted that his guns could overcome Liu's pen. ${ }^{48}$ Liu headed a local detachment, which he tried to use for a revolutionary coup; but his new recruits had only one day of weapons training, the attempt failed, and Liu shifted to working for the petty warlords of eastern Gansu. ${ }^{49}$ 
As the party sought a new path to revolutionary success, army work (bingyun), organizing mutinies within the old regime's military, was an important component. There was good precedent for this approach, both in China's own Republican Revolution and in Leninist practice during the Russian Revolution. Working in the army required high levels of secrecy, which meant that agents operated under single-line reporting and their activities were rarely recorded in the surviving documents of the provincial committee. Some reported directly to the Center. ${ }^{50}$ It was dangerous work, and the army was not always welcoming of new student recruits, funneling them into training units where they sang patriotic songs and did calisthenics but rarely handled weapons. ${ }^{51}$ Army life was tough, and most of the young students who joined the party in the 1920s were unsuited for work in the military. The party discovered that "our comrades cannot get used to the harsh life of soldiers." ${ }^{2}$ Certainly the results were not encouraging. The veteran Shaanxi revolutionary Xi Zhongxun reported that there were over seventy failed mutinies in the area. ${ }^{53}$ The east Gansu mutiny in which Xi himself was involved was a particularly chaotic and badly bungled affair. ${ }^{54}$ Liu Zhidan was more suited to this work, but he too had scant success.

In 1929-30, Liu spend most of his time organizing within small army units along the Shaanxi-Gansu border. The party's policy stressed building a base among the poorly paid and ill-treated soldiers, educating them about the oppressive system that enriched and empowered their officers. It cautioned against a top-down "officer line" of working through friends and sympathizers in the officer corps. ${ }^{55}$ In fact, Liu Zhidan and others were able to join the army precisely because of their personal relations with other officers, their local affiliations, and, in Liu's case, his past service in Ma Hongkui's army and the prestige of his Whampoa credentials. In many ways, it was an alliance of mutual convenience: the local warlords, some of whom were aware of Liu's past membership in the party, needed capable officers with an upstanding reputation to recruit allies, while Liu needed arms and recruits for his revolutionary aims. ${ }^{56}$ Once appointed as officers, party members like Liu could earn the loyalty of ordinary soldiers by treating them well. The hierarchical principles of military command, plus the fact that provisions, uniforms, ammunition, and the logistical supplies that soldiers relied on came from above, made this approach far more promising than the party's tactic of organizing from below.

Despite his success in gaining appointments in small warlord armies of the periphery, Liu's superiors in the party were not pleased, and for a time he was disciplined and expelled. ${ }^{57}$ Though Liu undoubtedly gained military experience through these efforts, the mutinies that he led all ended in failure. On one occasion he was captured by an enemy force, regaining his freedom only when that army was itself defeated. ${ }^{58}$ In another case, he led a successful mutiny, then allowed the regularization of his troops in order to secure weapons and uniforms. ${ }^{59}$ In the spring of 1931, he again let his band be absorbed by a local warlord, but when excessive exactions by his troops provoked the suicide of a powerful local landlord, 
his superiors turned on him. Liu was arrested, and it took the intervention of his former Yulin principal, Du Bincheng, and a Communist agent in Governor Yang Hucheng's staff to get him released. ${ }^{60}$ It was clear that working within the enemy's armed forces was not an easy path to revolutionary success. Liu needed a guerrilla force of his own, and for this he turned to the other armed groups in this border region, the bandits.

As we have seen, the line between petty warlords, local militia, and bandits was by no means clear. Indeed, one of the small warlords with whom Liu had served, Chen Guizhang, was himself a former bandit. ${ }^{61}$ Furthermore, the bandit gangs to which Liu turned were quite large, reflecting their quasi-legitimate status as armed groups on the frontier. The most famous of these bandit leaders was Zhao Lianbi, more commonly known by his childhood nickname, Zhao Erwa. Zhao was a poor peasant, a former agricultural laborer from Bao'an, who was related to Liu by marriage. The two had known each other since childhood and maintained a friendship. Zhao had a reputation as a fierce fighter, was much feared, and was an excellent shot. Sympathetic accounts say that Zhao was forced into banditry by poverty, but it is likely that his military skills were first learned in some local militia. By 1931, Zhao had assumed a position as militia head in the small town of Taibai just across the border in Gansu. ${ }^{62}$ His own band had seventy to eighty men and thirty guns; he was joined by a Gansu group about twice that size but with few weapons, and another led by a famine refugee from Shenmu in far northeastern Shaanxi, about half the size, also poorly armed. ${ }^{63}$

Liu Zhidan used his local connections and prominent position in the Society of Brothers to recruit these bandits into his guerrilla army, hoping to educate them to his revolutionary cause and gradually reform their bandit ways. The process was a slow one, and Liu was unusually patient and tolerant of established habits. Most of the bandits continued to smoke opium, and they expected their leaders to split the loot after raids on local elites. Leadership was personalized, and Liu Zhidan himself was typically addressed, not by any official title, but simply as "Old Liu" (老刘). Sworn brotherhood was the tie securing relationships within and between bands, and soldiers' committees gave power to the rank and file. ${ }^{64}$

Although the guerrillas supported themselves by raids on the local elite, Liu was cautious about making enemies unnecessarily. In general, the greatest threat along the Shaanxi-Gansu border was the local militia, but he was willing to make local non-aggression pacts with these forces. This allowed him to exchange opium and other loot for weapons, ammunition, and provisions and gain militia assistance to harbor wounded fighters. ${ }^{65}$ Similar arrangements were made with Society of Brothers leaders in the area ${ }^{66}$ In this way, over the course of 1930-31, Liu built a small guerrilla band of his own in this troubled border region. Then he was joined by a group led by the other key leader and martyr of the Shaanbei revolution-a man from the eastern side of the region where the party had established a foothold in the 1920s, Xie Zichang. 


\section{XIE ZICHANG}

Three counties in northern Shaanxi are named for martyrs of the revolution. Bao'an was renamed Zhidan shortly after Liu's death. Toward the end of the war against Japan, a new county was formed in the former guerrilla areas west of Suide and named for Li Zizhou, the Peking University graduate and member of the first revolutionary generation. Between these years, Anding County, also neighboring Suide, was renamed Zichang County, with its seat in the prominent town of Wayaobu. Zizhou honored the founding generation; Zhidan and Zichang were named for the leaders of the Shaanbei party's two factions, groups that both cooperated and competed and that continue to dispute the history of the revolution to this day. ${ }^{67}$

Official biographies provide few clues to the origins of the dispute that plagued the relationship between Shaanbei's two revolutionary leaders. Their backgrounds seem remarkably similar. Xie was born in January 1897 , six years before Liu Zhidan. He came from a prosperous Anding family that combined farming with an inn that provided shelter and fodder for passing mule trains. Like Liu, he was already an adolescent when he started school: fourteen when he went to winter school, and seventeen when he started primary school. In 1919, when the May Fourth Movement broke out, he was in Xi'an, and in 1920 he transferred to the same Yulin Middle School that Liu attended. While Liu went to the Nationalist Party's Whampoa Military Academy, Xie attended a military school established by Yan Xishan in neighboring Shanxi.

On the personal side, Xie lost both of his elderly parents, his father dying in 1925 and his mother in the following year. His mother had been a famine victim, bought into the family as a child, and she allegedly inspired Xie's concern for the poor. Xie's family arranged a marriage while he was young, but Xie never seems to have lived with the uneducated country girl. ${ }^{68}$ In 1933 , the party arranged a marriage to a young comrade, a former teacher in Anding with whom Xie had corresponded. The marriage was not a happy one, and his bride did not return with Xie to Shaanbei. ${ }^{69}$ The social and psychological implications of these personal details are impossible to judge, but Liu was clearly more easygoing and relaxed in his leadership style, while Xie was "sharp and determined," perhaps a bit uptight. ${ }^{70}$

Liu was very much a soldier and a man of the disorderly frontier, while Xie's life was regularly led within the party. Liu thrived in the military and looked the part as an army man. Xie, by contrast, was thin and short, with the sallow face of a student (figure 5). Some found him physically unimpressive. ${ }^{71}$ As far as their careers were concerned, some differences appear during the National Revolution. In the 1920s, while Liu served in the Nationalist armies in Guangzhou and with Feng Yuxiang, Xie traveled to Beijing, where he joined the Common Progress Society and then the Communist Party, returning to Anding to serve in the local militia. In the militia, Xie was active in local politics, mobilizing students, organizing peasant associations, working on democratic reforms with a progressive magistrate though also privately encouraging students to attack 


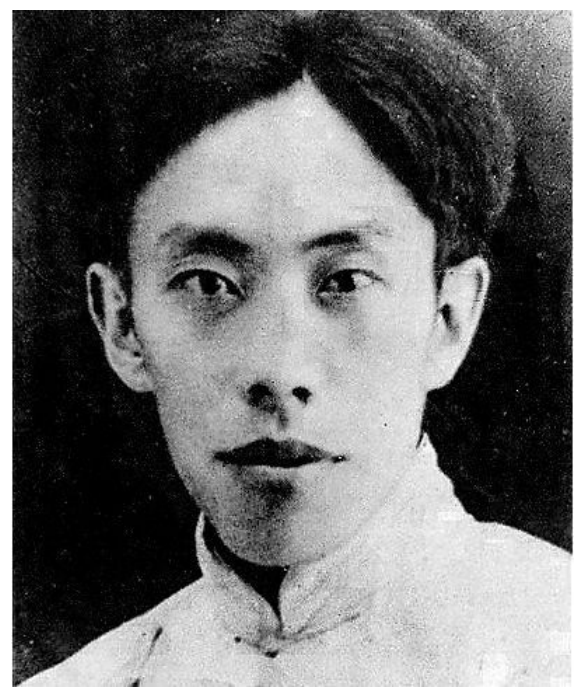

FIGURE 5. Xie Zichang.

the magistrate for corruption, and building a reputation for stern probity that earned him the sobriquet “Blue Sky Xie" (谢青天). Like many in the militia, he was a member of the Society of Brothers, indeed a local leader, which made him both respected and feared. ${ }^{72} \mathrm{He}$ was a strict disciplinarian, punishing rowdy arsenal workers in one New Year celebration and executing looters during the 1927 Qingjian Uprising, in which he played a leading role, before joining Liu Zhidan in the Wei-Hua Uprising. ${ }^{73}$

After the failure of the Qingjian and Wei-Hua uprisings, Xie sought refuge in Liu's Bao'an home, then moved to eastern Gansu, where he joined some of the same military units as Liu Zhidan, working to foment mutinies. Xie was probably responsible for one of these early fiascos, having recruited followers from an Anding bandit gang whose leader defected when the local militia commander offered his sister in marriage. ${ }^{74}$ Then, early in 1931, a small Communist group in Shanxi organized a guerrilla detachment whose leadership included Yan Hongyan, who came from the same Anding County as Xie and had served in the same local military units in 1927. After some success while the Shanxi warlord Yan Xishan was recovering from his failed challenge to Chiang Kai-shek, the effort faltered, and eventually some thirty well-armed guerrillas crossed the Yellow River to Shaanxi. They were able to contact the local party organization through Xie Zichang's brother, and they strengthened their numbers by the addition of a detachment of guards for opium smugglers. ${ }^{75}$ Their activity in Anding gained little popular support, and the provincial committee described it as "pure military opportunism, looting and burning like bandits." ${ }^{\prime 76}$ Failing to establish a base in the east, the group fled to the Shaan-Gan border where they sought out Liu Zhidan and offered Yan's prized Mauser pistol as a token of friendship. ${ }^{77}$ 
The combination of Liu Zhidan's band with this new group from Shanxi and eastern Shaanbei created a substantial guerrilla force on the Shaan-Gan border. The largely bandit armies that Liu had recruited numbered some four hundred, and the Shanxi group plus the opium guards added another two hundred or so. ${ }^{78}$ At this point, late in 1931, the provincial committee began to pay attention to the guerrilla movement and sent Xie Zichang to strengthen its leadership. ${ }^{79}$ A representative was dispatched from the provincial committee to provide political guidance: Gao Weihan, a returned student from Moscow. His reports on the guerrillas were not encouraging. The class composition of the guerrillas was deemed "exceptionally bad. . . . Most are still bandits, with proletarian thugs the great majority." Political consciousness was non-existent: "According to our investigations, when they have opium, then Communism and the Red Army are great. But when their addiction strikes, they go crazy. If left among the people, they pilfer things, but fortunately they do not dare steal openly or rape women. The second detachment [Liu Zhidan's group] is the worst. They often go out to steal and rape, exactly like bandits." 81 Since these guerrillas had been recruited through personal relations and brotherhood oaths, their loyalty was not to the party or the revolution but to their leaders. The peasants regarded them as the personal armies of the leaders: "In the area around the guerrillas' base or through which they have passed, the peasants know only of His Excellency Liu's [Liu daren 刘大人] army or His Excellency Xie's army. They have never heard of the Red Army, much less a soviet." ${ }^{2}$ Within the guerrilla bands, Liu Zhidan was still addressed as simply "Old Liu." 83

Among the guerrillas, personalized command was checked by a kind of primitive democracy. There were soldiers' committees for discipline, but they could also criticize commanders. Cooking and supply duties were shared by all, and loot was split among the men. To orthodox Bolsheviks, this all smacked of "ultra-democratic" errors. ${ }^{84}$ Party reports complained of fighting and petty quarrels among the troops and difficulty in carrying out any political education. "Among these ..., almost three-quarters are Shaanbei men. They did not join this army for political reasons but were recruited for their local affiliations [tongxiang ganqing 同乡感情]. The vast majority of soldiers are making revolution just for the twenty silver dollars per month. When there are economic difficulties, many just leave. In this group, there are many who, in the local dialect, 'like to show off' [kuangjiazi 诖架子].” 85 The economic appeal of life with the guerrillas was undeniable. Many obviously joined for the generous (by Shaanbei standards) guaranteed monthly salary of twenty dollars: "In the eyes of the masses, the Communist Party is where you eat well; so they call out, 'The Communist Party eats well!' or 'running dogs of the Communist Party." If the leaders could not deliver the promised pay, soldiers left with their weapons and returned to a life of banditry. ${ }^{86}$

Despite the questionable political commitments of this army, it was now a substantial force of some six hundred fighters. ${ }^{87}$ Not all had firearms; there were only 250 guns, and ammunition was particularly wanting. To solve this problem, the 
guerrillas chose a familiar solution: enrolling their force under a local warlord, who supplied uniforms for the coming winter, plus supplies and ammunition. Additional weaponry was supplied through an approach to Du Bincheng, teacher and patron to both Liu and Xie, then an aide to Yang Hucheng. With the army now supplied, eight key leaders cemented their new alliance with a sworn brotherhood ${ }^{88}$ It was now the winter of 1931. The Japanese had occupied Manchuria in September, and nationalist sentiment was strong. The party decided that their new army would be called the Northwest Anti-imperialist Alliance (Xibei fandi tongmeng jun 西北反帝同盟军), which could appeal to the rising nationalism without associating this problematic bandit-filled force with the Red Army name. ${ }^{89}$ This solution seems to have appealed to the "bandits" as well, for they were reluctant to submit to the kind of discipline expected in the Red Army. ${ }^{90}$

As Chinese New Year approached, the new army was located near the ShaanxiGansu border, each detachment in a separate hamlet near the village of Sanjiayuan (三嘉原). Zhao Erwa's band was sent out to collect provisions. He came back with 1,00o yuan, opium from a nearby market where it was used in lieu of cash, pigs for a feast, and several mules to haul the loot. His exactions irritated the local villagers, who also complained that Zhao and his gang had abused local women. ${ }^{91}$ According to one report, when Zhao's men passed a fortified village with a powerful landlord, the residents cursed them and threw stones. The band retaliated by attacking the village in a melee that degenerated into looting, beatings, and rape. ${ }^{22}$ Xie Zichang and Liu Zhidan had discussed disciplining the guerrillas and reforming their bandit ways, but Liu had always favored a more gradual and tolerant approach, hoping, over time, to reeducate bandits to focus their violence on those with wealth and power while protecting ordinary peasants. Xie, on the other hand, had severely punished misbehavior by his troops since his days as a militia commander in Anding. Stern punishment of any abuse of power had earned him that nickname "Blue Sky Xie," and this time, Xie was determined to act, so he met privately with the other cadres without informing Liu.

The next day, which was either Chinese New Year or the day after, a meeting of the entire guerrilla force was called, their weapons stacked to the side. Zhao Erwa's group stood in front as Xie Zichang mounted a millstone to address them. Xie stressed the absolute necessity of discipline in a guerrilla army and criticized Zhao Erwa by name. Zhao reacted, perhaps reaching for his pistol, and was immediately shot dead together with two of his followers. Liu Zhidan was disarmed (though Xie returned his gun that evening), and Liu's detachment was disarmed and then dismissed. The next day, the detachment of opium guards from Anding also left, reducing the guerilla force to a fraction of its former size. A fine coffin was bought for Zhao Erwa, in an attempt to soften the blow of this rift, but the damage had been done..$^{93}$

Several days later, another assembly was called to rename the Antiimperialist Alliance as the Shaanxi-Gansu Guerrilla Detachment of the Chinese 
Worker-Peasant Red Army (中国工农红军陕甘游击队). With the key bandit and opium guard units gone, the red flag could be proudly raised. Liu Zhidan was removed from command and sent to report to Xi'an. Xie Zichang was named commander of the now-reduced force, and the provincial delegate Gao Weihan became the political commissar. ${ }^{94}$ At last the region had an official Red Army unit, but the collaboration of Shaanbei's two guerrilla leaders had gotten off to a distinctly shaky start.

\section{PROBLEMS IN THE PROVINCIAL PARTY}

China entered the 1930 s with the revolution in retreat. Following his purge of the Communists in 1927, Chiang Kai-shek was briefly tested by leftist politicians in the Nationalist Party. By 1930, however, he had full control of the party and army, and the national government in Nanjing was gaining traction. Chiang crushed a 1930 challenge by the northern warlords Yan Xishan and Feng Yuxiang, creating a more unified political system than China had seen since the fall of the Qing. Internationally, his regime made progress rolling back the limits on Chinese sovereignty imposed by Western and Japanese imperialism, regaining tariff autonomy, which allowed it to increase customs taxes and protect Chinese industry, and recovering some foreign concessions in treaty ports. China's silver-based currency shielded it from the initial effects of the global depression, and the economy recovered at a decent pace. Across the country, Communists had been driven underground and into the hills, where they continued to threaten the local order, but no longer posed an existential threat to the Nationalist regime. All things considered, the future was not bright for the Chinese Communist Party.

In Shaanxi, following the arrests of 1929, the provincial Communist Party was in shambles. Many Communists defected and published criticisms of the party in the newspapers; others simply drifted away. The Xian branch was reduced to twelve members. The small remaining group felt isolated and neglected by the Center, complaining of the lack of money and direction..$^{95}$ Through all this, the Comintern sought to rally its forces with a strident optimism, heralding the coming "high tide" of revolution, a line that the Shaanxi party dutifully parroted. ${ }^{96}$ At the Center, new leadership under Li Lisan pushed this left line even further than Moscow wished, calling for uprisings in one or several provinces and more emphasis on urban struggle. This strategy was loyally repeated by the provincial leadership. ${ }^{97}$ In Shaanbei, where there were no cities and the proletariat was nonexistent, party orthodoxy prevailed over common sense as local cadres were urged to concentrate on urban work. ${ }^{98}$ The Center's policies were not always accepted without debate. Many remained sympathetic to the moderate intellectual leaders of the $1920 s .{ }^{99}$ When party elder Luo Zhanglong challenged Li Lisan's adventurist line and then broke with the Center's new Moscow-imposed leadership, organizing 
an alternative "emergency conference" in North China, the Xi'an committee temporized for a while, until the Comintern made clear that it would support only one Community Party. ${ }^{100}$ With the local party utterly dependent on the Center for financial support, it soon fell in line-despite any doubts on the appropriateness of the Center's radical optimism.

When Li Lisan was replaced by the new Moscow-supported leadership in 1931, the urban-oriented proletarian line continued. The Center urged Shaanxi to concentrate its efforts on "workshop workers as in Xian and the rural proletariat." The peasant movement was similarly expected to take "Xi'an as the center." ${ }^{01}$ The provincial party again fell in line. Its reports show a focus on May Day demonstrations in the cities, organizing salt workers, porters, printers, almost anyone it could find who looked like a member of the proletariat. In rural Fuping County, the committee resolved to "institute urban work, in order to establish the central leadership of the cities." 102 In rural work, a firm class line was advanced. As Stalin pressed his campaign against kulaks for their resistance to collectivization in the Soviet Union, the CCP obediently followed the Communist International by increasing attacks on the "rich peasant line." ${ }^{103}$

In Shaanxi, as elsewhere in China, the most common form of peasant protest was tax resistance. Such movements in Shaanxi took the specific form of demonstrations in which peasants deposited their tools at the magistrate's yamen, an act called jiaonong that amounted to a work stoppage protesting unbearable taxes. Such demonstrations were typically led by men with some influence in the area, usually rich peasants or gentry, the same people who bore the greatest tax burden. ${ }^{104}$ The party recognized this pattern and condemned it as an opportunist error: "In most mass struggles in Shaanxi, the greatest danger is the party's failure to go among the masses and establish its own leadership. . . Most rural struggles are under the leadership of rich peasants, local strongmen, and landlords and stop at tax resistance, not entering the stage of land revolution." What the party should do was carry out land revolution and "on this foundation, organize local uprisings and create soviet bases." ${ }^{105}$ Not only was it wrong to stress tax resistance over land redistribution and soviets, it was wrong to wage guerrilla struggles on the periphery and then escape into the mountains like bandits. ${ }^{106}$

All of these policies made perfect sense to Marxist theorists, but they were utterly impractical in the concrete conditions of Shaanxi. As Li Zizhou had pointed out in 1927 , land was relatively plentiful in Shaanxi, and peasants needed less taxes, not more land. Especially after the 1928-29 famine reduced the population and forced many to abandon their homes and fields, the party-promoted land revolution had little appeal. One local party committee dared to report that with warlord exactions increasing the tax burden, "For peasants, land brings harm, not benefit."107 The injunction to focus on Xian and the Wei River core was equally impractical. Guerrillas fled to the mountains precisely because they could survive there. 
In November 1930, the political situation in Shaanxi took another turn that, in the short term, posed a problem for the Communist Party. Yang Hucheng returned as governor, restoring rule by a Shaanxi militarist and a man with a simple background (some called him a former bandit) and a relatively progressive reputation. He reduced taxes and brought a more liberal policy toward his Shaanxi allies of the 1920s, releasing many leftists and Communists from prison. ${ }^{108}$ By the following spring, the drought had ended, grain prices had fallen, banditry had "largely disappeared" in the Wei River heartland, and Yang Hucheng's efforts to develop the local economy with canal building and other reforms convinced many that the revolutionary moment had passed. Party members who shared these sentiments were accused of reformism, opportunism, and violation of the International line, and many were expelled. ${ }^{109}$ Other simply abandoned the party, succumbing to defeatism and persistent financial difficulties as the arrest of couriers left the local party strapped for funds. ${ }^{110}$ With dogmatism dominating the party, most of those released from jail did not return to the CCP (which was always suspicious of members released from prison) but joined other former Communists in competing parties, especially the Trotskyites or the Third Party, which became even more important as the anti-Japanese movement gained momentum after 1931. ${ }^{111}$

On September 18, 1931, the Japanese launched the operation that would soon result in the occupation of Manchuria and the creation of the puppet state of Manchukuo (满洲国) under the deposed Qing emperor, Puyi. This marked the latest stage of Japanese aggression against China, a process that progressively encroached on Chinese territory in North China and ultimately sparked full-scale invasion and war in 1937. Chiang Kai-shek knew that his armies were still unprepared to confront Japan, so he ordered withdrawal from the Northeast (Manchuria) and followed a policy of "trading space for time" as he built up his armies and military industries, preparing for the war to come. Public impatience with Chiang's perceived appeasement of Japan grew over time, and by the mid-1930s leftists and Communists joined and benefited from this criticism. Accordingly, a narrative has developed in histories of the 1930s that Japanese aggression gradually weakened the Nationalists and strengthened the political position of the Chinese Communists. ${ }^{112}$ It is important to recognize, however, that this process did not begin until well after the Manchurian Incident. In late 1931 and 1932, the Communists found themselves lagging behind in the patriotic movement.

The problem derived from the party's obligatory deference to the policies of the Comintern and the Soviet Union. In 1932, the Comintern held that all the imperialist powers were threatening China, not just Japan. For this reason the guerrilla group in Shaanbei was called the Anti-Imperialist (fandi反帝) Alliance, not the ResistJapan (Kang-Ri 抗日) Alliance, as some would later call it. ${ }^{113}$ The party's insistence on anti-imperialism rather than resistance to Japan sometimes led it to oppose the patriotic movement against Japan, calling on party activists to "absolutely 
oppose the Anti-Japan Society carrying out exclusively anti-Japanese struggles" and arguing that protests directed only at Japan amounted to "surrendering to the gentry strongmen and capitalists of the Nationalist Party." 114 In the party's reports and propaganda, Japan's aggression in Manchuria was a threat not so much to China as to the socialist motherland in the USSR. Accordingly, local cadres were endlessly enjoined to mobilize the working masses for the "armed defense of the Soviet Union." ${ }^{115}$ Needless to say, with Japan occupying a large and strategic swath of Chinese territory, the party gained little political support with calls to defend the Soviet Union. This was particularly true as the Soviet Union vigorously defended its interest in the Chinese-Eastern Railroad (CERR) that crossed northern Manchuria to link Vladivostok to the Trans-Siberian Railroad. Soviet defense of the CERR first became an issue in 1929, when the Nationalist Party launched a campaign for its recovery and the Soviets sent troops to defend it. ${ }^{116}$ Once the Japanese occupied the area, the Russians started negotiating with Japan. In the dispute over the CERR, the Soviets squandered much of their early reputation as anti-imperialist defenders of China and were instead accused of acting like "Red imperialists."117 The CCP's complicity in this Soviet policy undermined its own anti-imperialist credentials.

As a result of these policies, the party missed the opportunity to lead the patriotic movement against Japan following the Manchurian Incident. Innerparty documents betray extraordinary concern over the growing influence of the Third Party and so-called "Trotskyites"-both dominated by former Communists-especially among patriotic students and intellectuals. ${ }^{118}$ Of course, the party labeled any former Communist or leftist who deviated from Stalin's orthodoxy of building socialism in one country a "Trotskyite," so the actual strength of genuine followers of Trotsky's Fourth International is difficult to judge. It is clear, however, that the influence of these groups was significantly enhanced when CCP founder Chen Duxiu broke with the party over its defense of the Soviet Union on the Chinese-Eastern Railroad issue and began to affiliate with the Trotskyites. ${ }^{119}$ These leftist groups and the Nationalist Party took the lead in the anti-Japanese movement, and the Shaanxi party admitted that "in the anti-Japanese movement after the Manchurian Incident, [the party] has become completely the tail of the petty bourgeoisie, or even behind the tail." Comparing its work against that of the Nationalist Party and the Trotskyites, it confessed that "the political influence of the party lags behind that of the counter-revolution." ${ }^{20}$ In the spring of 1932, the party organized violent demonstrations protesting the visit of the Nationalist Party leader Dai Jitao to Xi'an. When several students were beaten by the police, the party called it a "massacre," but the feeble local response only demonstrated the limited appeal of Communist propaganda. ${ }^{121}$ These reports remind us that the Communist Party was becoming a decidedly marginal force in the cities of North China, where long-forgotten competitors were often more effective critics of Nationalist Party rule. 
In the first years of the decade, the central figure in the Shaanxi party was $\mathrm{Du}$ Heng, a young intellectual from the northern Shaanxi county of Jia-xian. A former student of Suide Normal School, Du had joined the Communist Youth League in 1924 and the party soon thereafter. He served briefly as a special representative to Shaanbei, then held a variety of posts with the Xian party apparatus from 1930, rising to the secretary position in 1932 at the age of twenty-five. An able debater, he was adept at party jargon and a strong advocate of leftist activism to replace the moderate "bookish" style of the $1920{ }^{122}$ The Center, however, was never satisfied with the local leadership, and in 1932 and 1933 it twice dispatched outsiders to direct operations. ${ }^{123}$ One of those sent was unhappy in his new post, repeatedly asking reassignment for personal reasons, and was finally expelled. ${ }^{124}$ The other was arrested and defected in 1933 along with Du Heng in an incident discussed below. Several retrospective analyses attribute the leaders' problems to their unhappy sex lives: they were separated from their wives and apparently preying on younger female comrades. ${ }^{125}$ Obviously, this was not a strong leadership group. Du Heng remained the central figure, however, and in June 1932 it was he who attended a critical Shanghai meeting of provincial representatives from North China. There they debated policies to overcome the myth of "northern backwardness" and devise a strategy for the next stage of revolution in the north.

The Shanghai meeting was attended by six North China representatives, plus two members of the new party leadership from the "Internationalist" group of returned students from Moscow-Zhang Wentian and Qin Bangxian, also known as Bo Gu. ${ }^{126}$ The mandate of the meeting was premised on the Communist International's line that in the context of world economic crisis, the imperialist powers were preparing to attack the Soviet socialist motherland. China's Nationalist Party was aiding this conspiracy by selling out Manchuria and developing Shaanxi and the Northwest as "steps toward the invasion of the Soviet Union." Calls by patriotic opponents of the Nanjing government to break relations with Japan, declare war, or boycott Japanese goods were but a smokescreen to support Nationalist capitulation. Even non-Communist leftists who urged the government to end the Guomindang's one-party rule, restore relations with the Soviet Union, and permit open activity by the Communist Party were denounced as "supporters of the slavish administration of the imperialist Guomindang" and "the most dangerous enemies of the revolution." 127 All of this was supported by language adopted from Stalin's struggles against Trotsky, in which divisions within the party were characterized as a twoline struggle between a correct line and a "right opportunist" deviation. ${ }^{128}$

The meeting did nothing to change party policy in Shaanxi, but it certainly enhanced Du Heng's ability to speak on behalf of the Center and push the new left line. The meeting reinforced the idea that a "firm class line" and proletarian leadership were essential to the revolution's success, so the party should focus on poor peasants and agricultural laborers in the countryside and promote strikes in the cities, seeking ways to recruit workers into the newly formed Red Army 
units. It also called on the guerrillas to develop their capacity for plains warfare, in support of which a soviet should be established north of the Wei, centered on the old rural base in Sanyuan. ${ }^{129}$

\section{SANYUAN AND THE NORTH WEI BASE}

A key test of this strategy would come as the party sought to rebuild its old base in Sanyuan and organize a soviet in the surrounding area north of the Wei River. As we have seen, Sanyuan was an important cultural center, and teachers and students from its many schools had been instrumental in organizing peasant associations during the National Revolution of the 1920s. That movement had been protected and often led by enlightened gentry and rich peasant families, and their influence continued in the 1930 s. $^{130}$ One area where the party had success and managed to maintain a foothold following the end of the united front was the Wuzi district (武字区), a relatively isolated area on an elevated plain in the northeast of the county, bordering Fuping. The Wuzi district was home to the locally prominent Huang family, whose patriarch had been a Revolutionary Alliance member during the 1911 Revolution and a friend of Yu Youren. The large family owned over three hundred $m u$ of land and included the brothers Huang Ziwen and Huang Zixiang, both of whom joined the Communist Party. In 1928, Huang Ziwen mobilized the old peasant association networks in a jiaonong protest, leading tens of thousands of peasants to the county seat to oppose oppressive taxes. The protest was peaceful, but it was followed by attacks on tax collectors, several of whom were killed. During the famine of 1929-30, the brothers organized a relief committee (chouzhen weiyuanhui 筹赈委员会), donating grain and then forcing other wealthy families to do the same. Peasants saw this as a natural extension of traditional gentry charity in times of famine, but the authorities thought otherwise. The Huang brothers were arrested, released only after their mother sold $150 \mathrm{mu}$ of family property to purchase their freedom. ${ }^{131}$ At this point, Huang Ziwen fled to Beijing, then Shanxi, where he joined the guerrilla band that Yan Hongyan led back to Shaanbei in 1930. Local Communist organizing continued to emphasize famine relief, with a Famine Victims Rescue Team (Zaimin zijiudui 灾民自救队), but its activities were increasingly violent, with assassinations of tax collectors and wealthy landlords, even the abduction and execution of a county magistrate passing through the area. ${ }^{132}$ By the end of 1931, Huang Ziwen was back in Sanyuan, this time organizing local schoolteachers and students in demonstrations against the Japanese occupation of Manchuria. ${ }^{133}$

The revolutionary efforts of the Communists in Sanyuan were clearly having some success. The leaders came from influential local families and combined appeals to poor peasants suffering from the famine with patriotic appeals targeting students. In 1932, Huang Ziwen headed the revolutionary committee that controlled the area. The local peasants saw him as the source of authority and went to 
him with all their problems-even treating him with the special courtesy of wheat flour when he was invited for a meal. "It became a personal government . . . The reason for this is that Ziwen has been responsible for Sanyuan and the guerrillas. All along it has been a paternalistic system." ${ }^{34}$ Huang himself admitted that "the great majority of cadres are rich peasants" and that they were able to influence the party's work. Party cells were organized by village and often dominated by a single family. ${ }^{135}$ When the Bolsheviks in the provincial party insisted on greater representation from poor peasants, the county committee appointed a committee member's tenant as party secretary. ${ }^{136}$ It seems quite clear that the rural party of Sanyuan was built upon existing structures of local power, which allowed it to sink roots and grow but limited its ability to transform society. This was not a situation that the provincial party was prepared to tolerate.

To break the local power structures, provincial representatives were dispatched to enforce the party's class line and institute a level of Bolshevik discipline. The party established separate unions for poor peasants and agricultural laborers, but it was unclear who was to lead these, and confusion and differences within the party ensued. The women's organization brought consequences that the party was unprepared for. Young women fled to the Wuzi district to escape unwanted marriages, then started pursuing young men among the guerrillas, offering to cook and sew for them. ${ }^{137}$ An outside cadre from Guangdong was sent to bring order, but he had difficulty communicating in the local dialect and proved ineffective. ${ }^{138}$ The most basic problem was the peasants' enthusiasm for tax reduction and grain distribution in a time of poor harvests, but not for land redistribution. In the party's eyes, this was simply because the Sanyuan party was dominated by wealthy peasants pursuing an erroneous "rich peasant line." 139 The provincial authorities could not accept that land redistribution exposed peasants to retaliation if landlords returned and the party was unable to protect them, while grain distribution met immediate needs and was readily justified as a more coercive version of established norms of local elite charity.

As the struggle intensified, a greater problem arose as the party sought to control the guerrilla bands it had organized. Armed groups had been assassinating tax collectors and forcing the wealthy to distribute grain at least since 1930. Some turned to banditry, which the party attempted to control, without success. ${ }^{140}$ When the party organized guerrillas, it was largely these same groups. Many were familybased bands of brothers, cousins, and uncles who would rotate in and out of active membership so that members could tend the family's fields. ${ }^{141}$ Some had attended school together, and the party used classmate connections to mobilize them. ${ }^{142}$ One rich peasant and shopkeeper led a bandit group that worked for the party for a time, then quit when he was criticized. ${ }^{143}$ The party's biggest problem was its most powerful local gang, a family operation from a village along the Fuping border whose leader came to be known as Sun the Imperialist (Sun Diguo 孙帝 国). Sun and his brothers had been active in the peasant association since the 
National Revolution period of the 1920s. In the early 1930s, the Sun and Huang brothers dominated both the Wuzi district and the Sanyuan County party committees. ${ }^{144}$ The Sun family controlled the most powerful and best-armed gang in the district, but the Imperialist openly opposed land reform. He was also cautious in protecting his forces. When the army and local militia attacked the soviet in the fall of 1932, young activists in the Red Guards (Chiweidui) and Young Pioneers (Shaonian xianfengdui) were eager to resist, but "the guerrillas led by 'the Imperialist' cursed the masses and did not let them assemble: 'We have guns and still don't dare fight. You've only got sticks. What are you going to do?"' Later the Imperialist turned against the party's operations: driving off a guerrilla force sent from the Red Army and dispersing a meeting called to announce the land revolution, ripping up the revolutionary slogans pasted on walls. Activists "cursed 'the Imperialist' as the emperor of Wuzi district." Some in the party called for Sun's elimination, but others temporized. ${ }^{145}$ Sun's guerrillas were the local party's best fighters, and as one report acknowledged, the party was faced with the choice between good fighters or good class composition. ${ }^{146}$

By the fall of 1932, the Sanyuan effort had descended into hopeless disarray. The county committee was at odds with the rural party, frustrated by the latter's resistance to land reform but ignorant of the facts on the ground. ${ }^{147}$ Young activists were angry at the caution of their elders in the party, as a result of which "comrades of the Communist Youth League despise the party. Many league comrades and young people say only the young can get things done; the adults are worthless. This has created an opposition between the party and the league, between old and young." ${ }^{48}$ In the fall, the clueless Bolsheviks running the party insisted on a major celebration of Russia's October Revolution, an act of questionable meaning to peasants of the district. This provoked the government into a determined military effort to eliminate the new soviet, which was accomplished within a few weeks. The youth in the Red Guards were prepared to resist but had no effective weapons. Sun the Imperialist had the best weapons, but he chose not to fight. ${ }^{149}$ The remaining activists resorted to coercive grain distribution and assassinations of gentry strongmen, landlords, and tax collectors. These raids were usually made outside one's home base, with the result that the locals' guerrilla bands were bandits in the eyes of others. ${ }^{150}$

By this time, the Imperialist was convinced that the party had deceived him and turned against the revolution, inventing a new term to describe the party's doctrine, not Communism but “con-ism” (rinong-zhuyi 日弄主义). “The Communist Party is 'con-ism," his fighters said. "The party asked us to work for them, and when we did, they expelled us. We're not going to be their slaves." Sun's gang was a brotherhood, both blood brothers and sworn brothers. They believed in revenge, and now they were prepared to seek revenge against those in the party who had targeted them. Some former Communists joined them, informing on their comrades. Many peasants adopted their language: "The masses inform the enemy. They 
say, "The Communists are con-ism."' ${ }^{151}$ As the former Communist allies combined with local militia to eliminate revolutionaries, the result was a terrible bloodbath. Later accounts claim that as many as three to four hundred peasants were killed. ${ }^{152}$

Obedient to the line of the Comintern and the Center, the Shaanxi provincial committee sought to build a revolutionary movement near the urban centers of the province. To do this, they needed to draw the guerrillas from their mountain strongholds onto the plains of the Wei River valley. Sanyuan provided the best hope to accomplish this strategy, for it had a student-fueled movement that had sunk roots in the poorer northern section of the county. The problem was, the leadership of that movement was overwhelmingly wealthy peasants and landlords, and the armed militia and gangs that could provide a fighting force were controlled by locally prominent families. When the party pressed for land reform and a soviet government, they met determined resistance. The North Wei Soviet collapsed, and the best the local party could propose was to use "Bolshevik spirit and Stalinist methods" to carry out the directives of their superiors. ${ }^{153}$

\section{RISE OF THE TWENTY-SIXTH RED ARMY}

Following the January 1932 Sanjiayuan incident, with the execution of Zhao Erwa and the defections that followed, Liu Zhidan was sent to Xi'an, and Xie Zichang assumed command of the guerrilla force. Given the minimal military threat posed by this much-reduced rebel army, it was rarely challenged by the regular army. Their adversaries were small local garrisons and militia. Most of their operations were small-scale night or dawn attacks lasting at most a few hours and involving only several dozen men. In Xunyi County, a major area of guerrilla operations in the hills north of the Wei, the local army garrison was commanded by an underground Communist, Zhang Hanmin, who arranged mock battles with the guerrillas to keep up appearances. Other Communists in his unit supplied the guerrillas with weapons in exchange for stolen draft animals. ${ }^{154}$ On the rare occasions when the guerrillas attempted attacks on walled towns, the results could be disastrous. The seat of Zhengning County, across the border in Gansu, was the walled town of Shanhe (山河镇). The exactions of the local authorities in a time of famine had aroused local peasant opposition. Though the local militia was apparently led by rich peasants, the Red Army sought to combine with it to overrun the town. The locals had no firearms, only swords and spears, and they led the attack. But a defector sneaked into the town to warn the defenders, and this and a second attack were beaten back with heavy casualties to both the militia and the Red Army. ${ }^{155}$ Xie Zichang was blamed for the failed attack, and the provincial party dispatched him to Gansu to organize again within the warlord armies. Liu Zhidan resumed command of the Shaan-Gan guerrillas. ${ }^{156}$

In the summer of 1932, Liu Zhidan and Huang Ziwen, the Sanyuan leader who had joined Yan Hongyan's Shanxi band, issued a proclamation declaring the newly formed Shaan-Gan Red Army to be "the armed force of the poor workers and 
peasants, under the leadership of the Chinese Communist Party." It pledged to eliminate taxes; redistribute grain, property, and land; void all loan deeds; and establish a soviet regime. ${ }^{157}$ Judging from its actions, the emphasis was on the first two of these tasks: blocking tax collection and redistributing grain. Despite an earlier claim of one thousand men, this new Red Army unit had only three companies, each with about ninety men with seventy to eighty guns. ${ }^{158}$ With loose control of at most seventy villages along the Shaanxi-Gansu border, their activities mainly involved night attacks and kidnapping. ${ }^{159}$

Kidnapping wealthy landowners was a critical source of revenue, and one local cadre recalled the procedure: "To solve the problem of operating expenses, the guerrillas would go out to get some movable property. We would seize and hold a gentry strongman or landlord and let his family get money to ransom him. At that time, the people's voice was decisive. If the people said this guy had a good reputation, we would release him after we got the money; if the people said he was bad, we would take the money and then kill him." ${ }^{160}$ To gain popular support, the guerrillas distributed grain seized from local landlords, but even this could be problematic: peasants were unwilling to take grain from fellow villagers and feared reprisals once the Red Army moved on. ${ }^{161}$ There is little doubt that to many the guerrillas seemed indistinguishable from bandits: "The fighters wanted grain, and their selfish attitude was pronounced. They thought that if they joined the Red Army they would get clothes and things and make money." ${ }^{162}$ Veterans of this force would later admit that at this time the guerrillas had "the odor of bandits." 163

Some local brigands posed as Red Army guerrillas, making it even more difficult to tell Communist "bandits" from the real ones. ${ }^{164}$ According to one contemporary account, "Under the guerrilla headquarters there were over ten guerrilla units. What were these units? They were all reorganized bandits with certificates of appointment. Whoever came was given a certificate and appointed as guerrilla detachment number X. So even though there were supposed to be ten-plus detachments, some had never even been seen by the headquarters. These bandit groups used our red flag to extort from the masses, rape, and steal. People called them the 'bogus Red Army."'165

Despite such criticism from the provincial committee, its representative, Gao Weihan, a Moscow-returned cadre, temporized on the question of purging bandits and improving the class composition of the guerrillas. ${ }^{166}$ In response, the committee, led by Du Heng, turned on Gao, accusing him of opportunism and resisting the new International line. Significantly, part of Gao's error was appealing to the example of Mao Zedong on Jinggangshan-now regarded as a classic model of peasant revolutionary organizing but in 1932 criticized as inappropriate for the new task of organizing a soviet. "In his own words, he is 'using Mao Zedong's guerrilla tactics on Jinggangshan to understand the present task of establishing a soviet.' He completely fails to understand that in the current conditions of sharp revolutionary advance, tactics that were correct in the past are no longer appropriate." ${ }^{167}$ An appeal to Mao's writings was not yet the correct answer to all questions of revolutionary strategy. 
The provincial committee wanted armed struggle in the Wei River valley and believed that the mass movement there could correct the guerrillas' preference for kidnapping and hit-and-run warfare in the hills. ${ }^{168}$ Accordingly, Huang Ziwen and some of the guerrillas left to support the peasant movement in Sanyuan, but that only brought the grievous consequences described above. Another unit was dispatched even further east, to Hancheng, where there was even less local party support, and the result was another defeat and further losses for the Red Army. More importantly, the popular reaction was not favorable. According to a contemporary report, the rich called them "bandits, no good," the poor said, "What? They go and leave us?" and the general public said, “They did not share [gong 共] well. Real communism is not so great!... The peasants got cheated. They took the good things and the money, and we paid the price." 169

These setbacks exacerbated tensions between the guerrillas and the provincial committee. Following the June 1932 Shanghai meeting of North China provincial secretaries, there was growing pressure for proletarian leadership, enhanced class struggle, and carrying the revolution to Shaanxi's population centers with plains warfare in the Wei River valley. To carry out this ambitious offensive strategy, the guerrillas were reorganized as the Twenty-Sixth Red Army. ${ }^{170}$ A representative, Li Gen, was sent from Xi'an to lead the guerrillas on the correct path. That involved moving beyond roving attacks on the wealthy to establish a stable soviet. This, however, led to heavy losses after what was later described as an erroneous policy of “defending to the death" (sishou zhengce 死守政策). When the guerrilla leaders turned on him, Li Gen treated it as a "counter-revolutionary conspiracy" and tried to organize opposition among more pliant guerrillas, but this too failed, and after three weeks he was forced to abandon work with the guerrillas and return to Xi'an, where his colleagues subjected him to relentless criticism for his failure. ${ }^{171}$

Gao Gang was the next provincial representative sent to carry out the new line. A native of Shaanbei's Hengshan County and graduate of Yulin Middle School, Gao would rise through the Shaanxi party to become its most important leader in the wartime period. Favored by Mao in the early 1950s, he would fall out with the party leadership in 1953 , leading to his purge and suicide. That ignominious end to Gao's career would taint all subsequent accounts of his role in Shaanxi's revolutionary history. ${ }^{172}$ In the 1940 , Gao Gang would tie himself closely to Liu Zhidan's wing of the party, but in 1932 he clearly represented the Bolsheviks in the provincial committee. In a report that targeted both Xie Zichang (who had rejoined the guerrillas in the summer but was now identified as a "class enemy") and Liu Zhidan, identified as a "bandit, student, rich peasant," Gao wrote that "the guerrillas were created when comrades with a fuzzy understanding of class used kidnapping as a method to raise money and buy guns; they did not rise through the process of class struggle. . . Most of the masses who joined were bandits or opium-dealing hooligans." The political officers failed to engage in political education, and there was no "military core" controlled by the party. The guerrilla leaders openly resisted the provincial committee's strategy, saying, "If we follow the provincial committee 
line our troops will all be lost." This then developed into a debate over moving to safer ground further north or following the party representatives and seeking to expand southward into the Wei River valley. According to Gao Gang's report, "these northern bastards" wanted to shoot the provincial delegate (Gao Weihan), which helps explain why he temporized on purging them. They "publicly curse Li Gen [who, as we have seen, took an even harder line] as a son of a bitch and say the provincial line is incorrect. This is their counter-revolutionary plot to seize power." His conclusion was blunt: "To carry out the Bolshevik line, we must thoroughly purge these guys." 173

In the end, the band split. Huang Ziwen, under criticism for "rich peasant" errors, led his Sanyuan fighters back to their home base, while Liu and Xie launched an assault on Bao'an. Xie Zichang, at least in the eyes of the provincial committee, led the operation. "Among the guerrillas, Xie XX openly expressed the opinion that he was oppressed by the provincial committee, leading to the loss of several men. Now he was going to 'carry out dictatorship' and operate on his own, sending off the better cadres to return to the provincial committee. He said the only way to solve the guerrillas' problems was to get rid of these comrades. Zichang and Yan Hongyan then took the central group of the guerrilla cavalry to Bao'an and Fuzhou, the old bandit lair, returning to their old bandit livelihood."174

Xie and Yan's Bao'an attack failed miserably. Heavy casualties had a significant impact on morale, and many fighters departed or defected. ${ }^{175}$ By early 1933, the survivors again regrouped on the Shaanxi-Gansu border. ${ }^{176}$ At this time, the TwentySixth Red Army had been reduced to 160-70 men, thirty to forty horses, and about one hundred guns. ${ }^{177}$ Du Heng, after returning from Shanghai in mid-1932 with fresh instructions and the full authority of the party Center, was reassigned from his position as provincial secretary to political commissar of the TwentySixth Army. By this time, Xie Zichang and Yan Hongyan had been accused of a "counter-revolutionary conspiracy," and the party was determined to assert firm control of the gun. ${ }^{178}$

Du Heng was a skillful debater, a master of party jargon. He came with the full authority of the Center and a mandate from the province to dissolve the TwentySixth Army if necessary. ${ }^{179}$ But he was only twenty-six years old and spoke with the thick Shaanbei accent of his native Jia-xian as he expounded on the lessons of the Zhang Guotao's Hubei-Henan-Anhui Soviet and the need for firm proletarian leadership. One veteran guerrilla recalled Du's message to be "There is no Marxism in the remote mountains." 180 It was not a particularly effective speech for an audience of hardened guerrilla survivors. ${ }^{181} \mathrm{Du}$ vowed to carry out "the line of the Communist International and the CCP Center . . . to achieve the final victory of the Chinese soviet revolution and the world revolution." ${ }^{82}$ This was an ambitious goal for a ragtag group of 170 men.

Even more problematic was his plan for the Twenty-Sixth Army. The party had long criticized the personalized leadership of the guerrilla forces. Now they were again accused of right opportunism and avoidance of true revolutionary struggle 
through flight to the mountains. The military commanders were allowed to make a self-criticism, which showed that they were not counter-revolutionaries, and then Du carried out his reorganization. He wanted to follow Gao's recommendation and remove all of the guerrilla leaders, but Xie Zichang and Yan Hongyan were now the clear targets, having openly defied the Xi'an committee. They were sent to Shanghai for reeducation while Liu Zhidan, with his characteristic obedience to higher authority and firm support from the guerrillas, was kept on in a reduced capacity. ${ }^{183}$ These three were relatively lucky: the former commissar Zheng Yi, who was accused of collaborating with the enemy, was executed. ${ }^{184}$ Wang Shitai, a former student of Yan'an Middle School and loyal follower of Liu Zhidan, was named commander of the Twenty-Sixth Army with Du Heng as political commissar. ${ }^{185}$

By the spring of 1933, the main base of the Twenty-Sixth Army was centered in Zhaojin, a town in the west of Yao-xian. The population included many recent famine refugees, two hundred thousand according to one account, and with land already held in large plots by established families, this produced relatively fertile conditions for class-based appeals. The local guerrillas included the usual complement of local thugs and bandits. ${ }^{186}$ There was adequate grain to support the army for a time, but after a while the army supported itself by raiding outside, "fighting on external lines" in the usual euphemism, ${ }^{187}$ and the hilly wooded topography made the base relatively easy to defend. The most defensible stronghold was Xuejiazhai, a tall sandstone outcropping near Zhaojin, which became the military headquarters, site of a holding cell for kidnapped victims, a primitive hospital, and a small machine shop staffed by skilled workers recruited from the government arsenal in Xi'an (figure 6). Du Heng was especially pleased by the financial resources that the Twenty-Sixth Army had accumulated. The cavalry had twenty bags of opium, some one thousand ounces. With this, Du reported, "The financial problem can be solved. ... I plan to give it all to the [provincial] standing committee for its expenses," with some to be allocated for medicine and equipment for the Twenty-Sixth Army. ${ }^{188}$ As always, Du Heng was thinking first of the party organization. For him, an important function of the guerrillas was to finance the provincial party, supplementing the meagre subsidy that it received from Shanghai.

Zhaojin saw the brief appearance of a somewhat functional soviet regime. Technically the North Wei Soviet in Sanyuan preceded it, but as we have seen, that was a brief and chaotic episode in Shaanxi's revolutionary history. In Zhaojin, there was a revolutionary committee headed by a local peasant-an obligatory feature under the prevailing class line-but with Xi Zhongxun as his deputy, the first important post for this future party leader. ${ }^{189}$ The party called for three thousand peasant recruits from Sanyuan, to provide an alternative to reliance on bandits, but Sanyuan cadres vigorously opposed this depletion of their forces, and nothing close to that number was ever achieved. ${ }^{190}$ The primitive conditions in which the soviet operated are reflected in Du Heng's list of needs in January 1933: political and military cadres, skilled workers, doctors, pens, ink, and diaries. ${ }^{191}$ The medical needs were particularly serious: wounded soldiers were treated by a local veterinarian 


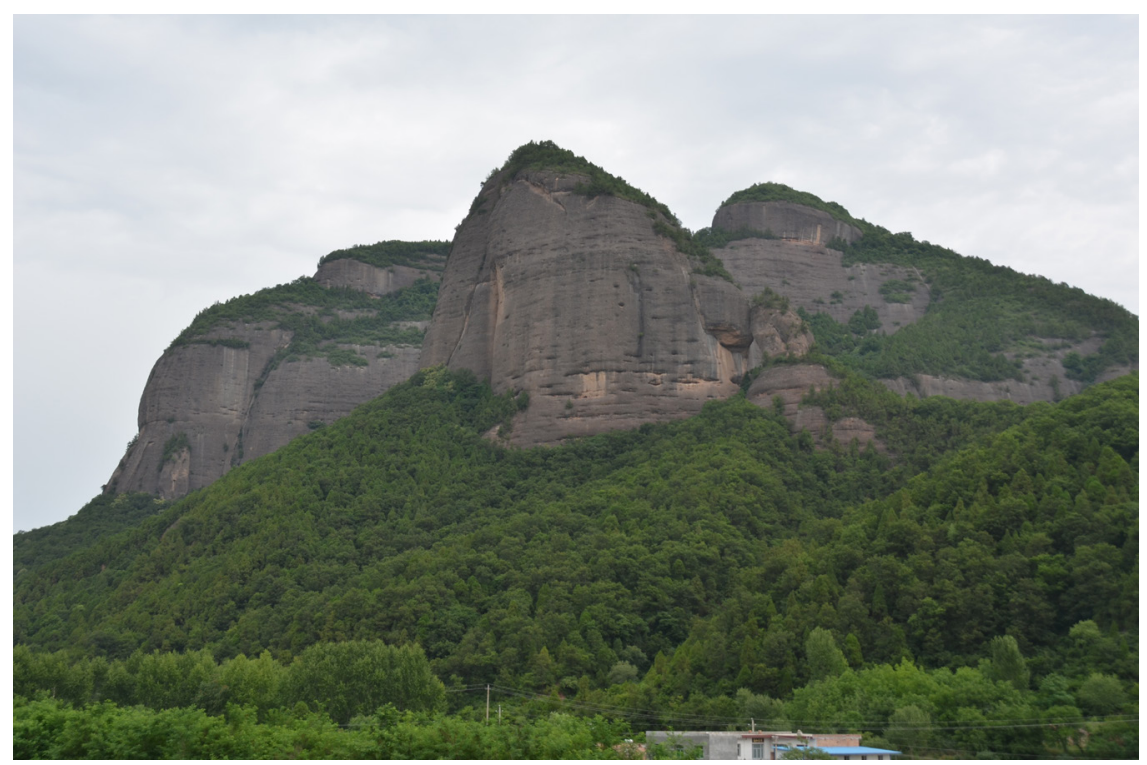

FIGURE 6. Xuejiazhai. Mountain fort of the Zhaojin Soviet. (Photo by author, 2016.)

who had only opium to use as anesthetic. Only critical officers were sent secretly to Xian for treatment in a modern hospital. ${ }^{192}$ Still, there is evidence that the guerrilla forces had reasonable control of this isolated border district, and the party was making its first tentative steps toward establishing a new local order.

Predictably, this progress was soon threatened by new leftist errors. It is conventional to blame these errors on Du Heng, but he was constantly under pressure from the provincial committee, which in turn responded to the leftist line of the party Center. ${ }^{193}$ Still, some of grievous decisions were certainly Du's own. He called for an attack on a local militia leader with whom the guerrillas had tacitly cooperated-even receiving arms from his forces. ${ }^{194}$ The attack failed, with major losses to the guerrillas. Du himself admitted that "I absolutely do not understand military affairs. ... My prestige among the fighters has been diminished." 195 He also offended local religious sensibilities by ordering his men to burn down a large local monastery. The monastery was a major local landowner, and its large store of grain had already been confiscated. Burning it down was defended on military grounds but was not welcomed by the local population. ${ }^{196}$

These actions weakened the guerrilla forces, but there was worse to come. All along, Du Heng and the party leadership had chafed against the guerrillas' military tactics of small-scale raids from mountain strongholds. The June 1932 meeting with the party Center had called for attacks on the more populous plains. The first attempt at this in Sanyuan had been unsuccessful. Now Du Heng presented even more radical plans. He first proposed that the guerrillas open up an international link by fighting through to the Soviet border, but this was quickly rejected as a 
foolhardy plan for an ill-armed local force of several hundred fighters. ${ }^{197} \mathrm{He}$ then proposed crossing the Wei River to establish a new base in the Weinan-Hua-xian (Wei-Hua) area east of Xian, where some of the earliest Communist cells had operated in the 1920s. Liu Zhidan and the other guerrilla commanders were skeptical, but Du was the army's political commissar, and his view prevailed. This was a rich area with a dense population and an established underground party base. In addition, the Fourth Red Army from the collapsing Hubei-Henan-Anhui (Eyuwan 鄂豫皖) Soviet was then retreating through southern Shaanxi in what party documents consistently called a "victorious advance." Against all evidence, Du Heng insisted that this created the "objective conditions for an uprising" in Shaanxi. The concern that the Wei-Hua area also had powerful local elites and was close to the center of provincial military power was dismissed as reflecting the "flightism" that had long afflicted guerrillas fighting and hiding in the hills. ${ }^{198}$

Such an aggressive military action naturally required money, arms, and provisions, and here the guerrillas turned to the same sort of local elite allies that had caused such trouble in Sanyuan. South of Zhaojin was a small guerrilla force led by Miao Jiaxiang, son of a wealthy and well-connected landlord family in the poor northern hills, who had joined the party as a student in 1927 , during the heady days of the united front. After a checkered career including service as an aide to the warlord governor Yang Hucheng, in 1933 he was back organizing friends into a small guerrilla band. Though lauded today as a revolutionary martyr, in 1933 he was fashionably dressed, always wearing dark glasses, smoking opium in the evening with his buddies, and described in the press as a "notorious criminal." 199 Soon a plan was hatched to kidnap a Norwegian engineer working on a new canal for the China International Famine Relief Commission. In May 1933, Miao's small band of ordinary peasants with red scarves around their waists and hammer-and-sickle emblems sewn onto their sleeves seized Eliassen and his aide. The captives were taken into the hills, where they were joined by some four hundred soldiers, mostly teenagers, of the Twenty-Sixth Army. Eliassen described them as well fed and dressed in padded uniforms but poorly armed: most had only "old muzzle-loaders, a sprinkling sported up-to-date rifles, and quite a number had only a sword stuck into the bandolier." For the ransom of the engineer and his aide, the guerrillas demanded $\mathrm{CH} \$ 200,000$, 120 rifles with 120 cartridges each, thirty-six machine guns with ammunition, five thousand sacks of grain, and four wireless transmitters. Though the escape of Eliassen and his aide aborted the delivery of most of this material, it seems clear that Liu Zhidan's band had allied itself with a questionable group of local toughs who, perhaps betting on Miao's prior connection to Yang Hucheng, promised to supply the arms and communication equipment for a major military action. ${ }^{200}$

In June 1933, Liu Zhidan led about three hundred men dressed as regular army soldiers in a daring crossing of the Wei River east of Xian. With seventy to eighty horses, several dozen mules, and an ample supply of weapons and ammunition (suggesting that some of the ransom may have been paid), they managed to hijack several trucks and headed for the foothills of the Qinling mountains south of 
Wei-Hua. Du Heng accompanied the army as far as Sanyuan, where the provincial committee belatedly attempted to halt the advance; then Du left the army for further discussions in Xian. ${ }^{201}$ In Wei-Hua, the Red Army was unable to locate the local party whose welcome had been promised and were instead ambushed in unfamiliar terrain by local militia and Red Spears. Their army was scattered, then hunted down in the hills and decimated. They buried their weapons, hid wherever they could, and hoped that underground comrades or sympathetic peasants would save them. The whole escapade was an unmitigated disaster. Liu Zhidan, wet and famished, hid in a mountain cave until discovered by his surviving comrades, after which a few dozen stragglers managed to escape back to Shaanbei. ${ }^{202}$

With its main military force away in the south, the soviet base in Zhaojin came under attack. The party leadership had favored Zhaojin because Yao-xian was still relatively close to targets in the Wei River valley, but this also made it more vulnerable. In July, the Zhaojin soviet was strengthened by a well-armed group of soldiers who had mutinied from the Yao-xian garrison under Wang Taiji, a former Communist and veteran of the 1928 Wei-Hua Uprising. ${ }^{203}$ But this was not enough. During the summer, the government conscripted peasants to build a road into the area, then hauled in artillery to pound the Xuejiazhai stronghold. In mid-October, a defector from the guerrilla forces led the enemy up a back trail and the hill was taken. The surviving defenders retreated westward into Gansu. ${ }^{204}$

Even before the fall of Xuejiazhai, the Shaanxi party suffered another devastating setback - though in the end it proved a godsend to the guerrillas. After leaving his position as political commissar of the Twenty-Sixth Army, Du Heng returned to Xi'an to consult with his colleagues in the provincial party committee. There is no indication that he ever sought to rejoin the guerrillas, and by mid-July he had certainly learned the disastrous consequences of his strategy to build a new base in Wei-Hua. Meanwhile, the underground party in Xi'an was itself in peril. In May, Chiang Kai-shek's resolutely anti-Communist Nanjing regime increased its influence in Shaanxi when Nationalist Party stalwart and former Communist Shao Lizi replaced Yang Hucheng as the civilian governor of Shaanxi. As we have seen, sympathizers on Yang's staff had often helped protect the Communists. Those days were coming to a close as Shao brought a corps of CCP defectors to press Nanjing's anti-Communist crusade. ${ }^{205}$ At the same time, the local CCP's foolish attempt to hold May Day demonstrations had attracted police attention to the underground party in Xian. During the summer, several Xi'an Communists had been arrested. While none of their comrades were exposed, the party's usual meeting places came under surveillance. On July 28, 1933, Du Heng was meeting in a Xian restaurant with the new secretary of the party's Shaanxi provincial committee, Yuan Yuedong, a printer and veteran of the 1925-26 Hong Kong seamen's strike whom the Center had dispatched to provide proletarian leadership for the Shaanxi party, and several colleagues including Gao Gang. The restaurant gathering was supposed to avoid police attention, but a couple of male patrons entered, sat at a nearby table, then departed. The Communists' suspicions were aroused, so Du and his comrades 
cut their meeting short and left separately. Too late. Du and Yuan Yuedong were arrested, while Gao Gang and one more escaped. Yuan Yuedong soon defected and began identifying other members of the Shaanxi organization.

By September, after various forms of enhanced interrogation, Du Heng also cracked and, together with nine of his comrades, published an open letter in the Xian press. ${ }^{206}$ Their "Declaration on Leaving the Communist Party" (Tuoli gongdang xuanyan 脱离共党宣言) appeared in six successive issues of the Nationalist Party's local paper, Xijing ribao. While reaffirming their commitment to revolution against imperialism and feudalism, they now claimed that this goal could best be achieved under the Nationalist rather than the Communist Party. "The Chinese Communist Party," they wrote, "ignores the special characteristics of China's political economy and mechanically copies the Russian Revolution in an attempt to use Marxism-Leninism to carry out [Marx's notion that] 'the workers have no fatherland [gongren wu zuguo 工人无祖国], establish communism, and destroy China and the Chinese nation." ${ }^{207}$ The Communists were attacked for dividing the nation by serving the Soviet Union and "Red imperialism" at a time when the greatest need was unity against Japan. Turning to Shaanxi, these urban Bolsheviks now admitted what their rural colleagues had long argued: the peasants were uninterested in land reform in a time of drought; they wanted grain and tax relief. While such forced public confessions should certainly not be taken at face value, much of the language was consistent with internal party documents. In any case, Du Heng and his colleagues gave the public a look inside a faction-ridden party that was distinctly unflattering. ${ }^{208}$

In the weeks and months after the July arrests, Du Heng and the other defectors' intimate knowledge of the party's apparatus allowed the Guomindang authorities to hunt down secret Communists throughout the province. In the Sanyuan base, Du's information convinced the authorities that the Communists' campaign of Red Terror disguised the actual weakness of the local organization, and they quickly moved to eliminate the remaining guerrillas. ${ }^{209}$ According to an early 1934 party report, "Of the arrested comrades, some were sentenced to prison, some were shot ...., and 90 percent of the rest defected and published so-called confession declarations [zishou xuanyan 自首宣言]. Some were forced to defect and confessions were published without their knowledge; some just wanted to save their skins; some wanted to go with their Guomindang buddies and get rich as officials." ${ }^{210}$ Arrests and further defections continued into 1934, effectively ending the work of the provincial committee and the party organization in many surrounding counties. Most party members were said to have defected, and total membership was down to an estimated two to three hundred. ${ }^{211}$ The urban-based Bolshevik wing of the party had collapsed. For Liu Zhidan and the surviving guerrillas in the field, this was not necessarily a bad thing: it liberated them from the impractical directives of the province and the party Center. Now they were free to pursue their own revolutionary path. ${ }^{212}$ 


\section{4 \\ The Rocky Road to Revolution}

In October 1934, Chiang Kai-shek's encirclement campaign forced the Communist leadership to abandon the Central Soviet in Jiangxi and set forth on the Long March. Over the course of its retreat from central China, the Red Army suffered enormous casualties, losing fully 90 percent of its numbers. Through much of 1935 , the main force of the Red Army fought for its life while wandering about western China with little clear direction. In June, Mao Zedong's troops joined those of Zhang Guotao in Sichuan, but soon these two founding members of the CCP parted ways and Mao continued north into Gansu. Despite the slogan and subsequently constructed narrative of going north to fight Japan (beishang kang-Ri 北上抗日), Mao in fact hoped to find refuge along the border of the Soviet Union. These plans changed after Mao entered southern Gansu and learned from a Guomindang newspaper that there was a substantial Communist soviet in northern Shaanxi. ${ }^{1}$ Exactly what Mao read is not known, but most likely it was a frontpage Dagongbao report of an alarmist speech by Shanxi governor Yan Xishan, under the attention-grabbing headline "Shaanbei Red Bandits Growing Peril: 23 Shaanbei Counties Almost All Red." The speech claimed that all northern Shaanxi counties were Red to a degree and eight were totally under Communist control. ${ }^{2}$ To the surprise of the weary soldiers on the long retreat from Jiangxi, they had discovered a vital soviet base in the hills of northern Shaanxi. That was enough to alter the direction of what would soon be called the Long March, and ultimately to change the course of Chinese history.

The survival of the Shaanbei soviet was no mean achievement. By 1935, the other Chinese soviets had all been crushed by Chiang Kai-shek's extermination campaigns. In a formula that became standard in the 1940s, the party lost 100 percent of its following in the "White" Nationalist Party areas and 90 percent in the Red bases. ${ }^{3}$ Shaanbei alone survived, and provided an indispensable refuge at the end of Mao's tortuous retreat from Jiangxi. Soon Mao was joined by He Long, from western Hunan, and the remnants of Zhang Guotao's army. From 1935 to 1948, the 
party Center was based in Shaanbei; during the War of Resistance against Japan, the Communists organized the Shaan-Gan-Ning Border Region with its capital in Yan'an. In the end, Shaan-Gan-Ning claimed control of thirty-one counties, of which eight were newly created. ${ }^{4}$ The area eventually became a stable Communist base, and Yan'an emerged as a Mecca for progressive youths seeking an alternative to Guomindang rule. In Yan'an, Mao and his colleagues developed the strategies that would lead the party to nationwide victory in 1949.

In most histories of the Communist revolution, the caves of Shaanbei provided a safe refuge for the Red Army to recuperate from the trials of the Long March and for Mao and his colleagues to plot their future course. Rarely mentioned is the fact that not long before Mao's army left Jiangxi on its wandering retreat to the north, the revolutionary movement in Shaanxi was in shambles. At the end of 1933, Liu Zhidan had just returned from the disastrous expedition south of the Wei River. He survived with only a few comrades, and fewer than a hundred soldiers would eventually straggle back to Shaanbei. While Liu was campaigning in Weinan, the Communist rear guard had been driven from its base in Zhaojin. In Liu's native county, Bao'an, the fragile party organization had been destroyed, and Communist activity came to a halt. ${ }^{5}$ Liu's small guerrilla detachment faced a severe winter in the poor and sparsely populated Nanliang hills on the Shaanxi-Gansu border.

At roughly the same time, Xie Zichang, leader of the Communist movement east of Yan'an, returned to his home in Anding. There the local guerrillas had recently suffered such losses that they decided to bury their weapons, hoping to live to fight another day. When Xie chastised them for defeatism, he was able to organize a force of only ten men. Everywhere in Shaanbei, the revolution was at a low point in the winter of 1933-34. Meanwhile, in Xi'an and the Wei River valley, the years of famine were over, and Shaanxi was at last escaping its reputation for lagging development and social isolation. By 1931 a motor road from Xian and the slowly advancing railway from the east had reduced the trip to Beijing from three weeks to three days. Irrigation works helped spur cotton production, and commercial agriculture was no longer confined to the opium poppy. Soon Xian would have electricity, running water, and the first modern factories. ${ }^{6}$ With economic progress in the Nationalist areas and the Communist Party decimated, how in the space of a year and a half did the revolutionary base expand to become a plausible refuge at the end of Mao's Long March? As we begin this narrative, it is important to remember that even before the disastrous defeats of 1933, most Shaanbei guerrilla actions were small-scale raids on isolated militia outposts or vulnerable landlords. Never before had they been able to take a fortified town, much less a county seat. Only a new set of contingencies can explain the dramatic victories of 1935 .

\section{NANLIANG AND THE TWENTY-SIXTH RED ARMY}

While Liu Zhidan led his forces on the ill-fated expedition south of the Wei River, the rear guard in the Zhaojin base was joined by a well-armed force under Wang 
Taiji. Wang had fought alongside Liu Zhidan in the Wei-Hua Uprising of 1928, then joined Yang Hucheng's army, where in 1933 he commanded a horseless "cavalry" battalion in Yao-xian. In July, Wang led 1,300 men in a mutiny, but after a confused uprising and several military setbacks, only 100 committed soldiers followed Wang to join the Communists at Zhaojin. He brought with him a hundred unassembled machine guns and several mortars, weapons that greatly increased the firepower of the guerrilla force. ${ }^{7}$ The machine guns were an especially prized acquisition; the guerrillas had long envied this powerful weapon of their opponents. ${ }^{8}$ Wang Taiji was made commander of the guerrilla forces and proved an able military tactician, leading the now better armed guerrillas to several military victories.

The Twenty-Sixth Army's new political commissar was Gao Gang, who had barely escaped the Xi'an arrest of the provincial leadership in July. With military command in the hands of a defector from the Nationalist army, Gao provided a commissar with considerable experience in the party and a potential link to higher party organs. On the other hand, just a year earlier, Gao had condemned the guerrillas as "bandits" and "opium-dealing hooligans" and urged a purge of the leadership to force them to follow the provincial committee's Bolshevik line. ${ }^{9}$ In the summer of 1933, Gao quickly changed his tune, in a reversal that would permanently link his fate to the Shaan-Gan revolutionary movement. Gao's motivations are lost in the mists of time, but his entire controversial life suggests a shrewd and ambitious Communist who quickly grasped the best way to advance the revolutionary cause and his own career. Having barely escaped arrest in Xi'an, Gao was a marked man in the cities. A Shaanbei native, he now hitched his fate to the guerrilla movement, beginning his ascent in the Shaanxi revolutionary movement as an ally of Liu Zhidan rather than an appointee of Xi'an. ${ }^{10}$ In August, he beat back efforts of the "rightist" Sanyuan Communists to disperse the guerrillas and wait for another day. Instead the army decided to expand into the hills to the north, and after Zhaojin was lost in October, Gao and Wang led their army north to a new base in Nanliang. ${ }^{11}$

In Nanliang, Liu Zhidan, after recovering from the trials of the Weinan fiasco, rejoined the guerrillas. The Bolsheviks in the provincial committee had long accused Liu of ignoring the cities and pushed him to concentrate attacks near the urban areas of the Wei River valley. Now he was free to chart his own revolutionary strategy. The new base in Nanliang was about 150 kilometers north of Zhaojin, separated from the center of provincial power by a low range of mountains, thick forests, and a lack of significant roads. The town of Nanliang lay on the Gansu side of the border, while the guerrilla strongholds were nestled in the hills south of neighboring Bao'an in Shaanxi. This was an ungoverned and ungovernable border region far from any concentration of state power. ${ }^{12}$ Most of the residents were recent migrants from counties in northeastern Shaanxi, fleeing famine in their home districts and repopulating an area still recovering from the Muslim Rebellion. Land was held by large landlords, many organized in corporate lineages unusual in this area. This provided a reasonably favorable environment for 
class-based revolutionary appeals. ${ }^{13}$ Of more immediate advantage to the guerrillas, however, was the local power of the Society of Brothers. Liu Zhidan was a member of this society, and it supplied intelligence for his guerrillas; Brothers in the militia provided ammunition; and their families harbored guerrilla casualties as they recovered from wounds suffered in combat. ${ }^{14}$

This isolated border area had long been plagued by bandits, and most landlords had retreated to walled towns or mountain fortresses, leaving the guerrillas space to operate in the hills and small hamlets. The Communists were regarded as a new generation of tramps (liulanghan 流浪汉), not so different from the ever-present bandits. Their struggle was not, however, on behalf of tenants opposing landlords. As always, it was oppressive taxes that aroused popular opposition, and tax collectors were the prime victims of guerrilla assassinations. Liu's forces avoided any complex Marxist propaganda. Their message was simple: they were attacking the rich to aid the poor. This justified the tactic that fed their army: collecting ransom by kidnapping members of wealthy families. ${ }^{15}$ Their efforts to reform local customs were minimal and easily deferred. Opium use was widespread in the area, and smokers made it clear that if the poppy was banned, they would support the Communists' enemies. In neighboring Shanxi, Yan Xishan had launched a vigorous antiopium campaign, and one result was that many opium smugglers and their guards were losing money and joining the Communist guerrillas. Responding to popular pressure, the guerrillas postponed any opium ban for two years. ${ }^{16}$

In the guerrilla army, Wang Taiji helped to inspire a greater degree of military discipline as he and Liu weeded out opium addicts unable to keep up on long marches and executed bandit leaders who failed to follow orders. They followed up with some basic political education, blaming peasant poverty on exploitation by the rich and powerful. ${ }^{17}$ Even Gao Gang was briefly removed from his commissar post for violation of discipline in the rape of a local woman. This disciplinary action lasted only a few months, however, an indication of Gao's indispensable role in the army and the small price paid for serious violations of local women. ${ }^{18}$ Wang Taiji's contribution to the military capacity of the Twenty-Sixth Army was substantial but short-lived. Soon after Liu rejoined the force, Wang departed, hoping to inspire a mutiny by an army colleague in Shandong; but on the way he was betrayed by a friend and executed. ${ }^{19}$ Liu assumed command, and the army continued to grow. A cavalry unit was organized, and it was able to coordinate quick attacks on local militia with small guerrilla actions against isolated landlords. The cavalry was responsible for several military victories in Gansu; it managed to capture more weapons, and by the end of 1934, Liu's army had grown from 270 to 600 men. ${ }^{20}$

The Twenty-Sixth Red Army was reemerging as a significant military force. However, attempts to reestablish contacts with higher party authorities were unsuccessful, and Liu made little effort to build a local party organization. ${ }^{21}$ According to an early party report on the guerrillas in eastern Gansu, "In the two thousand $l i$ the guerrillas passed through, there was not a single village or town with a party organization or member. The vast majority of the laboring masses 
had no idea what kind of weird thing this Communist army had come to do."22 In eastern Shaanbei, the party was based in rural schools, but schools hardly existed in the small and widely separated villages along the Gansu border. (Even when I visited the area in 1989, the county's largest village had only forty-eight families.) Bao'an, before the Communists expanded the school system, had only one higher primary and four lower primary schools in an area of roughly 3,300 square kilometers; 98-99 percent of the population was illiterate. ${ }^{23}$ The army supported itself by kidnapping wealthy targets for ransom, and Red Terror was mainly directed at local security agents and tax collectors. ${ }^{24}$ Significantly, along the Shaanxi-Gansu border, where education was undeveloped and degree holders were virtually nonexistent, the term gentry (shenshi 绅士) referred to those with power to assess taxes: baozhang (保长) and lizhang (里长). ${ }^{25}$ These were the enemies of the revolution, usually described as "gentry strongmen" (haoshen) in contemporary sources, and the Communists targeted them mercilessly. There was certainly an element of class struggle in this, but it was based, not on any distinction between landlord and tenant, but on links to the state and inequities in power and privilege. Without a local party organization, the struggle against local power holders was not part of any larger revolutionary movement against the ruling class.

\section{A CHANGING POLITICAL CONTEXT}

On the national scene, the most consequential development of the mid-193os was the steadily escalating crisis with Japan and rising domestic opposition to the Nanjing government's pusillanimous response. The 1931 Japanese occupation of Manchuria had been followed by incursions into neighboring Rehe, fierce battles along the Great Wall in Chahar, and Japanese efforts to separate Beijing, Tianjin, and all of North China as a new "autonomous region" independent of Nanjing. Japan's invasion now imperiled more than the distant Manchu homeland; the territorial integrity of the Chinese nation was at stake. After the Manchurian incident, Chiang Kai-shek's government had responded with loud cries of indignation, appeals for League of Nations support, cautious military withdrawals, and carefully negotiated truces with Japan. Initially, there was broad support for his policies, and as we have seen, Communist critics were rendered ineffective when they characterized the Japanese threat as directed against the Soviet Union, for whose "armed defense" they endlessly appealed. Other critics were more effective. Feng Yuxiang rushed to confront the Japanese on the Chahar front, receiving propaganda if not financial support from opinion leaders and militarists in southern China. In November 1933, a rebellion in Fujian opposed Nanjing's appeasement of Japan. Chiang easily crushed the rebellion, but military leaders across the country called for determined resistance to Japanese aggression. ${ }^{26}$

Slowly, the CCP learned from its mistakes. The anti-Japanese movement following the Manchurian incident had largely benefited the party's rivals. In 1932, party propaganda stressed a broad anti-imperialism targeting all the great powers 
that threatened the Soviet homeland, a policy with little appeal to Chinese patriots. Soon the party called for resistance to Japan and chided local operatives for insufficient attention to the growing anti-Japanese movement. ${ }^{27}$ The Red Army was rebranded as a patriotic force. As the Long March left central China, there were calls to "support the Red Army coming north to oppose Japan." 28 These appeals had an indisputable impact in the government's armed forces, whose officer corps included many who had chosen military careers to defend the nation. The most telling evidence of this was the mutiny of Wang Taiji; his officers were angry over Nanjing's retreat from Rehe, were inspired by the students' anti-Japanese demonstrations, and mutinied under the banner of the Northwest Popular Anti-Japanese Volunteers (西北民众抗日义勇军). ${ }^{29}$ As we have seen, only one hundred of the thousand who mutinied stayed with the revolutionary movement, and Wang himself soon left on a fatal attempt to join like-minded officers in Shandong. Nonetheless, his troops and their weapons greatly strengthened the guerrilla movement in northern Shaanxi.

Another important addition to Liu's forces was Guo Baoshan, who also joined under an anti-Japanese banner-though in his case more complex motivations were also involved. Guo led a large "bandit" army of some one thousand men based in the Huanglong mountains north of the Wei River. Guo was a former soldier, whose band was one of those large armies that was periodically absorbed into local warlord commands. Liu Zhidan had long courted Guo, sending a representative with gifts and an invitation to join the Red Army. In the summer of 1934, Yang Hucheng attempted to co-opt Guo's army and those of two other Huanglong "bandits," and the trio fled with their troops to eastern Gansu. There Liu contacted Guo through Society of Brothers intermediaries and again sent gifts, this time three horses. Soon Guo led a company of 120 men to join Liu's cause as an independent force of Northwest Anti-Japanese Volunteers (西北抗日义勇军). After guerrilla victories over the other "bandits" that had fled Huanglong, some of the defeated troops also joined Liu's army. Many of these men had the usual opium addiction of bandit armies, and Guo was allowed to continue smoking, though others were forced to quit or leave. After joining Liu's army, Guo's troops continued to bivouac together, and Liu avoided putting them on the front line in battle. Through such careful measures, Guo's loyalty to Liu and his cause was secured. His men contributed significantly to the victories of 1935, and Guo eventually rose to the rank of general in the People's Liberation Army. ${ }^{30}$ Although Guo's recruitment involved more than anti-Japanese sentiment, patriotism was at least a convenient and credible pretext for joining the revolution.

The national debate over resistance to Japan and Chiang's persistent campaigns against the Communists affected the Shaanxi context in other ways. It is widely recognized that as Chiang's armies chased the Communists across western China, the power of the Nanjing government penetrated areas previously beyond its reach. Chiang's crushing of the Fujian rebellion also increased his power in the 
south. ${ }^{31}$ In Shaanxi, Chiang restricted Yang Hucheng's authority by appointing Shao Lizi governor in 1933. He followed by reducing support for Yang's armies, leading to demobilization orders for twenty thousand soldiers. Now Yang was further threatened by the example of Fujian and the transfer of Chiang's loyal general, $\mathrm{Hu}$ Zongnan, to the Northwest to block the Red Army's northern advance. Feeling his independence in jeopardy, Yang halted aggressive actions against the Communists and even reached out (without success) to Zhang Guotao's Red Army as it passed through southern Shaanxi. ${ }^{32}$ The Shaanbei revolution gained further respite when Xu Haidong's Twenty-Fifth Red Army passed through southern Shaanxi on its retreat from the Hubei-Henan-Anhui Soviet. The Shaanxi Communists hailed this movement as a "victorious advance," and Xu's army briefly made a feint north to threaten Xi'an. The walled provincial capital was certainly beyond the military capacity of Xu's force, but with several thousand well-armed and battle-tested soldiers, his Hubei army was a more formidable force than anything in Shaanbei and proved a significant distraction for Yang Hucheng. Some military units were withdrawn from the southern parts of Shaanbei, giving Liu's Twenty-Sixth Army more room to maneuver. ${ }^{33}$

Finally, there was the weather. For years party documents had maintained that the prolonged drought in Shaanxi provided the objective conditions for revolution. In the words of one 1930 pronouncement, "The rural economy is bankrupt as never before, with endless barren fields abandoned to weeds; five million famine refugees are crying for relief, caught in a trap of hunger, cold, and death. . . . [In these conditions] the revolutionary struggle of the toiling masses unquestionably will expand, hastening the death of the ruling class and bringing complete victory to the revolutionary struggle throughout the province." ${ }^{44}$ In fact, famine rarely leads to revolution: peasants are too weak to fight and devote all their energy just to survive. Large-scale social movements are more likely when subsistence crises come to an end. ${ }^{35}$ In Shaanbei, the drought finally broke when a heavy snow blanketed the land in the winter of 1933-34. For guerrillas in the cold hills above Nanliang, the winter was exceptionally trying; they shivered in unheated caves and struggled to cover their tracks in the snow after an enemy attack. ${ }^{36}$ But snow promised a bumper crop in the summer. That meant ample grain stores for the rich, and ready targets for the guerrillas. It also meant falling prices and less money to pay taxes-taxes that were no doubt increased to make up for the long years of drought. ${ }^{37}$ For these reasons, the end of the drought contributed to peasant grievances and probably left more young men with the will and energy to join the revolution.

\section{THE RETURN OF XIE ZICHANG}

In January 1933, Xie Zichang was sent to Shanghai for reeducation as part of the Xian provincial committee's purge of the Twenty-Sixth Army leadership. What transpired in Shanghai remains hidden in the archives, but Xie was presumably 
cleared of significant wrongdoing and properly reeducated in the prevailing party line. He was sent to Beiping to work with the party's North China representative. In contrast to Liu Zhidan's Shaan-Gan branch of the party, which answered to the provincial committee in Xi'an, the "Shaanbei" party in the northeast had long communicated with the Center through the North China office. ${ }^{38}$ From the towns where the "Shaanbei" party operated, communication with Beiping was faster and cheaper through Shanxi and the rail line to Taiyuan, while it took some two weeks over narrow roads and trails for a courier to reach Xian. ${ }^{39}$ The "Shaanbei" party also received financial support directly from the North China office, enhancing its independence of Xian. ${ }^{40}$ In return, when his guerrillas generated money through kidnapping and ransom, Xie Zichang sent funds to support imprisoned cadres in Beiping. ${ }^{41}$ Xie's assignment to the North China office reinforced these longstanding relations between that office and his branch of the party and was symptomatic of the distinct organizational affiliations of the two northern Shaanxi factions. These separate lines of reporting, funding, and control only served to exacerbate the conflicts between Xie Zichang's "Shaanbei" Communists and Liu Zhidan in Shaan-Gan. ${ }^{42}$

From Beijing, Xie was sent to Zhangjiakou to work in a Nationalist army unit opposing the Japanese advance in Chahar. There he married a well-educated young woman from a wealthy family in Mizhi, a center of women's education in Shaanbei. In the 1920s, You Xiangzhai had taught school in Anding, and Xie had known her there. Later she undertook a number of chores for the party, and Xie sent several letters and proposed marriage. She hesitated, though the party strongly encouraged marriage between comrades. A married couple provided cover for party gatherings, while women who married outside the party risked exposing party secrets. ${ }^{43}$ When the two again came together in Zhangjiakou, a hasty marriage was celebrated. Despite her early admiration of Xie as a revolutionary leader, You was disappointed with her new conjugal life. She found herself cooking, sewing, and mending clothes for a house full of young male Communists. That was not what she had joined the revolution for. Soon the army Xie had joined was defeated in Chahar, the couple returned to Beiping, and Xie was sent back to Shaanbei. The two never saw each other again. A year later, You was in jail in Beiping, pregnant with a child that Xie had certainly not fathered. ${ }^{44}$

In November 1933, the party's North China representative sent Xie Zichang back to revive the guerrilla movement in his native Anding. Soon afterward, Guo Hongtao, from neighboring Mizhi, was dispatched to direct the party organization. ${ }^{45}$ The focus of their operation was an area quite different from the ShaanGan border where Liu Zhidan's guerrillas operated. The northeastern Shaanxi counties along the Wuding and Qingjian rivers were the richest, most densely populated, and best-educated parts of the region. This was also the place where the Shaanbei party had first grown. In the north, along the remains of the Great Wall and the blowing sands of the Gobi Desert, was Yulin, the political center and military base of the local warlord Jing Yuexiu. In Yulin, Jing founded a middle 


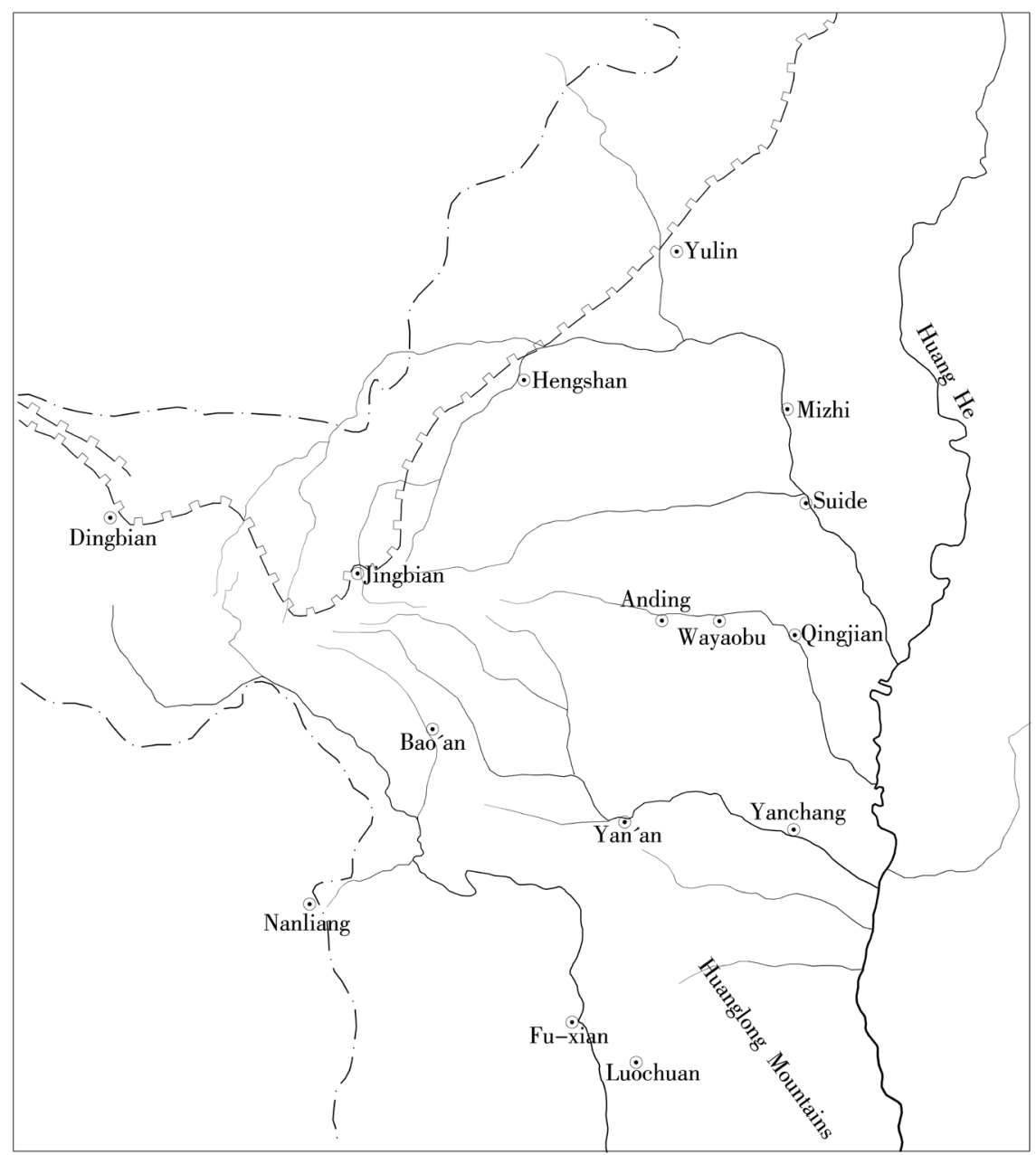

MAP 5. Map of northern Shaanxi.

school to serve the entire region, hiring teachers from Beijing, including Wei Yechou and Li Zizhou, who became the founders of the Communist Party in Shaanxi. As we have seen, both Liu Zhidan and Xie Zichang studied there. Further south along the Wuding River was Mizhi, whose gentry were the best educated and most powerful in the region. Suide, an independent department (zhilizhou 直隶州) under the Qing, had Shaanbei's first normal school, which also produced many Communists until Jing Yuexiu closed it in 1930. Suide and Mizhi were well known for their powerful landlords and a relatively high degree of land concentration. South of Suide was Qingjian, site of a Communist uprising in 1927 and a key ford across the Yellow River to Shanxi. Xie Zichang's home in Anding lay further up the Xiuyan River, west of Qingjian. It prided itself on a cultured and frugal literati tradition that supported a strong school system in the republican era (map 5). ${ }^{46}$ 
While Liu Zhidan's Shaan-Gan revolutionary movement was built from soldiers, militiamen, bandits, and Society of Brothers associates, the Communist Party in northeastern Shaanxi spread through the schools. The northeastern counties had the most and the best schools, and in the 1920s, during the united front with Sun Yat-sen's Nationalist Party, the Communists had been extraordinarily successful in penetrating the educational establishment. ${ }^{47}$ When the counterrevolution came in 1928, most of the leading Communists were killed or defected, but others survived, and sympathy for the early leftist teachers endured. Even in 1933, when 70 percent of the claimed 1,100 "Shaanbei" party members were peasants, party reports admitted that "the entire leadership is still intellectuals, right up to the present." ${ }^{\prime 8}$ One local cadre recalled that workers often defected and that the peasants were ineffective in leadership positions. ${ }^{49}$

Teachers were the reliable heart of the party. Communist teachers at Suide Normal recruited new members who went on to teach in the towns and villages of the area, often protected by sympathetic education commissioners. In Anding, every one of the local cells was headed by a teacher. Through these networks, the party established its rural base. ${ }^{50}$ This intellectual leadership was not without problems, as leftists in the party pointed out: "At that time, party cadres were all intellectuals, and eight or nine out of ten were sons of landlords and wealthy gentry. 'You find your associates, I gather my friends', so the party grew quickly. But the objective result was an organization full of internal conflicts. When they went home, they enrolled their tenants and agricultural laborers. They were the county, district, and local cell secretaries, and all the party propaganda and slogans were only empty talk. If there were any concrete struggles, it would conflict with their own interests." ${ }^{51}$ The party in Shaanbei was expanding through school and family networks deeply embedded in rural society, which produced a village-based organization with all the strengths and weaknesses of a revolutionary movement built on established authority structures.

In the early 1930s, Jing Yuexiu and his conservative supporters had effectively suppressed the party in the northern part of this region, driving them from the schools in Yulin and Mizhi and closing the normal school in Suide after Communist students engaged in the sort of "infantile leftism" typical of this era-leafleting in memory of the 1927 Canton Uprising. A small group of committed radicals persisted, using summer entrance examinations as cover for their meetings, using weddings and funerals as an excuse to travel, stressing secrecy, using passwords, and avoiding regional accents that might expose them away from home. Female comrades were asked to carry secret documents, as they were less subject to search. ${ }^{52}$ Communists lived in constant danger of exposure by defectors. In Mizhi, a Communist who had infiltrated the army as a clerk came under suspicion and was fired by the authorities. The party gave him a minor post, but it did not provide enough to support his wife. Unhappy with his lot, he defected and exposed the entire local organization. ${ }^{53}$ Perhaps as a result of this defection, six Mizhi 
students were arrested and executed in 1933. Their bodies were thrown into the Wuding River, but when they were dragged out downstream there was widespread sympathy for these educated youths. In this area, intellectuals were respected, and killing students - even Communist students-was never popular. There were limits to the effectiveness of White Terror, and the party gained sympathy even as it lost cadres. ${ }^{54}$

Government suppression drove the party from county seats and towns and into the countryside. It also forced the Communists out of the north-most of the small guerrilla operations of the "Shaanbei" party were in Qingjian and Anding, well south of the political-military center in Yulin. The Communists maintained an underground organization in the schools and had some success in supporting tax resistance movements, but in general the guerrilla actions involved very small bands, including the usual bandits and Society of Brothers members. When Yan Xishan launched an opium suppression campaign in Shanxi, the Shaanxi opium porters and guards lost their livelihood, the local economy suffered, and the guerrillas gained another source of recruits. Contemporary newspaper accounts link opium dealers to the growth of the revolutionary movement, and their antagonistic relations with the authorities make this plausible. ${ }^{55}$ Party efforts to discipline these groups could backfire, and one guerrilla organizer was shot by the bandits he was trying to reform. When the party sought alternatives to recruiting bandits, it found that peasants and students lacked the necessary military skills. In combat they just fired their weapons and ran. ${ }^{56}$

Party operatives' awareness of the difference between the "Shaanbei" and Shaan-Gan revolutionary movements is evident behind the inflated language of their reports. In "Shaanbei," "the enthusiasm of the masses is extremely high, now reaching the stage of armed mass action; but our weakness is the lack of weapons." In Shaan-Gan, by contrast, despite an active guerrilla movement, the lack of suitable cadres meant that "we have not generally been able to establish rural branches." ${ }^{57}$ In effect, Shaan-Gan had an army but no party organization, while "Shaanbei" had a rural organization but no army. ${ }^{58}$ The "Shaanbei" party desperately appealed for military support: "In the past, the Twenty-Sixth Army has consistently attacked toward Guanzhong, and has never come to the northern part of Shaanbei. . . They pay attention only to occupying Xi'an." ${ }^{59}$ Of course, it was the provincial committee in Xian that ordered Liu's army to attack Guanzhong; but now that committee had been crushed and Liu had moved north to Nanliang.

By 1934, the road was open to further collaboration, but it was not the first cooperation of the two party branches. Already in 1932, Qiang Shiqing, an Andingborn cavalry officer in Liu's army had returned home to revive the "Shaanbei" guerrilla movement. His first act, soon after the lunar New Year, was the dramatic assassination of the Anding County magistrate. After this, Qiang seems to have moved back and forth between Anding and Nanliang, building a small village-based revolutionary movement in the mountains west of Anding. After 
Liu Zhidan's return in the fall of 1933, Qiang was again sent to Anding with a small force and a little money to support the guerrilla movement there. Qiang, however, was overconfident and foolishly attacked an army unit in Xie Zichang's home village. He was wounded in battle, then sold out by a defector and executed. Others in the band fought on for a time, but they too were defeated. By the time Xie Zichang returned, the group had buried its weapons and disbanded. ${ }^{60}$

When Xie Zichang returned, he chastised his dispirited comrades for abandoning the struggle, dug up the weapons, and led a small band of about ten men to continue the fight in western Anding. As in Nanliang, the winter of 1933-34 was bitter, and Xie suffered from frostbite after sleeping on straw in the hills. The guerrillas could visit the villages only at night; during the day, Xie lectured his men on Shaanbei's history of rebellion and on the Communist movement in Jiangxi, of which he had learned in Shanghai. He reviewed the history of the party and its repeated setbacks, endlessly repeating his favorite slogan: "Defeat is the mother of victory." ${ }^{11}$ When spring came, Xie and his men worked in the fields as peasants during the day, then carried out night raids, gradually building a support network of young Red Guards. ${ }^{62}$ As Xie and others reignited the partisan struggle in eastern Shaanbei, their weapons were few and second-rate, worthless against regular army units. Their targets were yamen runners, tax collectors, and "local despots." 63 Still, this was sufficient evidence of class struggle that the party praised them for overcoming Shaanbei's history of "rich peasant" errors and correctly carrying out the Center's line. ${ }^{64}$

It is notable that this sort of low-grade, small-scale revolutionary movement was as much a family affair as an example of class warfare. The eastern part of Shaanbei had denser and stabler village populations, and kinship ties were more important than in the migrant-filled villages of the west. Activists recruited people whom they knew well and could trust, so they turned first to their own families. It is not surprising that Xie Zichang's deputy commander was his nephew. Indeed, Xie's family was so intimately involved in the revolution that twenty-six of his relatives aided the revolution and nine died for the cause. ${ }^{65}$ Xie's own family was hardly unique in this respect. Another Anding village had five sets of brothers or cousins who joined the revolution, and the lists of local Communists have dozens with identical surnames and generation characters-a telling indication of close kinship ties. ${ }^{66}$ Family loyalty and commitment to the revolution went hand in hand. After his return to Shaanbei, Xie Zichang's most dramatic revolutionary act was a daring assault on Anding to free dozens of imprisoned Communists from jail. Many had been arrested in early 1934 as Xie's guerrilla attacks escalated, and their families appealed for their rescue. In July 1934, Xie led a small band of six guerrillas to break open the jail in the weakly defended county seat-though his own jailed brother may have perished in the attack. ${ }^{67}$ This was, of course, but one side of a pattern in which families became inextricably bound up in the revolutionary process. In its effort to uncover Communist guerrillas, the state would 
arrest family members, holding the family responsible for the radical activities of its young men. The Communists, on their part, kidnapped the offspring of wealthy landowners for ransom and often killed family members of particularly hated strongmen. ${ }^{68}$ The inevitable result was a tangled connection between family bonds and political commitment.

\section{LIU AND XIE: RIVALS AND ALLIES}

Liu Zhidan and Xie Zichang, heroes of the Shaanbei revolutionary movement, were like two stars of a basketball team who never got on the same page. They needed each other to succeed: Liu's military tactics and Xie's organizational discipline would have made a powerful combination. But true cooperation was always just beyond reach. In the summer of 1934, they made one final attempt. Liu Zhidan made the first move, sending weapons to "Shaanbei" in exchange for grain to support his army in Nanliang. ${ }^{69}$ Then, shortly after springing the prisoners from Anding's jail, Xie Zichang led several hundred of his men to rendezvous with Liu Zhidan in Nanliang. Xie's guerrillas were under intense pressure following the Anding attack, and Nanliang provided a reasonably safe refuge. Xie was accompanied by Guo Hongtao, the young Mizhi native who had graduated from the same Yulin school as Liu and Xie. Having spent six years in prison in Shanxi, Guo was relatively inexperienced, but he had learned his Leninism well and was responsible for party-building in "Shaanbei." ${ }^{70}$ Both Guo and Xie had been sent by the North China bureau, where they were briefed on the long history of criticism of the Twenty-Sixth Army for "right opportunism," fleeing to the hills, and failure to carry out land reform. In the past, those criticisms had come from the provincial committee, but now they were advanced by Liu's comrades in the "Shaanbei" branch of the party. The party's ambition was clear: it wanted to gain greater party control of Liu's Twenty-Sixth Army, to unify with the guerrillas in "Shaanbei," and on that foundation to build one great soviet that stretched all the way from Sanyuan in the Wei River valley to the border of Suiyuan in Inner Mongolia. ${ }^{71}$

Given the past conflicts between Liu and Xie, this was a historic meeting. ${ }^{72}$ In 1932, Xie had ordered Liu Zhidan's friend and key officer Zhao Erwa shot at Sanjiayuan. After that incident, most of Liu's bandit-based army had been disbanded and Xie had assumed command. Xie still defended this action, with the "Shaanbei" committee writing in January 1935, "Because Liu's men were all acting like bandits, they were disarmed." ${ }^{73}$ Despite this troubled history, in the summer of 1934, Liu Zhidan welcomed Xie's band with a feast of pork and lamb and an offer of more weapons. ${ }^{74}$ Xie was not impressed. In his report to the party, referring to Liu's army by its new divisional appellation, he charged that "the FortySecond Division has consistently charged about helter-skelter and cannot carry out the hard mass work of the Northwest Soviet."75 The differences between the two leaders were as great as ever. The context, however, was different. Since the 
collapse of the Shaanxi provincial committee, Liu Zhidan had been operating without instructions from any higher party authority. Xie Zichang, however, arrived with the mandate of the Shanghai Center and its North China office. That mandate was embodied in two letters carried by Guo Hongtao.

The letters were based on years of critical reports from the provincial committee about the bandit composition and "opportunist" errors of the Shaan-Gan guerrillas. ${ }^{76}$ The North China message was written in disappearing ink between the lines of an unrelated book - a not uncommon way of transmitting highly secret and sensitive communications. ${ }^{77}$ After deciphering and transcribing the letters, Guo Hongtao carried them to Nanliang, where they were delivered to the TwentySixth Army. ${ }^{78}$ The precise language of the letters is unknown, but similar communications from the time provide a good indication of their content. The consistent tone is resolute optimism about the prospect for revolutionary victory. Though Mao's forces would abandon the Central Soviet just two months later, decisions of the Communist International and the writings of Wang Ming were cited to refute the "nonsense" that the Central Army had suffered defeat in Jiangxi and to argue that urban uprisings were still possible. Small guerrilla actions were criticized as "right opportunism" and as the product of lingering "peasant consciousness." The Shaan-Gan policy of clearing villages and fleeing to the mountains in the face of enemy attack was criticized with the assertion that "defense is the death of revolution." Instead, the Red Army in Shaanxi should prepare to attack towns and cities, eliminating these centers of reactionary armies, while at the same time seeing that "not a single inch of soviet territory is trampled by the enemy." Finally, these letters called for expanding the soviet movement in the direction of the Communist forces operating on the border of Sichuan and southern Shaanxi-unaware that, even as the 1935 letters were written, the Red Army in those areas was preparing to withdraw to Shaanbei. ${ }^{79}$

As these letters showed, the party leaders in the coastal cities were sadly divorced from the reality of revolution in the hinterland. Just a year earlier, Liu Zhidan's forces had suffered a devastating defeat by following similar orders from the party authorities in Xian. Liu was just beginning to have some success in rebuilding his army in Nanliang when he was again accused of right opportunism, hiding in the hills, and neglecting the urban centers. To many of Liu's followers, the message of these letters was a "staggering blow." ${ }^{80}$ Most of the resentment was directed at the young but articulate Guo Hongtao for acting like an "imperial delegate," but some felt that Xie Zichang gave local legitimacy to the twenty-five-year-old Guo and displayed a "factional attitude" in his relations with Liu's army ${ }^{81}$ Later that year the Shaan-Gan revolutionaries counter-attacked by accusing the "Shaanbei" party of ultra-leftism for establishing collective farms while party policy called only for land reform. ${ }^{82}$ While the two factions might have debated their differences on an equal basis, Xie presumed upon the support of Guo Hongtao and his own relations with the higher party organization in Beijing. ${ }^{83}$ Neither the participants' 
memoirs nor the contemporary documents provide any record of the debates in Nanliang, but it is clear that Xie and Guo Hongtao took the offensive in attacking the Twenty-Sixth Army's alleged errors. Given Liu's quiet manner and his consistent obedience to party orders, he is unlikely to have fought back aggressively. On one matter he seems to have given way immediately: Gao Gang was removed as political commissar and replaced by Xie Zichang. Both Xie and Guo Hongtao particularly opposed Gao Gang, with Guo attacking his "vile character" and Xie requesting his reassignment. Gao had been the first representative of the provincial committee to criticize the guerrillas, and despite his later rise and alliance with Liu Zhidan, Xie was no doubt wary of Gao's past affiliation with the hated Xian committee. The fact that Gao Gang had escaped the police raid and destruction of the party committee in Xi'an and fled to join Liu's army probably enhanced Xie's suspicions. Like Xie Zichang in 1933, Gao was ordered to Shanghai for reeducation, but he refused to go. ${ }^{84}$ On other matters as well, Liu and his lieutenants had some success in resisting the orders of their party superiors.

One thing on which Liu and Xie agreed was the folly of continued attacks in the Wei River valley. This had always been the Center's preference, as the best way to threaten Xian and build an urban proletarian revolution. Xie, however, wanted to support his movement in Shaanbei and argued that recent defeats left morale too low for continued attacks in Guanzhong. ${ }^{85}$ Liu agreed that the party should focus on the northern part of the province. In the following months, however, the Center continued to call for attacks on urban centers, and the "Shaanbei" party was

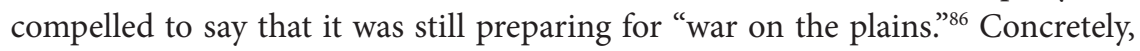
the result of the Nanliang meeting was that Liu Zhidan sent a strong unit under Wang Shitai to support Xie Zichang's struggle in Anding. Wang and his men seem to have returned to Nanliang after a couple months, and Liu and Xie's armies usually operated independently until 1935. Nonetheless, Liu's aid to "Shaanbei" was a significant gesture toward unity and may have dispelled some of the bad blood produced by the July meeting. ${ }^{87}$

After the meeting in Nanliang, Xie Zichang returned to Anding to rekindle the revolutionary movement with the military support of Wang Shitai's men from Shaan-Gan. ${ }^{88}$ The dramatic jailbreak early in the month had brought new attention to the long-dormant resistance to the state. As before, students and teachers provided a core of radicalized youth, and teachers were able to use their status as intellectuals and their local connections to protect the party. With most public appeals focusing on the resistance to oppressive taxation, the efforts enjoyed a certain degree of public support. In Anding, long-standing friendly relations with a local police official delayed the implementation of the Nationalists' efforts to revive the rural baojia public security system. The CCP was able to use the Nanjing government's campaign against corruption and opium smoking to remove a local magistrate. ${ }^{89}$ In the rural areas, the party spread from the villages of party leaders or radical teachers. ${ }^{90}$ Xie Zichang's influence was particularly great around his 
home in the mountainous region of western Anding, and a Chiyuan (Red Origins) Soviet was established there in the fall of 1934. The school system was more developed in the flatter and richer northeastern part of the county, and there a Xiuyan Soviet was established in early 1935 with critical support from teachers and students. But the military-dominated Nationalist government continued to control the area around the county seat, now located in the commercial center of Wayaobu. ${ }^{91}$

According to one contemporary account, half of the villages in Anding and neighboring Qingjian were "Red," and in nearby counties there were ten to fifty Red villages. The spread of the revolutionary movement in the countryside left it in a "stateless" condition. As the party's power grew, it was able to organize Red Guards for sentry duty to protect the local guerrillas. ${ }^{92}$ It is important to note, however, that the party's spread was measured by the number of villages it controlled. This was not a class-based movement that divided landlords and peasants within a village. It was a movement whose strength was determined by whether Communists or conservative elites were able to dominate a settlement. Sometimes this was related to topography: mountainous areas with few or poor roads and far from major towns could become Communist strongholds. In other cases, more schools and radical offspring of elite families were critical. In one case reminiscent of the role of the elite Huang family in Sanyuan, the son of a large landlord in eastern Anding was an underground Communist and also a district head (quzhang) in the local government. The local party cell was located in a school in his family compound..$^{93}$ The result of this process was a patchwork of rural party strongholds scattered across different parts of Shaanbei.

By the end of the year at least seven guerrilla detachments were operating in the "Shaanbei" area. These were relatively small units, in most cases thirty to fifty men in a county, with enough guns for about two-thirds of their members. ${ }^{94}$ However, unlike Liu Zhidan's Shaan-Gan guerrillas, the "Shaanbei" revolution was supported by a substantial local party organization. ${ }^{95}$ Contemporary reports indicate that in July 1933 there were 1,153 Communists in "Shaanbei"; in June 1934, less precise figures indicate over 1,900-2000; and by the end of 1934, there were over 2,200. The largest number, roughly one-third, were in the relatively independent party organization in Shenmu; but the other large concentrations were in Xie Zichang's home county, Anding, and neighboring Qingjian, Suide, Wupu, and Jia-xian. ${ }^{96}$ By and large, the party expanded by recruiting peasant youth from the schools and gained popular support by opposing taxes and official corruption. Still, higher party pressure for land reform was unrelenting, and in some cases it led to senseless excesses. In Qingjian, local cadres banned small commerce and promoted collective farms. ${ }^{97}$ Such measures certainly indicated firm party control of certain villages, but they were unlikely to earn broad peasant support.

While the strength of the revolutionary movement in "Shaanbei" was its rural party organization, Xie Zichang regarded himself as a military leader, and on his 
return to Anding he immediately resumed his guerrilla activities. ${ }^{98}$ Barely a month after his return, he led an attack on a well-defended ford on the Yellow River at Hekou. He was shot in the chest but tried to conceal the wound with a woman's purple jacket (presumably confiscated from some wealthy family) that did not show the blood stain. Even after abandoning the fight at Hekou, he continued to lead his men in battle. He is credited with the first successful seizure of a county capital, when Anding, now lightly defended as most troops had been moved to nearby Wayaobu, was briefly taken in September. ${ }^{99}$ By winter, infection from the wound seems to have spread and Xie was forced to retire from the field, protected by family and comrades until his death in an isolated mountain cave on February 21, 1935. ${ }^{100}$ As Xie Zichang lay dying, Liu Zhidan paid him a final visit. At the meetings in Anding, a unified command for all of northern Shaanxi was established. Liu and Xie reportedly deferred to each other's leadership of the military committee, and memories differ on who prevailed. In the end, it seems, Xie was appointed with Liu acting in his place while he recovered from his wounds. Most likely, Liu saw that Xie would not survive, so he was content to forgo the immediate honor of the formal title. ${ }^{101}$

Following Xie's death, there was no funeral, despite the family's wishes. The party feared a blow to guerrilla morale and did not wish to give the Nationalists an opportunity to claim victory. The strategy worked for many months, as Nationalist internal communications continued to refer to Xie as late as August $1935 .{ }^{102}$ Though Anding County was not officially renamed Zichang until 1942, the local party authorities had anticipated this decision in 1935, and surviving documents refer to such a county, in northwestern Anding. ${ }^{103}$ It is clear that Xie Zichang had a significant reputation in and around his base in Anding, but the basis for that reputation remains somewhat puzzling. There was nothing heroic in Xie's physical appearance. All surviving photographs reveal a thin, pale-faced young man who looks more like a student than a guerrilla commander. His comrades' memoirs recall his short, thin, and slightly stooped stature and youthful face. ${ }^{104}$ In declining the post of political commissar, he claimed to be more a military than a political leader, and it is certainly true that most of his career was spent in military roles: as a militia commander in Anding, as an officer in warlord armies in Gansu, and with the guerrillas. He seemed to believe that status and power in Shaanbei lay with the military-and in this he was not mistaken. His military record, however, was far from distinguished. In 1932 he was removed for the failed attack on the walled town of Shanhe in Gansu, and he commanded the forces defeated in Baoan at the end of the year. As one party historian confided, "Some people say Xie Zichang never fought a winning battle." 105 Though memoir accounts generally refrain from direct criticism, they mention low morale from frequent changes of command, often at times when the change was the appointment of Xie. ${ }^{106}$ Finally, of course, the attack on Hekou where he was mortally wounded can only be described as foolhardy. 
Newspaper accounts in the Guomindang press repeatedly mention battles against Liu Zhidan's guerrillas, and one article carried the title "Shaanbei Bandit Chief Liu Zidan."107 The "Communist bandit" most feared by the state was Liu Zhidan. Xie Zichang's name hardly appears. One cannot escape the suspicion that Xie's persistent criticism of his Communist rival was in part motivated by jealousy of Liu's loftier reputation. Xie was confident of his own political correctness, but he seemed to feel a need to demonstrate his military credentials. In the end that effort, plus his undeniable physical courage, proved to be his undoing. Xie was certainly more in tune with his superiors in the party, and in his final year in Shaanbei he was acting with the full support of the party apparatus. Now, however, Xie Zichang was gone, and Liu Zhidan's military command had no rival in the party. The road was open for the guerrilla movement to expand. On the other hand, the time had also come for Chiang Kai-shek and the Nanjing government to turn its attention to Shaanxi.

\section{NATIONALIST EXTERMINATION CAMPAIGN \\ AND COMMUNIST RESPONSE}

In the early 1930s, Chiang Kai-shek's anti-Communist campaigns concentrated on the soviets near the political and military centers of the Yangzi valley. These early military operations were briefly interrupted by the Japanese occupation of Manchuria in 1931, but by the fall of 1932, Chiang's armies had driven Zhang Guotao from the Hubei-Henan-Anhui Soviet, and two years later, Mao, Zhu De, and Zhou Enlai were forced to abandon the Central Soviet in Jiangxi. With the Central China Communists on the run, Chiang turned his attention to Shaanxi.

Major extermination campaigns against the northern Shaanxi soviets began in 1935, with the second encirclement in February and the third in July. The first of these mobilized twenty divisions and targeted the relatively independent Communist base in the far northeast counties of Shenmu and Fugu, which was effectively eliminated. ${ }^{108}$ In other parts of the region, the campaign had less success, and in July the third encirclement mobilized over one hundred thousand soldiers against a Red Army with at most one-tenth that number. The strategy called for the encirclement and gradual strangulation of the Shaanbei guerrillas, with the Muslim armies of Gansu-Ningxia warlords Ma Hongkui and Ma Hongbin attacking from the west, Yan Xishan sending troops across the Yellow River from Shanxi to the east, Jing Yuexiu exerting pressure from his Yulin base in the north, and Yang Hucheng, joined by the Northeast Army of Zhang Xueliang, moving up from the Wei River valley in the south. ${ }^{109}$ To strengthen the local forces in Shaanbei, Chiang dispatched a division under Gao Guizi, a native of the area, though his troops were from the North China plain. Gao established his headquarters in Suide, and an airfield was built to speed communications and permit reconnaissance and bombing operations. ${ }^{110}$ 
The total military force assembled against the Communists was unprecedented in size but consistently marred by internal rivalries and petty jealousies. Jing Yuexiu had long been the master of Shaanbei and had managed to prevent any Nationalist Party interference. The Xian authorities were also wary of Jing's independence and sought means to control him. Gao Guizi was a Shaanbei native who had been forced out by Jing. Now he was sent back to check the power of his former commander. Gao, however, had been sent by Nanjing, and Yang Hucheng in Xian did not necessarily welcome Nanjing's influence in the province, which had increased with the 1933 appointment of Shao Lizi as governor. Finally, of course, the armies of the Ma warlords and Yan Xishan had no real commitment to the struggle in Shaanxi and were, in any case, regarded by the local population as intruders. The result was a web of rivalries among national, provincial, regional, and local forces that made any coordinated military effort challenging. ${ }^{111}$

Despite the lack of coordination, the increased attention and new state resources brought real change to the Shaanbei environment. Chiang Kai-shek sought to institute his new anti-Communist policy of gradual step-by-step strangulation of the enemy through a network of well-defended blockhouses. To link these military strongpoints, roads were built and phone lines strung to improve communications. The population was moved from isolated mountain villages into strategic hamlets-larger, well-defended settlements - and a headquarters to coordinate all of this was established in Suide, with its new airfield. ${ }^{112}$ The Nationalist slogan called for an anti-Communist strategy that would be 70 percent political, with tax remissions, road passes for good citizens, and better military discipline to prevent abuse of the population. ${ }^{113}$

For Liu Zhidan in his Nanliang base, the greatest threat came from $\mathrm{Ma}$ Hongbin's troops in Gansu. As noted above, the area around Nanliang was sparsely populated. When the southern armies from Hubei or Mao's Long March passed through in 1935, they marched for days on end without finding a single village or source of food. ${ }^{114}$ Now Ma Hongbin's army occupied the fortified towns and moved the sparse rural population into strategic hamlets, depriving Liu's Red Army of its popular base. If the guerrillas were the proverbial fish in water, the encirclement campaign was drying up the water. The guerrillas' only response was to move residents of smaller isolated villages, together with their food and animals, into the hills to protect Red Army supporters from enemy reprisal. ${ }^{115}$ Even so, Ma Hongbin occupied most of Liu's home county in Bao'an. A unit was sent to dig up the Liu family graves; and Liu's father, never a fan of his son's revolutionary activities, was led into the Nanliang hills, where he grumbled at the primitive conditions and lack of opium, cursing his "bandit son" (zei wazi 戌娃子). ${ }^{116}$

After suffering defeat by the Ma warlords' cavalry, the nascent soviet in eastern Gansu was abandoned, and the Communist remnants withdrew to the lower 
reaches of the Luo River basin in Qanquan and Ansai. Ansai was the poorest county in the region with a notoriously weak government. ${ }^{117}$ The enemy controlled the fortified towns, but south of the river was forest, which provided cover for the guerrillas and removed the advantage of Ma Hongbin's Muslim cavalry. The guerrillas were able to organize in the villages, then escape into the forest when the enemy approached. Organizing of the peasantry also improved, so that young Red Guards were able to provide intelligence and act as sentries. ${ }^{118}$ As always in this region, many of the guerrillas were recruited from bandit gangs and the Society of Brothers. With the soviet government relying on expropriations from the wealthy, the soviet itself was acting like a bandit regime, and some local bandits even claimed to be Red Army guerrillas. The Communists, however, were resolutely trying to escape their bandit past, and some of these "Communist" bandit gangs were infiltrated and then eliminated, their leaders killed and the others disarmed and dismissed. ${ }^{119}$

The Bao'an-Ansai section of the Luo River was the one area in Shaan-Gan where Liu Zhidan's guerrillas were able to establish a sufficiently stable regime to attempt land reform. Higher party authorities had long accused Liu's forces of neglecting this policy, and initially this was certainly the case. The head of the land reform committee was a migrant from Hengshan who had gotten wealthy during the revolution and regarded rich peasants as people who profited from their own hard work. This was too generous a view even for Liu, and the cadre was soon removed. ${ }^{120}$ By 1935, Liu himself was campaigning elsewhere, but his brother Liu Jingfan was the local party secretary and responsible for land reform. Liu Jingfan's recollection reflects the moderate policy that he applied. From the time of the Muslim rebellions, "Sparse population over a wide area was a defining feature of the Shaan-Gan region. .. . There were few people and plenty of land. As a result, the people's demand for land was not that great; their greatest concern was eliminating debt and redistributing movable property." The party stressed burning land and loan deeds and redistributing grain, draft animals, sheep, and other property. In redistributing land, only rented valley land was affected, and confiscated land was usually simply given to the tenant. There was no demand for the unirrigated hill land, and it was left to the original landholder. ${ }^{121}$

Despite the precarious survival of a small soviet in the Luo River area, the arrival of Ma Hongbin's army fundamentally altered the balance of power on the ShaanGan border. For years this had been a no-man's-land, too far from the Shaanxi authorities in Xian, Jing Yuexiu in Yulin, or the Gansu militarists in Lanzhou for any of them to pay much attention. Chiang Kai-shek's intervention changed all that and made it impossible for Liu Zhidan's Twenty-Sixth Red Army to survive in the region. Just at this time, however, Xie Zichang lay dying in Anding. For Liu, that provided a new opportunity and a new area to expand. So early in 1935, the center of Liu's operations shifted to Xie's homeland in the northeast of the province, and with that, a new stage of the revolution began. 


\section{LIU ZHIDAN IN “SHAANBEI”}

The shift to the northeast came with a new organizational structure that unified party operations in northern Shaanxi. In 1934, there were two separate party committees: the Shaan-Gan and Shaanbei special committees (tewe $i$ 特委). At a February 1935 meeting in Anding, acting on a directive from the North China representative, a new CCP Northwest Work Committee (中共西北工作委员会) was formed. Hui Zijun, a worker from the Xi'an arsenal who had joined the guerrillas in Zhaojin and operated the machine shop there, was named secretary. Hui, however, was also the secretary of the Shaan-Gan party committee, and when he returned there, Cui Tianfu, a peasant from "Shaanbei," acted in his stead. Both of these were largely ceremonial appointments, to satisfy higher party authorities' insistence on worker-peasant leadership. Real power lay with the other members of the committee, which preserved a rough balance of the two factions, with five from Shaan-Gan and four from "Shaanbei"; but with Xie Zichang on his deathbed, the "Shaanbei" faction was substantially weakened. "Shaanbei," however, gained from Guo Hongtao's service as confidential secretary (mishuzhang 秘书长) and head of the Organization Department, which controlled party appointments. ${ }^{122}$

The real power of the Shaan-Gan group was the Red Army. A Northwest Military Committee was established with authority over both Liu Zhidan's Twenty-Sixth Army and Xie Zichang's newly formed Twenty-Seventh Army; and while the official chair may have been the dying Xie Zichang, it was Liu who acted in his stead, with Gao Gang as his deputy. In the army, then, Liu Zhidan and the Shaan-Gan group were now in command. This committee directed Liu Zhidan to shift his operations to "Shaanbei," which he was happy to do given the intense pressure on Shaan-Gan from Ma Hongbin's armies. ${ }^{123}$ In addition, the new Northwest Work Committee endorsed anti-Japanese as opposed to general "anti-imperialist" policies, condemning recent Nationalist Party concessions to Japan and accusing the new government command in Suide of being a "Japanese imperialist intelligence staff." ${ }^{24}$ Liu Zhidan's preference for a broad anti-Japanese united front was clearly gaining strength.

In northeastern Shaanxi, Liu targeted the weakest link in Chiang Kai-shek's encirclement campaign. Chiang had dispatched Gao Guizi's Eighty-Fourth Division from the North China plain to garrison Suide and eliminate the Communists in the area. Gao was from Shaanbei, a former subordinate of Jing Yuexiu, and this was a key reason for his appointment; but the move revealed a certain ignorance of the complex local politics. For one thing, Gao's long-standing rivalry with Jing made cooperation between the two officers problematic. ${ }^{125}$ In addition, Gao came from the province's far northwest, along the Inner Mongolian border, and paid greatest attention to this area, dispatching troops there and weakening the forces in the northeast, where they were most needed. ${ }^{126}$ Perhaps most critically, while Gao was from Shaanbei, his troops were from the North China plain and quite unused to the tactics of mountain warfare. ${ }^{127}$ Finally, the poorly supported troops 
were forced to rely on the opium trade to fund their operations. In the words of one Nationalist inspector, the entire military effort in Shaanbei was in crisis:

Public servants dare not enter the countryside; on the road they need an army escort. Trade is at a standstill, tax collection is sharply reduced, and alarms follow one on the other. Then look at the army: either planting opium, guarding opium shipments, or protecting travelers for easy profit. Everybody pursues his own interest. Even company or platoon commanders have their families with them; regiment and battalion commanders never meet their troops; they are sloppy and dejected, totally lacking in energy. The division is the brains of an army, but they have no plan to eliminate the bandits. The units do not work together, always avoiding responsibility. The key staff members are without a care in a cloud of opium smoke, glossing over problems and saying all is well, denying the Communists are even a threat. ${ }^{128}$

To confront this large but incompetent military force, Liu Zhidan could rely upon a significant rural party apparatus in "Shaanbei." In "Shaanbei," unlike Shaan-Gan, the school-based rural party organization was well developed. As the Nationalist army occupied the towns and built blockhouses to protect the larger villages, the Communists continued to operate in the countryside. ${ }^{129}$ Even the leading organs of the "Shaanbei" party retreated to the countryside until such towns as Yongping were taken later in $1935 .{ }^{130}$ Gradually the party strengthened its network of cells at the county, district ( $q u$ ), and township (xiang) levels. ${ }^{131}$ It should be stressed, however, that the party by no means controlled all of the countryside in northeastern Shaanxi. There was, instead, a patchwork of "Communist villages" where the party's strength was built upon the local influence of leftist teachers or prominent Communists. ${ }^{132}$ One plausible memoir says that in fact only one-tenth of the villages were under Communist control. ${ }^{133}$ In areas of Communist strength, new counties were created. In Xie Zichang's home county of Anding, important strongholds west of the capital became Chiyuan ("Red Origins)" County, and a new Xiuyan County was organized in the northeast. ${ }^{134}$ As noted above, the party's greatest strength was around the homes of such prominent leaders as Xie Zichang or the party secretary of the region, Cui Tianfu. ${ }^{135}$ The area around Anding was certainly a stronghold. According to a Nationalist official's report, "On [January] 24, [1935], I traveled from Wayaobu to Anding. . . . West of Qingjian, all is Communist controlled. ... Along the road there were many slogans of the Communist bandits. You cannot travel more than a few $l i$ from the town. ... The situation in Anding is even worse than Qingjian. The bandit force was at first not very powerful, but the people have been transformed and blindly follow the bandits, and their organization is very strong." ${ }^{136}$ In these Communist-controlled areas, new recruits were organized as Red Guards to serve as sentries. When the enemy came, the party would empty the villages and retire to the hills, protecting the population from tax collectors or military requisitions. ${ }^{137}$ This was a defensive posture that the higher party often condemned, but it was no doubt welcome if it protected the population from exactions by the state. 
When Liu Zhidan brought his Red Army forces to the northeast in 1935, the revolution was radically transformed. Military power allowed the Communists to control ever-expanding portions of the countryside and to recruit aggressively. One document from June 1935 claims that 70 percent of the adult male population had joined the Red Army and that seventy thousand in Shaanbei were in the party. ${ }^{138}$ These rough figures were certainly inflated, but they suggest that most of the party membership was in the northeast, for another report from the end of the year listed only two hundred party members in Liu's Twenty-Sixth Army and three thousand in the Shaan-Gan soviet. ${ }^{139}$ The expanded party membership supported Red Army recruitment. The regional soviet set aggressive army recruitment goals, asking each county to add thirty to sixty soldiers in successive fifteen-day periods, with similarly optimistic quotas of three thousand per month for the entire Shaanbei soviet. ${ }^{140}$ When a journalist entered the area in 1936, he reported that "almost all able-bodied males follow the Red Army." 141

While the party may have fallen short of these high recruitment quotas, there is little doubt that many peasants joined the party in 1935. Yanchang County records from 1948-49 describe seventy-nine rural cadres who joined the party before the Shaan-Gan-Ning Border Region was established in 1937. Seventy-three of these (94 percent) joined in 1935-36, and sixty-five (82 percent) in 1935 alone. The vast majority of these were poor and middle peasants under the age of thirty, so teenagers in $1935 .{ }^{142}$ Party leaders, we know, came mostly from educated families: Xie Zichang, Ma Mingfang, An Ziwen-to name only the most prominent from Shaanbei-were all educated men from locally prominent families. ${ }^{143}$ The party admitted that the local leadership was entirely composed of intellectuals, with teachers playing a key role. But in the shock recruitment campaigns of 1935, the net was cast much wider, even indiscriminately. Many of the new recruits were, predictably, bandits. ${ }^{144}$ The rest were young males, usually teenagers, who often joined for purely personal reasons: the death of a father, troubled relations with a new stepmother, or unhappiness in an adopted family. It may be significant that several of the leaders for whom we have biographies were orphaned at a fairly early age. ${ }^{145}$ Some were attracted to the excitement of life with the guerrillas: "it was the fad” (gan shimao 赶时髦), said one informant. Small guerrilla bands passed through his village, and it looked like an exciting sort of life. Others were hungry at home and discovered that with frequent raids on landlords, the guerrillas ate better than ordinary peasants, even feasting on slaughtered lambs. ${ }^{146}$ The party, however, wanted some assurance of revolutionary commitment; thus according to a contemporary party document in some areas, "When the suffering masses came to find the Communist Party, killing gentry strongmen was the condition for joining." ${ }^{47}$ One cadre recalled: "At that time . . . , left was always better than right. When you went down to work, you had to kill people. Killing people was the standard. If you didn't dare kill people, you were at least a rightist, or wavering; you might even be given the 'right liquidationist' label."148 
The result, in 1935, was a period of intense internecine warfare, largely along class lines but mediated by complex webs of party, village, and family loyalties. The party organization had long railed against the "rich peasant" line in Shaanbei, and now it claimed success. ${ }^{149}$ While in Shaan-Gan, Liu Zhidan had mostly kidnapped the wealthy for ransom, but now gentry strongmen and local tax collectors were publicly executed at mass meetings. ${ }^{150}$ According to one leftist recollection: "During the land revolution in Anding, anyone who had been a district head, or 'gentry', all local strongmen and evil gentry were killed. Only those who fled or had already died could escape. Landlords and some rich peasants, plus a few rich middle peasants, were also eliminated during war, the land revolution, the campaign against counter-revolutionaries, or land redistribution. In the whole country, Anding was probably the only county that eliminated all trace of local strongmen and evil gentry, corrupt officials, clerks, and landlords." 151 This no doubt exaggerated the efficacy of class warfare in Shaanbei, or conflated 1935 with later episodes of class warfare. Still, another account from the Guomindang side claims that all officials, teachers, gentry, merchants, and usurers were executed. ${ }^{152}$ Since local cadres were selected from middle school and higher primary school students, most of whom came from wealthy families, and since members of such families who supported the revolution were exempt from land distribution, it is clear that political as well as class distinctions governed revolutionary violence. Nonetheless, even this account admitted that there were leftist errors of "indiscriminate arson and executions." ${ }^{153}$ Explaining the execution of a bankrupt opium-addicted landlord, one peasant explained: "It was like that in 1935. If someone said something against you, you got shot." 154

For a time, the region descended into a brutal cycle of revenge killings-Red Terror countered by White Terror. In one well-documented incident, three brothers who had oppressed the people as tax collectors and allegedly raped local women were seized and bludgeoned to death with a shovel. The physical viciousness of the attack was striking: the local leftists lacked a knife and feared that a gunshot would attract the authorities' attention. ${ }^{155}$ After guerrilla executions of landlords, militia heads, and members of a hated strongman's family, Gao Guizi's Nationalist forces in Suide organized in defense. A wealthy Communist defected, and his information led to the arrest and public execution of twelve Red Guards on a crowded market day. This cruel act aroused public anger, and the Communists called for revenge, seizing two hundred village functionaries and killing thirty-two. ${ }^{156}$ In this murderous struggle, captives were routinely executed, and the Communists admitted "frequent violations" of discipline, including abuse of the people, rape, and appropriation of stolen property. ${ }^{157}$ The Nationalists also admitted that profiteering and abuse by their soldiers drove many peasants into the Communist camp, and they routinely hung the heads of executed Communists from city walls. ${ }^{158}$

There is little doubt that this spreading wave of political violence was linked to the growing power of the Red Army. In some areas, local cadres were reluctant 
to institute land reform until the party had military control. Peasants feared the return of landlords, the loss of redistributed land, and likely retribution. ${ }^{159}$ In this sense, the escalating social conflict was intimately connected to the success of the Red Army on the battlefield. By mid-1935, Xu Haidong's Twenty-Fifth Army from Hubei was ending its sojourn on the Shaanxi-Sichuan border and headed into Gansu and eventual union with the Shaanbei revolutionaries. Xu's advance drew off some of Ma Hongbin's forces that had been attacking the Nanliang base. ${ }^{160}$ This reduced the pressure on the Luo River soviet and allowed Liu Zhidan to focus on the campaign in the northeast. Liu did not, however, entirely abandon his old base on the Shaan-Gan border, and his cavalry still made long-distance raids on eastern Gansu for money and supplies. ${ }^{161}$

In Shaanbei, Liu's strategy was to harass Gao Guizi's Suide-based forces whenever they ventured forth to patrol the countryside. The object was to confine them to their garrisons and blockhouses, leaving the villages open to Communist organizing. The spreading network of young Red Guard sentries made this tactic increasingly effective, as the Communists were warned whenever the enemy ventured forth. ${ }^{162}$ With his forces confined to blockhouses, Gao had to arrange supply trains to support them, and these became targets for ambush. After a few such incidents and significant losses of supplies and ammunition, some strongpoints were abandoned, most significantly the small Anding County seat, with the government withdrawing to the larger nearby town of Wayaobu. With this, the Communists gained relatively secure control of their first county seat in Shaanbei. ${ }^{163}$ With Wayaobu now isolated, a supply column was ambushed, with the capture of several officers' wives. To secure their release, the Nationalist army surrendered weapons to the Red Army. Soon another supply train heading for Yanchuan was ambushed, adding more guns and ammunition to the Communists' arsenal. ${ }^{164}$

The victories by Liu Zhidan's forces greatly increased their fighting strength. While they used to enter battle with more men than guns and tightly rationed ammunition, now they had enough rifles and a reasonable number of highly prized machine guns. The machine guns permitted the concentrated firepower necessary to overwhelm fortified positions, and the mortars were their first artillery. The new weaponry certainly changed the nature of this guerrilla army, but there remained certain incentive systems from the bandit/guerrilla past: the unit that captured weapons was allowed to keep them. ${ }^{165}$ Victories over regular army units also brought valuable trained soldiers into their forces. Captives were given three options: join the Red Army, return home, or rejoin their units and promise to shoot in the air in future engagements. Special efforts were made to recruit medics and soldiers with experience using machine guns. ${ }^{166}$ This lenient policy toward captives was partly the product of necessity: there was simply no way to confine and feed a large number of prisoners of war. It was also politically effective, as released soldiers convinced their comrades that the Red Army posed no 
threat to ordinary soldiers. ${ }^{167}$ Officers were not treated so kindly, and many were simply executed. When a Whampoa classmate of Liu Zhidan pleaded for mercy, Liu bluntly ordered, "Kill the bastard."168

With his success, Liu Zhidan's confidence grew. Now he was ready to attack county seats and establish a more unified soviet regime in Shaanbei. The first target was Yanchang, lightly defended despite its treasured oil fields, then small and poorly served by any viable transport. Red Guards and local guerrillas drew off the local militia, then Liu attacked and took the town with his main force, holding it for four days in late May. The magistrate and several local strongmen were executed, and a large quantity of money was seized. ${ }^{169}$ Further victories followed quickly in June. Neighboring Yanchuan was abandoned by the Nationalists and briefly occupied. ${ }^{170}$ From there, Liu's armies swung north, again occupying Anding before moving on to small and weakly defended Ansai, which was easily occupied with the usual execution of county officials and local elites. ${ }^{171}$ Finally, after a fierce battle, Jingbian on the old Great Wall was taken after heavy losses. This was the first instance in which Liu called on the former bandit Guo Baoshan to commit his forces, which he did, despite substantial casualties. Jingbian was a major military stronghold in the north, and once it fell, Bao'an and Dingbian also succumbed to the Communist assault. ${ }^{172}$ These successive setbacks brought the Shanxi warlord Yan Xishan into the struggle, as he was induced to send troops across the Yellow River into Shaanxi. The result was much the same. In July, the Shanxi troops at Dingxianyan, a town on the road to Suide, were besieged and Liu then executed a successful ambush of the relief column. Two hundred were killed, another 1,800 captured, and a vast quantity of weapons, including fifty machine guns and some mortars, were captured. Following this defeat, Yan Xishan withdrew most of his troops to the safety of his native province. ${ }^{173}$

In two short months in the summer of 1935, Liu had taken, however briefly, seven county seats in Shaanbei. By the fall of 1935, the Communists claimed soviets or revolutionary committees in over twenty counties in northern Shaanxi and eastern Gansu. ${ }^{174}$ A Nationalist report from August 1935 indicates the extent of Communist power following Liu Zhidan's impressive string of victories. It estimated a total guerrilla force of twenty thousand men (certainly an exaggeration of the main force units) with forty to fifty machine guns. Most of these were in the hills, harassing the Nationalist forces, but the extent of their control was sobering:

Bao'an, Ansai, Anding, Qingjian, Fushi [Yan'an], Ganquan, Yanchang, Yanchuan, and Fu-xian are almost completely Communist controlled. Anding is the center, and the location of their government. In the Communist areas, they are already distributing land to the peasants. They have established control of education, culture, the economy, and grain. In Yulin, Hengshan, Suide, Mizhi, Shenmu, Fugu, Jia-xian, Wupu, Zhongbu, Luochuan, Dingbian, and Jingbian, half of the area is Communist controlled, half is a guerrilla area. [The Wei River counties of] Hancheng, Chengcheng, Baishui, Yichuan, Yijun, Tongchuan, Yao-xian, Xunyi, and Chunhua are all guerrilla 
areas. In the Communist areas, the people all follow these bandits. There are Young Pioneers, Red Guards, propaganda teams, support for the wounded, canteens, and teams for washing and mending clothes. ${ }^{175}$

Yan'an was now effectively surrounded by a Communist-controlled countryside. The Nationalist officials in the area admitted that they were losing the battle: "People are losing confidence that the army can protect them." ${ }^{176}$ But the Nationalists were also divided among themselves. The civil officials blamed the army. Shortly before his own county fell to Liu Zhidan's assault, the Yanchang magistrate complained that after suffering several defeats, Gao Guizi withdrew his forces to the towns and would not answer appeals for help. "Since Gao's division came to Shaanbei, the rebels' arms have increased by two thousand. Before, the rebels had no good guns; now they have machine guns and rifles, all lost by Gao's troops."177 The army, for its part, blamed the civil authorities: "Corrupt officials and clerks, local strongmen and evil gentry collude in their crimes, oppressing the people so that the masses of workers and peasants cannot bear it any longer and succumb to the Communist propaganda." 178 With the Communists winning battle after battle and the Nationalists in disarray, the tide had finally turned in Liu Zhidan's favor. But soon, once again, he would have to contend with critics within his own party.

\section{THE PARTY TAKES COMMAND}

In July 1935, as Liu Zhidan was completing his victorious campaign across Shaanbei, two representatives from the Shanghai party Center arrived in the area. The first and most important of these was Zhu Lizhi, a twenty-eight-year-old native of Nantong, across the Yangzi River from Shanghai, who had joined the party in 1927 while studying economics at Beiping's elite Tsinghua University. Zhu carried with him five letters of instruction from the party Center, written between January and May 1935. Upon arrival, Zhu conferred with the North China representative, Guo Hongtao, to understand the local situation. While Zhu was a Beijing-trained intellectual from the lower Yangzi, Guo was a Shaanbei native with presumed understanding of the local scene, and their alliance was later characterized as that of an "imperial commissioner" and a "local emperor."179 Zhu also emboldened the young and ambitious Guo Hongtao, telling Guo that he had learned in Shanghai that the way to rise in the party was by attacking one's comrades. ${ }^{180}$ In a series of speeches that lasted three and a half days, Zhu conveyed the thrust of the Center's letters. If anything, the errors of Liu Zhidan's Shaan-Gan soviet were made more serious than ever. The previous "right opportunism" now become "right liquidationism” (右傾取消主义), that is, seeking to eliminate (liquidate) the party's leading role-an error that Lenin had attributed to the Mensheviks. In the Leninist jargon of the April letter, "There is right liquidationism in the Shaan-Gan party; their conspiracy has been exposed. ... A liberal attitude toward right liquidationism and opportunism represents benevolence toward the imperialist rich peasant 
line and cruelty toward the revolution." The letter called on the Shaanbei party to combine with the south Shaanxi-Sichuan soviets so that they could "open an international connection through Xinjiang and Inner Mongolia," once again looking for Soviet assistance to save the revolution. ${ }^{181}$

After his string of military victories in the summer, Liu Zhidan displayed an uncharacteristic assurance in the face of his party superiors. In the past, he had obediently followed orders from higher party authorities, leading his troops on futile and ultimately disastrous attacks on the Guanzhong plains, even south of the Wei River. Now he resisted the Center's renewed attacks on his rightist errors. The Shaanbei party was excoriated for the "unforgivable error" and "crime against the revolution" of "ignoring preparations for urban uprisings." ${ }^{182}$ Nonetheless, when Zhu called for attacks on Yan'an, Wayaobu, and other walled towns in Shaanbei, Liu and his officers refused: their army was simply not equipped for such assaults. ${ }^{183}$ While Zhu wanted to open a northern link to the Soviet Union, Liu's concern was the Northeast Army advancing from the south. Some were openly dismissive of these new edicts from a dogmatic and uninformed Center. Huang Ziwen, who had led the Sanyuan organization and was now a political officer with Liu's army, attacked the "kids in charge" of the Center after the 1931 plenum-an unmistakable reference to the young and inexperienced Wang Ming. Zhu took such resistance as confirmation of rightist errors, but initially he was powerless to act. ${ }^{184}$ That situation would soon change.

In September, Xu Haidong's army from Hubei arrived, and now Zhu and Guo had the military support they needed to deal with Liu Zhidan. Xu and his TwentyFifth Army came from the Hubei-Henan-Anhui Soviet, which had witnessed some of the bloodiest violence of the Communist revolution, including summary purges of local revolutionaries deemed untrustworthy. ${ }^{185}$ When Edgar Snow met $\mathrm{Xu}$ in 1936, he described him as "the most strongly 'class-conscious' man ... of all the Red leaders I met." ${ }^{186}$ Xu's first contact with the Shaanxi revolutionaries came when an underground Communist agent, an officer in Yang Hucheng's army who had given significant aid to Liu Zhidan's guerrillas, approached Xu's army as it passed through south Shaanxi. Xu interrogated the contact, doubted his credentials, and had him shot. ${ }^{187}$ It was a telling sign of Xu's suspicious attitude toward the Shaanxi party's judgment.

In September 1935, Xu Haidong's army arrived at the new Red headquarters in the town of Yongping, northeast of Yan'an. Xu's Twenty-Fifth Army was not large, probably only about two thousand men, but they were well armed and battle tested. ${ }^{188}$ The recollection of one of their political officers indicates that the initial meeting with Liu Zhidan's forces did not go well.

The Twenty-Fifth Army had reached Shaanbei in victory. Everyone thought we were great: number one in the country. This arrogance increased after we joined with the Twenty-Sixth and Twenty-Seventh Armies. The Twenty-Fifth was well armed: many machine guns and good rifles. We had good uniforms. Because we had come from 
the white areas, had attacked the local strongmen, our clothing was quite elegant. We had eaten well; everyone was healthy and fat. We had plenty of ammunition. When we met our brother armies, the Twenty-Sixth and Twenty-Seventh, we thought: "What kind of army is this?" We looked down on them: only a few bullets and wearing all kind of clothes. They not only lacked good boots, they had no socks, no uniforms, and they tied a white cloth around their heads. ${ }^{189}$

Needless to say, the southern forces were uninterested in advice from the local Communists. In Yongping, Xu Haidong wanted to hear from Guo Hongtao and Zhu Lizhi, the representatives of the Center. Their criticism of Liu's Twenty-Sixth Army was critical in a series of September meetings that reorganized the entire structure of the revolutionary movement in Shaanbei. ${ }^{190}$

The Northwest Work Committee that Zhu Lizhi headed was replaced by a new CCP Shaanxi-Gansu-Shanxi provincial committee (中共陕甘晋省委) with Zhu Lizhi as secretary and Guo Hongtao as his deputy. The military committee of this new province was headed by Nie Hongjun, the other representative sent from Shanghai. Finally, the three armies of Liu, Xu, and the late Xie Zichang were reorganized into the Fifteenth Army Group commanded by Xu Haidong, with Cheng Zihua from Xu's army serving as political commissar. ${ }^{191}$ The local troops were not happy with their new leaders. Given the arrogance of the southern troops, and the fact that they were speaking a strange southern dialect, this is unsurprising. More important was the fact that the Shaanbei troops were accustomed to close relations between officers and men, with soldiers' committees to discuss operations and leaders like Liu Zhidan known simply as "Old Liu." Now they were confronted with a Red Army that looked and acted more like the enemy they had been fighting. They were particularly offended to see officers cursing and beating ordinary soldiers. ${ }^{192}$ The final step in the subordination of the Shaanbei forces came when Zhu Lizhi ordered the Twenty-Sixth Army to turn over its recently captured and much-prized machine guns to Xu Haidong's army. ${ }^{193}$ With the support of Xu Haidong's army from Hubei, Zhu Lizhi and Guo Hongtao had completely sidelined Liu Zhidan and were now prepared to launch a purge of "opportunist" elements in his movement.

The campaign against Liu Zhidan's unorthodox methods was long-standing. The Bolsheviks in the provincial committee had repeatedly criticized his recruitment of bandits, his preference for guerrilla warfare along the Shaan-Gan border, and his failure to carry out land reform. Critical reports from Xian had long circulated in Shanghai and had certainly been passed on to the North China bureau. When Guo Hongtao, followed by Zhu Lizhi, was sent to rectify the Shaanbei party, he was based in the northeast of the province, where negative reports on the Shaan-Gan guerrillas were reinforced by criticisms from Xie Zichang and the more orthodox "Shaanbei" party. Most of these reports were familiar criticisms of Liu's use of associates in the Society of Brothers, the militia, and even the Nationalist Party to build the revolutionary movement. ${ }^{194}$ From 1934, however, a new charge 
was added. Liu was alleged to be working with agents of Zhang Mutao. Zhang was a former head of the Shaanxi youth league who had quarreled with the provincial committee in 1928, then moved on to underground party work in North China, including anti-Japanese organizing in Chahar. There he had again fallen out with his comrades, had been expelled, and while working in Shanxi had formed a rival "New Communist Party." By 1935 Zhang was back in Xi'an. With the provincial apparatus in shambles, he seems to have worked with other leftists, progressive members of Yang Hucheng's entourage, and disaffected members of the Communist Party. While the activities of Zhang Mutao's rival group remain obscure, the Center's representatives were concerned, and rumors that Liu Zhidan was working with this new group of patriotic leftists provoked particular suspicion. Since Zhang Mutao was an independent leftist, operating outside the orthodox party apparatus, he was predictably (though inaccurately) labeled a "Trotskyite." 195 Liu Zhidan, for his part, had lost contact with the party Center in 1933 and was seeking a variety of plausible agents to reestablish connections and build a broad revolutionary movement in Shaanbei. Liu had never been an ideological thinker and was always willing to work with a diverse mix of allies with questionable histories. Zhang Mutao and his colleagues were among the people Liu's men contacted. Liu's preference for a broad united front would get him in trouble again.

First, however, there were military matters to attend to. In this case, Xu Haidong and Liu Zhidan were on the same page. Some of the party representatives wanted to attack north toward the Shenmu base-perhaps as preparation for opening a road to the Soviet border through Inner Mongolia-but Xu and Liu realized that the immediate threat came from the large Northeast Army of Zhang Xueliang, which had already occupied Yan'an and needed to keep a supply line open from Xian. ${ }^{196}$ In the critical Laoshan battle that ensued, Xu Haidong was technically in command, but he seems to have deferred to Liu's superior knowledge of the local topography. The road to Yan'an passed through Ganquan, so that town was first isolated and besieged. To relieve the siege and reopen the road, a relief column had to come from Yan'an. There was an obvious ambush site, but Liu correctly assumed that the enemy would prepare for an attack there. He chose the Laoshan site further south. As anticipated, the Northeast Army column relaxed after passing the first site, decided to press on to Ganquan, and was attacked. A fierce battle lasting six hours ensued in which the Nationalists lost a divisional commander, hundreds of casualties, and at least three or four hundred captured. The Communists also gained hundreds of new weapons and a large cache of ammunition. ${ }^{197}$ This was a major defeat for Zhang Xueliang's forces. In the short term, it led to the abandonment of Wayaobu and in the longer run to Zhang's serious doubts about the wisdom, both politically and militarily, of continuing to fight the Communists rather than the Japanese occupying his homeland. ${ }^{198}$

The Laoshan battle was Liu Zhidan's final military victory, and much laudatory prose has described his tactical brilliance. But there was another side of the story. Though Liu may have been responsible for the tactical details, Xu Haidong was 
in command, and he arrayed his own forces on the flanks and rear, leaving Liu responsible for the central assault. The battle lasted much longer than planned and certainly longer than the brief ambushes by Liu's army in the past, and some of Liu's officers felt that Xu was deliberately sacrificing the Shaanbei armies-a credible complaint given the arrangement of the forces and the disdain in which he held the Shaanbei armies. As a result, Liu's army suffered significant losses: seven of twelve company commanders were killed, and only two hundred men emerged unscathed from one regiment of seven hundred. ${ }^{199}$ The Guomindang press falsely reported that Liu himself had been killed. ${ }^{200}$ The situation was made worse when Xu Haidong threatened to execute an officer whom he deemed insufficiently aggressive. Opposition from the ranks halted this move, but the damage had been done, and there were defections and even suicides among the Shaanbei troops. After the battle, Xu's Twenty-Fifth Army got the best of the captured rifles, and the Shaanbei troops were sent to a desolate area with no food where they were ordered to attack a well-fortified enemy position, which only enhanced their discontent. ${ }^{201}$ Little did they realize that the worst was yet to come. Immediately after the Laoshan battle, Liu Zhidan was summoned to Wayaobu and thrown into jail. When the arrest warrant was mistakenly delivered to Liu himself, he read it and then, obedient as always, proceeded to Wayaobu to turn himself in. ${ }^{202}$ Many of his officers were reassigned or arrested. Others were threatened, then sent into poorly prepared battles, with heavy losses, much grumbling, and some departures. ${ }^{203}$ Throughout Shaanbei, a campaign against “counter-revolutionaries" (sufan 肃反) was spreading out of control.

\section{REVOLUTION AND COUNTER-REVOLUTION}

The sufan campaign in the late summer and fall of 1935 was a wholesale attack on Liu's Shaan-Gan soviet. All of his key lieutenants were arrested: Gao Gang, Liu's brother Jingfan, the Red Army officer Zhang Xiushan, and Xi Zhongxun, head of the Shaan-Gan soviet and father of China's current president and party secretary $\mathrm{Xi}$ Jinping. In all, over one hundred officers and cadres were arrested, with the key leaders imprisoned, shackled, and held in cold, dark, lice-infected caves in Wayaobu with only straw to sleep on. ${ }^{204}$ The Center's representatives, Zhu Lizhi and Guo Hongtao, had laid the groundwork with their attacks on the "right opportunism" of the Shaan-Gan revolutionaries. The execution of the sufan campaign was in the hands of the Twenty-Fifth Army operatives. In Wayaobu, the interrogations were led by Dai Jiying, political officer of the Twenty-Fifth Army and leader of the violent sufan in the Hubei-Henan-Anhui Soviet. His methods were direct and crude: "Dai Jiying was a cruel god; he loved to beat people. He cursed you in his Hubei dialect: 'Motherfucker!' Carrying a big club, he'd start cursing and beating as soon as he entered the door." ${ }^{205}$ One of Dai's first victims was Liu's lieutenant Zhang Xiushan. After repeated torture, Zhang was convinced that his persecutors were themselves enemies of the revolution and that his only option 
was confession and death. He apparently implicated Liu Zhidan, but once the torture stopped, he recanted. As this pattern was repeated again and again, even Zhu and Guo began to doubt the forced confessions and demanded to witness the interrogations, but they did nothing to stop the purge. ${ }^{206}$ This was the crudest form of factional struggle. None of the key lieutenants of the late Xie Zichang were affected. ${ }^{207}$ In the end, most of the confessions of the imprisoned leaders were rejected as false testimony extracted under torture. ${ }^{208}$ At the time, however, the threat was real: outside their caves, the prisoners heard workers digging a great pit and were told it would be their mass grave. ${ }^{209}$

As the Shaan-Gan leaders were arrested and imprisoned in Wayaobu, the purge spread to their subordinates and local cadres in the Shaan-Gan soviet. All cadres at the county level and above and all military officers at the battalion level and above were targeted. ${ }^{210}$ The agents of this purge were security officials from Xu Haidong's Twenty-Fifth Army, and the level of violence intensified. Memoirs speak of young armed men in black uniforms speaking southern accents, who came to seize, torture, and often execute local Communist officials. ${ }^{211}$ Sometimes they were able to find local allies, people with personal grievances or common thugs. Mass meetings were called, and if there were complaints against local cadres, they were promptly executed. There are numerous reports of people being buried alive in the purge. ${ }^{212}$ In all, according to the official verdict, two hundred perished in the campaign against alleged "counter-revolutionaries."213

With enemy forces encircling the newly formed soviets and the Red Army outnumbered ten to one, it is difficult to fathom why the Communists would have turned on their own comrades in an orgy of internecine carnage, but this was hardly an isolated incident in the history of the Chinese Revolution. In the Futian incident in 1930, allies of Mao Zedong executed several thousand dissidents on suspicion of disloyalty. ${ }^{214}$ More directly relevant was the "genocidal Party purge" in the Hubei-Henan-Anhui Soviet that cost the lives of thousands of local cadres. ${ }^{215}$ The executors of the Shaanbei campaign were precisely the men who had directed the purge in Hubei, and it was their model. ${ }^{216}$ The precarious state of the revolutionary forces did not prevent them from turning on their own. On the contrary, it seemed to enhance the fear of spies, disloyal elements, or those who harbored doubts and might waver in the face of the enemy. In most cases, it was agents of the party Center who harbored such fears, and local revolutionaries who were the victims. That was precisely the case in Shaan-Gan, where the purge was launched by Zhu Lizhi and the representatives of the party Center, and carried out by Xu Haidong's army from Hubei.

Local considerations inevitably influenced the progress of the purge. In the background, there was always the simmering conflict between the "Shaanbei" and Shaan-Gan factions. The "Shaanbei" party communicated with Beijing and resented the Shaan-Gan faction's connections to the provincial committee in Xian. ${ }^{217}$ This made them suspicious of any influence coming from the provincial capital. Liu Zhidan, however, was desperately trying to reestablish the Xian link 
after the arrests and collapse of the provincial committee in 1933. His contacts with CCP agents in Yang Hucheng's army naturally aroused the suspicions of the "Shaanbei" faction, which passed them on to Zhu Lizhi and the other representatives of the Center. As a result, the view spread that "everyone from Xian is problematic." 218 In fact, the Shaan-Gan revolutionaries had long recruited workers and students from Xi'an and other Wei River towns, but now these students and intellectuals came under suspicion. ${ }^{219}$ Zhang Mutao, the expelled Communist who had formed a "New Communist Party," was a particular object of suspicion, and Liu Zhidan's efforts to reach the Xi'an party had brought him into contact with Zhang Mutao's associates. One of these was Huang Ziwen, the Sanyuan leader and open critic of Wang Ming and the young leaders who dominated the Central Committee after 1931. Huang had joined the Shaan-Gan guerrillas, and while Liu treated him with some suspicion, the presence of such "right opportunists" in Liu's entourage was unacceptable to the sufan leaders. ${ }^{220}$

Whenever a leftist tide brought new attention to class status and purifying the party of class enemies, intellectuals inevitably bore the brunt of the attack. Most came from families of some means, and their superior education created a social distance from the general population. In normal times, that could earn them respect, and the party certainly grew in part because respected teachers spread its message. But when class lines came to the fore, intellectuals were likely to suffer. Among cadres, the better educated were often targeted. ${ }^{221}$ In the Shaan-Gan sufan, this took on an important gendered dimension. Many of the women who joined the revolution were students from urban schools. They seem to have come under particular suspicion in the sufan campaign, and a significant number of those killed were young women. ${ }^{222}$ But there were also local women whose reputations for loose sexual behavior brought them under suspicion. Indeed, a widespread purge such as this targeted a broad range of unconventional social types. According to Guo Hongtao, his team killed beggars as suspected spies, "and because we leaders acted in this manner, lower levels followed along, killing bandits, hooligans, prostitutes, yamen runners, and beggars." 223 The killings usually happened at night, secretly and without trials. ${ }^{224}$

The fear of enemy agents and the influence of alien class elements may have provided the pretext for a violent purge. But the ideological deviation that the party aimed to correct was Liu Zhidan's inattention to class status in building his movement and in land reform. Liu was a military man and began his career in the warlord armies of Feng Yuxiang and Ma Hongkui, then took positions under lesser warlords in Gansu, using his status as an officer to lead mutinies. This strategy was quite common during and immediately after the united front with the Nationalists in the 1920s. It was exactly the approach taken by Zhu De in founding the Red Army in Jiangxi. By the 1930s, however, as a left line dominated the party Center, underground work in Nationalist and warlord armies was supposed to target ordinary soldiers, arousing them to revolt against abusive officers. Liu, however, saw the impracticality of this approach and continued to seek out officers 
with whom he could work. He was also willing to use his connections in the Society of Brothers to approach local militia commanders. He even used a sympathetic Guomindang security chief in his soviet regime. ${ }^{225}$ In all these efforts, he especially appealed to the rising anti-Japanese movement in the press, among students and intellectuals, and in the military. He was carrying out a united front policy before it was officially authorized by the party Center.

In the course of the sufan campaign, all of these efforts aroused suspicion. In 1945, Zhu Lizhi offered a plausible summary of his conflict with Liu:

\begin{abstract}
At the time, Liu Zhidan and I had significant differences on the correct line. As a result, we had many fights. . . . In land reform, they only confiscated the rich peasant land under feudal exploitation [i.e., rented land], proposed uniting with rich peasants, and treated large and small landlords differently. We, however, proposed giving rich peasants only poor land and physically eliminating landlords, even expelling all army officers and soldiers with landlord and rich peasant backgrounds. In the White [Nationalist] army, Liu Zhidan and the others wanted to win over both officers and soldiers. We cursed their efforts to form a united front with Yang Hucheng or Sun Dianying as "conspiring with army officers." They adopted a policy of winning over bandits and members of the Society of Brothers; we cursed them for following a "bandit policy." Toward intellectuals from outside the soviets, they adopted a trusting posture; we said they were "ignoring the leadership of the proletariat." 226
\end{abstract}

In Zhu's account, class consciousness was the key link in all the policy differences. It was Liu's lack of a proper class consciousness that led him to conspire with Nationalist army officers, attract intellectuals with questionable backgrounds, recruit militia members from landlord families, and favor rich peasants in his land reform policies. Now the sufan campaign would correct these errors.

Naturally the campaign began by attacking Liu Zhidan himself. Because his family had land and a position in the militia, it was classified as a "bureaucratic landlord family." Many of the local militia leaders whom Liu had persuaded to join his movement were from similar families. ${ }^{227}$ When the Shaan-Gan soviet, under pressure from the party, carried out land reform in 1934-35, it had been quite moderate. Land was plentiful, and one wartime document claimed that "most people were rich or middle peasants; poor peasants were few." ${ }^{228}$ With no demand for unirrigated hill land, it was unaffected by land reform. Only rented valley land was redistributed, and landlords were allowed to keep enough to support themselves. All of this was sheer opportunism in the eyes of the sufan agents from Hubei and the Center. They launched a “land investigation" (chatian 查田) movement to correct past errors, calling for a "cruel class struggle against gentry strongmen, landlords, and rich peasants." 229 Hubei cadres were incredulous when ordinary peasants reported that they owned "several mountains" of land, and arbitrarily decided that anyone with over one hundred $m u$ (about sixteen acres) was a landlord. ${ }^{230}$ Such landlords had all their land confiscated; they were driven from their homes and sent to work for the government or to the hills to "eat grass." ${ }^{31}$ In one particularly 
ill-conceived policy, landlords' sheep were redistributed to agricultural laborers who were unwilling or unable to care for them, so they roamed free in the hills to be eaten by wolves. ${ }^{232}$

We should not assume that there was no local support for the radical "land investigation" campaign. Along the Shaan-Gan border, land was not equally distributed. In Baoan, almost all the land was owned by the old residents (laohu 老户) of the county, descendants of families that had survived the nineteenthcentury Muslim Rebellion, while perhaps 90 percent of the population were migrants from the densely populated, famine-stricken counties further east. ${ }^{233}$ While most of these migrants found land to rent or worked for the old families, the land investigation teams were probably able to locate and mobilize some disaffected migrants who wanted land of their own. ${ }^{234}$ In this sense, the memoirs and local informants who uniformly support the official narrative of popular opposition to radical land reform must be treated with a degree of skepticism. Nonetheless, it is clear that the arrest of Liu Zhidan, the execution of local cadres, and then a radical land reform imposed from the outside were not popular.

The reaction began soon after the purge was launched in September 1935. We have already seen the resentment toward Xu Haidong's Hubei troops and Liu's soldiers' reactions to losses during the Laoshan and later battles. Local soldiers began to sleep with their weapons at the ready, and some deserted at night. ${ }^{235}$ In the southern areas, close to Guanzhong, the purge was particularly intense, and many peasants fled the soviet zone as rumors spread that Xu Haidong had killed Liu Zhidan. ${ }^{236}$ The most serious reaction began in Liu Zhidan's home county of Bao'an. The precipitating factor was the arrest and execution of a number of former militia leaders, all from landlord families or former students in Yulin. They had been recruited to the revolutionary camp by Liu Zhidan and his allies, then summoned by the sufan leaders and executed-buried alive. In November, another arrest warrant fell into the hands of its intended target, a militia leader in northern Baoan. He led his men to turn against the revolution, held a mass meeting in early December, then joined one of the few Luo River militia leaders who had resisted the revolution from his well-protected mountain-top fortress. Soon, seven or eight guerrilla units with militia or Society of Brothers connections also defected, and six of the ten soviet districts near Liu's home on the Luo River turned against the revolution. When Liu Jingfan returned in the winter, only 150 of 1,000 party members remained. ${ }^{237}$

In other areas, when local cadres were arrested, party organizations were paralyzed. ${ }^{238}$ According to one Guomindang report, the soviet governments in four northwest Shaanxi counties were toppled. ${ }^{239}$ The response to the radical sufan campaign was not surprising. Liu Zhidan unquestionably had a substantial following as a local leader opposing oppressive taxation and warlord depredations. Above all, he was a Shaanbei native, from a respected family, and well connected to the powerful Brother networks. Now he had been removed and his nascent regime decapitated by an unknown group of outsiders speaking a strange southern dialect. The Shaanbei revolution was in crisis. 
At this critical moment, in mid-October 1935, Mao Zedong and the Central Red Army arrived on the western border of the Shaanbei soviet. Informed by the local authorities of the spreading purge, he issued a legendary order: "Halt the executions! Stop the arrests." ${ }^{240}$ Such, at least, is the official account. There are, however, reasons for skepticism. The sufan campaign led to widespread suspicion of unknown armies from the south. After the Laoshan battle, some claimed that "the Twenty-Fifth Army is a White [Guomindang] Army disguised as a Red Army to eliminate the Twenty-Sixth Army." ${ }^{411}$ When Mao's troops arrived in the small town of Wuqi in the western part of Baoan, the residents hid in the hills before local cadres convinced them to greet this new army in straw sandals and tattered clothes, which also claimed to be part of the Red Army. ${ }^{242}$ Over the next month and a half, as arrests and executions continued, Mao and the party Center passed through the headquarters of the local soviet, received a report from the architects of the purge, and met with Xu Haidong. Only in late November or early December, when Zhou Enlai and representatives of the central leadership arrived in Wayaobu, was the order given to release Liu Zhidan, Gao Gang, Xi Zhongxun, and the other arrested leaders. ${ }^{243}$ Though Mao at some point certainly judged the executions to be excessive, his sympathies were decidedly with Xu Haidong's more class-conscious policies, and not with the sort of militia leaders and Society of Brothers members that Liu Zhidan had attracted to his revolution.

A committee was established to investigate the sufan campaign, and it rendered a mixed verdict. The sufan campaign was deemed necessary but excessive. Zhang Mutao's "counter-revolutionary group" was alleged to have infiltrated the ShaanGan soviet, and its "right capitulationism" was identified as a grave threat to the revolution. The campaign's excesses were attributed to Dai Jiying of the TwentyFifth Army, while the key representatives of the Shanghai Center, Zhu Lizhi and Guo Hongtao, survived unscathed. Indeed, their power was enhanced: the Shaanxi-Gansu-Shanxi "province" was abolished and replaced by Shaanbei Province, with Guo Hongtao as secretary, and Shaan-Gan Province, with Zhu Lizhi as secretary. There they continued to discriminate in appointments against members of the Shaan-Gan faction, which was accused of conciliation, liberalism, and localism. ${ }^{244}$ Liu Zhidan, for his part, was left in limbo, accused in his dossier of "extreme rightist tendencies." ${ }^{245} \mathrm{He}$ was returned to the army, but in a subordinate position. The Twenty-Eighth Army that he now commanded was not his old army but a new unit, much smaller, that would serve him poorly in the year to come. ${ }^{246}$

In a brief flash of glory, Liu Zhidan's time had come and gone. He was free again, but the Shaanbei revolution was no longer his to shape. There was a new sheriff in town. 


\section{Accidental Holy Land}

Xi Zhongxun, father of President Xi Jinping, was a veteran of the revolutionary movement in northern Shaanxi. In a brief essay that set the tone for virtually every official history of the Shaanbei revolution, he linked the local insurrection to the larger destiny of the Chinese Communist Party. In a torrent of mixed metaphors and party jargon, he declared that

the party organization, Red Army fighters, and popular masses of the Shaan-Gan Border Region ... after several ups and downs, finally dispelled the dark clouds and allowed the red sun to spread its dawn light over the hills and streams of the ShaanGan plateau, planting the seeds of China's Northwest Soviet, creating the only base to survive the failures of the Wang Ming "left" opportunist line. [Shaanbei] would soon become the resting place for the party Center and Red Army at the end of the Long March, and the base from which the Red Army embarked to resist Japan, making a major contribution to the liberation of the Chinese masses under the leadership of the Chinese Communist Party. ${ }^{1}$

Such is the central myth of Shaanbei's place in the Chinese Revolution. Shaanbei's valiant revolutionaries built the base that harbored the party Center from October 1935 until the spring of 1948 , a period that witnessed spectacular growth of the long-beleaguered revolutionary movement. During this time the Red Army increased from a small and ill-armed force of some thirteen thousand soldiers to an army of millions. Shaanbei provided the refuge from which the party marched to nationwide victory (map 6).

From early 1937, the party Center was located in Yan'an, and this entire period is treated as the Yan'an era in China's revolutionary history. This was the time when Mao rose to undisputed dominance in the party. His seminal writings on the Sinification of Marxism, New Democracy, protracted war, art and literature, and a host of Marxist tracts on contradictions, practice, organizational problems of the party, and the mass line were all composed during this era. ${ }^{2}$ In the early 1940s, Mao led an intense process of party "rectification," institutionalizing practices of criticism 


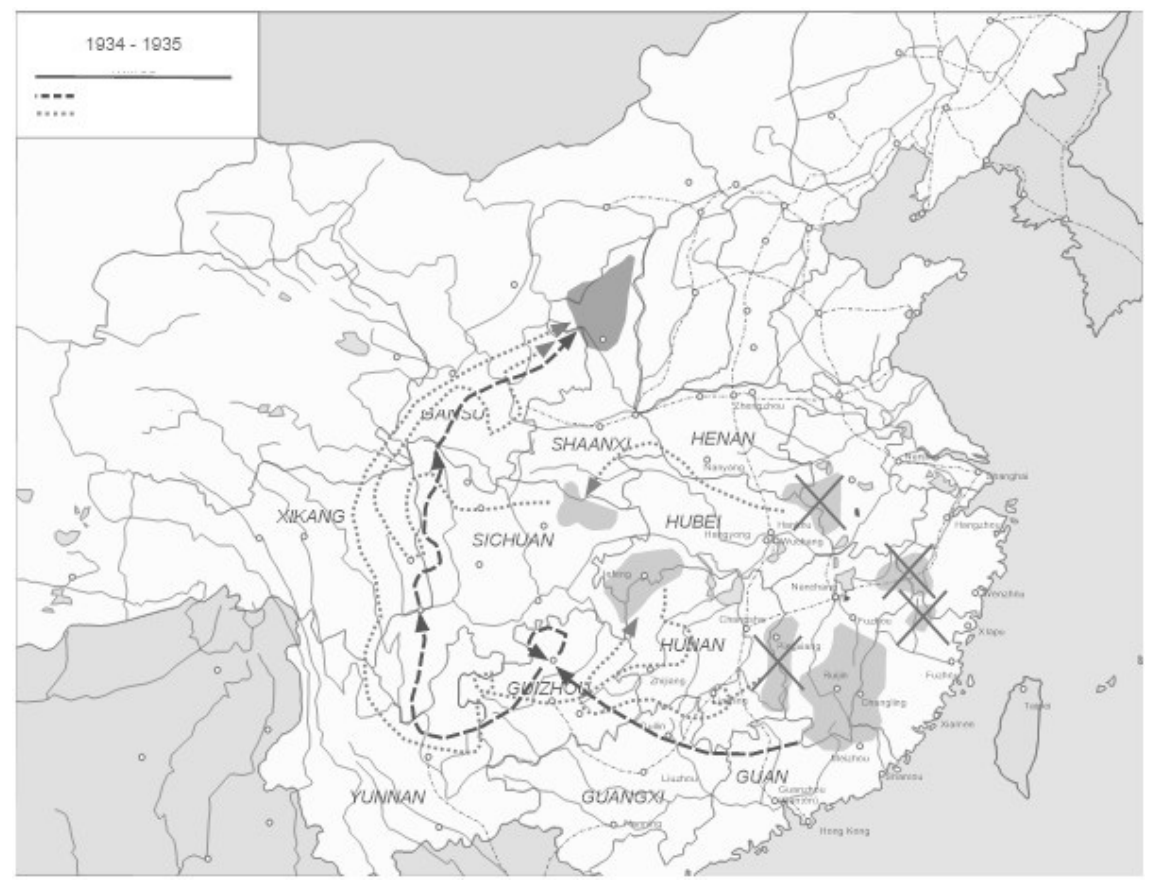

MAP 6. The conventional map of the Red Army's Long March, showing arrival in a large contiguous Yan'an-based soviet in northern Shaanxi. (Source: Wikimedia.)

and self-criticism that would shape party life for decades. Out of these writings and practices would emerge an enduring Chinese revolutionary style that has been characterized as the "Yanan Way." To this day, Yan'an is revered as a "revolutionary holy land," and the carefully restored wartime residences of the party leaders and its enormous revolutionary history museum make it a prime site for China's new Red tourism. ${ }^{4}$

Given the role that Yan'an played as a wartime Communist Center and the capital of the Shaan-Gan-Ning Border Region, it is important to recognize that Yan'an's prominence in China's revolutionary history came about quite by accident. With their preference for historical inevitability, China's official histories cast the story of the Shaan-Gan-Ning Border Region as the arduous building of a base that would protect the Red Army at the end of the Long March. The conventional map of the Long March ends in a well-delineated, Yan'an-centered northern Shaanxi base. But northern Shaanxi was only the last of many intended destinations of the Long March, and the scattered soviet zones of Shaanbei in 1935 looked nothing like the large compact base shown on these maps. Indeed, Liu Zhidan's soviet, with the exception of Anding, did not include a single county seat, "all of which were garrisoned by government troops." ${ }^{5}$ More importantly, Mao had no intention of staying in Shaanbei, which he found too poor and sparsely populated to support 
his revolutionary ambitions. It is time to explore the process whereby ShaanGan-Ning became the unintended terminus of the Long March, and the fundamental transformation of the Shaanbei revolution after the arrival of the party Center.

\section{THE CENTER COMES TO SHAANBEI}

The Red Army's mass withdrawal from the Central Soviet in Jiangxi was an epic tale of military retreat and political survival that left an indelible mark on the history of the Chinese Revolution. Less than one-tenth of the eighty thousand soldiers and cadres who left Jiangxi survived to the end of what is now celebrated as the Long March. The retreat was marked by desperate battles, sharp political conflicts, and grueling treks over high mountains and boggy grasslands. The mythology that grew around the survivors of the march has long shaped the history of the party. ${ }^{6}$ For our purposes, the critical question is how Mao's army ended up in Shaanbei. As early as 1930, Stalin had been skeptical of a soviet base near the Yangzi valley centers of Nationalist Party and imperialist power and urged the development of a base further west. ${ }^{7}$ By mid-1932, Zhang Guotao was forced to abandon the large Hubei-Henan-Anhui Soviet and flee toward Sichuan in the west. ${ }^{8}$ When Mao Zedong and his comrades were driven from the Jiangxi soviet, they first hoped to join He Long in the smaller western Hunan soviet. When this proved impossible, and after Mao's return to the party's leadership group at the Zunyi Conference of January 1935, they moved north to join Zhang Guotao's Fourth Army in Sichuan. ${ }^{9}$

The meeting of Mao's First Army and Zhang Guotao's Fourth Army in the summer of 1935 was one of the most fraught and fateful encounters in the history of the Communist revolution. Mao and Zhang were both senior members of the CCP, leaders since the party's founding congress in 1921, and each had ambitions to guide it in the future. As a former student at Peking University with close ties to the party's founders, a leader in the Shanghai labor movement, and a delegate to the Sixth Party Congress in Moscow, Zhang Guotao had academic and Bolshevik credentials superior to Mao's, but Mao had built the Central Soviet in Jiangxi. In 1935, Mao arrived with the support and authority of the Central Committee on his side; but Zhang Guotao commanded an army that was well rested, on its own turf, and roughly five times the size of Mao's forces. With leadership of the Chinese Revolution at stake, the two men clashed over the future direction of the march. ${ }^{10}$

There was general agreement that the aim should be a base in Northwest China close enough to the Soviet Union so that the Red Army could receive military assistance from the socialist motherland. Soviet economic and political penetration of the far western province of Xinjiang was widely known and a key consideration. ${ }^{11}$ In an August Politburo meeting, Mao argued that "the Soviet Union's influence in this area is great; we can see that from its work in Xinjiang. If we are geographically close to the Soviet Union, we can get political and material 
assistance, and militarily, get airplanes and artillery, which would be very significant for the civil war in our country." Zhang Guotao preferred a westward route through Qinghai to Xinjiang, while Mao wished to move north and east, with only a small force sent toward the "Xinjiang aircraft factory and arsenal." ${ }^{12}$ Zhang's plan involved an initial move to the Tibetan areas of western Sichuan, but Mao objected that the population there was sparse, there was little grain to support the Red Army, and collecting it would involve conflicts with the local Tibetan population. Mao and his colleagues pushed for a soviet in the densely populated area of southern Gansu, along the border with Sichuan and Shaanxi. ${ }^{13}$ On September 10, the two armies split. Mao left his military chief, Zhu De, and a portion of the First Army with Zhang Guotao and headed north into Gansu, while Zhang soon moved south toward western Sichuan. Two days later, at a Politburo meeting in Ejie, Gansu, Mao forcefully stated his strategic goals:

At present we should engage in guerrilla struggle, fighting toward the Soviet border. This is our basic policy at present. In the past, the Center opposed this policy. After the First and Fourth Armies combined, we should have developed a soviet on the Shaanxi-Gansu-Sichuan border. Now things have changed. Now we have only the First and Third Regiment of the First Army, so we should be clear about this problem, and through guerrilla warfare, fight through to open an international connection, and with the direction and help of the International, rest and restore our military strength and increase the size of our army.... We absolutely reject the idea that it is wrong to seek help from others. We are a branch of the International. We can first establish a base on the Soviet border and then expand to the east. Otherwise, we will be fighting a guerrilla struggle forever. ${ }^{14}$

Had this plan in fact succeeded, the Chinese Revolution might have followed the course of North Korea, whose Communist leader Kim Il Sung raised his army in the Soviet Union. ${ }^{15}$ We can hardly imagine such a strategy from Mao. Given Mao's enduring reputation as an advocate for the Sinification of Marxism and a uniquely Chinese form of socialism, this forthright acknowledgment that the Chinese Communist Party was but a branch of the Comintern is remarkable. However, the nature of the party in the 1930s, with its firm commitment to socialist internationalism, makes Mao's analysis less surprising. Indeed, it fits with the general tenor of the times. Soon, however, a fateful accident would redirect the path of the march-and eventually, of the Chinese Revolution itself. A few days later, Mao read newspaper accounts of a soviet in northern Shaanxi, and, as we have seen, the Long March was steered in that direction. The First Army was renamed the Shaan-Gan Detachment of the Red Army, continued its march to the northern Shaanxi-Gansu border and in October rendezvoused with the Shaanbei revolutionaries. ${ }^{16}$

With its arrival in Shaanbei, the Center achieved some security in a region already dominated by local Communists. The Shaanbei soviet, however, was far less than the eight counties and ten half-Red counties promised in the newspaper 


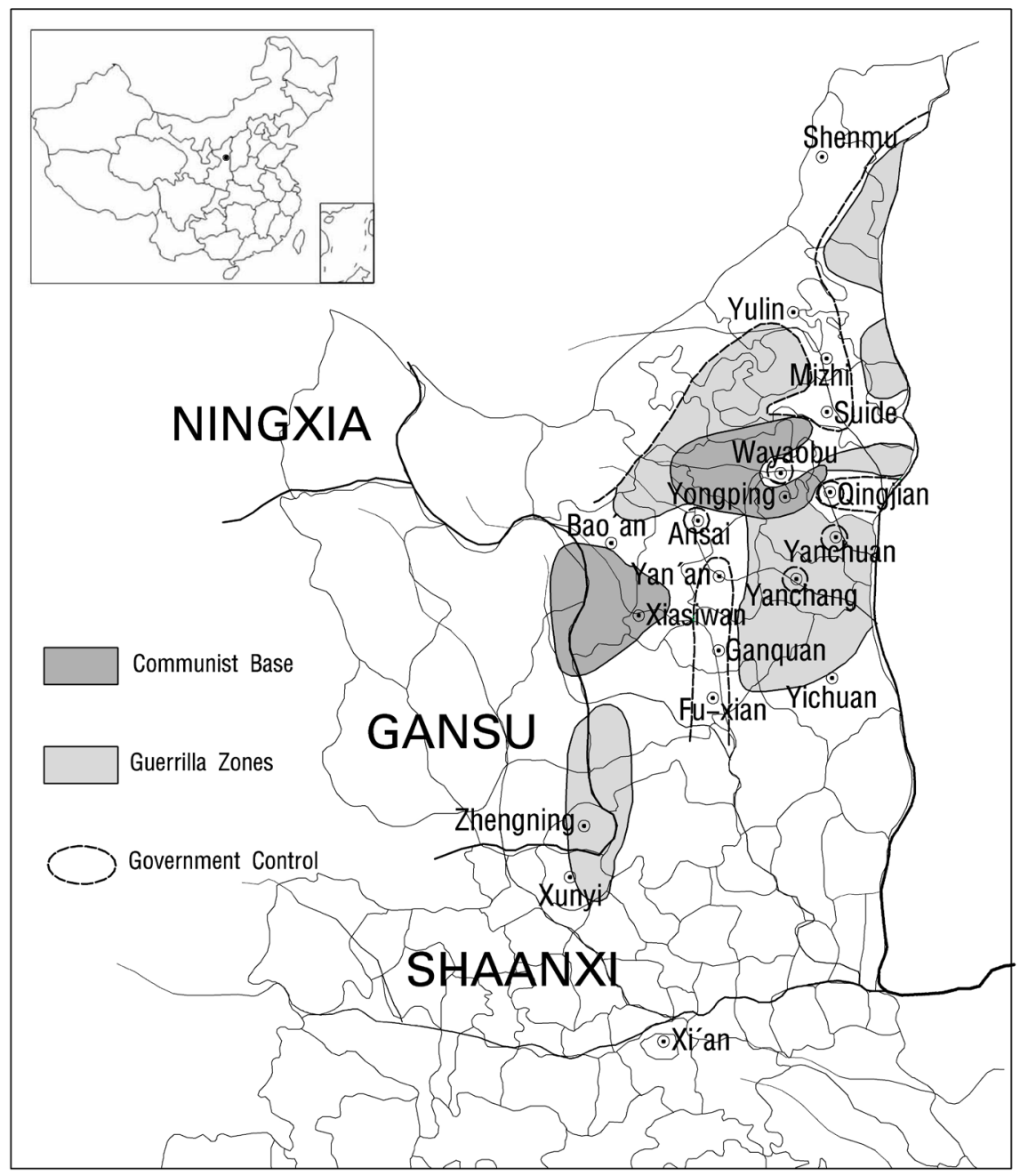

MAP 7. Northern Shaanxi Red bases and guerrilla zones in the fall of 1935, when Mao Zedong and Long March survivors arrived. Neither of the Communist political centers in Xiasiwan and Yongping was a county seat. (Based on SXDSTX, 1985, no. 12; XBGJD, map in front matter, pp. 246, 249, 268-80, 718-19; and author's fieldwork in 2018 and 2019.)

account. Indeed, the Communists controlled only a single county seat in Anding, their power being confined to the countryside (see map 7). Even there, as seen above, Liu Zhidan's new regime had been gravely weakened by the sufan campaign against "counter-revolutionaries." Indeed, when Mao and the Center arrived in Shaanbei, Liu and his closest associates were still imprisoned in Wayaobu; Yanan, Yulin, and all the major towns of Shaanbei were occupied by the enemy; and the Shaanbei soviet was surrounded by a massive array of Guomindang 
forces. To a large degree, the fate of the Shaanbei revolution lay in the hands of the Red Army, and military considerations would dominate the next stage of the struggle. The newspaper account Mao read in Gansu reported a Communist soviet with seven hundred thousand members, two hundred thousand Red Guards, and a Red Army force of twenty thousand. ${ }^{17}$ What he discovered was surely a disappointment.

It is generally agreed that Mao Zedong's First Army left Jiangxi with about 80,000 men. Estimates of the First Army's strength when it met Zhang Guotao's Fourth Army in Sichuan vary widely, ranging from 10,000 to 30,000, with the reality probably closer to the former figure. ${ }^{18}$ There were major losses crossing the grasslands and significant casualties and desertions in the battles of southern Gansu, so that on arrival in Shaanbei, companies with an official strength of roughly 120 were down to 75 men. ${ }^{19}$ Once again, estimates of the army's total size vary radically. Edgar Snow, who visited the Communist base in 1936, says there were "less than 20,000 survivors," but that is an generous estimate. ${ }^{20}$ Mao's rival Zhang Guotao claims he was told that "fewer than four thousand men" remained in Mao's army, and that surely errs in the opposite direction. ${ }^{21}$ In the absence of contemporary records, Peng Dehuai's memoir seems the most reasonable: 7,200 people, including hundreds of noncombatants. ${ }^{22}$ My own best estimate is that Mao arrived with an army of about 6,000 men, but the core was tough, disciplined, battle-tested veterans, under firm party leadership, though armed only with rifles and a few machine guns captured from the enemy. It should also be stressed that many of those who arrived in Shaanbei were recent recruits from Sichuan and elsewhere, so the casualty rate among the Jiangxi veterans was well over 90 percent. Those most likely to survive were the top leaders.

The other large external army in Shaanbei was Xu Haidong's Twenty-Fifth Army from Hubei, whose size is similarly difficult to estimate. It was certainly a powerful, experienced military force, and we have seen in the previous chapter that when Xu's army was combined with Liu Zhidan's Twenty-Sixth Army and the late Xie Zichang's Twenty-Seventh to form a new Fifteenth Army, it was Xu who was given command. While campaigning in South Shaanxi, Xu's army was reported to be only 1,500 men but "well armed with modern weapons;"23 a contemporary Guomindang source says Xu arrived with a force of 2,00o; Gao Gang in 1945 said 1,400; while Zhang Guotao's consistently low estimates report "less than 2,00o" in the entire Fifteenth Army, most of whom where Shaanxi and Gansu men fighting under Hubei officers. ${ }^{24}$ It seems reasonable to presume that there were at most 2,000 men in Xu Haidong's own army. As to the local forces, a contemporary report by Zhu De and Xu Haidong's later recollection put the combined armies of Xu Haidong and Liu Zhidan at 7,00o men. ${ }^{25}$ This is generally consistent with a Guomindang report that estimates that Liu's army had over two thousand guns, and Xie Zichang's over three thousand. ${ }^{26}$ Given that Shaanbei armies always had more soldiers than rifles, and that the Guomindang source is prior to the 
costly Laoshan battle and the defections following Liu Zhidan's arrest, we may estimate that on Mao's arrival in October 1935 there were about 5,00o men in the Shaanbei armies, plus roughly 2,00o men in Xu Haidong's army. All of this suggests a total Red Army force in Shaanbei of only 13,000 men.

On arrival in Shaanbei, the party Center's first concern was the security of its new base. In September, Chiang Kai-shek established a Xi'an headquarters for his anti-Communist campaign. Under this new command, some three hundred thousand troops surrounded the last remaining Communist base, a manpower advantage of perhaps 20:1. ${ }^{27}$ Chiang's forces were also better armed, with heavy machine guns, artillery, trucks for transport, and an air force of spotter planes. Chiang recognized that the split between the First and Fourth armies had critically weakened the Red Army, and he was determined to press his advantage. ${ }^{28}$ Mao's first response was to order an urgent recruitment campaign to redress this military disadvantage. The campaign yielded one thousand new recruits, an unprecedented achievement in Shaanbei. ${ }^{29}$ The new regime was much more aggressive in its demands on the local population, though these untrained recruits could hardly have been useful for more than porter duties.

Mao Zedong and Peng Dehuai immediately set out to stabilize the southern front. The Guomindang armies in this sector belonged to Zhang Xueliang's Northeast Army (NEA). Natives of Manchuria, they had left their homeland after the Japanese invasion in 1931 and were now used by Chiang Kai-shek to fight his domestic foes. As Japanese aggression and Chinese patriotic resistance grew in the mid-1930s, these armies were not entirely comfortable with Chiang's antiCommunist campaigns. For Mao, this provided an opportunity to strike a hard blow to dissuade them from fighting Chinese Communists rather than Japanese invaders. The battle that followed, at Zhiluozhen in Fu-xian near the Gansu border, was a key example of the new level of military expertise that came with Mao's First Army. While Liu Zhidan's tactics relied on his deep local knowledge of Shaanbei topography, Mao carefully prepared with precise military maps. ${ }^{30}$ With winter setting in, he supplied his troops with padded uniforms for the cold-though they were short some two thousand sets, and many still got sick and had to be sent for medical care. ${ }^{31}$ While Liu had fought short, quick battles, usually ambushes, that lasted a few hours, Zhiluozhen was a set-piece battle that lasted several days. In the end, a great victory was claimed. The NEA's 109th Division was decimated and its commander killed. The contemporary military report counted 5,367 captives, plus 3,400 rifles, 176 machine guns, eight mortars and 220,000 rounds of ammunition. In all, about 1,300 NEA soldiers were killed or wounded. The fight was also costly on the Red Army side, with 648 casualties, which was not a sustainable ratio given the relative size of the armies. ${ }^{32}$ Still, the battle achieved its political purpose: demoralizing Zhang Xueliang's NEA and provoking a renewed interest in some accommodation with the Communists to confront their common enemy, Japan. 


\section{NEW LEADERS FOR SHAANBEI}

On November 3, 1935, a new Military Committee of the Northwest Revolution was formed to command the Red Army in Shaanbei. Mao Zedong was chair, with Zhou Enlai and Peng Dehuai serving as deputies. Other members included Wang Jiaxiang, a Soviet-returned member of the Central Committee, Lin Biao from the First Army, Xu Haidong and Cheng Zihua from the Twenty-Fifth Army, and two representatives of the Shanghai Center, Nie Hongjun and Guo Hongtao. ${ }^{33}$ None of the leaders of the Shaanbei revolution were included. The only Shaanbei native on the committee was Guo Hongtao, who had returned in 1933 to lead the criticism of Liu Zhidan's Twenty-Sixth Army. Even the local guerrillas were placed under the command of an outsider, Xiao Jinguang, another Long March veteran from Mao's native Hunan. ${ }^{34}$ With these appointments, the Center took full control of the military in Shaanbei.

The Northwest Military Committee reflected the new political reality. The prominent role of Xu Haidong and his associates is particularly important. Even before Mao arrived, Xu Haidong had assumed command of the new Fifteenth Army, which included all of the Shaanbei armies. Mao was particularly anxious to ensure that his army made a good impression on Xu's troops, ordering his soldiers to bathe and wear clean uniforms for their first meeting. They were carefully instructed on what to say when they met the Fifteenth Army ${ }^{35}$ Xu Haidong was a former subordinate of Zhang Guotao, and just a month earlier, Zhang had escalated his dispute with the party Center by forming a rival Central Committee that expelled Mao, Zhou Enlai, and Zhang's rivals from Jiangxi. ${ }^{36}$ Mao could not allow this split to affect Xu Haidong's loyalty, and the orders on what to say to Xu's troops certainly involved instructions on how to discuss the breach with Zhang. In the September Politburo meetings in Gansu, Zhang Guotao had been harshly criticized for "opportunism" and "warlordism," but after the Center reached Shaanbei, the line shifted to avoid discussion of past differences in the interest of party unity. ${ }^{37}$ This was particularly important with Xu Haidong: avoid reopening the wounds inflicted by the split with Zhang Guotao.

One bond that linked Mao and Xu Haidong was the survival of their armies over the arduous course of their respective long marches to Shaanbei. As soon as he reached Shaanbei, Mao began promoting the lore of the Long March. On the eve of the Zhiluozhen battle, he exhorted his troops with the message that the survivors of the Long March were "the elite of the Chinese Revolution," who had endured such intense hardships that "one can withstand ten, or one hundred, or even one thousand." 38 The elite Long March survivors were to be protected and promoted. "The [First Army] Shaanxi-Gansu Detachment and the Twenty-Fifth Army are all veterans of the Long March. In principle, they should all be made cadres, they should not be wasted as ordinary soldiers." ${ }^{39}$ Presumably, the ordinary soldiers to be "wasted" in future battles would be new recruits from the Northwest. Mao was particularly upset when he learned of officers who had been demoted 
for past errors and then killed in battle when their junior officer status put them in exposed frontline positions. ${ }^{40} \mathrm{He}$ applied the same principle to Xu Haidong's army. Learning that some army veterans were still under suspicion as a result of Hubei's sufan campaigns against "counter-revolutionaries," Mao argued that their persistence during the march from Hubei was sufficient to prove their loyalty and erase past suspicions. ${ }^{41}$ Of course, not all Long March survivors were immediately treated as "the elite of the Chinese Revolution." With the death and defection of so many who had set out from Jiangxi, the Communists had steadily recruited during their march. These new recruits were regarded as less reliable, and special education was ordered for those who had joined the march in Guizhou, Yunnan, and Sichuan. ${ }^{42}$

In the alliance between Mao and $\mathrm{Xu}$, the clear losers were the local armies from Shaanbei. As seen in the last chapter, Xu Haidong's deputies had led the sufan campaign against Liu Zhidan and his allies. There was tension between the local and Hubei troops before and after the October battle at Laoshan, and Xu disparaged the local troops as "very backward" and ignorant of Soviet and Red Army regulations. ${ }^{43}$ Mao had to warn Xu's officers not to be arrogant, not to despise or excessively criticize the Shaanbei troops ${ }^{44}$ Mao was also aware of the past conflicts between Liu Zhidan's Shaan-Gan army and Xie Zichang's "Shaanbei" faction, instructing that because of their troubled historical relations the two armies should not be combined in the same units. ${ }^{45}$ Over time, the party Center came to accept much of Xu's negative assessment of the Shaanxi soldiers. It described Shaanbei as a land of opium and bandits and was concerned about the large number of Red Army soldiers recruited from bandit gangs and local militia. The influence of the Society of Brothers was a major concern: "Among the people of Shaan-Gan-Ning there is a common phenomenon: there are many former members of the Society of Brothers, so that in the Red Army there are quite a few Brothers." ${ }^{36}$

The Center was equally keen to control the commanding heights of the local soviet. The Central Soviet established a new Northwest office to direct the local administration, with Bo Gu (aka Qin Bangxian), one of the Twenty-Eight Bolsheviks, at its head. ${ }^{47}$ In the party apparatus, the old Shaanxi-Gansu-Shanxi committee was replaced by a Shaan-Gan provincial committee under Zhu Lizhi and a Shaanbei committee under Guo Hongtao. Thus the two leaders of the sufan movement against Liu Zhidan controlled the local party apparatus. Only much later was it recognized that they continued to discriminate against Liu's comrades in their appointments. ${ }^{48}$

In the long history of conflicts within the Communist Party, the most persistent and difficult to resolve were those between central authorities and local cadres. Local Communists typically joined the movement to advance their material or political interests, seeking access to land, local power, protection from state exactions, or some advantage in the unending competition for scarce resources. Higher party authorities had larger revolutionary goals and often called on local 
activists to sacrifice on behalf of the revolution. Any resistance from the local party could be interpreted as a counter-revolutionary conspiracy, and some of the bloodiest conflicts in party history-from the Futian incident in Jiangxi, to the sufan campaigns in Hubei or Shaanbei-pitted outside party authorities against the local party. ${ }^{49}$ With outsiders now firmly in control of the revolutionary movement in Shaanbei, the potential for conflict was real. The Nationalist enemy sought to encourage this conflict, painting (not implausibly) the Red Army as an external occupying force. ${ }^{50}$ The new southern leadership was well aware of this danger and sent clear orders for the Red Army to form close relations with local Red Guards, rely on local cadres in their work, and assist in the establishment of revolutionary committees. ${ }^{51}$

Conflict, however, was inevitable, and sometimes it could be sharp. Mao's admonition against cursing or issuing commands to local cadres is a sure sign that such conduct was a problem..$^{52}$ Even while warning against commandism, the Center was determined to transform the Shaanbei party. A directive on the local guerrillas warned against "conservatism and localism," 53 while another on peasant associations stressed the danger of localism and familism. ${ }^{54}$ Meanwhile, Zhou Enlai stipulated that Mao's First Army was to receive priority in supply efforts, ${ }^{55}$ and there were local conflicts when the Red Army violated regulations in confiscating rich peasants' property to meet their land reform quotas. ${ }^{56}$ Sometimes these conflicts could build into outright opposition to the new revolutionary regime. We have seen this with the Chian incident in Liu Zhidan's home county after his arrest. This resistance continued well into 1936, and at least one Long March veteran was killed in the effort to quell the unrest. ${ }^{57}$ A Dagongbao journalist touring Shaanbei in 1936 reported that two thousand followers of Liu Zhidan were actively opposing Mao and Xu Haidong on the Shaanxi-Gansu border. ${ }^{58}$

Liu Zhidan's still undetermined fate exacerbated these problems in late 1935. The party Center had halted arrests and executions, but Liu and his comrades remained imprisoned in Wayaobu until Zhou Enlai released them in early December. ${ }^{59}$ Even after his release, Liu's "historical problems" remained unresolved, as is clear from the leadership positions given to his two chief accusers. Liu was initially restored to command of the Twenty-Sixth Army, where Mao appears to have tested him, sending him north from Wayaobu with orders to eliminate the local warlord Jing Yuexiu in Yulin. ${ }^{60}$ Yulin was the well-defended political and military center of northeastern Shaanxi, the sort of town that the local Communists had never dared to attack. Liu's ill-armed force was clearly not up to the task, which failed, and on December 30 he was transferred to command a newly formed Twenty-Eighth Army. ${ }^{61}$ By the end of 1935, not only was Liu in political limbo, he had lost the army he had spent so many years building. With the Center now based in Shaanbei, it had taken charge. The Shaanbei revolution was no longer a local affair. It had new leaders with a much grander mission than Liu's, a mission that involved broader contacts and negotiations than Liu Zhidan would have been capable of. Ironically, 
though, new instructions from Moscow soon led the Center to flexible policies toward potential allies, united front policies that would be very close to those that Liu had long practiced-and long been criticized for.

In mid-December, the Politburo began a critical week-long meeting in Wayaobu, the leading town in the soviet base surrounding Anding County, northeast of Yan'an. Late in November, Lin Yuying, Lin Biao's cousin, returned from Moscow. For security reasons, he carried no documents, delivering only an oral report on the Seventh Comintern Congress. ${ }^{62}$ The party Center had been cut off from the International since September 1934, when arrests in Shanghai severed radio communication with Moscow. Through the entire Long March and the early weeks in Shaanbei, the CCP Center had acted without external advice. ${ }^{63}$ At Wayaobu, the party Center received first-hand news of the Comintern's new united front policy, designed to confront the Nazi threat in Germany and the global menace of fascism. The CCP adjusted its line to support "the broadest possible national antiJapanese united front" of "all classes, all political factions, all social organizations, and all armed forces." To this end, the worker-peasant soviets were renamed "soviet people's republics," and land reform policies were adjusted to protect "bourgeois" exploitation by rich peasants but not "feudal" exploitation by landlords. ${ }^{64}$

The Wayaobu meeting took a significant step toward the united front policy that would become increasingly important in 1936 and beyond. Just as the party was gathering in the small Shaanbei town, students in Beiping were engaged in fervent demonstrations, soon famous as the December Ninth Movement, against Japan's promotion of an "autonomous" North China and Chiang Kai-shek's conciliatory response. ${ }^{65}$ Immediately after the Wayaobu meeting, Liu Shaoqi was sent to Tianjin to organize leftist students there and in Beijing. ${ }^{66}$ Given the embattled status of the Shaanbei soviet, however, the immediate concern at Wayaobu was military. Here the conclusion was clear: it was time to resume the march toward the Soviet border.

\section{INTO SHANXI: THE LONG MARCH RESUMES}

When Mao Zedong rejected Zhang Guotao's decision to lead the Long March south and west in Sichuan, his reason was clear: in the proposed base "the population is only eight thousand and there is very little grain. In [the west Sichuan towns of] Maogong and Fubian the grain is already exhausted [from the Red Army's previous occupation]. A large army based there faces the threat of starvation." ${ }^{67}$ When Mao arrived in southern Gansu, the exaggerated newspaper reports of a large soviet in Shaanbei provided a better alternative, but on arrival the party Center was gravely disappointed by the poverty and sparse population of the region. As one report noted, the population density was less than 5 percent of the Lower Yangzi province of Jiangsu. ${ }^{68} \mathrm{~A} 1936$ report to the Comintern described the new base in stark terms: "The topography is mountainous with deep gullies. There are 
few trees and little water. Residents are few and communication extremely difficult. . . Population density is very low, no more than four hundred thousand total. Except along the west bank of the Yellow River, few villages have more than forty or fifty families. Even along the main roads, you can go fifteen or twenty kilometers without seeing a single home... Agriculture produces mostly millet, little wheat or other grains. There is not enough to support long occupation by a large army." ${ }^{39}$ Precisely the conditions that had precluded a west Sichuan base were now applied to Shaanbei.

Mao had consistently displayed a preference for aggressive mobile warfare, moving to the enemy's rear when his base was threatened and "fighting on external lines." He had advocated this strategy in Jiangxi and returned to it in Shaanbei. ${ }^{70}$ His first impulse was to expand the soviet to the south, toward the richer counties on the northern rim of the Wei River valley. There he hoped to find fresh recruits for the Red Army and reach the students who were increasingly committed to patriotic resistance to Japan. ${ }^{71}$ At the same time, as we have seen, he dispatched Liu Zhidan to take the more densely populated area around Yulin. All of these efforts failed, which was hardly surprising. Expansion toward Guanzhong was a strategy that Bolsheviks in the provincial committee had long urged on Liu Zhidan, with disastrous results. Within the central military leadership, Lin Biao seems to have abandoned all hope for Shaanbei: he proposed moving the Red Army to southern Shaanxi, along the border of his home province, Hubei. Mao rejected this option for the time being and summoned Lin to Wayaobu. ${ }^{72}$

As we have seen, the Wayaobu Politburo meeting followed Lin Yuying's return from Moscow. Politically, Lin's main message involved moderating the party line to accommodate the Comintern's new united front policy. Militarily, Lin reported that before leaving Moscow, "He obtained Stalin's agreement that the main force of the Red Army could advance to the north and northwest, and he [Stalin] was not opposed to it approaching the Soviet Union." In Lin's view the best policy was "to establish a broad base in the north, combine the domestic and national war, transform the Red Army into the true anti-Japanese vanguard, unite with the Red Army of the Soviet Union to oppose their common enemy, Japan, thus improving the technological capacity of the Red Army."73 There was considerable debate about the best route to the Soviet or Soviet-controlled Mongolian border. Zhang Wentian evidently preferred a route to the northwest through Ningxia, but Mao insisted on attacking east through Shanxi before turning north. This route had the distinct advantage that it could be portrayed as a campaign toward the front with Japan. ${ }^{74}$ Peng Dehuai, supported by Zhou Enlai, warned against abandoning the Shaanbei base, and Mao assured them that the campaigning army would retain a link to Shaanbei. Peng and Zhou seemed to doubt that the Red Army could push through Yan Xishan's armies in Shanxi before turning north through Suiyuan (now Inner Mongolia) to reach Mongolia and receive aid from the Soviet Union. ${ }^{75}$ In the end, Mao prevailed, and with the decision 
to attack through Shanxi, the next stage of the Long March to a Soviet rendezvous began. ${ }^{76}$

Mao seemed supremely confident. His famous poem "Snow", with its reference to the Yellow River, soon to be crossed, and the Great Wall, not far to the north, was written at this time. It refers to the great emperors of past dynasties, from the first emperor of the Qin to Genghis Khan, and concludes, "All are gone. / For heroes, now is the time." 77 With its evocation of China's landscape and ancient leaders, it was a testament to Mao and the party's national ambitions, and millions of Chinese can recite it today. It suited the fact that despite the secret plan to fight through to the Mongolian border, the public aim of the Eastern Expedition was to confront Japanese aggression. The army was called the "Anti-Japanese Vanguard" (Kang-Ri xianfengjun 抗日先锋军), and Yan Xishan, who bore the immediate brunt of the attack, was termed, along with Chiang Kai-shek, a "traitorous sellout" (maiguozei 卖国贼) acting under Japanese direction. ${ }^{78}$ With the December 9, 1935, student demonstration in Beijing spreading its influence over much of China, the tide of anti-Japanese sentiment was rising, and the Red Army did everything it could to harness this patriotic fervor for its purposes.

The most important fruit of the new united front policy was a truce with Zhang Xueliang's NEA to protect the southern flank of the Shaanbei base. As we will examine in more detail presently, the Communists used captives from Zhiluozhen and other battles to spread their message of anti-Japanese patriotism in the NEA. With preparations for the Shanxi campaign under way, a CCP security agent met with Zhang Xueliang to begin negotiations toward a united front. A de facto truce was arranged, Zhang promised not to assist Yan Xishan, and he apparently provided military maps of Shanxi, Hebei, and Suiyuan. ${ }^{79}$

With the southern flank secure, the party renewed its focus on recruitment. In November 1935, Mao termed the vigorous expansion of the Red Army "the most important, most important, most important task" of the party ${ }^{80}$ An order went out to recruit 7,000 new soldiers by early 1936, and 2,600 more by March. ${ }^{81}$ An additional 3,000 stretcher bearers were summoned from the Suide area. ${ }^{82}$ In all likelihood, both of these groups were mobilized from local Young Pioneers and Red Guards. An October 1935 order of the Shaanxi-Gansu-Shanxi soviet stipulated that "all young men and women aged fourteen to twenty-three sui are to enroll in the Young Pioneers. Those between twenty-three and thirty-five sui, females excepted, are to join the Red Guards." ${ }^{3}$ This mobilization would have almost doubled the size of the Red Army in Shaanbei, and Li Weihan admitted that it was exceedingly difficult to meet these goals. ${ }^{84}$ Shaanbei peasants were willing to fight to protect their families, but a distant expedition to fight Japan was not a cause they readily embraced. ${ }^{85}$ Some recruiting involved deception: summoning local cadres for "training" and then enrolling them in the Red Army. ${ }^{86}$ In the south, recruitment drives had been carried out with intensive political pressure that easily became coercive as local cadres sought to meet their quotas..$^{87}$ Now those practices were brought to Shaanbei. 
On February 20, 1936, the main force of the Red Army crossed the Yellow River and quickly established a headquarters in the Lüliang mountains of western Shanxi. Mao had calculated that the long-standing conflict between Yan Xishan and Chiang Kai-shek (the two had fought a bitter and costly war in 1930) would prevent Yan from calling on Chiang for support. ${ }^{88} \mathrm{He}$ was wrong. Chiang's forces established an effective line of blockhouses along the railway through the Fen River valley that the Red Army was unable to cross. Their assault stymied, Red Army commanders were soon reporting heavy losses. ${ }^{89}$ Mao pressed Lin Biao for one final victory, which was not achieved before an April retreat back to Shaanbei. ${ }^{90}$

Just before the withdrawal, the Shaanbei revolution endured one final blow: the loss of its hero, Liu Zhidan. To assist the Shanxi expedition, Liu Zhidan's newly formed Twenty-Eighth Army in northeast Shaanxi was ordered to cross the Yellow River into Shanxi and then move south to protect the fords for the coming retreat. It was an unimpressive force, a small group of five to six hundred former guerrillas, a "rotten army" in the opinion of Liu's former comrades. ${ }^{91}$ On April 13, Mao and Peng Dehuai ordered Liu to attack the well-defended fort protecting the ford at Sanjiaozhen. When the assault stalled, Liu moved to the front to direct the attack and was shot and killed. Several of his key lieutenants also died in the battle. ${ }^{92}$ The circumstances of Liu's death remain controversial. To this day, many in Shaanbei believe that Mao was responsible. ${ }^{93}$ If Mao and the party Center did not directly order Liu's elimination, one plausible theory is that after Liu and his lieutenants were criticized in 1935 and given an inferior army to lead, they sought to prove themselves and regain favor by "risking their lives on the battlefield" and paid the ultimate price. ${ }^{94}$ Unless and until the Chinese Central Archives are open to independent researchers, we will never know the answer to this puzzle. Nonetheless, the fact that so many Shaanbei people believe that the party was responsible for Liu's demise is a significant indication of enduring suspicion toward the party Center.

As the Red Army withdrew from Shanxi, it made energetic efforts to turn military defeat into political victory. Chiang Kai-shek and Yan Xishan were blamed for blocking the Red Army's attempt to fight the Japanese invaders. ${ }^{95}$ The party stressed its success in recruiting eight thousand new soldiers to the Red Army and confiscating $\$ 300,000$ from local coffers and the wealthy. ${ }^{96}$ In his speech to military officers, Mao was more critical. Complaining of "liberalism" and commanders' concern for their own units rather than larger revolutionary objectives, he blamed some for not pressing the attack for fear of losses. ${ }^{97}$ For the peasants of Shaanbei, the loss of their longtime leader and an untold number of young recruits caused many to wonder if this brief and dramatically unsuccessful foray into Shanxi was really worth the cost. There is no evidence that Mao felt similar remorse. 


\section{HARD TIMES}

Liu Zhidan's military victories of 1935 had brought much of the countryside and several towns in eastern Shaanbei under Communist control. When the Red Army attacked Shanxi, it forced Yan Xishan to withdraw his troops from Wupu and Jia-xian on the west bank of the Yellow River, and the Communists soon occupied these counties. ${ }^{98}$ For a time, there was relatively secure Communist control of much of Shaanbei. After the failure of the Shanxi expedition, with the Red Army in retreat, all of this was threatened as Chiang Kai-shek's armies continued their pursuit into Shaanxi. The party secretary in Shaanbei reported the loss of Red districts in northeast Shaanbei, difficulties in recruitment, and "rumors" that "the Red Army has come back in defeat. Now it's going to be awful." Communist headquarters in Wayaobu was abandoned as the town was running out of grain to feed the army, and the party leadership fled to Bao'an in the far northwest. The Center had hoped to surrender Wayaobu to the NEA, with which it had established a cooperative relationship, but Chiang Kai-shek sent his reliable general Tang Enbo to take the town. ${ }^{100}$

A Dagongbao journalist visited the former Communist areas of eastern Shaanbei in the fall of 1936. He found Tang Enbo engaged in an aggressive program of road building to connect the Nationalist stronghold in Yulin to the counties further south and the fords linking Shaanbei to Shanxi. A lazy magistrate was fired and arrested, and a corrupt opium-dealing military officer was shot. Soon all of the major towns and communication routes were in Nationalist hands. The Communists, however, controlled much of the countryside, and the same journalist reported that most of the adult males in the former Communist strongholds were now in the Red Army ${ }^{101}$ Even in occupied towns like Wayaobu, the Communists had left their mark. The reporter reluctantly admitted that as a result of the brief Communist occupation, the town residents displayed an unusual degree of political engagement. ${ }^{102}$ On the whole, however, the revolution was in retreat, and the eastern portion of the Shaanbei soviet was reduced to a guerrilla zone. ${ }^{103}$

From early 1936, the Communists had strengthened their rural organization. Participation in the Young Pioneers and Red Guards was made a "sacred responsibility of every soviet citizen." Women, rich peasants, and intellectuals were all included-though the party was also enjoined to guard against alien class elements. All these young people were to have weapons, though few would be firearms, and their military duties went beyond marching and parades to include sentry duty, intelligence, and the inspection of travel passes. With the Nationalists now occupying the towns, these young people formed the key network of activists to warn against enemy forays into the countryside. ${ }^{104}$ When government forces ventured into the rural areas, the Communists emptied the villages, leading the peasants with their meagre belongings to hide in the hills. The Communists also prepared for intense class struggle, giving local soviet cadres and guerrillas the authority 
to execute suspected spies and traitors. ${ }^{105}$ To coordinate these efforts, the party organization was gradually professionalized: members of the district ( $q u$ 区) party committee and rural headmen (xiangzhang) were "divorced from production" - that is, they became paid employees of the nascent Communist state. ${ }^{106}$

The return of the Nationalist Party and its enhanced military presence in eastern Shaanbei exacerbated the class struggle in the countryside. Some wealthier peasants demanded the return of land confiscated during the previous year's land reform, a move that the Communists vigorously contested. These conflicts often became violent, to the extent that, as noted in the previous chapter, in some Communist strongholds "all local strongmen and evil gentry were killed." ${ }^{107}$ However, class conflict was not the only form of social change. As in many social revolutions, gender relations became a key flash point. The Dagongbao reporter visiting Shaanbei noted the spread of "disorderly" gender relations, with young couples marrying within their own village. ${ }^{108}$ Presumably the young people were making their own marital choices and choosing partners whom they knew. The speed with which these changes occurred is notable. Since the Young Pioneers and Red Guards included both men and women, these new organizations provided opportunities for couples of marrying age to get to know each other. In addition, with so many men in the army, young women were performing more farm work, with chances to socialize away from the supervision of parents. ${ }^{109}$

Despite continuing strength in the countryside, by the late summer of 1936 the secure Communist base had been reduced to a small pocket in northwest Shaanxi and neighboring Gansu and Ningxia. An August report to the Comintern gives the clearest picture of the Shaan-Gan-Ning base at this juncture. Some soviet bases survived in eastern Shaanbei, but they were broken up into small pieces by Nationalist blockade lines and Communist-suppression units. In the counties just south of Yan'an, the Nationalists controlled the towns and the main roads, and the Communists the countryside. Similarly, the villages of northeastern Gansu were Communist controlled. The report claimed only four counties under complete Communist control: Huan-xian in Gansu; and Bao'an, Ansai, and Anding in Shaanxi. The Anding claim was certainly false, as its main town, Wayaobu, had been abandoned in June. Four small county seats were credibly claimed: Yanchi and Yuwang in Ningxia, and Dingbian and Jingbian in Shaanxi. "Except for Dingbian, all are minor towns of less than two hundred families." 110 The main towns in Shaanbei-Yan'an, Yulin, Suide, Wayaobu-were all in Nationalist hands. ${ }^{111}$ The Communist capital in Bao'an certainly did not look like the center of a national movement. Recall that in the 1920s, the local government had abandoned the town for the Yongningshan fortress because Bao'an itself was vulnerable to local bandits. In 1936, it was still smaller than the average town in the Lower Yangzi, with "most of the houses ... in ruins." 112 Edgar Snow visited Bao'an in the fall to conduct his famous interviews of Mao. His wife described Bao'an as "a place where life 


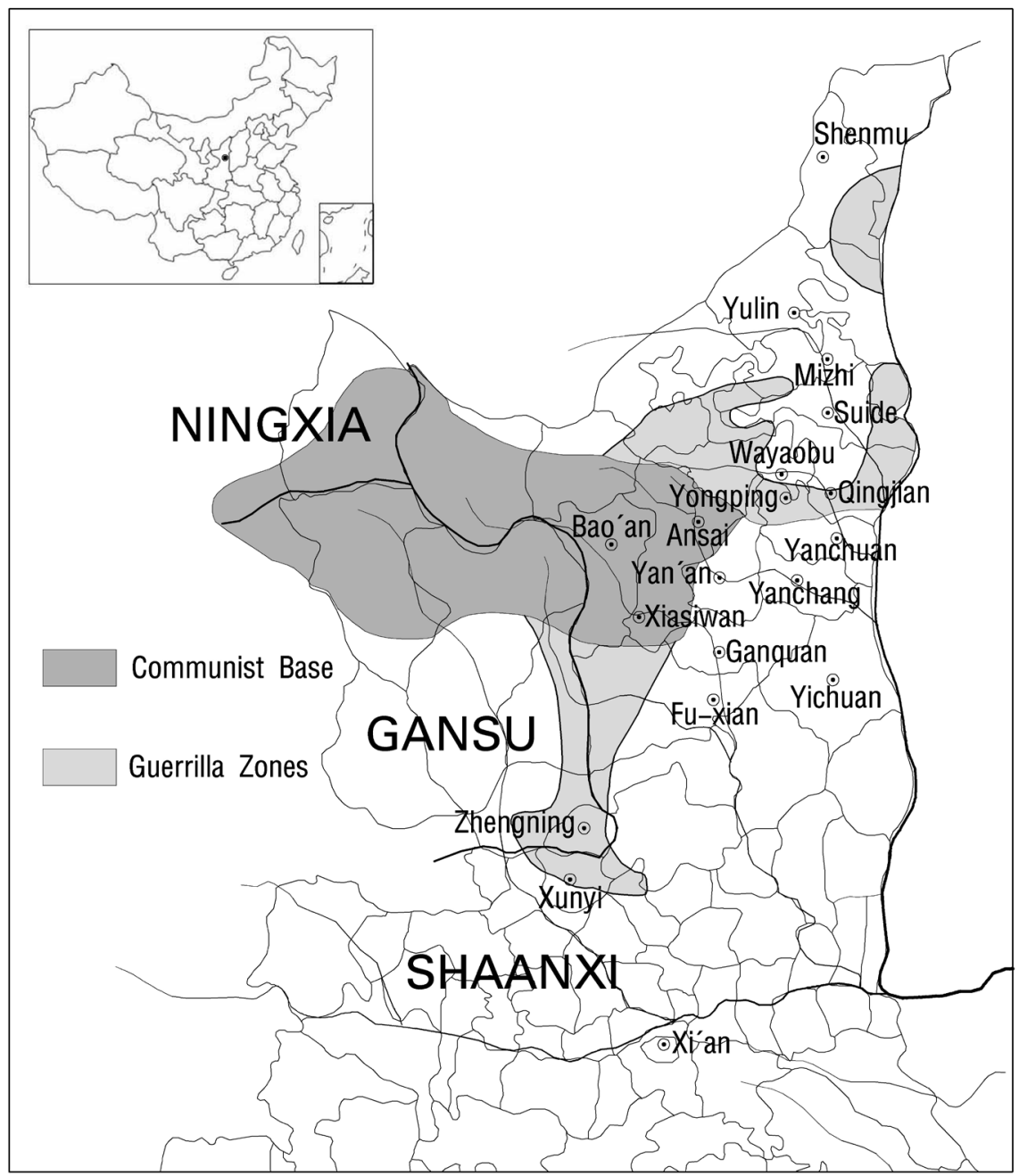

MAP 8. Northern Shaanxi Red bases and guerrilla zones in the fall of 1936, on the eve of the Xian Incident. Compared to map 7, the Communist base had been driven to the poorer west of the region. (Based on military staff to Comintern, August 28, 1936, CZWJ, 1102; and Guomindang BOI report, March 1937, BOI 270/815.)

was barely sustainable."113 Map 8 reconstructs the Communist-controlled areas and guerrilla zones of August 1936.

The Communists claimed a total population under their control of four hundred thousand. Assuming half of these were males, and half of those were able-bodied adults, that gives an adult male population of only one hundred thousand. There were allegedly thirty thousand in the Red Army, though this probably includes 
local guerrillas, a higher rate of participation than in Jiangxi, and certainly unsustainable over the long haul. ${ }^{114}$ Another report said that in the Communists' ShaanGan province, the poorer area along the provincial border, the total population was sixty thousand, with fifteen thousand adult males, of whom five thousand were already engaged in local administration or guerrilla action. The authorities saw little hope for additional army recruitment. ${ }^{115}$ Indeed, the party admitted that the heavy conscription of adult males into the Red Army had weakened the local self-defense forces. ${ }^{116}$ Perhaps the clearest indication of the dire straits of the Shaanbei revolution is a long gap, lasting from August 1936 until the spring of 1937, in the leading documentary collection on the revolution in the Northwest. ${ }^{117}$ It is unlikely that no reports survive from this period; more likely, there was no good news for historians of the revolution to report.

\section{A MULTI-SIDED UNITED FRONT}

As the local situation in Shaanbei became perilous for the CCP, national and global events were moving in directions more favorable to the revolution. Here the new central leadership was critical in rescuing the imperiled Shaanbei base. Mao Zedong had greater strategic vision and much broader contacts than Liu Zhidan, and he proved remarkably adept in adapting to the new situation. His rival Zhang Guotao, after his return in defeat from Gansu, described a telling interaction with Mao:

With a smile on his face, Mao once said to me that he was playing the market, implying that he was doing big business with little capital, namely, the small Red Army. According to his speculations, the Japanese aggressions against Northeast China and North China had upset the balance of power in the Far East and had very much displeased the Soviet Union, the United States, and Great Britain; while at home the anti-Japanese passion had spread deep into the Nationalist armed forces, and therefore it would be very hard for Chiang Kai-shek to persist in his nonresistance policy toward Japan. ${ }^{118}$

Mao was right, but the party's response to these new opportunities was necessarily multifaceted and involved a fair degree of duplicity as he dealt separately with the diverse parties involved. For much of this, he relied on Zhou Enlai, whose capacity for diplomatic sleight of hand was well developed.

Japanese aggression was the paramount threat that eclipsed all else. After occupying Manchuria in 1931, the Japanese army steadily encroached on the neighboring areas of Inner Mongolia and then North China itself. The Nationalist government in Nanjing appealed to the League of Nations and tried every diplomatic means to slow the aggression while Chiang Kai-shek prepared his military for a larger war that even he saw as inevitable. But concessions only led to further Japanese demands, which by 1935 included the "autonomy" of North Chinain essence severing the area around the old capital of Beijing from Nanjing's 
control and installing a puppet government favorable to Japan. When Nanjing again temporized in an agreement signed by the minister of war, withdrawing its forces and prohibiting "anti-Japanese" activities in the Beiping area, students in the former capital led massive demonstrations, which in turn sparked patriotic protests throughout the country. By June 1936, rival militarists in southern China had formed an Anti-Japanese National Salvation Army (Kang-Ri jiuguojun 抗日救国军) and began marching north to challenge Chiang and press for armed resistance to Japan. ${ }^{119}$

Japanese aggression had provided a rationale for the Red Army's Shanxi expedition as a self-proclaimed "Anti-Japanese Vanguard," while the student activism brought the dispatch of Liu Shaoqi to the Beijing-Tianjin area, where he sought to bring the fractious student movement under Communist Party guidance. ${ }^{120}$ Attracting broader support for an anti-Japanese united front necessarily involved moderating the class struggle. Land reform policies had been changed to protect rich peasant rights after the Wayaobu meeting; now there were further orders to guarantee land rights, encourage production, and import plows. Trade was promoted and commercial activities were protected. ${ }^{121}$ By September 1936, while the party insisted on maintaining clear class standards for party membership, it further revised the immediate goals of the revolution to be a democratic republic (minzhu gongheguo). ${ }^{122}$

There were two large government armies in Shaanxi at this time. Yang Hucheng's Northwest Army had dominated the province since 1931, had cooperated with the Communists in the National Revolution of the 1920s, and had several underground Communists in its officer corps. Party cells in the military were independent of the provincial committee, so these key leftist officers survived the repeated arrests of the provincial apparatus. By the fall of 1934, they were able to smuggle guns, ammunition, medicine, electronics, books, and military maps to both the Twenty-Sixth Army and the Fourth Army as it passed through southern Shaanxi. Yang's young, educated wife was apparently a Communist, and in early 1936, party operatives in Beiping sent agents with a powerful radio receiver to work in Yang's army. ${ }^{123}$ By 1936, however, Yang's army was dwarfed in size, influence, and armaments by Zhang Xueliang's NEA from Manchuria. Zhang Xueliang was the most immediate and important target of the Communists' united front policy. The process began in late 1935, directly after the battle at Zhiluozhen. Mao Zedong wrote to the commanding general, berating him for fighting Chinese rather than the enemy occupying his homeland, and promising to avoid hostilities if the NEA ceased further attacks. ${ }^{124}$ Soon it was discovered that an officer captured in an earlier battle was open to persuasion. Peng Dehuai went to talk to him: Gao Fuyuan, a former student of Beiping's Furen University, regiment commander in the NEA and a progressive patriot. Peng found Gao open to united front appeals, and he was returned to his old unit to spread the word of his kindly treatment in captivity. Peng arranged to have the besieged NEA garrison at Ganquan supplied with grain 
in exchange for cash. By January, Gao had conveyed word of the local arrangement to his commander, who in turn passed the news to Zhang Xueliang. ${ }^{125}$

The Communist Party had long engaged in underground work in Nationalist and warlord armies, but the purpose had been to encourage mutinies or defections. Now subversion was explicitly prohibited: "The aim of our work in the Northeast Army first is not to undermine or divide the Northeast Army . . . and second, is not to turn the Northeast Army into a Red Army, supporting the program of the Red Army, but to turn the Northeast Army into an ally of the Red Army, sharing our principles of national salvation and resistance to Japan." ${ }^{126}$ An open letter to NEA officers appealed for united resistance to Japan and the "traitor Chiang Kai-shek." ${ }^{27}$ At the same time, local efforts sought to eliminate conflict with NEA units. Markets were opened, and there was fraternization across enemy lines. Attentive party operatives found that older women were often best at carrying the party's message to young soldiers at the markets. Younger people performed patriotic dramas to promote their anti-Japanese message to NEA soldiers. ${ }^{128}$ At night, local activists near the front line organized young men and women to sing songs and invite the "White" soldiers to join them. ${ }^{129}$ Soldiers in enemy units were encouraged to form Anti-Japanese National Salvation Societies, but it was admitted that such open political activity was difficult, so sympathizers used old-style classmate, sworn brotherhood, secret society or local ties to spread their patriotic message: "Use an old-style exterior with an Anti-Japanese, Dump Chiang content."130 Captives were well treated, beating and cursing was prohibited, and the wounded received medical attention. Captured soldiers were lectured on the party's new patriotic program, invited to witness public celebrations, then released to their old units, where many conveyed positive messages of life in the Communist areas. ${ }^{131}$ Some, like Gao Fuyuan, who was instrumental in starting this process, secretly joined the Communist Party. ${ }^{132}$

All of these efforts were carried out with great care and appropriate secrecy. In early 1936, the Red Army was preparing its campaign into Shanxi, and a truce with the NEA was critical to protect its rear areas and southern flank. On January 20, Zhang Xueliang met with a Communist security agent to arrange a cease-fire in place and a restoration of trade. ${ }^{133}$ The Communists issued strict orders that commerce should be carried out by people in civilian clothes, all agreements were to be oral, and there should be no public announcement of the arrangements. ${ }^{134}$ Sometimes it was necessary to fake battles, with NEA soldiers firing in the air to satisfy or mislead anti-Communist officers or agents of the Nanjing regime. ${ }^{135}$ Still, the early meetings with Zhang Xueliang gave impetus to a complex process of negotiation that would develop in the following months.

Zhang Xueliang was unquestionably the pivotal actor in the convoluted web of conflict and cooperation that bound the actors in Northwest China. His father had begun his career as a bandit and had risen to become the warlord of Northeast China (Manchuria) before the Japanese blew up his train and killed him in 1928. 
Zhang Xueliang succeeded his father as head of the NEA and played a key role in Chiang Kai-shek's effort to bring North China under his control. Zhang was hampered, however, by a playboy reputation and a substantial addiction to opium, and in 1931 many blamed him for the loss of Manchuria to the Japanese. In 1933, cured of his addiction, he traveled to Europe, where he was much impressed by Mussolini's reforms in Italy and returned convinced that only fascism or communism could save China. ${ }^{136}$ Chiang Kai-shek appointed him to lead the Communistsuppression headquarters in Xian, where he quickly found himself torn between loyalty to Chiang and a passionate desire to recover his homeland from Japan. When his army suffered successive defeats at the hands of the Red Army in the fall of 1935, Zhang found himself shunned by Chiang Kai-shek and courted by leftist patriots supporting a united front against Japan. When he received the cease-fire overtures from Shaanbei, he met with the CCP representative, then arranged a secret meeting with Zhou Enlai in a Yan'an church on April 11, $1936 .^{137}$

In his late-night talk with Zhou Enlai, Zhang made clear that he could not oppose Chiang Kai-shek, only urge the Generalissimo to resist Japan. The problem was Chiang's commitment to first eliminating the Communist opposition. Chiang's consistent position was "first internal pacification, then external resistance" (rangwai bixian annei 攘外必先安内). ${ }^{138}$ Zhang Xueliang recognized that the literal meaning of the slogan was "[Before] resisting the external [foe], we must first pacify domestic [enemies].” In his diary, Chiang confirmed this interpretation, complaining that Zhang Xueliang did not realize "there are stages to any enterprise. You must complete one stage before moving on to the next." ${ }^{39}$ Having fought the Red Army in Shaanbei, Zhang was convinced that even if the Communists' main forces were defeated, the guerrilla struggle would continue indefinitely. With full domestic pacification unattainable, resistance to Japan could be postponed forever. ${ }^{140}$ To Zhang, this was unacceptable. On the other hand, he was unwilling to oppose Chiang openly unless the Generalissimo fully acceded to Japan's ambitions. He informed Zhou Enlai that despite his approval of the local cease-fire, if Chiang ordered him to attack the Communists, he would have to comply. ${ }^{141}$ He proposed an alternative to the Communists' "Oppose Japan, dump Chiang" policy, a change that the Communists would soon adopt: "Force Chiang to resist Japan" (bi-Jiang kang-Ri 逼蒋抗日). ${ }^{142}$

As Zhang Xueliang maneuvered between loyalty to Chiang and his patriotic sympathies for the Communist cause, he had several concrete problems to consider. For one thing, at age thirty-six, he was a relatively young commander, and many of his generals were older, more conservative, and more committed to the government's anti-Communist agenda than the officers who had negotiated the cease-fire in Shaanbei. ${ }^{143}$ In addition, when the NEA was forced out of Manchuria, it lost one of the largest arsenals in China and was now entirely dependent on Chiang Kai-shek's Nanjing government for arms and financial support. If Zhang Xueliang was to break with Chiang Kai-shek, he needed an alternative source of 
support, and the only viable provider was the Soviet Union. As perilous as this might seem, Zhang knew that Chiang Kai-shek was himself negotiating with the Russians (as we shall see presently), so he felt emboldened to pursue his own initiative. ${ }^{144}$ After the Yan'an meetings with Zhou Enlai, Zhang agreed to assist in sending a CCP representative to Moscow via Xinjiang, to dispatch his own representative via Europe, and to harbor party agents in his Xi'an headquarters. ${ }^{145}$ By June, cooperation between Zhang and the Communists was so close that he requested to join the Communist Party. This request was referred to Moscow, which was appalled at the idea of admitting a warlord with a questionable background into the vanguard of the proletariat and rejected it outright. ${ }^{146}$ As remarkable as it may seem for a warlord to join the Communist Party, these were extraordinary times. The Russian archives include a rambling letter from the Xinjiang warlord Sheng Shicai, received in mid-March, which chastised Chiang Kai-shek for his weak resistance to Japan; boasted of reading Marx, Lenin, and Stalin; requested introduction to the party; and promised, if Stalin agreed, to facilitate the secret transport of military assistance to the Red Army in Gansu. ${ }^{147}$ Zhang Xueliang was not the only warlord anxious to join the socialist camp.

The vehicle for the proposed Communist alliance with the NEA was a secret plan for a Northwest National Defense Government. This new Northwest government would "open a link to the Soviet Union and sign mutual assistance treaties with the Soviet Union and Mongolia." ${ }^{48}$ The aim was "to establish a great revolutionary base in China's Northwest, linked together as one [dacheng yipian 打成一片] with the Soviet Union and Outer Mongolia." ${ }^{149}$ In June 1936, radio contact with Moscow was restored, and the party Center was able to transmit its plans to the Communist International. In a long radiogram of June 26, the CCP Center reviewed the past differences with Zhang Guotao and presented the Northwest National Defense Government as a means to reunify the party as Zhang Guotao, allegedly at Zhu De's urging, resumed his march north toward Shaanbei. Lanzhou, capital of Gansu, was designated the seat of this new government, to be headed by Zhang Xueliang. After a summary of the united front negotiations with Zhang's NEA and the Northwest Army of Yang Hucheng, the letter noted that "the monthly payroll to the soldiers of the NEA, which amounts to $\$ 2,000,000$, completely depends on receipts from Nanjing and would completely cease if the army moved." For these soldiers, those of Yang Hucheng, and the Red Army, the party requested monthly Soviet aid in the amount of \$3 million. The letter then continued, "In addition to the financial question, there is a very important military question. We hope to get planes, heavy artillery, shells, infantry rifles, antiaircraft machine guns, pontoons . . . , etc. Please inquire whether the political situation makes it possible to give assistance, and to what extent."150 Such an enormous request for assistance naturally required approval at the highest levels, and the head of the Comintern, Georgi Dimitrov, forwarded the letter to Stalin in early July. 
Dimitrov was a Bulgarian who had headed the West European bureau of the Comintern from 1929. Arrested in Berlin, he was released from jail after a dramatic trial and returned to Moscow to assume leadership of the Comintern. Hitler's rise had convinced him that the party's leftist policies targeting social democrats as much as Nazis were an error, and under Dimitrov's leadership the Comintern began a fundamental revision of the international line. Its Seventh Congress, in July 1935, recognized that Hitler's Germany and Japanese militarism posed an existential threat to the socialist motherland and accepted the need for all Communists to enter united or popular front alliances with bourgeois parties to combat the global fascist menace. Wang Ming, the CCP representative to the Comintern, drafted an "August 1 Declaration" in the name of Mao and Zhu De, which was published in France in October. This was the first CCP call for a united front, whose message was communicated to the CCP leadership when Lin Yuying arrived in late $1935 .^{151}$

The "August 1 Declaration" has long been recognized as a critical moment in the CCP's shift to a united front policy, though Wang Ming's authorship and Mao's ignorance of the declaration in his name have only recently been established. ${ }^{152}$ The limits of the envisioned united front should be noted. The declaration still condemned the "step-by-step surrender of the sellout Nanjing government" and urged opposition to "Japanese brigands and the bandit Chiang."153 Though the Chinese united front has often been compared to the Popular Front uniting French progressives against Hitler, Wang Ming was thinking more of Germany and the need to unite all forces against Chiang Kai-shek just as progressive Germans should unite against Hitler. ${ }^{154}$ It is not surprising, therefore, that when the party Center received Lin Yuying's report at the Wayaobu Politburo meeting, it enlarged the united front to include, as we have seen, "all classes, all political factions, all social organizations, and all armed forces" but still directed the front against both Chiang Kai-shek and Japan. The Soviet Union was explicitly identified as “the strongest accomplice [bangshou 帮手] of the Chinese Revolution." 155

The Communist leadership was not alone in noting the 1935 shift in Comintern policy. With Hitler's rise imperiling German support for Nanjing's armies, Chiang Kai-shek also looked to the Soviet Union as a possible ally against Japan. Despite years of warfare against the Communists, there was an important precedent for Soviet support of the Chinese Revolution. The Russians had provided critical aid to the Nationalist Party in the 1920s, including arming Chiang's military. Chiang had visited Russia to learn about the Red Army, and his son had gone to study there and was still in the Soviet Union with a Russian wife. In 1932, the Chinese government restored diplomatic relations with the Soviet Union, and the Russian ambassador in Nanjing actively encouraged anti-Japanese sentiment. ${ }^{156}$ Following the Comintern's Seventh Congress, Chiang began exploring a restoration of the Soviet alliance. There were conversations with the Soviet ambassador in the fall of 1935; then in January of the new year the military attaché in Moscow held two 
long conversations with Wang Ming, the CCP representative to the Comintern, to discuss ways to resolve the civil war. According to Wang Ming's detailed transcript of the first exchange, the attaché was remarkably frank in discussing Nanjing's motives for the demarche. War with Japan was expected in September, but "Chiang Kai-shek said we have few bullets and artillery shells; our entire supplies are only sufficient for three months of warfare. We need to find a source for military supplies." The United States and Britain were willing to help, but they were far away. "If war breaks out, will the Soviet Union be willing to help?"157 When the second conversation got around to the terms of a potential united front, the exchange became more acrimonious. Wang Ming saw Chiang insisting on an end to the soviets and dispatch of the weak Red Army to the most perilous fighting fronts against Japan. When the talks adjourned so the attaché could consult with his superiors, Wang Ming concluded that the meetings were designed to gain information about the Red Army and that Chiang Kai-shek was acting in bad faith. ${ }^{158}$

In fact, the talks continued at an even higher level. Now, however, divisions within the Nationalist Party were evident for all to see-providing opportunities for Mao and the CCP to exploit, but also challenges in determining who could make a decision that would hold. Sun Yat-sen's widow, Song Qingling, had long been sympathetic to the Communists and represented a lonely left wing of the Guomindang, protected by her late husband's status and the fact that she was the sister of Mme. Chiang, Song Meiling. In January 1936, Song Qingling sent a message to the Communists in Shaanbei, in apparent coordination with her brother, T. V. Soong (Song Ziwen), the former finance minister. At the same time, Chiang Kai-shek asked Chen Lifu, leader of the powerful conservative CC Clique and the Investigation Bureau, to negotiate with the Soviets, first on an aborted mission to Moscow, then directly with the Soviet ambassador in Nanjing. In addition, Chen contacted the underground CCP to reach the Communists in the north. Representatives of these groups reached Wayaobu in February 1936, after which Mao and the CCP Center authorized negotiations in Shanghai between Chen Lifu and Pan Hannian, who had recently returned from Moscow. ${ }^{159}$

Mao recognized that such leftists as Song Qingling were powerless within the Nationalist Party. On the other hand, he knew that many patriotic Nationalists favored allying with the Soviet Union to combat Japan, and public opinion was growing to end the civil war and concentrate on resisting Japan. The sticking point was always the position of Chiang Kai-shek. The Communists had long treated Chiang as a "traitor" selling out the country to Japan. In his conversation with Zhou Enlai in Yan'an, Zhang Xueliang had indicated that he was unwilling to abandon Chiang and had urged the Communists to moderate their opposition to the Generalissimo. By April, Mao and the party leadership acknowledged that continued opposition to Chiang was inconsistent with their call to end the civil war. ${ }^{160}$ After radio contact with Moscow was resumed in June, the Comintern added its authority to this position: opposition to Chiang Kai-shek was an incorrect 
understanding of the Comintern's Seventh Congress intent. ${ }^{161}$ By August, Mao would write to Pan Hannian, his negotiator in Nanjing, to state explicitly that "the core of our policy is to unite with Chiang to resist Japan." ${ }^{162}$ A flurry of letters went to Guomindang politicians, progressive intellectuals, and regional militarists to promote the party's new united front policies and call for an end to civil war so the nation could prepare for the coming war against Japan. These communications were certainly facilitated by the dispatch of key Communist leaders to Zhang Xueliang's headquarters in Xi'an, with its ready access to national telegraph networks. ${ }^{163}$ Across China, left-leaning Guomindang members, disaffected local militarists, and progressive opinion leaders began reaching out to Communist operatives, making contact with the Red Army in Shaanbei and the International in Moscow. ${ }^{164}$

By October, Mao had drafted the Communist proposal for a united front with the Nationalist Party in terms that Zhou Enlai was to present in Nanjing. The purpose was "an anti-Japanese national salvation united front of all parties, all factions, all circles, and all armies of the whole country." To this end, the Nanjing government should cease attacks on the Communists and "demarcate the necessary and appropriate Red Army bases, provide the necessary military equipment, military uniforms, military expenses, food supplies, and all other military supplies" for the army to fight Japan. On the condition that Red Army leadership not be changed, the Communists promised to accept a specified field of battle under a unified military command. Politically, the Nanjing government should permit freedom of speech, press, and assembly, release political prisoners, and promise not to destroy the Communist organization in the future. For its part, the Communists promised that "the Soviet areas will carry out a democratic system identical to all of China." ${ }^{65}$ Nanjing seemed willing to agree to these general principles, though the negotiations that followed were marked by sharp debate on the size of the Red Army and the Soviet bases, the degree of national government support, and the designated field of battle. ${ }^{166}$ Chiang Kai-shek also continued his vigorous military campaign against the Communists to improve his bargaining position or even eliminate his rivals. Nonetheless, for two parties still fighting a decade-long civil war, this proposal reflected the new context created by Japanese aggression and foreshadowed of the terms of the united front to come.

\section{A WINDOW TO THE WORLD}

While all of these crisscrossing negotiations were going on, a new actor suddenly appeared on the scene: a young American journalist looking for a scoop from Red China. Edgar Snow was a thirty-one-year-old newsman with eight years of experience in China. He had long been part of an international group of left-leaning journalists and activists alarmed by the rise of Japanese militarism and the worldwide threat of fascism. In 1935, he and his wife were living in Beiping, where Ed 
taught journalism at Yenching University. Many of Snow's students were active in the anti-Japanese movement, and his home was a gathering place for young people who would organize the December 9 demonstrations for national unity in resistance to Japan. Snow was intimately familiar with the popularity of Marxist thought among the young, declaring with real evidence but characteristic exaggeration that among educated youth, "Lenin is almost worshipped, Stalin is by far the most popular foreign leader, Socialism is taken for granted as the future form of Chinese society." ${ }^{167}$ Snow had long wished to visit the Communist bases and write a book about the movement. In 1936, contacts in Beijing and a visit to Mme. Sun Yat-sen finally produced the proper introductions. He traveled to Xi'an, where he met his intermediaries in Zhang Xueliang's headquarters, traveled in an NEA truck to Yan'an, then walked to Ansai, where he met Zhou Enlai in July. Several days travel on foot and a broken-down horse brought him to Bao'an, where he would remain until October, with an extensive side trip to Peng Dehuai's headquarters in the nearby Sino-Muslim (Hui) areas of Ningxia. ${ }^{168}$

Snow's Red Star Over China is most remembered for the long interviews with Mao Zedong, which still provide the indispensable sources, cited in every biography, for Mao's early years. Snow's visit provided Mao his "first chance to speak to the world," and this young Missouri journalist would be his amanuensis. ${ }^{169}$ Mao was not only speaking to the world through Snow-he was also speaking to China. On Snow's return, several of the interviews were published in the China Weekly Review, then translated in the Chinese press. The impact was substantial, as was the influence of Red Star when it was first translated and published in 1937, just before full-scale war with Japan broke out, and then in a fuller version in $1938 .{ }^{170}$ When students flocked to Yan'an during the war, much of what they knew about Mao and Chinese communism came from reading Snow's work.

Placed in its proper historical context, Snow's account is nothing short of stunning. In 1936, Mao's Red Army was trapped in the desolate northwest corner of one of China's poorest provinces. Bao'an was a "ruin," the "dusty, poorly provisioned lair" of the Communists' "tiny state." 171 Yet in this context, Snow found in Mao - "this peasant-born intellectual turned revolutionary" - "a certain force of destiny." Impressed by Mao's "native shrewdness," Snow discovered in the caves of Bao'an "an accomplished scholar of Classical Chinese, an omnivorous reader, a deep student of philosophy and history, a good speaker, a man with an unusual memory and extraordinary powers of concentration, an able writer, careless in his personal habits and appearance but astonishingly meticulous about details of duty, a man of tireless energy, and a military and political strategist of considerable genius." In Mao, Snow also discerned “a power of ruthless decision" and a capacity for the "dialectics of 'the long view." 172

It is important to recognize that at this time Mao was not officially the highest-ranking member of the party. That position was held by the secretary-general Zhang Wentian, and Zhang was usually the first signatory of party decisions in 
this period. But there was no doubt in Snow's mind or anyone else's that Mao was already the preeminent authority in the party. At this time, Snow detected no "ritual of hero-worship," and that would come only later. There were still intense debates among the party leadership, and as Snow had heard but not witnessed, Mao was capable of considerable fury. Debates certainly did happen, but when they were over, this embattled rump of a party would come together again until the next struggle. ${ }^{173}$

Snow was certainly a sympathetic witness of the Chinese Revolution, and his later rosy accounts of life in the PRC have left him vulnerable to widespread criticism. One influential critic has dismissed Red Star as a "conscious propaganda piece," 174 another as a "monumental work of literary imagination." ${ }^{175}$ Nonetheless, for all his political biases, Snow was also an accomplished reporter with years of experience in China. His is the only foreign journalist's account that predates the Xian Incident and the move of the Communist capital to Yan'an. Red Star is, therefore, a unique window on the brief but important Bao'an era of the revolution in Shaanbei. Read carefully in the context of other sources, Snow's book provides useful insights into this particular moment in history and is most valuable when it records what Snow personally observed.

Snow had traveled all over China, but he still found Shaanbei "one of the poorest parts of China I had seen." The only road fit for wheeled traffic ended at Yan'an; from there he traveled along narrow trails. The first town he reached was Ansai, one of the few county seats controlled by the Communists. It was "completely deserted . . . crumbling ruins," the result of a flood a decade earlier. This poor county north of Yan'an was also the headquarters of the eastern front, an indication of losses in the northeast and the limits of the reduced soviet base. Even here, Snow had to move on quickly to Bao'an, as local militia had followed him from the south. There was no machine industry, no electricity anywhere in the soviet area; lighting came from rapeseed oil lamps. In the "industrial" center in Wuqi, the machines were lathes, stampers, and sewing machines brought along the Long March or captured in Shanxi; and the arsenal was capable of producing only mines and hand grenades or repairing old weapons. The machinists all came from elsewhere, mostly the Yangzi valley. Educators described Shaanbei as "very backward" compared to the Jiangxi soviet, where the cultural level was higher with a population only 10 percent literate. ${ }^{176}$

Although Snow reports that the majority of the small band that escorted him was from Shaanbei, it is striking that almost all of his interlocutors were outsiders. When he recounts a personal story, it typically begins with his informant's youth in Hunan, Fujian, Jiangxi, or occasionally Sichuan. Of the thirty-one interviews later published in his Random Notes on Red China, only one is with a local cadre. ${ }^{177}$ Those with the confidence and authority to speak to a foreigner were the Long March veterans now running the show. Though voiceless on their own lives, the locals were not absent. We see, for example, the "child sentinels" who inspected 
road passes. The local defense forces, armed with "spears, pikes and a few rifles," practiced earsplitting war cries that were allegedly effective in night attacks on local militia. Everywhere there was propaganda: chalked slogans on village walls condemning landlords, militia, and traitors; and simple dramas that Snow found "wholly unsophisticated" but nonetheless effective. Two groups in particular responded to the Communist message, youth and women. When Snow writes, "As I penetrated deeper into the Soviet districts I was to discover in these red-cheeked 'little Red devils'-cheerful, gay, energetic and loyal-the living spirit of an astonishing crusade of youth," it is plausible to assume that these young people had been prepped to appear lively and happy in the presence of a foreign visitor. But it would be wrong to ignore a wealth of evidence that young people did indeed respond to the Communist message. Women, too, in part because so many men were in the army, were finding more opportunities to work and to participate in public life. ${ }^{178}$

Snow's account is also useful in confirming important aspects of the new soviet's appeal that are not entirely consistent with the picture of a new democratic regime. This was, after all, a revolutionary movement, and it was based on revolutionary power. Taxes were largely eliminated, which was certainly popular, but was possible because the regime relied mainly on confiscations from the rich. ${ }^{179}$ When Snow traveled to the newly "liberated" Muslim areas of Ningxia, he heard more complaints. The people suffered under the seesaw battles that brought conflicting demands from the competing armies, and even without taxes, feeding the Communists' horses consumed precious fodder. Locals also resented the new prohibitions on opium and found the soviet currency worthless in the marketplace. Snow was appropriately skeptical that the Muslims believed the Communist promises of ethnic self-determination; and Peng Dehuai was frank in admitting that unless and until the local militia was neutralized, it was impossible to mobilize the population. While he was clearly uncomfortable with the process, Snow did not shrink from reporting the execution of a Guomindang tax collector after a mass trial during his Ningxia sojourn. ${ }^{180}$

When Snow goes beyond what he saw and reports stories that he has heard, he is more vulnerable to Communist exaggeration. He reports, for example, that Liu Zhidan controlled eleven Shaanbei counties in 1932 and twenty-two in 1935, which is demonstrably false. ${ }^{181} \mathrm{He}$ is overly credulous toward Communist claims of the size of their armies and the area they controlled. The Shaan-Gan-Ning soviet was certainly not the largest ever; the Red Army did not have twenty thousand men when Mao arrived; at most there were eight thousand, and certainly fifteen thousand recruits were not gained in the Shanxi campaign. Nor, to be sure, would the Red Army have ninety thousand men when the Fourth and Second Front Armies arrived. ${ }^{182}$ Snow was surely naive in seeing the people of Shaanbei as the "freest and happiest" in China, ${ }^{183}$ but his account is remarkable evidence that even after the losses of the Long March and the undeniable defeat in Shanxi, Mao and the Communist leadership maintained a striking optimism in the tiny impoverished 
soviet that they still controlled. That revolutionary optimism is reflected in secret internal party documents as much as in Mao's lengthy interviews with Snow.

These interviews and Snow's book served a number of different purposes. They unquestionably enhanced Mao's reputation in China and the world, and Mao's account of his early life provided a human element missing in most biographies of Communist leaders. ${ }^{184}$ The dramatic account of the Long March fit a narrative that Mao was anxious to establish. We have seen the elite status Mao sought for Long March survivors, and as he told the story to Snow, he began promoting the idea of a book on the subject. ${ }^{185}$ Most importantly, Snow provided a vehicle for Mao to reach both a domestic and an international audience with his new message of a broad united front for patriotic resistance to Japan. In a series of five interviews, Mao answered a wide range of questions about the purposes, terms, and reasons for the new united front policy. Most of his answers were directed at a domestic audience and related to the terms for an accommodation with the Nationalist Party, but to Snow he also stressed Japan's threat to other Pacific powers, and the hope that "farsighted" Americans would eventually join the struggle against Japanese fascism. ${ }^{186}$ Mao clearly recognized the utility of a wider international audience.

\section{A LAST GRASP FOR SOVIET AID}

While Snow was assembling data for his bullish report on the revolutionary movement in Shaanbei, a very different report was dispatched to the Comintern. As Mao had frankly acknowledged on the Long March, the CCP was a branch of the Communist International; and Communists did not dissemble to the Comintern. As in any large and diverse organization, lower reporting levels might arrange facts to suit their purposes. Nonetheless, the considerable faith in the leading role and invaluable experience of the Soviet Union and in Stalin's wisdom led Communist leaders to stick close to the facts in their reports to Moscow. Furthermore, although Otto Braun, the Comintern's military representative, had been pretty much sidelined by this time, he was still in Bao'an-sometimes even playing tennis with Snow. ${ }^{187}$ The long message to the Comintern was a request for substantial military assistance, and in that context the CCP dared not report anything that Braun could readily contradict.

The August 28 report began with a stark admission of the dire military situation. The eastern part of Shaanbei had been occupied by Tang Enbo, who controlled the fords to Shanxi and all the major towns, including the Communists' former headquarters in Wayaobu. Tang led seven divisions and one brigade and was busy opening motor roads and constructing blockhouses. To the west and northwest, the Muslim warlord Ma Hongkui with his strong cavalry occupied the prosperous areas of Ningxia along the northern bend of the Yellow River, while conservative elements of the NEA cooperated on his southern flank. To the 
southwest, one of Chiang Kai-shek's loyal generals, Hu Zongnan, had long been constructing a blockade line in southern Gansu to impede the Red Army's northern progress. In the spring of 1936, he had been dispatched to Hunan to confront the patriotic actions of the Southwest rebellion, but now he was rushing back to block He Long's Second and Zhang Guotao's Fourth Army's progress through Gansu. On the southern front, Zhang Xueliang's NEA maintained a tenuous ceasefire, but in all, 150 regiments with 150,000 men surrounded the Communist base. ${ }^{188}$

The secure Communist base was now reduced to a few counties on the Shaanxi-Gansu-Ningxia border. Contemporary reports list different places in this small and shrinking base, but it basically included Bao'an, Jingbian, and Dingbian Counties in the northwest corner of Shaanxi, plus Yanchi in neighboring Ningxia, and Huan-xian in Gansu. ${ }^{189}$ To the Comintern, the party reported 400,0oo people in their base, which certainly included guerrilla zones further east, but 30,000 were already in the Red Army, a higher ratio than in the former Jiangxi soviet. ${ }^{190}$ Local forces were retreating before the NEA and local militia in the south; military setbacks led to defeatist rumors that the Red Army was finished; and rural cadres were criticized for fleeing before the enemy. ${ }^{191}$ Military defeats affected morale, and some soldiers and party cadres were "wavering," their unflinching resolve tested as the noose tightened around their small base. ${ }^{192}$ Two-thirds of the grain collected from local strongmen was devoted to feed the central state and army, leaving little for the local apparatus or any developmental efforts. ${ }^{193}$

The report to the Comintern contained a detailed accounting of the Red Army's current strength. There were 8,00o soldiers in Mao's First Army and 6,00o in Xu Haidong's Fifteenth. The new locally recruited armies were the Twenty-Eighth with 1,400 men, the Twenty-Ninth with 1,200, and the Thirtieth with 1,300. Additional infantry, cavalry, artillery, security, and courier units totaled 3,350 men. The reported total of regular army troops was 21,00o. This was slightly less than the 25,000 that the party had reported when radio contact with Moscow was restored in June, reflecting losses and defections during the summer. ${ }^{194}$ In addition, there were 6,00o local defense forces and guerrillas. However, not all of these men were armed. The entire Red Army had something over 10,000 rifles, roughly one for every two soldiers in the regular army, and two for every five in the local forces. Beyond these basic infantry weapons, there was little: 100 heavy machine guns, 250 light machine guns with another 200 in storage (perhaps for lack of ammunition), sixteen mortars, and two mountain guns. If firearms were lacking, ammunition was a greater problem for any extended combat operation. In the regular army, each rifle had roughly forty bullets; local forces had about ten. The Red Army was heavily dependent on weapons captured from the enemy-which was one reason that Mao stressed battles of annihilation, in which entire enemy units would be captured or destroyed and their weapons and ammunition seized. ${ }^{195}$

The report to the Comintern included figures on recruitment, but these are particularly problematic, for they indicate massive recruitment despite relatively 
constant Red Army strength. The party reported 10,000 recruits from Shaanbei, 8,000 from Shanxi, and another 1,000 in the west-presumably Gansu and Ningxia. ${ }^{196}$ This represents 19,000 new recruits out of a total Red Army strength of 21,00o. It seems clear that the reported strength of the Red Army is the more credible figure. If 19,000 were indeed recruited, it is likely that many were quickly rejected as too old, weak, sick, or otherwise unsuited for combat. Families, after all, were reluctant to offer strong young men to the army. It is also likely that recruits who were not quickly dismissed often found ways to escape and return to their homes. ${ }^{197}$ Finally, a significant number presumably perished in combat or from exhaustion and disease, as is common in any army. Whatever the cause, it is obvious that the large recruitment numbers did not indicate a general eagerness to join the revolution or result in any large increase in the size and strength of the Red Army.

The report to the Comintern was prepared in connection with an urgent request for financial and military assistance. As we have seen, for at least a year Mao had hoped to draw close to the Soviet border to enhance the technical and military capabilities of his army. In the spring, with the Red Army trapped in Shaanbei, morale was suffering. Mao responded to this crisis of confidence by arguing, with characteristic dialectics, that the party needed to believe in itself but, at the same time, that it was incorrect to reject help from one's friends. ${ }^{198}$ In April, just as the Shanxi operation was stalling, he sought direct communication with the Soviet military to determine "whether or not they can provide rifles, ammunition, light and heavy machine guns, anti-aircraft guns, artillery, modern pontoon bridges, and radios." 199 The reference to river-crossing pontoons indicates that Mao was now considering the western route to the Soviet border, across the Yellow River as it made its great northern loop around Shaanxi. From crossing points in Gansu, the Red Army could either continue west along the Gansu corridor to Xinjiang or turn north to Dingyuanying in Ningxia, where they hoped to receive Soviet aid. The Ningxia route had been traveled by Feng Yuxiang and Deng Xiaoping on their return from the Soviet Union in 1927. Concrete planning began as soon as the Center was forced out of Wayaobu to its new base in Baoan.

The western routes posed significant logistical and military challenges. Both itineraries involved long treks across arid deserts and open grasslands, and the few towns and cities along the route were well fortified. Even after the better-equipped First Army arrived, Communists in Shaanbei found it difficult to take walled towns. When the Red Army moved to Shaanxi's far northwest in June, they needed to take the border towns of Anbian and Dingbian. For this, explosives were needed to breach the walls, and Mao determined that these would have to come from "outside"-presumably from Zhang Xueliang's NEA. ${ }^{200}$ Anbian and Dingbian, however, were tiny towns compared to those that would have to be passed on the road to the Mongolian border. The western route was predicated on a collaboration with the NEA and the plan we have seen for a Northwest National Defense 
Government. When this was presented to Moscow, however, the response was not encouraging.

The initial proposal was presented in June. A more detailed plan accompanied the long report of the military committee in August. The CCP now added airplanes and heavy artillery to its request, to attack the towns and forts along the route. ${ }^{201}$ Of course, these military plans came at the same time that both the CCP and Moscow were pursuing separate but coordinated united front policies. Moscow had rejected the plan for a Northwest regional government, as it conflicted with its preference for a broad national defense government, preferably including Chiang Kai-shek. The Comintern also rejected admitting militarists like Zhang Xueliang into the party, though it encouraged the party to continue working with him. ${ }^{202}$ Though Moscow strongly supported the efforts to form a united front with Chiang Kai-shek, it realized that as long as Chiang pursued the military elimination of the Communists, Moscow had to continue supporting the Red Army. The Comintern response to the request for military assistance did not come until September. Airplanes and heavy artillery were not included, and an approach through Xinjiang was rejected. However, if the Red Army could fight through Ningxia to Dingyuanying, the Soviets would provide fifteen to twenty thousand rifles, eighteen mortars, and appropriate ammunition. ${ }^{203}$ Though the response was far from what they had hoped, the CCP leaders were not in a position to bargain.

The party immediately set to making plans for the Ningxia campaign. Now, however, the Center had to address the issue of Mao's rival, Zhang Guotao, whose Fourth Army would be a significant addition to the Red Army. When Mao and Zhang Guotao had split in the summer of 1935, Mao moved north and Zhang moved south into western Sichuan. By the end of the year, Zhang realized his mistake, and, together with Mao's ally Zhu De, he again began moving north, joined by He Long's Second Front Army. The Comintern representative now in Baoan, Lin Yuying, sent repeated telegrams assuring Zhang that Stalin and the Comintern had approved an approach to the Soviet Union. Zhang Guotao, however, was skeptical of the Ningxia plan. He had always preferred approaching the Soviet Union by moving west to Xinjiang. For justification, he was now able to cite Lin Yuying's May radiogram that "the International hopes that the Red Army will approach Outer Mongolia and Xinjiang." 204 Mao briefly considered allowing the Fourth Army to move west while his First Army fought alone in Ningxia, but his commanders apparently persuaded him that neither army could accomplish its mission alone. ${ }^{205}$ The two armies would have to work together, with a plan to attack Ningxia in the winter, crossing the Yellow River after it had frozen.

Chiang Kai-shek, like the Chinese Communists and Moscow, was pursuing a policy of fighting and negotiating at the same time. Since late 1935 his agents had been reaching out to the Communists, and by September 1936, they invited Zhou Enlai to Hong Kong or Guangzhou for direct negotiations. In October the Communists proposed that Zhou and Chiang Kai-shek meet during the latter's 
coming visit to Xi'an. ${ }^{206}$ At the same time, both sides were pursuing aggressive military campaigns to improve their negotiating position. In the spring of 1936, the Southwest challenge to Nanjing's conciliatory policies toward Japan had caused a redeployment of Hu Zongnan's army, which had garrisoned southern Gansu to block the rest of the Red Army from moving north. When the southwestern rebellion fizzled out in the summer, Mao urged the Second and Fourth Armies to move quickly, to join the First Army for the Ningxia campaign before Hu Zongnan returned to Gansu. Mao was so anxious for a successful reunion that he ordered clean uniforms for his troops to properly greet the new arrivals. ${ }^{207}$ However, the completion of the railway to Xian at the end of 1934 allowed Chiang to transfer his armies with unprecedented speed. By mid-September, Hu Zongnan's army was back in Xi'an and preparing to move west along the Xi'an-Lanzhou highway. ${ }^{208}$

Mao urgently radioed Zhang Guotao and Zhu De that Ningxia was the key; the Center had requested aid from the Soviets, including airplanes and artillery, and the reply had promised aid once they reached Ningxia. Mao did not mention that Moscow's reply had omitted the planes and big guns. ${ }^{209}$ Zhang was not convinced. Three days later he announced that one part of his army would stay in southern Gansu to block Hu Zongnan, while the main force would cross the Yellow River and fight across the Gansu corridor to Xinjiang. In October, 25,000 troops of the Fourth Army crossed the Yellow River and headed west across the arid land. It was a fatal mistake. In the months ahead, exposed in the open field, with little food or water, this West Route Army was decimated by Muslim cavalry from Qinghai. Their commanders abandoned the field and sneaked back to Yan'an. When a few hundred stragglers reached Xinjiang in May 1937, Molotov denied entry to the Soviet Union. In the end, 407 survivors were admitted for military training in Russia. In all, some 20,000 men, half of the entire Red Army, were lost in this western campaign. ${ }^{210}$

For a brief period in the late fall of 1936, Mao tried to salvage the Ningxia campaign. The population of Ningxia was largely Muslim, and it was ruled by the implacably hostile Muslim warlord Ma Hongkui. Since the summer, the Communists had attempted to appeal to this population with promises of Hui and Mongol self-determination based on Soviet nationalities policy. ${ }^{211}$ There was also a substantial Society of Brothers population along this border region, and Liu Zhidan's early revolutionary movement had been able to use his own membership and connections in the Brotherhood. Now the party Center renewed efforts to court the Brotherhood and use it to infiltrate Ma Hongkui's army. ${ }^{212}$ There is no evidence that either of these policies was effective, and despite Mao's praise for the "courageous sacrifices" of his troops, Peng Dehuai was unable to break through Ma Hongkui's defenses. ${ }^{213}$ Soon he was forced to move key units south to assist the surviving units of the Second and Fourth Armies as they fought through to the north. Hu Zongnan, however, was able to seize the Yellow River ford and cut off the Fourth Army units in Gansu, then send his own units ahead to occupy 
Dingyuanying. ${ }^{214}$ The final straw came when the Soviet Union decided that a Japanese advance in Inner Mongolia and reports of Japanese spies in Dingyuanying made it too risky to send aid by that route. By November, the Ningxia plan was abandoned, and Mao was forced to settle for Moscow's offer of \$500,00o in financial assistance, with the first installment of \$150,000 sent through Song Qingling and reaching Bao'an in December. ${ }^{215}$

Even with the addition of the Second and Fourth Armies, Chiang Kai-shek now had a much-reduced Red Army trapped in the desolate northwest corner of Shaanbei. The total Red Army was less than 40,00o soldiers, many without weapons. The Long March survivors from the Second and Fourth Armies included many elderly and wounded soldiers and cadres and some children. In the Fourth Army alone, Mao reported 640 of these. ${ }^{216}$ Meanwhile, Shaanxi's Wei River heartland was experiencing unprecedented progress. By 1931 a motor road from Xian to Shaanxi's eastern border and the extension of the railroad from Henan reduced the trip to Beiping to as little as seventy-six hours. ${ }^{217}$ Gone were the days when a "backward" Shaanxi was farther from the former capital than London. By 1935, the railroad had reached Xi'an, allowing Chiang Kai-shek's troops to rapidly redeploy from the south. With the railway and trucks on the new roads, commercial development proceeded apace. Aided by new irrigation projects and spurred by commercial opportunity, cotton became a major crop in the Wei River valley, sold to the textile factories on the coast, while grain imports entered from the North China plain. Running water, electricity, new hotels, and paved roads modernized the face of Xi'an, and the first factories were established. Xi'an and the Guanzhong plain were quickly developing toward their wartime role as the economic center of the Northwest. ${ }^{218}$

With Guanzhong growing rapidly and the Red Army weakened in the north, Chiang Kai-shek's bargaining position stiffened. Chen Lifu insisted that the Red Army be limited to 3,00o soldiers and that its officers be removed and, as was common for Guomindang members under discipline, forced to go abroad. ${ }^{219}$ Through much of 1936, growing anti-Japanese sentiment had strengthened the Communist hand and left Chiang on the defensive. Now the tide had turned. Hu Zongnan was ordered to press the attack to finish off the Communists. Confident that at last victory was in sight, he advanced quickly across the desolate hills of eastern Gansu, where the villages were empty and the water in the streams too salty to drink. His parched and famished troops fell into a Communist trap, ambushed by Peng Dehuai with heavy losses. Hu's army fell back to regroup, and though the Red Army suffered substantial casualties as well, for the moment at least, Mao's revolution had survived. 220

\section{SAVED BY XI'AN}

From Zhang Xueliang's appointment to head the anti-Communist campaign in the Northwest, his fate and that of the Communist revolution were inextricably 
entwined. Mao's first battles in Shaanbei were fought against Zhang's armies. Northeast Army captives from those battles played a critical role in negotiating the first cease-fire. Zhang's neutrality was essential for the Red Army's expedition into Shanxi, and the subsequent negotiations between the two armies led to the plan for the Northwest National Defense Government and the Ningxia campaign. The extent of Zhang Xueliang's collaboration with the Communists is remarkable for a general who had always been loyal to Chiang Kai-shek and the Nationalist Party. The documentary record for that partnership is nonetheless incontrovertible, and Yang Kuisong, the preeminent historian of this era, is persuasive that Communist Party historians have gone out of their way to conceal this record to protect Zhang Xueliang's reputation while he spent his life under Guomindang house arrest in Taiwan. ${ }^{221}$

Zhang's collaboration with the Communists becomes more understandable when we recognize that he was hardly alone in responding to the Communists' united front appeals. Southern militarists, Guomindang operatives, and even Chiang Kai-shek's sister- and brother-in-law also sent representatives to Moscow or Bao'an. Especially as the split between pro- and anti-Japanese factions of the Nanjing government intensified in 1935-36, many in the South and Southwest were prepared to challenge Chiang's policies. In this context of rising patriotic sentiment, the Soviet Union was the most likely source of military assistance against Japan. Zhang's dealings with the Communists, even his request to join the Communist Party, must be understood as part of a search for military support if he had to cut his ties with Nanjing. As we have seen above, Zhang knew that Chiang Kai-shek, through his representatives, was also talking to the Soviets. There was no reason Zhang should not do the same. Finally, of course, we should remember that when full-scale war with Japan broke out in 1937, the one country that provided substantial military aid to China was precisely the Soviet Union. ${ }^{222}$

By December 1936, however, the Red Army's Ningxia campaign had collapsed in failure. Hopes had evaporated for a broad anti-Japanese front in the Northwest, tied to and armed by the Soviets. Now the Communists' remaining armies were much reduced in size and strength and all concentrated in a small base on the Shaanxi-Gansu-Ningxia border. Mao Zedong made a final appeal to Chiang Kai-shek's patriotism, condemning him for concentrating his forces against the Communists while Japan was invading Inner Mongolia. ${ }^{223}$ The appeal went unanswered. Chiang's generals, Hu Zongnan and Tang Enbo, controlled the fronts to the east and west. North of Shaanbei was the Gobi Desert, and Japan was advancing from the east. The only quiet front was the NEA front to the south. On December 6, 1936, Chiang Kai-shek flew to Xi'an to urge Zhang Xueliang to press his attack on the Communists or be removed. Six days later, Zhang Xueliang's soldiers overpowered Chiang's bodyguards and took the Generalissimo captive. With that decisive act, the history of Shaanbei was transformed. After tense negotiations in the weeks that followed, Chiang gave verbal assent to end the civil war, opening the door to Chinese unity against continuing Japanese aggression. 
The dramatic story of the Xian Incident has been much told and need not be repeated here. The incident unquestionably changed the course of Chinese history. ${ }^{224}$ It was, however, the product not of events in Shaanbei but of developments in the nation as a whole. In that respect, it was the culmination of the progressive eclipse of local agency that we have seen through this study. In Shaanbei, the revolution was in peril. But on the national scene, Chiang Kai-shek's anti-Communist crusade was also in crisis. In 1936, the press carried daily headlines of Japanese aggression and valiant Chinese resistance in what is now Inner Mongolia. ${ }^{225}$ The Japanese promotion of an autonomy movement in North China aroused strenuous Chinese objections to partition of the country. Then on November 22, Nanjing authorities arrested seven prominent leaders of the National Salvation Movement, provoking further nationwide protests. The arrests looked particularly impolitic when, three days later, Japan and Germany signed the Anti-Comintern Pact.26 Given the inflamed state of Chinese public opinion, it is hardly surprising that when Chiang Kai-shek came to Xian to press his anti-Communist campaign, he was met with student demonstrators from Northeast University, which had recently relocated to the city. It was Chiang Kai-shek's suggestion that such patriotic student demonstrations should be dispersed with force that precipitated his kidnapping on December 12. ${ }^{227}$

In Shaanbei the initial reaction was ecstatic. In Bao'an, there was a "huge celebration," and Mao Zedong called for a public trial of Chiang Kai-shek. ${ }^{228}$ At his local headquarters, Gao Gang's announcement to a mass meeting was greeted with enthusiastic cries to "Execute Chiang Kai-shek." 229 To Moscow the CCP forwarded an ambitious plan for a united front of the Red Army, Zhang Xueliang, Yan Xishan, and other generals, with the hope that T. V. Soong and others anti-Japanese elements would join their cause and the Soviet Union would render assistance. ${ }^{230}$ Moscow was alarmed. The Comintern suspected that the Chinese Communists were in on the plot, and the Soviet press blamed the kidnapping on a Japanese conspiracy. These fears were exacerbated by suspicions, inevitable in Stalin's Russia, that Trotskyite agents were somehow involved. ${ }^{231}$ After Stalin conferred with the Comintern leaders and Molotov, a radiogram instructed the CCP to work for a peaceful solution, and Zhou Enlai was dispatched to join the negotiations in Xi'an. ${ }^{232}$

In Xi'an, the plotters had seized, in addition to Chiang Kai-shek, several of his leading generals and the Guomindang governor of Shaanxi, Shao Lizi. The city was entirely in the hands of the mutineers, and enthusiasm for an end to the civil war and a united front against Japan was high. Nationwide, however, a contrary atmosphere prevailed. The Xi'an Incident provoked a nationwide storm of protest against the "mutiny" by Zhang Xueliang and his Northwest Army partner Yang Hucheng, and near-unanimous support for Chiang Kai-shek. The Guomindang divided, however, on how the Generalissimo was to be saved. Initially, real power fell to the "pro-Japanese" faction around the minister of war He Yingqin, who 
mobilized the army to attack and bomb the mutinous troops around Xian. As Nanjing's forces advanced from the east, and with Chiang's loyal supporter $\mathrm{Hu}$ Zongnan in Gansu to the west, Zhang Xueliang had to withdraw his own troops from eastern Gansu and Shaanbei and asked the Communists to move south to replace them. Mao and his military commanders engaged in a confused radio consultation, with some favoring a return to the Ningxia plan, and Mao proposing a typically aggressive strategy that involved advancing quickly beyond the Guomindang lines in Henan and threatening Nanjing-once again displaying his intense desire to escape his impoverished refuge in Shaanbei. To prepare for this option, Xu Haidong's forces were sent to prepare for military operations in southern Shaanxi, where they had left a small guerrilla force when passing through the area in 1934. However, most Red Army forces moved only as far as Sanyuan, occupying more populated Wei River areas that afforded access to provisions and fresh recruits for the army. ${ }^{233}$ This represented a vast expansion of the soviet base-a major recovery from the precarious position the Communists found themselves in just a month earlier.

On December 20, the political configuration on the Guomindang side changed when Song Ziwen (T. V. Soong) flew to Xian, soon joined by his sister, Mme. Chiang Kai-shek. They represented the "pro-British-American" faction in the Nanjing government, and the rivals of He Yingqin, whose military assault on Xian put the Generalissimo's life in danger. Song took over the negotiations with Zhang Xueliang and Zhou Enlai, eventually gaining Chiang's verbal agreement to a vague set of principles for an end to civil war and a reorganized united front government against Japan. Yang Hucheng and the radical officers in Xi'an were skeptical, doubting that Chiang would uphold such a vague set of promises. But Zhang Xueliang was insistent and flew off with the Generalissimo and Mme. Chiang on Christmas Day, 1936. ${ }^{234}$

Chiang emerged from the crisis more popular than ever and returned to a tumultuous welcome in Nanjing. Zhang Xueliang, for his part, was the main loser. Expecting to receive the sort of peremptory punishment given to previous opponents of the Generalissimo, he was instead put on trial, convicted of insubordination, removed from his command, and put under house arrest that would last long after the Guomindang was driven from the Chinese Mainland. The trial and punishment of Zhang Xueliang provoked a further crisis in Xi'an, as radicals called for revenge against Nanjing while the moderate NEA commanders sought to ease the conflict in hopes of gaining Zhang's release. The Communists, anxious to consolidate their gains in the north and advance the united front, supported the moderates.

When the Xian Incident broke out in December, the NEA withdrew from Yan'an, and the Red Army occupied the city, which would remain the Communist capital for the next decade. The final act of the Xian drama came in February, as Chiang Kai-shek sought to bring the region under firm Nanjing control. The NEA 
officers resisted, demanding the return of their commander. As the crisis escalated, radical officers assassinated Wang Yizhe and other senior commanders, precisely the men who had negotiated the initial truce with the Communists a year earlier. Divisions within the Xian mutineers provided the opportunity for Nanjing to reassert control of Xian and the Wei River valley, and many of the radicals fled to join the Communists. ${ }^{235}$

In Shaanbei, the revolution entered a new stage. The military threat in the north was much reduced. To the west, Hu Zongnan was closer to T.V. Soong's faction with its support of the united front; and to the east Tang Enbo led much of his army to the front against Japan in Suiyuan. Troops loyal to Nanjing occupied Xi'an, but Yang Hucheng withdrew to Sanyuan, providing a buffer between them and the Communists in the north. ${ }^{236}$ As a reward for CCP cooperation in the resolution of the crisis, and apparently feeling guilty for its failure to support the West Route Army in Gansu, Moscow increased its offer of financial assistance to $\$ 800,000 .{ }^{237}$ The revolution in Shaanbei was certainly not secure. The Guomindang still controlled most of the major towns, the local militia remained hostile to the Communists, and armed conflict with the guerrillas was common as they attacked local strongmen for grain to support the revolution. ${ }^{238}$ But the Xian Incident had ended Chiang's anti-Communist offensive and provided the Communists a new connection to the patriotic student movement in the cities. Many of those students sought out the Red Army units now within walking distance of Xian. What they found was not so different from what Edgar Snow had witnessed in Bao'an. In the words of a foreign journalist, "There are gaiety, comradeship, a touch of recklessness, for the average age of the Red Armies is probably under twenty; but there are also a strength and a self-reliance that are not common among Chinese brought up in the old family traditions." ${ }^{239}$ Others put a slightly more sinister spin on the same scene, seeing "a blend of sweet reasonableness with desperate declarations, of cheerful care-free countenances with sinister and terrifying aspects." ${ }^{240}$ One can well imagine passionate young students responding to this combination of youthful enthusiasm and resolute determination. But there was still a long road to travel before the Shaan-Gan-Ning base was secure. 


\section{6 \\ Dawn of the Yan'an Era}

Early in January 1937, Mao Zedong and the CCP Center moved into Yan'an. Over the next decade, this small Shaanbei town became the symbol of an alternative Chinese future. Here Mao Zedong rose to dominate the party, wrote the essayssome vivid and stirring, some turgid and pedantic-that came to define Mao Zedong Thought, and here the party developed the practices of self-reliance, political rectification, and "mass line" that would set the future course of the Communist revolution. Tens of thousands of young people flocked to Yanan to join the revolution, transforming the region and ultimately the nation. Their patriotic commitment to build a new China while living simply in harsh conditions would be celebrated as the "Yan'an spirit," and today Chinese and foreign tourists visit the city to explore the homes of the leaders and absorb the celebration of Yan'an's glory years in the town's massive Revolutionary Museum. But the Yan'an of today is far from the dusty frontier town with a mere three thousand residents that Mao entered in 1937. Described by one visitor as "the quaintest and most picturesque little fortress city imaginable," it was also a dirty town of flies and manure-littered streets that became impassable quagmires when it rained. There were no multistory buildings, only caves carved into the hillsides; no motorcars plied the unpaved streets; and a single rickety bridge crossed the Yan River that flowed through the center of town. ${ }^{1}$ When the Red Army entered, the local merchants greeted them with rations for the troops, just as they would have welcomed any warlord army that threatened public order. Most of the landlords fled, leaving their compounds to be occupied by the Communist leaders. ${ }^{2}$

If Yanan was small, so was the Communist border region that surrounded it. When the Xian Incident broke out, the Red Army controlled only Bao'an, which Edgar Snow had visited in 1936, and neighboring Ansai-both poor and sparsely populated counties-plus Yanchi in Ningxia, stretches along the Great Wall north of Bao'an, and the Shaanxi-Gansu border. In addition, several counties in eastern Gansu had been occupied by He Long's army at the end of its Long March. After 
the Northeast Army withdrew during the Xian Incident, the Communists occupied Yan'an and neighboring Ganquan and Yanchang Counties. ${ }^{3}$ This was a far smaller territory than the eventual Shaan-Gan-Ning Border Region, and as before the Xian Incident, Mao and the Communist leadership had no desire to stay in this poor, barren, and sparsely populated corner of China. Only a protracted series of complex negotiations and external events left Mao and the Communist Party reluctant occupants of the Yan'an caves.

\section{RENEGOTIATING THE XI'AN TRUCE}

As the party Center entered Yan'an, the shifting military situation in Shaanxi became a focus of ongoing negotiations with Chiang Kai-shek and the Nanjing government. During the Xian Incident, the armies of Zhang Xueliang and Yang Hucheng had withdrawn from the desolate north to protect Xi'an, and they invited the Red Army to move south as well. Xu Haidong's Fifteenth Army was dispatched across the Wei River and advanced all the way to southern Shaanxi, working to revive scattered guerrilla units in the area through which his army had passed in 1934-35. ${ }^{4}$ Mao hoped to move the main force of the Red Army to this same region, which was far richer than the north and offered multiple options for expansion. ${ }^{5}$ This, however, would have brought the Communist forces into the upper reaches of the Han River, an increasingly prosperous area whose navigable waters flowed into the Yangzi metropolis of Wuhan. This was the same area from which commoner rebels had risen to found the Han dynasty of ancient China, and from which Li Zicheng had launched his final assault to topple the Ming, precedents of which Chiang Kai-shek was surely aware, and he strongly opposed this option. ${ }^{6}$ At least one of Chiang's counter-proposals was equally unrealistic. He offered the Communists a base in the barren wastes of western Gansu, precisely the area where Muslim armies were decimating the remains of Zhang Guotao's forces, the West Route Army. The Communists were predictably unwilling to accept a desolate base far from the Japanese front. ${ }^{7}$ Some Communist commanders revived the plan to advance through Ningxia toward the Soviet border, taking advantage of the winter months to cross the frozen Yellow River. All these options to escape Yan'an were under active consideration until Chiang Kai-shek offered financial support for a reorganized Red Army, at which point the Communists withdrew the Fifteenth Army from southern Shaanxi and abandoned plans for offensive operations in the south. ${ }^{8}$ Resigned to making Shaanbei their base, they managed to maintain units on the northern fringes of the Wei River valley, more productive lands to help feed their armies. One clear advantage of Shaanbei was that it represented a plausible refuge for remnants of the battered West Route Army. When this elite portion of Zhang Guotao's Fourth Army had crossed the Yellow River in Gansu and headed west toward Xinjiang, it represented almost half of the entire Red Army. In early 1937, the party was anxious to recover what it could of its key units and officers. ${ }^{9}$ 
In the months leading up to the Xian Incident, the Communists had carefully cultivated relations with Zhang Xueliang's Northeast Army and Yang Hucheng's Northwest Army in hopes of establishing a secure anti-Japanese alliance in Northwest China. An alliance of these three armies remained the party's objective throughout the negotiations in Xian. ${ }^{10}$ These hopes were dashed when, following Chiang Kai-shek's release, the Nanjing government put Zhang Xueliang on trial and convicted him of gross insubordination. Zhang's Northeast Army was sent out of the region to bases in Henan and Anhui. ${ }^{11}$ At the same time, Chiang told Yang Hucheng that he would not tolerate an independent army in the Northwest. Chiang's lieutenants assured him that Yang was "rude and stupid," a "feudal" warlord and locally despised. By April, Yang had been removed and sent abroad, his local regime dismantled. Chiang Kai-shek sent a loyal general to take command in Xian, and once again the Communists were alone in the Northwest, forced to fend for themselves. ${ }^{12}$ Militarily, their situation was more precarious than before Xi'an.

Politically, the situation did not look much better. In December 1936, to resolve the Xi'an Incident, T. V. Soong had flown to the city with Song Meiling, his sister and Chiang's wife. T. V. served as the principal negotiator, shuttling back and forth between Chiang Kai-shek and Zhou Enlai. To the Communists, he represented the liberal Anglo-American faction of the Guomindang, in which they placed the greatest hope for a united front against Japan. Though Chiang Kai-shek resolutely refused to sign any agreement under duress, Soong assured the Communists that the Generalissimo had agreed to cease attacks on the Red Army and reorganize the Nanjing government to exclude pro-Japanese elements. Though Soong abjured any ambitions of his own, he obviously hoped that his efforts to save the Generalissimo's life would win him a key role in the new government.

Whatever concessions Soong had extracted from Chiang unraveled as soon as the Generalissimo returned to a joyous welcome in Nanjing. According to Soong, Chiang had assured Zhang Xueliang and Yang Hucheng that "he would pardon them for their act." Soong also reported that Chiang had agreed to keep Zhang Xueliang in the Northwest and not send in central government troops. None of these agreements were carried out. ${ }^{13}$ Soong had evidently promised more than he could deliver. For his part, Chiang Kai-shek displayed no gratitude for the role Soong had played in his release. The Generalissimo's relations with his brother-in-law would always be troubled. While Chiang relied on the suave Harvard-educated, English-speaking banker when he needed him, he remained suspicious of Soong's ill-disguised ambition. ${ }^{14}$ He offered Soong no position in a reformed government, keeping him out of power until 1940, when Soong's suave manner and business connections were required to secure aid from China's allies. With T. V. Soong's mediation in Xian, the Communists had hoped and expected that the incident would enhance the power of anti-Japanese elements in Nanjing, but in fact it was pro-Japanese forces that seemed to gain strength. Wang Jingwei, soon to become wartime leader of the Japanese puppet government in Nanjing, returned from 
forced exile in January, and He Yingqin, the military leader of the "pro-Japanese" clique whom Mao described as China's Franco, remained in power and would soon become chief of the general staff in Chiang's wartime armies. ${ }^{15}$ In the Yangzi valley, Chiang intensified military actions to eliminate the last pockets of Communist resistance, the guerrillas left behind by the Long March, soon to be reorganized as the New Fourth Army. ${ }^{16}$ In early March, Chiang Kai-shek met with the Japanese ambassador and assured him that "my government's policy toward the Communist Party has not changed." 17

With the collapse of the Xian understandings and the expulsion of the CCP's military allies in the Northwest, things looked bleak for the Communists in the early months of 1937. The Xian Incident did not look like a turning point in Chinese history. Beneath the surface, however, a subtle thaw was melting the sharp confrontation between the Communist and Nationalist parties. In its February 1937 plenum, the Guomindang adopted a policy to "root out the Red menace" (genjue chihuo 根绝赤祸). This hardly seemed promising, but the Communists took hope from Chiang Kai-shek's speech emphasizing political rather than military solutions. ${ }^{18}$ In March, the Soviet Union encouraged this thaw by promising to return the Generalissimo's son, Chiang Ching-kuo (Jiang Jingguo), who had been studying and working in Russia since the 1920s. He would arrive back in China in April. ${ }^{19}$ Most significantly, military operations against the Communist base stopped, as negotiations continued in Xi'an to resolve the crisis, and Chiang agreed to financial support of a reorganized Red Army. ${ }^{20}$

The initial negotiations focused not on the later Shaan-Gan-Ning Border Region, which was never a major concern of the Communist leadership, but on the size and control of the Red Army. Chiang Kai-shek thought that quantitative concessions on the army's size would satisfy his adversaries. During the pre-Xian negotiations, Chiang's representative, Chen Lifu, had offered to absorb and support a Red Army of 3,000 soldiers. In February 1937, Chiang indicated that he had already agreed to support 5,000 men, and now increased his offer to two divisions with 15,000 men. In March, the number had increased to 27,000, and in July to 45,00o. ${ }^{21}$ Similarly, when it came to the future border region in Shaanbei, Chiang told Zhou Enlai that he wished to debate, not the number of counties to be included, but the nature of the local regime. ${ }^{22}$ For Chiang, the issue was never the size of the Red Army or the territory it administered but the degree to which it would be subject to his authority.

In many respects, Chiang's position remained unchanged by the Xi'an episode. He was confident that the small Red Army represented a lesser threat to his power than the brief revolt of the Southwest warlords in the spring of 1936 . He denied that he had ever promised to reorganize the Nanjing government as T. V. Soong had alleged in Xian. He continued to use the divisive slogan of "internal pacification and external resistance." ${ }^{23}$ Most importantly, he insisted that his policy was not to tolerate the Communist armies (ronggong 容共) but to absorb and reorganize 
them (biangong 编共). Officers would be centrally appointed, and the Red Army had to obey the orders of the National Government. ${ }^{24}$ The Red Army would be treated like the many warlord armies that Chiang had absorbed since the Northern Expedition of 1927. As for the united front, Chiang's model was the Sun-Joffe agreement of 1922, which had led to the first GMD-CCP alliance: Communists had been admitted as members of the Nationalist Party and the Communist International had agreed that China was not ready for communism. ${ }^{25}$ But this was a model that the CCP had long denounced as "right opportunism," and there was little hope that it was willing to turn back the clock on this score. Finally, on the Communist demand for the release of political prisoners, Chiang agreed that if his critics would repent their errors (which amounted to renouncing Communism), he would release them. ${ }^{26}$

As Chiang Kai-shek deployed his own forces to surround the Red Army in Shaanxi, it became clear to the CCP that leaving Shaanbei for a more hospitable locale would no longer be possible. At this point, the status of the Shaanbei regime became a focal point of negotiation. Here again, Chiang's position was clear: the Communist-controlled soviet must be reorganized as a special administrative district following national laws with nationally appointed officials. On this, his stance was unwavering, and the National Government never formally recognized a border region (bianqu 边区) with a separate administration. ${ }^{27}$ In Chiang's words, "In order to maintain military and political unity, we cannot permit others to delimit regions that will be separate and independent." ${ }^{28}$ At the heart of his position was the conviction that a modern state could not have two separate administrations. He consistently characterized the alternative as "feudal" and linked it to a new form of warlordism. ${ }^{29}$

On paper, the Communist position was not that different. In a formal proposal to the National Government the party called for an end to civil war, protection of the freedom of political expression, the summoning of all parties for national salvation, preparation for war against Japan, and improvement of the people's livelihood. If the Guomindang would adopt these policies the Communists offered four significant concessions: (1) cessation of all military efforts to overthrow the National Government; (2) "transformation of the soviet government into a special administrative district [tequ zhengfu 特区政府] of the National Government, and the Red Army into a unit of the National Revolutionary Army, under the direction of the Nanjing central government and its military committee"; (3) establishment of a democratic regime by popular election in the special district; and (4) an end to the confiscation of landlord lands. ${ }^{30} \mathrm{On}$ its face, the second principle seemed to correspond to the Guomindang position.

Clearly, the devil was in the details. From the Wayaobu meeting of December 1935, when the party Center learned of the Communist International's new united front policy, a critical component of Communist policy was the independence of the party and its army. Mao and the party's new leaders stressed the clear distinction 
between this period and the united front of the 1920s: the party now had its own army and its own revolutionary base. It was not prepared to give these up. In this, it had the full support of the Communist International. ${ }^{31}$ In explaining its new policy, the party stressed that it would continue to guarantee the rights of workers and peasants in the former soviet and "the political and organizational leadership of the party" in the army. ${ }^{32}$ It also, in a separate document, assured local activists that the gains of the soviet period would not be reversed. ${ }^{33}$ The party seems to have assumed that just as Chiang had absorbed other local armies in his National Revolutionary Army without changing their command structure, so would he include the Red Army with its own commanders and political officers. This, however, was not Chiang's intent, and on the eve of full-scale war with Japan, his position was unwavering.

In June 1937, Zhou Enlai flew to Chiang's summer retreat in Lushan for one more round of negotiations. Now Chiang proposed a new joint organization, to be called the National Revolutionary Alliance (Guomin Geming Tongmenghui 国民革命同盟会), reviving the name of the party that Sun Yat-sen had led in the 1911 Revolution. Both parties were to be equally represented in this body, but Chiang insisted on the deciding voice in the likely event of disagreement. He raised the possibility that this Alliance might evolve into a single party in the future, which, once again, recalled the model of the 1920s. Chiang now agreed to a reorganized Red Army of forty-five thousand men, with officers appointed by the central government. Then came the poison pill: not only were Mao Zedong, Zhu De, and the other Red Army commanders excluded from positions in the reorganized Red Army, they were to leave the army for other work. ${ }^{34}$ Predictably, Zhou Enlai declared this totally unacceptable, and when Mao Zedong met a group of foreign journalists, he spoke of the "uncertain future" of the united front. ${ }^{35}$ Such was the fragile state of Communist-Guomindang relations when war broke out in July 1937.

\section{SHAAN-GAN-NING ON THE EVE OF WAR}

While these tortuous negotiations continued between the leaders of the rival parties, a seemingly tranquil dual regime was being established in Shaanbei. When the American journalist T. A. Bisson visited in June, he reported that "something approaching a political lull existed in Yenan [Yan'an] and elsewhere in China." ${ }^{36}$ Most Shaanbei counties still had Guomindang magistrates, and the old local tax and security apparatus (baojia) remained intact. ${ }^{37}$ In Yan'an and three neighboring counties to the south and east, there were dual administrations with Guomindang magistrates in the county towns. ${ }^{38}$ The remnants of the old administration persisted throughout most of the border region. The Guomindang hoped to gain favor by distributing relief grain, and its representative claimed to have done this in all Shaanbei counties except Bao'an, which alone was totally under Communist control. ${ }^{39}$ The rival armies had friendly interactions. In May, the Nanjing government 


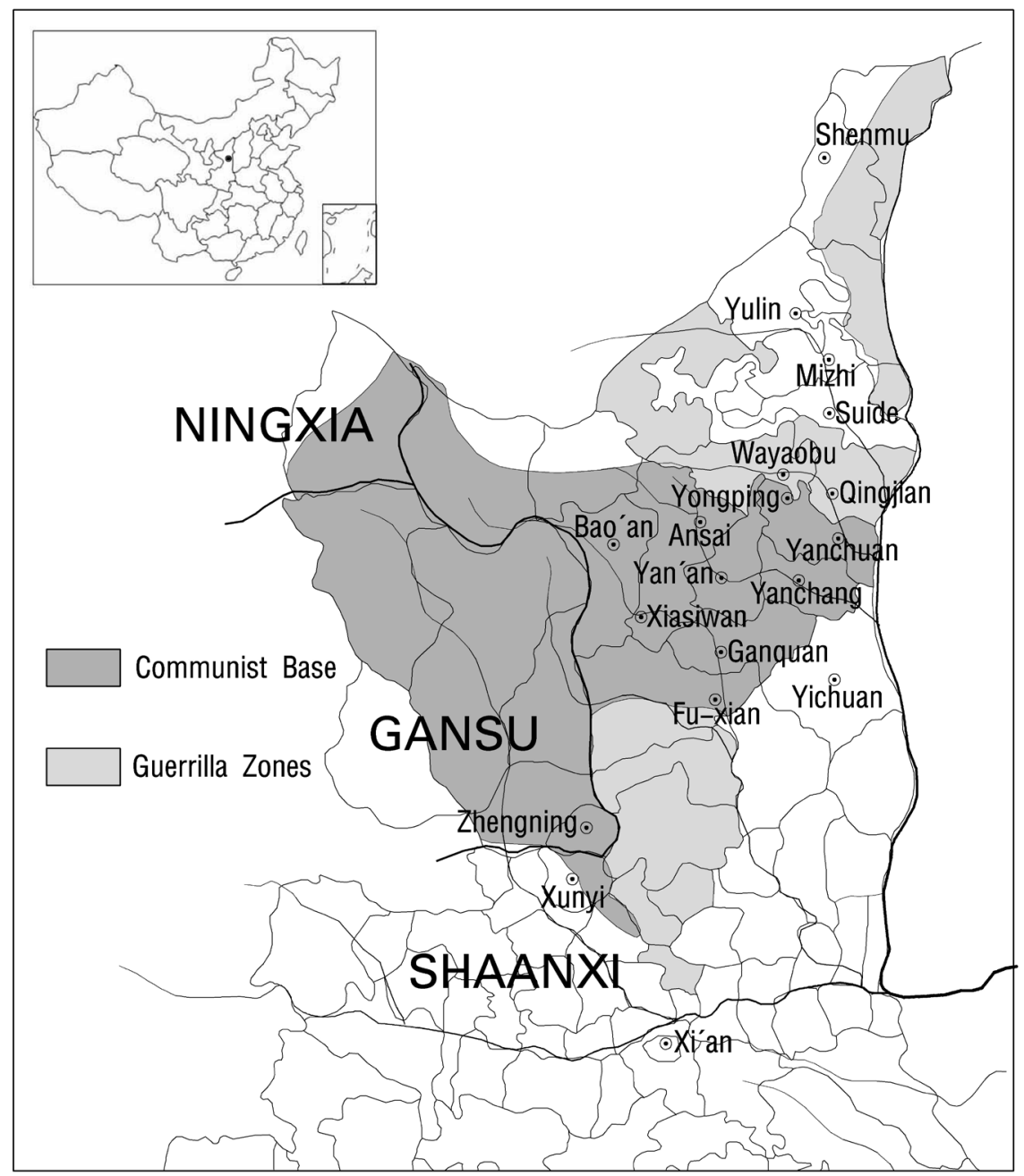

MAP 9. Shaan-Gan-Ning Border Region in June 1938, a year into the war with Japan. (Based on "Bianqu diaocha baogao," June 8, 1938, Guomindang Bureau of Investigation Archives, 270.15/810.)

sent an inspection team, which was greeted with great ceremony ${ }^{40}$ Slogans were painted on walls to support Generalissimo Chiang Kai-shek. The core areas under relatively secure Communist control were quite limited. When the Xi'an Incident broke out, the Red Army controlled only a few counties around Bao'an. Several sparsely populated areas in eastern Gansu had been occupied by He Long's army at the end of its Long March. After the Northeast Army withdrew during the Xi'an Incident, the Communists occupied Yan'an and most of neighboring Ganquan and Yanchang Counties. ${ }^{41}$ This was a much smaller area than the eventual twenty-three counties of the border region, and it included none of the richer counties in the northeast along the Wuding River (see map 9 above). 
As they set up their new "special administrative district," the Communists' first concern was security. In the former soviet areas along the Shaanxi-Gansu border, this took the form of eliminating "bandits." Bandit suppression began in the summer of 1936, but a year later the Communist leadership identified fortythree "bandit" gangs with 2,608 men in the soviet area, of which thirty-one with 2,147 men were allegedly eliminated. ${ }^{42}$ Two years later, there were still over forty gangs with roughly 4,00o members, including many seasonal outlaws, who spent much of their time as ordinary peasants. Now the party claimed to have eliminated twenty-six of these gangs and killed or captured roughly 1,500 bandits. ${ }^{43}$ Obviously, the revolution had not solved the problem of endemic banditry in Shaanbei. It was also clear, however, that the Communists had adopted the practice of previous regimes in classifying their political opponents as "bandits." In the words of Lin Boqu, Communist elder and head of the border region: "In the new ["democratic"] stage, the strongmen and landlords who were overthrown in the revolution have returned, and counter-revolutionary organizations have more opportunity to operate under the democratic system. The attempt of these reactionary powers to revive and arm themselves will not stop. Therefore bandit suppression is an important part of the revision of our work." 44

While Liu Zhidan had often used his personal connections and especially his Society of Brothers membership to win the support of local militia, the new leadership was far less forgiving of such local strongmen. In effect, the former "Communist bandits" (gongfei 共匪) now set about eliminating “militia bandits."

A classic example was Zhang Tingzhi in Bao'an. Zhang headed the local militia in a Luo River village not far from Liu Zhidan's home. The Zhang family owned large stretches of rich lowland at the point where the valley widened in the upper reaches of Luo. As many as two hundred retainers (menke 门客) cultivated the family's extensive landholdings. These vast holdings had been acquired by Tingzhi's great-great-grandfather, a drifter from Gansu with a gift for gambling and other semi-criminal activities. He is said to have acquired his wife in payment of a gambling debt and then to have finagled a job as a yamen runner in a nearby county. This minor government post generated enough wealth to buy up land in Bao'an. His sons and grandsons passed the military examinations under the Qing, the natural route to local status in this poor border region where Confucian education for the civil exams was unavailable. The Zhang family was unquestionably one of the established elite families in Bao'an, and it is not surprising that Liu Zhidan's family intermarried with the Zhangs and that Liu himself briefly joined Zhang Tingzhi's militia in an abortive attempt to convert it to his revolutionary cause. By 1935, Zhang was an implacable foe of the revolution and had taken a position in the local warlord's army. In 1937, he was a classic "local despot," advancing a slogan that opposed both the Communists and the united front: "Down with the Red Army and the White Army, Long live the Black 
Army." He was eventually driven from Bao'an but survived in the Guomindang areas to the north, leading his small band of militant anti-Communists to raid along the northern counties and even foment a brief mutiny in Wayaobu in 1937. Joining the Guomindang army, he survived until 1950, when he was executed as a "counter-revolutionary." ${ }^{4}$

In areas where the party shared control with the preexisting Guomindang administration, the policy toward local elites was a good deal more tolerant and flexible. The central principle was to organize on the basis of national salvation, targeting friendly armies, sympathetic militia members, women, and youth. Party members were enjoined to oppose oppressive taxation, encourage the wealthy to contribute to the resistance, and treat only the most recalcitrant as traitors. Though party members participated openly in patriotic political and propaganda activities, the party organization was to remain secret and be cautious and selective in recruiting new members. ${ }^{46}$ Party membership had increased significantly before and immediately after the Xi'an Incident, rising to 32,418 in May $1937 .{ }^{47}$ The composition of the party also changed. A systematic 1939 survey of party membership indicates that 71 percent joined in $1935^{-36}$, and since, as we have seen, the party was in retreat following the failure of the 1936 Shanxi expedition, most of these were ordinary peasants who joined during the radical expansion of the base under Liu Zhidan in 1935. Only 10 percent had even a primary education, and 41 percent were illiterate. ${ }^{48}$ Now the party wanted more disciplined and better-educated cadres, so it stipulated that the mass recruitment of party members should cease, that party members should be recruited individually, and that recruitment should not focus on relatives and friends of current members. ${ }^{49}$ The final prohibition indicates that past recruitment drives had focused on those most easily motivated: close friends and family members of current Communists.

With rising student opposition to Japanese aggression, the party turned increasingly to attracting young people. Even before the Xi'an Incident, the Communist Youth organization was transformed into a "non-party youth organization" advocating "democracy and freedom." In Guomindang areas, Communists were to eliminate their own separate organization and join legal patriotic organizations. In the soviet areas, Marxism-Leninism was still taught, but the emphasis was on culture, physical education, and military training. ${ }^{50}$ The Red Guards were transformed into Anti-Japanese Self-Defense Forces. There is little doubt that many young people responded to this appeal, and impressive numbers were enrolled in these organizations. ${ }^{51}$ Visitors routinely commented on soldiers in their midteens, or the independence and courage of the "little busybodies" in Yan'an. One enthusiastic Chinese visitor called Yan'an "the cradle of youth." ${ }^{52}$ Nationalist Party complaints that the Communists were misleading "gullible youth" with dancing and dramatic performances confirm the impression that the Communists were indeed winning the hearts and minds of the young. ${ }^{53}$ 
The most common conflict between the two rival parties was the competition to collect taxes. Shaanbei was bitterly poor, and a poor 1936 harvest left grain prices soaring and many without enough to eat. ${ }^{54}$ Still, a frugal and efficient local administration, plus a National Government subsidy of $\mathrm{CH} \$ 300,000$ to 500,000 for the Red Army, allowed the Communist regime to eliminate most of the old taxes, with the exception of the lucrative salt tax. Such taxes as the Communists collected were heavily progressive, amounting to forced contributions from the rich. ${ }^{55}$ In areas of dual control, however, the Guomindang authorities also collected taxes to support their apparatus, and most local "friction" between the two parties came over the issue of which regime had the right to tax. ${ }^{56}$

One critical element in the competition for local support and national legitimacy was the Communists' "democratic" appeal. In the twenty-first century, it is difficult to imagine a Communist regime as democratic. Autocratic rule by a single party that denies the freedom of speech and assembly violates all normal definitions of democracy. In 1937, however, the Communists launched a broad campaign to carry out local elections for village, county, and border region assemblies. After the Xi'an Incident, the Communist International had called on the CCP to transform its soviet into a "popular revolutionary government with a democratic foundation." ${ }^{57}$ Democratic governance was hailed as the "sacred mission" of the border region, whose purpose was to turn this "backward and ignorant" border region into a model for the entire country. ${ }^{58}$ As a precedent, the party cited Sun Yat-sen's support for self-governance in one province as a step toward nationwide constitutional governance. In conversations with foreign journalists in the spring of 1937, Communist leaders regularly cited these democratic elections to distinguish their regime from Chiang Kai-shek's autocratic rule. ${ }^{59}$

When elections were held in the fall, they began in villages, and the representatives selected in these elections chose delegates in indirect elections for district $(q u)$, county, and finally border region assemblies. The assemblies at each level chose the village, district, and county administrators. ${ }^{60}$ While all this appeared to be very democratic, the party was quite clear about the purpose of the exercise: "to thoroughly establish a democratic republican system and, in doing so, guarantee our party's leading role." ${ }^{11}$ While the regulations excluded only traitors, the interpretation of this term was broad. As the party explained, it was essential "not to let a single bad person get on the eligible list," and local organizers were enjoined to use the compilation of election rolls to identify "suspicious elements." ${ }^{2}$ There was no pretext of free and fair elections between competing parties. Lin Boqu, chairman of the border region, stressed that "in the villages, we must keep political power in the hands of the party." 63 The Communist Party was in control of the process, and the party cell prepared the list of nominees. The ground for village elections was first prepared in model districts, and elections could be delayed if a proper result was in doubt, which was easily monitored since this first election was 
usually carried out by a simple show of hands ${ }^{64}$ At higher and more important levels, party dominance was even more pronounced. Yanchang proudly reported the near-unanimous selection of the party's nominee for county magistrate "because all the delegates were party members." ${ }^{65}$ Nonetheless, for ordinary villagers unused to any voice in the selection of their leaders, the elections were undoubtedly a step forward. It is significant that when Guomindang supporters objected to the new regime, they argued that "even if popular," the independent Communist regime was incompatible with the idea of a unified modern nation. ${ }^{66}$

This, however, was precisely the purpose of the elections. While the elections may have helped nourish popular support for the new regime, they were far more important in protecting the border region's independence from Nanjing. Chiang Kai-shek still insisted that he should appoint the leaders of the border region, and in July he suggested such moderate Nationalist Party leaders as T. V. Soong, whom he thought the Communists might accept. ${ }^{67}$ The fact that they were in the process of electing representatives to the border region assembly allowed the Communists to reject these proposals as contrary to their commitment to a democratic republic and Sun Yat-sen's Three People's Principles. ${ }^{68}$ The elections, therefore, had less to do with establishing a democratic regime than with providing a rationale for an independent border region beyond the control of the Nanjing government.

There was, however, one election in the spring of 1937 that had real significance for local governance. In May, the party selected a new party committee for Shaan-Gan-Ning. The committee was a mixture of local Communists and such outsiders as Lin Boqu, who would become head of the new border region. As in any party election, the nominees were preselected, in this case by the deputy head of the Central Organization Department, Guo Hongtao, a key figure in the sufan campaign of 1935. Several of the targets of that campaign, including Gao Gang, were not nominated. In this election, however, the local cadres forced a significant display of inner-party democracy: Gao Gang received the most votes (eightythree) of any candidate, one more than Lin Boqu himself. Guo Hongtao, the man who had thrown Gao into prison, needed help from the Central leadership to even get elected, and in April he was packed off to lead the party movement in Shandong. ${ }^{69}$ Up to this point, Shaanbei had lacked anyone who could speak for the region in higher party circles. There is scant evidence that Gao ever saw himself as a representative of Shaanbei, and he certainly did not have the local reputation of the recently deceased Liu Zhidan. He was, however, indisputably a Shaanbei man, and this strong vote of support from the local party reflected its continued resentment of the sufan campaign and the resulting marginalization of the Shaanbei cadres. Following this election, Gao rose to lead the powerful security apparatus, the Shaan-Gan-Ning party committee, and then the party's Northwest Bureau, the most important regional post. Though his career would end with his purge and suicide in 1953, there was now at least one Shaanbei man at the center of power in Yan'an. 


\section{WAR AND THE UNITED FRONT}

On July 7, 1937, a local incident between Chinese and Japanese forces near the Marco Polo Bridge (Lugouqiao 卢沟桥) south of Beijing quickly escalated into full-scale war between China and Japan. With this, the War of Resistance began, the first stage in what would soon expand to become World War II. It was not at first clear that the conflict would spread, and several of Chiang Kai-shek's military advisers sought a local solution to the conflict. The Communists immediately called for a vigorous military response, and by the end of the month Chiang Kai-shek decided that further concessions to Japan were impossible and war was now inevitable. ${ }^{70} \mathrm{He}$ was not, however, ready to agree to the Communist terms for a united front.

As soon as war broke out. Zhou Enlai flew to Shanghai, then met with Chiang Kai-shek at his Lushan summer retreat. Again, the meetings with Chiang failed to produce agreement. As before, the key issue was command of the reorganized Red Army and leadership of the border region. Zhou found Chiang's offer worse than that of June, before the war broke out. In August, a draft agreement was apparently worked out, but then one of Chiang's anti-Communist advisers revised it in ways that were unacceptable. ${ }^{71}$ In July, Chiang had suggested such relatively progressive Guomindang members as T.V. Soong or Yu Youren (a leftist ally of the Shaanxi Communists in the 1920s) to head the border region; now he suggested a committed anti-Communist for the post. ${ }^{72}$ Obviously, the outbreak of war had not erased differences over the terms of the united front.

In August 1937, two distant events broke the deadlock and again demonstrated that Shaanbei would not determine its own fate. On August 13, rising tensions in Shanghai erupted into a major battle between Japan and Chiang's own armies, and the war now spread to China's economic center and the heartland of the Nationalist regime. At this point, total war with Japan became inescapable. ${ }^{73}$ At the same time, Chiang's agents were urgently seeking aid from abroad; and the Soviet Union, given its well-founded fears of Japanese hostility, was the most likely source of support. On August 29, a Sino-Soviet Non-Aggression Treaty was announced, and at the same time, arrangements were made for Soviet military assistance, the first tranche of which would start in November. In the early years of the war, the Soviet Union was the National Government's sole source of military assistance, ultimately providing over $\$ 173$ million in military equipment in exchange for Chinese agricultural products and raw materials. This critical equipment included 924 airplanes, 82 tanks, 1,516 trucks, 1,140 artillery pieces, 9,720 machine guns, 50,000 rifles, and the ammunition to go with them. ${ }^{74}$ By way of comparison, the Soviets offered the CCP $\$ 500,000$ in financial aid and delivered $\$ 150,000$ and no military supplies. ${ }^{75}$ With full-scale war with Japan now inevitable and Communists' Soviet patrons supporting the National Government, Chiang was prepared to accept the Communist terms for the united front. 
In the negotiations with Chiang Kai-shek in July, Zhou Enlai had presented a revised version of the Communists' four principles from February. They began with a promise to carry out Sun Yat-sen's Three People's Principles, thus endorsing the guiding ideology of the Guomindang; and they changed the Comintern's language of "democratic republic" to "a politics of people's rights" - again adopting a term sanctified by Sun Yat-sen. As before, the Communists promised to place their forces under the command of the central government, though the critical questions of command and political leadership remained unresolved. ${ }^{76}$ In August, the Guomindang finally accepted the Communist generals Zhu De and Peng Dehuai as commanders. The agreement established the basic principles of the united front. The Red Army would be reorganized into the Eighth Route Army of the central government's National Revolutionary Army, with offices for liaison and recruitment in Xian and other major cities. As a unit of the national army, it received a subsidy of $\mathrm{CH} \$ 500,000$ per month, in addition to $\$ 100,000$ for the border region. ${ }^{77}$ On September 23, the official government press agency published the Communist draft of the agreement. Chiang Kai-shek issued a statement on the following day, praising the Communists for abandoning their old ways, and the media hailed the new unity around Sun Yat-sen's principles. ${ }^{78}$ The National Government never officially ratified the accord, nor was there ever agreement on what its vague terms meant. As a result, the National Government consistently maintained that it had never legally recognized the Shaan-Gan-Ning Border Region. Nevertheless, there was now an official announcement that the border region had been established. Now the question became: What were the borders of Shaan-Gan-Ning? ${ }^{79}$

\section{DEFINING THE BORDERS OF THE BORDER REGION}

With the publication of the terms of the united front, all parties agreed that a Communist-dominated "special district" would exist, but the size and extent of that district were very much in dispute. The central government recognized a core area of six counties around Yan'an, and when the central army forces along the Yellow River joined the battle in Shanxi, the Shaanxi governor authorized a recruitment zone for the Eighth Route Army around this core. ${ }^{80}$ A Guomindang intelligence document from the time gave a fairly accurate picture of the actual situation on the ground: a core of six "Red" counties around Yan'an, surrounded by five "half-Red" counties to the north and south, then thirteen "partly Red" counties, plus a Communist presence in four counties of eastern Gansu (map 9).

Two of the areas represented zones that Communist armies had occupied only in the wake of the Xian Incident. When He Long's Second Army ended its Long March from western Hunan and reunited with the rest of the Red Army in the Northwest, most of its units remained in eastern Gansu. Once Zhang Xueliang's Northeast Army withdrew during the Xian Incident, the Red Army became the main force in this area. ${ }^{81}$ In late 1937 , these were recognized as a recruitment zone 
for the Eighth Route Army. The extension of Communist control was entirely a top-down process. As the secretary for the region put it, "The Red Army first established the soviet, then the party organization." 82 Gradually the Communists extended their political influence so that by the fall of 1937 , five counties in eastern Gansu were fully under Communist control, with Guomindang magistrates unable to assume their posts. ${ }^{83}$ The Communist presence north of the Wei in Guanzhong was also a product of military occupation following the Xian Incident. When the Northeast Army withdrew, it requested the Red Army to send its troops south in support, and Peng Dehuai led a unit to the Sanyuan area. As we have seen above, the party had long sought a base in the wealthy and strategic Guanzhong region, but it proved well beyond its military capabilities. Now this base on the northern fringe of Guanzhong became the border region's southernmost outpost, and after war with Japan broke out in 1937, it was both an assembly point for troops sent to the front and a recovery area for wounded soldiers. ${ }^{84}$ It provided a reliable link to the Communists' new office in Xian, and, in this relatively rich area, "contributions" from wealthy landlords were an important source of provisions for the Communist forces. ${ }^{85}$

War with Japan brought dramatic changes in military relations between the Nationalist and Communist armies. The Communists had long called for active resistance to Japanese aggression, and now their military leaders were anxious to prove their mettle in battle. Mao Zedong was more cautious, arguing persuasively that the Eighth Route Army was ill-equipped to confront the Japanese on the plains of North China and should confine itself to guerrilla warfare in the mountains. In September 1937, a well-executed ambush of a Japanese supply column at Pingxingguan in the hills of Shanxi provided a morale-boosting victory for the Chinese and a rare example of effective collaboration between Communist and Nationalist forces. For a time, both armies showed real enthusiasm for the united front. ${ }^{86}$ Slowly, however, relations began to sour. While the Communists were working effectively with Shanxi governor Yan Xishan and expanding their foothold in that province, Chiang Kai-shek's forces were defeated in Shanghai, lost the national capital in Nanjing (a military defeat that was followed by a horrific massacre), and finally abandoned the strategic central Chinese city of Wuhan. By the end of 1938, Japan had occupied all of the coastal and Yangzi valley cities where China's modern industry, finance, and infrastructure were concentrated, and Chiang had retreated to his wartime capital of Chongqing, far in the undeveloped interior. ${ }^{87}$ At this point, it was clear that the war with Japan would be long and costly. Chiang Kai-shek and his Guomindang supporters also realized that while their armies suffered successive defeats, the Communists were gaining strength in the north. The time had come to focus again on the Communist menace.

In the spring of 1939, the Guomindang circulated a new policy on "Guarding against Opposition Parties," followed by another that explicitly targeted the "Communist problem." The former noted the strong organization that allowed 
the Communists complete control of the border region and urged the Guomindang to "use organization to combat organization," while the latter stressed that the government "absolutely does not recognize the Communists' so-called 'Shaan-GanNing Border Region." 88 These policies were supported by a petition from unnamed local representatives of twenty-three Shaanbei counties who protested Communist tax collection, interference in education, misleading of young people, and a wide variety of violations of the principle that China should be a nation of "one ideology, one government, one leader." ${ }^{\prime 9}$ By now it was clear that despite Communists' promises that their "special district" would be under the direct guidance of the central government, and despite the dual administration in some counties with Guomindang magistrates operating alongside Communist personnel, Shaan-Gan-Nang was effectively becoming an independent state within a state. The Communist authorities were blocking all efforts to challenge the political, military, economic, or cultural initiatives of their new regime-ascribing such measures to a conspiracy of traitors and Trotskyites. ${ }^{90}$ For their part, the Guomindang intelligence services complained that the Communists' strict control of entry and the internal system of road passes made it impossible to get agents into the area. ${ }^{91}$ Now Chiang Kai-shek decided that the Guomindang should recover any areas not explicitly ceded to the Communists, and followed with orders to send capable magistrates to strengthen the local baojia tax-collection and security forces. ${ }^{92}$

At the same time, the Communist Party adjusted its position on the united front. Wang Ming, the young party leader in Shanghai in the early 1930 s and then the CCP delegate to the Comintern, returned from Moscow in late November 1937. He arrived in Yan'an with the imprimatur of the Comintern and briefly rivaled Mao as a leader of the party. In 1938, Wang Ming became the prime supporter of the party's united front with Chiang Kai-shek and the Guomindang and was sent to Wuhan to direct work in the Yangzi valley. When Wuhan fell, however, he lost his political base and much of the rationale for the united front. At the same time, Wang Jiaxiang returned from Moscow with news that the Comintern supported the more experienced Mao Zedong to lead the party. At a party plenum in November, Mao directly attacked Wang's slogan of "All through the United Front," and restored the emphasis on maintaining the party's independence..$^{93}$ By 1939, with Mao Zedong firmly back in power, both the Communists and Nationalists were ready to test the limits of the united front. As tensions mounted and armed conflict erupted in neighboring Shanxi and across the country, the Eighth Route Army commanders accused the Guomindang of turning its guns from the Japanese enemy to aim at domestic opponents, while Mao Zedong warned journalists from the Guomindang press: "We will not attack unless we are attacked; but if we are attacked, we will certainly counter-attack." ${ }^{4}$

All of this rhetoric reflected conflicts that had long been building on the ground. The war against Japan had brought a united front between Communists 
and Nationalists, but neither of the parties had any experience with political tolerance, and coexistence was challenging. Along the Shaan-Gan-Ning southern border, the Communists organized under the guise of a front organization, the National Salvation Society (Jiuguohui 救国会). The Guomindang resisted from its strongpoint in Yichuan, whose magistrate had been sent to Jiangxi for training in anti-Communist work. From Yichuan, the Guomindang tried, with only temporary success, to insert its magistrates into neighboring Yanchang and Yanchuan. The Communists mounted a vigorous resistance, eventually driving them off with organized mob activities. The Guomindang was accused of using education inspectors and ex-Communists as spies. ${ }^{95}$ As conflicts escalated, the border region authorities ordered the local magistrate to keep the initiative and seek out incidents to create friction. It went on to instruct:

From this time forward, if any incidents arise between you and the "friendly" [Guomindang] government, you should inform us as quickly as possible in a formal report to this office. You should, within reason, exaggerate the incident as much as possible, and you may even manufacture some facts. In addition, you should prepare a separate note informing us of the true situation and send it forward. In this way, we can on the one hand forward your formal report to the friendly government and on the other hand understand the true situation. Otherwise, they are always manufacturing facts and we are always looking for evidence, with the effect that we lose out in the war of words. ${ }^{96}$

We have a large collection that appears to contain summaries of the county reports of the actual incidents. What is most impressive is the petty nature of most disputes. Many (eighteen in total) come from Anding. In this area, the revolution had long pitted Communist-controlled "Red" villages against "White." Now the hilly southwestern part of the county, around the revolutionary martyr Xie Zichang's old home, was designated the Communist area, but the flatter and richer northeast was the Guomindang zone. Wayaobu, the major town and new seat of the county, stood at the juncture of the two zones and became the flash point of contention (see map 10). There was a branch campus of the Communists' Resistance University (Kangda) in Wayaobu, and several of the disputes involved the peremptory occupation of housing for the students. Both sides sought to organize in the other's area, with predictable disputes, accusations, and arrests. In general, when such agents were arrested, they were accused of being bandits, Society of Brothers members, or Japanese spies. The two sides competed for control of patriotic antiJapanese organizations, and joint banquets sometimes degenerated into mutual acrimony and cursing. Most tellingly, the Communists vigorously protested Nationalist propaganda, even when such "propaganda" was in fact accurate-for example, that Communist leaders, after the Xi'an Incident, had called for the execution of Chiang Kai-shek and had been blocked by the Soviet Union. The party was fully aware of the power of information, and it was determined to control the narrative in its territory. ${ }^{97}$ 


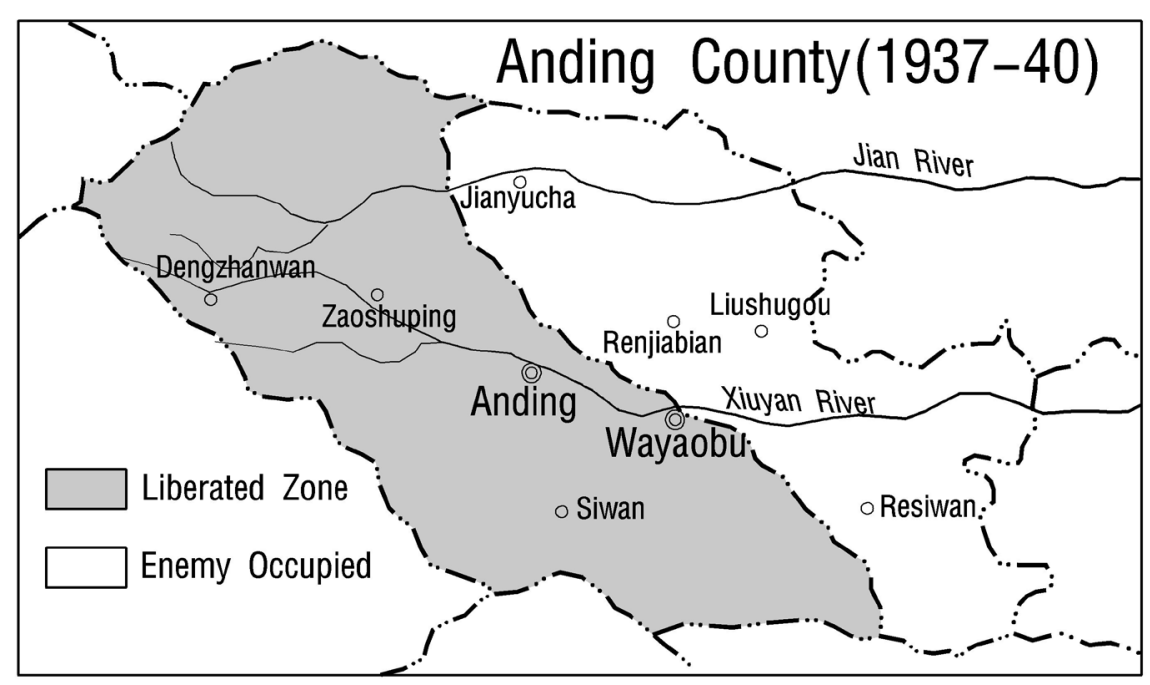

MAP 10. Separate Guomindang and CCP areas of Anding County, 1937-40. Wayaobu, the capital, is the dividing point in the middle. (Based on author's photo of map in Zichang County's Renjiabian [任家矿] Museum.)

With charges and countercharges of questionable accuracy flying back and forth, the rising tide of "friction" was building toward armed conflict, which broke out in earnest in early 1939. Xunyi County was in the southernmost extension of the border region, much resented by the Guomindang for its proximity to Xian, and also one of the richest parts of the border region and a key source of grain. An early survey of cultivated land shows 87 percent of the irrigated land in the entire border region in this one county. ${ }^{98}$ The area was along the Gansu border and not far from the old soviet base in Zhaojin (see chapter 3), but the local party organization was no longer strong. The main Communist presence was a branch campus for cadre training and a base for recovering Eighth Route Army casualties, which in late 1938 was moved to a different town, allegedly to escape Japanese bombing. The local Guomindang authorities resisted this intrusion and the burden that it imposed. Low-grade conflicts continued into the spring of 1939, with the Guomindang claiming that many of those relocated were not wounded soldiers but cadets in training. Soon the mysterious death of an Eighth Route Army soldier, for which both sides blamed the other, led to a major incident. The Communists organized protest demonstrations, arrested Guomindang security officers, and occupied the county seat. The Nationalists responded in force, driving off the Communists and inflicting 107 casualties against sixteen of their own. The Communist units retreated to a new base in a sparsely populated area near their old Zhaojin stronghold, and with this the southern extension of the border region in Xunyi and neighboring Chunhua Counties came to an end. ${ }^{99}$ 
The next test came 150 kilometers to the northeast in Fu-xian, its seat a true border town, and the county a contested area for both parties. In 1935, Mao's armies had fought their first major Shaanbei battle at Zhiluozhen, in the hills west of the small county seat. The Red Army's victory there was critical in protecting the Communist soviet to the north. The main road to Yan'an and then on to the Guomindang stronghold in Yulin passed through the county seat, and under the united front both parties sought to keep this vital artery open. In 1938, there were both Communist and Guomindang troops in the county, and for a time the two parties cooperated in the official Resistance Support Committee (Kangdi houyuanhui 抗敌后援会). In these border areas, the Communist strategy was to use antiJapanese organizations to recruit patriotic youth to their cause and undermine local elite domination of the tax and security apparatus. In this case, the chief Communist operatives joined the organization and gradually assumed control. In the countryside, Communist agents challenged the taxing authority of the local baojia. There is little doubt that local elites had used these bodies to enhance their power and enrich themselves, but the border region authorities criticized their own Fu-xian cadres for similar abuses and urged them to moderate their criticism of the Guomindang and to avoid putting their protests in writing. ${ }^{100}$ In the contest for local control, incidents became increasingly violent, with armed occupations, casualties on both sides, arrests, and forced confessions. Finally, in early 1940, Eighth Route Army forces occupied the county, arrested the magistrate, and brought him to Yan'an for trial. Concerned that the incident would break all communication along the road to Yulin, the Guomindang sued for peace, ransomed the return of its magistrate, and, in effect, conceded control of Fu-xian to the Communists. ${ }^{101}$

The Communists presence in Fu-xian was long-standing, and that local base was clearly a factor in their triumph. Eastern Gansu was another matter, and the results were quite different. With the exception of the immediate border with Shaanxi, the Communist regime in eastern Gansu was basically created from the top down by outsiders, primarily Long March survivors from the south. County regimes were established first, then rural districts, and finally village organizations. Since the cadres in charge were outsiders, they were often indiscriminate in their recruitment, and many local scoundrels, thugs, and opportunists found their way into the party. Members of the locally powerful Society of Brothers joined in large numbers when the party, at Mao's direction, treated it as a valuable ally. ${ }^{102}$ Once the united front had been established, the party targeted local military officers and students, neither of which proved to be reliable allies. ${ }^{103}$

A major problem that the party faced in this area was the unusually conservative local population. It was often reported that many of the men still wore the queues of the Qing dynasty and that nearly all of the women had bound feet. ${ }^{104}$ Almost none of the population was literate, so the party could not rely on schoolteachers or students in their local organization. When the Communists started promoting education, one county reported only four hundred students, a mere 
four of whom were girls. ${ }^{105}$ With a population devasted by the Hui Rebellion and natural disasters, land was plentiful, so the Communists' land reform policies had little appeal. What mattered was the exactions of the government, and this often worked to the Communists' disadvantage. With a growing local regime and a substantial army to support, cadres were forced to make significant demands on the population. Since the army, of necessity, supported the local cadres, selfserving corruption was a problem. When war with Japan increased the demand for recruits, coercive conscription prevailed as local cadres worked to fulfill quotas from above. ${ }^{106}$ When the regime required local government cadres to reclaim and cultivate land for their own support, they forced the local population to do the work for them or to provide loans. ${ }^{107}$

A damning report by a senior party official described armed cadres, in uniform and on horseback, carrying out their duties under military escort and acting like an occupying army:

In eastern Gansu, [cadre] work does not stay close to the people, it is opposed to the people. ... Everywhere you look there are coercive orders, arresting and fining people, peculation and corruption. ... [Then citing popular complaints:] "When you go to the people, on matters large and small, you immediately start to demand things." "In solving problems, you listen only to one side, so the people nurse grievances and become bandits." "Some low-level government organs are in the hands of bad people who oppress the poor." "Your methods are coercive: you assess four dou [forty liters], and if people balk you insist on eight. In conscription you ask, "Are you willing to fight the Japanese?" and if they say they are willing, you insist that they become a soldier, without exception. ${ }^{108}$

Following the 1939 Guomindang decision to deal with the "Communist problem," minor incidents mushroomed throughout the area. Since the Guomindang maintained a civil administration in Gansu, the conflict between the two parties typically amounted to competition for provisions between a Guomindang civil administration and the Communists' Eighth Route Army. ${ }^{109}$ Chiang Kai-shek decided that a military regime required a military response: armored cars and artillery were moved into the region. ${ }^{110}$ Along the road that followed the Jing River and connected Xi'an to Ningxia, the Guomindang assembled a force that in the winter of 1939-40 quickly recovered the county seats of Zhengning, Ning, and Zhenyuan Counties. The Society of Brothers sided with the Guomindang, and the Communists withdrew to sparsely populated hills to the north. ${ }^{111}$ Many of the businesses and even the students, who elsewhere were attracted to the Communists' progressive and patriotic appeals, withdrew to the Guomindang areas. ${ }^{12}$ As a result of these "frictions" the Communists lost over half of the population under their control in eastern Gansu. ${ }^{113}$

The biggest blow came in the spring of 1940 in Huan County, in the northwest corner of the border region, a vast and arid county where the population density of 12.7 people per square kilometer was less than one-fourth that of the counties 
along the Jing River. There, as elsewhere in the border region, local Communist and Nationalist authorities competed for control of tax revenues. They also had to deal with local power holders, including Zhao Laowu, whose family dominated a stronghold in the west of the county. The Communists initially tried to work with Zhao, then later targeted him and his local militia as "bandits," but that may have been because Zhao was remarkably successful in turning popular discontent over Communist exactions into opposition to the regime. ${ }^{114}$ In its 1940 offensive, the Nationalist authorities recruited this powerful local magnate to their side. ${ }^{115}$ When Zhao joined the effort to overturn Communist rule in Huan County he attracted support from all sides. One credible report counted 290 Communists in Zhao's local army, including 8o percent of its leadership. ${ }^{116}$ In August, however, Zhao was at his base in Huan County, far from the main Nationalist units along the Jing River. The Communists attacked and flattened his stronghold. ${ }^{117}$ Nonetheless, they had to admit that in Huan-xian "the people [laobaixing] rebelled against us." ${ }^{118}$ The fragility of the east Gansu regime was underlined later when 1,280 former Communists, including a significant number of Long March veterans, published an open letter announcing their defection to the Guomindang. ${ }^{119}$

The net result of these events was a significant loss for the Communists in the south and west of their border region. The Eighth Route Army commander in the area reported the loss of five county seats and forty-three townships. ${ }^{120}$ A 1944 summary of the size of the border region gave even larger and more precise figures: six counties, several thousand townships, a total of 30,640 square kilometers with a population of half a million-roughly a quarter of the area and population of the border region-was lost to the Guomindang in the course of this "friction" between the two parties. ${ }^{121}$ However, as the Guomindang was making major gains in Gansu to the west, the Communists were consolidating a more important position in the east.

Since the late Qing, the northeast had been the economic, political, and cultural center of Shaanbei. Its relative prosperity is indicated by a population density of forty-seven persons per square kilometer, more than four times the figure (eleven per kilometer) in the rest of the border region. ${ }^{122}$ It was the only part of the north with a local elite that included a respectable number of degree-holding gentry. Since the first decades of the Republic, the local warlord, Jing Yuexiu, was stationed in Yulin. In the mid-193os, the Guomindang headquarters leading the assault on the growing Communist movement was based in Suide. The area had the region's best schools, with half the number of students in the entire old border region. Shaanbei's first Communists came out of the middle school that Jing Yuexiu had established in Yulin and the normal school in Suide. In between was Mizhi, with a powerful gentry elite of landlords and Qing degree holders and a strong school system, including the best girls' schools, built up in the republican era. ${ }^{123}$ Though the Communists were active in this area during the united front of the 1920s, they were largely eliminated as the Guomindang and local elites regained control in the 
1930s. When the War of Resistance broke out, the Eighth Route Army established a presence here. Five counties along the Yellow River-Suide, Mizhi, Jia-xian, Wupu, and Qingjian—were designated a garrison area (jingbei qu警备区) for the Eighth Route Army as central government forces moved into Shanxi to fight the Japanese. ${ }^{124}$

Although this area was occupied by Communist troops and the Eighth Route Army was allowed to recruit here, the civil administration remained in Guomindang hands. The key official was He Shaonan, the Shaanbei commissioner based in Suide. His previous experience was in relief work, and in Shaanbei he aggressively sought relief funds from the central government. In his view, distributing relief was the most effective way to counter the appeal of the Communists' land reform policies. ${ }^{125} \mathrm{He}$ also controlled the education system and sent education inspectors to survey the area-an effort that the Communists treated as espionage-and reactivated the local baojia security apparatus. ${ }^{126}$ When the Communists sent activists to organize in the garrison area, He appealed to the central government for military assistance. ${ }^{127}$ There is substantial evidence that He Shaonan was a formidable opponent. Teachers and students were organized in Nationalist Party anti-Communist organizations; Communist defectors were recruited into "special work groups" to expose their former comrades; local security officials disrupted Communist efforts to collect taxes; landlords were encouraged to recover plots lost in the land confiscations of 1935-36; merchants and wealthy peasants were urged not to sell grain to the Eighth Route Army. All the evidence suggests that under He Shaonan the Guomindang was successfully resisting Communist control of the region. The opposition of the strong landlord gentry elite was to be expected, but the fact that the Nationalists were able to mobilize students and young people to their anti-Communist cause was particularly troubling. ${ }^{128}$

All of this changed at the end of 1939. As the Japanese army occupied Taiyuan, capital of neighboring Shanxi, and threatened the Eighth Route Army in that province, Wang Zhen's 359th Division was withdrawn to occupy Suide and allegedly defend the Yellow River. First came 2,700 men, then 5,000, and finally 18,000 crossed into Shaanxi. ${ }^{129}$ There is little doubt that in fact the Communists were compensating for their losses in the poor and distant regions of Gansu to the west by seizing this much richer area along the Yellow River. Indeed, early in 1939, the border region government had proposed a similar exchange to the National Government, explaining that the Gansu counties were far away and difficult to govern. ${ }^{130}$ Now, with the overwhelming military advantage that Wang Zhen's withdrawal brought, the National Government could only protest his troop movements as unauthorized retreat before the enemy, while He Shaonan organized student protests against the fiscal burden of the large Eighth Route Army garrison. ${ }^{131}$ After a series of conflicts between Communist cadres and Guomindang rural functionaries in which each side accused the other of violations, the Eighth Route Army demanded He's removal. When an officer for whom He Shaonan had 
provided a pass was caught allegedly smuggling opium, He was accused of corruption; driven from his post, he set fire to the arsenal on his departure. A replacement was appointed, but he too was driven off, and the area came firmly under Communist control. ${ }^{132}$

Throughout this process, Wang Zhen played a delicate double game. He recognized that some progressive elements in the local elite looked favorably on the Communist regime. The Japanese advance toward the Yellow River had aroused real concern, and the Eighth Route Army was the area's only defense. The Japanese had bombed Yanan in the winter of 1938-39, causing substantial damage but arousing predictable patriotic resolve in the local population. ${ }^{133}$ He Shaonan's aggressively anti-Communist regime had not been popular with all, and, as one CCP official put it, "We have used the gentry opposition to remove him." Needing competent officials to raise funds and run the government, Wang's new team retained some progressive and even "neutral" elements from the old regime. Not all local Communists were comfortable with this: the poor, inexperienced, and ill-educated local activists feared that these members of the old elite were "too capable." "The worker-peasant cadres and the old functionaries and intellectuals cannot work together. The gap between the two is very wide." In rural areas, for tax and security purposes, the Communists made sure they controlled the top of the apparatus, with 80 percent of the district lianbao (联保) heads newly appointed and two-thirds of them party members. On the other hand, 90 percent of the lower-level baojia officials were kept on from the old regime, usually rich peasants or landlords. ${ }^{134}$

By the summer of 1940, the Shaan-Gan-Ning Border Region was attaining its final shape. In July, Zhou Enlai met with Chiang's chief of staff, He Yingqin, in Chongqing and reached basic agreement on the borders that resulted from the year of "friction." Small adjustments were made on the northern and western borders, but the basic shape of the Communist zone was now established. ${ }^{135}$ As in the past, Chiang Kai-shek never formally approved this arrangement, nor did the National Government pass the required legislation, but the agreement held. ${ }^{136}$ The National Government recognized the reality on the ground by establishing a tight blockade around the border region. With Chiang's trusted general Hu Zongnan in charge, a defensive line of blockhouses with six layers of defensive moats and walls, scattered across a perimeter thirty to fifty kilometers wide, was constructed to contain the Communists in their northwestern refuge. ${ }^{137}$ (See map 11 for the agreed-on borders and the Guomindang defensive perimeter.) In the years to come, there would be international criticism of Chiang's use of prime troops to blockade the Communists instead of fighting Japan, ${ }^{138}$ but in 1940 attention had already shifted elsewhere. By the summer, a crisis was brewing over the growing strength of the Communists' New Fourth Army in the Yangzi valley. In January 1941, that controversy would erupt into an incident in which the Guomindang decimated the headquarters battalion of the New Fourth Army. ${ }^{139}$ With the 


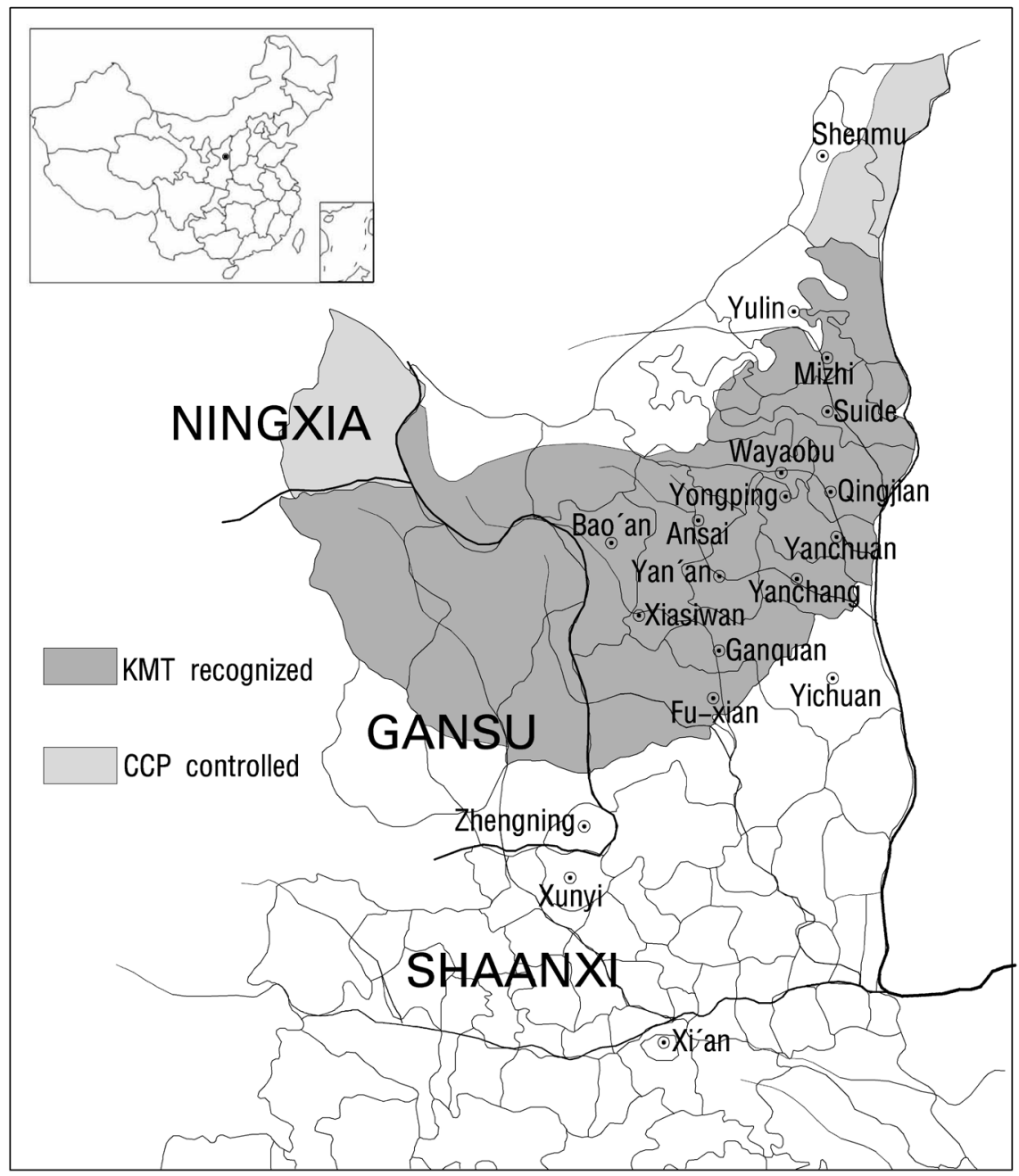

MAP 11. Shaan-Gan-Ning Border Region, July 1940. (Based primarily on He Yingqin to Chiang Kai-shek, July 16, 1940, in MGSL:ZG, 4:227-28.

Communist-Guomindang conflict shifting to other theaters, the shape of the Shaan-Gan-Ning Border Region was now secure-but what was the nature of the new regime within those borders?

\section{THE NEW REGIME}

The Shaan-Gan-Ning Border Region had an area of roughly 130,00o square kilometers and a population of 1.35 million in $1941 .{ }^{140}$ In a nation of some 400 million, this represented about 0.3 percent of China's population. The Shaanbei population 
density of roughly 10 people per square kilometer, compared to a national average of 39.5 , is an indication of the poverty of the region. ${ }^{141}$ Despite the tiny population, small area, and undeniable poverty, the region was hardly uniform, and its internal socio-economic variation was as important as its "backward" reputation. Not only was Shaan-Gan-Ning internally diverse, it also changed rapidly over time. The social and political transformation of the border region has been the subject of much excellent scholarship, and the manifold changes after 1941 are not my concern here. ${ }^{142}$ The subject of this study is the creation of the Shaan-Gan-Ning Border Region, and it is necessary to conclude with a brief sketch of the new regime as it was finally established.

Yan'an, it must be stressed, was a world apart. For all the political and scholarly focus on the locus of the party Center, Yanan was not Shaanbei. Before the Center moved there in 1937, it was a small frontier town, long eclipsed by Yulin and Suide to the east. Throughout the war, Yulin remained in Guomindang hands, and Suide was He Shaonan's base until he was driven off by Wang Zhen. Yan'an became the Communist headquarters by default, and to a large degree it was a blank slate on which the party could draft the contours of its new state. The party was never active there during the long process of revolutionary struggle. In the course of the war against Japan, Yan'an's population increased at least tenfold, with the addition of party cadres, officials, soldiers, and thousands of students who flocked to Resistance University and other schools. ${ }^{143}$ The vast majority of these were outsiders, many educated youth, and there was an obvious gap between them and the local population. As Nym Wales put it: "The North Shensi [Shaanxi] villagers are considered among the most backward in China." ${ }^{144}$ When her husband interviewed a party propaganda specialist, "He tended to despair of doing well in Shensi; the human material seemed far poorer to start with." ${ }^{145}$ Most of the young people who streamed into Yanan would study at one of the schools there. Kangda was the most famous, but its intensive six-month training course first taught Red Army soldiers and only after 1938 included more civilian youths. Nearly all of these were sent for military or support work on the front lines. They came, they studied, and they left for the front. Few had much contact with Shaanbei. For Shaan-Gan-Ning, the Shaanbei Public School (Shaanbei gongxue 陕北公学) was more important. Half of its graduates were posted to the border region. ${ }^{146}$

With its largely outsider population, Yan'an's public face in the early war years fully supported the united front. Slogans painted on walls, portraits of Sun Yat-sen and Chiang Kai-shek, and patriotic propaganda about the need for unity against Japan were an integral part of the Yan'an discourse. Elsewhere the reality was different. According to one Zhidan (formerly Bao'an) County report on the early war years, "As a central area of the Border Region, there is little united front work in Zhidan." It then went on to describe its vigorous suppression of the local "die-hard elements." ${ }^{147}$ Outside of Yan'an, the party was less concerned with preserving the united front than with eliminating its political opponents. It 
was a process that easily overlapped with the everyday public security practices of the state.

Along the borders both north and south, security was always an issue. In many central counties, the courts were largely concerned with civil cases, especially marriage and land disputes. On the borders, however, criminal cases prevailed by a factor of fifteen to one: banditry, gambling, opium cases, theft, assault and flight. ${ }^{148}$ Some of this was a persistence of long-standing patterns. Bandits always thrived in areas where they could flee to the mountains or a neighboring jurisdiction. The soldier-bandits that the Eighth Route Army suppressed in the Huanglong mountains to the south of the border region were certainly of this type. ${ }^{149}$ Others were political opponents, like Zhang Tingzhi in Bao'an or Zhao Laowu in Huan-xian, local magnates who, as we have seen, became opponents of the Communist regime and often sought refuge in neighboring Guomindang territory. Though Liu Zhidan had built his army from bandit gangs and though Communist doctrine had once treated bandits as oppressed peasants whose poverty drove them to criminal activity, once in power the Communists suppressed banditry as vigorously as any government. Bandits, in general, were not popular: peasants regarded them as a scourge, often neer-do-wells who avoided honest work. ${ }^{150}$ It is not surprising, therefore, that the Communists, in effect, politicized the term: painting all of their opponents as bandits and treating banditry in border areas as the work of Guomindang or Japanese agents or the criminal habits of the old society that prevailed beyond the area of Communist control. Warnings against "bandits and traitors" run through the documents of this period. ${ }^{151}$

The change in Communist policy toward the Society of Brothers is particularly notable. The Brothers were hardly a "secret society" in Shaanbei-most people knew who was a member-and the Communists had long appealed to the Brothers. After Mao moved to Bao'an and the Shaan-Gan border, where the society was particularly active, he issued a famous appeal to the Society of Brothers, noting its prominent role in the 1911 Revolution and aid to the Communist movement. He praised Liu Zhidan and Xie Zichang as "exemplary members of the Society of Brothers." The organization's tradition of "striking the rich and aiding the poor" was compared to the Communist program, and Mao promised legal status for the Brothers in the soviet areas and a reception bureau to welcome its leaders. ${ }^{152}$ That was the party's public face. One year later, the party drafted an internal directive on work with the Society of Brothers, now described as having a "strongly conservative, superstitious, feudal, and reactionary character." While the party should continue to court the society and recruit its members in Guomindang areas, within the border region all organizational forms of the society were prohibited in order to "eliminate opportunities for open activities."153

Eliminating the Society of Brothers proved to be a difficult task. In some areas, Brother bands trafficked in opium, now banned in the border region but a common sedative in Shaanbei society. ${ }^{154}$ Far more troubling was the substantial 
number of Brothers in the party. In one district, 115 society members were uncovered, 64 of whom were party members. Even more troubling was the fact that 35 had joined the society after they were already party members. ${ }^{155}$ Another pair of villages had 34 party members, 32 of whom were Brothers. ${ }^{156}$ The second case suggests that the party was recruited from preexisting Brother networks; but the case where many joined the society after they were already party members suggests that the Brothers were more successful at infiltrating the party than vice-versa. In effect, in these initial stages of regime formation, local webs of influence were successfully competing with the party for power in Shaanbei's rural communities.

The most important challenge that the party faced in these first years was creating a reliable rural apparatus. The new regime's local cadres were ordinary peasants who had joined the revolutionary movement, and they included many with undesirable habits. One credible Guomindang intelligence report criticized the gambling and hooligan behavior among county cadres but admitted that rural cadres were disciplined and worked hard for the new regime. ${ }^{157}$ The new regime made significant efforts to eliminate lifestyle practices of which it disapproved. As part of the "anti-traitor" campaign, it particularly targeted gambling, opium sales, and trafficking in women and children. ${ }^{158}$ Before they were displaced, Nationalist Party officials disparaged the CCP's local cadres from the "worker-peasant class: their education is slight and their thinking is simple-minded." ${ }^{59}$ The new party Center would not have disagreed. When the Center arrived, Shaan-Gan-Ning was "originally a backward, ignorant region on the border of three provinces." 160 Returning from the Soviet Union in late 1937 on the same plane with Wang Ming was Chen Yun, who was immediately put in charge of the Organization Department to bring a new level of Leninist discipline and a Stalinist commitment to the principle that "cadres decide everything." 161 In 1939, the Shaan-Gan-Ning Organization Department produced a set of statistics on county and rural cadres: only 2.49 percent had a middle school education, 10.42 percent had some primary education, 45.6 percent knew only enough characters to read a newspaper, and 41.26 percent were illiterate. ${ }^{162}$ These disappointing figures on education levels reflected the history of past recruitment: 71.2 percent had joined the party in 1935-36, mostly as Liu Zhidan's forces surged through the area in $1935 .{ }^{163}$ This was the rural apparatus of poor peasant activists that the new regime inherited and set about to transform.

This apparatus differed from the structures of the old regime in several important respects. It was larger and more successful in penetrating rural society. A recent detailed study of Guomindang rural administration notes that only during the war, and partly to handle such matters as conscription, was the Nationalist apparatus extended to the district (qu) level. ${ }^{164}$ The Communist apparatus extended even closer to the peasants, to the "township" (xiang) and administrative village levels, and cadres down to the township level were salaried and "divorced from production." 165 In the entire border region, there were only 179 districts, but 1,063 townships for a total of $1,242 .{ }^{166}$ This meant, in effect, a sevenfold increase over 
the size of the Guomindang rural administration. In addition, the Guomindang apparatus was self-funded, meaning that the local baozhang (the key tax and security person) kept a portion of the taxes and fees that he collected, so rural functionaries behaved more like independent contractors than employees of the state. When they first took over, especially in the eastern counties with an intact Guomindang apparatus, the Communists simply appointed their cadres in the old apparatus and allowed them to keep a portion of tax receipts for their own expenses. ${ }^{167}$ Throughout the region, rural work was initially ad hoc and even chaotic, a "guerrilla-style of work" with few records or supervision. As Chen Yun's Organization Department took control, the regime set up its own system with "meetings, reports, on-the-spot investigations, work reviews, and a division of labor in leadership." 168

One reason for the larger apparatus was the expanded range of activities of the local administration. The archival record demonstrates a close attention to the following aspects of local work: grain requisition, conscription, "anti-traitor" work, opium suppression, education, literacy, production, cultivation for soldiers' dependents, legal affairs, marriage and divorce, and consumer cooperatives. ${ }^{169}$ The highly progressive tax system and conscription that targeted families with more than one son required close knowledge of individual families and their resources. One local official suggested using popular customs like "dropping in on people" (chuan menzi 串门子) or using kinship relations to become familiar with everything. The key was to combine "public surveys and private visits." ${ }^{170}$ For this sort of work, the party required loyal cadres with good local knowledge, the respect of their community, but above all the ability to produce results. The shift from a local apparatus dominated by landholders with some reputation meant, in the words of one cadre, a shift from service by those with "face" to work by those with the ability to get things done. ${ }^{171}$

The expanded agenda of the new regime made competent rural cadres more important than ever. The largely illiterate party members from the soviet period were often not up to the task, so expanding education was essential. Initially, the party relied on teachers from the old schools, but some had suffered during the revolution and were reluctant to serve, and others were communicating the wrong political message: "In the worst cases, if you ask primary students which is better, the Guomindang or the Communist Party, some say the Guomindang." 172 This was unacceptable. To train a new generation of leaders, an expanded education network was necessary, and every work report recorded progress on this front. The foundation was low, the progress was slow, and setbacks were common. But there was progress. In 1937, there were only 320 primary schools with 1,600 students in the border region. By 1939, there were 890 schools, and in 1941, 1,341 schools with 43,846 students. Conflicts with the Guomindang, the end of the subsidy, and the elimination of smaller schools in isolated villages reduced the number to 723 schools in 1942, with about 30,000 students. ${ }^{173}$ In just five years, the Communists 
had achieved a nearly twentyfold increase in the number of students. Despite the substantial increases, attendance rates were low. In 1939, Gao Gang reported that 90 percent of the population was still illiterate, and only 20 percent of the schoolaged children were in school. ${ }^{174}$ Female participation lagged terribly: in Zhidan only 172 of 845 students (barely 20 percent) were girls. ${ }^{175}$

We should realize, however, that although the Communists' commitment to education and popular literacy was genuine, the immediate need was not an enlightened peasantry but basic literacy and numeracy, the mental tools necessary for administrative cadres and soldiers. Beyond that, education mostly instilled patriotic values, the virtues of the Communist Party, and the basic class consciousness of Marxism-Leninism. Peasants were quite cognizant of these purposes, seeing school as nothing more than preparation for life as a soldier or cadre. As a result, most families resisted sending their children to school. ${ }^{176}$ Peasants understood that learning “is for the sake of the state [gongjia 公家]." School attendance also deprived families of critical farm labor. This was especially true because in Shaanbei, school attendance started very late. In one survey of 115 primary school students, 111 were over the age of thirteen and half were already married. ${ }^{177}$ Rather quickly, however, the regime succeeded in training young people with the skills needed to be a local cadre, and as they were promoted up the ranks, each year a county would send ten or twenty of its functionaries to Yan'an for further study. ${ }^{178}$ Thus was built the apparatus to carry out the program of the new regime.

Communist-style democracy was an important part of this process. In the northeast counties, election participation was very high, averaging around 90 percent, in part because villages competed for representation at the next higher district level, from which tax assessments would come. It was claimed that with this new level of political participation, the quality of cadres improved. ${ }^{179}$ Village elections every six months provided ample opportunity for peasants to assess local leaders, and the high rate of cadre turnover indicates a close attention to selecting men (and they were all men) who could perform the tasks of the party and also work effectively with their peasant constituents. In 1940, Zhidan County reported that twelve of thirty-eight local cadres had been removed; and in the first two years, 70-80 percent were either promoted or demoted. ${ }^{180}$ In Suide, fifty of fiftyeight were reassigned. ${ }^{181}$ Statistics for the entire border region indicate that among cadres at the district level and above, 1,354 were promoted and 5,612 attended various types of training sessions. ${ }^{182}$ The party made sure that it was attentive to popular sentiment, so work reports routinely included a section on popular complaints (guaihua 怪话), and there is every indication that future work and cadre assessment took account of these complaints. ${ }^{183}$ In the Organization Department cadre statistics, of 1,316 purged from the party, 301 dismissals (23 percent) were for "not working," 204 (15 percent) were for corruption, and 93 (7 percent) were for gambling or opium. ${ }^{184}$ One abuse that the party was determined to eliminate was cadres taking married women as second wives, a practice that was strictly prohibited 
TABLE 2 Tax burden of new regime

\begin{tabular}{|c|c|c|c|c|c|}
\hline & 1937 & 1938 & 1939 & 1940 & 1941 \\
\hline Administrative and army personnel & 14,000 & 16,000 & 49,000 & 61,000 & 73,000 \\
\hline External support: percent of budget & & 50.6 & 85.8 & 74.7 & \\
\hline Grain tax $(\text { dan 石 })^{\mathrm{a}}$ & 14,000 & 15,000 & 60,000 & 100,000 & 200,000 \\
\hline Grain tax as percent of harvest & 1.28 & $1.27^{\mathrm{b}}$ & $4.72^{\mathrm{b}}$ & $7.35^{\mathrm{b}}$ & 13.8 \\
\hline
\end{tabular}

a One dan $=300$ jin = ca. 150 kilograms.

${ }^{\mathrm{b}}$ Percentage assumes uniform increase in harvest between 1937 and 1941.

SOURCE: Li Weihan, Huiyi yu yanjiu, 2:500-501.

"to eliminate popular discontent."185 Obviously, such statistics can be interpreted in different ways. On the one hand, they show significant abuse by Communist cadres. On the other hand, they indicate that people were objecting to such abuse and the party was responding.

In an area with no experience in democratic governance, the party struggled to establish its own definition of "democracy." With democracy promoted as an alternative to the old regime's arbitrary ways, many understood democracy to mean doing as one wished. Peasants used "democracy" as a reason for resisting taxes. Wang Zhen confronted such complaints in the northeast, where people protested, "If you are going to issue orders, why talk about democracy? You speak about democracy, but you still send down directives." Others made the familiar complaint that Communist democracy involved too many annoying meetings: with orders from above and resistance below, it was difficult to get anything done. The pressure on cadres was particularly great: meeting the demands of the state meant imposing burdens on friends and neighbors. Fear of offending people was the most common reason for avoiding cadre work. ${ }^{186}$

Naturally, the strongest complaints were against the growing burden of the new regime. When the Yan'an regime was established in the wake of the Xian Incident, the small local apparatus, substantial National Government subsidy, and heavy reliance on "guerrilla-style" demands on the wealthy kept extractions from the local population to a minimum; but all these factors changed in the following years. As detailed in table 2, the number of administrative and military personnel "divorced from production" increased dramatically when Wang Zhen's troops were recalled to the northeast. Then the National Government subsidy was halted in July 1940. With these changes, the tax burden on the border region population increased dramatically.

To meet the deficit and generate hard currency to buy medicine and essential supplies from Guomindang areas, the government required peasants to use their draft animals to transport salt from the fields in the far north to the Guomindang areas in the south. The loss of time in the fields and injury to draft animals on the long journey made it an extremely unpopular policy. ${ }^{187}$ Unsurprisingly, 
complaints quickly followed: "When you harvest chives, you need to wait a few days before you cut again. Now the burdens come more rapidly than the harvesting of chives. We haven't finished paying the grain requisition and then comes the borrowing for salt transport. We haven't finished paying these 'loans' and there comes a call for shares for cooperatives, savings certificates, education, grain, and expenses. Before these are collected it is time for the second collection of salt transport loans." 188

There were many complaints against coercive behavior by the army. The demands of the war brought conscription with an intensity never before seen in Shaanbei. In 1938, the recruitment plan called for five thousand soldiers in two months, equivalent to the entire Shaanbei Red Army before the arrival of the Long March. ${ }^{189}$ Women were naturally anxious about losing sons and husbands to the army, beloved family members and vital workers in the fields. They were targeted to assist in recruitment-presumably urging women not to resist losing their sons and husbands. In January 1939, border region chairman Lin Boqu reported that thirty thousand men had been mobilized for the front, half of whom had come from the local self-defense forces, which served as a feeder for the regular army. ${ }^{190}$ Every county had its local quota, and local cadres scoured the villages for recruits. The process was supposed to rely on persuasion, but there were many reports of coercion and beatings of those who resisted. ${ }^{191}$ Local work reports suggest that desertion was a major problem, and the use of force in capturing AWOL soldiers seems to have been more common than with conscription. In 1940, Zhidan County reported that 182 deserters had been returned to the army, which represented almost half of their total recruits. Another county reported the "not small" cost of an operation that had caught 156 deserters but caused others to flee, some of whom were killed in pursuit. ${ }^{192}$

In handling complaints about the policies of the new regime, there was a distinct difference between the old soviet areas and the former garrison areas that Wang Zhen occupied in 1940. These differences reflected the enduring contrast between the poor and sparsely populated region west and south of Yan'an and the wealthier, better-educated northeast with its powerful gentry elite. In the former soviet areas, people were generally willing to accept the demands of the new state as long as they were fair (gongping 公平). ${ }^{193}$ In the area around Suide in the east, skeptical landlord and pro-Guomindang elites posed a greater challenge. When Wang Zhen took control of the area, he allied with progressive members of the local elite to isolate and expel the Guomindang commissioner, He Shaonan. In 1940, competent progressive or "neutral" elements from the old regime were needed for technical work: accounting, tax collection, forestry, water control, and economic development. Local Communists were skeptical about working with these more competent elites. Initially, routine work was carried out by personnel from Wang's 359th Division, but the long-term solution involved developing local cadres who could work with the old elite and gradually replace them. 
As elsewhere in the border region, elections in the northeastern "garrison area" were an important part of the legitimation process, but the 1941 elections were different from those of 1937. As usual, the party prepared carefully and even delayed the elections to complete their propaganda work. ${ }^{194}$ The results of the election were generally positive, especially in the scattered areas where the party had carried out land reform during the soviet period. Here complaints mostly concerned the distribution of the tax burden, and assembly discussions were lively. The authorities were pleased that after the elections and the open airing of grievances, the quality of local cadres improved, and some were removed. The most striking differences were in the county assemblies. Recall that in the 1937 elections, the party's domination of the assemblies was absolute. Now in Mizhi there were intense debates between Nationalist and Communist representatives in the county assembly. ${ }^{195}$ As the border region expanded to include wealthier regions of the northeast with their entrenched gentry elites, the united front took a new form. In the west, local strongmen like Zhang Tingzhi would be attacked and eliminated as "bandits." In the counties around Mizhi and Suide, the party worked with the educated and technically competent members of the elite that it deemed progressive. Soon there would be new elections for the border region assembly, and some of these progressive educated elites would join the assembly in Yan'an. One of the most prominent was Li Dingming, a local educator, Chinese medicine practitioner, and cousin of the Nationalist general Du Yuming. In Yan'an, Li was elected vice-chair of the border region and became one of the foremost exemplars of the Communist united front policies. In the fiscal crisis of 1942, he proposed the policy of "crack troops and simple administration" (jingbing jianzheng 精兵简政), which became a signature example of frugal wartime administration. ${ }^{196}$

With the inclusion of the northeast "garrison area" within the Shaan-Gan-Ning Border Region, the Communists not only added a richer area to support their army and administration, and a better-educated population to provide cadres to enhance their rule, they also added an area with a social structure that more closely resembled the rest of North China. The original soviet on the ShaanxiGansu border was a sparsely settled land of small and widely dispersed villages, largely populated by recent migrants with weak lineage structures. Always poor, it had never fully recovered from the devastation of the Muslim Rebellion. A land of bandits and militia bands whose tightest social glue was the Society of Brothers, it provided a fertile breeding ground for Liu Zhidan's guerrilla forces. Here the party Center built its base, first in Liu's home county in Bao'an and along the Gansu border, then in Yan'an following the Xian Incident. But it was only with the incorporation of the garrison area around Suide that Shaan-Gan-Ning achieved its final form. And it was only with that addition that the party learned to confront, include, and control the kinds of local elites that they would soon encounter in Shanxi and North China generally. 
The addition of the garrison area also exposed another aspect of the Yan'an era. The northeast had been the site of the earliest growth of the Communist movement in Shaanxi, especially in Yulin Middle School and Suide Normal, where the founders of the Shaanxi party had taught, and in the well-developed school system of Mizhi. In that early stage of the movement, the leftist agenda stressed a general assault on conservative authoritarian principles in education and patriarchy in gender relations. As we have seen in chapter 2, allowing young women a more visible and public role-walking the streets to school, cutting their hair, and wearing skirts-was an important part of this movement, to the extent that more political elements of the party complained that students were "drunk with maudlin poetry and thoughts of love." 197 In its advocacy of education for women and free choice in marriage, Shaanxi's early Communist movement embraced the ideals of the May Fourth Movement. But gender was always a sensitive flash point of the Chinese revolution, and just as the modest reforms of the 1920 incited conservative reproach, the 1939 attack by hostile Shaanbei local elites included the charge that traditional gender norms were threatened by young men and women mixing in Yan'an, where "free love" was allegedly practiced and VD spread unchecked. ${ }^{198}$ Yan'an, of course, was a world apart, with a gender ratio of eight males to each female in the early 1940s, and a relatively relaxed attitude toward extramarital sex. ${ }^{199}$ Gender relations in the Shaan-Gan-Ning Border region as a whole were governed by a different dynamic.

The judgment of most past scholarship has been that the relatively conservative values of Shaanbei caused a retreat in commitment to women's rights when the party Center moved to Shaanbei. ${ }^{200}$ Ding Ling, with her famous 1942 essay on International Women's Day, certainly felt that the party had compromised its early commitment to gender equality. ${ }^{201}$ But with power firmly in the hands of the Long March veterans, Shaanbei was hardly responsible for the shift. The party's military priorities were more important. The founding of the Shaanbei soviet was largely a process of military conquest, and the establishment of the new regime was predicated on secure military control. In the south, some women had joined the army, and the Long March included a women's regiment; but those women became part of the disastrous Western Expedition where most were killed and those captured were married off to the local Muslim population. ${ }^{202}$ None reached Shaanbei. In Shaanbei, women mostly served a male military: encouraging their men to join the army (or at least not discouraging them), making shoes and socks for the soldiers, sometimes washing and darning their clothes. Women could not divorce husbands in the army, and the regime attempted (with some success) to ensure that they received help to cultivate their fields. ${ }^{203}$ Within the army, the sexual abuse and even rape of women was certainly less common than in warlord forces, but it did occur, and, as we have seen, such particularly valuable political officers as Gao Gang were only lightly punished for their transgressions. Perhaps the most notable measure of the party's priorities was the care it displayed for the conjugal needs of army officers. Eighth Route Army regulations stipulated that 
only regimental officers twenty-eight years or older with five years' party membership were permitted to marry. ${ }^{204}$ The policy clearly favored senior officers, and there are numerous accounts of Long March veterans, including Mao himself, discarding their peasant wives in favor of the young women who flocked to Yan'an during the war. ${ }^{205}$

As elsewhere in Asia, the earliest stages of the Chinese revolutionary movement were supported by an international group of professional revolutionaries who found that the best way to avoid colonial intelligence services was to travel first class. ${ }^{206}$ When Mao and other Communists formed their soviet bases in China's rural hinterland, the Communist movement moved to a new stage. Now simple living in harsh circumstances became the rule. In some respects, these conditions prevailed in Yan'an as well, for Shaanbei was poor even by the standards of the southern soviets. For the young people who flocked to Yan'an during the war against Japan, dirt caves and meatless meals were part of its appeal. In Shaanbei, simple living, meagre government salaries, and egalitarian poverty were the rule-and part of what distinguished the Communists from the Nationalist Party. This dedicated life of undifferentiated patriotic poverty was fundamental to Yan'an's identity as a revolutionary holy land. The one area where a clear hierarchy prevailed was in access to women. As the leftist intellectual Wang Shiwei noted to his peril, the highly skewed maleto-female ratio made access to the young women of Yan'an a significant source of tension. ${ }^{207}$ In this context, the party guaranteed its favored leaders preferential access to sex. They had endured years of military conflict, and the top leaders had survived the harrowing Long March retreat. Now at last they were safe and secure in Yan'an. They deserved a young female companion for a good night's sleep.

Beyond the special circumstances of Yan'an, this policy limiting marriage to the army's top leaders had its greatest impact in the northeast. There is a favorite rhyme in Shaanbei, describing the special features for which the eastern counties were famous: "The girls of Mizhi, the guys of Suide; millstones from Qingjian, coal from Wayaobu." It is not clear how old this ditty is, nor what exactly recommended the women of Mizhi, but it is certainly true that in the republican era, the county had the best girls' schools in Shaanbei. This advantage carried into the Communist era. Indeed, it seems to have increased, with the number of boys in school falling while the number of girls rose. The reason: education improved their chances of a favorable marriage. ${ }^{208}$ The report does not say whom they were marrying, but Mizhi is also called "father-inlaw's county" (zhangren xian 丈人县) because of the large number of Eighth Route Army officers who found a bride there. ${ }^{209}$ So the progressive promotion of female education in the northeast ended up serving the revolution in new and unexpected ways. Women's education, in the end, provided wives for the army.

In 1937, the American reporter Nym Wales (the pen name for Helen Foster Snow) visited Yan'an. She spent most of her time interviewing the Communist leadership, and her brief sketches of the leaders would, for the first time, introduce them to the 
world. An appendix to her book includes capsule biographies of seventy Chinese Communist leaders. None is from Shaanxi. ${ }^{210}$ She met with all the top leaders, and they in turn suggested others whom she might interview. She was the wife of Edgar Snow, whose Red Star Over China would soon carry Mao's and the Communist movement's story to the world. But the Communist leadership in Yan'an did not introduce her to a single Communist from Shaanbei. Theirs was a new regime of Long March survivors, and "The Kiangsi [Jiangxi] veterans of the Long March were already beings apart from mortal men." 211

Once the War of Resistance broke out, Shaan-Gan-Ning became the Communist rear base, safely removed from the front lines, and Yan'an would be the new center. We have seen the process whereby the borders of the region would be defined in "friction" and armed conflict with the Guomindang, and a local regime would be established, largely from the top down, with critical assistance from the army, especially in Gansu and the northeastern counties occupied by Wang Zhen. To consolidate local control, to build and discipline a local apparatus, it was necessary to turn to local men. By and large, these were not the guerrilla fighters, poor peasants, former bandits, or Society of Brothers leaders who formed the core of Liu Zhidan's Red Army. They were usually men of some education, though typically only at the middle school level, who rose as party organizers or soviet administrators. In the Guanzhong district in the south of the border region, Xi Zhongxun, father of China's current leader, was appointed. From a prosperous family of nearby Fuping, he had joined the party at age fourteen while in middle school in Sanyuan and had considerable experience as an administrator of the local soviet. ${ }^{212}$ In eastern Gansu, Ma Wenrui was the local representative. Ma had joined the party in middle school in Mizhi at age sixteen and been active in the party ever since, often working as a village schoolteacher for cover. In 1938, after brief study in Yan'an, he was sent to Gansu, where he served for seven years. ${ }^{213}$ Liu Zhidan's brother, Liu Jingfan, held ministerial and key secretarial positions in the border region government. ${ }^{214}$ All of these were local men, with some education, and longtime party members who could link the party Center to the local environment. None, however, ever achieved national prominence.

Among the Shaanbei revolutionaries, only Gao Gang rose to membership in the ruling Politburo. An incident from 1940 provides a poignant indication that Gao's status was comparable to that of the Long March survivors. He had just divorced his first wife by an arranged marriage, a local girl whose bound feet were inappropriate for the wife of a rising party leader. He had eyes for a nineteenyear-old normal school student from Jiangsu who had joined the tide of progressive patriots who poured into Yan'an. The party arranged for her to work in his office, then Mao Zedong invited her to dinner with Gao and others, praising Gao's various qualities. She understood the message well enough but had no interest in marriage and feared Gao's fierce temperament. Several days later, another group of party leaders, including Xi Zhongxun, invited her and Gao Gang to a wedding 
banquet. As she recalled the moment years later: "When I heard this, I ran away as fast as I could, ran to the bank of the Yan River. But Wang Ruofei [party elder, then in the central secretariat] found me and said, 'You've studied party-building haven't you? Party members must obey the party. This has been arranged by the party. . . . Just like that, we were married, without any emotion, without a day of love. After we were married, for half a year, Gao Gang wouldn't let me go into town. He was afraid I'd look for my old schoolmates." 215 This was how the party took care of its leaders, and the incident speaks volumes to Mao's regard for this rising son of Shaanbei and the party's treatment of young women as suitable rewards for favored older men.

In 1945, Mao was quite explicit about his thinking-though the gender relations implied by the forced marriage were of no concern to him. Speaking at the Seventh Party Congress, he discussed the importance of paying attention to different groups, which he called "mountain-tops" (shantou 山头), within the party. "When we first came to Shaanbei, we ignored this problem. This border region was built up by Gao Gang and the others by themselves. Because we did not handle this [mountain-top] problem well, some people in Shaanbei started to gossip. Some people said, 'Shaanbei people can only establish a soviet, they can't build a Red Army'. In response, the locals said: 'You marched a long way, but you lost your base, the Jiangxi soviet is no more. We didn't march, but we still have a base in Shaanbei." 216 The gulf separating southern Long March leaders from the Shaanbei revolutionaries could hardly have been clearer. For Mao, the way to bridge this gulf was to cultivate Gao Gang as the representative of the Shaanbei revolution.

Mao stayed in Yan'an until a Nationalist offensive in 1947 drove him from his wartime capital. For the next year, Mao and a small group of leaders hid and marched through the hills of Shaanbei in a much-lauded episode known as "fighting in circles through Shaanbei” (zhuanzhan Shaanbei 转战陕北). Though the enemy was often close on Mao's heels, his location was never revealed. ${ }^{217}$ When he finally crossed the Yellow River a year later, a story popular in the region has him looking back and saying, "Shaanbei is a good place!" There is no evidence that he ever said or even harbored such fond thoughts of the land that had protected him through the long war. After leaving Shaanbei, he would live almost thirty more years, ruling China for most of that period. He never returned to Yan'an. 


\section{Conclusion}

In 1935, Shaanbei was China's last remaining soviet. The rural revolution did not begin there. Long before Liu Zhidan organized his first guerilla bands along the Shaanxi-Gansu border, Mao Zedong was building his revolutionary movement in southern Jiangxi. At its greatest extent in 1933, the Jiangxi soviet was larger, richer, and more populous than Shaan-Gan-Ning, even at its final size. Important aspects of the Communist revolutionary strategy-land reform, class struggle, guerilla warfare, the mass line-were first developed in Jiangxi. ${ }^{1}$ In addition to Mao's Central Soviet, there were several smaller soviets in the hills of the Yangzi valley. But all these soviets failed while the Shaanbei soviet survived. Moreover, the Central Soviet in Jiangxi was not uniquely linked to Mao's leadership. After 1931, Mao Zedong was often in eclipse-his leadership in Jiangxi replaced by the party's Moscow-trained "Internationalist" wing. Mao returned to a leading position during the Long March, and by the time Edgar Snow interviewed him in Bao'an, he was clearly recognized as the leader of the party. Later, in Yan'an, Mao wrote the major essays of Mao Zedong Thought, worked out the strategy of the united front, successfully combined patriotic resistance to Japan with a class-based program to mobilize the poor, promoted self-sufficient development of a backward economy, and developed a model of party rectification that could discipline party members without destroying individual initiative. The Mao era began in Yanan.

Only an accident of history made Shaanbei, and eventually Yan'an, the end point of the Long March and the wartime Communist Center. When the Red Army set out from Jiangxi, its destination was one of the other soviets to the west. Only after it failed to reach He Long's base in western Hunan and then broke with Zhang Guotao in Sichuan did Mao's column continue north with the intent of reaching the Soviet border to recuperate and receive assistance from the Communist International. The chance discovery of a newspaper report on Liu Zhidan's soviet in Shaanbei rerouted the march in that direction. The historian embarks at some peril on counter-factual considerations of "if history," but it is important to 
acknowledge that there would have been no "Yan'an era" and the course of history would have been quite different if Mao had continued to the Soviet border.

As we know, Mao did not reach the Soviet (or Mongolian) border, and he did find refuge in the soviet that Liu Zhidan and his colleagues had so painfully built in Shaanbei. How that soviet was established is the subject of this book. We began our inquiry with a longue durée examination of the local history and geography of Shaanbei. An important theme was the manner in which local social structures were transformed by events whose origin lay elsewhere. This is a reminder that local history must not focus exclusively on the local: microhistory sometimes requires a macro lens. During the Ming dynasty, the court's decision to construct and garrison the Great Wall across Shaanbei imposed significant burdens on the local economy and was one factor sparking the rebellions that led Shaanbei's Li Zicheng to topple the dynasty in Beijing. That act brought the Manchus into the fray, and their Qing dynasty added Mongols to the ruling coalition, eliminating the need for the wall and introducing an era in which trade with Inner Mongolia in hides, fur, and horses brought two centuries of border peace to Shaanbei. In the mid-nineteenth century, the Sino-Muslim (Hui) Uprising began in the Wei River valley but was itself sparked by an incursion of Taiping rebels from the south. When the Hui were driven west into Gansu, they repeatedly sought to return to their homeland, bringing warfare and devastation to Shaanbei, especially along the Shaanxi-Gansu border and the region west and south of Yan'an. The result was a new socio-economic structure in Shaanbei with a more stable, developed political and cultural center in the northeast and a sparsely populated, migrantsettled, bandit-ridden, and militarized region along the Shaanxi-Gansu border and south of Yan'an. As a result of the Muslim Rebellion and the natural disasters that followed, Shaanbei entered the twentieth century with a new and highly unstable social ecology. The schools of the northeast nourished the early Communist Party, and the bandit-ridden Shaan-Gan border provided fertile grounds for a guerrilla movement.

After the Qing dynasty fell in 1911, political and economic conditions in the Northwest continued to deteriorate. Zuo Zongtang's suppression of the Muslim Rebellion in the 1870 s brought an army full of the Society of Brothers (Gelaohui). From that point forward, the Brothers were a powerful force in Shaanxi society, especially in its military. When the 1911 Revolution toppled the Qing, the Society of Brothers took the lead in Shaanxi, massacring Manchus in Xian and expanding their influence in many Shaanbei counties. Most observers attribute the spread of petty warlords and the rise of banditry to the influence of the Society of Brothers in 1911 and the new Republic's vast expansion of the military. There was also a larger process. As Kenneth Pomeranz has argued, the modernizing state concentrated attention and resources in the coastal regions where the return on state and private investment was greatest. As a result, interior regions with underdeveloped transport were left behind and a new hinterland was created. ${ }^{2}$ Shaanxi 
was unquestionably such a region. While Xian had been China's capital and Guanzhong its cultural center in the ancient period, modern-day Shaanxi was a backwater.

As elsewhere in China, Shaanxi's Communist Party was founded by intellectuals. Its first members studied in the political and cultural center of Beijing, attracted by the New Culture movement's opposition to Confucian society's patriarchal strictures, which fed their hopes for a future of freedom and democracy. They participated in the patriotic May 4 demonstrations against the Versailles Treaty and its acquiescence to the Japanese occupation in Shandong. While inspired by new intellectual and cultural trends in the coastal cities, they were dismayed by the "backward" warlord-dominated and bandit-ridden state of their native province. They conceived their mission as a movement of enlightened teachers and students struggling against the "armed class" whose internecine warfare obstructed the modernization of their homeland. Gradually some of these radical intellectuals coalesced to form a local Communist branch, which was little more than a loose group of teachers and students until the united front with the Nationalist Party linked their efforts to Sun Yat-sen's national revolutionary agenda. Even then, their movement was largely school based until the "Christian general" Feng Yuxiang returned from Moscow with Soviet arms, advisers, and military support for the Nationalist cause. In 1927, a brief flurry of radical activity and student-led peasant organizing came to a sudden halt when Chiang Kai-shek turned against the Communists, and Feng Yuxiang joined Chiang's new regime. In Shaanxi, however, Feng never followed Chiang's policy of mass executions, instead escorting Communists from the province. Some of his officers retained warm memories of the united front and welcomed their former comrades' return during the War of Resistance against Japan.

Following the collapse of the 1924-27 united front, there were two faces of the Communist Party in Shaanxi. One by one, the senior Beijing-trained intellectuals who had led the party were arrested, killed, or expelled for the "right opportunist" error of collaborating with the Guomindang. They were replaced in the Xian provincial committee by a new breed of young Bolsheviks whose financial dependence on the party Center made them loyal followers of the Communist International's left line. They sought to build a proletarian party in Shaanxi's tiny working class and to promote land reform in the surrounding countryside. While Bolsheviks dominated the party apparatus, the real work of revolution was done by guerrilla bands led by two men, Liu Zhidan from Bao'an on the Gansu border and Xie Zichang from Anding in the northeast, who both cooperated and competed to make revolution in the north. Liu Zhidan in particular built his guerrilla army from bandits, ex-soldiers, members of the Society of Brothers, and militia members-rootless young men willing to fight in the rough conditions of the northern hills. At times, their actions were little different from banditry: kidnapping for ransom, dividing the loot, attacking weak and isolated targets, and refusing to give up their opium addiction. 
As the guerrilla forces grew in strength, the Bolsheviks in Xi'an intensified their efforts to bring them under party discipline. The Shanghai Center pressed the local party to lead the guerrillas out of the hills, carry out land reform, and build a rural soviet on the rich and densely populated plains north of the Wei River. When the guerrillas resisted these impractical policies, the Center accused the Shaanxi party of succumbing to a theory of "northern backwardness" that saw land reform and rural soviets appropriate only in the more developed south. Briefly in 1933, the party established a base in the hills north of Sanyuan. It was led by elite families who had joined the party during the united front, but the fractious strongmen who provided the military muscle soon fell out with the party's leftist leaders, and the whole effort collapsed. This failure was quickly followed by other setbacks. The Xi'an Bolsheviks dispatched Liu Zhidan's guerrillas, now organized as the TwentySixth Army, to disastrous defeat in unfamiliar territory south of the Wei. Then the Guomindang authorities arrested the leaders of the party apparatus and through a combination of torture and enticement induced them to defect, then dismantled the party in and around Xian. It was a major loss for the Communists, but it liberated the guerrillas from impractical party direction.

With the Bolsheviks and the provincial committee temporarily out of the picture, Liu Zhidan's guerrilla movement was free to chart its own course, unconstrained by party dogma. Liu recruited widely among bandits, ex-soldiers, and local military units and sought contacts with sympathetic members of the provincial administration and leftists in Xian. In building his movement, he paid little attention to land reform or party-building but appealed to the growing patriotic resistance to Japanese aggression. When Japan occupied Northeast China (Manchuria) in 1931, the Communist Party treated the aggression as a threat to the socialist motherland and called for the "armed defense of the Soviet Union." It regarded anti-Japanese agitation as a distraction from the larger goal of antiimperialism targeting all capitalist powers. As a result, in the early 1930s, the party gained little from the growing anti-Japanese movement. By 1934, however, Liu Zhidan was able to appeal to anti-Japanese sentiment in the military, and several units joined his movement as Anti-Japanese Volunteers.

Liu's new strategy did not go unchallenged. In December 1933, Xie Zichang returned to revive the guerrilla movement in Anding, his home county in northeastern Shaanxi. The northeast had the most developed education system in Shaanbei, and the Communists had established a party network based in rural schools-a clear contrast to Liu's guerrilla-based revolution in the west. Xie also came with the imprimatur of the party apparatus, and the party representatives who joined him carried letters from the party Center critical of Liu's "right opportunism," "peasant consciousness," and error of fleeing to the hills rather than establishing and defending a soviet regime. These criticisms reflected an ongoing conflict between the "Shaan-Gan" and "Shaanbei" wings of the north Shaanxi party, a conflict that combined personal rivalry of the two leaders, the fact that 
"Shaan-Gan" reported to Xi'an while "Shaanbei" reported to Beijing, and, perhaps most importantly, the guerrilla-based approach of Liu Zhidan versus the schoolbased party of the northeast.

Despite these differences, the two wings of the party were able to establish a joint command in the summer of 1934, and much more effective cooperation after Xie was mortally wounded in the fall. As Xie Zichang clung to life in the winter of 1934, Liu Zhidan shifted his operations to the east, where he had the support of a strong rural apparatus in Communist-dominated villages. When Xie died in February 1935 , Liu was able to combine his military power with a rural party organization to launch an unprecedented string of military assaults in the summer of 1935 in which six counties briefly fell to his Twenty-Sixth Army. Before 1935, Liu's guerrillas had targeted only rural strongmen, local militia, or weakly defended towns. Now he was able to take county seats and seize their munitions and treasure. Inevitably, his success attracted the central government's attention. By this time, Chiang Kai-shek had driven the Communists from their bases in the Yangzi valley and was able to send reinforcements to Shaanbei. But these troops were unaccustomed to guerrilla warfare in the hills of Shaanxi and suffered defeat with significant loss of weapons to the enemy. More forces were dispatched from neighboring Shanxi with the same result.

As happened so often in the course of the Shaanbei revolution, success was rewarded with self-inflicted wounds. Soon after Liu Zhidan's string of military victories, his forces were joined by Xu Haidong's Twenty-Fifth Army from the failed Hubei-Henan-Anhui Soviet. That soviet had been the site of a bloody purge of alleged counter-revolutionaries, and the same men who had led this sufan campaign in the south brought their techniques to Shaanbei. There they aligned with representatives from the party Center to target Liu Zhidan and his deputies. The campaign was delayed long enough for one final battle against the Guomindang forces, a battle in which Xu Haidong, now in command, put Liu's army on the front line, where it suffered serious casualties. Immediately after this battle, Liu and dozens of his top deputies were imprisoned, including the later Politburo member Gao Gang and Xi Zhongxun, father of China's current president and CCP general secretary, $\mathrm{Xi}$ Jinping. The purge soon spread to the localities, where two hundred allegedly died, provoking a reaction to Communist rule in which peasants in Liu's homeland turned against the party. The whole episode was brought to a close only when Mao's column of the Red Army arrived in Shaanbei and called an end to the purge.

When Mao headed north from Sichuan, his objective was not the Shaanbei soviet. Mao intended to fight his way to the Soviet border to recuperate and receive assistance from its Red Army. It was only when he learned of Liu Zhidan's soviet in Shaanbei that the Long March was pointed in that direction. Upon arrival in Shaanbei, Mao was bitterly disappointed. The area's poverty and sparse population convinced him that it could not support a large army, and preparations began immediately to move on. When this foray eastward through Shanxi was 
blocked, the defeated force retreated to Bao'an to prepare a second approach to the Mongolian border through Ningxia. When this too proved impossible, the Red Army was forced to stay in Shaanbei. The Yan'an era, consequently, was the product of historical exigency, not any design of Mao or the party Center.

Even before the advance into Shanxi, the Center received an emissary from Moscow, bringing word of the Comintern's new united front policy. From that point forward, Mao embarked on a multi-stranded search for allies to protect his army from attack and bring together a united front against Japan. He reached out to both Chiang Kai-shek and his rivals in the Guomindang and had the greatest success with the Northeast Army of Zhang Xueliang, many of whose officers preferred to fight the Japanese occupiers of their homeland rather than the Communists in the hills of Shaanbei. Through Edgar Snow, who interviewed Mao at length in Bao'an, he addressed an international audience and also reached young Chinese who read translated copies of Snow's interviews and his upbeat account of the Red areas. In the end, only the overtures to Zhang Xueliang and to Yang Hucheng's Northwest Army proved effective, resulting in the kidnapping of Chiang Kai-shek in the December 1936 Xi'an Incident. This ended Chiang's military offensive against the Communists and brought crucial financial assistance for the Red Army, but it hardly settled the status of the Shaan-Gan-Ning Border Region.

The Xian Incident represented a turning point in Communist-Guomindang relations, but tough negotiations remained to establish the terms of the united front. The Communists had expected Zhang Xueliang and Yang Hucheng to stay in charge in Shaanxi and protect them from a hostile Nanjing regime. But Zhang Xueliang left Xi'an for a lifetime of house arrest, and Yang Hucheng was quickly deprived of command and sent abroad. Chiang Kai-shek's appointees took charge in Xi'an, and the Communists were now more isolated than ever. Still, Chiang held to his promise to halt the civil war, and in the negotiations that followed, the key sticking point was the degree of independence of the Red Army (soon to be incorporated into the national armed forces as the Eighth Route Army) and the Shaan-Gan-Ning Border Region. Even the July 1937 outbreak of the War of Resistance against Japan failed to break the stalemate, and final agreement was not reached until the fall. By that time, Chiang's forces had been driven from their capital in Nanjing (followed by a horrific massacre), had suffered major defeats in the Lower Yangzi and retreated to the Central China city of Wuhan. On the positive side, Chiang's government reached agreement with Moscow on a Sino-Soviet Non-Aggression Treaty, which was soon followed by a package of military aid that made the Soviet Union China's most reliable ally in the early years of the war. With Stalin now firmly committed to the wartime legitimacy of the Guomindang government, the two Chinese parties came to agreement on the incorporation of the Communist forces into the national army and the acceptance of a separate Communist regime in Yan'an-though the national government never officially ratified the autonomy of the Shaan-Gan-Ning Border Region. 
Through the early years of the war, both the size and the status of Shaan-GanNing remained undetermined. Though the Guomindang withdrew its military forces, most of the areas in eastern Gansu and along the Yellow River in the east were designated garrison areas and recruitment zones for the Eighth Route Army. They were not yet part of the border region. In these areas, and also in Yanan and other towns, the Guomindang still appointed magistrates, dispersed relief funds, surveyed education, and maintained at least a shadow regime. To enhance the legitimacy of their border region, the Communists held carefully controlled elections at the village, district, and county levels in which the party inevitably emerged victorious but was able to claim the democratic support of the people. At the same time, security forces were deployed to eliminate "bandits", a category that included both the habitual bandits that had long plagued the region and local strongmen and militia leaders who challenged the Communists" monopoly of "the legitimate use of physical force."

By 1939, the Communists were making significant advances to expand their influence behind Japanese lines in the east. In response, the Guomindang took firm measures to check its Communist rivals. In the Northwest, that involved asserting central government authority, both fiscal and military, in contested regions along the Shaan-Gan-Ning borders. "Friction" between Communist and Guomindang forces flared up until the Guomindang launched a major operation to recover lost territory in Gansu and the southwestern section of the region. The Communists responded by withdrawing sixteen thousand troops from Shanxi to drive off the Guomindang commissioner in Suide and incorporate the garrison and recruitment zone in the northeast into the border region. With this exchange, the final boundaries of Shaan-Gan-Ning were established. The Guomindang constructed a blockade line that isolated the region from the rest of the country but allowed the Communists to intensify their control within. There was, however, one final socio-political consequence of the exchange. For the first time, the Communists gained control of the better-educated, landlord-dominated, settled villages of the northeast. At first, the new regime had difficulty convincing local cadres to cooperate with better-educated and well-respected gentry colleagues in a united front regime. But the experience was useful in developing the techniques for expanding the revolution to similar areas in Shanxi and on the North China plain.

What does this history tell us about the larger process of the Chinese Revolution? First, for all the attention that local history must pay to parochial economic, political, and social structures, and to the individual actors and historical events of the area studied, a credible local history can never be entirely local. The Shaanbei revolution cannot be understood without recognizing the fundamental difference between the Shaanxi-Gansu border in the west and "Shaanbei" in the east-areas that produced two endlessly competing branches of the party. Yet that difference 
was created by the incursions of the Muslim Rebellion of the nineteenth century, a rebellion whose origins must be traced well beyond northern Shaanxi. In the early stages of Shaanxi's Communist movement, guerrilla forces in the north struggled endlessly under the dogmatic dictates of party authorities answering to policies set by the Communist International. Finally, Chiang Kai-shek's acceptance of the Shaan-Gan-Ning border region's autonomy must be understood in the context of the war with Japan and the Soviet Union's promise of substantial military assistance. Again and again, local, regional, national, and international events interacted to shape the course of history. Microhistory and macrohistory must be combined as historians narrow and broaden their lenses to analyze these intersecting influences.

In this interaction of local, regional, national, and international, the specific role of local actors must be acknowledged. Wherever the Chinese Communist Party established a foothold, local actors were critical: teachers, students, "secret society" members, bandits, workers, miners, or peasants. ${ }^{4}$ In Shaanbei, the role of Liu Zhidan was particularly important. He had local status and connections; he had military training and experience; and he had the intimate knowledge of local geography necessary for a guerrilla leader. Inevitably, despite later hagiographic accounts, Liu's role in the revolution was problematic. His success was contingent upon escaping the unrealistic and dogmatic dictates of the provincial party committee. This escape was in turn enabled by the fact that Liu was a military man uninterested in party-building or Marxist-Leninist theory. However, the full success of the revolutionary movement in Shaanbei came only when Liu combined his military forces with the rural party apparatus of the rival "Shaanbei" faction in the east. Finally, and most importantly, after the party Center arrived in the fall of 1935, Liu Zhidan and his entire group of lieutenants were sidelined by the new central leadership. ${ }^{5}$

This pattern of local leadership building a revolutionary foundation and then being sidelined after a Communist regime is established is by no means unique to Shaanbei. The same process happened, often with great violence, in the Futian Incident that rocked the Jiangxi-Fujian base and in the sufan movement of the Hubei-Henan-Anhui Soviet. ${ }^{6}$ Similarly, after the revolution was complete and the People's Republic of China was established in 1949, "cadres sent south" (nanxia ganbu 南下干部) sidelined local revolutionaries in Guangdong and on Hainan island. ${ }^{7}$ The process and the logic were common and understandable: local revolutionaries had the local knowledge and connections necessary to build the initial base, but those same connections entangled them in webs of influence that could compete with higher party authorities and complicate the revolutionary agenda. Liu Zhidan built a broad coalition of bandits, Brothers, ex-soldiers, and militia leaders to establish a soviet in Shaanbei, but those same people had interests and affiliations that could obstruct the process of land reform and challenge the authority of the party. In this sense, the sufan campaign launched by Xu Haidong's 
Twenty-Fifth Army both threatened Liu's regime and served a larger revolutionary purpose. While it imprisoned such future party leaders as Gao Gang and Xi Zhongxun, aroused discontent and some desertions in Liu's army, and provoked outright counter-revolution from some of Liu's militia allies, it also eliminated local elite elements of questionable commitment to the party's larger goals. Most importantly, albeit fortuitously, the party Center arrived just in time to stop the campaign, allowing Mao to take credit for limiting its excesses while benefiting from its purge of the revolutionary ranks.

A second theme that must be acknowledged is the role of violence in the revolutionary process. As Mao famously stated in his report on the peasant movement in Hunan, "A revolution is not like inviting people to dinner, or writing an essay, or painting a picture, or doing embroidery. . . . A revolution is an uprising, an act of violence whereby one class overthrows the power of another." ${ }^{\prime \prime}$ The party never shrank from answering the enemy's "White Terror" with "Red Terror." Their guerrilla movement was built on kidnapping wealthy targets and executing them when appropriate. In the most intense period of social violence, the conflict could descend into "indiscriminate arson and executions." In Shaanbei, the era of extreme violence was also the period of greatest party recruitment. The new recruits were often rootless young men-orphans, younger sons with problems at home, men for whom the guerrilla bands were an alternate family, indeed a brotherhood. Above all they were young. When the captured engineer Eliassen met the Twenty-Sixth Army, he found "mostly boys of fifteen or sixteen," poorly armed but full of excitement. ${ }^{10}$ Edgar Snow was told that the average age was nineteen. ${ }^{11}$ These young men became the willing executioners of revolutionary violence, as studies of the revolution elsewhere have shown. ${ }^{12}$

After the Communist regime was established, indiscriminate violence was checked, but the new authorities continued a harsh suppression of "bandits." As the new order was secured, violence diminished. The message had been conveyed: opposition would be met with deadly force. It is notable that even the highly coercive Rectification Campaign of 1942-43 was marked by imprisonment, forced confessions, even torture, but very few deaths. Despite all the excesses of rectification, it was qualitatively different from the mass executions of the Futian Incident of 1930. Mao Zedong seems to have learned the negative consequences of earlier instances of excessive violence and established the new mantra to "cure the disease but save the patient" (zhibing jiuren 治病救人). ${ }^{13}$ The negative example of Stalin's purges may also have influenced the new policy. In any case, by this time, critics of party policy had learned their lesson; threats of violence plus the example of a few carefully chosen targets were enough to compel compliance. Still, as land reform in the 1940 os and the suppression of counterrevolutionaries in the early PRC would show, when the revolution moved into new areas, the party was prepared to resort to extreme revolutionary violence to establish its authority. 
This book ends with the establishment of Shaan-Gan-Ning within its final borders. That watershed reflects a third theme: the new regime was not the product of fundamental social change; on the contrary, such social transformation was premised on the firm establishment of party control. Until that control was established, mobilization for fundamental social reform was impossible. Countless examples demonstrate that peasants were unwilling to support land reform and risk the revenge of landlord elites unless they were convinced that the Red Army was able to protect them. ${ }^{14}$ Once the Xian Incident halted Guomindang military operations against the border region, the Communists immediately classified the remaining pockets of militia resistance as "bandits" and launched operations to eliminate them. Full control would come only when Guomindang magistrates were expelled, the northeastern counties were incorporated, and the final borders of the border region were settled. In effect, the establishment of the Communist regime was largely a military process, and much of this account is an effort to explain how the poorly armed guerrillas emerged victorious. After 1940, the national government surrounded the territory with a tight blockade line; movement in and out of Shaan-Gan-Ning was dramatically reduced, and a truly autonomous regime was established. ${ }^{15}$ News from outside was reduced to a trickle, and the Communist press told its own story of the Eighth Route and New Fourth Armies' glorious battles against Japan and the Soviet Union's victories on the European front. Then came the Rectification Campaign and its insistence on each student and cadre's acceptance of the party's creed. With regime control came information control, and from that point forward the party would be the sole arbiter of truth.

The firm establishment of a revolutionary base had another important consequence: it permitted a crucial degree of independence of Moscow. Until the mid1930s, the Communist International determined which Communists were the official party and which were renegades or "Trotskyites." The Sixth Party Congress of 1928 was held in Moscow, and its members were the official party leaders until the Seventh Congress in 1945. The Bolsheviks in Xi'an, like the entire underground party apparatus, were dependent on the CCP's Comintern-dominated Center in Shanghai for financial support and diligently parroted the International line. Indeed, with their own focus on urban struggle, the guerrilla movement mostly served to supply loot to support the party apparatus. In Jiangxi, while Mao was briefly sidelined, it was the "Internationalist" faction that took control, supported by the Comintern military representative, Otto Braun. We should not, however, accept the conventional wisdom that the growing independence of the CCP was simply the product of Mao's rise and his own rural roots. On the final stage of the Long March, Mao argued for an approach to the Soviet border on the grounds that "we are a branch of the International." ${ }^{16}$ Even in Shaanbei, he still sought military and financial support from the Soviet Union, and he dutifully accepted the Comintern's intervention to protect Chiang Kai-shek during the Xi'an Incident. Only after the war with Japan began, as Soviet military assistance flowed to 
the Guomindang and not to the CCP, did the prospect of Soviet assistance fade. From 1937 to 1940, the national government offered substantial support for Shaan-Gan-Ning and the Communist armies, and there was a small amount of wartime aid from the Soviet Union. ${ }^{17}$ After that point, it was the base areas, not Moscow, that supported the party.

The full development of this process is beyond the scope of this study. There is little doubt that during China's 1946-49 civil war, Mao was willing and able to ignore Stalin's advice that the Communist armies should stop at the Yangzi River and accept a divided China. It is also common knowledge that the independence of the CCP grew in the post-Stalin era and finally resulted in the Sino-Soviet split. I would argue that this growing independence was precisely the product of the establishment and gradual expansion of a stable domestic political base. Ideologically, Mao continued to repeat Stalinist dogma, and indeed the rectification documents of 1942-43 were full of Stalinist tracts. At the same time, Mao was attacking the "dogmatism" of Wang Ming and the party's Internationalist faction and advocating the Sinification of Marxism. With his early essays on dialectics and "On Practice," Mao had established sufficient theoretical bona fides to lay down his own ideological line, and his astute use of a Chinese-style dialectical reasoning allowed him to creatively adopt Marxism but more importantly, to justify repeated changes in the party line. With a base of his own, Mao no longer needed to hew strictly to Comintern dictates; he could make necessary adjustments to everchanging local conditions.

The fourth and final element of this story was the propagation of an ideology that promised victory for the revolution and nourished a commitment to that cause. It is worth recalling the Qing dynasty official who urged arming local militia because peasants could not be expected a fight to the death but could perhaps scare off rebels by firing from a safe distance and then fleeing (see chapter 1). Imperial officials recognized that peasants wished mostly to defend their villages and families and would not sacrifice their lives for the dynasty. Even Liu Zhidan's guerrillas were often fighting only for steady pay and a share of the loot and were accustomed to brief ambushes or dawn attacks that lasted only a few hours. They were not yet committed soldiers ready to die for the revolution. When Xu Haidong's Twenty-Fifth Army forced them into a protracted battle with major casualties at Laoshan, those who survived the battle resented the losses, and many abandoned the cause. The survivors of the Long March had seen plenty of death on their long retreat north; now, far from home, they had little choice but to continue fighting for the revolution. The Red Army was now their family, and only the success of the revolution gave meaning to their lives. But how was this revolutionary commitment conveyed to the peasants of Shaanbei?

Eugen Weber's classic study Peasants into Frenchmen highlights the role of the army and education in creating a new national consciousness. ${ }^{18}$ The Communists amplified this process by militarizing education once they had secure control 
of the border region. We have seen that many peasant families resisted the new regime's educational initiatives when they perceived that the party sought to turn their children into "the state's people" (gongjiaren). They correctly understood that the new curriculum was most useful for those who became cadres or members of the army. The chairman of the border region was explicit that the purpose of the educational system was to "strengthen the people's national self-confidence and self-respect so that they will voluntarily and actively fight for the War of Resistance and national construction." ${ }^{19}$ The mandates for primary schools began with directives for the militarization of education: "In addition to strengthening the usual guerrilla warfare physical education, schools should practice guerrilla tactics. . . First their activities should be militarized, not necessarily confining instruction to the classroom. ... Second, they should practice mountain warfare, climbing the hills every day. ${ }^{20}$ Peasant families could reasonably assume that the new regime was preparing their children for service in the army.

It was also necessary to convince young people that victory was inevitable and thus worth dying for. This was a longer and far more difficult process. The constant need to round up and return AWOL soldiers to the army indicates that many still longed for the security of family life in their native village. The party needed to give meaning to the revolution and instill confidence in its success. Mao Zedong's recognition of this need is indicated by his 1939 essay "The Chinese Revolution and the Chinese Communist Party," in which he linked China's socialist revolution to Sun Yat-sen's democratic revolution: "The democratic revolution is the inevitable [biran 必然] preparation for the socialist revolution, and the socialist revolution is the inevitable trend of the democratic revolution. . . Except for the Communist Party, no political party . . . is capable of assuming the task of leading China's two great revolutions." ${ }^{21}$ Just days after completing this essay on the inevitability of the Chinese Revolution, he drafted his famous essay on behalf of the "spirit of absolute selflessness" represented by Norman Bethune's death for the revolution. ${ }^{22}$ Several years later, he would return to this theme in his equally famous essay on "serving the people." Memorializing a Chinese martyr of the revolution, he wrote that "wherever there is struggle there is sacrifice, and death is a common occurrence," but claimed that those who died for the revolution died an especially worthy death and should be celebrated. ${ }^{23}$

Any revolutionary movement requires a dedicated cadre to carry out the administrative and military imperatives of its mission. This is particularly necessary in a revolution as protracted as the Chinese. In its early stages the revolution could rely on students, bandits, and the rural riffraff that Mao highlighted in his report on the Hunan peasant movement. Once the CCP established a relatively stable regime in Shaanbei, it needed a reliable organization to spread and strengthen its revolutionary agenda. Among the revolutionary elite, the Rectification Campaign performed this function, forcing intellectuals to purge the personal "bourgeois" origins of their doubts and replace them with an unwavering 
commitment to the party. For intellectuals, this commitment to the party was aided by the widely shared Marxist belief that socialism was the inevitable result of the progressive tide of history. ${ }^{24}$ But for others, it was more easily linked to the rise of China and the message of the popular revolutionary anthem: "Without the Communist Party, there can be no New China." 25 Building a New China was a cause that many were willing to die for, and it remains a widely shared commitment to this day.

The belief that the Communist Party was riding to power on the tide of history may well have served to motivate its members, just as Islamic fundamentalism does for ISIS or Al Qaeda. This is the function of ideology. This book, however, is a challenge to such determinist views of history. The alternative to determinism and notions of historical inevitability is the importance of what I have called "accidental" factors. It is essential to stipulate that "accidental" does not mean random or lacking knowable causes. Accidents have causes. Police investigate the cause of an automobile accident; states establish regulations to reduce the causes of industrial accidents. As noted above, however, big events like the Chinese Revolution do not necessarily have big causes. In Isaiah Berlin's classic essay on the hedgehog and the fox, I side resolutely with the fox who knows many things, rather than the hedgehog who knows one big thing. ${ }^{26}$ That being said, I also sympathize with those who argue that we must continue to pay attention to those big events that fundamentally transformed modern society-and in the Chinese case, that means understanding the nature and roots of the Chinese Revolution. ${ }^{27}$

As we seek to analyze the Chinese Revolution, the old models of peasant revolution, peasant nationalism, Communist organization, or united front policies are helpful to understand broad comparative trends, but they are insufficient to unravel the complex fabric of history. The challenge of Western imperialism was undoubtedly greater than the antiquated structures of the imperial order could endure. The 1911 Revolution that ended the last empire may not have been inevitable, but it established a precedent that captivated Chinese elites for much of the twentieth century: revolution was the process through which Chinese wealth and power would be established. ${ }^{28}$ The Guomindang, the Communist Party, and most political elites subscribed to this faith in revolutionary transformation. In this sense, the inevitability of some Chinese Revolution is plausible. But the form that the revolution took was the product of a vast array of local, national, and international contingencies that can be unraveled only through precise attention to the details and indeed the accidents of history. To the extent that the Yan'an era set the parameters of the Maoist regime, we must remind ourselves that Mao never wanted to be in Yan'an and that the Yan'an era was itself an accident of history-the product of precise causes but by no means foreordained.

Similarly, though the Yan'an era established certain patterns and precedents that influenced the future development of the Chinese Revolution, it did not determine that course. The anti-rightist movement of 1957, the Great Leap Forward, 
and the Cultural Revolution were all products of concrete conditions of their own time, and not some inevitable logic that flowed inexorably from Yanan. This book on the origins of the Shaan-Gan-Ning Border Region was enabled by the relatively complete documentary record on Shaanxi's early revolutionary movement. I was forced to abandon plans to examine the transformation of the region after 1940 precisely because the archival record of the internal deliberations and concrete effects of the party's policies was unavailable. When I conducted fieldwork and read documents in Shaanbei's local archives in 1989, one explicitly closed area was documents on "important meetings." Throughout the entire Mao and post-Mao era of Communist rule in China, we have almost no contemporary records of the party's internal deliberations, only memoir accounts with all of the limitations that such retrospective records entail. ${ }^{29}$ Stephen Kotkin's superb multivolume biography of Stalin shows what is possible if one has access to the letters, notes, meeting transcripts, and original memoranda of the supreme party leader of a totalitarian state. ${ }^{30}$ We have no similar records for China, which makes it impossible to determine with any precision the full range of considerations-personal, psychological, social, ideological, political, economic, military, and diplomatic-that shaped the choices of key actors in the drama of the Chinese Revolution. This surely does not mean that we should abandon research on the recent history of China, but it does mean that we should be cautious in asserting continuities across long eras in which the larger political context was demonstrably changing.

China is a country that has always treasured its history. The oldest classic is a collection of ancient and imagined documents often called the "Book of History." Confucius allegedly edited the Spring and Autumn Annals to record the lessons of the past, and Sima Qian wrote the first true history in the second century BCE, leaving an account of past events and heroes that has been cited, used, and abused by scholars and statesmen to the present day. Throughout the imperial era, each dynasty compiled the history of its predecessor to establish an official record of the past; and China remains a nation with an almost religious devotion to its past. The People's Daily has long featured a regular section devoted to history; the nation is littered with museums that popularize the regime's official version of its history; and China's current president is fond of invoking "the tide of history" or "the law of history." ${ }^{31}$ We should remember, however, that officials do not, and must not, monopolize the use of the past. Dynastic rebels, dissident intellectuals, modern revolutionaries, and contemporary protesters have also appealed to past measures of justice, or such memorable repertoires of dissent as the May Fourth Movement. History, then, has been a powerful resource used by states, rebels, and dissidents to pursue their own purposes.

We must, however, distinguish the use of history from the practice of historiography. There is a price that the historian pays for this distinction. If the course of history is determined by the decisions people make in the unique spatial and temporal context of their time, then the ceaseless transformation of that context 
makes the past a poor predictor of the future. The broad contours of the present world were produced by the gradual accretion of multiple lesser developments of the past. Pundits who argue for grand narratives of the triumph of socialism, People's War, totalitarian rule, the China model, or a Thucydides Trap may provoke useful debate, but unless they pay close attention to the concrete conditions that governed those processes in the past, they mislead even as they provoke us. The same holds true for those who wrest from their historical context events like Yan'an's Rectification Campaign, the Cultural Revolution, or the Tiananmen protests in order to assert some resonance in the present day. History does not repeat itself; it does not even rhyme. If history is to help us to understand the present, it will not be through easy analogies or magical metaphors. The most important lesson of history is that things are complicated. Local context matters. National affairs matter. Global developments matter. Organization and discipline matter. The political choices of key leaders matter a great deal; and so does the personal agency of ordinary individuals-even the "backward" and "ignorant" peasants of Shaanbei. 


\section{Informants}

1. Hengshan native in Bao'an (now Zhidan). Age sixty-seven. Interviewed July 1989.

2. Zichang (Anding) native, head of Zhidan party history office. Interviewed July 1989.

3. Bao'an, local intellectual. Interviewed July 1989.

4. Bao'an, Yuziwan resident. Interviewed July 1989.

5. Married into Jintang in Bao'an around 1923. Age eighty-four. Interviewed July 1989.

6. Bao'an, Luzigou resident. Cousin of Liu Zhidan. Age seventy-five. Interviewed July 1989.

7. Bao'an resident. Age sixty-two. Interviewed July 1989.

8. Close relative of Liu Zhidan. Interviewed July 1989.

9. Twenty-Sixth Army veteran. Age seventy-seven. Interviewed July 1989.

10. Yichuan native. Age seventy-nine. Interviewed July 1989.

11. Former student at Yongning school, Bao'an. Age seventy-one. Interviewed July 1989.

12. Bao'an resident, family migrated from Hengshan in Qing. Age sixty-eight. Interviewed July 3, 1989.

13. Four Bao'an residents. Ages sixty-one, seventy-four, seventy-four, and eighty. Interviewed July 1989.

14. Bao'an, Yuziwan resident. Age seventy-one. Interviewed July 1989.

15. Bao'an resident, family migrated from Shenmu in Qing. Age seventy-nine. Interviewed July 1989.

16. Bao'an resident, niece of Liu Zhidan. Age around sixty. Interviewed July 1989. 
17. Zichang party historian. Age eighty-two. Interviewed June 2018.

18. Zichang party historian. Age in fifties. Interviewed June 2018.

19. Zichang Zhengxie member. Age eighty-two. Interviewed June 2018.

20. Wuqi party historian. Age in sixties. Interviewed May 2019.

21. Yanchang resident. Age seventy. Interviewed June 1989.

22. Mizhi local historian. Age in fifties. Interviewed February 1989. 


\section{GL OS S A RY}

Chinese characters are entered in the text for terms that appear in only one section.

Character forms in the text and glossary follow the documentary sources: complex characters for chapter 1 and Taiwan, simplified characters for the Communist movement in chapters 2-6.

$\begin{array}{ll}\text { An Ziwen } & \text { 安子文 } \\ \text { baihua } & \text { 白话 } \\ \text { bao or bu } & \text { 堡 } \\ \text { baojia } & \text { 保甲 } \\ \text { Beijing Higher Normal School } & \text { 北京高等师范学校 } \\ \text { bingyun } & \text { 兵运 } \\ \text { biran } & \text { 必然 } \\ \text { Cai Ziwei } & \text { 蔡子伟 } \\ \text { Cao Huoxing } & \text { 曹火星 } \\ \text { Cao Liru } & \text { 曹力如 } \\ \text { Chang Lifu } & \text { 常黎夫, } \\ \text { Chen Guizhang } & \text { 陈珪璋 } \\ \text { Chen Lifu } & \text { 陈立夫 } \\ \text { Chen Yunqiao } & \text { 陈云樵 } \\ \text { Chen Zhengren } & \text { 陈正人 } \\ \text { Chen Zhongliang } & \text { 陈仲良 }\end{array}$




\begin{tabular}{|c|c|}
\hline Cheng Jianwen & 程建文 \\
\hline Cheng Qian & 程潛 \\
\hline Cheng Zihua & 程子华 \\
\hline Chiweidui & 赤卫队 \\
\hline Chiyuan & 赤源(县) \\
\hline chunhou & 淳厚 \\
\hline chunpu & 淳樸 \\
\hline Cui Ruisheng & 崔瑞生 \\
\hline Cui Tianfu & 崔田夫 \\
\hline Cui Tianmin & 崔田民 \\
\hline Dai Jiying & 戴季英 \\
\hline Dai Li & 戴笠 \\
\hline Deng Baoshan & 邓宝删 \\
\hline Deng Wenyi & 邓文仪 \\
\hline Deng Zhongxia & 邓中夏 \\
\hline diji minpin & 地瘠民貧 \\
\hline Dingxianyan & 定仙墕 \\
\hline Dingyuanying & 定远营 \\
\hline Dong Fuxiang & 董福祥 \\
\hline Dongzhiyuan & 董志塬 \\
\hline Du Bincheng & 杜斌丞 \\
\hline Du Heng & 杜衡 \\
\hline Du Yuming & 杜聿明 \\
\hline Ejie & 俄界 \\
\hline Fan Zhongyan & 范仲淹 \\
\hline Gao Fuyuan & 高福源 \\
\hline Gao Gang & 高岗 \\
\hline Gao Guizi & 高桂滋 \\
\hline Gao Jianbai & 高建白 \\
\hline Gao Jinchun & 高锦纯 \\
\hline Gao Jinshang & 高锦尚 \\
\hline Gao Langting & 高朗亭 \\
\hline Gao Weihan & 高维翰 \\
\hline
\end{tabular}




\begin{tabular}{|c|c|}
\hline Gelaohui & 哥老會 \\
\hline Geng Bingguang & 耿炳光 \\
\hline Gongjin(she) & 共进(社) \\
\hline gongsheng & 贡生 \\
\hline Gu Zhutong & 顾祝同 \\
\hline Guo Baoshan & 郭宝珊 \\
\hline Guo Hongtao & 郭洪涛 \\
\hline Guo Shushen & 郭述申 \\
\hline Guomindang (Kuomintang) & 国民党 \\
\hline Guominjun & 国民军 \\
\hline Hang Yi & 杭毅 \\
\hline haoshen & 豪绅 \\
\hline He Jinnian & 贺晋年 \\
\hline He Long & 贺龙 \\
\hline He Shaonan & 何绍南 \\
\hline He Yingqin & 何应钦 \\
\hline He Yuchu & 何寓础 \\
\hline Hu Jingyi & 胡景翼 \\
\hline Huang Luobin & 黄罗斌 \\
\hline Huang Luowu & 黄罗武 \\
\hline Huang Ziwen & 黄子文 \\
\hline Huang Zixiang & 黄子祥 \\
\hline Hui Zijun & 惠子俊 \\
\hline Jia Tuofu & 贾拓夫 \\
\hline jianbi qingye & 坚壁清野 \\
\hline Jiang Zhaoying & 姜兆芗 \\
\hline Jiao Weichi & 焦维炽 \\
\hline jiaohan & 狡悍 \\
\hline jiaonong & 交农 \\
\hline Jin Like & 金理科 \\
\hline Jing Yuexiu & 井岳秀 \\
\hline jingbei qu & 警备区 \\
\hline Jinjibao & 金積堡 \\
\hline
\end{tabular}




\begin{tabular}{|c|c|}
\hline Jintang zhen & 金湯鎮 \\
\hline juewu & 觉悟 \\
\hline Kang Ze & 康泽 \\
\hline Kangda & 抗大 \\
\hline kao Tian chifan & 靠天吃飯 \\
\hline Li Dazhao & 李大钊 \\
\hline Li Dingming & 李鼎铭 \\
\hline Li Fuchun & 李富春 \\
\hline Li Jiefu & 李杰夫 \\
\hline Li Jinglin & 李景林 \\
\hline Li Peifu & 李培福 \\
\hline Li Shaotang & 李少棠 \\
\hline Li Tielun & 李铁论 \\
\hline Li Weihan & 李维汉 \\
\hline Li Weijun & 李维钧 \\
\hline Li Xiangjiu & 李象九 \\
\hline Li Zhongying & 李仲英 \\
\hline Li Zicheng & 李自成 \\
\hline Li Zizhou & 李子洲 \\
\hline lianbao & 联保 \\
\hline Lin Biao & 林彪 \\
\hline Lin Yuying & 林育英 \\
\hline Liu Huaqing & 刘华清 \\
\hline Liu Jingfan & 刘景范 \\
\hline Liu Jingrui & 刘景瑞 \\
\hline Liu Mingshan & 刘明山 \\
\hline Liu Qingshan & 刘青山 \\
\hline Liu Tianzhang & 刘天章 \\
\hline Liu Zhidan & 刘志丹 \\
\hline Liu Zidan & 刘子丹 \\
\hline liumang & 流讯 \\
\hline Liupan shan & 六盘山 \\
\hline Lü Wenhua & 吕文华 \\
\hline
\end{tabular}




\begin{tabular}{|c|c|}
\hline Lüliang shan & 呂梁山 \\
\hline Luo Chengde & 罗成德 \\
\hline Ma Hongbin & 马鸿宾 \\
\hline Ma Hongkui & 马鸿逵 \\
\hline Ma Mingfang & 马明方 \\
\hline Ma Peixun & 马佩勋 \\
\hline Ma Wenrui & 马文瑞 \\
\hline Ma Xiwu & 马锡武 \\
\hline Ma Yunze & 马云泽 \\
\hline Meng Tian & 蒙恬 \\
\hline Miao Jiaxiang & 苗家祥 \\
\hline minzhu gongheguo & 民主共和国 \\
\hline Nie Hongjun & 聂洪钧 \\
\hline Pan Hannian & 潘汉年 \\
\hline Peng Dehuai & 彭德怀 \\
\hline Peng Zhulin & 彭竹林 \\
\hline Qiang Shiqing & 强世清 \\
\hline Qiang Tieniu & 强铁牛 \\
\hline Qibigou & 七笔勾 \\
\hline Qin Bangxian (Bo Gu) & 秦邦宪 (博古) \\
\hline quzhang & 区长 \\
\hline Ren Bishi & 任貆炽时 \\
\hline Ren Ziliang & 任子良 \\
\hline rinong-zhuyi & 日弄主义 \\
\hline Sanjiaozhen & 三交镇 \\
\hline sanshen & 散紳 \\
\hline Shaanbei & 陕北 \\
\hline Shaannan & 陝南 \\
\hline Shao Lizi & 邵力子 \\
\hline Shaonian xianfengdui & 少年先锋队 \\
\hline shen & 紳 \\
\hline shengyuan & 生員 \\
\hline Shi Kexuan & 史可轩 \\
\hline
\end{tabular}




$\begin{array}{ll}\text { Shi Qian } & \text { 石谦 } \\ \text { shoukuren } & \text { 受苦人 } \\ \text { Song Jiahe } & \text { 宋嘉禾 } \\ \text { Song Meiling } & \text { 宋美龄 } \\ \text { Song Qingling } & \text { 宋庆龄 } \\ \text { Song Ziwen } & \text { 宋子文 } \\ \text { sufan } & \text { 肃反 } \\ \text { Sun Mingzhang } & \text { 孙铭章(帝国) } \\ \text { Sun Pingzhang } & \text { 孙平章 } \\ \text { Tang Enbo } & \text { 汤恩伯 } \\ \text { Tang Shu } & \text { 唐澍 } \\ \text { tongzhi } & \text { 同志 } \\ \text { tuanfei } & \text { 團匪 } \\ \text { tuhao lieshen } & \text { 土豪劣绅 } \\ \text { tuhuangdi } & \text { 土皇帝 } \\ \text { Wang Feng } & \text { 汪峰 } \\ \text { Xiasiwan } & \text { 王稼祥 } \\ \text { Wang Jiaxiang } & \text { 王若飞 } \\ \text { Wang Ruofei } & \text { 萧劲光 } \\ \text { Wang Shangde } & \text { 王尚德 } \\ \text { Wang Shitai } & \text { 王世泰 } \\ \text { Wang Shoudao } & \text { 王首道 } \\ \text { Wang Taiji } & \text { 王泰吉 } \\ \text { Wang Ying } & \text { 王英 } \\ \text { Wang Yizhe } & \text { 王以哲 } \\ \text { Wei Yechou } & \text { 魏野畴 } \\ \text { Western Xia } & \text { 西夏 } \\ \text { Wuifeng } & \text { 吴岱峰 } \\ \text { 吴华梓 } \\ \text { 无枪阶级 } \\ \text { Wuazi } \\ \text { Wiaji }\end{array}$




\begin{tabular}{|c|c|}
\hline Xie Zichang & 谢子长 \\
\hline Xiongnu & 匈奴 \\
\hline xiucai & 秀才 \\
\hline Xiuyan & 秀延(河/县) \\
\hline Xu Haidong & 徐海东 \\
\hline Xu Quanzhong & 许权中 \\
\hline Xuejiazhai & 薛家寨 \\
\hline Yan Hongyan & 阎红彦 \\
\hline Yan Xishan & 阎锡山 \\
\hline Yang Heting & 杨和亭 \\
\hline Yang Hucheng & 杨虎城 \\
\hline Yang Mingxuan & 杨明轩 \\
\hline Yang Pei & 杨沛 \\
\hline Yang Sen & 杨森 \\
\hline Yang Sheng & 杨声 \\
\hline Yang Yuxiu & 杨毓秀 \\
\hline Yang Zhongjian & 杨钟健 \\
\hline Yang Zhongyuan & 杨仲远 \\
\hline Yongningshan & 永寧山 \\
\hline You Xiangzhai & 尤祥斋 \\
\hline Yu Youren & 于右任 \\
\hline Yuan Yuedong & 袁岳栋 \\
\hline yипио & 愚懦 \\
\hline Zhang Bangying & 张邦英 \\
\hline Zhang Bingren & 张秉仁 \\
\hline Zhang Ce & 张策 \\
\hline Zhang Dazhi & 张达志 \\
\hline Zhang Guotao & 张国奉 \\
\hline Zhang Hanmin & 张汉民 \\
\hline Zhang Jinyin & 张金印 \\
\hline Zhang Mutao & 张慕陶 \\
\hline Zhang Qingfu & 张庆孚 \\
\hline Zhang Tingzhi & 张廷芝 \\
\hline
\end{tabular}




$\begin{array}{ll}\text { Zhang Wentian } & \text { 张闻天 } \\ \text { Zhang Xianzhong } & \text { 張獻忠 } \\ \text { Zhang Xiushan } & \text { 张秀山 } \\ \text { Zhang Zhanrong } & \text { 张占荣 } \\ \text { Zhang Zhongliang } & \text { 张仲良 } \\ \text { Zhao Boping } & \text { 赵伯平 } \\ \text { Zhao Erwa (Lianbi) } & \text { 赵二娃(连璧) } \\ \text { Zhao Laowu } & \text { 赵老五(赵思忠, 赵恕忠) } \\ \text { Zheng Yi } & \text { 郑毅 } \\ \text { Zhiluozhen } & \text { 直罗镇 } \\ \text { Zhou Zuyao } & \text { 周祖尧 } \\ \text { Zhu Lizhi } & \text { 朱理治 } \\ \text { Zhu Zixiu } & \text { 朱子休 } \\ \text { ziweidui } & \text { 自卫队 } \\ \text { zongshen } & \text { 縂紳 } \\ \text { Zuo Zongtang } & \text { 左宗棠 }\end{array}$




\section{ABBREVIATIONS USED IN NOTES}

BOI Guomindang Bureau of Investigation (國民黨調查統計局) archives. Taibei, Taiwan.

CZWX Yang Dezhi, Hongjun changzheng wenxian

Gongjinshe Zhonggong Shaanxi shengwei, Gongjinshe he "Gongjin" zazhi

Guoshiguan Guoshiguan (国史館) archives. Taibei, Taiwan.

H26J Zhonggong Qingyang diwei dangshi ziliao zhengji bangongshi, Hong ershiliu jun yu Shaan-Ganbian suqu

HMQY Bai Shouyi, Huimin qiyi

LDZL:Z Zhang Junyang, Longdong geming lishi dang'an ziliao xuanbian: Zhengquan jianshe

LDZL:D Zhang Junyang, Longdong geming lishi dang'an ziliao xuanbian: Dang de jianshe

Liangong Zhonggong zhongyang dangshi yanjiushi, Liangong (bu), gongchan guoji yu Zhongguo suweiai yundong 1931-1937

Mao junshi Zhonggong zhongyang wenxian, Mao Zedong junshi wenji

Mao nianpu Zhonggong zhongyang wenxian yanjiushi, Mao Zedong nianpu

MGSL:ZG Qin Xiaoyi, Zhonghua minguo zhongyao shiliao chubian-dui-Ri kangzhan shiqi, diwubian: Zhonggong huodong zhenxiang

$\mathrm{NCH} \quad$ North China Herald and Supreme Court and Consular Gazette

SA Shaanxi Provincial Archives, Records of Shaan-Gan-Ning Border Region Government (Shaan-Gan-Ning bianqu zhengfu dang'an)

SGGJD Zhonggong Shaanxi shengwei, Shaan-Ganbian geming genjudi

SGNCZJJ Shaan-Gan-Ning bianqu caizheng jingji shi bianxiezu and Shaanxi dang'an guan, Kang-Ri zhanzheng shiqi Shaan-Gan-Ning bianqu caizheng jingji shiliao zhaibian

SGNDW Zhongyang dang'an guan, Shaanxi sheng dang'an guan, Zhonggong Shaan-Gan-Ning bianqu dangwei wenjian huibian 
SGNMZ:HY Xibei wushengqu and Zhongyang dang'an guan, Shaan-Gan-Ning bianqu kang-Ri minzhu genjudi: Huiyilujuan

SGNMZ:WX Xibei wushengqu and Zhongyang dang'an guan, Shaan-Gan-Ning bianqu kang-Ri minzhu genjudi: Wenxianjuan

SGNWJ Shaanxi sheng dang'an guan, Shaanxi shehui kexueyuan, Shaan-Gan-Ning bianqu zhengfu wenjian

SLGB Xiao Liju et al., Jiang Zhongzheng zongtong dang'an: Shilüe gaoben

SXDSJ Zhonggong Shaanxi shengwei, Xin minzhuzhuyi geming shiqi Shaanxi dashi jishu

SXDSTX Shaanxi dangshi ziliao tongxun

SXGMWJ Zhongyang dang'an guan, Shaanxi geming lishi wenxian huiji

TDSW Zhonggong Shaanxi shengwei, Tudi geming zhanzheng shiqi de Zhonggong Shaanxi shengwei

WBGJD Zhonggong Xianyang shiwei, Weibei geming genjudi

XBGJD Zhonggong Shaanxi shengwei, Xibei geming genjudi

WHQY Zhonggong Shaanxi shengwei, Wei-Hua qiyi

ZCLZL Zichang xian minzhengju, Zichangling ziliao

Zhou nianpu Zhonggong zhongyang wenxian, Zhou Enlai nianpu 
NOTES

PREFACE

1. "China Boosts 'Red Tourism' in Revolutionary Bases," China Yearbook, 2003-2004, www.china.org.cn/english/government/120838.htm.

2. For the official English versions, see Mao Zedong, Selected Readings from the Works of Mao Tsetung (Beijing: Foreign Languages Press, 1971); for translations of the original texts, see Stuart R. Schram et al., eds., Mao's Road to Power: Revolutionary Writings, 1912-1949, 8 vols. (Armonk, NY: M.E. Sharpe, 1992-).

3. Stuart R. Schram, ed. and trans., The Political Thought of Mao Tse-tung (New York: Praeger, 1969); Stuart R. Schram, The Thought of Mao Tse-tung (Cambridge: Cambridge University Press, 1989) and Mao Tse-tung (Baltimore: Penguin Books, 1967).

4. Raymond Finlay Wylie, The Emergence of Maoism: Mao Tse-tung, Chen Po-ta, and the Search for Chinese Theory, 1935-1945 (Stanford, CA: Stanford University Press, 1980); Joshua A. Fogel, Ai Ssu-ch'i's Contribution to the Development of Chinese Marxism (Cambridge, MA: Council on East Asian Studies, Harvard University, 1987).

5. Yang Kuisong, Mao Zedong yu Mosike de enen yuanyuan (Nanchang: Jiangxi renmin chubanshe, 1999) and "Zhongjian didai" de geming: Guoji dabeijing xia kan Zhonggong chenggong zhi dao (Taiyuan: Shanxi renmin chubanshe, 2010). In English, see Alexander V. Pantsov, Mao: The Real Story, with Steven I. Levine (New York: Simon and Schuster, 2012), and the earlier and less convincing Michael Sheng, Battling Western Imperialism: Mao, Stalin, and the United States (Princeton, NJ: Princeton University Press, 1997).

6. Mark Selden, The Yenan Way in Revolutionary China (Cambridge, MA: Harvard University Press, 1971) and China in Revolution: The Yenan Way Revisited (Armonk, NY: M. E. Sharpe, 1995). 
7. Peter Schran, Guerrilla Economy: The Development of the Shensi-Kansu-Ninghsia Border Region, 1937-1945 (Albany: State University of New York Press, 1976), quoted passage on ix.

8. Pauline B. Keating, Two Revolutions: Village Reconstruction and the Cooperative Movement in Northern Shaanxi, 1934-1945 (Stanford, CA: Stanford University Press, 1997).

9. Zhu Hongzhao, Yanian: Richang shenghuo zhong de lishi, 1937-1947 (Guilin: Guangxi shifan daxue chubanshe, 2007).

10. Chen Yung-fa, "The Blooming Poppy under the Red Sun: The Yan'an Way and the Opium Trade," in New Perspectives on the Chinese Communist Revolution, ed. Tony Saich and Hans J. van de Ven (Armonk, NY: M. E. Sharpe, 1995), 264.

11. Selden, Yenan Way, 188-20o; see also Boyd Compton, ed., Mao's China: Party Reform Documents, 1942-44 (Seattle: University of Washington Press, 1952), xv-xxxiv.

12. Peter J. Seybolt, "Terror and Conformity: Counterespionage Campaigns, Rectification, and Mass Movements, 1942-43," Modern China 12, no. 1 (January 1986): 39-73.

13. Chen Yung-fa, Yanian de yinying (Taibei: Zhongyang yanjiuyuan jindaishi yanjiusuo, 1990).

14. Gao Hua, Hong taiyang shi zenyang shengqi de: Yanan zhengfeng yundong de lailong qumai (Hong Kong: Zhongwen daxue chubanshe, 2000). An English translation was recently published: How the Red Sun Rose: The Origin and Development of the Yanian Rectification Movement, 1930-1945, trans. Stacey Mosher and Guo Jian (Hong Kong: Chinese University of Hong Kong Press, 2019).

15. Frederick C. Teiwes, Politics and Purges in China: Rectification and the Decline of Party Norms, 1950-1965, 2nd ed. (Armonk, NY: M.E. Sharpe, 1993).

16. David E. Apter and Tony Saich, Revolutionary Discourse in Mao's Republic (Cambridge, MA: Harvard University Press, 1994).

17. Scholarship that makes this point is too numerous to list, but the most important works include Chalmers Johnson, Peasant Nationalism and Communist Power: The Emergence of Revolutionary China (Stanford, CA: Stanford University Press, 1967); Kathleen Hartford and Steven M. Goldstein, eds., Single Sparks: China's Rural Revolutions (Armonk, NY: M.E. Sharpe, 1989); Saich and van de Ven, New Perspectives; Yung-fa Chen, Making Revolution: The Communist Movement in Eastern and Central China, 1937-1945 (Berkeley: University of California Press, 1986); Odoric Y.K. Wou, Mobilizing the Masses: Building Revolution in Henan (Stanford, CA: Stanford University Press, 1994); Gregor Benton, New Fourth Army: Communist Resistance along the Yangtze and the Huai, 1938-1941 (Berkeley: University of California Press, 1999).

18. Joseph W. Esherick, Reform and Revolution in China: The 1911 Revolution in Hunan and Hubei (Berkeley: University of California Press, 1976) and The Origins of the Boxer Uprising (Berkeley: University of California Press, 1987); Joseph W. Esherick and Jeffrey Wasserstrom, "Acting Out Democracy: Political Theater in Modern China," Journal of Asian Studies 49, no. 4 (November 1990): 835-65.

19. Barrington Moore, Social Origins of Dictatorship and Democracy: Lord and Peasant in the Making of the Modern World (Boston: Beacon Press, 1967).

20. Karl Marx, The Eighteenth Brumaire of Louis Bonaparte (New York: International Publishers, 1963), 124-25.

21. Eric R. Wolf, Peasant Wars of the Twentieth Century (New York: Harper and Row, 1969); Jeffery M. Paige, Agrarian Revolution (New York: Free Press, 1975), quotation from 63. 
22. James C. Scott, The Moral Economy of the Peasant: Rebellion and Subsistence in Southeast Asia (New Haven, CT: Yale University Press, 1976).

23. Samuel L. Popkin, The Rational Peasant: The Political Economy of Rural Society in Vietnam (Berkeley: University of California Press, 1979).

24. Frederic Wakeman, "Rebellion and Revolution: The Study of Popular Movements in Chinese History," Journal of Asian Studies 36, no. 2 (1977): 201-37.

25. Elizabeth J. Perry, Rebels and Revolutionaries in North China, 1845-1945 (Stanford, CA: Stanford University Press, 1980).

26. Lucien Bianco, Peasants without the Party: Grass-Roots Movements in TwentiethCentury China (Armonk, NY: M.E. Sharpe, 2001); Lucien Bianco, Wretched Rebels: Rural Disturbances on the Eve of the Chinese Revolution, with Hua Chang-ming, trans. Philip Lidell (Cambridge, MA: Harvard University Asia Center, 2009).

27. Stephen C. Averill, Revolution in the Highlands: China's Jinggangshan Base Area (Lanham, MD: Rowman and Littlefield, 2006); Fernando Galbiati, P'eng P'ai and the Hai-Lu-Feng Soviet (Stanford, CA: Stanford University Press, 1985); Roy Hofheinz, The Broken Wave: The Chinese Communist Peasant Movement, 1922-1928 (Cambridge, MA: Harvard University Press, 1977); and literature cited in note 17.

28. See Joseph W. Esherick, "Deconstructing the Construction of the Party-State: Gulin County in the Shaan-Gan-Ning Border Region," China Quarterly, no. 140 (December 1994): 1052-79, and "Revolution in a Feudal Fortress: Yangjiagou, Mizhi County, Shaanxi, 1937-1948," Modern China 24, no. 4 (October 1998): 339-77.

29. An early series of articles by Mark Selden has told the story well, from the smaller source base of the 1960s: "The Guerrilla Movement in Northwest China: The Origins of the Shensi-Kansu-Ninghsia Border Region," China Quarterly 28 (October-December 1966): 63-81, and 29 (January-March 1967): 61-81.

30. On the "revolution of rising expectations," see James C. Davies, "The Revolutionary State of Mind," in James Chowning Davies, When Men Revolt and Why: A Reader in Political Violence and Revolution (New York: Free Press, 1971), 134-47, and also the sections by Tocqueville, who first suggested the idea, pages 93-98 of the same volume; for demographic models, see Jack Goldstone, Revolution and Rebellion in the Early Modern World (Berkeley: University of California Press, 1991).

31. James Tong, Disorder under Heaven: Collective Violence in the Ming Dynasty (Stanford, CA: Stanford University Press, 1991); Theda Skocpol, States and Social Revolutions: A Comparative Analysis of France, Russia, and China (Cambridge: Cambridge University Press, 1979), 112-59.

32. Other multi-year research projects have relied on rural interviews to gain important insights into the transformation of rural society in China. A model village in Hebei is the focus of Edward Friedman, Paul Pickowicz, and Mark Selden, Chinese Village, Socialist State (New Haven, CT: Yale University Press, 1991). Gail Hershatter, The Gender of Memory: Rural Women and China's Collective Past (Berkeley: University of California Press, 2011), is a particularly sophisticated analysis of memory among female cadres and labor models in Mao-era central and southern Shaanxi.

33. "Zhongguo gongzhandang zhongyang weiyuanhui guanyu ruogan lishi wenti de jueyi," in Zhonggong zhongyang shujichu, Liuda yilai, 2 vols. (Beijing: Renmin chubanshe, 1980), 1:1179-1200, translated in Tony Saich and Benjamin Yang, The Rise to Power of the Chinese Communist Party: Documents and Analysis (London: Routledge, 2015), 1164-79. 
34. In the field of party history, one of the best examples of the different picture one gets from the documentary and memoir record is the contrasting accounts of the CCP's founding in Hans J. van de Ven, From Friend to Comrade: The Founding of the Chinese Communist Party, 1920-1927 (Berkeley: University of California Press, 1991); Arif Dirlik, The Origins of Chinese Communism (New York: Oxford University Press, 1989); and Ishikawa Yoshihiro, The Formation of the Chinese Communist Party, trans. Joshua Fogel (New York: Columbia University Press, 2013).

35. See especially the briefly summarized complaints of Li Zhongying and seventeen others in the July 1945 meetings. My copy of the 1942 and 1945 meetings is an unpublished version from sources that cannot be identified.

36. On revolution in modern China's cultural tradition, see especially Luo Zhitian, Jindai dushuren de sixiang shijie yu zhixue quxiang (Beijing: Beijing University Press, 2009), 104-41; Elizabeth J. Perry, Anyuan: Mining China's Revolutionary Tradition (Berkeley: University of California Press, 2012).

37. Max Weber, "Politics as a Vocation" and "Science as a Vocation," in H.H. Gerth and C. Wright Mill, From Max Weber: Essays in Sociology (New York: Oxford University Press, 1958), 77-128 and 129-56, quotation from "Science as a Vocation," 145-47.

38. David Hackett Fischer, Historians' Fallacies: Toward a Logic of Historical Thought (New York: Harper and Row, 1970), 177.

\section{FRONTIER FOUNDATIONS FOR REVOLUTION}

1. Francis H. Nichols, Through Hidden Shensi (New York: C. Scribner's Sons, 1902), 1.

2. Nichols, Through Hidden Shensi, 91.

3. Wang Jinfu, Xibei zhi diwen yu renwen (Shanghai: Shangwu yinshuguan, 1935), 11, 67-69.

4. Yingcong Dai, The White Lotus War: Rebellion and Suppression in Late Imperial China (Seattle: University of Washington Press, 2019).

5. Liu Ts'ui-jung, Trade on the Han River and Its Impact on Economic Development, c. 1800-1911 (Nankang, Taipei: Academia Sinica Institute of Economics, 1980).

6. "Huatong," Shaan-Gan-Ning bianqu quanmao, September 1940, in Zhong-Gong bianqu genjudi de lishi wenjian xuanji, ed. Zhang Houde (Taibei, 1985), 200; Tongji yuebao, 1935, no. 5: 103-4; Shaanxi shengzhi, vol. 6, Qixiang zhi, ed. Shaanxi sheng difangzhi bianzuan weiyuanhui (Beijing: Qixiang chubanshe, 2001), 34-36, 43.

7. Shaanxi tongzhi xutongzhi, ed. Shen Qingya et al. (1933; repr., Taibei: Huawen shuju, 1969), 11:5976 (all citations are to volume and page number of the Taibei compressed version); Mizhi xianzhi (n.p., 1907), Preface 1; "Huatong," Shaan-Gan-Ning bianqu quanmao, 200; Edgar Snow, Random Notes on Red China, 1936-1945 (Cambridge, MA: Harvard University East Asian Research Center, 1971), 60-61.

8. On sandstorms from the Gobi Desert, see Bao'an xianzhilüe, ed. Hou Changming, 1898 ms. ed., http://xadfz.xa.gov.cn/difangzhinew/muluFrame.jsp?bookname=gx_baoan _xianzhiluo, 19.

9. Owen Lattimore, Inner Asian Frontiers of China (1940; repr., Boston: Beacon Press, 1962), 29-31; Nichols, Through Hidden Shensi, 91.

10. Ganquan xian xiangtuzhi (ca. 1905; repr., Taibei: Chengwen chubanshe, 1970), 18-19.

11. Kang Di, "Bianqu nongye huanjing," in Shaan-Gan-Ning bianqu caizheng jingji shi bianxiezu and Shaanxi dang'an guan, eds., Kang-Ri zhanzheng shiqi Shaan-Gan-Ning 
bianqu caizheng jingji shiliao zhaibian (Xi'an: Shaanxi renmin chubanshe, 1981) [hereafter SGNCZJJ], 2:14-15. In the Suide-Mizhi area, denser population led to increased use of fertilizer. Chai Shufan, Yu Guangyuan, and Peng Ping, Suide, Mizhi tudi wenti chubu yanjiu (1942; repr., Beijing: Renmin chubanshe, 1979), 10.

12. Eric Teichman, Travels of a Consular Officer in North-West China (Cambridge: Cambridge University Press, 1921), 63.

13. Edgar Snow, Red Star Over China (New York: Random House, 1938), 57.

14. Nym Wales [Helen Foster Snow], Inside Red China (New York: Doubleday, Doran, 1939), 291.

15. Suide zhouzhi (1905; repr., Taibei: Chengwen chubanshe, 1970), 110-11. On Meng Tian and the Qin dynasty defense, see Arthur Waldron, The Great Wall of China: From History to Myth (Cambridge: Cambridge University Press, 1990), 16-29.

16. See the introduction to the series on Northwest gazetteers in Yansui zhenzhi (1673; repr., Taibei: Taiwan xuesheng shuju, 1968); Suide zhouzhi, 62-82; Jingbian xianzhigao (1899; repr., Taipei: Chengwen chubanshe, 1970), 183-84.

17. Baoan xianzhilüe, 6-12.

18. Waldron, Great Wall, 72-139.

19. Yansui zhenzhi, 124-25.

20. Yansui zhenzhi, 147-77; Waldron, Great Wall, 81-84.

21. Frederick W. Mote and Denis Twitchett, The Cambridge History of China, vol. 7, The Ming Dynasty, 1368-1644, Part I (Cambridge: Cambridge University Press, 1988), 567-84; Frederick Wakeman Jr., "China and the Seventeenth Century Crisis," Late Imperial China 7, no. 1 (June 1986): 1-26, and The Great Enterprise: The Manchu Reconstruction of Imperial Order in Seventeenth-Century China (Berkeley: University of California Press, 1985), 1:1-224; Kenneth M. Swope, The Military Collapse of China's Ming Dynasty, 1618-44 (London: Routledge, 2014), 76-79.

22. Swope, Military Collapse, 103 ff.; James Bunyan Parsons, The Peasant Rebellions of the Late Ming Dynasty (Tuscon: University of Arizona Press, 1970), 20-21; Mizhi xianzhi, 10:15-16.

23. Swope, Military Collapse, $188-89$.

24. Parsons, Peasant Rebellions, $26 \mathrm{ff}$.

25. Yansui zhenzhi, 446-51; Suide zhouzhi, 390-94; Anding xianzhi (1846; repr., Taibei: Chengwen chubanshe, 1970), 86-89.

26. Swope, Military Collapse, 127, 145, 161; Parsons, Peasant Rebellions, 6, 30-32.

27. Swope, Military Collapse, 103-6, 118; Parsons, Peasant Rebellions, 23, 49, 63, 130-38; Suide zhouzhi, 393-94; Anding xianzhi, 87-89.

28. Pamela Kyle Crossley, A Translucent Mirror: History and Identity in Qing Imperial Ideology (Berkeley: University of California Press, 1999); Peter C. Perdue, China Marches West: The Qing Conquest of Central Eurasia (Cambridge, MA: Harvard University Press, 2005); Mark C. Elliott, The Manchu Way: The Eight Banners and Ethnic Identity in Late Imperial China (Stanford, CA: Stanford University Press, 2001).

29. Elliott, Manchu Way, 105, 313.

30. R. Kent Guy, Qing Governors and Their Provinces: The Evolution of Territorial Administration in China, 1644-1796 (Seattle: University of Washington Press, 2010), 216-17; Perdue, China Marches West, 303-23.

31. Guy, Qing Governors, 203-4. 
32. Yansui zhenzhi, 91, 124-25; Shaanxi tongzhi xutongzhi, 7: 3697-99. Yansuizhen was Yulin.

33. Yansui zhenzhi, 192-93.

34. Jingbian xianzhigao, 287, 294-302, 313-14; Shenmu xiangtuzhi (ca. 1915; repr., Taibei: Chengwen chubanshe, 1970), 12-14.

35. Shaanxi tongzhi xutongzhi, 6:3428-29.

36. Shaanxi tongzhi xutongzhi, 6:3428.

37. Bao’an xianzhilüe, 25, 29-30.

38. Wang Yeh-chien, Land Taxation in Imperial China, 1750-1911 (Cambridge, MA: Harvard University Press, 1973), 10.

39. Shaanxi tongzhi xutongzhi, 6:3459-60; Shenmu xiangtuzhi, 25; Ganquan xian xiangtuzhi, 6.

40. Ganquan xian xiangtuzhi, 4. On "living shrines," see Sarah Schneewind, Shrines to Living Men in the Ming Political Cosmos (Cambridge, MA: Harvard University Asia Center, 2018).

41. Shaanxi tongzhi xutongzhi, 12:6090-92; Jingbian xianzhi, 193-95.

42. Suide zhouzhi, 395-98.

43. "Huatong," Shaan-Gan-Ning bianqu quanmao, 224; Kuang Yuxiang, "Shaanxi Fushixian gaikuang," Kaifa xibei 2, no. 4 (October 1934): 70-74.

44. Shaanxi tongzhi xutongzhi, 11:5876-78.

45. Guomin zhengfu sifa xingzhengbu, Minshi xiguan diaocha baogaolu (Beijing: Zhongguo zhengfa daxue chubanshe, 2000), 1:389.

46. Alexander Hosie, On the Trail of the Opium Poppy: A Narrative of Travel in the Chief Opium-Producing Provinces of China (Boston: Small Maynard, 1914), 12; Ganquan xiangtuzhi, 23.

47. E. Snow, Red Star Over China, 26-27.

48. Hosie, On the Trail, 11; Wang Jinfu, Xibei zhi diwen, 126-27.

49. Suide zhouzhi, 328-30; Shaanxi tongzhi xutongzhi, 11:5976.

50. Nichols, Through Hidden Shensi, 229.

51. Tōa Dōbunkai, Shina shōbetsu zenshi, vol. 7, Shasei shō (Tokyo: Tōa Dōbunkai, 1918), 119-40; Shaanxi tongzhi xutongzhi, 11:3583.

52. Chen Xuezhao, Yan'an fangwenji (Hong Kong: Beiji shudian, 1940), 94-95.

53. Kuang Yuxiang, "Shaanxi Fushi-xian gaikuang," 70.

54. Suide zhouzhi, 327-28. The term remains in use to this day.

55. Juezhi quanlan (1904; repr., Taipei: Wenhai, 1967), 543.

56. Shaanxi tongzhi xutongzhi, 11:5977.

57. Suide zhouzhi, 711-12.

58. Nichols, Through Hidden Shensi, 1.

59. Shaanxi tongzhi xutongzhi, 11:5977; Suide zhouzhi, 329-30.

6o. Chen Xuezhao, Yanian fangwenji, 57. See also E. Snow, Red Star Over China, 230, where $\mathrm{Xu}$ Teli tells Snow that Shaanbei men bathed only twice, at birth and marriage.

61. Suide zhouzhi, 326; cf. Shaanxi tongzhi xutongzhi, 11:5977.

62. Chen Xuezhao, Yanian fangwenji, 70-71.

63. "Qibigou," quoted in Shang Jifang, "Zaizao 'Xibei': Minguo shiqi lüwai xueren dui xibei xingxiang de chongsu he jiangou," in Jinxiandai xibei shehui yanjiu: Fazhan yu biange, ed. 
Li Jianguo and Shang Jifang (Lanzhou: Gansu wenhua chubanshe, 2015), 55. Contemporary Northwest scholars are naturally offended by such views. Caves, furthermore, rarely leaked, or they would collapse. The author seems to have engaged in some poetic license.

64. E. Snow, Random Notes, 49.

65. Wales, Inside Red China, 79.

66. Shaanxi tongzhi xutongzhi, 11:5875-76; Suide zhouzhi, 325-27.

67. Jingbian xianzhi, 117, 119-21.

68. Shenmu xiangtuzhi, 63.

69. Guomin zhengfu sifa xingzhengbu, Minshi xiguan diaocha baogaolu, 2:1010, 1013, 1049 .

70. Guomin zhengfu sifa xingzhengbu, Minshi xiguan diaocha baogaolu, 1:383, 2:724, 1029; Jingbian xianzhi, 32.

71. Guomin zhengfu sifa xingzhengbu, Minshi xiguan diaocha baogaolu, 2:1037; Baoan xianzhilüe, 32; Matthew H. Sommer, Polyandry and Wife-Selling in Qing Dynasty China: Survival Strategies and Judicial Interventions (Stanford, CA: Stanford University Press, 2015), 23-54; see also Hershatter, Gender of Memory, 110, 330.

72. Guomin zhengfu sifa xingzhengbu, Minshi xiguan diaocha baogaolu, 2:1022.

73. Chen Xuezhao, Yan'an fangwenji, 57; cf. 306-7.

74. Wales, Inside Red China, 196; cf. Chen Xuezhao, Yanan fangwenji, 306-7; Hershatter, Gender of Memory, 157, 162.

75. Petition from Shaanbei counties, February 28, 1939, in Qin Xiaoyi et al., eds., Zhonghua minguo zhongyao shiliao chubian-dui-Ri kangzhan shiqi, diwubian: Zhonggong huodong zhenxiang (Taipei: Zhongguo Guomindang, 1985) [hereafter: MGSL:ZG], 2:86.

76. Shang Jifang, "Zaizao Xibei," in Li Jianguo and Shang Jifang, Jinxiandai xibei shehui yanjiu, 63-65.

77. Bao’an xianzhilüe, 29.

78. Jingbian xianzhi, 333-36.

79. Shaanxi tongzhi xutongzhi, 6:3215.

80. Bao'an xianzhilüe, 32.

81. Shaanxi tongzhi xutongzhi, 6:3213-3359.

82. Chung-li Chang, The Chinese Gentry: Studies on Their Role in Nineteenth-Century Chinese Society (Seattle: University of Washington Press, 1955), 54, See also T'ung-tsu Ch'ü, Local Government in China under the Ch ing (Cambridge, MA: Council on East Asian Studies, Harvard University, 1988), 168-92.

83. Jingbian xianzhi, 96-99.

84. Zhidan County, interviews, various.

85. On the Taiping, see Franz H. Michael, The Taiping Rebellion: History and Documents (Seattle: University of Washington Press, 1966); Yu-wen Jen, The Taiping Revolutionary Movement (New Haven, CT: Yale University Press, 1973); Jonathan D. Spence, God's Chinese Son: The Taiping Heavenly Kingdom of Hong Xiuquan (New York: W. W. Norton, 1996).

86. Ssu-yü Teng, The Nien Army and Their Guerrilla Warfare, 1851-1868 (Paris: Mouton, 1961); Perry, Rebels and Revolutionaries.

87. David G. Atwill, The Chinese Sultanate: Islam, Ethnicity, and the Panthay Rebellion in Southwest China, 1856-1873 (Stanford, CA: Stanford University Press, 2006).

88. Shaanxi tongzhi xutongzhi, 7:3496, 12:6072-73. 
89. Shaanxi tongzhi xutongzhi, 11:5514 ff.

90. Jen Yu-wen, Taiping Revolutionary Movement, 463-72.

91. Shaanxi tongzhi xutongzhi, 7:3742-43.

92. Lu Weidong, "Qingdai Shaanxi huizu de renkou biandong," Huizu yanjiu, 2003, no. 4: 71-77.

93. Jonathan N. Lipman, Familiar Strangers: A History of Muslims in Northwest China (Seattle: University of Washington Press, 1997). On derogatory and racist images of Hui, see Zeng Yuyu, "Zhengxi jilüe," in Huimin qiyi, ed. Bai Shouyi (Beijing: Shenzhou guoguangshe, 1952) [hereafter cited as HMQY], 3:21.

94. Harry Lamley, "Lineage Feuding in Southern Fujian and Eastern Guangdong under Qing Rule," in Violence in China: Essays in Culture and Counterculture, ed. Jonathan N. Lipman and Stevan Harrell (Albany: SUNY Press, 1990), 27-58.

95. Wen-djang Chu, The Moslem Rebellion in Northwest China, 1962-1878: A Study of Government Minority Policy (The Hague: Brill, 1966), 1-50; Kwang-ching Liu and Richard J. Smith, "The Military Challenge: the Northwest and the Coast," in The Cambridge History of China, vol. 11, Late Ch'ing, 180o-1911, Part 2, ed. John K. Fairbank and Kwang-ching Liu (Cambridge: Cambridge University Press, 1980), 211-19. The studies by Chu, Kwang-ching Liu and Smith, and Lipman are indispensable guides to the Muslim Rebellion in the Northwest. Much of the narrative below was guided by their research. In Chinese, see Shaanxi tongzhi xutongzhi, 11:5535-5715; HMQY, vol. 3; and Ma Xiaoshi, Xibei huizu geming jianshi (Shanghai: Dongfang shushe, 1951).

96. Shaanxi tongzhi xutongzhi, 11:5646-47, 5659; Yang Yuxiu, "Ping-Hui zhi," in HMQY, 3:84-85; Yi Kongzhao et al., "Pingding Guan-Long jilüe," in HMQY, 3:405.

97. Liu Rong memorial, June 6, 1866, in Shaanxi tongzhi xutongzhi, 11:5644-45.

98. Shaanxi tongzhi xutongzhi, 11:5656-58, 5663.

99. Shaanxi tongzhi xutongzhi, 11:5663.

100. Suide zhouzhi, 407-11; Jingbian xianzhi, 209, 308-11.

101. Perry, Rebels and Revolutionaries, 48-151.

102. Shaanxi tongzhi xutongzhi, 11:5667; Yang Yuxiu, "Ping-Hui zhi," in HMQY, 3:90.

103. Suide zhouzhi, 407-9.

104. Shaanxi tongzhi xutongzhi, 11:5663; Huo Weitao, "Dong Fuxiang qijia yu Tongzhi nian xibei zhengzhi xingshi," Ningxia shehui kexue, 1994, no. 1: 52-58; Lanxin Xiang, The Origins of the Boxer War: A Multinational Study (London: RoutledgeCurzon, 2003), 207-8, 291-93.

105. Yang Yuxiu, "Ping-Hui zhi," in $H M Q Y, 3: 85,88-89$; Yi Kongzhao et al., "Pingding Guan-Long jilüe," in $H M Q Y$, 3:401, 406-8, 428.

106. Zeng Yuyu, "Zhengxi jilüe," in $H M Q Y$, 3:29-31; Yi Kongzhao et al., "Pingding Guan-Long jilüe," in $H M Q Y, 3: 354-55,369-70,374,378$.

107. Shaanxi tongzhi xutongzhi, 11:5647-49, 5663; Yi Kongzhao et al., "Pingding Guan-Long jilüe," in $H M Q Y$, 3:405.

108. Yi Kongzhao et al., "Pingding Guan-Long jilüe," in $H M Q Y, 3: 391,396-97,420-21$, 423.

109. Yi Kongzhao et al., "Pingding Guan-Long jilüe," in HMQY, 3:442; Shenmu xiangtuzhi, 24-25, 46-51; Jingbian xianzhi, 306-17.

110. Yi Kongzhao et al., "Pingding Guan-Long jilüe," in $H M Q Y, 3: 381$; Ganquan xiangtuzhi, 7-8.

111. Yi Kongzhao et al., "Pingding Guan-Long jilüe," in $H M Q Y, 3: 427-28$. 
112. Bao’an xianzhilüe, 14-18, 23, 26, 36 .

113. Huang Zhenglin, "Tongzhi Huimin shibianhou Huanghe shangyou quyu de renkou yu shehui jingii," Shixue yuekan, 2008, no. $10: 81$.

114. Wen-djang Chu, Muslim Rebellion, 51-204; Kwang-ching Liu and Smith, "Military Challenge," 221-43; Hodong Kim, Holy War in China: The Muslim Rebellion and State in Chinese Central Asia, 1864-1877 (Stanford, CA: Stanford University Press, 2004).

115. Wen-djang Chu, Muslim Rebellion, 91-94; Shaanxi tongzhi xutongzhi, 11:5667.

116. Wen-djang Chu, Muslim Rebellion, 116-23; Kwang-ching Liu and Smith, "Military Challenge," 226-28.

117. Shaanxi tongzhi xutongzhi, 11: 5657-59; Nichols, Through Hidden Shensi, 115.

118. Shaanxi tongzhi xutongzhi, 11: 5654.

119. Shaanxi tongzhi xutongzhi, 11:5653, 5662-64; Yi Kongzhao et al., "Pingding Guan-Long jilüe," in HMQY, 3:435, 438-39.

120. Yi Kongzhao et al., "Pingding Guan-Long jilüe," in $H M Q Y, 3: 436$.

121. Suide zhouzhi, 407-11.

122. Jingbian xianzhi, 31-35, 84-87, 308-17.

123. Huo Weitao, "Dong Fuxiang," 56-58; Yi Kongzhao et al., "Pingding Guan-Long jilüe," in HMQY, 3:405, 447-48.

124. Suide zhouzhi, 405-7; Yi Kongzhao et al., "Pingding Guan-Long jilüe," in HMQY, 3:371-72, 461-64. On the Gelaohui in Shaanxi, see Carl Whitney Jacobson, "Brotherhood and Society: The Shaanxi Gelaohui, 1867-1912" (PhD diss., University of Michigan, 1993).

125. Ganquan xiangtuzhi, 12, 14; Shenmu xiangtuzhi, 24-25.

126. Zuo Zongtang, quoted in Huang Zhenglin, “Tongzhi Huimin shibianhou," 85.

127. Hosie, On the Trail, 26.

128. Shaanxi tongzhi xutongzhi, 7:3480-82.

129. Shaanxi tongzhi xutongzhi, 6:3429. Contemporary demographers, working back from more reliable census figures of the 1950s and accounting for normal population increase in the intervening period, have estimated a population loss in Yan'an Prefecture of 57.5 percent, but this seems to underestimate the extent to which lost population was later replaced by in-migration. Cao Shuji, Zhongguo renkou shi, vol. 5, Qing shiqi (Shanghai: Fudan daxue chubanshe, 2001), 599.

130. Huang Zhenglin, "Tongzhi Huimin shibianhou," 8 o.

131. Mizhi xianzhi, 2:11.

132. Suide zhouzhi, 211.

133. Shenmu xiangtuzhi, 55; Li Xiaoying, "Jindai Tianjin yanghang zai xibei diqu de yunxing jizhi-yi yangmao maoyi wei zhongxin de kaocha," in Li Jianguo and Shang Jifang, Jinxiandai xibei shehui yanjiu: Fazhan yu biange (Lanzhou: Gansu wenhua chubanshe, 2015), 16-26.

134. Suide zhouzhi, 343-44.

135. Bao'an xianzhilüe, 38. Data on juren were assembled by Jin Zhixia from Shaanxi tongzhi xutongzhi, 7:3605-92.

136. Shaanxi tongzhi xutongzhi, 9:4847-51.

137. Chai Shufan, Yu Guangyuan, and Peng Ping, Suide, Mizhi tudi wenti, 111-12.

138. Shaanxi tongzhi xutongzhi, 7:3594-95; Mizhi xianzhi, 2:7-8.

139. Chester Tan, The Boxer Catastrophe (New York: Norton, 1967), provides a classic account of the negotiations to settle the Boxer Uprising. 
140. Joseph W. Esherick and C.X. George Wei, eds., China: How the Empire Fell (London: Routledge, 2014); Douglas R. Reynolds, China: 1898-1912-The Xinzheng Revolution and Japan (Cambridge: Council on East Asian Studies, Harvard University, 1993); Zhang Haipeng and Li Xizhu, Xinzheng, lixian yu xinhai geming (Nanjing: Jiangsu renmin chubanshe, 2005).

141. Shaanxi tongzhi xutongzhi, 7:3721-22.

142. Shaanxi tongzhi xutongzhi, 7:3696; Zhonggong Shaanxi shengwei dangshi ziliao zhengji yanjiu weiyuanhui, Xinhai geming zai Shaanxi (Xi'an: Shaanxi renmin chubanshe, 1986), 181-88.

143. Zhang Pengyuan, Lixianpai yu xinhai geming, 3rd ed. (Changchun: Jilin chubanshe, 2007). This classic study was first published in Taiwan in 1969.

144. Shaanxi tongzhi xutongzhi, 7:3693-94.

145. Joseph W. Esherick, "Reconsidering 1911: Lessons of a 'Sudden Revolution," Journal of Modern Chinese History 6, no. 1 (2012): 1-14.

146. Zhonggong Shaanxi shengwei dangshi ziliao zhengji yanjiu weiyuanhui, Xinhai geming zai Shaanxi, 8-12, 181-97.

147. Jacobson, "Brotherhood and Society," 3-53.

148. For a similar Jiangxi example, see Perry, Anyuan, 44-45, 55-56.

149. "Xinhai geming zhong de Gelaohui," in Xinhai geming huiyilu, ed. Zhongguo renmin zhengzhi xieshang huiyi quanguo weiyuanhui (Beijing: Zhonghua shuju, 1963), 5:104-12; J. C. Keyte, The Passing of the Dragon: The Story of the Shensi Revolution and Relief Expedition (London: Hodder and Stoughton, 1913), 21-26.

150. Guo Xiaocheng, "Shaanxi guangfu ji," in Xinhai geming, ed. Zhongguo shixuehui (Shanghai: Renmin chubanshe, 1957), 6:40-41.

151. Jacobson, "Brotherhood and Society," 203-26; Keyte, Passing of the Dragon, 16-19; Ernest Frank Borst-Smith, Caught in the Chinese Revolution: A Record of Risks and Rescue (London: T. F. Unwin, 1912), 20-21.

152. Guo Xiaocheng, "Shaanxi guangfu ji," in Zhongguo shixuehui, Xinhai geming, 6:43.

153. Zhu Shuwu and Dang Zixin, "Shaanxi xinhai geming huiyi," in Zhongguo renmin zhengzhi xieshang huiyi quanguo weiyuanhui, Xinhai geming huiyilu, 5:12-16.

154. Li Wenzheng, "Yulin xinhai geming jilüe," in Zhongguo renmin zhengzhi xieshang huiyi quanguo weiyuanhui, Xinhai geming huiyilu, 5:73-87.

155. Borst-Smith, Caught, 47-54, 76-77, 89.

156. Jacobson, "Brotherhood and Society," 260-79, 284.

\section{SHAANXI'S EARLY COMMUNIST MOVEMENT}

1. Yang Zhongjian, "Guanyu Gongjinshe de huiyi," in Gongjinshe he "Gongjin" zazhi, ed. Zhonggong Shaanxi shengwei dangshi ziliao zhengji yanjiu weiyuanhui (Xi'an: Shaanxi renmin chubanshe, 1985) [hereafter: Gongjinshe], 407-8; Yang Zhongjian, talk, 1959, in Gongjinshe, 420; Wang Bocai, interview, 1965, in Gongjinshe, 457; Zhang Baotong, "Lüjing xuesheng qunti yu Zhonggong Shaanxi zaoqi dangzuzhi de yuanqi," Suqu yanjiu, 2020, no. 2: 13-24.

2. The Shaanxi residence and eating club was east of the Jingshan park, at Jiansuo zuoxiang (吉安所左巷), no. 6. Mao had lived at No. 8. “Tianxia renwu de boke” [Blog on world leaders], accessed July 21, 2021, http://blog.sina.com.cn/s/blog_59e5d1350102yws2.html.

3. Yang Zhongjian, "Guanyu Gongjinshe de huiyi," in Gongjinshe, 403-4. 
4. Tse-tsung Chow, The May Fourth Movement: Intellectual Revolution in Modern China (Cambridge, MA: Harvard University Press, 1960). On Wei Yechou, see Zhang Shouxian et al., "Wei Yechou," Zhonggong dangshi renwu zhuan 5 (1982): 131-74; on Li Zizhou, see Zhang Shouxian et al., "Li Zizhou," Zhonggong dangshi renwu zhuan 7 (1983): 77-100. For a contemporary account of these and other early Shaanxi student journals, see Yang Zhongjian, "Tan Shaanxi jinnian qingnianjie chubanwu," Gongjin, no. 65 (July 10, 1924): 1-6.

5. "Fakan ci," Qinzhong, no. 1 (January 20, 1920), 2. On the theme of "awakening," see John Fitzgerald, Awakening China: Politics, Culture, and Class in the Nationalist Revolution (Stanford, CA: Stanford University Press, 1996), 1-63.

6. Wei Fengbiao [Wei Yechou], “Tongguanwai de xin sichao," Qinzhong, no. 1 (January 20, 1920): 8-9.

7. See, for example, Qinzhong, no. 1 (January 20, 1920): 14, 21; no. 5 (May 20, 1920): 28; no. 6 (June 20, 1920): 26.

8. Yang Pei, "Shaanxi yaoren yu guojidang," Qinzhong, no. 5 (May 20, 1920): 25-28.

9. Documents of the Second Congress of the Common Progress Society, July 25, 1925, reprinted in Gongjin (Beijing: Renmin chubanshe, 1983), 2:28. On the split, from which a more moderate and later pro-Guomindang Evolution Society (Jinhuashe 进化社) was formed, see Yang Mingxuan, "Gongjinshe yu xibei geming," in Gongjinshe, 429. This is precisely the process so brilliantly described in van de Ven, From Friend to Comrade.

10. “1922 nian benshe huiyi an gailüe," Gongjin, no. 23 (October 10, 1922), in Gongjinshe, $20-21$.

11. Gongjin, nos. 1-105 (1921-26), reprinted in Gongjin (Beijing: Renmin chubanshe, 1983), 2 vols.

12. Van de Ven, From Friend to Comrade, 69-70.

13. Maurice J. Meisner, Li Ta-chao and the Origins of Chinese Marxism (Cambridge, MA: Harvard University Press, 1967), 52-89; Ishikawa Yoshihiro, Formation, 16-80; Dirlik, Origins of Chinese Communism, 23-35.

14. Zhang Shouxian et al., "Wei Yechou," 139; Zhang Shouxian et al., "Li Zizhou," 80. I say "allegedly" because there are no contemporary records of how Wei and Li joined the party, and by the 1930s, both were dead. Attributing their membership to the revered Li Dazhao may have been a way to enhance the prestige of these revolutionary martyrs.

15. Yang Pei, "Shaanxi yaoren yu guojidang," Qinzhong, no. 5 (May 20, 1920): 25-28.

16. "Zhongguo gongchandang duiyu shiju de zhuzhang," Gongjin, no. 17 (July 10, 1922): 1-3; excerpted translation in Saich and Yang, Rise to Power, 34-38.

17. "Eluosi geming liu zhounian jinian," Gongjin, no. 49 (November 10, 1923): 1-2.

18. “Shi, Lin ji ' 2.7 ' beihai zhulieshi zhuidaohui yougan," Gongjin, no. 31 (February 10, 1923).

19. "Jieji douzheng he jieji yishi," Gongjin, no. 60 (April 20, 1924): 1-2. See also Gongjin, no. 8 (January 25, 1922): 1, for an appeal to the "unarmed class" to expel their warlord enemy.

20. [Liu] Tianzhang, "Qu Liu zhihou," Gongjin, no. 16 (June 25, 1922).

21. "Di'erqu daibiao dahui xuanyan," reprinted in Gongjin, vol. 2 (1983), 1.

22. Published in Xiangjiang pinglun 2-4 (August-September 1919), translation in Schram et al., Mao's Road to Power, 1:378-89.

23. "Qinzhong yuekan zongzhi de jieshi," Qinzhong, no. 2 (February 20, 1920).

24. "Shaanxi de chiru," Gongjin, no. 18 (July 25, 1922): 1.

25. Borst-Smith, Caught, 17-18. 
26. Cao Peiyan, "Wo duiyu Shaanxi jiaoyu de yijian," Qinzhong, no. 1 (January 20, 1920): $13-14$.

27. Hans J. van de Ven, War and Nationalism in China, 1925-1945 (London: Routledge, 2003), 64-81; Luo Zhitian, Jibian shidai, 19-54.

28. Zhang Fang, "Minguo chunian de Shaanxi zhengju," in Zhonggong Shaanxi shengwei dangshi ziliao, Xinhai geming zai Shaanxi, 842-88.

29. See Keyte, Passing of the Dragon, 262, on the "parochial self-importance" of "Shensi for the Shensians" in the 1911 Revolution.

30. See the editors' series "Qu-Liu pian," Gongjin, nos. 5-8 (December 10, 1921-January 25, 1922); Li Yongchun and Luo Li, "Shaanxi qu-Liu yundong chutan," Hunan xingzheng xueyuan xuebao, 2015, no. 1: 114-20.

31. The record of the Qing effort to suppress opium in Shaanxi is mixed. Harold Frank Wallace, in a trip across Shaanxi in 1911, found opium suppression successful enough to produce an increase in tobacco smoking (The Big Game of Central and Western China; Being an Account of a Journey from Shanghai to London Overland across the Gobi Desert [New York: Duffield, 1913], 30). On the other hand, Edward Alsworth Ross, The Changing Chinese (New York: Century, 1911), 139, cites a local saying: "Out of ten Shensi men, eleven smokers!" By the early Republic, opium suppression was obviously failing (Hosie, On the Trail). The concern of progressive intellectuals was undeniable. See articles in Gongjin, no. 8 (January 25, 1922), no. 10 (February 25, 1922), no. 11 (March 10, 1922), and no. 12 (March 25, 1922).

32. Yang Zhongjian, "Guanyu Gongjinshe," in Gongjinshe, 403, 417. Yang even suggests that students from northern Shaanxi could travel via Shanxi, which had fewer bandits and was much safer, and thus they were relatively numerous in the Common Progress Society, planting the seeds for later revolution.

33. Liu Tianzhang, "Shaanxi de tufei," Gongjin, no. 19 (August 10, 1922): 2.

34. Robert Sterling Clark, Arthur de Carle Sowerby, and Claude Herries Chepmell, Through Shên-Kan: The Account of the Clark Expedition in North China, 1908-9 (London: T. F. Unwin, 1912), 34. See also Keyte, Passing of the Dragon; Borst-Smith, Caught. Ross, Changing Chinese, 266, makes the observation that camel caravans traveled at night to avoid conflict with mules. Night travel in the 1920 s or '3os would have been unthinkable.

35. Liu Tianzhang, "Shaanxi de tufei." For a profusely documented recent study of bandits in Northwest China, see Yuan Wenwei, Fanpan yu fuchou-minguo shiqi de xibei tufei wenti (Beijing: Renmin chubanshe, 2011), esp. 56-57, 92-93, 112, 134-35.

36. Teichman, Travels, 74.

37. Liu Tianzhang, "Shaanxi de tufei."

38. Yang Mingxuan, "Gongjinshe yu xibei geming," in Gongjinshe, 429.

39. Zhang Shifeng, "Minguo xiaoxiong Jing Yuexiu," Lantai shijie, 2012, no. 7: 45-46; Yulin diquzhi, ed. Yulin diqu difangzhi zhidao xiaozu (Xi'an: Xibei daxue chubanshe, 1994), 747; Shaanxi tongzhi xutongzhi, 7:3693.

40. Song Xinyong et al., "Du Bincheng," in Zhonggong dangshi renwu zhuan 54 (1994): 288-91; Dai Maolin and Zhao Xiaoguang, Gao Gang zhuan (Xian: Shaanxi renmin chubanshe, 2011), 13-18.

41. Tian Boyin, "Shaanbei jiandang ji huodong qingkuang," Shaanxi dangshi ziliao tongxun [hereafter: SXDSTX], 1982, no. 2: 2-4; He Yuchu, "Suide sishi dang de huodong jiankuang," SXDSTX, 1982, no. 7: 14-21. 
42. Ren Ziliang, report to Center, August 22, 1929, in Shaanxi geming lishi wenxian huiji, ed. Zhongyang dang'an guan, Shaanxi dang'an guan (n.p., 1991-) [hereafter: SXGMWJ], 2:411. (Ren, from Sichuan, was profoundly unhappy in his Shaanbei appointment and regularly requested transfer. NB: Party documents from the period are reprinted with titles that were often added by the collections' editors. Rather than cite these unwieldy titles, I have given summary titles, preserving authorship and date. The multiple volumes of this essential source have both a jia (甲) and a limited yi (乙) series. I have access only to one volume of the $y i$ series, which I call "series 2." All other citations are from the volumes of the main jia series.

43. Decision of Shaan-Gan military committee, November 26, 1927, in SXGMWJ, 2:266.

44. Zhao Tongru, Shaanbei gexian zaoqi dangshi ziliao (N.p., 1958), 125-38; Zhang Shouxian et al., "Li Zizhou," 82-86. One of the military officers in the Suide region was Xie Zichang, leader of the subsequent guerrilla movement in the area.

45. Li Jinglin, speech at the Symposium on Northwest Revolutionary History, July 4, 1945.

46. Zhonggong Shaanxi shengwei dangxiao dangshi jiaoyanshi and Shaanxi sheng shehui kexueyuan dangshi jiaoyanshi, Xin minzhuzhuyi geming shiqi Shaanxi dashi jishu (Xian: Shaanxi renmin chubanshe, 1980) [hereafter: SXDSJ], 34-107; Gongjin, passim.

47. Wang Shangde to Deng Zhongxia, June 16, 1924, in SXGMWJ, 1:3.

48. Wang Shangde to Center, December 28, 1924, Li Bingqian to Center, December 18, 1924, and Wu Huazi, report on Xi'an, October 16, 1925, all in SXGMWJ, 1:4, 64, 111.

49. Geng Bingguang, report on Shaanbei, June 14, 1926, in SXGMWJ, 1:341.

50. Zhang Bingren and Wu Huazi, report on Xi'an, October 16, 1925, in SXGMWJ, 1:105; report on Xi'an, January 31, 1926, in SXGMWJ, 1:130.

51. See reports of December 1924, August 22, 1925, and May 18, 1926, all in SXGMWJ, $1: 61,28,49$.

52. Wang Shangde, report, February 1925, in SXGMWJ, 1:13-14.

53. Wu Qi, report, February 7, 1925; Zou Jun, report, February 1925, both in SXGMWJ, 1:68-69, 75-79.

54. Shaanbei special committee, February 25, 1925, in SXGMWJ, 1:221.

55. Qinzhong, no. 4 (April 20, 1020): 42. Significantly, all the other distributors were schools.

56. Li Zhenmin, ed., Shaanxi jinxiandai mingren lu (Xian: Xibei daxue chubanshe, 1988), 1:205-8; Zhang Bingren and Wu Huazi to Socialist Youth Center on Xian, October 16, 1925, in SXGMWJ, 1:103-4.

57. Xu Youcheng and Xu Xiaobin, Yu Youren zhuan (Shanghai: Fudan daxue chubanshe, 1997), 10-123.

58. Sanyuan xianzhi (Xi'an: Shaanxi renmin chubanshe, 2000), 13, 291-95.

59. Borst-Smith, Caught, 37.

6o. Xu Youcheng and Xu Xiaobin, Yu Youren zhuan, 24-25.

61. Wang Qianyi, "Huiyi liushi nianqian Sanyuan xuesheng de geming huodong," Sanyuan wenshi ziliao 2, (December 1986): 120-29.

62. Wang Qianyi, "Huiyi liushi," 123; SXDSJ, 75-80.

63. Sanyuan Communist Youth, report to Center, June 18, 1926, in SXGMWJ, 1:458.

64. Zhang XX, report, October 1926, SXDSTX, 1984, no. 1: 17. 
65. Sanyuan xianzhi, 677; SXDSJ, 89-90.

66. Zhang Shouxian et al., "Wei Yechou," 143-53; Bai Chaoran, “Dule 'Gongjinshe jianshi' sanpian wenzhang hou de jidian yijian," in Gongjinshe, 443.

67. Wang Shangde and Zhang Bingren, report, February 1925, in SXGMWJ, 1:13-14.

68. Xu Youcheng and Xu Xiaobin, Yu Youren zhuan, 130.

69. Zhang Shouxian, "Wei Yechou," 152-53; Sanyuan xianzhi, 26.

70. Angus W. McDonald, The Urban Origins of Rural Revolution: Elites and the Masses in Hunan Province, China, 1911-1927 (Berkeley: University of California Press, 1978), 264-71.

71. James E. Sheridan, Chinese Warlord: The Career of Feng Yü-hsiang (Stanford, CA: Stanford University Press, 1966), 122-206; C. Martin Wilbur and Julie Lien-ying How, Missionaries of Revolution: Soviet Advisers and Nationalist China, 1920-1927 (Cambridge, MA: Harvard University Press, 1989), 262-63, 314-16; Li Taifen, Guominjun shigao [1930], repr. in Xibei jun jishi (Hong Kong, 1978), 301-11.

72. Song Jiahe, report to Center, March 17, 1927, in SXGMWJ, 2:2, 10.

73. Song Jiahe, report to Center, March 17, 1927, in SXGMWJ, 2:8; provincial committee report on party affairs, September 26, 1927, in SXGMWJ, 2:135, 145.

74. SXDSJ, 134-35.

75. SXDSJ, 136-37; Sheridan, Chinese Warlord, 210-14.

76. Shaanxi provincial committee to Suide, July 25, 1927, in SXGMWJ, 2:59; on Gao Gang, see Chen Zhengren, speech at the High Cadre Conference, November 1942.

77. Song Jiahe, March 17, 192, in SXGMWJ, 2:12-13.

78. SXDSJ, 115-16, 132-33.

79. Report on party affairs of the first enlarged meeting of the Shaanxi provincial committee, September 26, 1927, in SXGMWJ, 2:83.

8o. Shaan-Gan provincial committee, work plan, March 17, 1927, in SXGMWJ, series 2, $1: 23$.

81. Report of the Shaanxi provincial committee, September 26, 1927, in SXGMWJ, 2:109-12.

82. Xi'an work plan, March 22, 1927, in SXGMWJ, 2:16-17.

83. Shaanxi-Gansu committee, directive to party branches, March 1927, in SXGMWJ, 2:34.

84. Report on party affairs of the first enlarged meeting of the Shaanxi provincial committee, September 26, 1927, in SXGMWJ, 2:87-88. Li Zizhou's oral report to the party Center in August gave even more problematic statistics: of a similar 2,179 members, he reported that 80 percent were intellectuals, 20 percent were peasants, and there were "almost no" workers. Li Zizhou, report to Center, August 12, 1927, in SXGMWJ, series 2, 1:33. Perhaps the September numbers were massaged to count students from rural backgrounds as peasants.

85. Past, present, and future of Shaan-Gan Communist Youth, October 1927, in SXGMWJ, 2:239.

86. Shaanxi-Gansu committee, directive to party branches, March 1927, in SXGMWJ, 2:31, 36 .

87. Provincial committee to Suide, July 25, 1927, in SXGMWJ, 2:57-58.

88. Bai Yingkui and Zhang Jiaxiu, in Zichang xian minzhengju and Zhengxie wenshiziliao weiyuanhui, eds., Zichangling ziliao (Yan'an, n.d. [1991 preface]) [hereafter: ZCLZL], 2:109, 176.

89. Provincial committee to Weinan, July 30, 1927, in SXGMWJ, 2:62-63. 
90. The CCP's attitude toward the Common Progress Society in 1927 is interesting: "Eighty to 90 percent of the leftists in the society are our comrades, the rest are really reactionary. ... The Common Progress Society is now under fierce attack [for its radicalism]. So we really cannot promote it. We have decided not to let it assume a prominent role. On the one hand, let it serve as a 'shield' for our activities, on the other hand, let it live or die; and when our own organization is solid, then we can again show our face in it." The Common Progress Society had now become a front to be used or discarded as the party decided. Shaanxi-Gansu committee, directive to party branches, March 1927, in SXGMWJ, 2:50.

91. SXDSJ, 119-21.

92. Shaanxi-Gansu committee, directive to party branches, March 1927, in SXGMWJ, 2:39.

93. Shaanxi-Gansu enlarged plenum political report, September 26,1927 , in SXGMWJ, 2:149; report on Shaanxi politics and party affairs, March 20, 1928, in SXGMWJ, 2:319; SXDSJ, 122-31. In Sanyuan, 154 villages had peasant associations; in neighboring Fuping, 284. Zhonggong Shaanxi shengwei dangshi ziliao zhengji yanjiu weiyuanhui and Zhonggong xianyang shiwei dangshi bangongshi, eds., Weibei geming genjudi (Xi'an: Shaanxi renmin chubanshe, 1990) [hereafter: WBGJD], 1-2; Zhao Tongru, Shaanbei gexian, 160; speeches at the High Cadre Conference by Gao Gang, November 17-18, 1942, and Chen Zhengren, November 1942; "Anding (jin Zichang) xian zaoqi dang zuzhi de chuangjian jiqi zhuyao huodong," unpublished, 1988, copy supplied by Zichang party history office.

94. Shaanbei committee to Center, April 1925, in SXGMWJ, 1:226; Zhonggong Zichang xianwei zuzhibu, Zhonggong Zichang xianwei dangshi yanjiushi, and Zichang xian dang'an guan, Zhongguo gongchandang Shaanxisheng Zichangxian zuzhishi ziliao (Spring 1925October 1987) (Xi'an: Shaanxi renmin chubanshe, 1994), 16-18. For a careful analysis of the similar process in Jiangxi, see Averill, Revolution in the Highlands, 109-43.

95. Shaanxi-Gansu committee, directive to party branches, March 1927, in SXGMWJ, 2:40-43. In Sanyuan, a CCP member of a wealthy family arranged for the key organizer to live with the local militia head. Li Hongru, in WBGJD, 272.

96. Shaanxi minguo ribao, June 20, 1927, in ZCLZL, 1:85. See also Wang Shucai, Shaanbei gongchandang de lao zhanggui Cui Tianfu (Beijing: n.p., 2010), 35-43.

97. Zhao Tongru, Shaanbei gexian, 41-42, 51, 90-91. The head of the education bureau was Yang Mingxuan, a senior Shaanxi educator and progressive who joined the CCP in late 1926. Li Zhenmin, Shaanxi jinxiandai mingren lu, 1:202-5.

98. Sheridan, Chinese Warlord, 215-16.

99. Report on party affairs at first enlarged meeting of Shaanxi provincial committee, September 9, 1927, in SXGMWJ, 2:134.

100. Huaiyin Li, Village Governance in North China (Stanford, CA: Stanford University Press, 2005), 209-14; Patrician Thornton, Disciplining the State: Virtue, Violence and StateMaking in Modern China (Cambridge, MA: Harvard University Asia Center, 2007), 100-126. 101. Li Peiwen, in WBGJD, 264-65.

102. Sheridan, Chinese Warlord, 25, gives a telling list of warlord era taxes.

103. SXDSJ, 121-31, 151-52.

104. Bianco, Peasants without the Party; Bianco, Wretched Rebels.

105. Shaanxi provincial committee on military situation, August 6, 1927, in SXGMWJ, 2:70-71; party affairs report of September 26,1927 , meeting of Shaanxi provincial committee, in $S X G M W J$, 2:156-57. 
106. Sheridan, Chinese Warlord, 216-32; SXDSJ, 140-54; recollections of Geng Bingguang, Liu Jizeng, and Wang Lin, in Zhonggong Shaanxi shengwei dangshi yanjiushi, Tudi geming zhanzheng shiqi de Zhonggong Shaanxi shengwei (Xian: Shaanxi renmin chubanshe, 1991) [hereafter: TDSW], 620, 631-32, 638; Zhang Xiushan, interview, September 1985, in 1942 High Cadre Conference documents.

107. Marcia R. Ristaino, China's Art of Revolution: The Mobilization of Discontent, 1927 and 1928 (Durham, NC: Duke University Press, 1987), 39-55, gives an excellent account of the August 7 Conference. For the conference documents, see Saich and Yang, Rise to Power, 296-317. Cited passages from Ristaino, China's Art of Revolution, 53; Saich and Yang, Rise to Power, 317 .

108. Du Heng, Shaanxi gongdang yange, in TDSW, 880-81. The full text of Du Heng's history of the Shaanxi party is in the Shaanxi provincial archives and has never been published. After years trying to obtain a copy, I have yet to see one.

109. Li Zizhou, report to the Center, August 12, 1927, in SXGMWJ, series 2, 1:33-36.

110. Li Zizhou, report to Center and Center response, August 12, 1927, in SXGMWJ, series 2, 1:33-39.

111. Mao Zedong, "Hunan nongmin yundong kaocha baogao," in Mao Zedong xuanji (Beijing: Renmin chubanshe, 1951), 1:19-20. The original version is in Takeuchi Minoru, Mō Takutō shū (Tokyo: Hokubōsha, 1972), 1:207-49.

112. Decisions of the provincial committee, December 2, 1927, in TDSW, 169; party affairs report of September 26, 1927 enlarged meeting, in SXGMWJ, 2:173; plan for organization work, November 1, 1927, to January 31, 1928, in TDSW, 150. A table following p. 170 of the party affairs report gives the figure as 1,591 .

113. Party affairs report of September 26, 1927 enlarged meeting, in SXGMWJ, 2:155-56.

114. Provincial committee to Suide, July 25, 1927, in SXGMWJ, 2:58-61; party affairs report of September 26, 1927, enlarged meeting, in SXGMWJ, 2:86, 93; He Yuchu, "Suide sishi dang de huodong jiankuang," SXDSTX, 1982, no. 7: 14-21; Huo Zhongnian and Li Wenfang, "Yuzhong dang zuzhi de chansheng he zai da geming shiqi de huodong," SXDSTX, 1982, no. 7: 22-26.

115. The report on party affairs listed 2,147 members in Shaanxi and 30 in Gansu. SXGMWJ, 2:113.

116. Provincial committee, announcement, October 8, 1927, in SXGMWJ, 2:209-11.

117. Provincial committee to Center, July 11, 1927, in TDSW, 86; Geng Bingguang, political report to September 26, 1927, meeting, in TDSW, 102.

118. Song Jiahe on Northwest military, March 17, 1927, in SXGMWJ, 2:8-9; provincial committee to local branches, March 1927, in SXGMWJ, 2:44; provincial committee to Center on political and military situation, August 6, 1927, in SXGMWJ, 2:70-71. As late as October 1927, the provincial peasant association still called for support of "the lone revolutionary leader of our northwest: Yu Youren." Provincial Peasant Association, open letter, October 2, 1927, in SWGMWJ, series 2, 1:60-61.

119. Decision of provincial committee, December 2, 1927, in TDSW, 163.

120. Enlarged meeting of provincial committee, decision on peasant struggle, September 26, 1927, in SXGMWJ, 2:189-90. The Red Spears (Hongqianghui 红枪会) were a peasant self-defense force with invulnerability rituals reminiscent of the Boxers, who often organized against warlord exactions. See Perry, Rebels and Revolutionaries, 152-207. 
121. Chen Zhengren, speech at the High Cadre Conference, November 1942; Ma Wenrui, speech at the Symposium on Northwest Revolutionary History, July 12, 1945.

122. Fang Chengxiang and Huang Zhao'an, Shan-Gan-Ning bianqu geming shi (Xian: Shaanxi Normal University Press, 1991), 2-3.

123. Zhang Shouxian et al., "Wei Yechou," 160-73.

124. Geng Bingguang, "Wo zai Shaanxi shengwei de gongzuo," in TDSW, 620; Li Zizhou to Center, August 6, 1927, in SXGMWJ, 2:67; Chen Jiazhen to Center, November 2, 1927, in $S X G M W J$, series 2, 1:81; provincial committee to Center on political, military affairs, August 6, 1929, in SXGMWJ, 2:71-72.

125. Zhao Tongru, Shaanbei gexian, 95-97, 131-38, 156-64.

126. "Guanzhong daoke," in Zhonggong Shaanxi shengwei dangshi ziliao, Xinhai geming zai Shaanxi, 244-55.

127. "Shi Qian," accessed July 22, 2021, http://ren.bytravel.cn/history/6/shiqian34925920 .html.

128. Zhao Tongru, Shaanbei gexian, 160; Shaanxi minguo ribao, June 20, 1927, in ZCLZL, 1:85-86; Zhang Jiaxiu, in ZCLZL, 2:179-9o.

129. Shaanxi provincial committee report on Shaanbei military activities, November 1927, in Zhonggong Shaanxi shengwei dangshi ziliao zhengji yanjiu weiyuanhui, Qingjian Xunyi dengdi de wuzhuang qiyi (Xian: Shaanxi renmin chubanshe, 1988), 16. This same document appears in SXGMWJ, series 2, 1:91-97, with the implausible date of January 1928; provincial committee to Shaanbei, October 1927, in SXGMWJ, series 2, 1:76-78.

130. The best accounts of the Qingjian Uprising are collected in SXDSTX, 1983, no. 1, especially Li Xiangjiu, "Qingjian qiyi qianhou," 19-25; Huyan Zhenxi, "Qingjian qiyi de huiyi," 25-33, and Li Ruiyang, "Dang zai Shi Qian budui de huodong' de buchong," 35-37. After some further editing, these were published in Zhonggong Shaanxi shengwei dangshi ziliao, Qingjian Xunyi dengdi de wuzhuang qiyi. The official version, hostile to Li Xiangru's vacillation, is in SXDSJ, 161-65. See also Du Heng, Shaanxi gongdang yange, in TDSW, 883; provincial committee to Center, October 13, 1927, in TDSW, 144-45; Shaanxi military committee, report, November 17, 1927, in SXGMWJ, 2:252-54; Zhao Tongru, Shaanbei gexian, 59-60, 101-4.

131. Party affairs report of the enlarged meeting, September 26,1927 , in TDSW, 112.

132. Provincial committee to Center, October 13, 1927, in SXGMWJ, series 2, 1:67-68.

133. Zhonggong Shaanxi shengwei dangshi ziliao zhengji yanjiu weiyuanhui, ed., Wei-Hua qiyi (Xian: Shaanxi renmin chubanshe, n.d.) [hereafter: WHQY], 3-7; Center to Xu Quanzhong, March 20, 1928, in WHQY, 32-33; Li Jizeng, recollections, in WHQY, 118-21.

134. Center to provincial committee, January 2, 1928, in WHQY, 27.

135. Political report, March 20, 1928, in SXGMWJ, 2:316. Xiao Ming to Center, September 6, 1928, in SXGMWJ, series 2, 1:118, claims over one thousand in Weinan alone, where he worked. For fall 1927 figures, party affairs report of first enlarged party committee, September 26, 1927, in SXGMWJ, 2: table following p. 170. On early peasant organizing, see Chishui reports from 1925-26 in SXGMWJ, 1:35-43, 47, 127.

136. Averill, Revolution in the Highlands, 109-12.

137. Gao Gang, speech at the Symposium on Northwest Revolutionary History, August 2, 1945. This was a popular slogan elsewhere in the radical phase of the peasant movement. See the original version of Mao's Hunan report in Takeuchi, Mō Takutō shū, 1:212. 
138. He Yuchu, recollection, 1951, in WHQY, 237-38.

139. "Weinan Xuanhua baodong," March 10, 1928, in WHQY, 87; provincial committee, announcement, March 13, 1928, in TDSW, 226-27.

140. WHQY, passim; Du Heng, Shaanxi gongdang yange, in TDSW, 884-85; Pan Zili, "Youguan Wei-Hua qiyi wenti," SXDSTX, 1982, no. 9: 4-11; provincial committee, report on Wei-Hua, August 1, 1928, in SXGMWJ, 2:339-42.

141. The party history office of the Shaanxi provincial party published special collections on each of these uprisings: Zhonggong Shaanxi shengwei dangshi ziliao, Qingjian Xunyi dengdi de wuzhuang qiyi (1988) and WHQY (1985). The first of these also describes a 1928 uprising in Xunyi in which the magistrate was killed, but it too was short lived and followed a pattern of local elite collaboration seen elsewhere.

142. In 1943, Xi Zhongxun criticized the Xunyi leaders for "joining with local strongmen and landlords, asking them to distribute grain to the masses." Xi Zhongxun, in Hong ershiliu jun yu Shaan-Ganbian suqu, ed. Zhonggong Qingyang diwei dangshi ziliao zhengji bangongshi (Lanzhou: Lanzhou daxue chubanshe, 1995) [hereafter H26J], 2:98o. NB: my copy of vol. 1 is a scanned version for which the page numbers do not correspond to the original.

143. Geng Bingguang to provincial committee, February 12, 1928, in TDSW, 211, 213. The youth league leader was Zhang Jinyin, better known by a later name: Zhang Mutao.

144. Communist Youth League to Center, January 8, 1928, in SXGMWJ, series 2, 1:83-90; provincial committee on expulsion of Geng, January 29, 1928, in TDSW, 199-200; Geng Bingguang, response, December 12, 1928, in TDSW, 205-15; Du Heng, Shaanxi gongdang yange, in TDSW, 884 .

145. Provincial committee on guerrilla struggle, January 12, 1928, in SXGMWJ, 2:271-72; Communist Youth League, political report, October 1927, in SXGMWJ, 2:224.

146. Report on politics and party work, March 20, 1928, in SXGMWJ, 2:316-17.

147. Provincial committee to Center, May 4, 1929, in TDSW, 280-82.

148. Shaanxi representatives, report to Center, May 4, 1929, in SXGMWJ, 2:370-71, 375-77; Shaanxi provisional committee to Center on August work, September 2, 1929, in SXGMWJ, 2:434-36.

149. Provisional committee to Center, March 3, 1929, in TDSW, 264-67; Cao Zhilin and Ren Qingyun, recollections, in TDSW, 647-51; Zhang Shouxian et al., "Li Zizhou," 95-99.

150. Du Heng, Shaanxi gongdang yange, in TDSW, 880.

151. Provincial representatives to the Center on Shaanxi work, March 18, 1928, in SXGMWJ, series 2, 1:116.

152. Provincial committee, decision on the Gongjinshe and Jinhuashe, September 27, 1927, in SXGMWJ, 2:202-4.

153. Party affairs report of September 26, 1927 enlarged meeting, in SXGMWJ, 2:119.

154. Shaanxi representative to Center, June 11, 1929, in SXGMWJ, series 2, 1:129-30.

155. Wang Shangde to Socialist Youth Center, February 2, 1925, in SXGMWJ, 1:10.

156. Provincial committee to Center, December 9, 1928, in SXGMWJ, series 2, 1:128; Zhang Xiushan, H26J, 1:260; Wang Shitai in Shan-Ganbian geming genjudi, ed. Zhonggong Shaanxi shengwei dangshi yanjiushi and Zhonggong Gansu shengwei dangshi yanjiushi (Beijing: Zhonggong dangshi chubanshe, 1997) [hereafter: SGGJD], 296.

157. Provincial committee to Weinan, October 17, 1927, in SXGMWJ, series 2, 1:75.

158. Instruction of the Shaan-Gan regional committee, March 1927, in SXGMWJ, 2:31. 
159. Wang Shangde to Communist Youth Center, December 28, 1924, reported receiving 780 yuan in 1924 but said he still needed 400, some of which he raised locally, in SXGMWJ, 1:4; see also $63-64,87$, 110-11.

160. Li Zizhou, report to party Center, August 6, 1927, in SXGMWJ, 2:67, indicates that party organizers were supported by the Guomindang or the peasant movement.

161. Zhao Tongru, Shaanbei gexian, 142-43. The Chinese dollar was roughly equal to the U.S. dollar in this period.

162. Provincial committee to Center on finances, October 1928, in SXGMWJ, series 2, 1:122-25. As is often the case with Chinese statistics, the numbers in this document are problematic: the listed totals are not the sum of the separate categories. A note at the top of the original document indicates that some unspecified parts were unclear (kanbuqing 看不清), so the problem may have been in deciphering the original message. The greatest discrepancy is in the income for October, where $\$ \mathbf{2 , 2 2 2 . 2 0}$ is given as the sum of items that in fact total $\$ 1,007.20$. This sum would be correct if the "Center subsidy remitted by comrade $\mathrm{Pu}$ [蒲]" was $\$ 1,350$ instead of $\$ 135$. Furthermore, the surplus listed for October, $\$ 911.22$, is more consistent, though still inexact, with that sum than with the actual total. If this is correct, then the total Center subsidy for October would increase from $\$ 877.30$ to $\$ 2,092.30$. This is not impossible, as there may have been an extraordinary addition for the support and rescue of arrested comrades, though this conclusion would be pure speculation.

163. Li Zizhou, report to party Center, August 6, 1927, in SXGMWJ, 2:67. His report promises a budget in a separate document, but that is not included in this collection.

164. Ren Ziliang to Center, August 5, 1929, in SXGMWJ, 2:408.

165. Provincial committee to Center on finances, August 18, 1928, in SXGMWJ, 2:343; Zhao Tongru, Shaanbei gexian, 143 .

166. Provincial committee to Center on finances, January 2, 1929, in SXGMWJ, 2:360-61.

167. Shaanxi provisional committee, report, March 3, 1929, in TDSW, 263.

168. Patricia Stranahan, Underground: The Shanghai Communist Party and the Politics of Survival, 1927-1937 (Lanham, MD: Rowman and Littlefield, 1998), 52, 132.

169. Li Xiaolan, Xijing ribao, July 30, 1933, cited in Joseph W. Esherick, "The CCP in the 1930s: The View from Defectors' Declarations (脱离共党宣言), PRC History Review 2, no. 2 (April 2017): 4 .

170. Li Zizhou, report to party Center, August 6, 1927, in SXGMWJ, 2:66-69; decision of the provincial committee, September 27, 1927, in SXGMWJ, 2:205.

171. Yang Kuisong, "Zhongjian didai" de geming, esp. 30-32, 176; Ishikawa Yoshihiro, Formation, 13, 126-50.

\section{BANDITS AND BOLSHEVIKS}

1. The best general narratives of the military struggles of this era are the editors' introductions to $S G G J D, 1-22$, and $H_{2} 6 J, 1: 1-75$. In general, I have relied on these introductions for reference, but my notes' preference is for the primary sources: first contemporary party documents and secondarily memoir accounts.

2. Informants 5 and 6.

3. E. Snow, Red Star Over China, 199. See also Xu Youwei and Philip Billingsley, "Heroes, Martyrs, and Villains in 1930 S Shaanbei: Liu Zhidan and His 'Bandit Policy," Modern China 44, no. 3 (2018): 243-50; and Ishikawa Yoshihiro, "Xiaoshuo 'Liu Zhidan' Shijian de lishi 
beijing," Riben dangdai Zhongguo yanjiu, 2012, 25-32, www.waseda.jp/prj-wiccs/wp/wp -content/uploads/2012/o7/jscc2012.pdf, for a good summary of Liu's career.

4. Heng Zhi, "Shaanbei feikui Liu Zidan," Zhongwai wenti 14, no. 3 (1936): 136-37.

5. Informants 7 and 8 .

6. Li Zhenmin and Zhang Shouxian, "Liu Zhidan," Zhonggong dangshi renwu zhuan 3 (1981): 191.

7. Informant 8. See chapter 1 on gentry status in Shaanbei.

8. Informant 5 .

9. Informant 8.

10. Joseph W. Esherick, Ancestral Leaves: A Family Journey through Chinese History (Berkeley: University of California Press, 2011), 39.

11. Liu Zhidan, Liu Zhidan wenji (Beijing: Renmin chubanshe, 2012), 7, 90-95; Li Zhenmin and Zhang Shouxian, "Liu Zhidan," 3:191-99; Wang Ziyi, interview, 1978, Zhidan party history office; Liu Jingfan, in Liu Mila and Liu Dudu, Liu Jingfan jinian wenji (Beijing: Zhongyang wenxian chubanshe, 2015), 1:17-18.

12. Liu Jingfan, in Liu Mila and Liu Dudu, Liu Jingfan jinian wenji, 1:9, 38, 45.

13. Liu Jingfan, in Liu Mila and Liu Dudu, Liu Jingfan jinian wenji, 1:20-21; Zhang Dazhi, interview, 1978, Zhidan party history office; informant 5 (a Jintang resident).

14. Zhang Dazhi, interview, 1978, Zhidan party history office.

15. Zhang Ce, interview, 1978, Zhidan party history office. Zhang was Liu Zhidan's branch secretary in 1933 and punished him to force Liu to quit his opium habit. On opium in society, see Zheng Yangwen, The Social Life of Opium in China (Cambridge: Cambridge University Press, 2005), 62-63, 146-50.

16. Liu Zhidan and Xi Zhongxun, "Shaan-Gan bian genjudi 'Shi da zhengce," November 1934, in Liu Zhidan, Liu Zhidan wenji, 38.

17. "Shaan-Gan bian genjudi junzheng ganbu xuexiao shouke tigang," November 9, 1934, in Liu Zhidan, Liu Zhidan wenji, 29.

18. Liu Jingfan, in Liu Mila and Liu Dudu, Liu Jingfan jinian wenji, 1:11.

19. "Zai junzheng ganbu xuexiao kaixue dahuishang de jianghua yaodian," November 1934, in Liu Zhidan, Liu Zhidan wenji, 31.

20. "Zhongguo gongnong hongjun Shaan-Gan youjidui bugao," 1932, in Liu Zhidan, Liu Zhidan wenji, 22-23. The term haoshen (豪绅) is pervasive in contemporary documents and memoirs as a description of the party's enemies. It is related to (essentially shorthand for) tuhao lieshen, "local bullies and evil gentry" in the conventional translation, who were the enemy of the National Revolution of the 1920s. "Gentry strongmen" seems the best translation for the sorts of people described, with the provision that few "gentry" in Shaanbei had passed the exams for their degrees.

21. "Zai junzheng ganbu xuexiao," in Liu Zhidan, Liu Zhidan wenji, 32.

22. Zhang Zhongliang, in $S G G J D, 466-67$. NB: This citation format (a name but no date) is used for essays or memoirs included in such collections as SGGJD.

23. Li Zhenmin and Zhang Shouxian, "Liu Zhidan," 225; Ma Wenrui and Zhang Dazhi, interviews, 1978, Zhidan party history office.

24. Liu Jingfan, in H26J, 2:501; Wang Shitai, in H26J, 2:511.

25. Documents of the Second Congress, in Gongjin, 2:11.

26. Lü Wenhua, interview, 1978, Zhidan party history office. 
27. Ma Yunze, in $S G G J D, 476$.

28. Zhang Zhanrong, in $\mathrm{H}_{2} 6 \mathrm{~J}$, 1:255.

29. Zhang Ce, interview, 1978, Zhidan party history office.

30. Report of the Shaanbei special committee, December 20, 1932, in SXGMWJ, 5:407; Liu Jingfan, in SGGJD, 412-13.

31. Liu Jingfan, in $H_{26} 6$, 1:317; Shaanxi work report, September 13, 1930, in SXGMWJ, 3:207.

32. Zhao Boping, in TDSW, 707-8; Shaanxi military committee report, November 17 , 1927 , in SXGMWJ, 2:252-53.

33. Shaanxi committee on the guerrilla movement, February 15, 1932, in TDSW, 451; SXGMWJ, 4:291-94; Zhang Xiushan, H26J, 1:259.

34. Shang Jifang, "Xianzhang nanwei: Minguo shiqi xianji guanyuan de jinnan chujing-yi Gansu sheng weili," in Li Jianguo and Shang Jifang, Jinxiandai xibei shehui yanjiu, 250-52.

35. Phil Billingsley, Bandits in Republican China (Stanford, CA: Stanford University Press, 1988).

36. Liu Jingfan, in Liu Mila and Liu Dudu, Liu Jingfan jinian wenji, 1:12-13; Zhang Zhanrong, in H26J, 1:255-56; "Shaan-Gan-Ning diaocha zhuanbao," report, n.d. [ca. 1938], Guomindang Bureau of Investigation (国民党调查统计局) archives, Taibei, Taiwan [hereafter BOI], BOI 575.292/815, copy from Stanford Library.

37. Liu Jingfan, in Liu Mila and Liu Dudu, Liu Jingfan jinian wenji, 1:37; Jacobson, "Brotherhood and Society"; Yuan Wenwei, Fanpan yu fuchou, 85-114.

38. Informant 3 .

39. Report on east Gansu guerrillas, September 23, 1932, in SXGMWJ, 5:98; Ma Yangxi and Li Peifu, in SGGJD, 662-63.

40. Liu Jingfan, in $\mathrm{H}_{2} 6 \mathrm{~J}$, 2:502.

41. Report on Twenty-Sixth Army, July 14, 1933, in SXGMWJ, 7:123-24; Zhang Zhongliang, in SGGJD, 461.

42. Huang Jingui and Zhang Xiushan, in H26J, 1:258, 259.

43. Jiao Weichi, report, June 12, 1932, in SXGMWJ, 5:272-73.

44. Li Zhihe, in SGGJD, 498-500.

45. Chang Youfu and Zhao Yuanheng, in $H_{26} 6 \mathrm{~J}, 1: 316-17$.

46. Liu Jingfan, in Liu Mila and Liu Dudu, Liu Jingfan jinian wenji, 1:12-14, 38, 45.

47. Informant 1.

48. Informant 4 .

49. The Bao'an militia commander was Zhang Tingzhi, whom we will meet again in chapter 6 as an implacable foe of the revolution. Zhang's reactionary history has colored memoir sources on Liu's early collaboration. Liu's brother Jingfan says that the sister who married into the Zhang family complained of mistreatment when she returned to her natal home. Liu's father, who presumably arranged his daughter's marriage, still worked with Zhang Tingzhi and later urged Liu to rejoin the local militia. Zhang on the one hand sought to use Liu, once proposing a sworn brotherhood with Liu as elder brother, but that was allegedly refused. On the other hand, Zhang was jealous of Liu's superior credentials. Behind the revolutionary narrative, there was the usual complex mix of cooperation and competition between these two local elite families. Liu Jingfan in Liu Mila and Liu Dudu, 
Liu Jingfan jinian wenji, 1:7, 13, 15-17, 21; Liu Jingfan, in H26J, 2:502; Yuan Xuxiu, interview, 1978, Zhidan party history office; Ma Xiwu, in SGGJD, 415-16; [an unnamed PLA officer], interview, 1977, Zhidan party history office.

50. Center to Shaanxi provincial committee, January 2, 1928, in TDSW, 191-92; Xie Hua, in TDSW, 877-78; provincial committee, February 28, 1928, in SXGMWJ, 2:278; Zhang Dazhi, interview, 1978, Zhidan party history office.

51. Wang Shitai, speech at the High Cadre Conference, November 11, 1942.

52. Provincial committee to Center, April 31, 1930, in SXGMWJ, 3:65.

53. Xi Zhongxun, "Lishi de huigu," in SGGJD, 2; "Shaan-Gan gaoyuan geming zhengcheng," in SGGJD, 247.

54. Du Heng, report to northern secretaries' meeting, June 2, 1932, in SXGMWJ, 3:245-49.

55. Provincial committee to Center, May 4, 1929, in SXGMWJ, 2:389-90; provincial committee, directives on army work, September 12, 1932, in SXGMWJ, 5:32-36, and February 18, 1933 [original says February 28, but this appears to be an error], in SXGMWJ, 6:252-57, 261.

56. Li Zhenmin and Zhang Shouxian, "Liu Zhidan," 200-201; Jiang Zhaoying, in H26J, 1:250, also in SGGJD, 552-57; Jiang Yuntai, in H26J, 1:263, and SGGJD, 1-3; speeches at the Symposium on Northwest Revolutionary History by Zhang Xiushan, July 1945, and Wang Shitai, July 1945. Contemporary evidence of Liu's friendly relations with army officers in the area is provided by a letter written to a comrade hospitalized in Xian, telling him whom to turn to for assistance. Liu Zhidan to Bai Guanwu (白冠五), April 2, 1934, in Liu Zhidan, Liu Zhidan wenji, 26.

57. Chen Zhengren, speech at the High Cadre Conference, November 1942. Significantly, this expulsion is never mentioned in future published writings about Liu.

58. Zhang Xiushan, in H26J, 1:260-61; Jiang Yuntai, in H26J, 1:263-64.

59. Lü Wenhua, interview, 1978, Zhidan County party history office.

6o. Liu Jingfan, in H26J, 1:243-44; Ma Xiwu, in H26J, 1:239; Wang Shitai, in SGGJD, 295-97.

61. Zhang Xiushan, interview, 1978, Zhidan County party history office.

62. Liu Jingfan, in SGGJD, 404; Zhang Zhanrong, in H26J, 1:255.

63. Wang Shitai, in SGGJD, 293-94.

64. Jiang Zhaoying, in H26J, 1:252-53; Zhang Xiushan, in H26J, 1: 262, 379; Yan Hongyan, in SGGJD, 268-69; informant 2. Yuan Wenwei's thorough study of banditry in Northwest China, Fanpan yu fuchou, contains a chapter (pp. 175-87) on the political tendencies of bandits, much of it devoted to Communist policy. In a richly documented study, only this chapter lacks footnotes, and Liu Zhidan is never mentioned. Party censorship today reflects the enduring sensitivity of shifting party policy on banditry.

65. Xi Zhongxun, in SGGJD, 249; Zhang Xiushan, in SGGJD, 380.

66. Liu Jingfan, in $S G G J D, 405$.

67. The conflict between the two factions became so intense that meetings were called in the 1980 os to resolve the differences. The result was to enjoin both sides from writing any further on the issue-an unfortunate result for those attempting to determine the facts. The report is summarized in SXDSTX, 1986, no. 8. See also Wang Xiaozhong, Zhongguwei gongzuo jishi, 1982-1987 (Hong Kong: Tiandi tushu youxian gongsi, 2013), 5-75; and the compelling account in Ishikawa Yoshihiro, "Xiaoshuo 'Liu Zhidan." One dubious account 
claims that the Northwest Work Committee decided to rename Anding County in Xie's honor in 1935, which would have been before Bao'an was renamed (Xie Shaoming [谢绍明], Xie Zichang's apparently adopted son, in ZCLZL, 2:316).

68. Qiang Tieniu, in ZCLZL, 2:383-84; informant 17.

69. You Xiangzhai, Xie's wife, in ZCLZL, 2:290-93. Informant 18 stated that Xie "had problems" in his conjugal life, suggesting that this may account for the lack of heirs.

70. "Shaanbei shoufu chiqu shichaji," pt. 8, Dagongbao, December 18, 1936.

71. Ma Peixun, in ZCLZL, 2:140-41; Li Chiran, Li Chiran jiangjun huiyilu (Beijing: Dongfang chubanshe, 2000), 5-7.

72. Zhao Tongru, Shaanbei gexian, 164 .

73. Li Zhenmin, Zhang Shouxian, and Liang Xingliang, "Xie Zichang," in Zhonggong dangshi renwu zhuan, 3: 229-58; ZCLZL, 1:52-86, 131-32; 2:1-9 (He Jinnian), 50-58 (Yan Hongyan), 91-97 (Yang Ziwei).

74. "Xie Zichang tongzhi zaoqi de bingyun huodong," Zichang party history office, n.d., 3-4; informant 19.

75. Yan Hongyan, in SGGJD, 264-67; Wu Daifeng, in SGGJD, 420-21; Ma Wenrui, SXDSTX, 1985, no. 13: 80-84.

76. Provincial committee to Center, February 15, 1932, in SXGMWJ, 4:15.

77. Yan Hongyan, in SGGJD, 267; Wu Daifeng, Ma Peixun, and Ma Yunze, in H26J, 2:546-55.

78. Liu Jingfan, in $S G G J D$, 406-7.

79. Yan Hongyan, in $S G G J D, 267$.

80. Provincial committee directive to Shaan-Gan guerrillas, January 20, 1932, in SXGMWJ, 4:4.

81. Report on Shaan-Gan guerrillas, received by Center, April 27, 1932, in SXGMWJ, 4:119.

82. Provincial committee decision on Shaan-Gan guerrillas, March 6, 1932, SXGMWJ, 4:39; cf. Wang Shitai, in H26J, 1:249.

83. Zhang Xiushan, in $S G G J D, 379$.

84. Yan Hongyan, in SGGJD, 268-69.

85. Report from Shaan-Gan guerrillas, March 22, 1932, in SXGMWJ, 4:57.

86. Du Heng, report to North China secretaries' meeting, June 2, 1932, in SXGMWJ, 4:212-13.

87. Du Heng, report to North China secretaries' meeting, June 2, 1932, in SXGMWJ, 4:232-33.

88. Liu Jingfan, in SGGJD, 407; Yan Hongyan, in SGGJD, 268; Ma Yunze, in ZCLZL, 2:246-49.

89. Report on Shaan-Gan guerrillas, February 15, 1932, in SXGMWJ, 4:16. Subsequent memoirs often substitute "Resist Japan” (Kang-Ri 抗日) in the name of this army, but this is incorrect. Liu Jingfan, in $S G G J D, 407$.

90. Ma Yunze, in ZCLZL, 2:248-51; Wu Daifeng et al., in H26J, 2:557.

91. There were credible charges of rape against Zhao's band (see accounts of Ma Peixun and Li Weijun cited below). When I asked a member of the Liu family about this incident, her response was simply "She was a widow," as though that explained, even justified, the rape. Matthew Sommer's research has shown that this region of eastern Gansu was known 
for unorthodox sexual relations, including polyandry and extramarital relations by poor women needing financial and perhaps emotional support. See Sommer, Polyandry and Wife-Selling, 53-54. Zhao certainly had a large sexual appetite: he had two wives with him in the guerrilla band. (Li Weijun's account, in SGGJD, 490-93).

92. Ma Peixun, in ZCLZL, 2:144.

93. The Sanjiayuan incident is a contentious subject in Shaanxi party history. Contemporary documents give it only passing mention. See report of April 27, 1932, and Du Heng's less reliable report to the North China secretaries' meeting, June 2, 1932, in SXGMWJ, 4:118-22 and 200-203. The best memoir accounts are in SGGJD (Liu Jingfang, 407-8, Wu Daifeng, 424-25, Ma Peixun, 469-70, Cao Enjun, 485-88, Li Weijun, 490-93, and Yang Peisheng, 495-96); in H26J (Lei Enjun, 1:265-66; Liang Huaide, 1:266, and Wu Zhixue, 1:267; and in ZCLZL (Ma Peixun, 2:143-44); also informant 2. There is sharp disagreement on who shot Zhao Erwa. Liu Jingfan (Zhidan's brother) names Yan Hongyan, leader of the Shanxi guerrillas and a native of Xie Zichang's home county of Anding. Wu Daifeng, Ma Peixun, Cao Enjun, and Lei Enjun name another aide of Xie Zichang, Bai Xilin. Li Weijun names a third person. Most likely, the majority view is correct, and Liu Jingfan's version is colored by his animosity to Yan Hongyan.

94. Party committee on Shaan-Gan guerrillas, March 20, 1932, in H26J, 1:88; H26J, 1:11; Liu Jingfan, in H26J, 1:246-47; Ma Yunze, in ZCLZL, 2:251.

95. Provincial committee, October 9, 1929, in SXGMWJ, 2:490; report of the temporary committee, March 3, 1929, in TDSW, 264-67; Ren Qingyun, in TDSW, 649-51; provincial committee to Center, March 31, 1931, in SXGMWJ, series 2, 1:181-84.

96. See, for example, provincial committee to Pucheng, April 4, 1930, in SXGMWJ, 3:12; provincial committee announcement, April 7, 1930, in SXGMWJ, 3:15-16.

97. On the Comintern and the party Center, see Saich and Yang, Rise to Power, 277-88; on Li Lisan, see Perry, Anyuan, 57-89; Benjamin Yang, "Complexity and Reasonability: Reassessment of the Li Lisan Adventure," Australian Journal of Chinese Affairs 21 (January 1989): 111-41; for Shaanxi, see provincial committee, September 14, 1930, in SXGMWJ, 3:260-75.

98. See provincial committee to Shaanbei, May 25, 1930, in SXGMWJ, 3:97, 104-7.

99. Ji Guozhen to Center, April 20, 1931, in SXGMWJ, series 2, 1:240, 254, 261.

100. Provincial committee to Center, February 13, 1931, in SXGMWJ, 3:303-8; Shaanxi sixth plenum decision, March 28, 1931, in SXGMWJ, 3:325-32; Zhang Wenhua, in TDSW, 699-700. On Luo Zhanglong's challenge, see Saich and Yang, Rise to Power, 287-88, 463-71.

101. Center to provincial committee, May 24, 1931, in TDSW, 429-30.

102. Fuping committee, work plans, April 1931, in SXGMWJ, 3:364. Throughout 1931, the documents in this volume reflect the same urban focus.

103. Zhao Boping, speech at the Symposium on Northwest Revolutionary History, July 1945.

104. SXDSJ, 56-58. The novel Bailuyuan by Cheng Zhongshi (Beijing: Renmin wenxue chubanshe, 1993), 95-108, has a compelling account of this movement.

105. Northern bureau, directive to Shaanxi, October 17, 1930, in TDSW, 364-65.

106. Decision on Autumn Harvest struggles in Shaanbei, July 9, 1930, in SXGMWJ, 3:169.

107. Shaanbei special committee, work report, June 27, 1934, in SXGMWJ, 7:379. 
108. Li Dazhang, one of those released, in TDSW, 646; Min Jiqian, in TDSW, 695; Chen Yunqiao, in TDSW, 773. On Yang Hucheng, see Mi Zanchen, The Life of General Yang Hucheng, trans. Wang Zhao (Hong Kong: Joint Publishing, 1981).

109. Fuping County decision, April 6, 1930, and Li Gen et al., March 25, 1931, in SXGMWJ, series 2, 1:134-35, 149; North China Herald and Supreme Court and Consular Gazette [Hereafter: NCH], December 2, 1930, February 10, 1931, and May 5, 1931; speeches at the High Cadre Conference by Gao Gang, November 17-18, 1942, and Chen Zhengren, November 1942; Jia Tuofu, speech at the Symposium on Northwest Revolutionary History, July 1945 .

110. Chen Zhengren, speech at the High Cadre Conference, November 1942.

111. Provincial committee to Center, April 31, 1930, in SXGMWJ, 3:53; May Day announcement, April 1931, in SXGMWJ, 3:396-97; August work report, September 30, 1931, in SXGMWJ, 3:544-46; provincial committee, notice, October 10, 1931, in SXGMWJ, 3:578.

112. The best history of Japanese aggression and Chinese politics in the 1930 s is Parks M. Coble, Facing Japan: Chinese Politics and Japanese Imperialism, 1931-1937 (Cambridge, MA: Council on East Asian Studies, Harvard University, 1991).

113. Liu Jingfan, in $H_{2} 6 \mathrm{~J}, 1: 246$.

114. Provincial committee to the Center, April 27, 1932, in SXGMWJ, 4:147.

115. Provincial committee on May Days, April 21, 1932, in SXGMWJ, 4:108; provincial committee on September 18 anniversary, September 5, 1932, in SXGMWJ, 5:1-7; and countless other examples.

116. Michael H. Walker, The 1929 Sino-Soviet War: The War Nobody Knew (Lawrence: University Press of Kansas, 2016).

117. Esherick, “CCP in the 1930s": The View from Defectors' Declarations (脱离共党宣言), PRC History Review 3, no. 3 (December 2015): 1-5; on the effectiveness of Guomindang propaganda over the Chinese-Eastern Railroad, see provincial committee to Center, September 3, 1929, in SXGMWJ, 2:436; NCH, September 28, 1929.

118. Report on Shaanxi Trotskyites, September 10, 1932, in SXGMWJ, series 2, 1:296-305; report on Guanzhong, October 9, 1931, in SXGMWJ, 3:575; provincial committee, announcement on Japanese imperialism, October 3, 1931, in SXGMWJ, 3:559; provincial committee to Center, April 27, 1932, SXGMWJ, 4:156; provincial propaganda department, July 24, 1932, in SXGMWJ, 4:396.

119. Yang Kuisong, "Zhongjian didai" de geming, 206-10; Chen's statement is translated in Saich and Yang, Rise to Power, 414-28. On the Trotskyite movement in China, see Gregor Benton, ed., Prophets Unarmed: Chinese Trotskyites in Revolution, War, Jail, and the Return from Limbo (Chicago: Haymarket Books, 2015).

120. Provincial committee on central tasks, December 7, 1931, in SXGMWJ, 3:610, 613-14, and December 7, 1932, in SXGMWJ, 5:339-40.

121. The incident is described in SXDSJ, 209-12; the provincial committee report of April 28, 1932, is in SXGMWJ, 4:153-57; Jia Tuofu, in a speech at the Symposium on Northwest Revolutionary History, July 1945, cites this as an example of infantile leftism and false propaganda.

122. Zhang Xiushan, in $S G G J D$, 379; Jia Tuofu, speech at the Symposium on Northwest Revolutionary History, July 1945. 
123. Provincial committee to Center, March 23, 1933, in TDSW, 188; provincial committee (Jia Tuofu) to Center, November 25, 1933, in SXGMWJ, 7:274-75. On the provincial committee's composition, see SXDSTX, 1984, no. 2: 3-16.

124. Provincial committee to Center, April 15, 1933, in SXGMWJ, 7:53-54.

125. Jia Tuofu to Center, December 2, 1933, Shaanxi party to Center, February 16, 1934, Chen Jingbo, February 27, 1934, in SXGMWJ, series 2, 1:420, 432, 455, 466-68.

126. Du Heng, "Shaanxi gongdang yange," in TDSW, 893.

127. "Geming weiji de zengzhang yu beifang dang de renwu," "basically adopted" by the meeting of North China provincial representatives, June 24, 1932, in Zhonggong zhongyang shujichu, Liuda yilai, 1:252-6o.

128. For more examples of this new "two-line" trope, see Communist Youth provincial committee, April 12, 1932, in SXGMWJ, 4:91; Communist Youth Xian committee, April 12, 1932, in SXGMWJ, 4:103-4; Center, directive, August 25, 1932, in TDSW, 483.

129. Decision of the North China provincial representatives, June 26, 1932, in Zhonggong zhongyang shujichu, Liuda yiyai, 1:262-64.

130. Shaanxi work report, September 13, 1930, in SXGMWJ, 3:216.

131. Li Shengyun (李盛云), Huang Ziwen's widow, in WBGJD, 459-6o; Zhang Baotian, in $W B G J D, 263$; Tang Yimin and Guo Lisan, in $W B G J D, 267$; editors, in WBGJD, 2-5; Xi Zhongxun, in SGGJD, 248; Esherick, Sanyuan survey, June 2016.

132. Tang Yimin and Guo Lisan, in WBGJD, 268; Chen Yunqiao, in WBGJD, 295-97; provincial committee, work report, September 13, 1930, in SXGMWJ, 3:222. Memoir accounts usually call this band the Famine Victims Rescue Army (灾民自救军), but I follow the WBGJD editors (p. 23), and the contemporary document.

133. Sun Haizhang, in WBGJD, 315-16; Wang Ruiqi, in WBGJD, 283-84.

134. Oral report of North Wei secretary, Cheng Jianwen, November 19, 1932, in SXGMWJ, 5:288-89.

135. Huang Ziwen to province on Sanyuan work, November 20, 1932, in SXGMWJ, 5:300-303.

136. Provincial committee to Center, September 1932, in $W B G J D, 65$. From the date of this report, and the membership of the committee listed in WBGJD, 471, the landlord was probably Huang Ziwen, and the tenant Jin Like, who would be exposed and defect in the events described at the end of this chapter (Xijing ribao, September 17, 1933).

137. North Wei report to province, November 1, 1932, in SXGMWJ, 5:270-71; Cheng Jianwen report to Center, in SXGMWJ, 5:290-92.

138. Wang Feng, in TDSW, 738.

139. Provincial committee to Sanyuan, October 4, 1932, in SXGMWJ, 5:127-40; Li Jiefu (code for Gao Weihan), report, November 2, 1932, in SXGMWJ, 5:256-59; provincial committee to Center, September 27, 1932, in SXGMWJ, series 2, 1:319-22; Zhang Ce, Wo de lishi huigu (Beijing: Gaige chubanshe, 1997), 27-28.

140. Provincial committee, work report, September 13, 1930, in SXGMWJ, 3:217-26; Chen Yuqiao, in TDSW, 771-72; Huang Zixiang, in SGGJD, 561-62.

141. Zhao Boping, in TDSW, 713.

142. Provincial committee, work report, September 13, 1930, in SXGMWJ, 3:222.

143. Report of Peishu (培述), April 2, 1933, in SXGMWJ, 7:2-4.

144. Table of Weibei party and mass organizations, in WBGJD, 470-75. 
145. Oral report of North Wei secretary, Cheng Jianwen, November 19, 1932, in SXGMWJ, 5:284-89; Jia Tuofu, report on North Wei, February 6, 1933, in SXGMWJ, 6:188.

146. Yang Sheng on Sanyuan, January 25, 1933, in SXGMWJ, 6:130; cf. Li Jiefu (Gao Weihan), November 12, 1932, in SXGMWJ, 5:261-62, 268-69.

147. Yang Sheng on Sanyuan, January [20-30], 1933, in SXGMWJ, 6:138-41.

148. Jia Tuofu, report on North Wei, February 6, 1933, in SXGMWJ, 6:191.

149. Provincial committee directive, October 7, 1932, in WBGJD, 104; oral report of North Wei secretary, Cheng Jianwen, November 19, 1932, in SXGMWJ, 5:294-96; provincial committee (Jia Tuofu), report to Center, November 25, 1933, in SXGMWJ, 7:225; Huang Ziwen, report on Weibei, November 27, 1932, in SXGMWJ, series 2, 1:330-41.

150. Li Jiefu (Gao Weihan) to province, November 2, 1932, in SXGMWJ, 5:253; Lie Jun on North Wei, January 24, 1933, in SXGMWJ, 6:114; Jia Tuofu to province, February 6, 1933, in SXGMWJ, 6:169; Peishu report, April 2, 1933, in SXGMWJ, 7:2-3.

151. Tianhua, a Sanyuan guerrilla leader, to Sanyuan committee, February 7, 1933, in SXGMWJ, 6:204-6; cf. Jia Tuofu on North Wei, February 6, 1933, in SXGMWJ, 6:176-77. The role of the Sun brothers in the revolution remains a sensitive and unresolved problem for party historians. The Imperialist Sun Mingzhang was still alive in 1961, and a small extract from an interview at that time is included in the WBGJD collection (p. 313). His role in the soviet, however, is not identified, nor is he given a biography. His brother, Sun Pingzhang, who was killed by a Fuping militia commander in 1933, is listed (449). During a 2016 visit to Sanyuan, I inquired about the Imperialist. The most that local sources would say was that he was brave and a good shot.

152. Wang Shitai, speech at the Symposium on Northwest Revolutionary History, July 1945; Chen Zhongliang, speech at the High Cadre Conference, November 14, 1942.

153. Sanyuan County to Wuzi district, February 16, 1933, in SXGMWJ, 6:249.

154. Ma Peixun, in SGGJD, 470, and ZCLZL, 2:147. Zhang's secret life as a Communist agent would later come to a tragic end. In 1935 he was sent to liaise with the Twenty-Fifth Red Army passing through southern Shaanxi. The Twenty-Fifth Army, suspecting him to be an enemy agent, tortured and killed him. Huang Zhenglin, "1935-nian Shaan-Gan bian suqu he hong26jun sufan wenti kaolun," Shixue yuekan, 2011, no. 6: 65-66.

155. Tian Zhiqi, in SGGJD, 505-6; Lei Hongxuan and other accounts in H26J, 1:274-79. At the time, the Shanhe attack was criticized as "resisting taxes and besieging a town on behalf of rich peasants." Jiefu [Gao Weihan], statement, August 16, 1932, in SXGMWJ, series 2, $1: 293$.

156. Ma Peixun, in ZCLZL, 2:155-56; Ma Yunze, in ZCLZL, 2:253-54; Wang Shitai, speech at the High Cadre Conference, November 15, 1942.

157. Liu Zhidan and Huang Ziwen, 1932 [probably May or June] proclamation in SGGJD, $67-68$.

158. The earlier claim of one thousand men is from provincial committee to Center, received April 27, 1932, in SXGMWJ, 4:146. The other figures are from provincial committee, decision on Shaan-Gan soviet, June 1, 1932, in SXGMWJ, 4:187; Du Heng (June 2, 1932, in SXGMWJ, 4:202, 233) later reported to the Center a force of six hundred men with 250 working weapons.

159. Du Heng's report in June 1932 claimed seventy villages (Du Heng report to North China secretaries' meeting, June 2, 1932, in SXGMWJ, 4:233), but the confession following 
his 1933 arrest said the Zhaojin base extended 7-8 li (about four kilometers) in each direction and contained ten villages. Du Heng et al., "Tuoli gongdang xuanyan," Xijing ribao, September 20, 1933.

160. Li Shenghua, in $H_{2} 6 J$, 1:324.

161. Report on Shaan-Gan guerrillas, received April 27, 1932, in SXGMWJ, 4:120-23.

162. North Wei guerrillas to Sanyuan, received April 2, 1933, in SXGMWJ, 7:12-13.

163. Speeches at the High Cadre Conference by Zhang Xiushan, November 15, 1942, and Wang Shitai, November 15, 1942.

164. Li Delu, in H26J, 2:999-1003.

165. Jia Tuofu, report to the Center, November 25, 1933, in SXGMWJ, 7:244.

166. Provincial committee to Center, received April 27, 1932, in SXGMWJ, 4:144-45.

167. Provincial committee, decision on Jiefu [Gao Weihan], August 20, 1932, in SXGMWJ, series 2, 1:287.

168. Li Gen to provincial committee, November 29, 1932, SXGMWJ, series 2, 1:342-48.

169. Hancheng party work report, June 30, 1932, in SXGMWJ, 4:331-34; cf. Yan Hongyan, in SGGJD, 271; Wu Daifeng, in SGGJD, 431-32.

170. Provincial committee, decision on Twenty-Sixth Army, August 25, 1932, in SXGMWJ, 4:428-55; provincial committee, military plan, September 17, 1932 [date received], in SXGMWJ, 5:55-67; decision of northern secretaries' meeting, June 26, 1932, in H26J, 1:121-22.

171. Provincial committee, report on Li Gen inspection of the border region, December 31, 1932, in SXGMWJ, series 2, 1:360-68.

172. Dai Maolin and Zhao Xiaoguang, Gao Gang zhuan, present a reasonably balanced account of Gao's career. On his purge in 1953, see the compelling account in Frederick C. Teiwes, Politics at Mao's Court: Gao Gang and Party Factionalism in the Early 1950s (Armonk, NY: M.E. Sharpe, 1990). Given the extreme controversy surrounding Gao's role, I have made every effort to rely on contemporary documents in his case.

173. Gao Gang to provincial committee, November 29, 1932, in H26J, 1:153-58.

174. Provincial committee to Center, October 11, 1932, in SXGMWJ, series 2, 1:328-29.

175. Wang Shitai, in $\mathrm{H}_{2} 6 \mathrm{~J}, 2: 543-45$.

176. Gao Gang to provincial committee, November 29, 1932, in H26J, 1:156-58; Huang Ziwen to provincial committee, January 5, 1933, in H26J, 1:166-68; Wu Daifeng, Liu Jingfan, and others, in H26J, 1:282-89; Cui Pingyuan and others, in SGGJD, 528-33.

177. Gao Gang, report, November 29, 1932, in H26J, 1:158-59; Jia Tuofu, report to Center, November 25, 1933, in SXGMWJ, 7:242.

178. Provincial committee to Center, September 27, 1932 [received], in SXGMWJ, series 2, 1:314-16; Li Gen to provincial committee, November 29, 1932, in SXGMWJ, series 2, 1:344-47.

179. Yuan Yuedong to Center, March 12, 1933, and provincial committee to Center, March 23, 1933, both in SXGMWJ, series 2, 1:408-9, 411.

180. He Jinnian, in ZCLZL, 2:31.

181. Report on Xunyi party work, March 13, 1933, in SXGMWJ, 6:316-17; Han Wenxi, in SGGJD, 512.

182. Du Heng, report on Twenty-Sixth Army, January 9, 1933, in SXGMWJ, 6:67.

183. Huang Ziwen to provincial committee, January 5, 1933, in SXGMWJ, series 2, 1:389-92; Du Heng, report on Twenty-Sixth Army, January 9, 1933, in SGGJD, 150. (The SXGMWJ, 6:68 version of this passage says "after the two comrades responsible for military affairs were killed," which does not accord with the facts.) Gao Gang's role in this purge 
remains something of a mystery. In his November 1932 recommendation, acting as an agent of the provincial committee, he targeted all of the guerrilla leaders, including Liu Zhidan. Now, only the Shaanbei leaders, Xie and Yan, were removed, while Liu was spared; and eventually Gao Gang became a firm ally of Liu Zhidan. It seems likely that Gao's role in Xie's purge and his later alliance with Liu Zhidan enhanced Xie Zichang's suspicions of the Shaan-Gan faction.

184. This execution was apparently carried out secretly, for the provincial committee later criticized Du Heng for not publicizing Zheng's "counterrevolutionary" crimes. No available documents specify what those crimes were. Provincial committee to TwentySixth Army, March 15, 1933, in SXGMWJ, 6:324, 337-38; Zheng Yi, report, January 9, 1933, in SXGMWJ, 6:63-65.

185. Wang Shitai, in SGGJD, 290-94, 307-10.

186. Huang Luobin, in $S G G J D$, 367; Zhang Xiushan, in $S G G J D, 384-85$.

187. Zhang Bangying, in $\mathrm{H}_{26} 6 \mathrm{~J}, 2: 684-87$.

188. Du Heng to provincial committee, December 22, 1932, in $S G G J D, 139-42$. On Xuejiazhai, see Zhang Xiushan, in SGGJD, 384-85; Gui Shengfang, in SGGJD, 603-9.

189. Wang Shitai, in SGGJD, 317; Jia Juchuan, Xi Zhongxun zhuan (Beijing: Zhongyang wenxian chubanshe, 2008), 130-31. Significantly, there is only a small local museum in Sanyuan, but Zhaojin features a large memorial hall with regular visits by officially organized groups of “Red tourists." At a similar museum in Nanliang, Xi Zhongxun's headquarters in the hills features a prominent statue whose features bear a remarkable similarity to China's current president.

190. Provincial committee to Sanyuan, January 3, 1933, in SXGMWJ, 6:7, 12-13; Yang Sheng to Wuziqu, January 25, 1933. in SXGMWJ, 6:132-33; Tian Hua, report on TwentySixth Army, January 25, 1933, in SXGMWJ, 6:135.

191. Du Heng, report, January 9, 1933, in $S X G M W J$, 6:71-72.

192. Zhang Xiushan, in SGGJD, 383, 385; Liu Zhidan, Liu Zhidan wenji, 26.

193. See the provincial committee criticism of Du in directive to Twenty-Sixth Army, in SXGMWJ, 6:322-24.

194. Wang Shitai, in SGGJD, 313-14; Yang Sheng on Yao-xian, January 25, 1933, in SXGMWJ, 6:121; Tian Hua report on Twenty-Sixth Army, January 25, 1933, in SXGMWJ, 6:135.

195. Du Heng on Twenty-Sixth Army defeats, January 15, 1933, in SXGMWJ, 6:87-99.

196. Wang Shitai, in $S G G J D$, 311-2; Huang Luobin, in $S G G J D, 363$; Zhang Xiushan, in $S G G J D$, 380-81; Gao Gang, speech at the Symposium on Northwest Revolutionary History, August 2, 1945 .

197. Jia Tuofu, November 25, 1933, in SXGMWJ, 7:245; speeches at the High Cadre Conference by Xi Zhongxun, November 11, 1942, Wang Shitai, November 15, 1942, and Chen Zhengren, November 1942.

198. Huang Ziwen to provincial committee, January 5, 1933, in WBGMWJ, 195-96; Jia Tuofu to Center, in SXGMWJ, 7:246-50. According to one account, the Moscow-returned Gao Weihan proposed going north to open a link to the Soviet Union (Wang Feng, in $S G G J D, 27,3)$. If true, it would not be the last time Shaanbei was regarded as a possible route to Russia.

199. Sigurd Eliassen, Dragon Wang's River, trans. Katherine John (London: Methuen, 1957), 19-20, 184-219. Eliassen calls him Miao Hsiang Feng. China Press, May 11, 1933; 
"Xianyang renwu chuan: Miao Jia xiang," Sanqinyou.com, July 22, 2013, www.sanqinyou .com/mingren/info/137221123219532.html.

200. Eliassen, Dragon Wang's River, 184-219; Wang Shitai, in SGGJD, 316; Shanghai Times, May 12, 1933. Eliassen offers a telling portrait of Miao's wealthy, well-connected, and fashionable mother, who also arranged for another son to serve as the engineer's "boy." In Eliassen's view, plausible but unverifiable, Miao Jiaxiang's plot was motivated by an attempt to recover losses on land speculation when the famine commission's canal failed to water his village's fields. Yuan Wenwei (Fanpan yu fuchou, 183-84) also mentions a Miao-led guerrilla band from the same county that reverted to banditry in 1933. Despite local websites claiming Miao as a revolutionary martyr, the incident provides a glimpse of the complex social realities that have largely erased this dramatic kidnapping of a foreigner from the official historiography.

201. Zhao Boping, in WBGJD, 384-85; Wang Shitai, in H26J, 2:629-33.

202. Jia Tuofu, account to Center, November 25, 1933, in SXGMWJ, 7:246-50; Wang Shitai, in SGGJD, 319-24, and H26J, 2:633-58; Wang Shitai, speech at the Symposium on Northwest Revolutionary History, July 1945; Huang Luobin, in SGGJD, 365-67; Wu Daifeng, in SGGJD, 435-36.

203. Xi Zhongxun, in SGGJD, 251-54; Wang Shitai, in SGGJD, 325-30; Zhang Xiushan, in SGGJD, 389-90; Wang Ying, SXDSTX, 1984, no. 4: 23-29.

204. Zhang Xiushan, in $S G G J D$, 395-97; Yang Yucai et al., in SGGJD, 585-96; Xijing ribao, October 16, 1933.

205. See Xijing ribao, May 5, 1933, on Shao's appointment the previous day; Jia Tuofu, speech at the Symposium on Northwest Revolutionary History, July 1945.

206. Jia Tuofu, report to Center, November 13, 1933, in SXGMWJ, 7:151-68; Zhao Boping, in $W B G J D, 376$.

207. Xijing ribao, September 17, 1933. The phrase gongren wu zuguo translates Marx's statement in the Communist Manifesto that "the working men have no country." Karl Marx, The Communist Manifesto (Chicago: Henry Regnery, 1954), 50.

208. Under the title "Tuoli gongdang xuanyan," this declaration appears in Xijing ribao, September 17, 1933, to September 22, 1933. For an analysis of this and similar declarations, see Esherick, "CCP in the 1930s," $1-5$.

209. Huang Zixiang, in SGGJD, 561-62.

210. Report of Shaanxi committee to restore work, February 16, 1934, in TDSW, 565.

211. Report from Shaanxi, May 26, 1934, in TDSW, 575-81. The BOI archives in Taiwan have a small collection of CCP documents from Shaanxi from the early 1930s. As Shaanxi is poorly represented in BOI records, I suspect that most of these resulted from the 1933 arrests.

212. Xi Zhongxun made the same point, in different words. Xi Zhongxun, in SGGJD, 464.

\section{THE ROCKY ROAD TO REVOLUTION}

1. Ding Zhi, "Zhongyang hongjun beishang fangzhen de yanbian guocheng," Wenxian he yanjiu, 1985, 266-74; Yang Kuisong, Xian shibian xintan: Zhang Xueliang yu Zhonggong guanxi zhi mi (Nanjing: Jiangsi renmin chubanshe, 2006), 22-25; Harrison E. Salisbury, The Long March: The Untold Story (New York: Harper and Row, 1985), 286. 
2. Zhang Wentian cited this from Dagongbao, July 23, 1935, along with several other Dagongbao pieces in a September 22, 1935, article titled "Fazhanzhe de Shaan-Gan suweiai geming yundong," in H26J, 1:225-28. Sun Shuyun, in The Long March: The True Story of Communist China's Founding Myth (New York: Doubleday, 2006), 183, says Mao read the July 23 Dagongbao story.

3. Speeches at the High Cadre Conference by He Long, November 2, 1942, and Ren Bishi, January 8-11, 1943.

4. See the map in Lei Yunfeng et al., Shaan-Gan-Ning bianqu shi (Xian: Xian ditu chubanshe, 1994).

5. "Zhidan geming lishi fazhan de jige shiqi," undated document (ca. 1943) from Zhidan County archives.

6. Eduard B. Vermeer, Economic Development in Provincial China: The Central Shaanxi since 1930 (Cambridge: Cambridge University Press, 1988), 28-55, 70-88; NCH, February 13, 1935, August 7, 1935, January 29, 1936, and May 20, 1936.

7. Zhang Xiushan, in SGGJD, 389-9o; Zhang Xiushan and Zhang Bangying, in H26J, 2:690.

8. Wang Shitai, in $\mathrm{H}_{2} 6 \mathrm{~J}, 2: 535-37$.

9. See chapter 3.

10. Zhang Xiushan and Zhang Bangying, in H26J, 2:689-91; Wang Ying, in H26J, 2:69294; Song Fei, in H26J, 2:694-98. A note to the 1945 "Resolution on Certain Historical Questions" in the original edition of Mao's selected works credits Liu Zhidan and Gao Gang with the creation of the Shaanbei base. Gao's name was removed after his fall and suicide in 1953. Ishikawa Yoshihiro, "Xiaoshuo 'Liu Zhidan," 38-39.

11. The August meeting in Chenjiapo (陈家坡) became the subject of much controversy. Critics of the Shaan-Gan guerrillas accused them of subordinating the Red Army to Wang Taiji, a White army commander. Defenders saw victory over a defeatist line and the beginning of Gao Gang's rise in the movement. Speeches at the High Cadre Conference by Zhang Xiushan, November 1942, and Xi Zhongxun, November 11, 1942.

12. Wang Shitai, in SGGJD, 334-35. One local described Nanliang as a classic sanbuguan (三不管) area, spurned by any governing authority. Zhang Mingke, in H26J, 2:885.

13. Wang Shengjin, in SGGJD, 668; Liu Jingfan, in H26J, 1:318; Ma Yangxi, in H26J, 2:942. The most famous landlord firm had a classic name of commercial prosperity: Yumaolong (裕茂隆).

14. Wang Ying, in H26J, 2:812-15; Cai Ziwei, in H26J, 2:939-40.

15. Zhang Zhongliang, in SGGJD, 464-67; informant 9.

16. Zhang Xiushan, speech at the High Cadre Conference, November 5, 1942; "Shaan-Gan-Ning diaocha zhuanbao," BOI 575.292/815.

17. Zhang Ce, Wo de lishi huigu, 38-40.

18. Zhang Bangying, in $S G G J D$, 284; Wang Shitai, in $S G G J D$, 339. Zhang is vague on Gao Gang's offense, and Wang says only that he "planned to rape a woman," but accusations of sexual impropriety marked Gao's entire career, and informant 2 suggested that this was more than attempted rape. By the summer of 1934, Gao was again political commissar. Wang Shitai, in SGGJD, 350 .

19. Zhang Bangying, in SGGJD, 283.

20. Huang Luobin, in $H_{2} 6 J$, 2:881; Wang Ying, in $H_{2} 6 J$, 2:971-72; Gao Jinchun, in $H_{2} 6 J$, 2:789-96. 
21. Twenty-Sixth Army, Forty-Second Division, to Center, June 20, 1934, in SGGJD, 219; Zhu Lizhi, July 1945, in Xibei geming genjudi, ed. Zhonggong Shaanxi shengwei dangshi yanjiushi (Beijing: Zhonggong dangshi chubanshe, 1998) [hereafter: XBGJD], 432.

22. Report to Center, received September 23, 1932, in SXGMWJ, 5:98.

23. Zhidan County, "Liangnianban gongzuo baogao shu," August 22, 1940, Shaanxi provincial archives, Records of Shaan-Gan-Ning Border Region Government (Shaan-Gan-Ning bianqu zhengfu dang'an) [hereafter SA], SA 2-1-157-1.

24. Gao Jinchun, in $H_{2} 6 J$, 2:791.

25. Informant 11.

26. Coble, Facing Japan, 90-181.

27. SXGMWJ is replete with examples of this shift. See, for example, provincial committee to Sanyuan, April 4, 1933, in SXGMWJ, 7:19.

28. Shaanbei special committee to North China representative, published January 31, 1935, in SXGMWJ, 7:461; Shaanxi-Gansu-Shanxi committee announcement, October 3, 1935, in $X B G J D, 101$.

29. Jia Tuofu, report to Center, November 25, 1933, in SXGMWJ, 7:252-56.

30. Guo Baoshan, in $S G G J D, 610-11$; Huang Luowu, responsible for the early courting of Guo, in SGGJD, 616-20; Wang Shitai, in SGGJD, 356-58; Zhang Bangying, in SGGJD, 287-88; Zhang Xiushan, in H26J, 2:867-70. Xu Youwei and Billingsley, "Heroes, Martyrs, and Villains," 254-64, has a useful account of Gao Baoshan's background and recruitment.

31. Hung-mao Tien, Government and Politics in Kuomintang China, 1927-1937 (Stanford, CA: Stanford University Press, 1972), esp. 177-82.

32. South Shaanxi to Center, February 20, 1934, in SXGMWJ, 7:323; Zhang Xiushan, in H26J, 2:875; speeches at the Symposium on Northwest Revolutionary History by Gao Gang, August 2, 1945, and Jia Tuofu, July 1945; NCH, September 5, 1934.

33. On the "victorious advance," see provincial committee welcome, in SXGMWJ, 5:304-6; provincial committee to Shaannan, February 5, 1933, in SXGMWJ, 6:152; Jia Tuofu to province, February 6, 1933, in SXGMWJ, 6:167-68; survey by Guomindang officer, Gao Jinshang, August 19, 1935, in XBGJD, 729; NCH, March 13, 1935, and August 7, 1935.

34. Provincial committee decision on political tasks, September 14, 1930, in SXGMWJ, 3:253. Similar language can be found throughout volumes of this series from 1930 through 1933 .

35. Louise A. Tilly, "Food Entitlement, Famine and Conflict," Journal of Interdisciplinary History 14, no. 2 (Autumn 1983): 333-49.

36. Zhang Ce, Wo de lishi huigu, 46.

37. Shaanbei special committee work report, June 27, 1934, in SXGMWJ, 7:378-79; Shaanbei letters to North China representative, published January 31, 1935, in SXGMWJ, 7:462-63.

38. To distinguish Xie Zichang's "Shaanbei" branch of the party from Shaanbei as a name for all of northern Shaanxi, I add quotation marks to the former.

39. Ren Ziliang, report to Center on Shaanbei, August 22, 1929, in SXGMWJ, 2:423; Huang XX to Center, February 18, 1932, in SXGMWJ, 4:23; Zhao Tongru, Shaanbei gexian, $34-35$.

40. Cui Tianfu, the Shaanbei secretary, once carried $\$ 1,000$ from Tianjin. Wang Shucai, Shaanbei gongchandang de lao zhanggui, 87. 
41. Wu Daifeng, in SGGJD, 434.

42. Wang Xiaozhong, Zhongguwei gongzuo jishi, 55 .

43. Zhao Tongru, Shaanbei gexian, 76, 142.

44. You Xiangzhai, in ZCLZL, 2:290-93; informants 17, 18. Xie’s colleague, Yan Hongyan, is rumored to be the father of her child.

45. ZCLZL, 1:99; He Jinian, in ZCLZL, 2:34; Guo Hongtao, Guo Hongtao huiyilu (Beijing: Zhonggong dangshi chubanshe, 2004), 25.

46. Zhao Tongru, Shaanbei gexian, 70-77, 95-172; Chai Shufan, Yu Guangyuan, and Peng Ping, Suide, Mizhi tudi wenti.

47. Zhao Tongru, Shaanbei gexian, 158-6o.

48. Shaanbei representative Cui Ruisheng, December 4, 1933, in SXGMWJ, 7:285.

49. Ma Wenrui, speech at the Symposium on Northwest Revolutionary History, July 1945.

50. Zhao Tongru, Shaanbei gexian, 74-77, 90-91, 101-4, 136, 158-60; Ma Mingfang, SXDSTX, 1985, no. 13: 57-58; Chang Lifu, SXDSTX, 1985, no. 13: 63-65; Zhonggong Zichang xianwei zuzhibu, Zhongguo gongchandang Shaanxisheng Zichangxian zuzhishi ziliao, 16-18.

51. Huang XX to Center on Shaanbei, February 18, 1932, in SXGMWJ, 4:24.

52. Zhao Tongru, Shaanbei gexian, 15-16, 23.

53. Cui Ruisheng, December 4, 1933, report, in SXGMWJ, 7:299-300.

54. Wang Shucai, Shaanbei gongchandang de lao zhanggui, 64-67.

55. "Shaanbei shoufu chiqu shichaji," pt. 2, Dagongbao, November 26, 1936; pt. 3, November 27, 1936; and pt. 8, December 18, 1936.

56. Cui Ruisheng to Center, December 5, 1933, in SXGMWJ, 7:304-8. See also Ma Wenrui, SXDSTX, no. 13 (1985): 83-84. My account of the Shaanbei party omits the largely independent party organization in the far northeast county of Shenmu, bordering Inner Mongolia. In 1933, Shenmu claimed 40 percent of "Shaanbei's" party members (October 20, 1933, report, in SXGMWJ, 7:133-34), but by 1935 the movement there was effectively eliminated. See memoir accounts in XBGJD, 321-34; Ma Wenrui, speech at the Symposium on Northwest Revolutionary History, July 12, 1945; and a separate volume of the Shaanxi party history series: Zhonggong Shaanxi shengwei dangshi ziliao zhengji yanjiuhui and Zhonggong Yulin diwei dangshiban, Zhonggong Shenmu xianwei dangshiban, Shenfu geming genjudi (Xian: Shaanxi renmin chubanshe, 1990).

57. Report of the Twenty-Sixth Army, Forty-Second Division, June 20, 1934, in SGGJD, 219-20.

58. This was Zhu Lizhi's conclusion in 1945. See XBGJD, 432.

59. Cui Ruisheng to Center, December 6, 1933, in SXGMWJ, 7:309.

6o. Wang Shitai, in $H_{2} 6 J$, 2: 719-20; He Jinnian, in ZCLZL, 2:34-35; Ma Peixun, in ZCLZL, 2:159-64.

61. Liu Minshan and Liu Qingshan, in ZCLZL, 2:122-28.

62. Ma Peixun, in ZCLZL, 2:160.

63. Guo Hongtao, Guo Hongtao huiyilu, 34-39; Wang Shucai, Shaanbei gongchandang de lao zhanggui, 72-75.

64. Shaanbei special committee to the Center, December 8, 1934, in SXGMWJ, 7:428-29.

65. Liu Mingshan and Liu Qingshan, in ZCLZL, 2:130, 271; Qiang Tieniu, in ZCLZL, 2:383-91. 
66. Exhibition in Museum of the Xiuyan County Soviet, Liushugou (柳树沟), Zichang; Zhonggong Zichang xianwei zuzhibu et al., Zhongguo gongchandang Shaanxisheng Zichangxian zuzhishi ziliao, 21-6o.

67. Liu Mingshan and Liu Qingshan, in ZCLZL, 2:263-64; He Jinnian, speech at the High Cadre Conference, November 13, 1942. Qiang Tieniu, in ZCLZL, 2:387, notes Xie's elder brother dying in the Anding jail at this time, but other accounts avoid any link to Zichang's attack. Zhao Tongru, Shaanbei gexian, 166, says the jailbreak freed Yan Hongyan's father, and Xie's brother was arrested and killed in a separate incident.

68. Wang Shucai, Shaanbei gongchandang de lao zhanggui, 78-95.

69. Wang Shitai, in SGGJD, 350. This was before Xie's attack on Anding, so the weapons presumably helped in that assault. It is unclear from Wang's account if the grain was ever received.

70. Guo Hongtao, Guo Hongtao huiyilu, 2-22.

71. Shaan-Gan special committee, July 1934, in Zhonggong zhongyang shujichu, Liuda yilai, $1: 662-66$.

72. See Ishikawa Yoshihiro, "Xiaoshuo 'Liu Zhidan," 27-29, 48-49, for an excellent summary.

73. Shaanbei representative to Center, January 24, 1935, in SXGMWJ, 7:444.

74. Wang Shitai, in $\mathrm{H}_{2} 6 \mathrm{~J}, 2: 734$.

75. Xie Zichang to North China representative, September 5, 1934, in SGGJD, 233.

76. Jia Tuofu confessed to writing a December 1933 article based on these reports and his own work in the provincial committee. Jia Tuofu, speech at the Symposium on Northwest Revolutionary History, July 1945.

77. Yang Heting, who transcribed the letter, in XBGJD, 250.

78. Guo Hongtao, Guo Hongtao huiyilu, 45-47.

79. North China representative and Hebei committee to Shaan-Gan and Shaanbei, May 10, 1935, and North China representative to Shaan-Gan and Northwest committee, May 25, 1935, in XBGJD, 28-51. Guo Hongtao's published directives (July 1934 and September 1934) to the Twenty-Sixth Army (Zhonggong zhongyang shujichu, Liuda yilai, 662-68) and Zhang Ce's recollection of the letters contain similar criticisms. (H26J, 2:917-18).

80. Liu Jingfan, in Liu Mila and Liu Dudu, Liu Jingfan jinian wenji, 1:87.

81. Xi Zhongxun, speech at High Cadre Conference, November 1942; Zhang Xiushan, October 8, 1978, speech in Zhidan archives.

82. Zhang Xiushan to Ren Bishi, June 10, 1941, in documents of the High Cadre Conference, 1942. These "collective farms" arose spontaneously when guerrillas harvested and planted on land abandoned in the intense class warfare of the time. Speeches at the Symposium on Northwest Revolutionary History by Cui Tianmin, June 28, 1945, and Li Jinglin, July 1945 .

83. Zhang Ce, in $\mathrm{H}_{26} 6 \mathrm{~J}, 2: 917-18$. This earlier version is more direct than Zhang Ce's published memoir of 1997, Wo de lishi huigu (49-50), which edits out the sharp criticism of Xie Zichang.

84. Xie Zichang to North China representative, September 5, 1934, in SGGJD, 232-33; Guo Hongtao, Guo Hongtao huiyilu, 45-47. Xie Zichang soon yielded the political commissar post to Guo Hongtao. Gao's removal in 1934 helps explain the vehemence of his attack on Guo at the 1942 High Cadre Conference. 
85. Xie Zichang to North China representative, September 5, 1934, in SGGJD, 232-33.

86. North China representative to Twenty-Sixth Army, September 1934, in SGGJD, 239-40; report on Shaanbei meeting, 1934 [no precise date, probably late 1934], in SXGMWJ, $7: 434$.

87. He Jinnian, in $S G G J D, 675-76$, and $X B G J D, 281$; XBGJD, preface, 3.

88. Cui Tianfu's 1943 account attributes the rise of the Anding movement to the arrival of the Twenty-Sixth Army, but Gao Gang was then in charge, and this account may not be fully credible. Wang Shucai, Shaanbei gongchandang de lao zhanggui, 118.

89. Zhao Tongru, Shaanbei gexian, 167.

9o. Guo Hongtao, Guo Hongtao huiyilu, 43-44.

91. Exhibition in Museum of the Xiuyan County Soviet, Liushugou (柳树沟), Zichang; Zhonggong Zichang xianwei zuzhibu, Zhongguo gongchandang Shaanxisheng Zichangxian zuzhishi ziliao, 37-39; Zhonggong Zichang xianwei dangshi bangongshi, "Anding (jin Zichang) xian suweiai zhengquan to jianli he fazhan," manuscript, May 30, 1988.

92. Shaanbei Communist Youth League representative to Center, July 15, 1934, in SXGMWJ, 7:385-86; Chang Zijian to Center, received March 4, 1934, in SXGMWJ, 7:339-40.

93. Zhonggong Zichang xianwei zuzhibu, Zhongguo gongchandang Shaanxisheng Zichangxian zuzhishi ziliao, 23-24; display in Renjiabian (任家砭) Museum for first rural CCP branch in Shaanbei; cf. Li Chiran, Li Chiran jiangjun huiyilu, 18, 24.

94. Shaanbei special committee to Center, June 27, 1934, and December 8, 1934, in SGGJD, 7:381, 423-26.

95. One of the new party leaders' main complaints against the Shaan-Gan guerrillas was the weakness of local party leadership. "Zhonggong Shaan-Gan-Jin shengwei dui jinxing youji zhanzheng yu youji tuji de jueding," September 15, 1935, Lishi dang'an, 1986, no. 4: 56-59.

96. Shaanbei reports of October 20, 1933, June 27, 1934, and December 8, 1934, in SXGMWJ, 7:133, 379-81, 423-25.

97. Shaanbei Communist Youth representative to Center, July 15, 1934, in SXGMWJ, 7:388. See also Guo Hongtao, Guo Hongtao huiyilu, 54.

98. When appointed political commissar of the Forty-Second Division, Xie protested that he was a military man unsuited to political tasks and passed the assignment to Guo Hongtao. Xie Zichang to North China representative, September 5, 1934, in SXGMWJ, 7:233.

99. ZCLZL, 1:102; Li Zhenmin, Zhang Shouxian, and Liang Xingliang, "Xie Zichang," 252-53.

100. I visited the cave in the tiny village of Dengzhanwan (灯戞湾), deep in the mountains of western Zichang, in June 2018.

101. Gao Langting, in XBGJD, 251; Guo Hongtao, Guo Hongtao huiyilu, 58-65; ZCLZL, 1:105-6; SXDSTX, 1986, no. 8: 29-30.

102. ZCLZL, 1: 106, 136; Xie Shaoming, Xie's adopted “son," in ZCLZL, 2:315-16; Jing Yuexiu to Shao Lizi, June 10, 1935, in XBGJD, 708; Gao Jinshang, report, August 19, 1935, in $X B G J D, 729$.

103. Xie Shaoming, in ZCLZL, 2:316. A Shaanbei soviet document of August 10, 1935 $(X B G J D, 72)$, lists a recruitment quota for Zichang County, but there are also quotas for Chiyuan and Xiuyan, two soviet counties carved out of Anding. To add to the confusion, Zichang County had previously been named Zhongyuan County, for another local martyr, 
Yang Zhongyuan. Zhonggong Zichang xianwei dangshi bangongshi, "Anding (jin Zichang) xian suweiai zhengquan," $5-6$.

104. Ma Peixun, in ZCLZL, 2:140-41.

105. Informant 18.

106. Wang Shitai, in H26J, 2:539, 543-45; Ma Peixun, in ZCLZL, 2:153-56; Ma Yunze, in ZCLZL, 2:253-54.

107. Heng Zhi (possibly Du Heng), "Shaanbei feikui Liu Zidan." See also Xijing ribao, June 3,7 , and 9 and October 16,1933 . In these accounts, Liu is always referred to by an earlier name: Liu Zidan (刘子丹).

108. XBGJD, 11-12; Zhao Tongru, Shaanbei gexian, 36-45.

109. $X B G J D, 13-15$; Wang Shitai, in $H_{2} 6 J$, 2:760-61; various Nationalist officer memoirs, in $X B G J D, 619-41$, and Nationalist telegrams, 699-722.

110. Shaan-Gan special committee decision, August 5, 1935, in XBGJD, 63-64; Gao Jianbai (高建白), an officer in Gao Guizi’s army, in XBGJD, 595-98.

111. Zhao Tongru, Shaanbei gexian, 8, 83; Wu Hongbin to Center, March 12, 1934, in SXGMWJ, 7:344.

112. Gao Jinchun, in $H_{2} 6 J$, 2:795; Wang Ying, in H26J, 2:823; Zhao Tongru, Shaanbei gexian, 93-94.

113. North China representative to Shaan-Gan and Shaanbei, May 10, 1935, in XBGJD, 30.

114. Xu Haidong, in $X B G J D$, 350; Liu Huaqing, in $X B G J D, 359$.

115. Wang Shitai, in SGGJD, 344; Northwest Work Committee, April 4, 1935, in XBGJD, 26. This policy of emptying villages was called "strengthening walls and clearing the countryside" (jianbi qingye), the same formula used by the Qing and the Nationalists. The Red Army, however, did not strengthen walls: villages were simply emptied to protect the population. The North China office criticized this policy as overly defensive in the May 10, 1935, report cited above (in $X B G J D, 32$ ).

116. Zhang Ce, in $H_{26}$ J, 2:917; Wang Shitai, in SGGJD, 344; Zhidan County informants $6,7,8$, and 11 .

117. Zhao Tongru, Shaanbei gexian, 54-57.

118. Liu Jingfan, in $X B G J D$, 335-36; Wang Ying, in $X B G J D, 345-46,820-25$; Gao Jinchun, in $X B G J D, 318$, and in $H_{2} 6 J, 795$; Ma Peiqing (马培清), a Nationalist officer, in H26J, 2:900-901; SXDSTX, 1985, no. 12: 14-33.

119. Li Peifu, in H26J, 2:966-68; SXDSTX, 1985, no. 12: 27.

120. Cai Ziwei, in $H_{26} 6$, 2:934.

121. Liu Jingfan, in SGGJD, 412-13; Liu Zhidan and Xi Zhongxun, "Ten Great Policies," November 1934, in Liu Zhidan, Liu Zhidan wenji, 35-36. See also SXDSTX, 1985, no. 12: 22-23; Gao Gang, speech at the Symposium on Northwest Revolutionary History, August 2, 1945 .

122. XBGJD, 4-5. The members of the new work committee were Hui Zijun, Cui Tianfu, Liu Zhidan, Xie Zichang, Xi Zhongxun, Ma Mingfang, Guo Hongtao, Zhang Xiushan, and Gao Gang. On Hui Zijun, see Zhang Xiushan, in SGGJD, 384-85.

123. XBGJD, 5; Guo Hongtao, in XBGJD, 246-47; Guo Hongtao, Guo Hongtao huiyilu, $64-65$.

124. Northwest Work Committee announcement, April 1935, in XBGJD, 26-27.

125. Zhang Dazhi, in $X B G J D$, 268; Shaanbei committee to Center, January 24, 1935, in SXGMWJ, 7:440-41. 
126. Gao Jianbai, one of Gao Guizi's officers, in XBGJD, 596-99.

127. Zhao Tongru, Shaanbei gexian, 107-8; Zhang Dazhi, interview, 1978, Zhidan archives.

128. Hang Yi to Shao Lizi, July 19, 1935, in XBGJD, 711.

129. Zhao Tongru, Shaanbei gexian, 107-8.

130. Yang Heting, in $X B G J D, 249$.

131. Informant 2.

132. Shaanbei Communist Youth League representative to Center, July 15, 1934, in SXGMWJ, 7:385-86. The same pattern was revealed in the south: report on southwest Shaanxi work, November 9, 1934, in SXGMWJ, 7:416.

133. Zhao Tongru, Shaanbei gexian, 143.

134. Shaanbei provisional soviet announcement, in $X B G J D$, 72; Zhonggong Zichang xianwei dangshi bangongshi, "Anding (jin Zichang) suweiai zhengquan," 4-5, 31.

135. Guo Hongtao, Guo Hongtao huiyilu, 43-44.

136. Hang Yi to Shao Lizi, January 24, 1935, in XBGJD, 699-70o.

137. Shaanxi-Gansu-Shanxi revolutionary committee, October 1, 1935, in XBGJD, 92-93; Zhang Dazhi, in XBGJD, 267.

138. Report of Shaanbei soviet, June 3, 1935, from the Central Archives, in H26J, 2:1018.

139. "Shaanbei notes," December 1, 1935, from the Central Archives, in H26J, 2:1020.

140. Northwest Work Committee on assault month for army recruitment, September 1935, in XBGJD, 79; Shaanbei soviet directive on recruitment, August 10, 1935, in XBGJD, 72.

141. "Shaanbei shoufu chiqu shichaji," pt. 3, Dagongbao, November 27, 1936.

142. Esherick, "Deconstructing the Construction," 1071-74.

143. For another example of a college student from Beiping in the CCP, see Li Shaotang, in XBGJD, 613-16, on Zhao Yangpu.

144. Guo Hongtao, Guo Hongtao huiyilu, 36.

145. Esherick, "Deconstructing the Construction," 1058; Wang Shucai, Shaanbei gongchandang de lao zhanggui, 15-16; Qiang Tieniu, in ZCLZL, 2:383-84, on Xie Zichang.

146. Joseph W. Esherick, "The Chinese Communist Revolution from the Bottom Up: Shaan-Gan-Ning," paper presented at the American Historical Association annual meeting, December 1989.

147. South Shaanxi report, received November 9, 1934, in SXGMWJ, 7:410.

148. Li Jingbo, speech at the High Cadre Conference, November 1942.

149. Shaanbei special committee to Center, December 8, 1934, in SXGMWJ, 7:429.

150. Shaanbei special committee to Center, January 24, 1935, in SXGMWJ, 7:448; Zhonggong Xibei zhongyangju xuanchuanbu, Gulin diaocha (Yan’an, 1942), 99.

151. Zhao Tongru, Shaanbei gexian, 168.

152. Dagongbao, July 23, 1935.

153. Guo Hongtao, Guo Hongtao huiyilu, 55-57.

154. Informant 21. For other accounts of leftism and arbitrary executions on "Shaanbei," see Li Tielun, speech at the High Cadre Conference, November 1942; speeches at the Symposium on Northwest Revolutionary History by Cui Tianmin, June 28, 1945, and Ma Wenrui, July 12, 1945.

155. Three accounts in SXDSTX, 1984, no. 4: 37-47.

156. Wang Shucai, Shaanbei gongchandang de lao zhanggui, 90-95.

157. Red Guard provisional regulations, August 15, 1935, in XBGJD, 75-76. 
158. "Shaan-Gan-Ning diaocha zhuanbao," BOI 575.292/815; Ma Peixun, in SGGJD, 473.

159. Zhao Tongru, Shaanbei gexian, 56 .

16o. Ma Hongbin, report, July 20, 1935, in XBGJD, 712; Li Peifu, in H26J, 2:965.

161. Wang Shitai, in $H_{2} 6 J, 2: 748$.

162. Zhang Dazhi, in $X B G J D, 266-67$; He Jinnian, in $X B G J D, 284$; Gao Jianbai, in $X B G J D, 597$.

163. Wang Shitai, in H26J, 2:753-55; Mao Kan, May 16 and 23, 1935, and Hang Yi, May 19, 1935, reports to Shao Lizi, in XBGJD, 703-4.

164. Zhang Dazhi, in $X B G J D, 269-72$; Chen Kegong, in $X B G J D, 307-8$; Li Shaotang [GMD officer], in $X B G J D, 612$.

165. He Jinnian, in $X B G J D, 285$.

166. Zhang Dazhi, in $X B G J D, 271-72$.

167. Gao Jianbai, in $X B G J D, 606$.

168. Gao Jinchun, in $H_{2} 6 \mathrm{~J}, 2: 777-78$.

169. Zhang Dazhi, in $X B G J D, 274$; He Jinnian, in XBGJD, $285-87$.

170. Zhang Dazhi, in XBGJD, 274; Mao Kan, telegram, June 1, 1935, in XBGJD, 706.

171. Zhang Dazhi, in XBGJD, 275; He Jinnian, in XBGJD, 288.

172. Wang Shitai, in H26J, 2:755-56; Zhang Dazhi, in H26J, 2:276-77; He Jinnian, in H26J, 2:291-92; Li Chiran, Li Chiran jiangjun huiyilu, 64-67. The Dagongbao, July 29, 1935, reported six counties, omitting Dingbian.

173. Gao Lanting, in $X B G J D, 257-58$; He Jinnian, in $X B G J D, 294-96$; Wang Shucai, Shaanbei gongchandang de lao zhanggui, 98-99; Yu Jundu (于浚都), a Yan Xishan officer, in $X B G J D, 619-21$.

174. Shaanbei soviet order on third encirclement, October 1935, in XBGJD, 120. It should be noted that many of these were newly established small counties.

175. Gao Jinshang et al, August 19, 1935, in XBGJD, 730.

176. Hang Yi to Shao Lizi, September 23, 1935, in XBGJD, 718-19.

177. Yanchang magistrate Dong Yinzhi (董印支) to Shao Lizi, May 14, 1935, in XBGJD, 724.

178. Gao Jinshang et al, August 19, 1935, in XBGJD, 730.

179. Jia Tuofu, speech at the High Cadre Conference, November 11, 1942.

180. Guo Hongtao, speech at the High Cadre Conference, November 12, 1942.

181. The letter is quoted in Zhu Lizhi, "Wangshi huiyi," in Zhang Wenjie et al., Jinian Zhu Lizhi wenji (Zhengzhou: Henan renmin chubanshe, 1993), 552. On Zhu's background, see his memoir, "Wangshi huiyi," 529-50, and Wu Dianyao and Song Lin, Zhu Lizhi zhuan (Beijing: Zhonggong dangshi chubanshe, 2007), 661-66.

182. Shaan-Gan special committee decision, August 5, 1935, in XBGJD, 66-67.

183. Gao Langting, in $X B G J D$, 256-57; Zhu Zixiu, speech at the High Cadre Conference, November 5, 1942.

184. Zhu Lizhi, in XBGJD, 431.

185. William T. Rowe, Crimson Rain: Seven Centuries of Violence in a Chinese County (Stanford, CA: Stanford University Press, 2007), 292-319.

186. E. Snow, Red Star Over China, 299. 
187. The agent was Zhang Hanmin, who had helped Liu's men as a local commander in Yao-xian. See Guo Shushen, director of Twenty-Fifth Army political department, in $X B G J D, 450-51$. Zhang's execution would later complicate relations with Yang Hucheng's army, in which Zhang was an officer, in the context of the Xian incident. Yang Shangkun, Yang Shangkun huiyilu (Beijing: Zhongyang wenxian chubanshe, 2007), 158.

188. The precise size of the Twenty-Fifth Army is a mystery. As we will see in the next chapter, Mao treated the army with real deference and particularly favored Xu Haidong, which probably explains the vague estimates of the army's great strength. A contemporary Guomindang report estimates 2,00o soldiers (Jing Yuexiu to Shao Lizi, September 20, 1935, in XBGJD, 717); Gao Gang in 1945 said there were only 1,400 (Gao Gang, speech at the Symposium on Northwest Revolutionary History, August 2, 1945); and a recent history says 3,00o (Zhonggong Zhidan xianwei dangshi yanjiushi, ed., Zhongguo gongchandang Zhidan lishi, vol. 1 (Xian: Shaanxi renmin chubanshe, 2019), 37.

189. Guo Shushen, speech at the High Cadre Conference, November 1942.

190. Gao Langting, in $X B G J D, 263-64$; Dai Jiying, speech at the High Cadre Conference, November [7], 1942.

191. XBGJD, 6-7; Wang Shitai, in H26J, 2:766-67.

192. He Jinnian, speech at the High Cadre Conference, November 13, 1942; speeches at the Symposium on Northwest Revolutionary History by Cui Tianmin, June 28, 1945, and Gao Gang, August 2, 1945. It is worth noting that these criticisms came as much from the Xie Zichang's Twenty-Seventh as Liu and Gao's Twenty-Sixth Army.

193. Zhu Lizhi, speech at the Symposium on Northwest Revolutionary History, July 12, 1945.

194. "Zhonggong Shaan-Gan-Jin shengwei dui jinxing youji zhanzheng yu youji tuji de jueding," September 15, 1935, Lishi dang'an, 1986, no. 4: 56-59.

195. Zhu Lizhi, "Wangshi huiyi," 550-56; Zhu Lizhi, in XBGJD, 431-32; Nie Hongjun, in $X B G J D, 434-35$. For contemporary documents attacking Zhang Mutao's influence, see "Shaan-Gan bianqu tewei guanyu Shaan-Gan bianqu dang de renwu de jueyi," July 1934, and "Xibei zhengzhi weiji yu dang de jinji renwu de jueyi," September 1934, in Zhonggong zhongyang shujichu, Liuda yilai, 1:662-68. On Zhang Mutao, see Zhang Junxiao, "Yige you zhengyi de lishi renwu: Guanyu Zhang Mutao de jige wenti," Xibei daxue xuebao (zhexue shehui kexue ban) 30, no. 1 (2000): 142-49. Zhang persisted in his opposition to Chiang Kai-shek and opposed his release in the Xi'an incident. In 1941, he was killed on Chiang's orders (144). Significantly, Benton's Prophets Unarmed on the Trotskyite movement makes no mention of Zhang. An additional concern was another agent from Shanghai, a professor who arrived wearing Western clothes and eyeglasses, with credentials that could not be authenticated until the Center arrived and Zhou Enlai recognized him. Zhang Qingfu, also known as "Fatty Zhang" (张胖子), was extricated and sent to Shaanbei for technical (apparently radio) and cultural work after the Shanghai apparatus was exposed. After criticizing Zhu Lizhi, he came under attack and was arrested and tortured. See Zhang Qingfu, in XBGJD, 437-39; Li Tielun, in XBGJD, 440-49; Zhang Qingfu, speech at the High Cadre Conference, November 1942; Zhu Lizhi, speech at the Symposium on Northwest Revolutionary History, July 12, 1945. Interestingly, Edgar Snow was confused (perhaps deliberately) by his informants and made Zhang the instigator of the attack on Liu Zhidan. See Snow, Red Star Over China, 202-3. 
196. Xu Haidong, in $X B G J D$, 351; Liu Huaqing, in $X B G J D, 361$.

197. Predictably Communist and Nationalist accounts differ widely on the extent of Northeast Army losses. See XBGJD, 14, which claims over two thousand captives; Wang Yizhe, 1935 report, in $H_{2} 6 J$, 2:1027; Zhou Zuyao, in $X B G J D$, 625; Gao Jinchun, in XBGJD, $374-76$.

198. Gao Jianbai, in XBGJD, 608, on the abandonment of Wayaobu. In 1936, the Communists abandoned the town to Tang Enbo and shifted their headquarters to Baoan (XBGJD, 609-10).

199. He Jinnian, speech at the Symposium on Northwest Revolutionary History, July 2, 1945; Liu Jingfan in Liu Mila and Liu Dudu, Liu Jingfan jinian wenji, 1:58-59; Zhongtong, "Shaan-Gan-Ning diaocha zhuangbao," [ca. 1937], BOI 575.292/815 (Stanford Library).

200. Zhongyang ribao, November 18, 1935, November 30, 1935.

201. Li Chiran, Li Chiran jiangjun huiyilu, 77-81; "Shaan-Gan-Ning diaocha zhuanbao," KMT Bureau of Investigation report (Stanford Library).

202. I confess to being suspicious of this typically laudatory tale, but the accounts of Dai Jiying, November [7], 1942, and Nie Hongjun, November 15, 1942, both hostile witnesses, at the High Cadre Conference are convincing.

203. Huang Luobin, in $X B G J D, 426-29$; Li Chiran, in $X B G J D$, 368-73; Wang Shoudao, Huiyilu, 169.

204. Huang Luobin, speech at the High Cadre Conference, November 1942.

205. Liu Jiangfan, in Liu Mila and Liu Dudu, Liu Jingfan jinian wenji, 1:60.

206. Speeches at the High Cadre Conference by Guo Hongtao, November 12, 1942, Chen Zihua, November 14, 1942, and Nie Hongjun, November 15, 1942; speeches at the Symposium on Northwest Revolutionary History by Guo Hongtao, July 5, 1945, and Zhu Lizhi, July 12, 1945.

207. Cheng Zihua, speech at the High Cadre Conference, November 14, 1942. The most prominent "Shaanbei" leaders, Yan Hongyan and He Jinnian, later went on to successful careers in the party, and Yan played a prominent role in censoring a laudatory novel about Liu Zhidan in the 1960s. David Holm, "The Strange Case of Liu Zhidan," Australian Journal of Chinese Affairs 27 (January 1992): 91-94; IshikawaYoshihiro, "Xiaoshuo 'Liu Zhidan," $16-24$.

208. Wang Shoudao, who was appointed to examine and correct the sufan abuses, Wang Shoudao huiyilu (Beijing: Jiefangjun chubanshe), 1987, 169-70; Xi Zhongxun, in XBGJD, 416. 209. In $H_{2} 6 J, 2: 926$; in $X B G J D, 405-51$, for many accounts of sufan.

210. Zhao Qimin, in $X B G J D, 423$.

211. Liu Jingfan in Liu Mila and Liu Dudu, Liu Jingfan jinian wenji, 1:57-61, 66; Zhang $\mathrm{Ce}$, in $\mathrm{H}_{2} 6 \mathrm{~J}, 2: 923$.

212. Liu Jingfan in Liu Mila and Liu Dudu, Liu Jingfan jinian wenji, 1:72-73; Ma Yingxi, in $\mathrm{H}_{26}$ J, 2950; "Zhidan geming lishi fazhan de jige shiqi," Zhidan archives.

213. $X B G J D, 7$.

214. Stephen C. Averill, "The Origins of the Futian Incident," in Saich and van de Ven, New Perspectives, 79-115; Gao Hua, Hong taiyang, 9-54; and a forthcoming book by Joseph Fewsmith.

215. Rowe, Crimson Rain, 310.

216. Speeches at the High Cadre Conference by Dai Jiying, November [7], 1942, and Guo Shushen, November 10, 1942. 
217. Shaanbei special committee, December 6, 1933, in SXGMWJ, 7:309.

218. Wang Shitai, in $\mathrm{H}_{2} 6 \mathrm{~J}, 2: 767$.

219. Zhu Lizhi, in $X B G J D, 431-32$.

220. Guo Hongtao, Guo Hongtao huiyilu, 73-74; Nie Hongjun, in $X B G J D, 434$; speeches at the Symposium on Northwest Revolutionary History by Gao Gang, August 2, 1945, and Guo Hongtao, July 5, 1945.

221. 1959 survey of twenty-five Red Army soldiers, SXDSTX, 1985, no. 12: 33; Liu Jingfan in Liu Mila and Liu Dudu, Liu Jingfan jinian wenji, 1:81.

222. Wang Shitai, in $H_{2} 6 J, 2: 752,767$. This is a particularly poignant case: the young woman had once cared for a wounded soldier, teasing his modesty in hesitating to pull down his pants so she could cleanse his wound; Cai Ziwei, in H26J, 2:936; Li Jingbo, speech at the High Cadre Conference, November 1942.

223. Guo Hongtao, speech at the Symposium on Northwest Revolutionary History, July 1945; See also Ma Wenrui, speech at the High Cadre Conference, November 1942; Gao Gang, speech at the Symposium on Northwest Revolutionary History, August 1945.

224. Li Jinglin, speech and audience interruptions at the Symposium on Northwest Revolutionary History, July 4, 1945.

225. Xi Zhongxun, speech at the Symposium on Northwest Revolutionary History, July 1945.

226. Zhu Lizhi, July 10, 1945, in XBGJD, 431-32. This account, of course, came after Zhu Lizhi was harshly criticized by Gao Gang at the 1942-43 High Cadre Conference, and the language reflects his admission of "errors" in 1935. Nonetheless, the articulation of policy differences seems quite accurate. For an example of intellectuals and underground CCP in Yang Hucheng's administration who joined Liu Zhidan and came under suspicion, see Cai Ziwei, from Lantian, in SSGJD, 621-29; Nie Hongjun, in XBGJD, 434, where Cai is accused by being a Zhang Mutao agent; Northwest Work Committee decision, July 21, 1935, in XBGJD, 54; Shaanxi sheng diqingwang 陕西省地情网, “Cai Ziwei” 蔡子伟, October 19, 2012, accessed March 31, 2018, https://baike.baidu.com/item/蔡子伟/5765510. The contemporary document that best reflects Zhu's criticisms of the guerrillas in the Shaan-Gan region is "Zhonggong Shaan-Gan-Jin shengwei dui jinxing youji zhanzheng yu youji tuji de jueding," September 15, 1935, Lishi dang'an, 1986, no. 4: 56-59. Significantly, this harsh criticism of Liu's guerrilla policy is not included in the documentary collections on the Shaanbei revolution.

227. Informant 9.

228. "Zhidan geming lishi fazhan de jige shiqi" [ca. 1943], Zhidan archives.

229. Shaanxi-Gansu-Shanxi committee directive on land investigation, October 3, 1935 , in $X B G J D, 95$.

230. Liu Jingfan, in Liu Mila and Liu Dudu, Liu Jingfan jinian wenji, 1:72-73; informant 12.

231. Liu Jingfan, in $X B G J D, 336$, and $S G G J D, 412-13$; informant 13.

232. Informant 14 .

233. Informants 12 and 15.

234. Xi Zhongxun, in a speech at the Symposium on Northwest Revolutionary History, July 1945, said the sufan teams used thugs, opportunists, and bad and disciplined cadres as their local agents.

235. Speeches at the High Cadre Conference by Li Zhongying, October 12, 1942, and Huang Luobin, November 1942. 
236. Speeches at the High Cadre Conference by Zhu Zixiu, November 5, 1942, and Nie Hongjun, November 15, 1942.

237. "Zhonggong Shaan-Gan-Jin shengwei dui jinxing youji zhanzheng yu youji tuji de jueding," September 15, 1935, Lishi dang'an, 1986, no. 4: 56; Zhonggong Zhidan xianwei dangshi yanjiushi, Zhongguo gongchandang Zhidan lishi, 1:44-49; Liu Jingfan in Liu Mila and Liu Dudu, Liu Jingfan jinian wenji, 1:61-75; Liu Jingfan, August 7, 1960, recollection in Zhidan archives; informants 9, 13, and 14.

238. Ma Wenrui, in $X B G J D, 421$.

239. "Shaan-Gan-Ning diaocha zhuanbao," BOI 575.292/815.

240. Wang Shoudao, Wang Shoudao huiyilu, 166; Pang Xianzhi and Jin Chongji, Mao Zedong zhuan, 6 vols. (Beijing: Zhongyang wenxian chubanshe, 2011), 1:374. The only nearcontemporary account I have seen of the "Halt the executions!" order is Mao's rambling speech at the High Cadre Conference, November 21, 1942, and he does not claim to have issued it himself. At the Shaan-Gan soviet headquarters at Xiasiwan, Mao listened to a long report from Guo Hongtao and appears to have made no objection (Yang Yuting, speech at the High Cadre Conference, November 1942). Then Mao went to the front with Xu Haidong to direct the battle at Zhiluozhen. The halt to sufan came only when Zhou Enlai arrived at Wayaobu, where Liu and the others were detained. Ishikawa Yoshihiro ("Xiaoshuo 'Liu Zhidan," 33-34) credits Zhang Wentian with stopping the purge.

241. Zhang Ce, in $\mathrm{H}_{2} 6 \mathrm{~J}$, 2:923.

242. Zhonggong Zhidan xianwei dangshi yanjiushi, Zhongguo gongchandang Zhidan lishi, 1:39.

243. Zhonggong zhongyang wenxian yanjiushi, ed., Mao Zedong nianpu, 1893-1949 (Beijing: Renmin chubanshe and Zhongyang wenxian chubanshe, 1993) [hereafter: Mao nianpu], 1:481-89; Zhonggong zhongyang wenxian yanjiushi, Zhou Enlai nianpu, 1898-1949 (Beijing: Zhongyang wenxian chubanshe, 2007) [hereafter: Zhou nianpu], 301; Wang Shoudao, Wang Shoudao huiyilu, 166-72. Significantly, Mao nianpu, usually scrupulous about dates, gives no entry for Mao's "Halt the executions!" order, indicating only that, when he met Zhu Lizhi and Nie Hongjun on November 3 (p. 484), he had "previously" ordered a halt to the sufan campaign, an order that, if issued, had certainly not been effective.

244. Northwest Bureau decision on sufan, November 26, 1935, Zhonggong zhongyang shujichu, Liuda yilai, 2:372-73; Li Weihan, Huiyi yu yanjiu (Beijing: Zhonggong dangshi ziliao chubanshe, 1986), 1:370-73; XBGJD, 9-10.

245. Ma Wenrui, speech at the High Cadre Conference, November 1942.

246. Informants 8 and 16.

\section{ACCIDENTAL HOLY LAND}

1. Xi Zhongxun, "Lishi de huigu," in $S G G J D$, 1. For a similar summary, see $X B G J D, 1$.

2. Schram et al., Mao's Road to Power, vols. 5-8; Schram, Political Thought; Compton, Mao's China; Wylie, Emergence of Maoism; Fogel, Ai Ssu-ch'is Contribution.

3. Selden, Yenan Way; Selden, China in Revolution; Apter and Saich, Revolutionary Discourse; Chen Yung-fa, Yan'an de yinying; Gao Hua, Hong taiyang.

4. For recent articles, see "Red Tourism' Thrives in Yan'an, China," New York Times, December 31, 2010, www.nytimes.com/slideshow/2010/12/31/world/20101231_CHINA.html; 
Michael Bristow, “China’s Communist Party: 'Red Tourism' in Yan'an,” June 30, 2011, www .bbc.com/news/world-asia-pacific-13973159; Baidu Baike, "Yan’an jingshen," accessed October 1, 2018, https://baike.baidu.com/item/延安精神/2411494? fr=aladdin.

5. NCH, January $27,1936$.

6. The epic story of the Long March was first recorded in E. Snow, Red Star Over China. Subsequent studies in English include Dick Wilson, The Long March, 1935: The Epic of Chinese Communism's Survival (New York: Viking Press, 1972); the sometimes unreliable Salisbury, Long March; a scholarly study by Benjamin Yang, From Revolution to Politics: Chinese Communists on the Long March (Boulder, CO: Westview Press, 1990); a retracing of the march by Ed Jocelyn and Andrew McEwen, The Long March: The True Story behind the Legendary Journey That Made Mao's China (London: Constable, 2006); and a rich account by Sun Shuyun, Long March. For an invaluable collection of contemporary documents, see Yang Dezhi et al., Hongjun changzheng wenxian (Beijing: Jiefangjun chubanshe, 1995) [hereafter: $C Z W X]$.

7. Wang Shulin, "Gongchan guoji, Sulian yu Zhongguo gongnong hongjun changzheng luojiaodian de queli," Zhongguo Yan'an ganbu xueyuan xuebao, 2017, no 2: 93.

8. Chang Kuo-t’ao [Zhang Guotao], The Autobiography of Chang Kuo-t'ao, vol. 2, The Rise of the Chinese Communist Party, 1928-38 (Lawrence: University Press of Kansas, 1972), 290-365.

9. In many communications with the Comintern, Sichuan was considered the "northwest," producing some confusion as to the meaning of the term. See Wang Shulin, "Gongchan guoji," 91-92; Manfred Stern to Comintern, September 16, 1934, in Zhonggong zhongyang dangshi yanjiushi, trans., Liangong (bu), gongchan guoji yu Zhongguo suweiai yundong (Beijing: Zhonggong dangshi chubanshe, 2006) [hereafter cited as Liangong], 14: 239-40.

10. Stuart R. Schram and Nancy Hodes, introduction to Schram et al., Mao's Road to Power, vol. 5, Toward the Second United Front, January 1935-July 1937, ed. Stuart R. Schram and Nancy Hodes (Armonk, NY: M. E. Sharpe, 2017), xlii; B. Yang, From Revolution to Politics, 129-61, 292. Yang cites five estimates of the relative size of the First and Fourth Armies. If we exclude Edgar Snow's second-hand numbers, the average of the others yields almost exactly a 1:5 ratio of the two armies.

11. On Soviet influence in Xinjiang, see Justin M. Jacobs, Xinjiang and the Modern Chinese State (Seattle: University of Washington Press, 2016), 89-126.

12. Cited in Ding Zhi, "Zhongyang hongjun beishang fangzhen," 269. I am indebted to Yang Kuisong, Xian shibian xintan, for pointing me to this critical source.

13. Central Committee to Zhang Guotao et al., September 8, 1935, in Mao Zedong, Mao Zedong junshi wenji, ed. Zhonggong zhongyang wenxian yanjiushi and Zhongguo renmin jiefangjun junshi kexueyuan (Beijing: Junshi kexueyuan and Zhongyang wenxian chubanshe, 1993) [hereafter: Mao junshi], 1:364-65.

14. Cited in Ding Zhi, "Zhongyang hongjun beishang fangzhen," 271-72.

15. Dae-Sook Suh, Kim Il Sung: The North Korean Leader (New York: Columbia University Press, 1988), 47-73.

16. Mao nianpu, 1:473; Zhou nianpu, 297-98.

17. Dagongbao, July 23, 1935.

18. Chang Kuo-t'ao, Autobiography, 2:379, gives the ten thousand figure; the official Zhou nianpu, 287, gives thirty thousand. See also note 10. 
19. Lin Biao and Nie Rongzhen to Mao and Peng Dehuai, November 7, 1935, in CZWX, 750; on "serious" casualties and desertions in Gansu, see Peng Dehuai to Mao, October 13, 1935, in CZWX, 721; also Yang Kuisong, Xian shibian xintan, 27.

20. E. Snow, Red Star Over China, 194. Because of the controversy over editorial changes made to this book, I have used the original Random House 1938 edition rather than the more accessible 1961 Grove Press edition. For the controversy, see notes 174, 175 below.

21. Chang Kuo-t’ao, Autobiography, 2:445.

22. Peng Dehuai, in $X B G J D, 381$.

23. NCH, September 25, 1935.

24. Jing Yuexiu to Shao Lizi, September 20, 1935, in XBGJD, 717; Gao Gang, speech at the Symposium on Northwest Revolutionary History, August 2, 1945; Chang Kuo-t'ao, Autobiography, 2:463.

25. Zhu De et al. to Lin Biao et al., October 26, 1935, in CZWX, 801; Xu Haidong, "Huishi Shaanbei" (1959), in Lu Zhenguo and Jiang Wemin, Hong ershiwu jun changzheng jishi (Zhengzhou: Henan renmin chubanshe, 1986), 156. Xu also mentions (p. 152) three thousand in his Twenty-Fifth Army in southern Shaanxi, before major losses crossing the Wei into Shaanbei. It should be stressed that Zhu De was still with Zhang Guotao's army at this time, and his information surely came from other officers already in Shaanbei.

26. Gao Jinshang et al. to Shaanxi government, August 19, 1935, in XBGJD, 729. This report also mentions over one thousand guns under Yang Sen, a Shenmu Communist whose army was soon eliminated and is not counted here.

27. Mao nianpu, 1:476-77; Yan Daogang, in XBGJD, 637-38.

28. Wang Shulin, "Gongchan guoji," 102.

29. Mao nianpu, 1:487.

30. Mao nianpu, 1:495, 486; Mao junshi, 1:380-93, November 6-24, 1935.

31. Nie Rongzhen, in $X B G J D, 390$.

32. Mao and Peng Dehuai to Zhang Wentian and Zhou Enlai, in CZWX, 775; Nie Rongzhen, in $X B G J D$, 390-93. Former Guomindang commanders give particularly exaggerated accounts, one claiming the NEA lost twenty thousand men (Peng Zhulin, in XBGJD, 638). Mao's November 30 speech on the battle is in Mao junshi, 1:398-407.

33. Northwest Military Committee, order, November 3, 1935, in CZWX, 745.

34. Mao nianpu, 1:492.

35. Mao and Peng Dehuai to commanders, November 2, 1935, in CZWX, 743.

36. Zhang Guotao, order, October 5, 1935, in CZWX, 840. On Xu's close relations with Zhang Guotao, see Chang Kuo-t’ao, Autobiography, 2:461-66.

37. For the September 1935 attacks on Zhang Guotao, see CZWX, 681-86; for the new line of forgetting past differences, see CZWX, 845-46, 940-41.

38. Mao nianpu, 1:485.

39. Mao nianpu, 1:503.

40. Mao junshi, 1:436.

41. Mao nianpu, 1:566.

42. CZWX, 733 .

43. Chang Kuo-t'ao, Autobiography, 2:464-65.

44. Mao nianpu, 1:501.

45. Mao nianpu, 1:484. 
46. Military committee to Comintern, August 28, 1936, in CZWX, 1103-5, quote on 1105.

47. Soviet announcement, November 1935, in XBGJD, 128.

48. Li Weihan, Huiyi yu yanjiu, 1:373-76; XBGJD, 21. Later, during the 1942-43 Rectification Campaign's reconsideration of the revolutionary movement in the Northwest, Gao Gang would wreak his revenge and focus his attack on Zhu and Guo.

49. Averill, "Origins," 79-115; on Hubei-Henan-Anhui, see Rowe, Crimson Rain, 269-319.

50. Ma Mingfang, July 1, 1936, in XBGJD, 187.

51. Shaan-Gan Detachment, directive on political work, October 23, 1935, in CZWX, 732-34; Mao nianpu, 1:481-82.

52. Mao, November 30, 1935, in Mao junshi, 1:404-5.

53. CCP Center, November 21, 1935, in XBGJD, 129.

54. Central Soviet Northwest office, February 8, 1936, in XBGJD, 146.

55. Zhou nianpu, 301.

56. Shaan-Gan-Ning committee to Qingyang, July 12, 1936, in $X B G J D, 227$.

57. Li Weihan, Huiyi yu yanjiu, 1:376.

58. Dagongbao, December 4, 1936. Most likely, this report reflected the final stages of the defections in Bao'an occasioned by the sufan campaign, an event known locally as the Chi'an Incident, after the Communist new name for Bao'an County in 1935. (See chapter 4.)

59. Zhou nianpu, 301.

6o. Mao to Peng Dehuai, December 17, 1935, in Mao junshi, 1:410.

61. Mao nianpu, 1:501.

62. Li Weihan, Huiyi yu yanjiu, 1:374-75.

63. Wang Shulin, "Gongchan guoji," 92.

64. Decision of the Wayaobu Politburo meeting, December 25, 1935, in Zhonggong zhongyang shujichu, Liuda yilai, 1:734-45; Center policy on land reform, July 22, 1936, in XBGJD, 160-61; Mao nianpu, 1:496-97.

65. On the December 9 movement, see John Israel, Student Nationalism in China, 19271937 (Stanford, CA: Stanford University Press, 1966); John Israel and Donald W. Klein, Rebels and Bureaucrats: China's December gers (Berkeley: University of California Press, 1976).

66. Zhou nianpu, 302.

67. Mao et al. to Zhang Guotao et al., September 8, 1935, in Mao junshi, 1:364.

68. Northwest office of the soviet, spring 1937, in XBGJD, 165.

69. Military committee to Comintern, August 28, 1936, in CZWX, 1102.

70. B. Yang, Revolution to Politics, 117-21.

71. Shaan-Gan provincial committee plan for January-February 1936, December 1935 , in XBGJD, 192-98; Mao, speech to army, November 30, 1935, in Mao junshi, 1:400; Mao to Peng, December 17, 1935, in Mao junshi, 1:410-11.

72. Mao nianpu, 1:498-99.

73. Lin Yuying et al. to Zhang Guotao et al., February 14, 1936, in CZWX, 862-63.

74. Mao to Zhang Wentian, November 30 and December 1, 1935, in Mao junshi, 1:396, 408-9.

75. Mao nianpu, 1:508; Zhou nianpu, 305. For a helpful and reliable account of these debates, see Yang Kuisong, Xian shibian xintan, 30-34, 41-43, 54-58.

76. An article by Deng Xiaoping's grandnephew is the best study of the Eastern Expedition: Deng Ye, "Yan Xishan dui Hongjun dongzheng de lanjie jiqi duofang zhengzhi zhouxuan," Jindaishi yanjiu, 2010, no. 5: 49-68. See also Wang Shulin, “Gongchan guoji," 99-100. 
77. Mao Zedong, "Snow" (雪), in Poems of Mao Tse-tung, ed. Hua-ling Nieh Engle and Paul Engle (New York: Dell, 1972), 78. For the original, see The Poems of Mao Tse-tung, trans. Willis Barnstone (New York: Bantam, 1972), 84-86.

78. Military order for Eastern Expedition, February 18, 1936, in Mao junshi, 1:442-44; Proclamation of the Anti-Japanese Vanguard, March 1, 1936, in Mao junshi, 1:470-71.

79. Yang Kuisong, Xian shibian xintan, 34-50; Deng Ye, "Yan Xishan dui Hongjun," 67; Deng Jingyuan, in Xian shibian qinliji, ed. Wu Fuzhang (Beijing: Zhongguo wenshi chubanshe, 1986), 45-46.

8o. Mao Zedong, November 30,1935 , in $C Z W X, 777$. It is worth noting that this official collection on the Long March includes the continuation into Shanxi.

81. Li Weihan, Huiyi yu yanjiu, 1:377-78.

82. Mao Zedong, February 21, 1936, in Mao junshi, 1:449.

83. Shaanxi-Gansu-Shanxi soviet regulations on Red Guards and Young Pioneers, October 1, 1935, in XBGJD, 92. Chinese ages are calculated in sui (岁). A person is counted as one sui at birth and two sui on the New Year following birth, so biological age averages one and a half years less than age in sui.

84. Li Weihan, Huiyi yu yanjiu, 1:378.

85. Li Chiran, Li Chiran jiangjun huiyilu, 88-90.

86. Shaanxi-Gansu-Shanxi party committee on recruitment, October 5, 1935, in XBGJD, $108-9$.

87. Sun Shuyun, Long March, 14-22, 29-30.

88. Deng Ye, "Yan Xishan dui Hongjun," 55-58; Mao nianpu, 1:534-35.

89. Mao to Lin Biao et al., April 14, 1936, in Mao junshi, 1:517.

9o. Deng Ye, "Yan Xishan dui Hongjun," 52-65; Mao nianpu, 1:534-35; Mao junshi, 1:521-27.

91. Speeches at the High Cadre Conference by He Jinnian, November 13, 1942, and Ma Wenrui, November 1942. It bears noting that both He and Ma were from the "Shaanbei" faction of the party.

92. Li Zhenmin and Zhang Shouxian, "Liu Zhidan," 3:191-228; Mao nianpu, 1:510-11, 535 .

93. Apter and Saich, Revolutionary Discourse, 49-54; Ishikawa Yoshihiro, "Xiaoshuo 'Liu Zhidan," 51-52. I heard similar suspicions in 1988-89, from informants who are best unidentified.

94. Guo Hongtao, speech at the Symposium on Northwest Revolutionary History, July 5 , 1945.

95. Mao Zedong, April 5, 1936, in Zhonggong zhongyang shujichu, Liuda yilai, 1:752-53.

96. Mao junshi, 1:445n; Deng Ye, "Ýan Xishan dui Hongjun," 68.

97. Li Chiran, Li Chiran jiangjun huiyilu, 98-99.

98. Mao to Zhou Enlai, February 17, 1936, in Mao junshi, 1:440.

99. Guo Hongtao on recruitment plans, June 13, 1936, in XBGJD, 182.

100. Mao to Peng Dehuai, May 29, 1935, in CZWX, 940-41; Mao, June 14, 1936, in Mao junshi, 1:544; Zhou nianpu, 318-19; Yang Kuisong, Xian shibian xintan, 116-18.

101. "Shaanbei shoufu chiqu shichaji" (An investigation of the Shaanbei areas recovered from the Communists), pts. 2, 3, 4, and 5, Dagongbao, November 27 and December 2, 3, and 4, 1936. Further Dagongbao citations in this chapter are all from this series of articles. 
102. Dagongbao, December 4, 1936.

103. Northwest Soviet office, spring 1937, in XBGJD, 164; Zhongtong, "Bannianlai Shaan-Gan-Ning ji Chuan-Kang bianjing chifei zhi cuanrao gaikuang," March 1937, BOI 270/815 (Stanford Library).

104. Shaanbei provincial committee, order on Red Guards, January 10, 1936, in XBGJD, 176-79.

105. Ma Mingfang, July 1, 1936, in XBGJD, 185-87.

106. Central Organization Department to Shaan-Gan-Ning committee, August 15, 1936, in $X B G J D, 237$.

107. Zhao Tongru, Shaanbei gexian, 168.

108. Dagongbao, November 27, 1936.

109. Northwest office of the soviet, May 9, 1936, in XBGJD, 156.

110. Military staff to Comintern, August 28, 1936, in CZWX, 1102. The report also claimed the eastern town of Yanchuan, but that was visited by the Dagongbao reporter, who dates the Communist occupation from May 1935 to September 1936. Thus Communist control ended soon after the report to the Comintern. Dagongbao, December 3, 1936.

111. Yang Kuisong, Xian shibian xintan, 43-44, 229, 264-66, 276.

112. Chang Kuo-t’ao, Autobiography, 2:474-75.

113. Helen Foster Snow, My China Years (New York: William Morrow, 1984), 232.

114. Military staff to Comintern, August 28, 1936, in CZWX, 1102.

115. Xiao Jinguang, February 1, 1936, in XBGJD, 202-3.

116. Mao to Peng Dehuai, July 23, 1936, in Mao junshi, 1:558.

117. XBGJD, 162-64.

118. Chang Kuo-t'ao, Autobiography, 2:478.

119. Coble, Facing Japan; Jay Taylor, The Generalissimo: Chiang Kai-Shek and the Struggle for Modern China (Cambridge, MA: Harvard University Press, 2009), 97-137.

120. Liu Shaoqi, "Suqing Lisan luxian de canyu_guanmen zhuiyi maoxian zhuyi," April 10, 1936, in Zhonggong zhongyang shujichu, Liuda yilai, 1:754-59.

121. Northwest office of the soviet, November 25, 1935, and January 24, 1936, in XBGJD, 131-32, 134-35.

122. Party Center decision on united front, September 17, 1936, in CZWX, 974.

123. Chart of military cells, 1933, in SXGMWJ, series 2, 1:426-28 (showing the predominance of officers in these military cells); Zhao Renfu, November 23, 1936, in SXGMWJ, series 2, 1:499-509; Tien-wei Wu, The Sian Incident: A Pivotal Point in Modern Chinese History (Ann Arbor: University of Michigan Center for Chinese Studies, 1976), 22, 51-53; E. Snow, Random Notes, 3-4.

124. Mao nianpu, 1:49o.

125. Zhou Zuyao, in Wu Fuzhang, Xian shibian qinliji, 16-20.

126. CCP Center on work in the NEA, June 20, 1936, in CZWX, 948.

127. Mao et al. to NEA officers, January 25, 1936, in CZWX, 902-6.

128. Zhang Ce, $X B G J D$, 510; Yang Zuixiang, in $X B G J D$, 567-68; Yang Kuisong, Xian shibian xintan, 133.

129. E. Snow, Random Notes, 123.

130. CCP Northwest Bureau on army work, February 3, 1936, in XBGJD, 140-41.

131. Gao Jianbai, a Guomindang officer, in XBGJD, 605; Zhou nianpu, 303. 
132. Wang Enshou, "Gao Fuyuan: Hongjun he dongbeijun de zhongyao qianxianren," Dang'an tiandi, 2014, no. 6: 16-19.

133. Mao nianpu, 1:507.

134. Mao et al., March 5, 1936, in CZWX, 917-18.

135. Zhang Ce, in $X B G J D$, 511.

136. He Zhuguo and Dai Jingyuan, in Wu Fuzhang, Xian shibian qinliji, 3, 52; Tien-wei Wu. Sian Incident, 1-6.

137. He Zhuguo and Shen Bochun, in Wu Fuzhang, Xian shibian qinliji, 1-5, 54-62; Yang Kuisong, Xian shibian xintan, is surely the best study of Zhang Xueliang in this era and notably stresses (pp. 10-11) the unreliability of memoir accounts, which often try to obscure Zhang's dealings with the Communists to protect him while he was still under house arrest in Taiwan. See also E. Snow, Red Star Over China, 16-24.

138. Coble, Facing Japan, 56-59.

139. Chiang Kai-shek, diary entry for November 28, 1936, cited in Meng Guanghan et al., Kangzhan shiqi Guo-Gong hezuo jishi (Chongqing: Chongqing chubanshe, 1992), 249.

140. Yang Kuisong, Xian shibian xintan, 66-67.

141. Zhou nianpu, 310-11.

142. Li Haiwen, "Xian shibian qian Guo-Gong liangdang jiechu he tanpan de lishi guocheng," Wenxian he yanjiu, 1984, 355; Mao nianpu, 1:533-34; CCP Center on "forcing Jiang to resist Japan," September 1, 1936, in CZWX, 970-71.

143. Mao et al. to He Long et al., September 8, 1936, Wenxian he yanjiu, 1985, 162-63.

144. Yang Kuisong, Xian shibian xintan, 89-150; Chang Kuo-t’ao, Autobiography, 2:451. Li Haiwen, "Xi'an shibian," 354.

145. Zhou nianpu, 310-11; Mao nianpu, 1:534, 536.

146. Yang Kuisong, Xian shibian xintan, 1-7, 121-23. Yang's account is the most thorough and convincing analysis of this remarkable story. For a rare published document confirming the incident, see Moscow's reaction in Dimitrov to Stalin, July 27, 1936, in Alexander Dallin and F. I. Firsov, eds., Dimitrov and Stalin, 1934-1943: Letters from the Soviet Archives (New Haven, CT: Yale University Press, 2000), 102.

147. Sheng Shicai to Wang Ming, received March 15, 1936, in Liangong, 15:168-77.

148. Lin Yuying et al. to Zhang Guotao et al., May 20, 1936, in CZWX, 865.

149. Lin Yuying et al. to Zhang Guotao et al., July 1, 1936, in CZWX, 1075.

150. CCP Secretariat to Wang Ming, June 26, 1936, in Dallin and Firsov, Dimitrov and Stalin, 96-99.

151. Editors' Introduction, in Liangong, 15:3-9.

152. Schram and Hodes, introduction to Schram et al., Mao's Road to Power, 5:li. Lyman van Slyke's classic study of the CCP's united front policy erroneously held that the August 1 declaration was made from the Long March (Lyman P. van Slyke, Enemies and Friends: The United Front in Chinese Communist History [Stanford, CA: Stanford University Press, 1967], 56-57).

153. Guo Dehong, Wang Ming nianpu (Beijing: Shehui kexue wenxian chubanshe, 2014), 290-91. For the full text, see "Message to Compatriots on Resistance to Japan," in Saich and Yang, Rise to Power, 692-98.

154. Wang Ming to Executive Committee of the Communist International, January 9, 1935, in Liangong, 15:352-54. 
155. Political decision of the Wayaobu meeting, December 25, 1935, in CZWX, 887; Zhonggong zhongyang shujichu, Liuda yilai, 1:734-45.

156. Jiang Tingfu, Jiang Tingfu huiyilu, trans. Xie Zhonglian (Taipei: Zhuanji wenxue, [1979]), 191-93; John W. Garver, “The Soviet Union and the Xi'an Incident," Australian Journal of Chinese Affairs 26 (July 1991): 145-53.

157. Wang Ming, discussion with Deng Wenyi, January 17, 1936, in Liangong, 15: 89-102, quote from 94-95.

158. Wang Ming, discussion with Deng Wenyi, January 22, 1936, and report of January 23, 1936, in Liangong, 15:104-10.

159. Li Haiwen, "Xi'an shibian," 351-54; Mao et al. to Bo Gu, March 4, 1936, Wenxian he yanjiu, 1985, 180-81. For a careful study of these multi-party negotiations, see Hans van de Ven, War and Nationalism, 172-88. See also Sidney H. Chang and Ramon H. Myers, eds., The Storm Clouds Clear over China: The Memoir of Chen Lifu, 1900-1993 (Stanford, CA: Hoover Institution Press, 1994), 116-25. Chen's account is not particularly reliable. In particular, he reproduces a September 1 letter from Zhou Enlai, but the 1935 date added to it and mentioned in the text is in error. The letter is from 1936 (Zhou nianpu, 325).

160. Mao nianpu, 1:533-34; CCP open letter to all parties, April 25, 1936, in Zhonggong zhongyang shujichu, Liuda yilai, 1:760-61. Significantly, in internal party documents, Chiang was still referred to as the "traitorous bandit headman." CCP Center on NEA work, June 20, 1936, in CZWX, 947.

161. Comintern to CCP, August 15, 1936, in Dallin and Firsov, Dimitrov and Stalin, 101-5. As seen above, the CCP's opposition to Chiang agreed with Wang Ming's authoritative speech at the Seventh Congress. The party had not misinterpreted the Comintern; the Comintern had changed its position.

162. Mao to Pan Hannian, August 23, 1936, Wenxian he yanjiu, 1985, 159.

163. Mao Zedong, letters in Wenxian he yanjiu, 1983, 12-17; Mao nianpu, 1:540, 569, 570-71, 590; Zhou nianpu, 310, 322, 323, 325. Translations are in Schram et al., Mao's Road to Power, 5:295, 311-21, 338-39, 344-47, 356-58, 362-69.

164. See various 1936 communications in Liangong, 15:112-13, 193-95, 210-21; Mao et al. to Zhang Guotao et al., September 27, 1936, Wenxian he yanjiu, 1985, 182-83.

165. "Draft Agreement between Guomindang and CCP to Resist Japan," in Mao junshi, 1:640-42. Schram has translated this in Schram et al., Mao's Road to Power, 5:399-401.

166. Guomindang instructions to Zhang Chong, October 5, 1936, in MGSL:ZG, 1:63-64. 167. E. Snow, Red Star Over China, 369. The best biography of Snow is S. Bernard Thomas, Season of High Adventure: Edgar Snow in China (Berkeley: University of California Press, 1999); see also Snow's autobiographical Journey to the Beginning (New York: Random House, 1958). On the popularity of Marxism among Chinese students in the 1930s, see Olga Lang, Chinese Family and Society (New Haven, CT: Yale University Press, 1946), 275-80, 310, 364 .

168. E. Snow, Journey to the Beginning, 150-82, and Red Star Over China, 25 ff.; Thomas, Season of High Adventure, 126-47.

169. E. Snow, Journey to the Beginning, 161. Snow refers to himself as Mao's Boswell (150).

170. E. Snow, Journey to the Beginning, 183-84; Thomas, Season of High Adventure, 156-59.

171. E. Snow, Journey to the Beginning, 159-60.

172. E. Snow, Red Star Over China, 66, 67, 69, 70, 72. 
173. E. Snow, Red Star Over China, 68-70; Chang Kuo-t’ao, Autobiography, 2:482, 517-20.

174. Anne-Marie Brady, Making the Foreign Serve China: Managing Foreigners in the People's Republic (Lanham, MD: Rowman and Littlefield, 2003), 46.

175. John Pomfret, The Beautiful Country and the Middle Kingdom: America and China, 1776 to the Present (New York: Henry Holt, 2016), 231.

176. Snow's original notes are even more blunt. The educator/propagandist "tended to despair" over work in Shaanxi, where "the human material seemed far poorer" (E. Snow, Random Notes, 49).

177. E. Snow, Random Notes, passim.

178. E. Snow, Red Star Over China, 39, 57, 230, 248-52.

179. E. Snow, Red Star Over China, 225-26. This is confirmed in Mao nianpu, 1:504, $571-72$.

180. E. Snow, Red Star Over China, 323-24.

181. E. Snow, Red Star Over China, 201-2.

182. See E. Snow, Red Star Over China, 6, 39, 194, 261, and 386 for these claims.

183. E. Snow, Journey to the Beginning, 177.

184. Stuart R. Schram (Mao Tse-tung, 19n) calls Snow's account "the most important single source regarding [Mao's] early life."

185. Mao nianpu, 1:566. The date of this entry is August 5, right in the middle of Snow's visit.

186. See "Interview with Edgar Snow on Foreign Affairs," July 15, 1936, in Schram et al., Mao's Road to Power, 5:249-57, much of which appears in Red Star Over China, 80-83.

187. E. Snow, Red Star Over China, 365-66.

188. CCP military committee to Comintern, August 28, 1936, in CZWX, 110o. This appears to be the same report cited by Yang Kuisong in Xian shibian xintan, 151-54, from the Soviet archives.

189. Mao to Peng Dehuai et al., October 10, 1936, in Mao junshi, 1:576, 625; Mao nianpu, 1:617. The Dagongbao journalist (December 8, 1936) reported a base only in the Bao'an-Yuwangbu area.

190. CCP military committee, August 28, 1936, in CZWX, 1102. Guomindang intelligence reported guerrilla zones around Anding, Qingjian, Hengshan, and Fu-xian. Zhongtong, "Bannianlai Shaan-Gan-Ning ji Chuan-Kang bianjing chifei zhi cuanrao gaikuang," March 1937, BOI 270/815 (Stanford Library).

191. Tang Liru, October 12, 1936, in XBGJD, 205-6; Shaan-Gan-Ning to Qingyang, July 12, 1936, in XBGJD, 225-26.

192. Li Fuchun, party secretary of Shaan-Gan-Ning, July 20, 1936, in XBGJD, 228-29.

193. CCP Center on grain collection, August 1, 1936, in XBGJD, 163.

194. CCP to Comintern, June 26, 1936, cited in Dallin and Firsov, Dimitrov and Stalin, 96-97. The population reported in June was also larger, five hundred thousand versus four hundred thousand in August.

195. Mao Zedong, "Zhongguo geming zhanzheng de zhanlüe wenti," December 12, 1936, in Mao junshi, 1:693-94, 717-20.

196. CCP military committee, August 28, 1936, in CZWX, 1104.

197. Desertion occurred at a much higher rate than the party wished to admit. For telling examples from the Long March, see Sun Shuyun, Long March, 67-69. 
198. Mao nianpu, 1:525.

199. Yang Kuisong, "Sulian daguimo yuanzhu Zhongguo hongjun de yici changshi," Jindaishi yanjiu, 1995, no. 1: 262. Yang cites Mao nianpu for this April 2 radiogram, but the passage does not appear on the cited page or date.

200. Mao and Zhou Enlai to Peng Dehuai, June 6, 1936, in CZWX, 944.

201. Mao nianpu, 1:573, entry for August 25, 1936.

202. Comintern to CCP, August 15, 1936, in Dallin and Firsov, Dimitrov and Stalin, 102-4; Yang Kuisong, "Sulian daguimo," 264.

203. Kaganovich and Molotov to Stalin, September 8, 1936, in Liangong, 15:251-52.

204. Lin Yuying to Zhu De et al., May 25, 1936, in CZWX, 867-68.

205. Mao to Peng Dehuai, August 22, 1936, in Mao junshi, 1:572.

206. Mao Zedong et al. to Zhang Guotao et al., September 27, October 8, and October 17, 1936, Wenxian he yanjiu, 1985, 182-84, 191.

207. Mao nianpu, 1:569; Jing Shenghong, Hu Zongnan dazhuan (Beijing: Tuanjie chubanshe, 2009), 73-98; Lin Yuying, radiograms, in CZWX, 845-46, 862-63, 865-68.

208. Jing Shenghong, Hu Zongnan dazhuan, 97-98. On the Longhai railway, see SXDSJ, 222-23.

209. Mao to Zhu De and Zhang Guotao, September 19, 1936, in Mao junshi, 1:592.

210. Yang Kuisong, "Sulian daguimo," 267-75; B. Yang, Revolution to Politics, 228-36; Dallin and Firsov, Dimitrov and Stalin, 109-10n; Mao nianpu, 1:586-88. Key radiogram sources are in CZWX, 1109-84; Mao junshi, 1: 572-618; Zhongguo renmin jiefangjun junshi kexueyuan, ed., Zhongguo renmin jiefangjun zhanshi (Beijing: Junshi kexue chubanshe, 1987), 358-69. For a dramatic account from oral history sources, see Sun Shuyuan, Long March, 219-44.

211. Mao nianpu, 1:549, 582; Li Fuchun, July 20, 1936, in XBGJD, 230; Wang Shoudao, in XBGJD, 408-12. E. Snow, Red Star Over China, 319-24, presents an optimistic account of efforts to replace "racial animosity" with class antagonism. Liu Xiaoyuan's account of Mao's autonomy promises to the Mongols is useful but insufficiently sensitive to the 1936 context (The Reins of Liberation: The Entangled History of Mongolian Independence, Chinese Territoriality and Great Power Hegemony, 1911-1950 [Washington, DC: Woodrow Wilson Press, 2006], 94-99).

212. Mao nianpu, 1:576; Li Weihan, Huiyi yu yanjiu, 381; Shaan-Gan-Ning to Qingyang, July 12, 1936, in XBGJD, 223-24.

213. Mao to Peng et al., July 27, 1936, in Mao junshi, 1:56o. Snow had been sent to accompany Peng Dehuai on the western front but in September was brought back to Bao'an as Hu Zongnan's troops poured into Gansu. E. Snow, Red Star over China, 365.

214. Jing Shenghong, Hu Zongnan dazhuan, 104.

215. Yang Kuisong, "Sulian daguimo," 268-71. In addition to archival sources cited by Yang, see Song Qingling to Wang Ming, January 26, 1937, in Liangong, 15:286-87; Peng Dehuai, in XBGJD, 384-85; Mao to Zhu De et al., November 8, 1936, in Mao junshi, 1:652-53; Mao nianpu, 1:602-5. For a military history of the abortive Ningxia campaign, see Zhongguo renmin jiefangjun junshi kexueyuan, Zhongguo renmin jiefangjun zhanshi, 1:342-54.

216. Mao nianpu, 1:599. Yang Kuisong, Xian shibian xintan, 264, estimates 18,00o in the First Army, 12,000 in the Fourth Army, and 10,000 in the Second Army. This may be overly generous. The First Army had been involved in heavy fighting since the report of 21,000 
soldiers in all Shaanbei regular army units in August; and the Second Army had certainly suffered losses since its reported 13,300 men in southern Gansu in September. He Long to Mao, September 28, 1936, in CZWX, 1164. For a detailed Guomindang report on Red Army defeats in 1936, see Zhongtong, "Bannianlai Shaan-Gan-Ning ji Chuan-Kang bianjing chifei zhi cuanrao gaikuang," March 1937, BOI 270/815 (Stanford Library).

217. NCH, April 14, 1931.

218. Vermeer, Economic Development, 28-55, 70-88; NCH, February 13 and August 7, 1935; January 29 and May 20, 1936.

219. Mao nianpu, 1:607-8; messages on the negotiations in Wenxian he yanjiu, 1985, 179-99.

220. Jing Shenghong, Hu Zongnan dazhuan, 105-8; Peng Dehuai, in XBGJD, 385-86; Peng Zhulin, in XBGJD, 635-36; Yu Da, Hu Zongnan nianpu (Taipei: Taiwan Shangwu yinshuguan, 2014), 72-75. According to Yu Da, writing from Hu's perspective, Hu's plans had been revealed by the NEA commander Wang Yizhe. This may overstate the treachery, but Wang certainly failed to carry out Chiang's order to occupy Shanchengbao so that Hu could advance to Yanchi. Chiang to Zhang Xueliang, November 23, 1936, in Meng Guanghan et al., Kangzhan shiqi Guo-Gong, 250.

221. Yang Kuisong, Xian shibian xintan, 4-6, 11-14.

222. John W. Garver, Chinese-Soviet Relations, 1937-1945: The Diplomacy of Chinese Nationalism (New York: Oxford University Press, 1988), 15-52.

223. Mao to Chiang Kai-shek, December 1, 1936, Wenxian he yanjiu, 1983, 16-18.

224. Here I disagree with Jay Taylor's judgment (Generalissimo, 136-37) that Chiang would have agreed to a united front even without the Xian Incident. Chiang's military moves make clear that his preference was a military solution of the Communist problem.

225. Dagongbao, September-December, 1936, passim.

226. Coble, Facing Japan, 325-42.

227. James M. Bertram, First Act in China: The Story of the Sian Mutiny (New York: Viking Press, 1938), is an early first-person account; Tien-wei Wu, Sian Incident, adds many memoir and interview sources. Yang Kuisong's Xian shibian xintan is skeptical of memoirs and provides an authoritative account, based on original and archival sources. The incident itself is described on $298-320$.

228. E. Snow, Random Notes, 1 , citing a postcard apparently from George Hatem, a doctor who had accompanied Snow to Bao'an and who stayed with the Communists for the rest of his life.

229. Li Weihan, Huiyi yu yanjiu, 1:383.

230. CCP to Comintern, December 12, 1936, in Yang Kuisong, Xian shibian xintan, $322-23$.

231. Executive Committee of the Communist International to CCP, January 19 and 28 , 1937, in Liangong, 15:271-72, 278-80. The Trotskyite fears were closely related to the trial of Radek in Moscow at this time. In China, the involvement of Zhang Mutao, who had been expelled from the party and organized an independent "Communist party" in Shanxi, in Yang Hucheng's entourage was one problem. E. Snow, Random Notes, 9-11. On Zhang Mutao, see chapter 4. Another problem was Agnes Smedley, who propagandized for the coup from a radio station in Xian. Her independent spirit made her, in Moscow's eyes, a Trotskyite as well. Bertram, First Act, 154-78; Executive Committee of the Communist International to CCP, January 19, 1937, in Liangong, 15:271-72. 
232. Dallin and Firsov, Dimitrov and Stalin, 106-8; Yang Kuisong, Xian shibian xintan, 321-35; Chang Kuo-t’ao, Autobiography, 2:480.

233. Kang Yongsheng, $X u$ Haidong (Chengdu: Sichuan remin chubanshe, 2009), 160-64; Lu Zhenguo and Jiang Weiguo, Hong ershiwu jun, 302; Song Yijun, "Zhonggong zai Xian shibian qianhou de junshi zhanlüe fangyu," Junshi lishi yanjiu, 1992, no. 4: 15-25; Mao to Zhou, December 19, 1936, to Zhou and Bo Gu, December 25, 1936, in Mao junshi, 1:686, 688-89.

234. T. V. Soong, "Sian Diary," Hoover Institution Archives; Yang Kuisong, Xian shibian xintan, 339-93; Zhou Enlai to Mao, December 22, 25, and 29, 1936, in Meng Guanghan et al., Kangzhan shiqi Guo-Gong, 261-63.

235. Yang Kuisong, Xian shibian xintan, 367-455; Tien-wei Wu, Sian Incident, 113-85; Bertram, First Act, 159-236.

236. Jing Shenghong, Hu Zongnan dazhuan, 109-15.

237. Executive Committee of the Communist International to CCP, March 2, 1937, in Liangong, 15:283. Yang Kaisong, "Sulian daguimo," 273, mentions a further promise of $\$ 800,000$ for a total as high as $\$ 2$ million, but it is unclear of any of this was delivered.

238. Li Weihan on Guanzhong work, April 4, 1937, in XBGJD, 212-15.

239. Bertram, First Act, 241.

240. NCH, January $27,1937$.

\section{DAWN OF THE YAN'AN ERA}

1. Wales, Inside Red China, 76; Chen Xuezhao, Yanian fangwenji, 85-86, 104, 108, 232-33; Chu Yun, Shaan-xing jishi (Hankou: Dushu shenghuo chubanshe, 1938), 2.

2. Zhu Hongzhao, Yarian, 301-3, 310.

3. Hou Jiaguo, Zhonggong Shaan-Gan-Ning bianqu zhengfu-chengli jiqi yunzuo (Taibei: Liming wenhua shiye, 1979), 38; Gu Zhutong, "Xi'an shibian yiwang," in MGSL:ZG, 1:243; T. A. Bisson, Yenan in June 1937: Talks with the Communist Leaders (Berkeley: University of California Center for Chinese Studies, 1973), 30. There was also the Red Army detachment under Peng Dehuai in Sanyuan, north of Xi'an, but it engaged in limited political activity and did not attempt to extend the border region into the strategic Wei River valley.

4. Kang Yongsheng, $\mathrm{Xu}$ Haidong, 160-64.

5. Mao nianpu, 1:640-44; Mao Zedong to Zhou Enlai et al., January 7, 1937, and Mao to Peng Dehuai and Ren Bishi, January 8, 1937, in Mao junshi, 1:775-78.

6. The historical geographer Tang Xiaofeng called my attention to the Han precedent.

7. Mao nianpu, 1:645.

8. Song Yijun, "Xi’an shibian qianhou," 22-25.

9. Mao nianpu, 1:650-83.

10. Zhou Enlai, radiograms, December 22, 1936, in Meng Guanghan et al., Kangzhan shiqi Guo-Gong, 261-63; Center directive following Chiang's release, December 27, 1936, in Zhonggong zhongyang shujichu, Liuda yilai, 1:795.

11. Qin Xiaoyi, Zongtong Jiang-gong, 4:1049-52, 1069.

12. Qin Xiaoyi, Zongtong Jiang-gong, 1055-59, 1081; MGSL:ZG, 1:236-42, 263-67 (Gu Zhutong account).

13. Song Ziwen, “T. V. Soong Sian Diary," T. V. Soong Papers, Box 59, folio 21, Hoover Institution Archives. 
14. Joseph W. Esherick, "Prologue: China and the World in 1943" in 1943: China at the Crossroads, ed. Joseph W. Esherick and Matthew T. Combs (Ithaca, NY: Cornell University East Asia Program, 2015), 33-36.

15. Wales, Inside Red China, 265; Qin Xiaoyi, Zongtong Jiang-gong, 4:1052; Howard L. Boorman and Richard C. Howard, Biographical Dictionary of Republican China (New York: Columbia University Press, 1968), 2:82-84.

16. Gregor Benton, Mountain Fires: The Red Army's Three-Year War in South China, 1934-1938 (Berkeley: University of California Press, 1992), 432-33.

17. Qin Xiaoyi, Zongtong Jiang-gong, 4:1069-70.

18. "Genjue chihuo" decision, February 21, 1937, and Declaration of Guomindang plenum, February 22, 1937, in Meng Guanghan et al., Kangzhan shiqi Guo-Gong, 295-303. On the CCP reaction, see Mao nianpu, 1:654, and that of the Communist International, Executive Committee of the Communist International to CCP, March 5, 1937, in Liangong, 15:284.

19. Qin Xiaoyi, Zongtong Jiang-gong, 4:1071, 1079. Some historians have speculated that the promise to reunite Chiang father and son was critical in resolving the Xi'an Incident. Steve Tsang, "Chiang Kai-shek's 'Secret Deal' at Xian and the Start of the Sino-Japanese War," Palgrave Communications, January 2015, 1-12.

20. Chiang Kai-shek to $\mathrm{Gu}$ Zhutong (the new governor and military commander in Xi'an), January 31, February 8, and 16, 1937, Gu to Chiang, February 13, 1937, in MGSL:ZG, 1:261-64; NCH, January 27, 1937. Yang Kuisong, Xian shibian xintan, 429-30, shows that the funds for the Red Army were to be passed through Yang Hucheng's forces.

21. See chapter 5 above; Chiang Kai-shek to Gu Zhutong, February 16, 1937, in MGSL:ZG, 1:264; Mao nianpu, 1:661; Zhou Enlai to Chiang Kai-shek, July 16, 1937, in MGSL:ZG, 1:270-71.

22. Memo for Chiang Kai-shek meeting with Zhou Enlai, June 10, 1939, in MGSL:ZG, 4:219-20.

23. Qin Xiaoyi, Zongtong Jiang-gong, 4:1092; Chiang Kai-shek, speech, February 18, 1937, in Qin Xiaoyi, Zongtong Jiang-gong, 4:1063-65; Chiang Kai-shek, interview with Dagongbao, in Qin Xiaoyi, Zongtong Jiang-gong, 4:1062.

24. Chiang Kai-shek to Gu Zhutong, February 16, 1937, and day's diary entry, in MGSL:ZG, 1:264-65.

25. Chiang Kai-shek to Gu Zhutong, February 8, 1937, in MGSL:ZG, 1:262.

26. Chiang Kai-shek, interview with Central News Agency, February 21, 1937, in MGSL:ZG, 1:259-60.

27. Hou Jiaguo, Zhonggong Shaan-Gan-Ning, 31-37.

28. Chiang Kai-shek to Yang Hucheng, January 19, 1937, in Qin Xiaoyi, Zongtong Jianggong, 4:1058.

29. Chen Cheng seems to have been the first to suggest the term feudal for the Communist insistence on independence. Chen Cheng to Chiang Kai-shek, February 15, 1937, in MGSL:ZG, 1:263-64. For Chiang's use of the term, see Qin Xiaoyi, Zongtong Jiang-gong, 4:1093. He would continue to use this term to attack the Communists in China's Destiny. See Chiang Kai-shek, China's Destiny and Chinese Economic Theory, trans. Philip Jaffe (New York: Roy, 1947), 130.

30. CCP Central Committee to Guomindang Third Plenum, February 10, 1937, in Zhonggong zhongyang shujichu, Liuda yilai, 1:798. See also the explanation of this policy on February 15, 1937, as a "great principled concession," in Liuda yilai, 1:80o. 
31. Dimitrov to Wang Ming, November 20, 1936, in Liangong, 15:262; Shen Qiang and Wang Xinhua, Kangzhan shiqi Sulian yuanhua shilun (Beijing: Shehui kexue wenxian chubanshe, 2013), 158.

32. Center on propaganda principles after Xi'an, February 15, 1937, in Zhonggong zhongyang shujichu, Liuda yilai, 1:80o.

33. Propaganda outline on resolution of Xian Incident, February 15, 1937, in Xibei wushengqu bianzuan lingdao xiaozu and Zhongyang dang'an guan, eds., Shaan-GanNing bianqu kang-Ri minzhu genjudi: Wenxianjuan (Beijing: Zhonggong dangshi ziliao chubanshe, 1990) [hereafter: SGNMZ:WX], 1:83-85.

34. CCP Center to International, June 17, 1937, in Meng Guanghan et al., Kangzhan Guo-Gong, 336-37; Zhou nianpu, 373-74. Interestingly, the Guomindang Bureau of Investigation reported that Mao and Zhu would go abroad. Zongtong report, "Ge bianqu chifei liucuan gaikuang," June 1937, BOI 270/815 (Stanford Library).

35. Zhou Enlai to Chiang Kai-shek, July 16, 1937, in MGSL:ZG, 1:270; Bisson, Yenan in June 1937, 57.

36. Bisson, Yenan in June 1937, 24.

37. Hou Jiaguo, Zhonggong Shaan-Gan-Ning, 35-36; Wales, Inside Red China, 92.

38. Gao Gang, speech at the High Cadre Conference, January 14, 1943. The neighboring counties were Ganquan, Yanchuan, and Yanchang.

39. Dagongbao (Shanghai), January 1, 1937.

40. He Shaonan, "Shaanbei shicha baogaoshu," April 10, 1937, Guoshiguan Archives, 002-080104-00oo1-004; Bisson, Yenan in June 1937, 46.

41. Hou Jiaguo, Zhonggong Shaan-Gan-Ning, 38; Gu Zhutong, "Xi'an shibian yiwang," in MGSL:ZG, 1:243; Bisson, Yenan in June 1937, 30. There was also the detachment under Peng Dehuai in Sanyuan (see note 3 above).

42. Mao Zedong and Zhu De to local military, July 7, 1936, in SGNMZ-WX, 1:269-70.

43. Xiao Jinguang, November 18, 1938, in SGNMZ-WX, 1:274-75.

44. Lin Boqu, May 31, 1937, in SGNMZ-WX, 1:196.

45. Xin Zhonghua bao, June 24, 1937, in SGNMZ-WX, 1:273-74; Shaan-Gan-Ning party committee, directive on bandit elimination, 1937, in Zhonggong Shaan-Gan-Ning bianqu dangwei wenjian huibian, 1937-1939, ed. Zhongyang dang'an guan, Shaanxi sheng dang'an guan (n.p., 1994) [hereafter cited as $S G N D W]$, 112-73; informant 20. Xu Youwei and Philip Billingsley discuss Zhang in "Heroes, Martyrs, and Villains," 265-68, though their retrospective sources seem overly colored by PRC-sponsored memory. The rise of this frontier elite family is remarkably similar to the situation on the Yunnan frontier (Chow Yung-teh, Social Mobility in China: Status Careers among the Gentry in a Chinese Community [New York: Atherton Press, 1966]).

46. CCP Center, directives of December 20, 1936, and spring 1937, in SGNMZ-WX, 1:159-66.

47. SGNMZ-WX, 1:10.

48. Organization report, October 27,1939 , in $S G N D W, 326,330$. See also chapter 4 above on growth in 1935 .

49. CCP Soviet Congress, organization report, May 17, 1937, and Li Fuqun on party work, November 1939, in SGNMZ-WX, 491-92, 498-99.

50. Center, decision on youth work, November 1, 1936, in SGNMZ-WX, 1:141-43. 
51. Center, decision of Shaan-Gan-Ning party committee on Red Guards, August 25, 1937, in SGNMZ-WX, 1:175-77; Guomindang, Zhongtong report, April 10, 1939, BOI 256.2/815.

52. Wales, Inside Red China, 97-107; Chen Xuezhao, Yanian fangwenji, 45-47, 267-72; quote from 268.

53. Petition from twenty-three Shaanbei counties, February 28, 1939, in MGSL:ZG, 2:76.

54. He Shaonan, "Shaanbei shicha baogaoshu," April 10, 1937, Guoshiguan Archives, 002-080104-00001-004.

55. Lin Boqu, report to assembly, January 1939, in Shaan-Gan-Ning bianqu zhengfu wenjian xuanbian, ed. Shaanxi sheng dang'an guan, Shaanxi shehui kexueyuan (Beijing: Dang'an chubanshe, 1986) [hereafter: SGNWJ], 1:141; Bisson, Yenan in June 1937, 32, 44. Shaan-Gan-Ning, proclamation, October 1937, in SGNWJ, 1:18-27. At this time, the US dollar was equal to about 3.30 Chinese dollars (Wales, xvi-xvii), so the monthly GMD subsidy would have been worth about US\$90,000-150,000.

56. Mao to Gao Shuangcheng, July 2, 1937, in SGNMZ-WX, 1:270-71.

57. Executive Committee of the Communist International decision, January 20, 1937, in Liangong, 15:274.

58. Li Fuchun on party work, November 1937, in SGNMZ-WX, 2:492-93; border region assembly announcement, February 3, 1939, in Shaan-Gan-Ning geming genjudi shiliao xuanji, ed. Gansu sheng shehui kexueyuan lishi yanjiushi (Lanzhou: Gansu renmin chubanshe, 1981), 1:21-22.

59. CCP to GMD, July 7, 1939, in Meng Guanghan et al., Kangzhan Guo-Gong, 831; Mao nianpu, 1:675; Bisson, Yenan in June 1937, 45; Wales, Inside Red China, 208-17. Significantly, Nym Wales's leftist sympathies made her suspicious of the replacement of soviets with new democratic forms.

6o. Shaan-Gan-Ning assembly and administrative program, May 12, 1937, and election regulations, May 31, 1937, in SGNMZ-WX, 1:189-90, 199-200.

61. CCP organization report to border region assembly, May 17, 1937, in SGNMZ-WX, 2:486.

62. Shaan-Gan-Nang party committee on elections, July 1937, in SGNDW, 1937-39, 18-24; Fang Chengxiang and Huang Zhao'an, Shan-Gan-Ning bianqu, 63.

63. Lin Boqu, speech at High Cadre Conference, October 1942.

64. Shaan-Gan-Ning party committee, directive on elections, July 1937, in SGNDW, 1937-39, 18-24; Wales, Inside Red China, 215.

65. Shaan-Gan-Ning party committee on elections, December 1937, in SGNDW, 1937-39, 103.

66. Petition from twenty-three Shaanbei counties, February 28, 1939, in MGSL:ZG, 2:88.

67. Zhou Enlai to Chiang Kai-shek, July 16, 1937, responding to Chiang's proposal, in MGSL:ZG, 1:270-71.

68. Shaan-Gan-Ning CCP committee on relations with the Guomindang, May 1938, in SGNMZ:WX, 1:290-94.

69. Shaan-Gan-Ning party committee on election results, May 16, 1937, in SGNDW, 1937-39, 3; speeches at the High Cadre Conference by Huang Luobin, November 1942, Zhang Zixiu, November 5, 1942, Gao Gang, November 17-18, 1942; small group decision on Guo Hongtao for the 1945 Symposium on Northwest Revolutionary History, November 13, 1944; Dai Maolin and Zhao Xiaoguang, Gao Gang zhuan, 80-81. 
70. Yang Tianshi, "Chiang Kai-shek and the Battles of Shanghai and Nanjing," in The Battle for China: Essays on the Sino-Japanese War of 1937-1945, ed. Mark Peattie, Edward J. Drea, and Hans van de Ven (Stanford, CA: Stanford University Press, 2011), 143-45; CCP Center open letter, July 8, 1937, in Zhonggong zhongyang shujichu, Liuda yilai, 1:843.

71. Yang Kuisong, "Kangzhan chuqi Zhonggong junshi fazhan fangzhen biandong de shishi kaoxi," Jindaishi yanjiu, 2015, no. 6: 10.

72. Zhou nianpu, 380; Mao to Ye Jianying, August 30, 1937, in SGNMZ-WX, 1:284.

73. Peter Harmsen, Shanghai 1937: Stalingrad on the Yangtse (Philadelphia: Casemate, 2013).

74. Shen Qiang and Wang Xinhua, Kangzhan shiqi Sulian, 51-87; Qin Xiaoyi, Zongtong Jiang-gong, 1152. For an earlier account, see Garver, Chinese-Soviet Relations, 15-52.

75. See chapter 5.

76. Declaration on GMD-CCP united front, July 15, 1937, in Zhonggong zhongyang shujichu, Liuda yilai, 1:844-45.

77. James P. Harrison, The Long March to Power: A History of the Chinese Communist Party, 1921-72 (New York: Praeger, 1972), 278-79; van Slyke, Enemies and Friends, 90-99.

78. Meng Guanghan et al., Kangzhan Guo-Gong, 398-411.

79. Hou Jiaguo, Zhonggong Shaan-Gan-Ning, 31-32.

8o. Different sources give slightly different lists of the counties involved. Wang Jianmin lists Yan'an, Bao'an, Ansai, Yanchang, Yanchuan, and Ganquan as the core and Dingbian, Jingbian, Anding, Jia-xian, Qingjian, Ganquan again, Fu-xian, Xunyi, and Yanchi as the recruitment area (Wang Jianmin, Zhongguo gongchandang shigao [Hong Kong: Zhongwen tushu gongyingshe, 1974-75], 3:256-57). He Shaonan includes parts of Jingbian, Dingbian, and Anding in the core (He Shaonan, "Shaanbei shicha baogaoshu"). Mao Zedong claimed that Nanjing had promised twenty counties, adding Chunhua, Mizhi, and Suide to Wang's list, plus five Gansu counties: Qingyang, Heshui, Zhengning, Ning, and Huan (Mao and Xiao Jinguang, orders, October 17, 1937, and November 3 and 25, 1937, SGNMZ-WX, 1:287-89; Shaan-Gan-Ning party committee on recruitment, in SGNDW, 1937-39, 152).

81. National Consultative Assembly, inspection report, April 1940, in MGSL:ZG, 2:105; Yang Kuisong, "Kangzhan chuqi," 6.

82. Ma Wenrui, April 13, 1942, report on east Gansu work, in Longdong geming lishi dang'an ziliao xuanbian: Dang de jianshe, ed. Zhang Junyang (Beijing: Zhonggong dangshi chubanshe, 2017) [hereafter: LDZL:D], 118.

83. Jiang Dingwen (Shaanxi governor) to Chiang Kai-shek, November 8, 1937, in MGSL:ZG, 2:68-69.

84. National Consultative Assembly, report, April 1940, in MGSL:ZG, 2:105, 109-11; Wales, Inside Red China, 62-63.

85. Yang Shangkun, May 1937, in SGNMZ-WX, 1:187.

86. Yang Kuisong, "Kangzhan chuqi," 10-20. The Pingxingguan victory came just three days after the publication of the united front agreements.

87. Lloyd E. Eastman, "Nationalist China during the Sino-Japanese War, 1937-1945", in The Cambridge History of China, vol. 13: Republican China, 1912-1949, Part 2, ed. John K. Fairbank and Albert Feuerwerker (Cambridge: Cambridge University Press, 1986), 547-65.

88. "Fangzhi yidang huodong banfa," April 1939, and "Gongdang wenti chuzhi banfa," June 1939 (three slightly different versions), in Meng Guanghan et al., Kangzhan Guo-Gong, 644-70, quotations from pp. 644-45, 651. 
89. Petition from twenty-three Shaanbei counties to abolish the Shaan-Gan-Ning government and garrison area, February 28, 1939, in MGSL:ZG, 2:72-89.

90. Shaan-Gan-Ning government decision, June 9, 1938, in SGNWJ, 1:72-73.

91. Dai Li to Chiang Kai-shek, August 24, 1938, in MGSL:ZG, 2:70-71.

92. Chiang Kai-shek, rescript on February 7, 1939, telegram from Zhu Shaoliang, in MGSL:ZG, 2:354-55; Chiang Kai-shek to Jiang Dingwen and Zhu Shaoliang, March 5, 1940, in MGSL:ZG, 2:102.

93. Guo Dehong, Wang Ming nianpu, 346-439; Thomas Kampen, Mao Zedong, Zhou Enlai and the Evolution of Chinese Communist Leadership (Copenhagen: Nordic Institute of Asian Studies, 2000), 88-98. Page 88 has a telling picture of the December 1937 meeting on Wang's return, with Wang sitting proudly in the center and Mao off in the corner.

94. Zhu De et al., December 25, 1939, in Zhonggong zhongyang shujichu, Liuda yilai 1:1078-79, which lists the twenty-three counties claimed for the border region; and Mao Zedong, interview with Guomindang journalists, September 16, 1939, in Mao, Mao Zedong xuanji, 2: 580. The translation here follows Schram et al., Mao's Road to Power, 7:204, where it's noted that Mao based his stand on the Confucian principle of reciprocity, a passage omitted from the official Chinese version.

95. These conflicts are reported in a number of documents in the Shaanxi archives. See especially Zhao Jianguo, September 20, 1938, SA 2-1-274-11, and December 16, [1938], SA 2-1-274-17.

96. Tan Shengbin, May 11, [1939], SA 2-1-293-3. Needless to say, this document makes it difficult for the historian to trust the veracity of border region reports.

97. Survey material on friction in Shaan-Gan-Ning, April 1939, in SGNSW, 1937-39, 468-85. Though dated April 1939, internal evidence indicates this compilation could not be earlier than June 1939.

98. Shaan-Gan-Ning government, "Tudi xingzheng" [1940], in SGNCZJJ, 2:9. The Communist-occupied area had been renamed Xinzheng (新正) County, and figures are for this county.

99. The most detailed and convincing account of this incident is the report of the Guomindang investigation, May 25, 1939, in "Huatong," Shaan-Gan-Ning bianqu quanmao, 251-53, and a similar summary report of April 1940, in MGSL:ZG, 2:109-12. For the less detailed Communist accounts, see Xi Zhongxun, reports of April 15, 1940, and June 18, 1940, in SGNMZ-WX, 1:317-18, 323-24; Xinhua ribao, February 25, 1939, in Meng Guanghan et al., Kangzhan Guo-Gong, 717-19; and Fang Chengxiang and Huang Zhao'an, ShaanGan-Ning bianqu, 150. This area was under Xi Zhongxun's leadership, and he was criticized for the losses here. Gao Gang et al. to Xi Zhongxun, May 18, 1940, June 5, 1940, in SGNDW, 1940-41, 106-7, 121.

100. Lin Boqu and Gao Zili to Xi Zhongxun, May 9, 1940, and to Luo Chengde, June 1, 1940, in SGNMZ-WX, 1:315-17, 318-20.

101. Wang Jianmin, Zhongguo gongchandang shigao, 3: 258-60; Luo Chengde, May 20, 1940, in SGNMZ:WX, 1:321-22.

102. Ma Wenrui on party work in eastern Gansu, February 13, 1942, in LDZL:D, 118-19. For Mao's appeal to the Gelaohui, see Center's declaration, July 15, 1936, in SGNMZ-WX, 1:153-55, and translation in Schram et al., Mao's Road to Power, 5:245-47.

103. Shaan-Gan-Ning party to East Gansu, January 14, 1939, in LDZL:D, 70-71. 
104. Ma Wenrui on party work in eastern Gansu, February 13, 1942, in LDZL:D, 118; Shaan-Gan-Ning, Ning-xian report, May 21, 1939, in SGNWJ, 1:276; E. Snow, Random Notes, 110, citing his Gansu travel diary of August 5, 1936.

105. Huan-xian report, January 31, 1939, in SGNWJ, 1:174.

106. Huan-xian report, November 5, 1938, in Longdong geming lishi dang'an ziliao xuanbian: Zhengquan jianshe, ed. Zhang Junyang (Beijing: Zhonggong dangshi chubanshe, 2017) [hereafter: LDZL:Z], 28-32; Ning-xian report, February 28, 1939, and border region reply, March 16, 1939, in SGNWJ, 1:185-93.

107. Shaan-Gan-Ning to Guanzhong, June 8, 1939, in SGNWJ, 1:273-74.

108. Xie Juezai on east Gansu work, May 18, 1940, in LDZL:D, 83. Notably, 1940 is not included in the published version of Xie's diary.

109. Zhongtong, "Zhonggong zai Gansu zhi zuzhi yu huodong," July [1940], BOI 279.16.815 (Stanford Library).

110. Xiao Liju et al., Jiang Zhongzheng zongtong dang'an: Shilüe gaoben (Taibei: Guoshiguan, 2010) [hereafter: $S L G B$ ], 43:9.

111. Cheng Qian to Chiang Kai-shek, December 21, 1939, and He Yaozu and Dai Li, January 18, 1940, in MGSL:ZG, 2:359-60, 363; Geng Biao and He Jinnian, in Xibei wushengqu bianzuan lingdao xiaozi, and Zhongyang dang'an guan, eds., Shaan-Gan-Ning bianqu kang-Ri minzhu genjudi: Huiyilujuan (Beijing: Zhonggong dangshi ziliao chubanshe, 1990) [hereafter: SGNMZ:HY], 185-86; Fang Chengxiang and Huang Zhao'an, ShaanGan-Ning bianqu, 151; Yuan Wenwei, Fanpan yu fuchou, 144-45.

112. Qingyang report, March 10, 1940, and Wang Weizhou to Lin Boqu, March 30, 1940, in $L D Z L: Z, 77,79$.

113. Lin Boqu, "Shaan-Gan-Ning bianqu zhengfu gongzuo baogao," April 1941, in SGNCZJJ, 1:11-14; and Guomindang population figures in Gansu sheng difangzhi bianzuan weiyuanhui, and Gansu shengzhi renkouzhi, ed. Gansu shengzhi renkouzhi bianzuan weiyuanhui (Lanzhou: Gansu wenhua chubanshe, 2001), 198.

114. Mao et al. to Liu Jingfan, July 6, 1936, and Shaan-Gan-Ning Border Region to Ma Xiwu, January 30, 1940, in SGNMZ-WX, 1:268-69, 275-76. Zhao Laowu was his nickname. His real name is variously given as Zhao Sizhong and Zhao Shuzhong.

115. Zhu Shaoliang to Chiang Kai-shek, April 29, 1940, in SLGB, 43:433-34.

116. Xie Juezai, May 18, 1940, in LDSL:D, 80-81; cf. Shaan-Gan-Ning committee on East Gansu work, April 1, 1940, in SGNDW, 1940-41, 47-48.

117. Gao Gang to Mao, August 5, 1940, in SGNDW, 1940-41, 152-53; cf. Lin Boqu at al. to Luo Chengde, June 1, 1940, in SGNMZ-WX, 1:319; Shaan-Gan-Ning CP committee on East Gansu, April 1, 1940, in LDZL:D, 76-77.

118. Shaan-Gan-Ning CP committee to East Gansu CP, May 8, 1940, in LDSL:D, $78-79$.

119. Yanchi reports, November 24,1939 , to March 12,1940 , BOI $270.544 / 824 ; 1,280$ CCP defectors, open letter, December 1940, in MGSL:ZG, 2:379-80.

120. Geng Biao, in SGNMZ-HY, 188.

121. "Shaan-Gan-Ning bianqu fuyuan de shuoming," 1944, in SGNCZJJ, 1:10 and table on 11-14.

122. Calculated from figures in Northwest Bureau, "Bianqu caizheng jingji qingkuang jianshu," February 19, 1948, in SGNCZJJ, 1:15. 
123. Wang Zhen and Liu Jingbo, May 9, [1940], SA 2-1-164-1. On this area, see also Joseph W. Esherick, "Revolution in a Feudal Fortress: Yangjiagou, Mizhi County, Shaansi, 1937-1948," Modern China 24, no. 4 (1988): 339-77.

124. National Consultative Assembly, report, April 1940, in MGSL:ZG, 2:115.

125. He Shaonan, report on Shaanbei, April 10, 1937, Guoshiguan 002-080104-0oo1-114.

126. Border region to Shaanxi governor, July 5, 1938, and border region to Anding magistrate, May 22, 1939, in SGNWJ, 1:74-77, 261-62.

127. He Shaonan, May 23, 1938, in MGSL:ZG, 69. This report was forwarded to Chiang Kai-shek by Kang Ze, suggesting that He was reporting through the Guomindang security apparatus.

128. Survey material on friction in Shaan-Gan-Ning, April 1939, in SGNSW, 1937-39, 524-39; Fang Chengxiang and Huang Zhao'an, Shaan-Gan-Ning bianqu, 142.

129. Zhongtong, "Shaan-Gan-Ning bianqu Zhonggong junshi gaikuang diaocha," n.d. [1940], BOI 270/815.

130. Border region government to Executive Yuan, February 12, 1939, in SGNWJ, 1:166.

131. He Yingqin-Ye Jianying meeting memo, January 4, 1940, in MGSL:ZG, 4:222-23; Shaan-Gan-Ning party committee on united front, December 1939, 302.

132. Fang Chengxiang and Huang Zhao'an, Shaan-Gan-Ning bianqu, 158; He Shaonan, open telegram, January 13, 1940, in MGSL:ZG, 2:361-62; protest letter of Shaanbei mass organizations, in MGSL:ZG, 2:368-69.

133. Yan'an report, November 4, 1939, in SGNWJ, 1:428-29.

134. Liu Jingfan, work report, May 9, 1940, SA 2-1-164-2.

135. He Yingqin to Chiang Kai-shek, July 16, 1940, in MGSL:ZG, 4:227-28.

136. Wang Jianmin, Zhongguo gongchandang shigao, 3:257, 261-63.

137. Mao Zedong, "Guomindang xiang Shaan-Gan-Ning bianqu jingong de jinkuang," 1941, in SGNMZ-WX, 1:330-33. This document is not included in Schram et al.s collection of Mao's writings, Mao's Road to Power.

138. Herbert Feis, The China Tangle (Princeton, NJ: Princeton University Press, 1953), 136-44; Tang Tsou, America's Failure in China, 1941-50 (Chicago: University of Chicago Press, 1963), 150-51.

139. Benton, New Fourth Army, 511-616.

140. Fang Chengxiang and Huang Zhao'an, Shaan-Gan-Ning bianqu, 608-11; Wang Jianmin, Zhongguo gongchandang shigao, 3: 255. Fang and Huang's population figure for the area $(500,000)$ is not reliable. This uses Lin Boqu's April 1941 report to the border region assembly, in SGNCZJJ, 1:11-14.

141. Fang Chengxiang and Huang Zhao'an, Shaan-Gan-Ning bianqu, 65, for the national density.

142. For major English-language studies, see Selden, Yenan Way; Schran, Guerrilla Economy; Keating, Two Revolutions; and Apter and Saich, Revolutionary Discourse.

143. Zhu Hongzhao, Yanian, 5.

144. Wales, Inside Red China, 79.

145. E. Snow, Random Notes, 49.

146. "Huatong," Shaan-Gan-Ning bianqu quanmao, 227-30, 233.

147. Zhidan report on last 2.5 years, August 22, 1940, SA 2-1-157-1.

148. Wang Zhen et al., Suide work report, February 29, 1942, SA 2-1-221-3; Zhidan work report, August 22, 1940, SA 2-1-157-1; Gulin work report, January 30. 1943, SA 2-1-216.

149. Mao to Peng Dehuai, April 5, 1938, in SGNMZ-WX, 1:224-25. 
150. Chen Zhongliang, speech at High Cadre Conference, November 14, 1942; YuanWenwei, Fanpan yu fuchou, 77-84, 120-25, 157-74.

151. See, for example, August 25, 1937, document on reform of Red Guards, or Lin Boqu, May 31, 1937, on the transition to a democratic republic, in SGNMZ-WX, 1:175-77, 196.

152. Mao Zedong, declaration on the Gelaohui, July 15, 1936, in SGNMZ-WX, 1:153-55, translated in Schram et al., Mao's Road to Power, 5:245-47. In his Political Thought of Mao Tse-tung (169), Schram cites this text as evidence of Mao's "admiration for the outlaw."

153. CCP, directive on Gelaolui work, July 15, 1937, in SGNDW, 1937-39, 9-13.

154. Gulin government, report, June 27, 1939, SA 2-1-141-11.

155. Liu Jingrui (probably a cousin on Liu Zhidan), [October] 21, [1939] 1, SA 2-1-292-15. [This date, from the catalogue, is problematic as the report mentions events in November.] 156. Liu Jingrui, November 10, [1939], SA 2-1-292-16. For further examples, see Gulin report, March 18, 1938, SA 2-1-20-1.

157. Zhongtong, survey of Jing-Ding-Heng Counties, 1940, BOI 270/815.

158. Regulations of anti-traitor committees, March 5, 1939, in SGNWJ, 1:182-83. Cf. Gulin 1942 work report, January 30, 1943, SA 2-1-216.

159. He Shaonan, report on Shaanbei, April 10, 1937, Guoshiguan 002-080104-0ooo1004 .

160. Li Fuchun, November 1939, on party work in Shaan-Gan-Ning, in SGNDW, 1937-39, 550.

161. Chen Yun, Chen Yun wenxuan, 1926-1949 (Beijing: Renmin chubanshe, 1984), 44-89; on Stalin's slogan, see Stephen Kotkin, Stalin, vol. 2, Waiting for Hitler, 1929-1941 (New York: Penguin Press, 2017), 463-64.

162. Shaan-Gan-Ning Organization Department statistics on party members and cadres, October 27, 1939, in SGNDW, 1937-39, 326.

163. Shaan-Gan-Ning Organization Department statistics on party members and cadres, October 27, 1939, in SGNDW, 1937-39, 330. Zhonggong xibei zhongyangju xuanchuanbu, Gulin diaocha, 72, has similar figures on literacy.

164. Wang Qisheng, Geming yu fangeming: Shehui wenhua shiyexia de minguo zhengzhi (Beijing: Shehui kexue wenxian chubanshe 2010), 395-438.

165. Wang Zhen and Cao Liru, Suide 1941 work report [1942], SA-2-1-191-1.

166. Fang Chengxiang and Huang Zhao'an, Shaan-Gan-Ning bianqu, 611.

167. Wang Zhen and Liu Jingbo, work report, May 9, [1940], SA 2-1-164-1.

168. Zhidan County, 2.5-year work report, August 22, 1940, SA 2-1-157-1; Wang Zhen and Cao Liru, Suide 1941 work report, n.d. [1942], SA 2-1-191-1.

169. These categories appear repeatedly in the work reports of the Shaan-Gan-Ning Border Region archives.

170. Shenfu work report, January-February, n.d. [1941], SA 2-1-19o-2.

171. Zhonggong xibei zhongyangju xuanchuanbu, Gulin diaocha, 187.

172. Gulin report, March 4, 1940, SA 2-1-29-1; Zhonggong xibei zhongyangju xuanchuanbu, Gulin diaocha, 93.

173. Fang Chengxiang and Huang Zhao'an, Shaan-Gan-Ning bianqu, 102-4, which gives 847 for the number of schools in 1942; Li Weihan, Huiyi yu yanjiu, 2:567-68.

174. Gao Gang, speech, at Shaan-Gan-Ning party plenum, November 15, 1939, in SGNDW, 1937-39, 377. Cf. Zhonggong xibei zhongyangju xuanchuanbu, Gulin diaocha, $86-90,166$, for a rate of about 30 percent.

175. Zhidan 2.5 year work report, August 22, 1940, SA 2-1-157-1. 
176. Zhao Yuwen, 1941 Zhidan work report, May 11, 1942, SA 2-1-188-1.

177. Zhonggong xibei zhongyangju xuanchuanbu, Gulin diaocha, 87, 92.

178. Zhao Yuwen, 1941 Zhidan work report, May 11, 1942, SA 2-1-188-1.

179. Wang Zhen and Cao Liru, 1941 Suide work report, n.d. [1942], SA 2-1-191-1.

180. Zhidan report, March 3, 1940, SA 2-1-28-1.

181. Wang Zhen and Cao Liru, 1941 Suide work report, n.d. [1942], SA 2-1-191-1.

182. Shaan-Gan-Ning Organization Department, report, October 27, 1939, in SGNDW, 1937-39, 321.

183. Wang Zhen and Cao Liru, Mizhi-Jia report, May 18, 1941, SA 2-1-191-2; Zhonggong xibei zhongyangju xuanchuanbu, Gulin diaocha, 36-38.

184. Shaan-Gan-Ning Organization Department, report, October 27, 1939, in SGNDW, 1937-39, 331.

185. Organization Department, directive on marriage, March 24, 1940, in SGNDW, $1940-41,39$.

186. Wang Zhen and Cao Liru, 1941Suide work report, n.d. [1942], SA 2-1-191-1.

187. Zhonggong xibei zhongyangju xuanchuanbu, Gulin diaocha, 35-40; Schran, Guerrilla Economy, 132-33. Gao Gang was a major advocate of a more coercive approach to salt transport, and Mao relied on him as a leader with local knowledge. Dai Maolin and Zhao Xiaoguang, Gao Gang, 111-18.

188. Wang Zhen and Cao Liru, Suide April work report, 1942, SA 2-1-221-5.

189. Center military committee and Shaan-Gan-Ning committee, decision on expanding the Eighth Route Army and Defense Forces, November 20, 1938, in SGNMZ:WX, 1:234-36.

190. Lin Boqu, report to Shaan-Gan-Ning Assembly, January 1939, in SGNWJ, 1:123.

191. Shaan-Gan-Ning government to Ganquan, April 24, 1939, and Shaan-Gan-Ning government to Guanzhong, November 5, 1939, in SGNWJ, 1:246, 420.

192. Zhidan 2.5 year report, August 22, 1940, SA 2-1-157-1; Wang Zhen and Cao Liru, Suide June 1942 work report, July 24, 1942, SA 2-1-221-6.

193. Zhidan 1941 work report, May 11, 1942, SA 2-1-188-1; Shenfu January-February work report, n.d. [1941], SA 2-1-190-2.

194. Wang Zhen et al., work report, May 9, [1940], SA 2-1-164-1.

195. Wang Zhen et al., Suide region 1941 work report, [1942], SA 2-1-191-1.

196. Mark Selden, Yenan Way, 212-16. On Li Dingming, see Qiao Xiongbo, "Aiguo, aimin, aidang-Li Dingming xiansheng zhuyao lishi gongji," Mizhi wenshi ziliao, no. 1 (1998): 27 .

197. See chapter 2, note 54 .

198. Shaanbei protest against border region, February 28, 1939, in MGSL:ZG, 2:86.

199. Zhu Hongzhao, Yarian, 216-58.

200. Kay Ann Johnson, Women, the Family and Peasant Revolution in China (Chicago: University of Chicago Press, 1983), 63-83.

201. Ding Ling, "San-bajie yougan," Jiefang ribao, March 9, 1942.

202. Sun Shuyun, Long March, 128-32, 219-43.

203. Johnson, Women, Family, 65-68; Cong Xiaoping, Marriage, Law, and Gender in Revolutionary China, 1940-1960 (Cambridge: Cambridge University Press, 2016), 90-95, 134. Periodic work reports in SA routinely reported disappointing results in cultivating fields for army dependents. 
204. Huang Daoxuan, "Erba-wu-tuan xia de xinling shi." Jindaishi yanjiu, 2019, no. 1: 4-22. 205. Zhu Hongzhao, Yarian, 236-40.

206. Tim Harper, Underground Asia: Global Revolutionaries and the Assault on Empire (Cambridge: Belknap Press, 2021).

207. Wang Shiwei, Ye baihehua (Hong Kong: Zilian chubanshe, 1968), 5.

208. Wang Zhen et al., Mizhi, Jia-xian work report, May 1941, SA 2-1-191-2.

209. Informant 22.

210. Wales, Inside Red China, 329-37.

211. Wales, Inside Red China, 96.

212. Jia Juchuan, Xi Zhongxun zhuan.

213. Ma Wenrui, Ma Wenrui huiyilu (Xi'an: Shaanxi renmin chubanshe, 1998), 1-126.

214. Liu Mila and Liu Dudu, Liu Jingfan jinian wenji, 2:1200-1208.

215. Dai Maolin and Zhao Xiaoguang, Gao Gang, 92-95.

216. Cited in Dai Maolin and Zhao Xiaoguang, Gao Gang, 84.

217. See Joseph W. Esherick, "Tracking an Iconic Photograph," PRC History Review 2, no. 2 (April 2017): 1-6.

\section{CONCLUSION}

1. Huang Daoxuan, Zhangli yu xianjie: Zhongyang suqu de geming (1933-34) (Beijing: Shehui kexue chubanshe, 2011).

2. Kenneth Pomeranz, The Making of a Hinterland: State, Society, and Economy in Inland North China, 1853-1937 (Berkeley: University of California Press, 1993).

3. This is Max Weber's classic definition (derived from Trotsky) of a state: M. Weber, "Politics as a Vocation," 78.

4. Averill, Revolution in the Highlands; Perry, Anyuan; Galbiati, P'eng P'ai; Huang Daoxuan, Zhangli yu xianzhi; Hartford and Goldstein, Single Sparks; David S. G. Goodman, Social and Political Change in Revolutionary China: The Taihang Base Area in the War of Resistance to Japan, 1937-1945 (Lanham, MD: Rowman and Littlefield, 2000).

5. Liu's place in history remains problematic. On the one hand, museums in Shaanbei feature statues of Liu and laud his role. On the other hand, in Yuan Wenwei's richly documented book on banditry in Northwest China, Fanpan yu fuchou, Liu Zhidan is mentioned only once (when he executed a bandit), and an entire chapter on the party's shifting policy toward the revolutionary recruitment of bandits includes not a single footnote.

6. Rowe, Crimson Rain.

7. Ezra F. Vogel, Canton under Communism: Programs and Politics in a Provincial Capital, 1949-1968 (Cambridge, MA: Harvard University Press, 1969); Jeremy A. Murray, China's Lonely Revolution: The Local Communist Movement of Hainan Island, 1926-1956 (Albany: State University of New York Press, 2017).

8. Mao Zedong, "Report on the Peasant Movement in Hunan" (1927), translation in Schram et al., Mao's Road to Power, 2:434.

9. See chapter 4, p. 110.

10. Eliassen, Dragon Wang's River, 191.

11. E. Snow, Red Star Over China, Part V.

12. Friedman, Pickowicz, and Selden, Chinese Village, Socialist State. 
13. Mao Zedong, "Zhengdun dang de zuofeng," in Mao Zedong xuanji, 3:829-30, and English translation in Schram et al., Mao's Road to Power, 8:33. On the Rectification Campaign, see Preface above, notes 11-16.

14. In addition to the evidence above, see Yung-fa Chen, Making Revolution, 63, 499-500.

15. Zhu Hongzhao, Yanian, 49.

16. Mao Zedong at Ejie Politburo meeting, September 12, 1935, cited in Ding, "Zhongyang hongjun beishang fangzhen," 271-72.

17. The limits of this aid are worth stressing. In his biography of Chiang Kai-shek, Jay Taylor wrote that Soviet aid offered in 1940 amounted to " 42 percent of the CCP's total military and civilian expenditures" (Generalissimo, 171). Although others have cited Taylor's estimate, he generously admitted in a personal communication that this estimate was the result of misreading a source cited in Dallin and Firsov, Dimitrov and Stalin, 121-25. The Soviets supported 3.8 percent, not 42 percent, of the Communist budget.

18. Eugen Weber, Peasants into Frenchmen: The Modernization of Rural France, 18701914 (Stanford, CA: Stanford University Press, 1976).

19. Lin Boqu, report to the first border region assembly [January 1939], in Zhongguo kexueyuan lishi yanjiusuo, Shaan-Gan-Ning bianqu canyihui wenxian huiji (Beijing: Kexue chubanshe, 1958), 25.

20. Shaan-Gan-Ning Education Department, "Announcement on Primary School Work during the War of Resistance," March 6, 1938, in Shaanxi shifandaxue jiaoyu yanjiusuo, Shaan-Gan-Ning bianqu jiaoyu ziliao (xiaoxue jiaoyu bufen) (Xi'an: Jiaoyu kexue chubanshe, 1981), 1.

21. Mao Zedong, "Zhongguo geming he Zhongguo gongchandang," in Mao Zedong xuanji, 2:646. Translation adapted from Schram et al. in Mao's Road to Power 7:306 [emphasis added].

22. Mao Zedong, "In Memory of Norman Bethune," in Schram et al., Mao's Road to Power, 7:312-13; Chinese original in Mao Zedong xuanji, 2:653-54.

23. Mao Zedong, "Wei renmin fuwu," in Mao Zedong xuanji, 3:1003-4, translated in Schram et al., Mao's Road to Power, 8:616-18.

24. A. Doak Barnett, Communist China: The Early Years, 1949-55 (New York: Praeger, 1964), 5 .

25. This was the title of a song written in 1943 by Cao Huoxing (曹火星), young member of a Communist propaganda team. The new of "New China" was added later, allegedly by Mao. The original slogan, however, was first proclaimed by Chiang Kai-shek, who in China's Destiny claimed that "without the Nationalist Party, there would be no China." See "Cao Huoxing: Pu jiu jingdian xinhuo zhuan," Beijing qingnian bao, September 30, 2014; Daniel D. Knorr, "Debating China's Destiny: Writing the Nation's Past and Future in Wartime China," in Esherick and Combs, eds., 1943, 192-94.

26. Isaiah Berlin, The Hedgehog and the Fox: An Essay on Tolstoy's View of History (New York: New American Library, 1957).

27. For a powerful argument to remember the Chinese Revolution, see Elizabeth J. Perry, "Reclaiming the Chinese Revolution," Journal of Asian Studies 67, no. 4 (2008): 1147-64.

28. Esherick, "Reconsidering 1911." 
29. The most famous and frequently cited of these is certainly Bo Yibo, Ruogan zhongda juece yu shijian de huigu, 2 vols. (Beijing: Zhonggong dangshi chubanshe, 2008). This currently accessible volume has already suffered excisions (See Ishikawa Yoshihiro, "Xiaoshuo 'Liu Zhidan,"' 2on).

30. Stephen Kotkin, Stalin, vol. 1, Paradoxes of Power, 1878-1928 (2014); Kotkin, Stalin, vol. 2, Waiting for Hitler, 1929-1941.

31. Tanner Greer, "The Theory of History That Guides Xi Jinping," Palladium, July 8, 2020. 



\section{B I B L I O G R A P H Y}

Anding xianzhi 安定縣志 [Anding County gazetteer]. 1846. Reprint, Taibei: Chengwen chubanshe, 1970.

Apter, David E., and Tony Saich. Revolutionary Discourse in Mao's Republic. Cambridge, MA: Harvard University Press, 1994.

Atwill, David G. The Chinese Sultanate: Islam, Ethnicity, and the Panthay Rebellion in Southwest China, 1856-1873. Stanford, CA: Stanford University Press, 2006.

Averill, Stephen C. "The Origins of the Futian Incident." In New Perspectives on the Chinese Communist Revolution, edited by Tony Saich and Hans van de Ven, 79-115. Armonk, NY: M. E. Sharpe, 1995.

Averill, Stephen C. Revolution in the Highlands: China's Jinggangshan Base Area. Lanham, MD: Rowman and Littlefield, 2006.

Bai Shouyi 白寿彝, ed. Huimin qiyi 回民起义 [The Hui Uprising]. Beijing: Shenzhou guoguangshe, 1952.

Baoan xianzhilüe 保安縣志略 [Bao’an County gazetteer draft]. 1898 ms. ed. Edited by Hou Changming 侯昌銘. http://xadfz.xa.gov.cn/difangzhinew/muluFrame.jsp?bookname=gx _baoan_xianzhiluo.

Barnett, A. Doak. Communist China: The Early Years, 1949-55. New York: Praeger, 1964.

Benton, Gregor. Mountain Fires: The Red Army's Three-Year War in South China, 1934-1938. Berkeley: University of California Press, 1992.

Benton, Gregor. New Fourth Army: Communist Resistance along the Yangtze and the Huai, 1938-1941. Berkeley: University of California Press, 1999.

Benton, Gregor, ed. Prophets Unarmed: Chinese Trotskyites in Revolution, War, Jail, and the Return from Limbo. Chicago: Haymarket Books, 2015.

Bertram, James M. First Act in China: The Story of the Sian Mutiny. New York: Viking Press, 1938.

Bianco, Lucien. Peasants without the Party: Grass-Roots Movements in Twentieth-Century China. Armonk, NY: M.E. Sharpe, 2001. 
Bianco, Lucien. Wretched Rebels: Rural Disturbances on the Eve of the Chinese Revolution. With Hua Chang-ming. Translated by Philip Lidell. Cambridge, MA: Harvard University Asia Center, 2009.

Billingsley, Phil. Bandits in Republican China. Stanford, CA: Stanford University Press, 1988.

Bisson, T. A. Yenan in June 1937: Talks with the Communist Leaders. Berkeley: University of California Center for Chinese Studies, 1973.

Bo Yibo 薄一波. Ruogan zhongda juece yu shijian de huigu 若干重大决策与事件的回顧 [A review of several important decisions and policies]. 2 vols. Beijing: Zhonggong dangshi chubanshe, 2008.

Boorman, Howard L., and Richard C. Howard. Biographical Dictionary of Republican China. New York: Columbia University Press, 1968.

Borst-Smith, Ernest Frank. Caught in the Chinese Revolution: A Record of Risks and Rescue. London: T. F. Unwin, 1912.

Brady, Anne-Marie. Making the Foreign Serve China: Managing Foreigners in the People's Republic. Lanham, MD: Rowman and Littlefield, 2003.

Cao Shuji 曹树基. Zhongguo renkou shi 中国人口史 [A history of China's population]. Vol. 5. Qing shiqi 清时期 [The Qing]. Shanghai: Fudan daxue chubanshe, 2001.

Chai Shufan 柴树藩, Yu Guangyuan 于光遠, and Peng Ping 彭平. Suide, Mizhi tudi wenti chubu yanjiu 绥德, 米脂土地问题初步研究 [A preliminary study of the Suide-Mizhi land problem]. 1942. Reprint, Beijing: Renmin chubanshe, 1979.

Chang, Chung-li. The Chinese Gentry: Studies on Their Role in Nineteenth-Century Chinese Society. Seattle: University of Washington Press, 1955.

Chang Kuo-t'ao [Zhang Guotao]. The Autobiography of Chang Kuo-t'ao. Vol. 2. The Rise of the Chinese Communist Party, 1928-38. Lawrence: University Press of Kansas, 1972.

Chang, Sidney H., and Ramon H. Myers, eds. The Storm Clouds Clear over China: The Memoir of Chen Lifu, 1900-1993. Stanford, CA: Hoover Institution Press, 1994.

Chen Xuezhao 陳學昭. Yanian fangwenji 延安訪問記 [Account of a visit to Yan'an]. Hong Kong: Beiji shudian, 1940.

Chen Yun 陈云. Chen Yun wenxuan,1926-1949 陈云文选, 1926-1949 [Collected works of Chen Yun]. Beijing: Renmin chubanshe, 1984.

Chen, Yung-fa. “The Blooming Poppy under the Red Sun: The Yan'an Way and the Opium Trade." In New Perspectives on the Chinese Communist Revolution, edited by Tony Saich and Hans J. van de Ven, 263-98. Armonk, NY: M. E. Sharpe, 1995.

Chen, Yung-fa. Making Revolution: The Communist Movement in Eastern and Central China, 1937-1945. Berkeley: University of California Press, 1986.

Chen Yung-fa 陳永發. Yan'an de yinying 延安的陰影 [Yan'an's shadow]. Taibei: Zhongyang yanjiuyuan jindaishi yanjiusuo, 1990.

Cheng Zhongshi 陈忠实. Bailuyuan 白鹿原 [White Deer Plain]. Beijing: Renmin wenxue chubanshe, 1993.

Chiang Kai-shek. China's Destiny and Chinese Economic Theory. Translated by Philip Jaffe. New York: Roy, 1947.

Chow, Tse-tsung. The May Fourth Movement: Intellectual Revolution in Modern China. Cambridge, MA: Harvard University Press, 1960.

Chow Yung-te. Social Mobility in China: Status Careers among the Gentry in a Chinese Community. New York: Atherton Press, 1966. 
Ch'ü, T’ung-tsu. Local Government in China under the Ch 'ing. Cambridge, MA: Council on East Asian Studies, Harvard University, 1988.

Chu, Wen-djang 朱文長. The Moslem Rebellion in Northwest China, 1962-1878: A Study of Government Minority Policy. The Hague: Brill, 1966.

Chu Yun 楚雲. Shaan-xing jishi 陝行紀實 [A Shaanxi journey]. Hankou: Dushu shenghuo chubanshe, 1938.

Clark, Robert Sterling, Arthur de Carle Sowerby, and Claude Herries Chepmell. Through Shên-Kan: The Account of the Clark Expedition in North China, 1908-9. London: T.F. Unwin, 1912.

Coble, Parks M. Facing Japan: Chinese Politics and Japanese Imperialism, 1931-1937. Cambridge, MA: Council on East Asian Studies, Harvard University, 1991.

Compton, Boyd, ed. Mao's China: Party Reform Documents, 1942-44. Seattle: University of Washington Press, 1952.

Crossley, Pamela Kyle. A Translucent Mirror: History and Identity in Qing Imperial Ideology. Berkeley: University of California Press, 1999.

Dagongbao 大公報. Tianjin, 1902-.

Dai Maolin 戴茂林 and Zhao Xiaoguang 赵晓光. Gao Gang zhuan 高岗传 [A biography of Gao Gang]. Xi'an: Shaanxi renmin chubanshe, 2011.

Dai, Yingcong. The White Lotus War: Rebellion and Suppression in Late Imperial China. Seattle: University of Washington Press, 2019.

Dallin, Alexander, and F.I. Firsov, eds. Dimitrov and Stalin, 1934-1943: Letters from the Soviet Archives. New Haven, CT: Yale University Press, 2000.

Davies, James Chowning, ed. When Men Revolt and Why: A Reader in Political Violence and Revolution. New York: Free Press, 1971.

Deng Ye 邓野. "Yan Xishan dui Hongjun dongzheng de lanjie jiqi duofang zhengzhi zhouxuan”阎锡山对红军东征的拦截及其多方政治周旋 [Yan Xishan's interception of the Red Army's Eastern Expedition and his many political dealings]. Jindaishi yanjiu, 2010, no. 5: 49-68.

Ding Zhi 丁之. “Zhongyang hongjun beishang fangzhen de yanbian guocheng” 中央红 军北上方针的演变过程 [Changes in the direction of the Red Army's march north]. Wenxian he yanjiu, 1985, 266-74.

Dirlik, Arif. The Origins of Chinese Communism. New York: Oxford University Press, 1989.

Eastman, Lloyd E. "Nationalist China during the Sino-Japanese War, 1937-1945." In The Cambridge History of China, vol. 13, Republican China, 1912-1949, Part 2, edited by John K. Fairbank and Albert Feuerwerker, 547-65. Cambridge: Cambridge University Press, 1986.

Eliassen, Sigurd. Dragon Wang's River. Translated by Katherine John. London: Methuen, 1957. Originally published as Gamle Drage Wangs (Oslo: Gyldendal, 1955).

Elliott, Mark C. The Manchu Way: The Eight Banners and Ethnic Identity in Late Imperial China. Stanford, CA: Stanford University Press, 2001.

Esherick, Joseph W. Ancestral Leaves: A Family Journey through Chinese History. Berkeley: University of California Press, 2011.

Esherick, Joseph W. “The CCP in the 1930s: The View from Defectors' Declarations (脱离共党宣言).” PRC History Review 2, no. 2 (April 2017): 1-7.

Esherick, Joseph W. "The Chinese Communist Revolution from the Bottom Up: ShaanGan-Ning." Paper presented at the annual meeting of the American Historical Association, December 1989. 
Esherick, Joseph W. "Deconstructing the Construction of the Party-State: Gulin County in the Shaan-Gan-Ning Border Region." China Quarterly, no. 140 (December 1994): 1052-79.

Esherick, Joseph W. The Origins of the Boxer Uprising. Berkeley: University of California Press, 1987.

Esherick, Joseph W. “Reconsidering 1911: Lessons of a 'Sudden Revolution.”' Journal of Modern Chinese History 6, no. 1 (2012): 1-14.

Esherick, Joseph W. Reform and Revolution in China: The 1911 Revolution in Hunan and Hubei. Berkeley: University of California Press, 1976.

Esherick, Joseph W. "Revolution in a Feudal Fortress: Yangjiagou, Mizhi County, Shaanxi, 1937-1948." Modern China 24, no. 4 (October 1998): 339-77.

Esherick, Joseph W. “Tracking an Iconic Photograph.” PRC History Review 2, no. 2 (April 2017): 1-6.

Esherick, Joseph W., and Jeffrey Wasserstrom. "Acting Out Democracy: Political Theater in Modern China." Journal of Asian Studies 49, no. 4 (November 1990): 835-65.

Fang Chengxiang 房成祥 and Huang Zhao'an 黄兆安. Shan-Gan-Ning bianqu geming shi 陕甘宁边区革命史 [History of the Shaan-Gan-Ning revolution]. Xian: Shaanxi Normal University Press, 1991.

Fischer, David Hackett. Historians' Fallacies: Toward a Logic of Historical Thought. New York: Harper and Row, 1970.

Fitzgerald, John. Awakening China: Politics, Culture, and Class in the Nationalist Revolution. Stanford, CA: Stanford University Press, 1996.

Fogel, Joshua A. Ai Ssu-ch'i's Contribution to the Development of Chinese Marxism. Cambridge, MA: Council on East Asian Studies, Harvard University, 1987.

Friedman, Edward, Paul Pickowicz, and Mark Selden. Chinese Village, Socialist State. New Haven, CT: Yale University Press, 1991.

Galbiati, Fernando. P'eng P'ai and the Hai-Lu-Feng Soviet. Stanford, CA: Stanford University Press, 1985.

Ganquan xian xiangtuzhi 甘泉縣鄉土志 [Ganquan local gazetteer]. Ca. 1905. Reprint, Taibei: Chengwen chubanshe, 1970.

Gansu sheng shehui kexueyuan lishi yanjiushi 甘肃省社会科学院历史研究室, ed. ShaanGan-Ning geming genjudi shiliao xuanji 陕甘宁革命根据地史料选辑 [Selection of historical materials on the Shaan-Gan-Ning revolutionary base]. Lanzhou: Gansu renmin chubanshe, 1981.

Gansu shengzhi renkouzhi 甘肃省志·人口志 [Gansu provincial gazetteer: Population]. Edited by Gansu shengzhi renkouzhi bianzuan weiyuanhui. Lanzhou: Gansu wenhua chubanshe, 2001.

Gao Hua 高華. Hong taiyang shi zenyang shengqi de: Yan'an zhengfeng yundong de lailong qumai 紅太陽是怎樣升起的: 延安整風運動的來龍去脈 [How the Red Sun rose: The origins and development of the Yan'an Rectification Movement]. Hong Kong: Zhongwen daxue chubanshe, 2000.

Gao Hua. How the Red Sun Rose: The Origin and Development of the Yanian Rectification Movement, 1930-1945. Translated by Stacey Mosher and Guo Jian. Hong Kong: Chinese University of Hong Kong Press, 2019.

Garver, John W. Chinese-Soviet Relations, 1937-1945: The Diplomacy of Chinese Nationalism. New York: Oxford University Press, 1988. 
Garver, John W. “The Soviet Union and the Xi'an Incident.” Australian Journal of Chinese Affairs 26 (July 1991): 145-75.

Goldstone, Jack. Revolution and Rebellion in the Early Modern World. Berkeley: University of California Press, 1991.

Gongjin 共進 [Common Progress]. 1921-26, Reprint, Beijing: Renmin chubanshe, 1983.

Goodman, David S. G. Social and Political Change in Revolutionary China: The Taihang Base Area in the War of Resistance to Japan, 1937-1945. Lanham, MD: Rowman and Littlefield, 2000.

Greer, Tanner. “The Theory of History That Guides Xi Jinping.” Palladium, July 8, 2020.

Guo Dehong 郭德宏. Wang Ming nianpu 王明年谱 [Chronological biography of Wang Ming]. Beijing: Shehui kexue wenxian chubanshe, 2014.

Guo Hongtao 郭洪涛. Guo Hongtao huiyilu郭洪涛回忆录 [Memoirs of Guo Hongtao]. Beijing: Zhonggong dangshi chubanshe, 2004.

Guomin zhengfu sifa xingzhengbu 国民政府司法行政部. Minshi xiguan diaocha baogaolu 民事习惯调查报告录 [Survey report on civil customs]. Beijing: Zhongguo zhengfa daxue chubanshe, 2000 .

Guy, R. Kent. Qing Governors and Their Provinces: The Evolution of Territorial Administration in China, 1644-1796. Seattle: University of Washington Press, 2010.

Harmsen, Peter. Shanghai 1937: Stalingrad on the Yangtse. Philadelphia: Casemate, 2013.

Harrison, James P. The Long March to Power: A History of the Chinese Communist Party, 1921-72. New York: Praeger, 1972.

Hartford, Kathleen, and Steven M. Goldstein, eds. Single Sparks: China's Rural Revolutions. Armonk, NY: M. E. Sharpe, 1989.

Heng Zhi 衡之. “Shaanbei feikui Liu Zidan.” 陝北匪鬼劉子丹. Zhongwai wenti 14, no. 3 (1936): 136-37.

Hershatter, Gail. The Gender of Memory: Rural Women and China's Collective Past. Berkeley: University of California Press, 2011.

Hofheinz, Roy. The Broken Wave: The Chinese Communist Peasant Movement, 1922-1928. Cambridge, MA: Harvard East Asian Series, 1977.

Holm, David. "The Strange Case of Liu Zhidan." Australian Journal of Chinese Affairs 27 (January 1992): 77-96.

Hosie, Alexander. On the Trail of the Opium Poppy: A Narrative of Travel in the Chief Opium-Producing Provinces of China. Boston: Small Maynard, 1914.

Hou Jiaguo 侯家國. Zhonggong Shaan-Gan-Ning bianqu zhengfu-chengli jiqi yunzuo 中共陝甘寧邊區政府一成立及其運作 [The establishment and operations of the Communists' Shaan-Gan-Ning Border Region]. Taibei: Liming wenhua shiye, 1979.

Huang Daoxuan 黄道炫. Zhangli yu xianjie: Zhongyang suqu de geming (1933-34) 张力与限界: 中央苏区的革命 (1933-34) [Power and limits: Revolution in the Central Soviet, 1933-34]. Beijing: Shehui kexue chubanshe, 2011.

Huang Zhenglin 黃正林. “1935-nian Shaan-Gan bian suqu he hong26jun sufan wenti kaolun” 1935年 陕甘边苏区红26军肃反问题考论 [An examination of the 1935 sufan movement against the 26th Army of the Shaan-Gan soviet]. Shixue yuekan, 2011, no, 6: 56-68.

Huang Zhenglin 黃正林. “Tongzhi Huimin shibianhou Huanghe shangyou quyu de renkou yu shehui jingji” 同治回民事变后黄河上游区域的人口与社会经济 [Demography and socio-economy in the upper Yellow River basin after the Tongzhi era Hui incident]. Shixue yuekan, 2008, no. 10: 78-88. 
“Huatong” 華統. Shaan-Gan-Ning bianqu quanmao 陝甘寧邊區全貌 [A full view of the Shaan-Gan-Ning Border Region] (September 1940). In Zhong-Gong bianqu genjudi de lishi wenjian xuanji 中共邊區根據地的歷史文件選輯, edited by Zhang Houde 張厚德. Taibei, 1985.

Huo Weitao 霍维洮. “Dong Fuxiang qijia yu Tongzhi nian xibei zhengzhi xingshi” 董福祥 起家与同治年西北政治形势 [The rise of Dong Fuxiang and the Northwest political situation in the Tongzhi reign]. Ningxia shehui kexue, 1994: no. 1: 52-58.

Ishikawa Yoshihiro. The Formation of the Chinese Communist Party. Translated by Joshua Fogel. New York: Columbia University Press, 2013.

Ishikawa Yoshihiro 石川祯浩. “Xiaoshuo 'Liu Zhidan' shijian de lishi beijing” 小说《刘志 丹》的历史背景 [The historical background of the novel Liu Zhidan]. Riben dangdai Zhongguo yanjiu, 2012. www.waseda.jp/prj-wiccs/wp/wp-content/uploads/2012/o7 /jscc2012.pdf.

Israel, John. Student Nationalism in China, 1927-1937. Stanford, CA: Stanford University Press, 1966.

Israel, John, and Donald W. Klein. Rebels and Bureaucrats: China's December gers. Berkeley: University of California Press, 1976.

Jacobs, Justin M. Xinjiang and the Modern Chinese State. Seattle: University of Washington Press, 2016.

Jacobson, Carl Whitney. “Brotherhood and Society: The Shaanxi Gelaohui, 1867-1912.” PhD diss., University of Michigan, 1993.

Jen, Yu-wen. The Taiping Revolutionary Movement. New Haven, CT: Yale University Press, 1973.

Jia Juchuan 贾巨川. Xi Zhongxun zhuan 习仲勋传 [Biography of Xi Zhongxun]. Beijing: Zhongyang wenxian chubanshe, 2008.

Jiang Tingfu 蔣廷䟦. Jiang Tingfu huiyilu 蔣廷䟦回憶錄 [Memoir of Jiang Tingfu]. Translated by Xie Zhonglian 謝種璉. Taipei: Zhuanji wenxue, [1979?].

Jing Shenghong 经盛鸿. Hu Zongnan dazhuan 胡宗南大传 [Biography of Hu Zongnan]. Beijing: Tuanjie chubanshe, 2009.

Jingbian xianzhigao 靖邊縣志稿 [Jingbian draft gazetteer]. 1899. Reprint, Taipei: Chengwen chubanshe, 1970.

Jocelyn, Ed, and Andrew McEwen. The Long March: The True Story behind the Legendary Journey That Made Mao's China. London: Constable, 2006.

Johnson, Chalmers. Peasant Nationalism and Communist Power: The Emergence of Revolutionary China. Stanford, CA: Stanford University Press, 1967.

Johnson, Kay Ann. Women, the Family and Peasant Revolution in China. Chicago: University of Chicago Press, 1983.

Juezhi quanlan 爵秩全覽 [Complete list of officials]. 1904. Reprint, Taipei: Wenhai, 1967.

Kampen, Thomas. Mao Zedong, Zhou Enlai and the Evolution of Chinese Communist Leadership. Copenhagen: Nordic Institute of Asian Studies, 2000.

Kang Yongsheng 康永升. Xu Haidong 徐海东 [Xu Haidong]. Chengdu: Sichuan renmin chubanshe, 2009.

Keating, Pauline B. Two Revolutions: Village Reconstruction and the Cooperative Movement in Northern Shaanxi, 1934-1945. Stanford, CA: Stanford University Press, 1997.

Keyte, J.C. The Passing of the Dragon: The Story of the Shensi Revolution and Relief Expedition. London: Hodder and Stoughton, 1913. 
Kim, Hodong. Holy War in China: The Muslim Rebellion and State in Chinese Central Asia, 1864-1877. Stanford, CA: Stanford University Press, 2004.

Kotkin, Stephen. Stalin. Vol. 2. Waiting for Hitler, 1929-1941. New York: Penguin Press, 2017. Kuang Yuxiang 匡裕祥. “Shaanxi Fushi-xian gaikuang” 陝西膚施縣概況 [Conditions in Fushi County, Shaanxi]. Kaifa xibei《開發西北》2, no. 4 (October 1934): 70-74.

Lamley, Harry. "Lineage Feuding in Southern Fujian and Eastern Guangdong under Qing Rule." In Violence in China: Essays in Culture and Counterculture, edited by Jonathan N. Lipman and Stevan Harrell, 27-58. Albany: SUNY Press, 1990.

Lang, Olga. Chinese Family and Society. New Haven, CT: Yale University Press, 1946.

Lattimore, Owen. Inner Asian Frontiers of China. 1940. Reprint, Boston: Beacon Press, 1962.

Lei Yunfeng 雷云峰 et al. Shaan-Gan-Ning bianqu shi [History of the Shaan-Gan-Ning Border Region]. Xi'an: Xian ditu chubanshe, 1994.

Li Chiran 李赤然. Li Chiran jiangjun huiyilu 李赤然将军回忆录 [Memoir of General Li Chiran]. Beijing: Dongfang chubanshe, 2000.

Li Haiwen 李海文. “Xi'an shibian qian Guo-Gong liangdang jiechu he tanpan de lishi guocheng” 西安事变前国共两党接触和谈判的历史过程 [The process of GuomindangCommunist contacts and negotiations before the Xian Incident]. Wenxian he yanjiu, 1984, 350-61.

Li, Huaiyin. Village Governance in North China. Stanford, CA: Stanford University Press, 2005.

Li Jianguo 李建国 and Shang Jifang 尚季芳, eds. Jinxiandai xibei shehui yanjiu: Fazhan yu biange 近现代西北社会研究: 发展与变革 [Studies in modern Northwest society: Development and change]. Lanzhou: Gansu wenhua chubanshe, 2015.

Li Taifen 李泰荣. Guominjun shigao 國民軍史稿 [Draft history of the National People's Army] [1930]. Reprinted in Xibei jun jishi 西北軍紀事 [Record of the Northwest Army]. Hong Kong, 1978.

Li Weihan 李维汉. Huiyi yu yanjiu 回忆与研究 [Memoir and study]. Beijing: Zhonggong dangshi ziliao chubanshe, 1986.

Li Yongchun 李永春 and Luo Li雒丽. “Shaanxi qu-Liu yundong chutan” 陕西驱刘运动初 探 [On the Shaanxi movement to expel Liu]. Hunan xingzheng xueyuan xuebao, 2015, no. 1: 114-20.

Li Zhenmin 李振民, ed. Shaanxi jinxiandai mingren lu 陕西近现代名人录 [Prominent people of modern Shaanxi]. Xi'an: Xibei daxue chubanshe, 1988.

Li Zhenmin 李振民and Zhang Shouxian张守宪. “Liu Zhidan 刘志丹” Zhonggong dangshi renwu zhuan [Biographies of persons in Chinese Communist Party history] 3 (1981): 191-228.

Li Zhenmin李振民, Zhang Shouxian张守宪, and Liang Xingliang 梁星亮. “Xie Zichang” 谢子长. Zhonggong dangshi renwu zhuan [Biographies of persons in Chinese Communist Party history] 3 (1981): 229-58.

Lipman, Jonathan N. Familiar Strangers: A History of Muslims in Northwest China. Seattle: University of Washington Press, 1997.

Lishi dang'an 历史档案 [Historical archives]. Beijing: 1981-present.

Liu, Kwang-ching, and Richard J. Smith. "The Military Challenge: The Northwest and the Coast." In The Cambridge History of China, vol. 11: Late Ching, 180o-1911, Part 2, edited by John K. Fairbank and Kwang-ching Liu, 202-73. Cambridge: Cambridge University Press, 1980. 
Liu Mila 刘米拉 and Liu Dudu 刘都都. Liu Jingfan jinian wenji 刘景范纪念文集 [Essays in memory of Liu Jingfan]. Beijing: Zhongyang wenxian chubanshe, 2015.

Liu Ts'ui-jung. Trade on the Han River and Its Impact on Economic Development, c. 1800-1911. Nankang, Taipei: Academia Sinica Institute of Economics, 1980.

Liu Zhidan 刘志丹. Liu Zhidan wenji刘志丹文集 [Collected works of Liu Zhidan]. Beijing: Renmin chubanshe, 2012.

Lu Weidong 路伟东. “Qingdai Shaanxi huizu de renkou biandong” 清代陕西回族的人口 变动 [Demographic change of the Hui in Qing dynasty Shaanxi]. Huizu yanjiu 回族研 究, 2003, no. 4: 71-77.

Lu Zhenguo 芦振国 and Jiang Weimin姜为民. Hong ershiwu jun changzheng jishi 红二十五军长征纪事 [Narrative of the Twenty-Fifth Army's Long March]. Zhengzhou: Henan renmin chubanshe, 1986.

Luo Zhitian 罗志田. Jibian shidai de wenhua yu zhengzhi-Cong xin wenhua yundong dao beifa 激变时代的文化与政治一从新文化运动到北伐 [Culture and politics of a radical age: From the New Culture movement to the Northern Expedition]. Beijing: Peking University Press, 2009.

Luo Zhitian 罗志田. Jindai dushuren de sixiang shijie yu zhixue quxiang 近代读书人的思 想世界与治学取向 [The intellectual world and scholarly choices of modern scholars]. Beijing: Beijing University Press, 2009.

Ma Wenrui 马文瑞. Ma Wenrui huiyilu 马文瑞回忆录 [Memoir of Ma Wenrui]. Xian: Shaanxi renmin chubanshe, 1998.

Ma Xiaoshi 马霄石. Xibei huizu geming jianshi 西北回族革命简史 [A brief history of the northwest Hui Rebellion]. Shanghai: Dongfang shushe, 1951.

Mao Zedong. Mao Zedong junshi wenji 毛泽东军事文集 [Military writings of Mao Zedong]. Edited by Zhonggong zhongyang wenxian yanjiushi 中共中央文献研究室 and Zhongguo renmin jiefangjun junshi kexueyuan. 中国人民解放军军事科学院 Beijing: Junshi kexueyuan and Zhongyang wenxian chubanshe, 1993.

Mao Zedong. Mao Zedong xuanji 毛泽东选集 [Selected works of Mao Zedong]. 4 vols. Beijing: Renmin chubanshe, 1964.

Mao Zedong. Poems of Mao Tse-tung. Edited by Hua-ling Nieh Engle and Paul Engle. New York: Dell, 1972.

Mao Zedong. Selected Readings from the Works of Mao Tsetung. Beijing: Foreign Languages Press, 1971.

McDonald, Angus W. The Urban Origins of Rural Revolution: Elites and the Masses in Hunan Province, China, 1911-1927. Berkeley: University of California Press, 1978.

Meisner, Maurice J. Li Ta-Chao and the Origins of Chinese Marxism. Cambridge, MA: Harvard University Press, 1967.

Meng Guanghan 孟广涵 et al. Kangzhan shiqi Guo-Gong hezuo jishi 抗战时期国共合作 纪实 [Wartime cooperation between the CCP and the GMD]. Chongqing: Chongqing chubanshe, 1992.

Mi Zanchen. The Life of General Yang Hucheng. Translated by Wang Zhao. Hong Kong: Joint Publishing, 1981.

Michael, Franz H. The Taiping Rebellion: History and Documents. Seattle: University of Washington Press, 1966.

Mizhi xianzhi 米脂縣志 [Mizhi County gazetteer]. N.p., 1907. 
Moore, Barrington. Social Origins of Dictatorship and Democracy: Lord and Peasant in the Making of the Modern World. Boston: Beacon Press, 1967.

Mote, Frederick W., and Denis Twitchett. The Cambridge History of China. Vol. 7, The Ming Dynasty, 1368-1644, Part I. Cambridge: Cambridge University Press, 1988.

Murray, Jeremy A. China's Lonely Revolution: The Local Communist Movement of Hainan Island, 1926-1956. Albany: State University of New York Press, 2017.

Nichols, Francis H. Through Hidden Shensi. New York: C. Scribner's Sons, 1902.

North China Herald and Supreme Court and Consular Gazette. Shanghai, 1870-.

Paige, Jeffery M. Agrarian Revolution. New York: Free Press, 1975.

Pang Xianzhi 逢先知 and Jin Chongji 金冲及. Mao Zedong zhuan 毛泽东传 [Biography of Mao Zedong]. 6 vols. Beijing: Zhongyang wenxian chubanshe, 2011.

Pantsov, Alexander V. Mao: The Real Story. With Steven I. Levine. New York: Simon and Schuster, 2012.

Parsons, James Bunyan. The Peasant Rebellions of the Late Ming Dynasty. Tucson: University of Arizona Press, 1970.

Peattie, Mark, Edward J. Drea, and Hans van de Ven. The Battle for China: Essays on the Sino-Japanese War of 1937-1945. Stanford, CA: Stanford University Press, 2011.

Perdue, Peter C. China Marches West: The Qing Conquest of Central Eurasia. Cambridge, MA: Harvard University Press, 2005.

Perry, Elizabeth J. Anyuan: Mining China's Revolutionary Tradition. Berkeley: University of California Press, 2012.

Perry, Elizabeth J. Rebels and Revolutionaries in North China, 1845-1945. Stanford, CA: Stanford University Press, 1980.

Perry, Elizabeth J. "Reclaiming the Chinese Revolution.” Journal of Asian Studies 67, no. 4 (2008): 1147-64.

Pomeranz, Kenneth. The Making of a Hinterland: State, Society, and Economy in Inland North China, 1853-1937. Berkeley: University of California Press, 1993.

Pomfret, John. The Beautiful Country and the Middle Kingdom: America and China, 1776 to the Present. New York: Henry Holt, 2016.

Popkin, Samuel L. The Rational Peasant: The Political Economy of Rural Society in Vietnam. Berkeley: University of California Press, 1979.

Qiao Xiongbo乔雄波. “Aiguo, aimin, aidang_Li Dingming xiansheng zhuyao lishi gongji." 爱国、爱民、爱党一一李鼎铭先生主要历史功绩 [Love of country, people and party: The historical contributions of Li Dingming]. Mizhi wenshi ziliao, no. 1 (1998): 27 .

Qin Xiaoyi 秦孝儀 et al., eds. Zhonghua minguo zhongyao shiliao chubian-Dui-Ri kangzhan shiqi, diwubian: Zhonggong huodong zhenxiang 中華民國重要史料初編一對日 抗戰時期: 第五編: 中共活動真相 [Important historical materials of the Republic of China-Wartime period, section 5: The true face of Communist activities]. Taipei: Zhongguo Guomindang, 1985.

Qin Xiaoyi 秦孝儀 et al., eds. Zongtong Jiang-gong dashi changpian chugao 總統蔣公大事 長編初稿 [Draft of key events of President Chiang Kai-shek]. Taibei: n.p., 1977.

Qinzhong 秦钟 [Shaanxi Clarion]. Beijing, 1920. Reprint, Beijing: Renmin chubanshe, 1983. Reynolds, Douglas R. China: 1898-1912-The Xinzheng Revolution and Japan. Cambridge, MA: Council on East Asian Studies, Harvard University, 1993. 
Ristaino, Marcia R. China's Art of Revolution: The Mobilization of Discontent, 1927 and 1928. Durham, NC: Duke University Press, 1987.

Ross, Edward Alsworth. The Changing Chinese. New York: Century, 1911.

Rowe, William T. Crimson Rain: Seven Centuries of Violence in a Chinese County. Stanford, CA: Stanford University Press, 2007.

Saich, Tony, and Hans J. van de Ven, eds. New Perspectives on the Chinese Communist Revolution. Armonk, NY: M.E. Sharpe, 1995.

Saich, Tony, and Benjamin Yang, eds. The Rise to Power of the Chinese Communist Party: Documents and Analysis. Armonk, NY: M.E. Sharpe, 1996.

Salisbury, Harrison E. The Long March: The Untold Story. New York: Harper and Row, 1985. Sanyuan xianzhi 三原县志 [Sanyuan gazetteer]. Xian: Shaanxi renmin chubanshe, 2000.

Schneewind, Sarah. Shrines to Living Men in the Ming Political Cosmos. Cambridge, MA: Harvard University Asia Center, 2018.

Schram, Stuart R. Mao Tse-tung. Baltimore: Penguin Books, 1967.

Schram, Stuart R., ed. and trans. The Political Thought of Mao Tse-tung. New York: Praeger, 1969.

Schram, Stuart R. The Thought of Mao Tse-tung. Cambridge: Cambridge University Press, 1989.

Schram, Stuart R., et al., eds. and trans. Mao's Road to Power: Revolutionary Writings, 19121949. 8 vols. Armonk, NY: M. E. Sharpe, 1992-.

Schran, Peter. Guerrilla Economy: The Development of the Shensi-Kansu-Ninghsia Border Region, 1937-1945. Albany: State University of New York Press, 1976.

Schwarcz, Vera. The Chinese Enlightenment: Intellectuals and the Legacy of the May Fourth Movement of 1919. Berkeley: University of California Press, 1986.

Scott, James C. The Moral Economy of the Peasant: Rebellion and Subsistence in Southeast Asia. New Haven, CT: Yale University Press, 1976.

Selden, Mark. China in Revolution: The Yenan Way Revisited. Armonk, NY: M.E. Sharpe, 1995.

Selden, Mark. "The Guerrilla Movement in Northwest China: The Origins of the ShensiKansu-Ninghsia Border Region." China Quarterly 28 (October-December 1966): 63-81, and 29 (January-March 1967): 61-81.

Selden, Mark. The Yenan Way in Revolutionary China. Cambridge, MA: Harvard University Press, 1971.

Seybolt, Peter J. “Terror and Conformity: Counterespionage Campaigns, Rectification, and Mass Movements, 1942-43." Modern China 12, no. 1 (January 1986): 39-73.

Shaan-Gan-Ning bianqu caizheng jingji shi bianxiezu and Shaanxi dang'an guan, eds. Kang-Ri zhanzheng shiqi Shaan-Gan-Ning bianqu caizheng jingji shiliao zhaibian 抗日战争时期陕甘宁边区财政经济史料摘编 [Financial and economic materials on Shaan-Gan-Ning during the war]. Xian: Shaanxi renmin chubanshe, 1981.

“Shaan-Gan-Ning diaocha zhuanbao" 陝甘寧調查專報 [Special survey report on ShaanGan-Ning]. Guomindang Bureau of Investigation report, n.d. (ca. 1938), BOI 575.292/815. Shaanxi dangshi ziliao tongxun 陕西党史资料通讯 [Shaanxi party history newsletter]. 1983-.

Shaanxi sheng dang'an guan 陕西省档案馆, Shaanxi shehui kexueyuan 陕西社会科学院, ed. Shaan-Gan-Ning bianqu zhengfu wenjian xuanbian 陕甘宁边区政府文件选编 
[Selected documents of the Shaan-Gan-Ning Border Region government]. Beijing: Dang'an chubanshe, 1986.

Shaanxi shengzhi 陕西省志 [Shaanxi provincial gazetteer]. Vol. 6, Qixiang zhi 气象志 [Climate]. Edited by Shaanxi sheng difangzhi bianzuan weiyuanhu. Beijing: Qixiang chubanshe, 2001.

Shaanxi shifandaxue jiaoyu yanjiusuo 陕西师范大学教育研究所, ed. Shaan-Gan-Ning bianqu jiaoyu ziliao 陕甘宁边区教育资料[Shaan-Gan-Ning materials on education]. Xian: Jiaoyu kexue chubanshe, 1981.

Shaanxi tongzhi xutongzhi 陝西通志續通志 [Shaanxi provincial gazetteer and supplement]. Edited by Shen Qingya 沈青崖et al. 1933. Reprint, Taibei: Huawen shuju, 1969.

Shen Qiang 沈强 and Wang Xinhua 王新华. Kangzhan shiqi Sulian yuanhua shilun 抗战时 期苏联援华史论 [On the history of Soviet wartime aid to China]. Beijing: Shehui kexue wenxian chubanshe, 2013.

Sheng, Michael. Battling Western Imperialism: Mao, Stalin, and the United States. Princeton, NJ: Princeton University Press, 1997.

Shenmu xiangtuzhi 神木鄉土志 [Shenmu local gazetteer]. Ca. 1915. Reprint, Taibei: Chengwen chubanshe, 1970.

Sheridan, James E. Chinese Warlord: The Career of Feng Yü-hsiang. Stanford, CA: Stanford University Press, 1966.

Skocpol, Theda. States and Social Revolutions: A Comparative Analysis of France, Russia, and China. Cambridge: Cambridge University Press, 1979.

Snow, Edgar. Journey to the Beginning. New York: Random House, 1958.

Snow, Edgar. Random Notes on Red China, 1936-1945. Cambridge, MA: Harvard University East Asian Research Center, 1971.

Snow, Edgar. Red Star Over China. New York: Random House, 1938.

Snow, Helen Foster. My China Years. New York: William Morrow, 1984.

Sommer, Matthew H. Polyandry and Wife-Selling in Qing Dynasty China: Survival Strategies and Judicial Interventions. Stanford, CA: Stanford University Press, 2015.

Song Xinyong 宋新勇 et al. “Du Bincheng” 杜斌丞. Zhonggong dangshi renwu zhuan [Biographies of personalities in Chinese Communist Party history] 54 (1994): 287-324.

Song Yijun 宋毅军. “Zhonggong zai Xian shibian qianhou de junshi zhanlue fangyu” 中共在西安事变前后的军事战略防御 [Chinese Communist strategic defense during the Xi'an Incident]. Junshi lishi yanjiu, 1992, no. 4: 15-25.

Song Ziwen 宋子文. “T. V. Soong Sian Diary” T. V. Soong Papers, Box 59, folio 21, Hoover Institution Archives.

Spence, Jonathan D. God's Chinese Son: The Taiping Heavenly Kingdom of Hong Xiuquan. New York: W. W. Norton, 1996.

Stranahan, Patricia. Underground: The Shanghai Communist Party and the Politics of Survival, 1927-1937. Lanham, MD: Rowman and Littlefield, 1998.

Suide zhouzhi 绥德州志 [Suide gazetteer]. 1905. Reprint, Taibei: Chengwen chubanshe, 1970.

Sun Shuyun. The Long March: The True Story of Communist China's Founding Myth. New York: Doubleday, 2006.

Swope, Kenneth M. The Military Collapse of China's Ming Dynasty, 1618-44. London: Routledge, 2014. 
Takeuchi Minoru 竹内实. Mō Takutō shū 毛泽东集 [Writings of Mao Zedong]. Tokyo: Hokubōsha, 1972.

Tan, Chester. The Boxer Catastrophe. New York: Norton, 1967.

Taylor, Jay. The Generalissimo: Chiang Kai-Shek and the Struggle for Modern China. Cambridge, MA: Harvard University Press, 2009.

Teichman, Eric. Travels of a Consular Officer in North-West China. Cambridge: Cambridge University Press, 1921.

Teiwes, Frederick C. Politics and Purges in China: Rectification and the Decline of Party Norms, 1950-1965. 2nd ed. Armonk, NY: M. E. Sharpe, 1993.

Teiwes, Frederick C. Politics at Mao's Court: Gao Gang and Party Factionalism in the Early 1950s. Armonk, NY: M.E. Sharpe, 1990.

Teng, Ssu-yü. The Nien Army and Their Guerrilla Warfare, 1851-1868. Paris: Mouton, 1961.

Thomas, S. Bernard. Season of High Adventure: Edgar Snow in China. Berkeley: University of California Press, 1999.

Thornton, Patricia. Disciplining the State: Virtue, Violence and State-Making in Modern China. Cambridge, MA: Harvard University Asia Center, 2007.

Tien, Hung-mao. Government and Politics in Kuomintang China, 1927-1937. Stanford, CA: Stanford University Press, 1972.

Tōa Dōbunkai 東亞同文會. Shina shōbetsu zenshi 支那省別全誌 [Gazetteer of China]. Vol. 7, Shasei shō 陝西省 [Shaanxi Province]. Tokyo: Tōa Dōbunkai, 1918.

Tong, James. Disorder under Heaven: Collective Violence in the Ming Dynasty. Stanford, CA: Stanford University Press, 1991.

Tongji yuebao 统计月报 [Statistical monthly]. Xian, 1930-.

Tsang, Steve. "Chiang Kai-shek's 'Secret Deal' at Xian and the Start of the Sino-Japanese War." Palgrave Communications, January 2015, 1-12.

Tsou, Tang. America's Failure in China, 1941-50. Chicago: University of Chicago Press, 1963. Van de Ven, Hans J. From Friend to Comrade: The Founding of the Chinese Communist Party, 1920-1927. Berkeley: University of California Press, 1991.

Van de Ven, Hans J. War and Nationalism in China, 1925-1945. New York: Routledge, 2003.

Van Slyke, Lyman P. Enemies and Friends: The United Front in Chinese Communist History. Stanford, CA: Stanford University Press, 1967.

Vermeer, Eduard B. Economic Development in Provincial China: The Central Shaanxi since 1930. Cambridge: Cambridge University Press, 1988.

Vogel, Ezra F. Canton under Communism: Programs and Politics in a Provincial Capital, 1949-1968. Cambridge, MA: Harvard University Press, 1969.

Wakeman, Frederic, Jr. "China and the Seventeenth Century Crisis." Late Imperial China 7 , no. 1 (June 1986): 1-26.

Wakeman, Frederic, Jr. The Great Enterprise: The Manchu Reconstruction of Imperial Order in Seventeenth Century China. 2 vols. Berkeley: University of California Press, 1985.

Wakeman, Frederic, Jr. "Rebellion and Revolution: The Study of Popular Movements in Chinese History." Journal of Asian Studies 36, no. 2 (1977): 201-37.

Waldron, Arthur. The Great Wall of China: From History to Myth. Cambridge: Cambridge University Press, 1990.

Wales, Nym [Helen Foster Snow]. Inside Red China. New York: Doubleday, Doran, 1939.

Walker, Michael H. The 1929 Sino-Soviet War: The War Nobody Knew. Lawrence: University Press of Kansas, 2016. 
Wallace, Harold Frank. The Big Game of Central and Western China; Being an Account of a Journey from Shanghai to London Overland across the Gobi Desert. New York: Duffield, 1913.

Wang Jianmin 王建民. Zhongguo gongchandang shigao 中國共產黨史稿 [Draft history of the Chinese Communist Party]. Hong Kong: Zhongwen tushu gongyingshe, 1974-75.

Wang Jinfu 王金紱. Xibei zhi diwen yu renwen 西北之地文與人文 [Natural and human geography of the Northwest]. Shanghai: Shangwu yinshuguan, 1935.

Wang Qianyi 王谦益. "Huiyi liushi nianqian Sanyuan xuesheng de geming huodong" 回忆六十年前三原学生的革命活动 [Revolutionary activities of Sanyuan students sixty years ago]. Sanyuan wenshi ziliao 三原文史资料 2, no. 12 (1986): 120-29.

Wang Qisheng 王奇生. Geming yu fangeming: Shehui wenhua shiyexia de minguo zhengzhi 革命与反革命: 社会文化视野下的民国政治 [Revolution and counter-revolution: A socio-cultural perspective on republican politics]. Beijing: Shehui kexue wenxian chubanshe, 2010.

Wang Shoudao 王首道. Wang Shoudao huiyilu 王首道回忆录 [Memoir of Wang Shoudao]. Beijing: Jiefangjun chubanshe, 1987.

Wang Shucai 王树才. Shaanbei gongchandang de lao zhanggui Cui Tianfu 陕北共产党的老 掌柜崔田夫 [Cui Tianfu: The Communist boss of Shaanbei]. Beijing, 2010.

Wang Shulin 王树林. “Gongchan guoji, Sulian yu Zhongguo gongnong hongjun changzheng luojiaodian de queli” 共产国际, 苏联与中国工农红军长征落脚点的确立 [The Comintern, the Soviet Union, and settling the end of the Chinese Red Army's Long March]. Zhongguo Yanian ganbu xueyuan xuebao, 2017, no. 2: 90-108.

Wang Xiaozhong 王曉中. Zhongguwei gongzuo jishi 中顧委工作紀實 (1982-1987) [Work record of the Central Advisory Committee, 1982-1987]. Hong Kong: Tiandi tushu youxian gongsi, 2013.

Wang Yeh-chien. Land Taxation in Imperial China, 1750-1911. Cambridge, MA: Harvard University Press, 1973.

Weber, Eugen. Peasants into Frenchmen: The Modernization of Rural France, 1870-1914. Stanford, CA: Stanford University Press, 1976.

Weber, Max. "Politics as a Vocation" and "Science as a Vocation." In From Max Weber: Essays in Sociology, edited by H. H. Gerth and C. Wright Mill, 77-128, 129-56. New York: Oxford University Press, 1958.

Wenxian he yanjiu 文献和研究 [Documents and Studies]. Beijing, 1982-87.

Wilbur, C. Martin, and Julie Lien-ying How. Missionaries of Revolution: Soviet Advisers and Nationalist China, 1920-1927. Cambridge, MA: Harvard University Press, 1989.

Wilson, Dick. The Long March, 1935: The Epic of Chinese Communism's Survival. New York: Viking Press, 1972.

Wolf, Eric R. Peasant Wars of the Twentieth Century. New York: Harper and Row, 1969.

Wou, Odoric Y.K. Mobilizing the Masses: Building Revolution in Henan. Stanford, CA: Stanford University Press, 1994.

Wu Dianyao 吴殿尧 and Song Lin 宋霖. Zhu Lizhi zhuan 朱理治传 [Biography of Zhu Lizhi]. Beijing: Zhonggong dangshi chubanshe, 2007.

Wu Fuzhang 吴福章, ed. Xian shibian qinliji 西安事变亲历记 [Accounts by participants in the Xi'an Incident]. Beijing: Zhongguo wenshi chubanshe, 1986.

Wu, Tien-wei. The Sian Incident: A Pivotal Point in Modern Chinese History. Ann Arbor: University of Michigan Center for Chinese Studies, 1976. 
Wylie, Raymond Finlay. The Emergence of Maoism: Mao Tse-tung, Chen Po-ta, and the Search for Chinese Theory, 1935-1945. Stanford, CA: Stanford University Press, 1980.

Xiang, Lanxin. The Origins of the Boxer War: A Multinational Study. London: RoutledgeCurzon, 2003.

Xiao Liju 蕭李居 et al. Jiang Zhongzheng zongtong dang'an: Shilüe gaoben 蔣中正總統檔案: 事略稿本 [From the archives of President Chiang Kai-shek: Draft of daily events]. Taibei: Guoshiguan, 2010.

Xibei wushengqu bianzuan lingdao xiaozu 西北五省区编纂领导小组 and Zhongyang dang’an guan 中央档案馆, eds. Shaan-Gan-Ning bianqu kang-Ri minzhu genjudi: Huiyilujuan 陕甘宁边区抗日民主根据地: 回忆录卷 [Shaan-Gan-Ning anti-Japanese democratic base: Memoirs]. Beijing: Zhonggong dangshi ziliao chubanshe, 1990.

Xibei wushengqu bianzuan lingdao xiaozu 西北五省区编纂领导小组 and Zhongyang dang’an guan 中央档案馆, eds. Shaan-Gan-Ning bianqu kang-Ri minzhu genjudi: Wenxianjuan 陕甘宁边区抗日民主根据地: 文献卷 [Shaan-Gan-Ning anti-Japanese democratic base: Documents]. Beijing: Zhonggong dangshi ziliao chubanshe, 1990.

Xie Juezai. Xie Juezai riji 谢觉哉日记 [Xie Juezai diary]. Beijing: Renmin chubanshe, 1984. Xijing ribao 西京日报 [Eastern Capital Daily]. Xian, 1933-.

$\mathrm{Xu}$ Youcheng 许有成 and Xu Xiaobin 许晓涁. Yu Youren zhuan 于右任传 [Biography of Yu Youren]. Shanghai: Fudan daxue chubanshe, 1997.

Xu Youwei and Philip Billingsley. "Heroes, Martyrs, and Villains in 1930s Shaanbei: Liu Zhidan and His 'Bandit Policy."' Modern China 44, no. 3 (2018): 243-84.

Yang, Benjamin. "Complexity and Reasonability: Reassessment of the Li Lisan Adventure." Australian Journal of Chinese Affairs 21 (January 1989): 111-41.

Yang, Benjamin. From Revolution to Politics: Chinese Communists on the Long March. Boulder, CO: Westview Press, 1990.

Yang Dezhi 杨得志 et al. Hongjun changzheng wenxian 红军长征文献 [Documents of the Long March]. Beijing: Jiefangjun chubanshe, 1995.

Yang Kuisong 杨奎松. “Kangzhan chuqi Zhonggong junshi fazhan fangzhen biandong de shishikaoxi一抗战初期中共军事发展方针变动的史实考析一兼谈所谓'七分发展, 二分应付, 一分抗日'方针的真实性问题 [A historical analysis of changes in Chinese Communist military policy in the early War of Resistance-including the question of the authenticity of the so-called policy of "seven parts expansion, two parts dealing [with the GMD], one part resistance to Japan”]. Jindaishi yanjiu, 2015, no. 6: 4-26.

Yang Kuisong 杨奎松. Mao Zedong yu Mosike de enen yuanyuan 毛泽东与莫斯科的恩恩 怨怨 [Mao Zedong and Moscow: Gratitude and grievance]. Nanchang: Jiangxi renmin chubanshe, 1999.

Yang Kuisong 杨奎松. "Sulian daguimo yuanzhu Zhongguo hongjun de yici changshi" 苏联大规模援助中国红军的一次尝试 [A Soviet attempt to greatly aid the Red Army]. Jindaishi yanjiu, 1995, no. 1: 254-75.

Yang Kuisong 杨奎松. Xian shibian xintan: Zhang Xueliang yu Zhonggong guanxi zhi mi 西安事变新探: 张学良与中共关系之谜 [A new inquiry into the Xian Incident: The mystery of Zhang Xueliang's relations with the Chinese Communists]. Nanjing: Jiangsu renmin chubanshe, 2006.

Yang Kuisong 杨奎松. “Zhongjian didai” de geming: Guoji dabeijing xia kan Zhonggong chenggong zhi dao “中间地带”的革命: 国际大背景下看中共成功之道 [Revolution in 
the "middle realm": The international environment of the Chinese Communists' road to victory]. Taiyuan: Shanxi renmin chubanshe, 2010.

Yang Shangkun 杨尚昆. Yang Shangkun huiyilu 杨尚昆回忆录 [Memoirs of Yang Shankun]. Beijing: Zhongyang wenxian chubanshe, 2007.

Yang Tianshi. "Chiang Kai-shek and the Battles of Shanghai and Nanjing." In The Battle for China: Essays on the Sino-Japanese War of 1937-1945, edited by Mark Peattie, Edward J. Drea, and Hans van de Ven. Stanford, CA: Stanford University Press, 2011.

Yansui zhenzhi 延綏鎮志 [Gazetteer of Yansui town]. 1673. Reprint, Taibei: Taiwan xuesheng shuju, 1968.

Yu Da 於達. Hu Zongnan nianpu 胡宗南年譜 [Chronological biography of Hu Zongnan]. Taipei: Taiwan Shangwu yinshuguan, 2014.

Yuan Wenwei 袁文伟. Fanpan yu fuchou一minguo shiqi de xibei tufei wenti 反叛与复仇一 民国时期的西北土罒问题 [Resistance and revenge-Northwest bandits in the republican era]. Beijing: Renmin chubanshe, 2011.

Yulin diquzhi 榆林地区志 [Gazetteer of Yulin prefecture]. Edited by Yulin diqu difangzhi zhidao xiaozu 榆林地区地方志指导小组. Xi'an: Xibei daxue chubanshe, 1994.

Zhang Baotong 张宝同. “Lüjing xuesheng qunti yu Zhonggong Shaanxi zaoqi dangzuzhi de yuanqi” 旅京学生群体与中共陕西早期党组织的源起 [Student groups in Beijing and the origins of the Shaanxi Communist Party organization]. Suqu yanjiu, no. 2 (2020): $13-24$.

Zhang Ce 张策. Wo de lishi huigu 我的历史回顧 [My historical recollections]. Beijing: Gaige chubanshe, 1997.

Zhang Haipeng 张海鹏 and Li Xizhu 李细珠. Xinzheng, lixian yu xinhai geming 新政, 立宪与辛亥革命 [The New Policies, constitutionalism, and the 1911 Revolution]. Vol. 5 of Zhongguo jindai tongshi 中国近代通史 [A general history of modern China], edited by Zhang Haipeng. Nanjing: Jiangsu renmin chubanshe, 2005.

Zhang Junxiao张军孝. “Yige zhengyi de lishi renwu: Guanyu Zhang Mutao de jige wenti” 一个争议的历史人物一关于张慕陶的几个问题 [A controversial historical figure: Some questions about Zhang Mutao]. Xibei daxue xuebao (zhexue shehui kexue ban) 30, no. 1 (2000): $142-49$.

Zhang Junyang 张君洋, ed. Longdong geming lishi dang'an ziliao xuanbian: Dang de jianshe 陇东革命历史档案资料选编：党的建设 [Historical archives of eastern Gansu: Partybuilding]. Beijing: Zhonggong dangshi chubanshe, 2017.

Zhang Junyang 张君洋, ed. Longdong geming lishi dang'an ziliao xuanbian: Zhengquan jianshe 陇东革命历史档案资料选编: 政权建设 [Historical archives of eastern Gansu: Establishing a regime]. Beijing: Zhonggong dangshi chubanshe, 2017.

Zhang Pengyuan 张朋园. Lixianpai yu xinhai geming 立宪派与辛亥革命 [The Constitutionalists and the 1911 Revolution]. 3rd ed. Changchun: Jilin chubanshe, 2007.

Zhang Shouxian 张守宪 et al. “Li Zizhou” 李子洲 [Li Zizhou]. Zhonggong dangshi renwu zhuan [Biographies of persons in Chinese Communist Party history] 7 (1983): 77-100.

Zhang Shouxian 张守宪 et al. “Wei Yechou” 魏野畴. Zhonggong dangshi renwu zhuan [Biographies of persons in Chinese Communist Party history] 5 (1982): 131-74.

Zhang Wenjie 张文杰 et al. Jinian Zhu Lizhi wenji 纪念朱理治文集 [Essays in honor of Zhu Lizhi]. Zhengzhou: Henan renmin chubanshe, 1993. 
Zhao Tongru 赵通儒. Shaanbei gexian zaoqi dangshi ziliao 陕北各县早期党史资料 [Shaanbei county materials on early party history]. N.p., 1958.

Zheng Yangwen. The Social Life of Opium in China. Cambridge: Cambridge University Press, 2005.

Zhonggong dangshi renwu zhuan 中共党史人物传. Xian: Shaanxi renmin chubanshe, $1980-$.

Zhonggong Gansu shengwei dangshi yanjiushi 中共甘肃省委党史研究室, ed. ShaanGanbian geming genjudi 陕甘边革命根据地 [The Shaan-Gan revolutionary base]. Beijing: Zhonggong dangshi chubanshe, 1997.

Zhonggong Qingyang diwei dangshi ziliao zhengji bangongshi 中共庆阳地委党史资料 征集办公室. Hong ershiliu jun yu Shaan-Ganbian suqu 红二十六军与陕甘边苏区 [The Twenty-Sixth Army and the Shan-Gan Soviet]. 2 vols. Lanzhou: Lanzhou daxue chubanshe, 1995 .

Zhonggong Shaanxi shengwei dangshi yanjiushi 中共陕西省委党史研究室. Tudi geming zhanzheng shiqi de Zhonggong Shaanxi shengwei 土地革命战争时期的中共陕西省委 [The Shaanxi provincial committee during the land revolution period]. Xian: Shaanxi renmin chubanshe, 1991.

Zhonggong Shaanxi shengwei dangshi yanjiushi 中共陕西省委党史研究室. Xibei geming genjudi 西北革命根据地 [The Northwest revolutionary base]. Beijing: Zhonggong dangshi chubanshe, 1998.

Zhonggong Shaanxi shengwei dangshi yanjiushi 中共陕西省委党史研究室and Zhonggong Gansu shengwei dangshi yanjiushi 中共甘肃省委党史研究室. Shaan-Ganbian geming genjudi 陕甘边革命根据地 [The Shaan-Gan revolutionary base]. Beijing: Zhonggong dangshi chubanshe, 1997.

Zhonggong Shaanxi shengwei dangshi ziliao zhengji yanjiu weiyuanhui 中共陕西省委党 史资料征集 研究委员会, ed. Gongjinshe he “Gongjin” zazhi 共进社和《共进》杂志 [The Common Progress Society and Common Progress magazine]. Xian: Shaanxi renmin chubanshe, 1985 .

Zhonggong Shaanxi shengwei dangshi ziliao zhengji yanjiu weiyuanhui 中共陕西省委 党史资料征集 研究委员会. Qingjian Xunyi dengdi de wuzhuang qiyi 清涧旬邑等地 的武装起义 [The military uprisings of Qingiian, Xunyi, etc.]. Xian: Shaanxi renmin chubanshe, 1988.

Zhonggong Shaanxi shengwei dangshi ziliao zhengji yanjiu weiyuanhui 中共陕西省委 党史资料征集 研究委员会. Wei-Hua qiyi 渭华起义 [The Wei-Hua Uprising]. Xian: Shaanxi renmin chubanshe, n.d.

Zhonggong Shaanxi shengwei dangshi ziliao zhengji yanjiu weiyuanhui 中共陕西省委党 史资料征集 研究委员会. Xinhai geming zai Shaanxi 辛亥革命在陕西 [The 1911 Revolution in Shaanxi]. Xian: Shaanxi renmin chubanshe, 1986.

Zhonggong Shaanxi shengwei dangshi ziliao zhengji yanjiu weiyuanhui 中共陕西省委党 史资料征集 研究委员会and Zhonggong Xianyang shiwei dangshi bangongshi 中共咸 阳市委党史办公室, eds. Weibei geming genjudi 渭北革命根据地 [The Weibei revolutionary base]. Xi'an: Shaanxi renmin chubanshe, 1990.

Zhonggong Shaanxi shengwei dangshi ziliao zhengji yanjiu weiyuanhui 中共陕西省委党史 资料征集 研究委员会and Zhonggong Yulin diwei dangshiban 中共榆林地委党史办, Zhonggong Shenmu xianwei dangshiban 中共神府县委党史办, Shenfu geming genjudi 神 府革命根据地 [The Shenfu revolutionary base]. Xi'an: Shaanxi renmin chubanshe, 1990. 
Zhonggong Shaanxi shengwei dangxiao dangshi jiaoyanshi 中共陕西省委党校党史教研 室and Shaanxi sheng shehui kexueyuan dangshi jiaoyanshi 陕西省社会科学院党史 教研室. Xin minzhuzhuyi geming shiqi Shaanxi dashi jishu 新民主主义革命时期陕 西大事记述 [Chronology of Shaanxi in the new democratic revolution period]. Xian: Shaanxi renmin chubanshe, 1980.

Zhonggong xibei zhongyangju xuanchuanbu 中共西北中央局宣传部. Gulin diaocha 固林调查 [Gulin survey]. Yan'an, 1942.

Zhonggong Zhidan xianwei dangshi yanjiushi 中共志丹县委党史研究室, ed. Zhongguo gongchandang Zhidan lishi 中国共产党志丹历史 [History of the Communist Party in Zhidan]. Xi'an: Shaanxi renmin chubanshe, 2019.

Zhonggong zhongyang dangshi yanjiushi 中共中央党史研究室, trans. Liangong bu, gongchan guoji yu Zhongguo suweiai yundong 1931-1937 联共[布], 共产国际与中国苏 维埃运动 (1931-1937) [The Soviet Communist Party, the Comintern, and the Chinese soviet movement (1931-1937)]. Beijing: Zhonggong dangshi chubanshe, 2006.

Zhonggong zhongyang shujichu 中共中央书记处, ed. Liuda yilai 六大以来 [Since the Sixth Congress]. 2 vols. Beijing: Renmin chubanshe, 1981.

Zhonggong zhongyang wenxian yanjiushi中共中央文献研究室, ed. Mao Zedong nianpu 毛泽东年谱, 1893-1949 [Chronological biography of Mao Zedong, 1893-1949]. 3 vols. Beijing: Renmin chubanshe and Zhongyang wenxian chubanshe, 1993.

Zhonggong zhongyang wenxian yanjiushi中共中央文献研究室, ed. Zhou Enlai nianpu 周恩来年谱, 1898-1949 [Chronological biography of Zhou Enlai, 1898-1949]. Beijing: Zhongyang wenxian chubanshe, 2007.

Zhonggong Zichang xianwei dangshi bangongshi 中共子长县委党史办公室. “Anding (jin Zichang) xian suweiai zhengquan de jianli he fazhan” 安定(今子长)县苏维埃政权的 建立和发展 [The establishment and development of the Anding (now Zichang] soviet regime]. Manuscript, May 30, 1988.

Zhonggong Zichang xianwei dangshi bangongshi 中共子长县委党史办公室. “Anding (jin Zichang) xian zaoqi dang zuzhi de chuangjian jiqi zhuyao huodong” 安定(今子长)县早 期党组织的创建及其主要活动 [The establishment and activities of the early Anding (now Zichang) party organization]. Manuscript, 1988.

Zhonggong Zichang xianwei zuzhibu, Zhonggong Zichang xianwei dangshi yanjiushi, and Zichang xian dang'an guan 中共子长县委组织部, 中共子长县委党史研究室, 子长县档案馆. Zhongguo gongchandang Shaanxisheng Zichangxian zuzhishi ziliao 中国共产党陕西省子长县组织史资料 (Spring 1925-October 1987) [Organizational history materials on the CCP of Zichang County]. Xian: Shaanxi renmin chubanshe, 1994.

Zhongguo kexueyuan lishi yanjiusuo 中国科学院历史研究所, Shaan-Gan-Ning bianqu canyihui wenxian huiji 陕甘宁边区参议会文献汇辑 [Collection of documents from the Shaan-Gan-Ning Border Region Assembly]. Beijing: Kexue chubanshe, 1958.

Zhongguo renmin jiefangjun junshi kexueyuan 中国人民解放军军事科学院, ed. Zhongguo renmin jiefangjun zhanshi 中国人民解放军战史 [Military history of the Chinese People's Liberation Army]. Beijing: Junshi kexue chubanshe, 1987.

Zhongguo renmin zhengzhi xieshang huiyi quanguo weiyuanhui 中国人民政治协商会议 全国委员会, ed. Xinhai geming huiyilu 辛亥革命回忆录 [Memoirs of the 1911 Revolution]. Beijing: Zhonghua shuju, 1963.

Zhongguo shixuehui 中国史学会, ed. Xinhai geming 辛亥革命 [The 1911 Revolution]. Shanghai: Renmin chubanshe, 1957. 
Zhongtong 中统. "Bannianlai Shaan-Gan-Ning ji Chuan-Kang bianjing chifei zhi cuanrao gaikuang” 半年来陕甘宁及川康边境赤匪之窝扰概况 [Communist bandit disturbances in Shaan-Gan-Ning and Sichuan-Xikang in the last six months]. March 1937, BOI 270/815 (Stanford Library).

Zhongyang dang'an guan中央档案馆, Shaanxi dang'an guan 陕西档案馆, ed. Shaanxi geming lishi wenxian huiji 陕西革命历史文件汇集 [Collection of historical materials on the revolution in Shaanxi]. N.p., 1991-.

Zhongyang dang'an guan中央档案馆, Shaanxi dang'an guan 陕西档案馆, ed. Zhonggong Shaan-Gan-Ning bianqu dangwei wenjian huibian 中共陕甘宁边区党委文件汇集, 1937-1939 [Collection of documents from the Shaan-Gan-Ning party committee]. N.p., 1994.

Zhongyang ribao 中央日报 [Central Daily]. Nanjing, 1929-.

Zhu Hongzhao 朱鸿召. Yan'an: Richang shenghuo zhong de lishi, 1937-1947 延安: 日常 生活中的历史, 1937-1947 [Yan'an: A history of daily life, 1937-1947]. Guilin: Guangxi shifan daxue chubanshe, 2007.

Zichang xian minzhengju 子长县民政局 and Zhengxie wenshiziliao weiyuanhui 政协文 史资料委员会, eds. Zichangling ziliao 子长陵资料 [Materials from the Zichang mausoleum]. Yan’an, n.d. (1991 preface). 


\section{N D E X}

Academia Historica, $\mathrm{xx}$

Anding, 49, 66, 102, 103, 108, 112

Ansai, 10, 24, 106, 112, 149, 161

Anti-Comintern Pact, 158

Anti-Japanese National Salvation Army, 141,

142,147

Anti-Japanese Self-Defense Forces, 169

Apter, David, xiv, xv

archives, xiii, xvii-xviii, xx, 55, 93, 136, 187, 209

baihua, 33

bandits: censorship and, 244n64; famine and, 5; guerrillas as, $68,76,77,79-82$; military strength of, 38 ; opium addiction, 92; peasant movement and, 46, 47; recruitment, 65, 109; social origins, 62; Society of Brothers and, $37,65,197$; soldiers as, $5,30,37,46,185$; state authority and, xix; suppression of, 168, 185, 202; warlords and, 37. See also militia-bandits

Bao'an, 88, 138-39, 148: assaults on, 81, 112; education, 91; examinations, 27; Muslim Rebellion, 20, 24; renaming of, 58, 66; sufan campaign, 121, 132, 267n 58

baojia, 16, 101, 166, 175, 178, 181, 182

beggar bands, 13-14

Beijing Higher Normal School, 32, 38

Beiping, 94, 133, 141

Bethune, Norman, 207

Bianco, Lucien, 46, xvi

Billingsley, Phil, 62

Bisson, T. A., 166
Bolshevism, 33-34

Boxer Uprising, xvii, 28

Braun, Otto, 151, 205

Britain, 140, 146

Canton Uprising, 96

cave dwellings, 10, 12

censorship, xxi, 176, 205, 244n64

Chahar, 43, 91, 94, 116

Chen Duxiu, 47, 56, 73

Chen Guizhang, 65

Cheng Zihua, 115, 130

Chen Lifu, 146, 156, 164

Chen Shufan, 36

Chen Yun, 186, 187

Chen Yung-fa, xiii, xiv

Chiang Ching-kuo, 164

Chiang Kai-shek, xxiii, 137, 154-56, 179: elections and, 171; extermination campaigns, 87 , 104-7; Fujian rebellion, 92; Japan and, 72, 91, 133, 135, 140, 143, 146, 159, 163, 164, 203; kidnapping of, 1, 49, 158; military academy and, 42; negotiations and, 162-66, 173; party dominance, 70; Shanghai massacre, 46; Soviet Union and, 144-46, 154, 176, 203; united front and, 1, 145, 147, 154, 165, 172, 173, 274n224; warlords and, 46, 49, 70, 136, 143-44, 146, 157, 163, 198; Xi'an headquarters, 129, 143. See also Xi'an Incident

Chian incident, 132, 267n 58 
Chinese Communist Party: center-local conflict, 131-32, 203-4; couriers, $\mathrm{xx}, 54,72$, 94; democracy and, 141, 170, 188-89, 207; determinism and, 208; education and, 40, 206-7; expulsions, 72; founders, 34; land reform, 47-48, 53, 71, 106, 110; membership, 44, 86, 169; memoirs, $\mathrm{xx}-\mathrm{xxi}, 44,103,108$, 118, 128, 209; mutinies, 142; official histories, xviii-xxi, 123-25, 140; peasants and, 45, 47, 71; propaganda, 44, 46, 47, 91; scholarship on, xii-xvii; Soviet aid and, 155, 172, 205-6, 286n17; women and, 119, 150, 192-93, 195. See also united front; specific topics

Chinese Communist Party, Shaanxi: factions, xxi, 66, 94, 96, 108, 114, 115, 118, 132, 199-200, 255n56; financing, 55-57; founders, 95 , 198; membership, 47, 53, 54, 57; Northwest Military Committee, 107, 130; Northwest Work Committee, 107, 115, 245n67; purges, 54; schools and 38-42, 96, 108; youth and, 35,40

Chinese Communist Party, Shaanxi, provincial committee of: overview, 48, 50, 86, 118, 131; Bolsheviks, 80, 89, 115, 134, 198; collapse, xxii, 100, 119, 199; Comintern and, 56, 198; expulsions, 54; factions, 118, 199-200; guerrillas and, xxii, 67-68, 78-86, 89, 101, 115; peasant revolution and, 45; purges, 93; warlords and, 51

Chinese-Eastern Railroad, 73

Chinese Revolution (1911): elites and, 208; military and, 36; Society of Brothers and, 23, 28, 30; warlords and, 31

\section{Chongqing, 174}

class struggle, 34-35, 46, 80, 91, 98, 120, 137-38, 141,196

class warfare, $35,98,110,256 \mathrm{n} 82$

Common Progress Society (Gongjinshe), 33-39, $44,49,53-54,60,61,66,237$ ngo

Communist International (Comintern), 47, 70; democracy and, 170; financial support from, 55-56, 144; guerrillas and, 203; imperialism and, 72, 74; Long March and, 126, 196; peasant movement and, 71; provincial committee and, 56, 198; reports to, xx, 144, 151, 152-54; Seventh Congress, 145, 147; united front and, 133-35, 154, 165-66, 201; Xian Incident and, 158

Communist Youth League, 44, 55, 74, 77

Confucianism, 13, 17-18, 32, 33, 198

Confucius, 209

contingency, xii, xxiv, 208-210 corvée labor, 8

Cui Tianfu, 107, 108

Dai Jitao, 73

Dai Jiying, 117, 122

December Ninth Movement, 133

democracy, 33, 141, 170, 188-89, 207

Deng Baoshan, 44, 49

Deng Xiaoping, xviii, 43-44, 153

Dimitrov, Georgi, 144-45

Dingbian, 13, 112, 138, 153

Ding Ling, 192

Dong Fuxiang, 19, 22-23

Dongzhiyuan, 18-19

drought, 5, 12, 19, 24, 27, 72, 86, 93

Du Bincheng, 38-40, 65, 69

Du Heng, 74, 79, 81-86

Eighth Route Army, 173-175, 177-81, 185, 192-93, 205

Eliassen, Sigurd, 84, 204, 252n200

Empress Dowager Cixi, 27-28

Engels, Friedrich, xvi

Evolution Society (Jinhuashe), 53

examinations, 10-12, 15, 26-28

famine, 4, 5, 7, 10; peasants and, 63, 78; refugees and, 82; relief, 75; revolution and, 93

February 7 Incident, 34-35

Feng Yuxiang: overview, 42-43; army of, 42-43, 45, 47, 52, 55, 60, 119; Chiang Kai-shek and, 46-47, 70, 198; peasant movement and, 45; Shaanxi party and, $48,51,55$

fieldwork, xvii, xix, xx, 209. See also archives

Fifteenth Army, 115, 128, 152, 162

First Army, 125-26, 128-30, 132, 152-55, 273n216. See also Long March

Fourth Army, 84, 125-26, 141, 152, 154-55, 162

Fujian, 91-93, 203

Futian Incident, 118, 132, 203, 204

Fu-xian, 178

Ganquan, 116, 141, 162, 167

Gansu, 18, 21, 105, 245n91

Gao Fuyuan, 141-42

Gao Gang: criticism of guerrillas, 80-81, 89; education and, 39 , 188; election, 171 ; imprisonment, 117, 122, 200; leadership, 44, 107, 253n10, 284n187; marriage, 194-95; purge, 251n183; rape, 90, 192, 253n18; Rectification Campaign, xxi; Twenty-Sixth Army and, 89, 101, 107; Xian meeting/escape, 85-86 
Gao Guizi, 104-5, 107, 110-11, 113

Gao Hua, xiv

Gao Weihan, 68, 70, 79, 81, 251n198

Gelaohui. See Society of Brothers

Geng Bingguang, 53

Genghis Khan, 6, 135

gentry: overview, 14-16; constitutional reforms and, 28; executions, 109-10, 138; famine and, 75; kidnapping, 79; militia and, 17-19, 37; oppression by, 113; peasant movement and, 46; strongmen, $61,73,77,79,91,109-10,120$, 242n20; taxes and, 71, 91. See also juren

Germany, 133, 145, 158

Great Wall, 4-5, 7, 197

Guangxu emperor, 27

Guanzhong, 1, 15, 174

guerrillas: overview, 58; banditry, 68, 76, 77, 79-82; Comintern and, 203; criticism of, 8o-82, 89, 99-100, 113-14; executions, 110; expansion of, 65, 68-70, 89-91, 101-2, 108-13; extermination campaign and, 105-6; kidnapping, 79, 80, 84, 90; mountain strongholds, 71, 78, 83; opium and, 68, 69, 90; raids by, 83, 88, 109; Red Army and, 69-70, 139-40; schools and, 207; taxes and, 76, 90; weapons, 89, 92, 111. See also Liu Zhidan; Twenty-Sixth Army; Xie Zichang

Guo Baoshan, 92, 112

Guo Hongtao, 94, 100, 107, 113, 115, 131, 171; imprisonment of, 99, 122; sufan campaign and, 117-19; Twenty-Sixth Army and, 101, 130

Guojidang, 34

Guomindang. See Nationalist Party

Guominjun, 42-43, 45, 47, 52, 55, 60, 119

Han River, 3, 24, 162

He Long, 87, 125, 152, 161, 167, 173

He Shaonan, 181-82, 184, 190

He Yingqin, 158-59, 164, 182

High Cadre Conference (1942), xxi, 264n240

Hitler, Adolf, 145

Huan County, 179-80

Huang Ziwen, 75-78, 80-81, 114, 119

Huang Zixiang, 75

Hubei-Henan-Anhui Soviet, 81, 84, 114, 117, 118, 203

Hui, 17-22, 191. See also Muslim Rebellion

Hui Zijun, 107

Hu Jingyi, 40-41

Hunan, 45, 47-48

Hu Zongnan, 93, 152, 155-57, 159, 160, 182 ideology, 206-8

Inner Mongolia, 43, 99, 114, 116, 140, 156-58, 197

Japan: autonomy movement, 91, 133, 140, 158; Chiang Kai-shek and, 72, 91, 133, 135, 140, 143, 146, 159, 163, 164, 203; Comintern and, 145; Korea and, 5; Liu Zhidan and, 107, 199; Manchuria and, 69, 72-73, 75, 91, 104, 140; Mao Zedong and, 140, 157, 174; Nationalist Party and, 72, 91, 107, 140-41, 146, 157, 163, 174; Qing dynasty and, 27; Shaan-Gan-Ning and, 88, 203; Soviet Union and, 73, 134, 156, 157, 172; Sun Yat-sen and, 29; Versailles Peace Treaty and, 32; Yan'an bombing, 182. See also War of Resistance

Jiangxi, 87, 104, 125, 149, 196

jiaonong, 71, 75

Jingbian, 7, 16, 112, 138

Jinggangshan, 79

Jing Yuexiu, 40, 132, 180; overview, 38, 62; assassination by, 50; extermination campaign and, 104-5, 107; revolution and, 48; schools and, 94-96

juren, 15, 24, 26-27, 40

Keating, Pauline, xiii

Kim Il Sung, 126

Korea, 5, 126

land reform, 47-48, 53, 71, 106, 110

Lanzhou, 21-22, 144

Laoshan battle, 116-17, 121, 122, 129, 131, 206

Lenin, Vladimir, 45, 113, 148. See also Marxism-Leninism

Li Dazhao, 33-34, 39, 56

Li Dingming, 191

Li Gen, $80-81$

Li Lisan, 70-71

Lin Biao, 130, 133, 134, 136

Lin Boqu, 168, 170-71, 190

Lin Yuying, 133 134, 145, 154

Lipman, Jonathan, 18

literacy, 10, 91, 186-88

Liu Jingfan, 121, 194

Liu Shaoqi, 133, 141

Liu Tianzhang, 35

Liu Zhenhua, 36, 43

Liu Zhidan, 84-86, 92, 97, 105-16, 124, 137, 150, 169, 253n10; overview, 58-61, 203; bandits and, 8o, 185, 198; Bao'an and, 20, 63, 81; criticism of, $80,100,114,115,119-20,122$; death, 136; education, 38; family, 59-6o, 105, 120; 


\section{Liu Zhidan (continued)}

guerrillas and, 65, 67-70, 78, 82, 89-90, 106, 191, 198, 206; imprisonment of, 117-18, 121, 122, 127, 129, 132, 200; Japan and, 107, 199; military academies and, 42, 44, 60; militia and, 63, 65, 120, 168; mutinies and, 64, 67, 119; opium habit of, 242n15; Society of Brothers and, 65, 90, 92, 120, 155, 168, 185, 191; Wei-Hua Uprising, 51-52, 60, 88-89; Xie Zichang and, 51-52, 65, 67-70, 94, 99-101, 103-4, 198. See also Twenty-Sixth Army

Li Weihan, 135

Li Xiangjiu, 49-50

Li Zicheng, 5-6, 162, 197

Li Zizhou, 32, 41, 53; party center and, 47-48, 56; peasant movement and, 47,53 ; teaching career, 38-39, 43-44, 49, 95; writings, 34-35

local history, 197, 202-3

Loess soil, 3,10

Lominadze, Besso, 47

Long March: overview, xii; Comintern and, 126, 196; direction of, $87,124,125,133$; encirclement campaign and, 87; survivors, $125,128,130,131,151,193,194,206$

Luo River, 4, 19-20, 24, 106, 111

Luo Zhanglong, 70

Ma Hongbin, 104-7, 111

Ma Hongkui, 62, 64, 104-5, 119, 151, 155

Manchuria, 69, 72-75, 91, 104, 140, 142-43, 199 Manchus, 5, 6, 9, 18, 197. See also Qing dynasty Mao Zedong, 3, 134, 146, 152, 159; Beijing sojourn, 32; center-local conflict and, 132; Chiang Kai-shek and, 158; Comintern and, xiii, 126, 206; Gao Gang and, 194; interviews, xii, 138, 148, 151, 196; Japan and, 87, 146, 157, 174; Liu Zhidan and, 136; marriage, 193; party leadership, 123, 148-49, 161, 195-96; peasants and, 42, 45, 47-48, 79; recruitment campaign and, 129, 135; revolutionary optimism, 150-51; Society of Brothers and, 178, 185; Soviet Union and, 125-26, 134-35, 153-56; sufan campaign and, 122, 131, 264n240; united front and, $140,145,147,151,166,196$, 201; violence and, 204; writings, xii, 79, 123-24, 135, 161, 206, 207; Yan'an and, xi, 88, 123, 162, 197, 208. See also Long March

Marx, Karl, xvi

Marxism, 34, 81, 123, 126, 206, 208

Marxism-Leninism, 34, 35, 86, 169, 188

Ma Wenrui, 194

May Fourth Movement, 32-33, 35, 36, 192, 209
May Thirtieth Incident, 42 memoirs, $\mathrm{xx}-\mathrm{xxi}$, 44, 103, 108, 118, 128, 209

Meng Tian, 4

Miao Jiaxiang, 84, 252n2oo

migrants, 3, 7-8, 12-13, 19, 61, 89, 121, 191

militia, 17-19, 37, 65, 67, 78, 120, 160, 168, 205

militia-bandits, 19-20, 22, 63

Ming dynasty, 4-5, 7, 162, 197

Mizhi, 24, 26, 27, 95, 180

Mongols, 4, 6, 7, 22, 38, 155, 197

Muslim Rebellion, 16-25, 61, 89, 106, 121, 197, 203

mutinies, 64, 67, 89, 119, 142

\section{Nanjing, 174}

Nanliang, 89, 105

National Government: divisions within, 157; extermination campaign, 87, 104-7; Japan and, 91, 140-41, 157, 163, 174; Northeast Army and, 143, 144; Shaan-Gan-Ning Border Region and, 171, 173, 181, 182, 189, 201, 205; Soviet Union and, 145, 146, 172, 201, 205-6; united front and, 147, 165, 173

Nationalist Party, 34, 35, 74; baojia officials and, 16; Bureau of Investigation, $\mathrm{xx}, 146$; divisions within, 146; executions, 110; February 1937 plenum, 164; Japan and, 72, 107, 146; propaganda, 46. See also Chiang Kai-shek; National Government; united front; specific topics

National Pacification Army, 40-41

National Revolution (1920s), 40-42, 45, 46, 51, $53,75,141,242 \mathrm{n} 2 \mathrm{O}$

National Revolutionary Alliance, 166

National Revolutionary Army, 165-66, 173

National Salvation Society, 176

New Culture movement, 33, 198

New Fourth Army, 164, 182, 205

Nian Rebellion, 16, 18, 19, 22

Nie Hongjun, 115, 130

Ningxia, 150, 154-57, 162

Northeast Army (NEA), 104, 114, 116, 137, 151-53, 157, 162, 201; Chiang Kai-shek and, xxii, 129, 143; united front and, 135, 141-42, 144, 163; Xi'an Incident and, 163, 167, 173-74

North Wei Soviet, 78, 82

Northwest Anti-imperialist Alliance, 69, 72

Northwest Anti-Japanese Volunteers, 92

Northwest Army, 141, 144, 158, 160, 163, 201

Northwest Bureau, xxi, 171

Northwest National Defense Government, 144, 153-54, 157

Northwest Popular Anti-Japanese Volunteers, 92 
Northwest Soviet, 99, 123

Northwest Work Committee, 107, 115, 245n67

opium: addiction, 68 , 92, 143, 198; archival research and, xiii; guerrillas and, 68, 69, 90; male bonding and, 60; medical use, 82-83; militia and, 65; Nationalist army and, 108; New Culture movement and, 33; purges and, 188; Society of Brothers and, 23, 185; suppression, 97, 101, 150, 234n31; taxes and, $30,37,46,47$

Opium Wars, 16, 17

oral histories, xix

Pan Hannian, 146, 147

peasant movement, 42, 45-47, 51, 54, 71, 80 Peasant Movement Training Institute, 42, 45 peasant revolution, xvi, 45, 51, 53, 208

Peking University, 32, 34, 39, 53, 66, 125

Peng Dehuai, 128-30, 134, 136, 141, 150, 155, 156, 173,174

People's Liberation Army, xii, xxiv, 92

Perry, Elizabeth, xvi, 19

Pingxingguan, 174

Pomeranz, Kenneth, 197

Popkins, Samuel, xvi

proletarian revolution, 58, 101

purges, xiv, xvii, xxi, 54, 70, 89, 93, 114, 188. See also sufan campaigns

Qiang Shiqing, 97-98

Qin Bangxian (Bo Gu), 74, 131

Qing dynasty: overview, 5-9; decline, 27-30; opium and, 37234 n31; rebellions and, 16; Society of Brothers and, 28-30, 36-37; state apparatus, 14; Xinjiang and, 22. See also Manchus

Qingjian, 49-52, 67, 95, 102, 108

Rectification Campaign, xiii, xiv, xxi, 204, 205, 207 Red Army: captives of, 142; guerrillas and, 69-70, 139-40; Japan and, 92, 135; land confiscation, 132; militia and, 78; recruitment, 109, 129, 135, 136, 140, 153; size of, 139-40, 150, 152-53, 156; Society of Brothers and, 131; Soviet Union and, 125, 144, 153; students and, 160; united front and, 166, 173; weapons, 111-13, 152. See also specific armies

Red Guards, 77, 106, 111-13, 128; execution of, 110; gender relations, 138; guerrillas and, 102; Japan and, 169; recruitment, 108, 135, 137; Red Army and, 132, 135; Xie Zichang and, 98
Red Spears, 52, 62, 85, 238n120

Red Tourism, xi

refugees, 5, 12, 13-14, 65, 82, 93

Resistance Support Committee, 178

Resistance University (Kangda), xii, 176, 184

revolution: contingency and, xxiv, 208; famine and, 93; memory and, xxiii; peasant, xvi, 45, 51, 53, 208; proletarian, 58, 101; protests and, xv; violence and, 204. See also specific revolutions

Revolutionary Alliance (Tongmenghui), 29, 30, $31,38,40$

right liquidationism, 109, 113

right opportunism, 74, 81, 99, 100, 113, 117, 119, 165,199

Russian Revolution, xxiii, 33-35, 64, 86

Saich, Tony, xiv, xv

Sanjiayuan incident, 78, 99, 246n93

Sanyuan, 38, 41, 75-78, 82

Schram, Stuart, xii

Schran, Peter, xiii

Second Army, 154-55, 173, 273n216

Selden, Mark, xiii, xiv

Seybolt, Peter, xiv

Shaanbei: demographics, xix, 4, 23-25, 133-34, 180; frontier and, 12; gender relations, 12-13, 138; geography, 3-5, 9, 133-34; hygiene, 11-13; official history and, 123; poverty, 3-4, 9-10, 170, 193; Qing officials in, 14; scholarship on, xiii; soviet, 87, 126-28, 133; transport, 9-10. See also specific topics

Shaanbei Public School, 184

Shaan-Gan-Ning Border Region, 175: autonomy, 201, 203; blockade, 138, 182, 202, 205; borders, 173-74, 182, 185, 194, 202; education, 186-88; elections, 171, 188, 191, 202; founding, xviii-xix, 173; garrison area, 191-92; gender relations, 192-93; Japan and, 88, 203; population, 183-84; rural administration, 186-87; taxes, 187-89, 191; Yan'an and, xv. See also specific topics

Shaan-Gan Red Army, 78-79

Shaanxi: ancient capitals, 1; backwardness, 1 , 27, 32, 35-36, 50, 156; conservatism, 11, 36; geography, 1-4; land, 71; roads, 8 . See also Chinese Communist Party, Shaanxi; specific topics

Shaanxi Clarion, 32-35, 40

Shaanxi-Gansu border: bandits, 62-63, 65, 168; guerrillas, 58, 65, 67-68; militia, 63, 65; Muslim Rebellion, 24, 61; population, 106; soviet, 109, 113, 120; strategic importance, 61 
Shaanxi-Gansu Provincial Party Committee, 48,53

Shanghai, 42, 46, 174

Shanxi expedition, 136-37, 141, 169

Shao Lizi, 85, 93, 105, 158

sheep, 7, 9, 121

Sheng Shicai, 144

Shen Zhihua, xviii

Shi Kexuan, 43, 50

Shi Qian, 49

Sino-Soviet Non-Aggression Treaty, 172

Sino-Soviet split, 206

Smedley, Agnes, 274n231

Snow, Edgar: overview, 147-51; Liu Zhidan and, 59; Long March and, 128; Mao Zedong and, xii, 138, 148, 151, 196; Shaanbei and, 4; Twenty-Sixth Army and, 204; Xu Haidong and, 114

Socialist Youth Corps, 40

Society for Common Progress, 33-39, 44, 49, 53-54, 6o, 61, 66, 237ngo

Society of Brothers (Gelaohui): overview, 23; bandits and, 37, 65, 197; crime, 62; elimination of, 185-86; guerrillas and, 90; Muslim Rebellion and, 197; Nationalist Party and, 179; opium and, 23, 185; purges, xvii; Qing dynasty and, 28-30, 36-37; Red Army and, 131; rituals, 29; swordsmen and, 49 . See also specific individuals

Sommer, Matthew, 13, 245ng1

Song Meiling, 146, 163

Song Qingling, 146, 156

Song Ziwen (T. V. Soong), 146, 158-6o, 163, 164, 171,172

Soviet Union: CCP and, 72, 160, 155, 172, 205-6, 286n17; collectivization, 71; Guominjun and, 43; imperialism and, 73, 86; Japan and, 73, 134, 156, 157, 172; National Government and, 145, 172, 201, 205-6; North Korea and, 126; Red Army and, 125, 144, 153

Stalin, Joseph, 125, 144, 151, 158; biography, 209; kulaks and, 71; Mao Zedong and, 206; popularity, 148; purges, 204; Red Army and, 134, 154; Trotsky and, 74

sufan campaigns, 117-22, 127, 131, 132, 200, 203-4, $264 \mathrm{n} 240$

Suide: culture, 27, 39; landlords, 95; rebellions, 8-9, 24; schools, 48; Society of Brothers, 30

Suide Normal School, 39, 74, 96, 192, 180, 192

Sun Dianying, 120

Sun the Imperialist, 76-77
Sun Yat-sen, xxiii, 29, 31, 39, 43, 170, 207. See also Three People's Principles

Sun Yat-sen Military Academy, 43-44, 50

swordsmen, 49

Symposium on Northwest Revolutionary History, xxi, 263n234

Taiping Rebellion, 16-18, 22, 197

Tang Enbo, 137, 151, 157, 160

Tang Shu, 50-52

taxes: baozhang and, 91, 187; drought and, 93; elimination of, 150; guerrillas and, 90; Ming dynasty and, 7-8; Nationalist Party and, 34, 187; opium and, $30,37,46,47$; party rivalry and, 170; protests against, 71, 75; Qing dynasty and, 8

Teiwes, Frederick, xiv

terror, xiv, 53, 54, 86, 91, 97, 110, 204

Three People's Principles of, 41, 171, 173

Tibetan borderlands, 6, 126

Tongmenghui. See Revolutionary Alliance

Tongzhi emperor, 17

Trotskyites, 72, 73, 116, 158, 175, 205, 274n231

Twenty-Eight Bolsheviks, 131

Twenty-Eighth Army, 122, 132, 136, 152

Twenty-Fifth Army, 93, 111, 200, 204-6; Hubei-Henan-Anhui Soviet and, 114; Long March and, 130; Shaanbei revolution and, 93; size of, 114, 128-29, 261n188; sufan campaign and, 117-18, 122; weapons, 128

Twenty-Sixth Army, 128, 199, 200; criticism of, 114-15; defeat in Weinan, 84-5; Liu Zhidan and, 90, 97, 99, 106, 132; membership, 109, 204; Northwest Military Committee and, 107; party control of, 99, 100; purge, 93; rise of, 58, 80-85; sufan campaign and, 122; supplies, 141; weapons, 128

Twenty-Seventh Army, 107, 114-15, 128

United States, xi, 140, 146

united front, 34-35, 41, 45, 47, 55, 140-47, 163 , 172-75; Chiang Kai-shek and, 1, 145, 147, 154, 165, 172-73, 274n224; Comintern and, 133-35, 154, 165-66, 201; Mao Zedong and, 140, 145, 147, 151, 166, 196, 201; Zhang Xueliang and, $135,141-44,147,157-58$

Van de Ven, Hans, 34

venereal disease, 13, 192

Versailles Peace Treaty, 32, 198

Vietnam War, xv

violence, 109-11, 119-21, 204. See also terror 
Wakeman, Frederic, xix

Wales, Nym, 184, 193-94, 278n59

Wang Jiaxiang, 130, 175

Wang Jingwei, 163

Wang Ming, xii, xx, 100, 114, 123, 145, 146, 175, 206

Wang Ruofei, 195

Wang Shitai, 82, 101

Wang Shiwei, 193

Wang Taiji, 85, 89, 90, 92, 253n11

Wang Yizhe, 160

Wang Zhen, 181-82, 184, 189, 190, 194

warlords, 62, 144, 197; CCP and, 51, 144; intellectuals and, 36 ; opium and, 37,46 ; peasant movement and, 46; revolution and, 31; students and, 41. See also specific warlords

War of Resistance, 3, 88, 172, 174, 181, 194, 201, 207

Wayaobu, 102, 111, 116, 117, 133, 137, 176

Wei-Hua Uprising, 50-53, 60, 67, 85

Wei River valley: overview, 1 ; bandits, 72 ; cotton, 156; education, 28, 38, 39; gentry, 26-27; guerrillas, 80; military control of, 41, 43; Muslim Rebellion, 16-18; peasants, 47; proletarian revolution, 101

Wei Yechou, 32-34, 39, 41, 49, 53, 56, 60, 95

Western Xia, 4

West Route Army, 155, 160, 162

Whampoa Military Academy, 42, 50, 58, 60, 66

White Lotus Rebellion, 3, 17

Wuchang, 28, 29

Wuding River, xxii, 27, 61, 95, 167

Wuhan, 174

Xi'an: ancient capital, 4; Empress Dowager, 28; Manchus, 6, 29; modernization, 88, 156; peasant movement, 71 ; railway to, 155,156 ; schools, 38 ; siege of, 43 ; truce negotiations, 162-66

Xi'an Incident, 49, 158-64, 167, 173, 201, 261 n195, $274 n 224$

Xianfeng emperor, 17

Xie Zichang: overview, 66-67; death, 103, 106, 107, 200; education, 38 ; family, 66, 98, 109; guerrillas and, 67-70, 78, 80-81, 88, 94, 98, 102-3, 115, 199; Liu Zhidan and, 51-52, 65, 67-70, 94, 99-101, 103-4, 198; marriage, 94; prisoners freed by, 98, 99, 101, 256n67; reeducation, 82, 93-94; reputation, 103; Society of Brothers and, 67, 185; uprisings and, 50-52, 67

Xi Jinping, xxiii, 117, 123, 209
Xinjiang, 6, 22, 114, 125-26, 153-55

Xi Zhongxun: appointments, xxi, 82, 194; imprisonment, 117, 122, 200; mutinies and, 64; official history and, 123; sufan campaigns and, 263n234; Xunyi leaders and, $240 n 142$

Xuejiazhai, 82, 83, 85

Xu Haidong, 114-17, 122, 130, 159. See also Fifteenth Army; Twenty-Fifth Army

Xunyi, 78, 177

Xu Quanzhong, 51-52

Yan'an: overview, 161, 184; accidental holy land, xi-xii, 123-25, 196, 201, 208-9; battle for, 113, 114; era, xii, 123, 197, 201, 208; examinations, 27; Japan and, 182; Mao Zedong and, xi, 88, 123, 162, 197, 208; occupation of, 159, 161; party Center, 123, 161-62; progressive youths, 88, 193; Red tourism, xi, 161; Shaan-Gan-Ning and, xv; Society of Brothers, 30

Yanchang, 109, 112, 113, 171, 176

Yanchuan, 112, 176

Yang Hucheng, 62, 93; aides, 40, 69, 84; CCP and, 44, 49; extermination campaign and, 104-5; governance, 72, 85; Liu Zhidan and, 65, 92, 119-20; Xi'an incident and, 158-59, 162, 163, 201. See also Northwest Army

Yang Kuisong, xiii, 157

Yan Hongyan, 67, 75, 78, 81-82

Yan Xishan, 112, 135, 137, 174; Chiang Kai-shek and, 70, 136; extermination campaign and, 104-5; military school of, 66; opium suppression and, 97; red bandits and, 87; united front and, 158

Ya’qub Beg, 22

Yongningshan, 20

You Xiangzhai, 94

Young Pioneers, 77, 113, 135, 137, 138

Yuan Shikai, 30, 31, 36

Yuan Yuedong, 85-86

Yulin, 10, 24, 26, 27, 30, 48, 132

Yulin Middle School, 38-39, 58, 66, 80, 180, 192

Yu Youren, 40, 43, 45, 48-49, 172, 238n118

Zhang Guotao: CCP and, 93, 140, 144, 152, 154; criticism of, 130; Hubei-Henan-Anhui Soviet and, 81, 104, 125; Long March and, 87, 125-26, 128, 133, 196; Ningxia campaign and, 154-55. See also Fourth Army

Zhang Hanmin, 78, 261n187

Zhang Mutao, 116, 119, 122, 261n195, 274n231

Zhang Tingzhi, 168-69, 185, 191, 243n49

Zhang Wentian, 74, 134, 148 
Zhang Xianzhong, 5-6

Zhang Xiushan, 117

Zhang Xueliang: arrest of, 159, 163;

Chiang Kai-shek and, 49, 143-44, 146, 157, 159, 163; Comintern and, 154;

extermination campaign and, 104; united front and, 135, 141-44, 147, 156-58; Xi'an Incident and, 49, 157-58. See also Northeast Army

Zhao Erwa (Lianbi), 65, 69, 78, 99, 246n93

Zhaojin, 82-83, 85, 88-89, $251 n 189$

Zhao Laowu, 18o, 185, 281 n114
Zheng Yi, 82

Zhiluozhen, 129-30, 135, 141, 178

Zhou Enlai, 134, 143, 146, 148, 164; diplomacy, 140, 154, 158, 159, 166, 172, 173, 182; First Army and, 132; Northwest Military Committee and, 130; united front and, 147, 172, 173; sufan campaign and, 122, $264 \mathrm{n} 24 \mathrm{O}$ Zhu De, 119, 126, 128, 144-45, 154, 155, 166, 173

Zhu Hongzhao, xiii

Zhu Lizhi, 113-15, 117-20, 122, 131

Zhu Long, 8-9

Zuo Zongtang, 22, 23, 197 
Founded in 1893 , UNIVERSITY OF CALIFORNIA PRESS publishes bold, progressive books and journals on topics in the arts, humanities, social sciences, and natural sciences - with a focus on social justice issues-that inspire thought and action among readers worldwide.

The UC PRESS FOUNDATION raises funds to uphold the press's vital role as an independent, nonprofit publisher, and receives philanthropic support from a wide range of individuals and institutions - and from committed readers like you. To learn more, visit ucpress.edu/supportus. 
Yan'an is China's "revolutionary holy land," the heart of Mao Zedong's Communist movement from 1937 to 1947. Based on thirty years of archival and documentary research and numerous field trips to the region, Joseph W. Esherick's book examines the origins of the Communist revolution in Northwest China, from the political, social, and demographic changes of the Qing dynasty (1644-1911), to the intellectual ferment of the early Republic, the guerrilla movement of the 1930s, and the replacement of the local revolutionary leadership after Mao and the Center arrived in 1935. In Accidental Holy Land, Esherick compels us to consider the Chinese Revolution not as some inevitable peasant response to poverty and oppression, but as the contingent product of local, national, and international events in a constantly changing milieu.

"If the Shaan-Gan-Ning Border Region, the homeland of Xi Jinping's family, is the 'holy land' of Mao's revolution, then Esherick's new book is its indispensable Baedecker guide. This thoroughly researched and clearly written narrative helps us understand the complex historical roots of the People's Republic of China as it incubated in Shaanxi Province's 'yellow earth' hills."

ORVILLE SCHELL, Arthur Ross Director of the Center on US-China Relations, Asia Society

"Shattering the myth of historical inevitability, this meticulously researched and beautifully crafted study is a refreshing corrective to previous interpretations of the Chinese Revolution. Esherick's gripping tale of battling bandits and Bolsheviks in the making of Mao's wartime sanctuary lays bare the indeterminate and contingent course of one of the most momentous events of the twentieth century. Scholars and general readers alike will learn much from this authoritative work by America's premier historian of the Chinese Revolution."

ELIZABETH J. PERRY, Henry Rosovsky Professor of Government, Harvard University

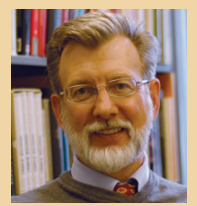

JOSEPH W. ESHERICK is Emeritus Professor of History at the University of California, San Diego. He is the author of The Origins of the Boxer Uprising (UC Press), Ancestral Leaves (UC Press), and other works on modern Chinese history.

\section{UNIVERSITY OF CALIFORNIA PRESS www.ucpress.edu}

A free open access ebook is available upon publication. Learn more at www.luminosoa.org.

Author photo: David Cheng Chang. Cover design: Glynnis Koike. Cover illustration: United Front. Lu Xun Arts Academy woodblock, 1938.

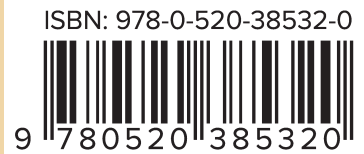

